\title{
Dwingend recht voor de besloten vennootschap : een beschouwing over de contractsvrijheid van aandeelhouders in rechtsvergelijkend perspectief
}

Citation for published version (APA):

Meinema, M. (2003). Dwingend recht voor de besloten vennootschap : een beschouwing over de contractsvrijheid van aandeelhouders in rechtsvergelijkend perspectief. [Doctoral Thesis, Maastricht University]. Kluwer. https://doi.org/10.26481/dis.20031114mm

Document status and date:

Published: 01/01/2003

DOI:

10.26481/dis.20031114mm

Document Version:

Publisher's PDF, also known as Version of record

Please check the document version of this publication:

- A submitted manuscript is the version of the article upon submission and before peer-review. There can be important differences between the submitted version and the official published version of record.

People interested in the research are advised to contact the author for the final version of the publication, or visit the DOI to the publisher's website.

- The final author version and the galley proof are versions of the publication after peer review.

- The final published version features the final layout of the paper including the volume, issue and page numbers.

Link to publication

\footnotetext{
General rights rights.

- You may freely distribute the URL identifying the publication in the public portal. please follow below link for the End User Agreement:

www.umlib.nl/taverne-license

Take down policy

If you believe that this document breaches copyright please contact us at:

repository@maastrichtuniversity.nl

providing details and we will investigate your claim.
}

Copyright and moral rights for the publications made accessible in the public portal are retained by the authors and/or other copyright owners and it is a condition of accessing publications that users recognise and abide by the legal requirements associated with these

- Users may download and print one copy of any publication from the public portal for the purpose of private study or research.

- You may not further distribute the material or use it for any profit-making activity or commercial gain

If the publication is distributed under the terms of Article $25 \mathrm{fa}$ of the Dutch Copyright Act, indicated by the "Taverne" license above, 


\section{Dwingend recht voor de besloten vennootschap}





\section{Dwingend recht voor de besloten vennootschap}

Een beschouwing over de contractsvrijheid van aandeelhouders in rechtsvergelijkend perspectief

\section{PROEFSCHRIFT}

ter verkrijging van de graad van doctor

aan de Universiteit Maastricht, op gezag van de Rector Magnificus, Prof. dr. A.C. Nieuwenhuijzen Kruseman, volgens het besluit van het College van Decanen, in het openbaar te verdedigen op vrijdag 14 november 2003 , om 14.00 uur

door

Martha Meinema

Kluwer - Deventer - 2003 
Van dit proefschrift is tevens een handelseditie verschenen in de serie Uitgaven vanwege het Instituut voor Ondernemingsrecht, Rijksuniversiteit Groningen nr. 43, onder ISBN 9013008569 .

\section{3, M. Meinema, Maastricht}

Alle rechten voorbehouden. Niets uit deze uitgave mag zonder voorafgaande toestemming van de uitgever worden verveelvoudigd of openbaar gemaakt.

Voor zover het maken van kopieën uit deze uitgave is toegestaan op grond van art. 16b Auteurswet 1912 jo. het Besluit van 20 juni 1974, Stb. 351, zoals gewijzigd bij Besluit van 23 aug. 1985, Stb. 471, en art. 17 Auteurswet 1912, dient men de daarvoor wettelijk verschuldigde vergoedingen te voldoen aan de Stichting Reprorecht (Postbus 3060, 2130 KB Hoofddorp).

Hoewel aan de totstandkoming van deze de uiterste zorg is besteed, aanvaarden de auteur(s), redacteur(en) en uitgever(s) geen aansprakelijkheid voor eventuele fouten en onvolkomenheden, noch voor gevolgen hiervan.

Kluwer BV legt de gegevens van abonnees vast voor de uitvoering van de (abonnements) overeenkomst. De gegevens kunnen door Kluwer, of zorgvuldig geselecteerde derden, worden gebruikt om $\mathrm{u}$ te informeren over relevante producten en diensten. Indien $\mathrm{u}$ hier bezwaar tegen heeft, kunt u contact met ons opnemen.

Op alle uitgaven van Kluwer zijn de algemene leveringsvoorwaarden van toepassing. Deze kunt u lezen op www.kluwer.nl of opvragen via telefoonnummer 0570-6734 49. 


\section{Voorwoord}

"Waarom doen wij voort? Als je een alpinist vraagt waarom hij een berg beklimt antwoordt hij: omdat de berg er is. Er is bij mijn weten nooit op gewezen dat dit antwoord onzin is. De wil van de alpinist ontstaat namelijk niet door de berg, maar is er ook zonder berg. De wil van de alpinist is niet zoiets gerings dat hij zoiets toevalligs als de uiterlijke vorm van de aarde nodig zou hebben om te bestaan. Ook als de aarde zo plat was als een biljartbal zouden er alpinisten zijn: de ware alpinisten. De ware alpinist zou zich er zelfs voor schamen zijn wil vorm te laten geven door dingen van een lagere orde als bergen. Er is dus maar één vraag die men met recht aan de ware alpinist zou kunnen stellen: waarom beklimt $u$ nooit een berg? Zijn antwoord zou luiden: omdat er bergen zijn."

Eenieder kent waarschijnlijk het verlangen zijn eigen grenzen te leren kennen. Voor mij bood het schrijven van het boek dat voor $u$ ligt deze gelegenheid. In de jaren dat ik zocht naar de dwingendrechtelijke grenzen aan de contractsvrijheid van aandeelhouders, heb ik regelmatig ook andere grenzen gezocht en overschreden. Eerst door grenzen te overschrijden kun je ze vaststellen. Veel grenzen zijn echter flexibel (deadlines voor het inleveren van stukken vormen daarvan een goed voorbeeld). Wat vandaag de grens was, hoeft dat morgen niet meer te zijn. Dat houdt het leven boeiend.

Je kunt echter alleen je eigen grenzen leren kennen als je in staat bent keuzes te maken. Keuzevrijheid als de noodzakelijke voorwaarde voor het stellen van grenzen, zoals contractsvrijheid in mijn ogen de noodzakelijke voorwaarde is voor de gebondenheid aan de overeenkomst. De keuzes die ik heb gemaakt, vloeien mede voort uit het vertrouwen dat de mensen die mij dierbaar zijn mij hebben geschonken.

In de eerste plaats wil ik mijn promotores Harm-Jan de Kluiver en Kid Schwarz bedanken voor het vertrouwen dat ze in me hebben gesteld. Kid Schwarz was altijd enthousiast en steunde me wanneer dat nodig was. Harm-Jan de Kluiver heeft de bijzondere gave werkelijk 'opbouwende' kritiek te geven en het juiste evenwicht aan te voelen tussen vrijheid en betrokkenheid. In de tweede plaats wil ik de leden van de beoordelingscommissie bedanken voor de goedkeuring van het manuscript. Door hun snelle beoordeling hebben zij een voor mij spannende tijd zo kort mogelijk gehouden.

Aangezien het onderzoek rechtsvergelijkend van aard is, heb ik, dankzij de faculteit en de Onderzoeksschool Ius Commune, een maand in

Tím Krabbé, De Renner. 
Cambridge doorgebracht voor een Summer School English Legal Methods. Bijzonder hartelijk ben ik voorts ontvangen door prof. dr. Peter Hommelhoff, dr. Carl-Heinz Witt, dr. Christoph Teichmann en Jan Gernoth van het Institut für deutsches und europäisches Gesellschafts- und Wirtschaftsrecht te Heidelberg, waar ik een aantal keer van de bibliotheek gebruik heb mogen maken. Het recht weerspiegelt de cultuur van een land, vandaar dat de inzichten opgedaan buiten de bibliotheek minstens zo belangrijk zijn geweest.

In de jaren die ik aan het proefschrift heb gewijd, heb ik veel geleerd en vooral ook veel plezier gehad. De juridische faculteit in Maastricht, en in het bijzonder de capgroep Privaatrecht, bood daarvoor een prettige werkomgeving en volop mogelijkheden. Het secretariaat van de capgroep vervulde daarbij een spilfunctie. Gedurende mijn tijd in Maastricht heb ik een bijzondere band opgebouwd met een aantal collega's: Sven Bostyn, Igor van Loo en vooral ook Rankie ten Hoopen, met wie het zo fijn was om de kamer (en het mooie uitzicht!) te delen.

Het schrijven van een proefschrift is een solitaire bezigheid. Niettemin was het niet eenzaam; boeken, muziek en schilderkunst boden inspiratie, terwijl voetballen, wandelen en fietsen een mooi tegenwicht vormden. Goede vrienden zijn daarbij onontbeerlijk; ik ben blij met de mensen die ik in de loop der jaren heb leren kennen. Een aantal vrienden wil ik in het bijzonder bedanken voor hun steun: Jeltsje Dijkstra, Alessandro en Claudia de Botton, Enrico Todisco Grande. Frea Rijnsbergen heeft me geïntroduceerd in de universitaire wereld. Met Heleen Janssen ben ik tegelijkertijd begonnen. We hebben veelal dezelfde ontwikkeling doorgemaakt. Ik ben vereerd dat zij aan mijn zijde staan.

Mijn ouders hebben me geleerd oprecht te zijn en te geloven in mijn mogelijkheden. Mijn broer Jasper heeft me relativeringsvermogen bijgebracht. In het laatste jaar heeft Roel Oosterwijk zich bij mijn dierbaren gevoegd. Hij heeft me andere kanten van het leven laten zien. Dankzij hem heb ik kunnen genieten van de laatste periode.

Ine Corstjens heeft in het heetst van de zomer op betrokken en vakkundige wijze het manuscript camera ready gemaakt. Jan Gernoth en Jacqueline Schoonheim hebben op zeer korte termijn de Duitse resp. Engelse samenvatting verbeterd. Ieder heeft - op eigen wijze - bijgedragen aan de totstandkoming van dit boek. Daarvoor dank ik allen. Het onderzoek is afgesloten op 1 juli 2003 .

Den Haag, augustus 2003 


\section{Inhoudsopgave}

Voorwoord

Inhoudsopgave

Lijst van afkortingen

Lijst van verkort aangehaalde literatuur

Hoofdstuk $1 \quad$ Inleiding

1.1 Aanleiding

1.2 Probleemstelling

1.3 Rechtsvergelijking

1.4 Uitwerking: dwingend vennootschapsrecht

1.5 Uitwerking: keuze uitgangspunten

1.6 Evaluatie

Hoofdstuk 2 Het Wettelijk Systeem

$2.1 \quad$ Inleiding

2.2 Nederland

2.2.1 De geschiedenis van artikel 2:25 BW

2.2.2 Dwingende en aanvullende regels

2.2.3 Afwijking of aanvulling?

2.3 Duitsland

2.3.1 Satzungsstrenge in het fktienrecht

2.3.2 Gestaltungsfreiheit in het GmbH-recht

2.4 Engeland

2.4.1 Statutes vs common law

2.4.2 Dwingende en aanvullende regels

2.5 Evaluatie 
$3.1 \quad$ Inleiding

3.2 Nederland $\quad 48$

3.2.1 Afstand van recht $\quad 48$

3.2.2 Afstand van vennootschapsrechten? $\quad 50$

3.2.3 Afzien van de uitoefening van individuele rechten 53

3.2.4 Onderwerping van rechten van aandeelhouders aan arbitrage

3.3 Duitsland

3.3.1 Unentziehbare en unverzichtbare rechten van aandeelhouders

3.3.2 Individuele afstand van rechten van aandeelhouders

3.3.3 Onderwerping van vennootschapsrechtelijke geschillen aan arbitrage

3.4 Engeland

3.4.1 Mandatory rights

3.4.2 Individuele afstand van rechten

3.4.3 Onderwerping van rechten van aandeelhouders aan arbitrage

3.5 Evaluatie

Hoofdstuk 4 Statuten

4.1 Inleiding

$\begin{array}{lll}4.2 \text { Nederland } & 77\end{array}$

4.2.1 Het rechtskarakter van statuten 77

4.2.2 Statuten in formele en/of materiële zin $\quad 78$

4.2.3 De interpretatie van de statuten 82

4.2.4 Wijziging van de statuten bij meerderheidsbesluit 84

4.2.5 Beperking van de bevoegdheid tot statutenwijziging $\quad 86$

$\begin{array}{lll}4.3 & \text { Duitsland } & 89\end{array}$

4.3.1 Het rechtskarakter van de Satzung $\quad 89$

4.3.2 Statuten in formele en/of materiële zin 90

4.3.3 De interpretatie van de Satzung 93

4.3.4 Wijziging van de Satzung bij meerderheidsbesluit 95

4.3.5 De Satzungsautonomie 96 
4.4 Engeland

4.4.1 Het rechtskarakter van de articles 98

4.4.2 Statuten in formele en/of materiële zin $\quad 100$

4.4.3 De interpretatie van de articles 101

4.4.4 Wijziging van de articles

102

4.5 Evaluatie

103

Hoofdstuk 5 Uit de statuten voortvloeiende rechten en verplichtingen

$5.1 \quad$ Inleiding

107

5.2 Nederland

5.2.1 Statutaire rechten van aandeelhouders

108

5.2.2 'Bijzondere' rechten van aandeelhouders

5.2.3 Rechten van derden

5.2.4 Extra verplichtingen voor aandeelhouders

5.2.5 Statutaire kwaliteitseisen aan aandeelhouders

5.3 Duitsland

5.3.1 Aanvullende rechten van aandeelhouders

5.3.2 Sonderrechte

5.3.3 Rechten van derden

5.3.4 Nebenleistungen

5.3.5 Kwaliteitseisen aan aandeelhouders

5.4 Engeland

5.4.1 Aanvullende rechten van aandeelhouders $\quad 130$

5.4.2 Class rights

5.4.3 Outsider rights

5.4.4 Extra verplichtingen aan aandeelhouders

5.5 Evaluatie

Hoofdstuk $6 \quad$ Besluiten

6.1 Inleiding

6.2 Nederland

6.2.1 Besluiten van de algemene vergadering

6.2.2 Nietigheid als uitgangspunt

6.2.3 Uitzondering op de nietigheid: besluiten in afwijking van procedurevoorschriften 
Inhoudsopgave

6.2.4 Uitzondering op de nietigheid: wettelijke doorbreking van statutaire bepalingen

6.2.5 Uitbreiding van de vernietigbaarheid als sanctie? 148

6.2.6 Bekrachtiging

6.2.7 Conversie

157

6.3 Duitsland

6.3.1 Besluiten

158

6.3.2 Nietigheid als limitatieve categorie

159

6.3.3 Vernietigbaarheid als restcategorie

6.3.4 Satzungsdurchbrechung als uitzondering op de vernietigbaarheid

6.3.5 Satzungsdurchbrechung als geldig besluit

6.3.6 Conversie

167

6.4 Engeland

168

6.4.1 Besluiten

168

6.4.2 Nietige en vernietigbare besluiten

170

6.4.3 De 'unamimous consent rule'

173

6.5 Evaluatie

179

Hoofdstuk 7 Aandeelhoudersovereenkomsten

183

7.1 Inleiding

183

7.2 Nederland

185

7.2.1 De toelaatbaarheid van aandeelhoudersovereenkomsten

185

7.2.2 Contractuele sancties op niet-nakoming van stemovereenkomsten

189

7.2.3 Grenzen aan aandeelhoudersovereenkomsten

190

7.2.4 Vennootschapsrechtelijke werking van aandeelhoudersovereenkomsten

7.3 Duitsland

7.3.1 De toelaatbaarheid van stemovereenkomsten

7.3.2 Contractuele sancties aan de niet-nakoming van stemovereenkomsten

7.3.3 Grenzen aan aandeelhoudersovereenkomsten

7.3.4 Vennootschapsrechtelijke werking van aandeelhoudersovereenkomsten

7.4 Engeland

225

7.4.1 De toelaatbaarheid van stemovereenkomsten

7.4.2 Contractuele sancties op niet-nakoming van stemovereenkomsten 
7.4.3 Grenzen aan de geldigheid van aandeelhoudersovereenkomsten

7.4.4 Vennootschapsrechtelijke werking van aandeelhoudersovereenkomsten

7.5 Evaluatie

Hoofdstuk $8 \quad$ Conclusie

8.1 Inleiding

8.2 Wat is dwingend vennootschapsrecht?

8.3 Statuten als bijzondere overeenkomst

8.4 Besluiten als bijzondere overeenkomst

8.5 Aandeelhoudersovereenkomsten

8.6 Voorbeeld: de invloed van derden in de vennootschap

8.7 Slotopmerkingen

Zusammenfassung

Summary

Lijst van aangehaalde literatuur

Jurisprudentieregister

Trefwoordenregister 



\begin{tabular}{|c|c|}
\hline AA & Ars Aequi \\
\hline ABLR & Australian Business Law Review \\
\hline Abs. & Absatz \\
\hline Anh. & Anhang \\
\hline $\mathrm{AC}$ & Appeal Cases \\
\hline $\mathrm{AcP}$ & Archiv für die civilistische Praxis \\
\hline AG & Aktiengesellschaft, Die Aktiengesellschaft \\
\hline AktG & Aktiengesetz \\
\hline All ER & All England Law Reports \\
\hline BB & Betriebsberater \\
\hline $\mathrm{BCC}$ & British Company Law Cases \\
\hline BCLC & Buttersworth's Company Law Cases \\
\hline BGB & Bürgerliches Gesetzbuch \\
\hline BGH & Bundesgerichtshof \\
\hline BGHZ & Entscheidungen des Bundesgerichtshofes \\
\hline BV & Besloten Vennootschap \\
\hline BVerfG & Bundesverfassungsgericht \\
\hline BW & Burgerlijk Wetboek \\
\hline $\mathrm{CA}$ & Court of Appeal \\
\hline CA 1985 & Companies Act 1985 \\
\hline $\mathrm{CAO}$ & Collectieve arbeidsovereenkomst \\
\hline CFilLR & Company Financial and Insolvency Law Review \\
\hline $\mathrm{Ch}$ & Chancery \\
\hline CLJ & Cambridge Law Journal \\
\hline DB & Der Betrieb \\
\hline Dep. rl. & Departementale Richtlijnen 1986 \\
\hline DNotZ & Deutsches Notarzeitschrift \\
\hline DTI & Department of Trade and Industry \\
\hline EWCA & England and Wales Court of Appeal \\
\hline EWHC & England and Wales High Court \\
\hline FS & Festschrift \\
\hline GG & Grundgesetz \\
\hline $\mathrm{GmbH}$ & Gesellschaft mit beschränkter Haftung \\
\hline GmbHG & GmbH-Gesetz \\
\hline GmbHR & GmbH-Rundschau \\
\hline Hand. & Handelingen \\
\hline HvJEG & Hof van Justitie van de Europese Gemeenschap \\
\hline $\mathrm{HL}$ & House of Lords \\
\hline
\end{tabular}




$\begin{array}{ll}\text { HR } & \text { Hoge Raad } \\ \text { J } & \text { Judge } \\ \text { JBL } & \text { Journal of Business Law } \\ \text { JOR } & \text { Jurisprudentie Onderneming en Recht } \\ \text { KB } & \text { King's Bench } \\ \text { KNB } & \text { Koninklijke Nederlandse Beroepsorganisatie } \\ \text { LJ } & \text { Learned Judge } \\ \text { LQR } & \text { Law Quarterly Review } \\ \text { Ltd } & \text { Private limited company } \\ \text { MLR } & \text { Modern Law Review } \\ \text { MR } & \text { Master of the Rolls } \\ \text { MvT } & \text { Memorie van Toelichting } \\ \text { NJ } & \text { Nederlandse Jurisprudentie } \\ \text { NJB } & \text { Nederlands Juristen Blad } \\ \text { NILQ } & \text { Northern Ireland Law Quarterly } \\ \text { NJV } & \text { Nederlandse Juristen Vereniging } \\ \text { NJW } & \text { Neue Juristische Wochenschrift } \\ \text { NV } & \text { Naamloze Vennootschap, De Naamloze Vennoot- } \\ & \text { schap } \\ \text { OK } & \text { Ondernemingskamer van het Gerechtshof } \\ & \text { Amsterdam } \\ \text { OLG } & \text { Oberlandesgericht } \\ \text { PIc } & \text { Public limited company } \\ \text { QC } & \text { Queen's Council } \\ \text { Rb } & \text { Rechtbank } \\ \text { RIW } & \text { Recht der internationalen Wirtschaft } \\ \text { RM Themis } & \text { Rechtsgeleerd Magazijn Themis } \\ \text { RO } & \text { Wet op de rechterlijke organisatie } \\ \text { Rv } & \text { Wetboek van Burgerlijke Rechtsvordering } \\ \text { RvdW } & \text { Rechtspraak van de Week } \\ \text { SAS } & \text { Société par Actions Simplifiée } \\ \text { S \& V } & \text { Stichting en Vereniging } \\ \text { TK } & \text { Tweede Kamer } \\ \text { TVVS } & \text { TVVS, Maandblad voor ondernemingsrecht en } \\ & \text { rechtspersonen } \\ \text { W } & \text { Weekblad voor het Recht } \\ \text { WLR } & \text { Weekly Law Reports } \\ \text { WM } & \text { Wertpapier-Mitteilungen } \\ \text { WOR } & \text { Weekblad voor Privaatrecht, Notariaat en Regis- } \\ \text { WPNR } & \\ & \text { tratie } \\ & \end{array}$


WvK

ZGR

ZHR

ZPO
Wetboek van Koophandel

Zeitschrift für Unternehmens- und Gesellschaftsrecht

Zeitschrift für das gesamte Handels- und Wirtschaftsrecht

Zivilprozeßordnung 

Lijst van verkort aangehaalde literatuur

Asser-Hartkamp 4-II

Asser-Maeijer 2-III

Asser-Scholten

Asser-Van der Grinten-Maeijer 2-II

Baumbach/Hueck

Belinfante

Davies

Farrar

Großkommentar
A.S. Hartkamp, Asser-Hartkamp deel 4-II Verbintenissenrecht. Algemene leer der overeenkomsten, $11^{e}$ druk, Tjeenk Willink, Deventer 2001 J.M.M. Maeijer, Asser-Maeijer deel 2-III Vertegenwoordiging en rechtspersoon. De naamloze en de besloten vennootschap, $2^{\mathrm{c}}$ druk, Tjeenk Willink, Deventer 2000

P. Scholten en G.J. Scholten, Asser's handleiding tot de beoefening van het Nederlands burgerlijk recht, Algemeen Deel, I-2, $3^{\mathrm{e}}$ druk Tjeenk Willink, Zwolle 1974

J.M.M. Maeijer, Asser-Van der Grinten-Maeijer deel 2-II Vertegenwoordiging en rechtspersoon. De rechtspersoon, $8^{\mathrm{e}}$ druk, Tjeenk Willink, Deventer 1997

GmbH-Gesetz, $16^{e}$ druk, C.H. Beck Verlag, München 1996

Ontwerpen van wetten op de vennootschappen en andere: wijziging en aanvulling van de bepalingen omtrent de naamlooze vennootschap en regeling van de aansprakelijkheid voor het prospectus, Den Haag, Belinfante 1929

P.L. Davies, Gower's Principles of Modern Company Law, $6^{\mathrm{e}}$ druk, Sweet \& Maxwell, Londen 1997

J.H. Farrar en B.M. Hannigan, Farrar's Company Law, $4^{e}$ druk, Butterworths, Londen 1998

V. Röhricht, Großkommentar zum Aktiengesetz, $4^{\mathrm{e}}$ druk, $\S \S 23-40$, Walter de Gruyter, Berlijn 1997 
Handboek

Hüffer

Kübler

Lutter/Hommelhoff

Münchener Kommentar

Münchener Kommentar

Pitlo-Raaijmakers

Raiser

Rowedder/Schmidt-Leithoff

Sanders

Sanders/Westbroek
W.C.L. van der Grinten, Handboek voor de Naamloze en de Besloten Vennootschap, $12^{\mathrm{e}}$ druk, Tjeenk Willink, Zwolle 1992

U. Hüffer, Kurzkommentar AktG, $4^{\mathrm{c}}$ druk, C.H. Beck Verlag, München 1999

F. Kübler, Gesellschaftsrecht, $4 \mathrm{e}$ druk, C.F. Müller Juristischer Verlag, Heidelberg 1994

M. Lutter en P. Hommelhoff, GmbH-Gesetz, Kommentar, $15^{\mathrm{e}}$ druk, Verlag Dr. Otto Schmidt, Keulen 2000

Münchener Kommentar zum Aktiengesetz, $2^{e}$ druk, $\S \S 1-53$, C.H. Beck Verlag, München 2000

Münchener Kommentar zum Bürgerlichen Gesetzbuch, Allgemeiner Teil, $\S \S 1-240,2^{\mathrm{e}}$ druk, C.H. Beck Verlag, München 1984

M.J.G.C. Raaijmakers, Pitlo's Vennootschaps- en rechtspersonenrecht, $4^{\mathrm{e}}$ druk, Gouda Quint, Deventer 2000

Th. Raiser, Recht der Kapitalgesellschaften: ein Handbuch für Praxis und Wissenschaft, $3^{\mathrm{e}}$ druk, Franz Vahlen, München 2001

$\mathrm{H}$. Rowedder en Ch. SchmidtLeithoff, Gesetz betreffend die Gesellschaften mit beschränkter Haftung: Kommentar, $4^{\mathrm{e}}$ druk, Franz Vahlen, München 2002

P. Sanders, Het nieuwe arbitragerecht, $3^{\mathrm{e}}$ druk, Kluwer, Deventer 1996

P. Sanders en W. Westbroek, BV en NV, bewerkt door F.K. Buijn en P.M. Storm, 7e druk, Kluwer, Deventer 1994 
Sealy

Soergel

K. Schmidt

Staudinger

Van Schilfgaarde
L.S. Sealy, Cases and Materials in Company Law, $6^{\mathrm{c}}$ druk, Butterworths, Londen 1996

Bürgerliches Gesetzbuch mit Einführungsgesetz und Nebengesetzen, $11^{\mathrm{e}}$ druk, Verlag W. Kohlhammer, Stuttgart 1978

K. Schmidt, Gesellschaftsrecht, $4^{\mathrm{e}}$ druk, Carl Heymanns Verlag, Keulen 2002

J. von Staudingers Kommentar zum Bürgerlichen Gesetzbuch mit Einführungsgesetz und Nebengesetzen, $12^{\mathrm{e}}$ druk, J. Schweitzer Verlag, Berlijn 1980

P. van Schilfgaarde, Van de BV en de NV, 12e druk, Gouda Quint, Deventer 2001 



\section{Hoofdstuk 1 Inleiding}

"The words ['just and equitable'] are a recognition of the fact that a limited company is more than a mere judicial entity, with a personality in law of its own: that there is room in company law for recognition of the fact that behind it, or amongst it, there are individuals, with rights, expectations and obligations inter se which are not necessarily submerged in the company structure."

\section{$\S 1.1$ Aanleiding}

Waarom hebben wij dwingend vennootschapsrecht? Deze vraag werd in 1991 door Timmerman op een congres in Groningen gesteld. ${ }^{2}$ Het stellen van deze vraag impliceert dat het niet vanzelfsprekend is dat 'wij' dwingend vennootschapsrecht hebben. Dwingend recht behoeft kennelijk rechtvaardiging. Bovendien zou in de vraagstelling een soort verwijt kunnen worden geproefd. Dwingend recht dat als knellend wordt ervaren.

Onder invloed van het sturende optreden van de nationale en Europese overheid is het vennootschapsrecht de laatste dertig jaar veel uitgebreider en gedetailleerder geworden. Sinds de jaren tachtig van de vorige eeuw gaan er stemmen op de complexiteit van de regelgeving te verminderen. Een aanzet tot heroverweging van het vennootschapsrecht bracht de law \& economics-stroming uit de Verenigde Staten. ${ }^{3}$ Hoewel de economische analyse van het recht niet volledig in Europa is geaccepteerd, heeft deze wel een discussie in gang gezet over het nut van dwingend recht. ${ }^{4}$ Ook in Nederland hebben auteurs in de jaren negentig gepleit voor afschaffing en

Lord Wilberforce in Ebrahimi $v$ Westbourne Galleries [1973] AC 360, [1972] 2 All ER 492.

Timmerman, Waarom hebben wij dwingend vennootschapsrecht?, in: Ondernemingsrechtelijke contracten, uitgave vanwege het Instituut voor Ondernemingsrecht, 1991, blz I e.v.

Zie voor een uitgebreid overzicht het themanummer The debate on contractual freedom in corporate law, Columbia Law Review 1989, blz. 1395 e.v. en Easterbrook en Fischel, The economic structure of corporate law, 1991.

Zie bijvoorbeeld in Duitsland Lutter en Wiedemann (red.), Gestaltungsfreiheit im Gesellschaftsrecht: Deutschland, Europa und USA, Sonderheft 13, ZGR 1998. 
versoepeling van bepaalde regelingen, steeds echter onder de bewoordingen dat er "nog veel onduidelijkheid bestaat", of dat een "meer fundamenteel onderzoek noodzakelijk is".

Een ander thema dat opgang vindt in de jaren negentig is 'corporate governance'. De discussie over de juiste balans tussen bestuur en toezicht binnen de vennootschap is al zo oud als de Vereenigde Oostindische Compagnie $e^{\circ}$ maar wordt nu internationaal en interdisciplinair gevoerd. Wederom werd het startsein aan Anglo-Amerikaanse zijde gegeven met de publicatie van het Britse Cadbury Report en het opstellen van de Principles of Corporate Governance door het American Law Institute." Daarna is in menig continentaal Europees land een soortgelijk onderzoek verricht. ${ }^{9}$

In 1997 verschijnt het rapport van de Commissie Peters over Corporate Governance in Nederland. ${ }^{10}$ Deze door de Vereniging van Effecten Uitgevende Ondernemingen en de Amsterdams effectenbeurs ingestelde commissie pleit in 40 aanbevelingen voor een beter 'vennootschappelijk bestuur' door onder meer de nadruk te leggen op de verantwoording van bestuurders en commissarissen, meer transparantie en meer onafhankelijkheid van commissarissen. Eén van de kernpunten in de Nederlandse discussie is de vergroting van de invloed van de kapitaalverschaffers. Beschermingsconstructies, waarmee besturen van vennootschappen zich tegen - vriendelijke of vijandige - aandeelhouders wapenen, komen in een steeds donkerder daglicht te staan. De zelfregulerende werking van de aanbevelingen lijkt wel enig effect te sorteren, maar met name op dit laatste gebied acht de - Europese - wetgever zich genoodzaakt in te grijpen." Inmiddels ligt ook de structuurregeling onder vuur. ${ }^{12}$ Boven-

Zie o.a. Timmerman, "Is versoepeling van het Nederlandse n.v./b.v.-recht wenselijk?", TVVS 1992, blz 163-168, en "Het krakende gebouw van het vennootschapsrecht", TVVS 1995, blz. 178-181 en De Kluiver, "Het vennootschapsrecht dient te worden versoepeld... en verscherpt", TVVS 1994, blz 174-179 en "Mag het nog ietsje meer zijn?", NJB 1996, blz. 143-145. Zie bijvoorbeeld Van der Heijden, De ontwikkeling van de naamlooze vennootschap in Nederland vóor de codificatie, 1908, blz. 61 e.v. over de strijd tussen participanten en bewindhebbers over het afleggen van verantwoording. Cadbury Committee, Report of the Committee on the Financial Aspects of Corporate Governance, 1992. Gevolgd door het Greenbury Report en het Hampel Report. American Law Institute, Principles of Corporate Governance: Analysis and Recommendations, American Law Institute Publishers, 1994.

Zie ook OECD Principles of Corporate Governance, 1999, beschikbaar op www.oecd org, die naar verwachting in de loop van 2004 zullen worden herzien. Commissie Peters, Corporate Governance in Nederland - veertig aanbevelingen, rapport van 25 juni 1997, gevolgd door het rapport "Monitoring Corporate Governance" in 1999.

Gedoeld wordt op de overnamebodrichtlijn. Hierover is een rapport beschikbaar van de High level group of company law experts, januari 2002, op www.europa.eu.int/comm/internal_market en/company/company/modern/consult/report_en.pdf. In juli 2003 is nog geen zicht op het lot van 
dien is in 2003 de commissie Tabaksblat ingesteld, die op 1 juli 2003 een ontwerpcode heeft gepubliceerd. ${ }^{10}$

De corporate governance discussie spitst zich met name toe op grote, beursgenoteerde ondernemingen. Dat is niet zo vreemd. Beursgenoteerde vennootschappen voldoen het meest aan de 'modelkapitaalvennootschap', waarin sprake is van 'separation of ownership and control'. Middelgrote en kleinere ondernemingen, veelal in de vorm van een BV gedreven, kennen vaak een andere feitelijke zeggenschapsstructuur, doordat aandeelhouders als participanten nauw bij het bestuur zijn betrokken, of - in de meeste gevallen - tegelijkertijd bestuurders zijn. ${ }^{14}$

Dit onderscheid in de werkelijke structuur van de vennootschap wordt niet of nauwelijks weerspiegeld in Boek 2 BW. De besloten vennootschap is in 1971 in het Nederlandse vennootschapsrecht geïntroduceerd uit opportunistische overwegingen; men wilde een kapitaalvennootschap die niet aan Europese regelgeving was gebonden. Daarom zijn inhoudelijk weinig gedachten gewijd aan het creëren van specifieke regels voor ondernemingen in de vorm van een BV, uitgezonderd de blokkeringsregeling. ${ }^{15}$

Dit is anders in de ons omringende landen. In tegenstelling tot de 'open' kapitaalvennootschappen, die in de praktijk zijn ontstaan en geëvolueerd vooraleer een wettelijke regeling tot stand kwam, zijn de 'besloten' vennootschappen als de Gesellschaft mit beschränkter Haftung, de Société à responsabilité limité en de Besloten Vennootschap met Beperkte Aansprakelijkheid een creatie van de wetgever, als reactie op het 'oneigenlijk gebruik' ${ }^{16}$ van de kapitaalvennootschap door kleinere ondernemingen, voor welke de rechtsvorm oorspronkelijk niet was bedoeld." Deze rechtsstelsels laten de besloten vennootschap een flexibelere inrichting dan de 'open' kapitaalvennootschap.

Bovendien tonen buitenlandse wetgevers zich actief in het creëren van nieuwe soorten kapitaalvennootschappen en het hervormen van bestaande wetgeving. In de Verenigde Staten heeft de limited liability company een opmars door vrijwel alle staten gemaakt. De Franse wetgever heeft de

de overnamebod-richtlijn in zijn huidige vorm.

12 Zie wetsvoorstel Wijziging van boek $2 \mathrm{BW}$ in verband met aanpassing van de structuurregeling, TK 2001-2002, 28179 , nrs 1-2, dat klaar ligt voor behandeling door de Tweede Kamer.

13 Zie www.commissiecorporategovernance.nl/conceptcode. Een definitieve code wordt eind 2003 verwacht.

14 Vgl. Raaijmakers, " 'Besloten' vennootschappen: quasi-nv of quasi-vof?". AA 1994, blz. 340 e.v. Zie hierover Schwarz, Blokkering van aandelen, 1986, blz. 38 e.v.

De term is ontleend aan Zeylemaker, Verleden, heden en toekomst van de naamlooze vennootschap, 1947 , blz. 61 e.v.

17 De GmbH werd in 1892 geintroduceerd, waarop deze navolging kreeg in andere continentaalEuropese landen. 
Société par Actions Simplifiée geïntroduceerd, die als kenmerk heeft dat de aandeelhouders geheel vrij zijn in de inrichting van de vennootschap. ${ }^{18}$ In Duitsland is sinds 1994 een wet van kracht, die de Aktiengesellschaft ook voor kleinere ondernemingen geschikt beoogt te maken." De limited liability partnership is een Engelse uitvinding. ${ }^{20}$ In Engeland wordt een algehele revisie van de Companies Act 1985 voorgesteld, met als uitgangspunt "think small first". ${ }^{21}$ Ook in andere lidstaten wordt, mede in het licht van de jurisprudentie van het Hof van Justitie inzake Centros en Uberseering met nieuwe wetsgevingsinitiatieven de concurrentie tussen rechtspersonen verder aangewakkerd. ${ }^{p}$

De Europese regelgeving is voornamelijk gericht op de naamloze vennootschappen, maar recentelijk zijn initiatieven ontplooid om ook tot een Europese besloten vennootschap te komen. ${ }^{24}$ De Europese Vennoot-

Is Wet van 3 januari 1994. Zie hierover bijvoorbeeld Guyon, "Die Société par Actions Simplifiée (SAS) - eine neue Gesellschaftsform in Frankreich -", ZGR 1994, blz. 551 e.v. en recentelijk Kiersch, Grensoverschrijdende samenwerking en de noodzaak van een eenvoudig bv recht, in: Nederlands ondernemingsrecht in grensoverschrijdend perspectief, uitgave vanwege het Instituut voor Ondernemingsrecht deel 40,2003 , blz. 141 e.v.

19 Gesetz fur kleine Aktiengesellschaften und zur Deregulierung des Aktienrechts van 2 augustus 1994, Bundesgesetzblatt I nr. 52, 9 augustus 1994, blz. 1961 e.v.

20 Limited Liability Partnership Act 2000. Zie hierover o.a. Griffiths, "Professional Firms and Limited Liability: an Analysis of the Proposed Limited Liability Partnership", Company Financial and Insolvency Law Review 1998, blz, 157 e.v.

21. Het Department voor Trade and Industry heeft een werkgroep ingesteld ter hervorming van het vennootschapsrecht onder de titel Modern Company Law for a Competitive Economy. De rapporten zijn beschikbaar op www.dti.gov.uk/cld/review.htm. Zie hierover onder meer Rickford, "Forthcoming Change in Corporate Law in the UK - the British Company Law Review and Beyond", Ondernemingsrecht 2002, blz. 325 e.v.

22 HvJEG zaak C-212/97, 9 maart 1999, NJ 2000, 48 (Centros) en HvJEG zaak C-208/00, 5 november 2002 (Überseering), NJ 2003, 58.

25 Vgl. o.m. de Spaanse Ley $7 / 2003$ aangaande de Sociedad Limitada Nueva Empresa, in werking getreden op 1 april 2003, zie www.circe.es, de hervorming van het Italiaanse vennootschapsrecht die op 1 januari 2004 in werking treedt, www.governo.it/GovernoInforma/Dossier/DIRITTO SOCIETARIO/INDEX.HTML, het Franse Projet de Loi sur l'initiative économique (Projet Dutreil), in juli 2003 voor tweede lezing naar de Sénat, zie www.pme-commerce-artisanat.gouv. fr en de lerse Companies Bill, die in de tweede helft van 2003 naar het parlement wordt gestuurd, www.entemp.ie/cr/consolidation.htm.

24 Vgl. La Société Privée Européenne: une société de partenaires, Chambre de Commerce et d'industrie de Paris/Conseil National du Patronat Français, 1998. Zie ook reeds De Kluiver/Van Gerven (red.), The European Private Company?, 1995 en Boucourechliev (red.), Propositions pour une société fermée européenne, CREDA 1997. Zie ook de opinie van het Europees Economisch en Sociaal Comité omtrent een Europees Vennootschapsstatuut voor het midden- en kleinbedrijf, maart 2002, www.esc.eu.int/pages/avis/03_02/en/CES363-2002_AC_de.DOC. In het Actieplan van de Europese Commissie van 21 mei 2003 ("Modernising Company Law and Enhancing Corporate Governance in the European Union - A Plan to Move Forward") wordt gewag gemaakt van een haalbaarheidsstudie voor de Europese besloten vennootschap op korte termijn, zie www.europa.eu.int/comm/internal_market/en/company/company/modern/index. 
schap is in 2001 tot stand gebracht en dient vóór 8 oktober 2004 in het Nederlandse recht te zijn geïmplementeerd. ${ }^{2 s}$

Terwijl de Nederlandse overheid al sinds de jaren tachtig 'deregulering' als credo hanteert, leek die trend in de jaren negentig aan het vennootschapsrecht voorbij te gaan. Pas in het jaar 2000 wordt actie ondernomen met de afschaffing van het preventief technisch-juridisch toezicht. ${ }^{26}$ Hoewel inmiddels met enige voortvarendheid nieuwe regelgeving voor beursgenoteerde vennootschappen wordt geëntameerd, laat de hervorming van het BV-recht vooralsnog op zich wachten. ${ }^{27}$ Dit boek hoopt hiervoor een aanzet te geven, en een eventuele hervorming van onderbouwing te voorzien door aansluiting te zoeken bij het Engelse en Duitse recht.

\section{$\S 1.2$ Probleemstelling}

Bovenstaande ontwikkelingen - over de rechtvaardiging van dwingend recht, de machtsverhoudingen binnen de kapitaalvennootschap en de bijzondere aard van de besloten vennootschap - vormen in het kort de aanleiding tot schrijven van dit boek. Een combinatie van deze ontwikkelingen leidt naar de aandeelhouder als centraal onderzoeksobject.

In een besloten vennootschap zijn de aandeelhouders veelal de voornaamste actoren. $\mathrm{Zij}$ geven de vennootschappelijke verhoudingen gestalte in de statuten. Zij nemen de besluiten in de algemene vergadering die van invloed zijn op de vennootschappelijke ontwikkeling, en bovenal maken zij vaak zelf deel uit van het bestuur of houden intensief toezicht op het bestuur. De aandeelhouder in een besloten vennootschap is geen anonieme kapitaalverschaffer, maar persoonlijk betrokken bij de gang van zaken in de vennootschap en de met haar verbonden onderneming. ${ }^{28}$ Dat betekent dat hij - op een andere manier dan een belegger - invloed kan uitoefenen op de vennootschappelijke verhoudingen. Daar staat tegenover

25 Verordening 2001/2157/EC van 8 oktober 2001 over het Statuut voor een Europese vennootschap (SE), Pb. 2001, L 294/1. Zie hierover Kiersch/Ter Huurne, "Het statuut van de Europese vennootschap", Ondernemingsrecht 2001 , blz 183 e.v. Zie over mogelijke implementatieproblemen Huizinga/Meinema, in: The European Company - All over Europe, Teichmann/Oplustil (red.), 2003.

26 Wet van 22 juni 2000 , Staatsblad 2000, 283 .

27 In de literatuur lijkt men ongeduldig te worden, vgl. De Groot, "Waarom krijgen wij geen LLC?" Ondernemingsrecht 2001 , blz. 254 e.v. Van Schilfgaarde, "De ontwikkeling van de rechtspersoon in het privaatrecht", NJB 2000, blz 1097, pleit voor een "totale herorientatie". Zie ook Raaijmakers, "Herziening van het Nederlandse ondernemingsrecht", WPNR 2002, blz. 683 e.v. Van Duuren pleit in zijn proefschrift uit 2002 voor een nieuwe rechtsvorm "De joint venturevennootschap: een persoonsgebonden kapitaalvennootschap".

$\mathrm{Vgl}$. Raaijmakers, die het begrip 'quasi-vof' voor dergelijke vennootschappen hanteert. 
dat zijn aandelen minder goed overdraagbaar zijn, hetgeen het ontstaan van conflictueuze patstellingen in de hand werkt. ${ }^{29}$

De meeste conflicten spruiten voort uit het feit dat een minderheidsaandeelhouder het niet eens is met de meerderheid van de aandeelhouders. In de sfeer van de onderlinge machtsverhoudingen is dit het meest ingrijpend als de samenwerking niet kan worden voortgezet. Dit kan zich uiten door het ontslag van de minderheidsaandeelhouder als bestuurder of door een gedwongen uittreding of uitstoting. Door wijziging van de statuten kan de positie van een minderheidsaandeelhouder eveneens verslechteren. Omgekeerd kan een minderheidsaandeelhouder door zijn gedrag de besluitvorming in de vennootschap blokkeren.

Aandeelhouders hebben rechten en verplichtingen jegens de vennootschap en elkaar. Daarnaast hebben de gezamenlijke aandeelhouders in de algemene vergadering bepaalde bevoegdheden. Door de uitoefening van rechten en bevoegdheden vormen de aandeelhouders een machtsfactor, zowel collectief als individueel, binnen de vennootschap. Waar weinig aandeelhouders zijn, kan de besluitvorming op meer informele wijze plaatsvinden, terwijl bovendien onderlinge overeenkomsten een grotere rol kunnen spelen..$^{30}$

Het contrast tussen de juridische gelijkenis van de NV en de BV enerzijds en de verscheidenheid aan ondernemingen in werkelijkheid anderzijds zou een andere kijk op de noodzaak van dwingend vennootschapsrecht voor de besloten vennootschap kunnen rechtvaardigen. Voor Raaijmakers is het onderscheidend criterium de al dan niet afhankelijkheid van de persoon van de leden. Los van de juridische kwalificatie, differentieert hij tussen persoonsgebonden (societas) en niet-persoonsgebonden (universitas) associaties. Als voorbeelden van de eerste categorie noemt hij de dochter-BV, de joint-venture-BV en de 'quasi-vof-BV'. Hij constateert een spanning tussen de dwingendrechtelijke regels van boek $2 \mathrm{BW}$ en de werkelijkheid van het recht. ${ }^{31}$ De veronderstelling is dan dat minderheidsaandeelhouders enerzijds meer bescherming behoeven, anderzijds dat zij door hun kleine aantal beter in staat zijn zelf te bepalen hoe zij de vennootschap willen inrichten en daar in de dagelijkse praktijk vorm aan geven.

29 Miller, "Minority Shareholder Oppression in the Private Company in the European Community: A Comparative Analysis of the German, United Kingdom, and French "Close Corporation Problem", Cornell International Law Journal 1997, blz. 385.

Vgl. O'Neill, "Toward a new theory of the closely-held firm", Seton Hall Law Review 1993, blz. 605.

3 Pitlo-Raaijmakers, Vennootschaps- en rechtspersonenrecht, $4^{c}$ druk, 2000, nr. 1.58. 
Tegelijkertijd meer en minder dwingend recht, oftewel versoepeling en verscherping van het vennootschapsrecht. ${ }^{32}$

Bovenstaande overwegingen leiden tot de volgende probleemstelling:

In hoeverre mogen aandeelhouders afwijken van dwingend vennootschapsrecht, dan wel dwingend vennootschapsrecht aanvullen?

Dit is tevens een vraag naar de reikwijdte van dwingend vennootschapsrecht. Daarbij wordt uitgegaan van de mogelijkheden die de bestaande wetgeving mijns inziens biedt. De daaropvolgende vraag of deze mogelijkheden moeten worden verruimd of beperkt valt buiten het bestek van dit boek.

De aandacht is gericht op de aandeelhouder, hetgeen inhoudt dat slechts die rechten en bevoegdheden aan de orde komen, waarover de aandeelhouders alleen of gezamenlijk beschikken. Het onderzoek beperkt zich derhalve tot de interne vennootschappelijke verhoudingen. Werknemers en crediteuren spelen slechts een passieve rol. Als rolmodel wordt de enkelvoudige vennootschap genomen, die niet voldoet aan de wettelijke vereisten voor het structuurregime. Er zijn geen certificaten uitgegeven.

\section{$\S 1.3$ Rechtsvergelijking}

Bovenstaande vragen worden in rechtsvergelijkend perspectief aan de orde gesteld. Daartoe wordt het op de besloten vennootschap toepasselijke recht vergeleken met het recht van toepassing op de Duitse Gesellschaft mit beschränkter Haftung en de Engelse private limited company. Beide rechtsstelsels zijn inspiratiebronnen voor het (Europese) vennootschapsrecht en in sommige opzichten elkaars tegenpolen." Het Duitse recht vormt als exponent van het 'Rijnlandse model' de basis van veel Europese richtlijnen, terwijl Engeland door de prominente rol van de London Stock Exchange en de prioriteit die het Engelse recht geeft aan de belangen van de kapitaalverschaffers in de jaren negentig van de vorige eeuw tot 'gidsland' is geworden. Bovendien is het Verenigd Koninkrijk bezig op integrale wijze het vennootschapsrecht te hervormen. ${ }^{34}$ Een andere tegenstelling is dat het Engelse systeem één soort vennootschap kent, de private

Zie De Kluiver, TVVS 1994, blz. 174-179.

Het Verenigd Koninkrijk kent twee verschillende rechtsstelsels: het recht van Engeland en Wales en het recht van Schotland. In het vervolg wordt uitsluitend ingegaan op het Engelse recht (inclusief dat van Wales), waarbij Engeland als pars pro toto (Engeland en Wales) geldt.

Zie infra. 
limited company, waarvan de public limited company een species is, terwijl in het Duitse recht de Aktiengesellschaft en de Gesellschaft mit beschränkter Haftung twee duidelijk onderscheiden vennootschappen zijn met elk hun eigen recht.

De Duitse tegenhangers van de NV en de BV zijn de Aktiengesellschaft (AG) en de Gesellschaft mit beschränkter Haftung $(\mathrm{GmbH})$. In tegenstelling tot de $\mathrm{AG}$ en de personenvennootschappen, die in de praktijk zijn ontstaan, is de $\mathrm{GmbH}$ een uitvinding van de wetgever. Terwijl het Aktienrecht kan worden gekarakteriseerd als de Geschichte der Reformgesetze, waarbij de wetgever het voortouw in de ontwikkeling nam, wordt met betrekking tot het $\mathrm{GmbH}-$ recht gesproken van de Geschichte der Rechtsfortbildung.s5 De GmbH-Gesetz (GmbHG) stamt uit 1892 en is sindsdien vrijwel ongewijzigd gebleven. Jurisprudentie en doctrine vullen begrippen nader in, nu eens aan de hand van het Aktienrecht, dan weer met name wat betreft de interne verhoudingen - aan de hand van het personenvennootschapsrecht. ${ }^{36}$ Ook het verenigingsrecht heeft uitstralende invloed op de $\mathrm{GmbH}$.

In tegenstelling tot de continentale rechtsstelsels, kent het Engelse vennootschapsrecht één rechtsvorm met beperkte aansprakelijkheid: de limited company. Weliswaar wordt ook in Engeland een onderscheid gemaakt tussen een 'private limited company' (Itd) en een 'public limited company' (plc), maar dit onderscheid wordt bewerkstelligd door de plc als species van de ltd te definiëren.

De eerste Companies Acts van 1856 en 1862 waren afgekondigd om grotere ondernemingen van een rechtsvorm met beperkte aansprakelijkheid te voorzien, die hen in staat stelde kapitaal aan te trekken van het beleggend publiek. Daartoe was het minimum vereiste aantal aandeelhouders van de company aanvankelijk vijfentwintig, later zeven. Het was oorspronkelijk niet de bedoeling dat de company als rechtsvorm gebruikt zou worden door eenmansondernemingen of kleine partnerships. ${ }^{37}$ Dit gebeurde in de daaropvolgende decennia echter wel, zodat de company doordrong in alle sectoren van de economie. ${ }^{38}$ De eerste test naar de rechtmatigheid van het gebruik van de limited company door een de facto eenmansbedrijf deed zich voor in de zaak Salomon $v$ Salomon and Co Ltd. ${ }^{3 \prime}$

\footnotetext{
K. Schmidt, blz. 819.

Kabler, blz. 216.

Ireland, The triumph of the company legal form, 1856-1914 in: Essays for Clive Schmitthoff, Adams (red.), 1983, blz. 38.

Ireland, Essays for Clive Schmitthoff, 1983, blz. 40.

Salomon v Salomon and Co. Ltd. [1897] AC 22.
} 
In 1892 zette Aron Salomon zijn schoen- en laarzenmakerij om in een private limited company. Zijn vrouw, dochter en vier zonen kregen ieder één aandeel, terwijl de overige 39993 aan hemzelf toebehoorden. Een jaar na de oprichting gingen de zaken slechter, zodat de company geld moest lenen van een zekere Broderip. De lening mocht niet baten en de company ging failliet. In drie instanties werd de vraag opgeworpen of de limited company als rechtsvorm was bedoeld voor dergelijke eenmanszaken. De House of Lords sanctioneerde het gebruik van de limited company door een letterlijke interpretatie te geven van de Companies Act van $1862 .{ }^{40}$ In de woorden van Lord Macnaghten:

"In order to form a company limited by shares, the Act requires that a memorandum of association should be signed by seven persons, who are each to take one share at least. If those conditions are complied with, what can it matter whether the signatories are relations or strangers? There is nothing in the Act requiring that the subscribers to the memorandum should be independent or unconnected, or that they or any one of them should take a substantial interest in the undertaking, or that they should have a mind or a will of their own, as one of the learned Lords Justices seems to think, or that there should be anything like a balance of power in the constitution of a company."'st

Zodoende kon de limited company haar opmars onder de kleinere ondernemingen voortzetten. In 1907 werd de 'private company' in de Companies Act geïntroduceerd, aan de hand van drie kenmerken: 1) beperkte overdraagbaarheid van de aandelen; 2) minder dan 50 aandeelhouders en 3) geen publiek beroep op het spaarwezen. ${ }^{42}$ In de huidige Companies Act 1985 is het juist de public company die wordt gedefinieerd. ${ }^{33}$ Enerzijds kent de Companies Act 1985 verdergaande verplichtingen voor de public company, bijvoorbeeld een minimumkapitaal, ${ }^{4}$ anderzijds kunnen private companies bepaalde regelingen terzijde stellen door middel van een elective resolution. ${ }^{45}$ Zo hoeft een private company niet elk jaar een auditor te benoemen, de jaarrekening aan de algemene vergadering voor te leggen, of jaarlijks een algemene vergadering te houden. ${ }^{46}$

In maart 2000 is een Consultation Report van het Department of Trade and Industry verschenen, waarin het gehele vennootschapsrecht wordt gemoderniseerd. Het rapport gaat uit van het "think small first" beginsel, hetgeen inhoudt dat de wetgeving standaard voor de private companies geschikt zou

Sealy, Company Law and Commercial Reality, 1984, blz. 47. Ireland, Essays for Clive Schmitthoff, 1983, blz. 56.

Salomon $v$ Salomon and Co. Ltd. [1897] AC 22.

Ireland, Essays for Clive Schmitthoff, 1983, blz. 43.

Section 1(3) CA 1985.

Section 117/118 CA 1985.

Section 379A CA 1985.

Ss. 386, 252, 366A CA 1985. 
moeten zijn, en, waar nodig, zou moeten afwijken voor public companies. ${ }^{47}$ Dit is inmiddels uitgewerkt in een White Paper. ${ }^{\text {ts }}$

Het Engelse vennootschapsrecht kent een lage drempel om een limited company op te richten. Er is geen minimumkapitaalvereiste en de vennootschap kan 'off-the-shelf' worden gekocht bij een solicitor. Anders dan in Nederland en Duitsland is een vennootschap niet verplicht om articles te laten registreren. $\mathrm{Bij}$ afwezigheid van articles zijn namelijk de bepalingen uit Table $A$ van toepassing. Dit zijn standaard articles, die als annex tot de Companies Act behoren. De bepalingen uit Table A gelden, voor zover de articles de toepassing van Table $A$ niet uitsluiten of wijzigen, section 8(2) CA 1985. Dit alles heeft enerzijds tot gevolg dat het ondernemerschap wordt gestimuleerd, anderzijds dat de kans op misbruik of misstanden door de verminderde zorgvuldigheid wordt vergroot. Dit vereist andere beschermingsmechanismen dan wanneer een rechtsstelsel kiest voor beschermingsmethodes vooraf.49 Zo wordt in Duitsland preventief toezicht uitgeoefend door de notaris bij bekrachtiging van de Gesellschaftsvertrag en door de Registerrichter bij de inschrijving in het handelsregister. Bovendien wordt een minimumkapitaalseis voor de $\mathrm{GmbH}$ gehanteerd van 25.000 euro.

De vergeleken stelsels worden als referentiekader voor het Nederlandse vennootschapsrecht gebruikt. Door de tegenstellingen tussen het Duitse en het Engelse recht, is het juist daar waar beide stelsels overeenkomsten vertonen interessant na te gaan in hoeverre het Nederlandse recht hierbij kan aansluiten.

\section{$\S 1.4$ Uitwerking: dwingend vennootschapsrecht}

In Nederland is het vennootschapsrecht te vinden in boek 2 van het Burgerlijk Wetboek (hierna: BW). Daarnaast krijgt het gestalte in de statuten en reglementen van vennootschappen en door middel van besluiten van vennootschapsorganen. Dit is echter geen volledige opsomming; een groot deel van het recht dat de vennootschap beheerst wordt gevormd door overeenkomsten - tussen oprichters, aandeelhouders, bestuurders, de vennootschap en/of derden - die evenzeer hun invloed op de vennootschap hebben, maar waarvan grotendeels ongewis is in hoeverre zij het vennoot-

47 DTI Consultation Report, Modern Company Law for a Competitive Environment - Developing the Framework, 2000. Zie over de hervorming van het vennootschapsrecht Ferran, Company Law and Corporate Finance, 1999, blz. 639 e.v.

$4 \times$ White Paper "Modernising company law", juli 2002, www.dti.gov,uk/companiesbill/whitepaper. htm.

49 Vgl. ook Cheffins, Trust, Loyalty and Cooperation in the Business Community: Is Regulation Required?, in: The Realm of Corporate Law, 1998, blz. 53 e.v. 
schapsrecht beïnvloeden. Aandeelhoudersovereenkomsten worden in boek 2 BW namelijk nauwelijks vermeld. . $^{\text {so }}$

Artikel 25 van boek 2 BW verwoordt het dwingendrechtelijke uitgangspunt van het Nederlandse vennootschapsrecht: van de beperkingen van dit boek kan slechts worden afgeweken, voor zover dat uit de wet blijkt. Er zijn ook andere bepalingen die het dwingendrechtelijk karakter van het vennootschapsrecht onderstrepen. Zo voorziet artikel 2:14 lid $1 \mathrm{BW}$ in de nietigheid van een besluit dat naar inhoud of strekking in strijd is met de wet of de statuten. Bovendien kan een vennootschap waarvan de statuten niet zijn ingericht in overeenstemming met de eisen der wet worden ontbonden op grond van artikel 2:21 BW. De ratio van het dwingendrechtelijk uitgangspunt hangt volgens Van Schilfgaarde samen met het bijzondere karakter van de vennootschap als rechtspersoon; de vennootschap als 'deelrechtsorde' is aan voortdurende verandering onderhevig, die niet aan de willekeur van toevallige machthebbers kan worden overgelaten, terwijl de vennootschap als operationele eenheid deelneemt aan het economisch verkeer, hetgeen vaste regels vereist in het belang van degene die met de vennootschap in contact treedt. ${ }^{\text {s1 }}$

Het vennootschapsrecht bestaat niet alleen uit dwingende regels. In het Anglo-Amerikaanse recht wordt een onderscheid gemaakt tussen mandatory, suppletory/default en permissive rules (resp. dwingend, aanvullend recht en 'optioneel' recht). ${ }^{32}$ 'Optionele' regels treden slechts in werking zodra partijen daarvoor kiezen (opt-in). In de wet staat bijvoorbeeld "de statuten kunnen bepalen". Voor aanvullende regels geldt juist het omgekeerde; deze zijn van toepassing zolang partijen de werking ervan niet uitsluiten (opt-out). Zij fungeren als aanvulling op hetgeen partijen expliciet zijn overeengekomen. De wet kan in een dergelijk geval luiden "tenzij de statuten anders bepalen". In Nederland wordt het verschil tussen 'optioneel' en aanvullend recht overigens niet altijd even sterk gevoeld."

In het wetsvoorstel 26277 werd artikel 2:195b BW als aanvullende regel geformuleerd: tenzij de statuten anders bepalen kan de aandeelhouder die niet of niet langer aan in de statuten gestelde eisen voldoet, het stemrecht niet uitoefenen,

Artt. 2:24a (stemovereenkomst), 2:153/263 lid 3 sub d, 2:155/265 lid 1 sub b (onderlinge regeling tot samenwerking) en art. 2:337 (alternatieve geschillenregeling). in de eerste twee gevallen gaat het niet zozeer om de overeenkomst, maar om de gevolgen die de overeenkomst heeft voor de juridische kwalificatie van de verhouding tussen twee of meer rechtspersonen. Van Schilfgaarde, Van de BV en de NV, $12^{\circ}$ druk, Deventer 2001, nr. 9.

Vgl. Cheffins, Company law; theory, structure and operation, 1997, hoofdstuk 3. Zie ook Eisenberg, "The Structure of Corporation Law", Columbia Law Review 1989, blz. 1461.

5. In tegenstelling tot het Engelse recht, dwingt het Nederlandse recht aandeelhouders om statuten op te stellen en derhalve steeds keuzes te maken. 
is hij niet gerechtigd tot deelname aan de algemene vergadering en verliest hij zijn recht op winstuitkering. Het voorstel werd aangepast als 'optionele' regel. Nu heet het dat "de statuten kunnen bepalen". De wijziging werd gemotiveerd met een beroep op de congruentie met artikel 2:195a BW.4

In het vervolg zal daarom met name worden uitgegaan van het onderscheid tussen dwingend en aanvullend recht. Als ratio van aanvullend recht kan worden aangemerkt dat verwachtingen van aandeelhouders in de loop der tijd steeds minder in de statuten gereflecteerd zijn, zodat de wet aanvullende voorzieningen heeft die partijen zouden hebben gewenst. ${ }^{35}$ Op basis van deze gedachten beschrijft Freedman het vennootschapsrecht als het resultaat van verworven kennis en ervaring, waar met name aandeelhouders in besloten vennootschappen hun voordeel mee kunnen doen. Freedman ziet ook een 'opvoedende' functie van wetgeving, omdat de aandeelhouders gedwongen zouden worden een aantal opties te overwegen. ${ }^{56}$

Het onderscheid tussen de verschillende soorten regels is niet absoluut. De kapitaalvennootschap als zodanig dankt haar bestaan aan een positieve actie, nl. de oprichting. Wanneer een vennootschap eenmaal is opgericht, wordt zij in Nederland in beginsel geregeerd door dwingend recht." ${ }^{57} \mathrm{De}$ functie van vennootschapswetgeving kan dan ook als tweeledig worden beschouwd: enerzijds stelt de wetgeving personen in staat te doen wat ze anders niet zouden kunnen doen; anderzijds verbindt deze voorwaarden aan de oprichting, het functioneren en de beëindiging van een vennootschap ter bescherming van aandeelhouders, crediteuren en het publiek. ${ }^{58}$ De vraag is hoe deze functies zich ten opzichte van elkaar verhouden. Wordt uitgegaan van de keuzevrijheid van individuen tot oprichting en inrichting van een kapitaalvennootschap, of begint het vennootschapsrecht pas na deze keuze, met de vennootschap als doelgebonden entiteit? $?^{\text {s9 }}$

In de nota naar aanleiding van het verslag van de wet herziening preventief toezicht schrijft de minister: "Besluitvorming over de inrichting van de statuten is bij uitstek een zaak van de ondernemer. De overheid dient zich in dergelijke

Vgl. Nota naar aanleiding van het verslag, TK 1999-2000, 26 277, nr. 5, blz. 8.

Cheffins, 1997, blz 467.

Freedman, "Small Businesses and the Corporate Form: Burden or Privilege?", Modern Law Review 1994, blz. 566, 576. Zie over de rol van wetgeving ook Copp, "Company law and alternative dispute resolution: an economic analysis", Company Lawyer 2002, blz. 361 e.v.

Vgl. voor het Duitse Aktienrecht Hopt, Gestaltungsfreiheit im Gesellschaftsrecht in Europa Generalbericht, ZGR Sonderheft 1998, blz. 124 (System der Normativbestimmungen).

Davies, Gower's Principles of Modern Company Law, 6 druk, 1997, blz. 7.

Pitlo-Raaijmakers, nr. 1.62, stelt nadrukkelijk de vrijheid van ondernemen en associatie centraal. $\mathrm{Vgl}$. ook Van Schilfgaarde, Vrijheid van vennootschap, in: Vrijheid en recht, opstellen aangeboden aan prof. mr. E.H. 's Jacob, 1975, blz. 247 e.v. 
aangelegenheden terughoudend op te stellen. Inmenging moet worden beperkt tot die gevallen waarbij de belangen van andere betrokkenen uitsluitend door actief interveniëren van de overheid kunnen worden gewaarborgd."

In hoofdstuk 2 worden de verschillende wettelijke systemen en hun uitgangspunten uiteengezet, waarbij de nadruk ligt op de verhouding tussen de wet en de statuten, alsmede op de rechterlijke interpretatie van de wet. De vraag is in hoeverre het verschil in wettelijk uitgangspunt van invloed is op de reikwijdte, het aantal en de identificatie van dwingende regels.

Niet alleen de mate van dwingend recht varieert, maar ook de kracht ervan. Verschillende gradaties van dwingend recht kunnen worden geïdentificeerd. Bekend uit het arbeidsrecht zijn de noties 'semi-dwingend' recht, waarvan slechts ten gunste van de werknemer mag worden afgeweken, en 'driekwart-dwingend' recht, waarvan afwijking slechts bij collectieve arbeidsovereenkomst is toegestaan. Daarnaast wordt binnen het privaatrecht een onderscheid gemaakt tussen 'gewoon' dwingend recht en 'super'dwingend recht, dat de openbare orde en de goede zeden omvat. ${ }^{61}$ De kracht van dwingend vennootschapsrecht kan worden vastgesteld door deze te toetsen aan de vrijheid die aandeelhouders hebben bij het vormgeven van de vennootschappelijke verhoudingen, in en buiten de statuten. In hoofdstuk 3 wordt de notie van dwingend vennootschapsrecht getoetst aan de vraag in hoeverre aandeelhouders vrij zijn in de uitoefening van hun rechten, met name de vraag of zij van deze rechten afstand mogen doen. Een andere vraag die in dit verband aan de orde komt is in hoeverre aandeelhouders afstand kunnen doen van hun recht de boordeling van geschillen aan de overheidsrechter te onderwerpen, met andere woorden: of de rechten en bevoegdheden van aandeelhouders in het kader van vennootschappelijke geschillen voor arbitrage vatbaar zijn.

Allereerst gaat het om de afbakening van dwingend recht ten opzichte van de statuten. Wanneer de statuten verschillen van de wet, is er dan sprake van een - ontoelaatbare - afwijking van dwingend recht of mogen de statuten de wet 'aanvullen', indien de wet niet uitputtend is bedoeld? Hoofdstuk 4 biedt een nadere beschouwing over de aard en werking van statuten, teneinde inzichtelijk te maken waarom een onderscheid bestaat tussen statutaire en contractuele afwijking van dwingende wettelijke bepalingen. In hoofdstuk 5 wordt vervolgens onderzocht, op welke wijze

Nota naar aanleiding van het verslag, TK 1999-2000, $26277, \mathrm{nr} .5$, blz 2.

Snijders, Maten van dwingend recht, in: Contractvrijheid, Hartlief/Stolker (red.), 1999, blz 153 e.v. 
aandeelhouders worden beschermd door aanvullende statutaire bepalingen, dan wel tegen aanvullende statutaire bepalingen.

De vraag is voorts in hoeverre aandeelhouders bij besluit in de algemene vergadering af mogen wijken van de wet en/of de statuten. Deze reikwijdte wordt in eerste instantie bepaald door artt. 2:14 en $15 \mathrm{BW}$, die als sanctie nietigheid resp. vernietigbaarheid stellen. Dit komt aan de orde in hoofdstuk 6. Onderzocht wordt welke middelen de verschillende rechtsstelsels te bieden hebben om zoveel mogelijk de geldigheid van afwijkende besluiten te bewerkstelligen.

Vervolgens is de vraag hoe dwingend vennootschapsrecht zich verhoudt tot aandeelhoudersovereenkomsten. Terwijl het vennootschapsrecht in beginsel als dwingend wordt beschouwd, staat in het verbintenissenrecht de contractsvrijheid voorop. Iemand is vrij om een overeenkomst te sluiten, met wie dan ook, over wat dan ook. Keerzijde van die vrijheid is de gebondenheid die daarop volgt (pacta sunt servanda). ${ }^{62}$ Dat maakt de overeenkomst zowel een uitoefening van vrijheid als een inperking ervan. De contractsvrijheid wordt begrensd door dwingend recht, zoals blijkt uit artikel 3:40 BW, terwijl de redelijkheid en billijkheid als norm wordt gesteld (zie artt. 6:2 en 248 BW).

Indien bij overeenkomst wordt toegestaan wat in statuten is verboden, maakt dat het vennootschapsrecht minder dwingend dan wanneer de vennootschapsrechtelijke normen grenzen stellen aan de overeenkomst. Waar het dan om gaat is of het vennootschapsrecht en het verbintenissenrecht los van elkaar moet worden beschouwd, in de zin dat overeenkomsten zijn onderworpen aan de regels van het verbintenissenrecht en statuten aan de vennootschapsrechtelijke voorschriften, of dat overeenkomsten, gesloten in een vennootschappelijke context, ook naar vennootschapsrechtelijke maatstaven moeten worden beoordeeld. De wisselwerking tussen vennootschapsrecht en verbintenissenrecht kan zich ook manifesteren in omgekeerde richting. Dan is de vraag in hoeverre overeenkomsten een normerende werking hebben op statuten en besluiten. Hoofdstuk 7 omvat hiertoe een analyse van de toelaatbaarheid en inzetbaarheid van aandeelhoudersovereenkomsten.

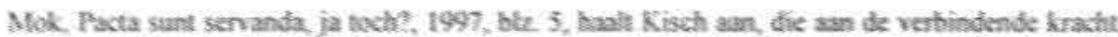

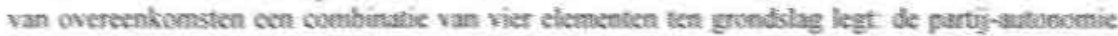

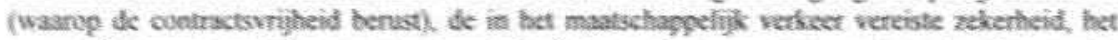

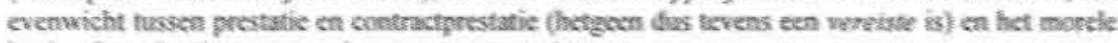
heginsel van het instan veer het gegeven woord" 


\section{$\S 1.5$ Uitwerking: keuze uitgangspunten}

Bij de zoektocht naar antwoorden op bovenstaande vragen hanteer ik als uitgangspunt de keuzevrijheid van aandeelhouders. Aandeelhouders zijn vrij om hun onderlinge verhouding en hun verhouding tot de vennootschap vorm te geven. Dwingend vennootschapsrecht stelt grenzen aan die vrijheid. Het zijn de grenzen aan de vrijheid die rechtvaardiging behoeven. De reikwijdte van dwingend vennootschapsrecht dient mijns inziens te worden bepaald door de onderliggende doelstellingen. ${ }^{63}$

Dwingend privaatrecht kan als oogmerk hebben dat de 'zwakkere' partij wordt beschermd. De ongelijkheid tussen partijen wordt verondersteld, zoals in het consumentenrecht, het arbeidsrecht of het huurrecht. ${ }^{64}$ Cheffins acht dwingend recht geboden indien individuen hun eigen belangen niet voldoende kunnen behartigen. ${ }^{.5}$ Dwingend recht kan eveneens dienen om te voorkomen dat negatieve gevolgen worden afgewenteld op derden. ${ }^{6}$ Dit is bijvoorbeeld één van de achterliggende gedachten van het mededingingsrecht. Andere doelstellingen van dwingend recht hebben een meer regulerend karakter, zoals het bevorderen van deeltijdwerken of de participatie van werknemers. ${ }^{67}$ Dwingende medezeggenschapsregels voor werknemers zouden kunnen worden opgevat als het tegengaan van het afwentelen van negatieve gevolgen op derden, maar deze doelstellingen worden vooral geacht in het algemeen belang te zijn. Onder het algemeen belang kan tevens het handhaven van de rechtszekerheid worden geschaard. Cheffins schetst andere waarden die op grond van het algemeen belang bescherming verdienen, zoals vertrouwen, loyaliteit en samenwerking. ${ }^{6.8} \mathrm{Hij}$ beantwoordt de vraag of deze waarden door middel van regulering zouden

6. Vgl. Ronse, Vennootschaps- en verbintenissenrecht, in: Op grenzen van komend recht, opstellen aangeboden aan prof. mr. Beekhuis, 1969, blz. 214: "De vennootschap wortelt in het verbintenissenrecht. $\mathrm{Zij}$ ontstaat uit overeenkomst en de rechtsbetrekkingen tussen de rechtspersoon en zijn leden en tussen de rechtspersoon en zijn beheerders (bestuurders) zijn van contractuele aard en worden rechtstreeks door de regelen van het algemeen contractenrecht beheerst voor zover die niet terzijdegesteld worden door het bijzonder recht van het vennootschaps- en rechtspersonenrecht."

De bescherming van de zwakkere partij is zozeer een kenmerk van het verbintenissenrecht geworden, dat betoogd wordt dat de contractsvrijheid en de bescherming van de zwakkere partij op gelijke voet staan als paradigmata van het contractenrecht, zie Hondius, De zwakke partij in het contractenrecht; over de verandering van paradigmata van het privaatrecht, in: Contractvrijheid, Hartlief \& Stolker (red.), 1999, blz. 387 e.v.

Cheffins, 1997, blz. 237.

Vgl. Cheffins, 1997, blz 244.

Cheffins, 1997, blz. 247. Zie over functies dwingend recht ook Gordon, "The mandatory structure of corporate law", Columbia Law Review 1989, blz. 1551.

68 Zie Cheffins, Trust, Loyalty and Cooperation in the Business Community: Is Regulation Required?, 1998, blz. 53 e.v. 
moeten worden afgedwongen, uiteindelijk negatief, omdat enerzijds andere factoren als flexibiliteit, creativiteit en innoverende capaciteit wellicht belangrijkere bijdragen aan het economische succes leveren dan de eerste, anderzijds omdat regulering andere nadelen met zich meebrengt die uiteindelijk contraproductief kunnen werken. ${ }^{\circ}$

In het vennootschapsrecht zijn deze verschillende doelstellingen te herkennen.Verschillende doeleinden van dwingend vennootschapsrecht kunnen worden geïdentificeerd: ${ }^{70}$

\section{Bescherming van (minderheids)aandeelhouders}

In het vennootschapsrecht zou de minderheidsaandeelhouder kunnen worden beschouwd als de 'zwakkere partij', die bescherming verdient tegen het bestuur, resp. de meerderheidsaandeelhouder(s). Terwijl het effectenrecht zich ontfermt over beleggers, wordt de 'zwakkere partij' in het vennootschapsrecht vooral aangetroffen in de besloten vennootschap. De aandeelhouder in een besloten vennootschap kan namelijk zijn aandelen niet zomaar overdragen als hem de samenwerking niet langer zint. Derhalve wordt de minderheidsaandeelhouder beschermd door dwingende rechten, zoals het uittredingsrecht, het enquêterecht of het recht om vernietiging van een besluit te vorderen, en beginselen als het gelijkheidsbeginsel." De meerderheid kan hem deze rechten niet ontnemen. Bovendien kan de meerderheid een aandeelhouder tegen zijn wil niet meer verplichtingen opleggen dan zijn inbreng.

Als de aandeelhouder daadwerkelijk als 'zwakkere partij' wordt gezien, impliceert dit dat hij niet alleen tegen de meerderheid, maar ook tegen zichzelf zou dienen te worden beschermd, in de zin dat hij geen beschikkingsvrijheid zou hebben ten aanzien van de hem toekomende dwingende rechten. Zo acht Riley dwingend vennootschapsrecht gerechtvaardigd ter bescherming van (minderheids)aandeelhouders, omdat er sprake is van een lange termijn verhouding, die aandeelhouders niet voldoende kunnen overzien. ${ }^{n}$ In hoeverre de verschillende rechtsstelsels met deze vragen omgaan, komt met name aan de orde in de hoofdstukken 3 en 5 .

69 Cheffins, 1998, blz. 80.

to De vraag of deze doeleinden ook worden gerealiseerd door de betreffende regeling, alsmede de vraag naar de neveneffecten ervan, vallen buiten het bestek van dit boek.

$\mathrm{Vgl}$. Tilquin en Simonart, Traité des sociétés, deel 1, 1996, blz. 138 e.v.

Riley, "Contracting Out of Company Law: Section 459 of the Companies Act 1985 and the Role of the Courts", MLR 1992, blz. 788. 


\section{Bescherming van crediteuren}

Doordat aan een kapitaalvennootschap rechtspersoonlijkheid is toegekend, gekoppeld aan de beperkte aansprakelijkheid van aandeelhouders, wordt dwingend vennootschapsrecht noodzakelijk geacht om waarborgen te bieden voor crediteuren van de vennootschap. Hansmann en Kraakman stellen dat uitsluitend het vennootschapsrecht bescherming van crediteuren kan bewerkstelligen, niet het algemene verbintenissenrecht. ${ }^{3}$

Crediteuren kunnen op verschillende wijzen worden beschermd. Specifieke vormen van crediteurenbescherming zijn de verplichte openbaarmaking van vennootschappelijke gegevens als de jaarrekening en het kapitaalbeschermingsrecht. Daarnaast kunnen meer indirecte vormen van crediteurenbescherming worden onderkend, die echter niet exclusief op crediteuren zijn gericht, maar op alle bij de vennootschap betrokkenen, resp. de vennootschap zelf.

\section{Bescherming van toekomstige aandeelhouders}

Teneinde toekomstige aandeelhouders die hun geld willen investeren in een kapitaalvennootschap te beschermen, dienen zij zo volledig mogelijk te worden geïnformeerd over de status quo, zodat zij zoveel mogelijk weten waar zij aan beginnen. Dit geschiedt onder meer door de openbaarmaking van de statuten en de jaarrekening. Hirte schetst de kapitalmarktschutzende functie van dwingend recht; de verhandelbaarheid van de aandelen zou gebaat zijn bij standaardisatie van de rechten en verplichtingen die aan het aandeel zijn verbonden. ${ }^{74}$

Terwijl van beleggers niet kan worden verwacht dat zij bij elke transactie de statuten van een vennootschap opvragen, ligt dit enigszins anders in persoonsgebonden vennootschappen. Het gaat dan om de vraag wat aandeelhouders die in een besloten vennootschap investeren redelijkerwijze mogen verwachten. Een aspect hiervan is wat Timmerman noemt de Institutionenschutz, dat "de zuiverheid van de vennootschappelijke instituties" wordt gehandhaafd. De verplichte blokkeringsregeling voor de BV acht hij hiervan een voorbeeld. ${ }^{\text {s }}$ Ook dit is mede van belang voor andere bij de vennootschap betrokkenen.

\footnotetext{
33. Hansmann en Kraakman, The Essential Role of Organizational Law, Yale Law Journal 2000, blz. 387 e.v.

Vgl. Hirte, Die aktienrechtliche Satzungsstrenge, Sonderheft ZGR 1998, blz 64 e.v.

Timmerman, Waarom hebben wij dwingend vennootschapsrecht?, in Ondernemingsrechtelijke contracten, IVO deel 14, 1991, blz 9. e.v.
} 


\section{Bescherming van de vennootschap}

Of de vennootschap zelf bescherming vereist door dwingend recht, hangt af van de opvatting die wordt gehuldigd ten opzichte de aard van de vennootschap. In de meer contractueel georiënteerde opvatting wordt de vennootschap beschouwd als een instrument voor ondernemers teneinde hun doel te verwezenlijken. ${ }^{76}$ De vennootschap als middel heeft dan geen zelfstandig belang dat gewaarborgd hoeft te worden. Dwingend recht dient in deze optiek om de belangen van de bij de vennootschap betrokkenen te waarborgen. In de institutionele benadering wordt uitgegaan van de vennootschap als zelfstandig instituut, met een eigen belang dat meer is dan de som der deelbelangen van de bij de vennootschap betrokkenen, $\mathrm{nl}$. het belang bij het eigen gezonde voortbestaan."

De legitimatie van de zeggenschap van de aandeelhouders vloeit voort uit de koppeling tussen invloed en risico; zij die investeren in de vennootschap hebben het recht en zijn de eerst aangewezenen om belangrijke beslissingen te nemen en bestuurders te benoemen en te ontslaan. In AngloAmerikaanse opvattingen vloeit deze zeggenschap nogal eens voort uit noties als 'eigendom' of 'contract', die tot gevolg hebben dat in de interne machtsverdeling van de vennootschap de aandeelhouders de bestuurders controleren. ${ }^{78}$

De institutionele benadering klinkt door indien de nadruk wordt gelegd op het dualistisch karakter van de vennootschap. Hiermee wordt bedoeld de 'machtenscheiding' tussen het bestuur van de vennootschap enerzijds en het toezicht op het bestuur door algemene vergadering of raad van commissarissen anderzijds. De machtenscheiding dient zodanig te zijn, dat tussen de organen een 'machtsevenwicht' bestaat. Wat het aangewezen evenwicht is, is echter nog niet zo evident, gelet op de corporate governance discussie de afgelopen jaren die mede is gericht op het vaststellen van het optimale evenwicht tussen aandeelhouders en bestuur.

De gedachte is dat bestuurders beter functioneren als zij verantwoording moeten afleggen aan een ander orgaan. Daarnaast wordt het evenwicht tussen organen geacht misbruik van de vennootschap, hetzij door bestuur-

\footnotetext{
76. Vgl. Raaijmakers, Rechtspersonen tussen contract en instituut, 1987, blz. 18 e.v. Zo ook Ten Berg, Statuten zonder bezwaar, preadvies KNB, 2002, blz. 161 e.v.

$\mathrm{Vgl}$. Maeijer, Het belangenconflict in de naamloze vennootschap, 1964.

Greenfield, From Rights to Regulations in Corporate Law, in: Perspectives on Company Law: 2, F. Macmillan Patfield (red.), 1997, blz. 15, wijst op het gevaar van het gebruik van 'contract' en 'eigendom' als metaforen voor de vennootschap. In plaats van te beschrijven, worden ze normatief gebruikt. Zoals Greenfield zegt, "such rights ought to come at the end of the conversation, not at the beginning."
} 
ders, hetzij door aandeelhouders, te voorkomen. ${ }^{79}$ Daartegenover staat het principe van de bestuursautonomie; het bestuur dient te handelen in het belang van de vennootschap en hoeft in beginsel geen instructies van de algemene vergadering op te volgen..$^{n t}$

\section{$\S 1.6$ Evaluatie}

De kracht van deze verschillende motieven kan evolueren in de tijd. Verschillende auteurs hebben de laatste jaren gepleit voor versoepeling van het Nederlandse vennootschapsrecht.." Timmerman relativeert de notie van het vennootschappelijk belang als gevolg van de toegenomen flexibiliteit van en binnen ondernemingen. ${ }^{{ }^{2} 2} \mathrm{Hij}$ schetst eveneens de verzwakking van de institutionele kant van het vennootschapsrecht, die gepaard gaat met een versterking van vennootschapsrechtelijke gedragsregels, bijvoorbeeld een verscherping van de notie van 'tegenstrijdig belang'. ${ }^{\mathrm{s}}$

De koppeling van invloed en risico, hoewel van alle tijden, heeft de laatste jaren meer nadruk gekregen in het corporate governance debat en bij de herziening van de structuurregeling. Deze notie wordt ook onderstreept door de High Level Group of Company Law Experts:

"In the Group's view, proportionality between ultimate economic risk and control means that share capital which has an unlimited right to participate in the profits of the company or in the residue on liquidation, and only such share capital, should normally carry control rights, in proportion to the risk carried. The holders of these rights to the residual profits and assets of the company are best equipped to decide on the affairs of the company as the ultimate effects of their decisions will be borne by them. (...) The holder of the majority of risk-bearing capital should be able to exercise control." $"$

Hierboven is het centrale thema van het boek geschetst, alsmede de lijnen waarlangs het onderzoek zich zal bewegen. De vraag in hoeverre aandeel-

Vgl. Van Schilfgaarde, nr. 11.

Hoewel het beginsel is benadrukt door de minister in de memorie van toelichting bij de Wet herziening preventief toezicht, blz. 11 , blijkt het in de praktijk lastig grenzen te stellen, vgl. HR 21 december 2001, RvdW 2002, 6 (SOBI/Hurks).

Zie o.a. De Kluiver, "Het vennootschapsrecht dient te worden versoepeld... en verscherpt", TVVS 1994, blz. 174-179, en "Mag het nog ietsje meer zijn?", NJB 1996, blz 1439-145. Den Boogert, "Aanpassing van boek 2 BW voor joint venture-doeleinden?", Ars Aequi 1995, blz 357-363. De Monchy, Op weg naar een joint-venture regime?. TVVS 1996, blz. 4.

Timmerman, "Over de toekomst van het vennootschapsrecht", RM Themis 1999, blz. 44.

Timmerman, "Kroniek van het vennootschapsrecht", NJB 2002, blz. 1545.

Zie het rapport van de High level group of company law experts, januari 2002, op www.europa.eu.int/comm/internal_market/en/company/company/news, blz 3. 
houders mogen afwijken van dwingend vennootschapsrecht, dan wel dwingend vennootschapsrecht aanvullen, is het vertrekpunt. Door de keuze van de vrijheid van aandeelhouders als uitgangspunt te nemen, krijgt de vraag een andere lading: in hoeverre stelt dwingend vennootschapsrecht grenzen aan de keuzevrijheid van aandeelhouders om hun vennootschappelijke verhoudingen gestalte te geven? 


\section{Hoofdstuk 2 Het wettelijk systeem}

\section{$\S 2.1$ Inleiding}

Artikel 2:25 BW bepaalt dat van de bepalingen van boek 2 BW slechts kan worden afgeweken, voor zover dat uit de wet blijkt. Dit dwingendrechtelijk uitgangspunt is sinds 1928 in de wet vervat en leek lange tijd vanzelfsprekend. Terwijl voorheen het departement de grenzen van de wet bewaakte, ligt die taak sinds 1 september 2001 op het preventieve vlak exclusief bij het notariaat. De rechtsontwikkeling die van tijd tot tijd gestuurd werd door het departement, vindt nu plaats bij de notaris, eventueel aan de hand van door de KNB opgestelde richtlijnen. ' De kans is niet denkbeeldig dat de ene notaris de grenzen wat ruimer interpreteert dan de andere. Deze ontwikkeling op zich relativeert reeds het dwingendrechtelijke uitgangspunt van de wet. ${ }^{2}$

Recentelijk heeft Timmerman betoogd dat de regel en uitzondering van artikel 2:25 BW dienen te worden omgekeerd. Hij stelt voor om van uitgangspunt te veranderen, door een regel die de wetgever ertoe verplicht om het dwingend karakter van een regel van rechtspersonenrecht steeds expliciet te rechtvaardigen. ${ }^{3}$ Van Schilfgaarde stelt daar tegenover dat vrijheid in het vennootschapsrecht compensatie verlangt in de vorm van meer bescherming van minderheidsaandeelhouders en crediteuren. ${ }^{+}$Wel bepleit hij een grondige heroriëntatie, omdat een wettelijk systeem waarin belangrijke rechten en plichten worden toebedeeld in voorschriften voor de

Zie hierover Buijn, "De inrichting van statuten van vennootschappen", Ondernemingsrecht 2002, blz. 265 e.v.

Volgens Timmerman, "Kroniek van het vennootschapsrecht", NJB 2002, blz. 1545, past de afschaffing van het preventief toezicht in de ontwikkeling van de verzwakking van institutionele regels van het vennootschapsrecht, met daartegenover de versterking van gedragsregels.

Timmerman, Onderstromen in het privaatrechtelijke rechtspersonenrecht, preadvies NJV, 2000, blz. 162 .

Van Schilfgaarde, "De ontwikkeling van de rechtspersoon in het privaatrecht", NJB 2000, blz. 1094. 
redactie van statuten, volgens hem niet goed werkt wanneer er geen preventief toezicht is.

In dit hoofdstuk wordt gepoogd de discussie omtrent artikel 2:25 BW van meer diepte te voorzien, in de eerste plaats door aan de hand van de geschiedenis van de bepaling de reikwijdte en functie te bepalen. Voorts wordt in kaart gebracht welke regels als dwingend of aanvullend worden aangemerkt en welke ruimte nu concreet aan opstellers van statuten wordt geboden. De daadwerkelijke invloed van artikel 2:25 BW op de mate van dwingendheid in het Nederlandse vennootschapsrecht kan echter pas op waarde worden geschat wanneer deze wordt vergeleken met de onderliggende uitgangspunten van andere stelsels van vennootschapsrecht.

De Companies Act 1985 kent geen bepaling als artikel 2:25 BW. Hetzelfde geldt voor de GmbHG. Van elke wetsbepaling afzonderlijk moet door middel van interpretatie worden vastgesteld of zij dwingend dan wel regelend van aard is. Zowel in het Engelse vennootschapsrecht als in het $\mathrm{GmbH}$-recht is de contractsvrijheid, resp. de Gestaltungsfreiheit het uitgangspunt: op een dwingendrechtelijke minimuminhoud na zijn de aandeelhouders vrij de vennootschappelijke verhoudingen vorm te geven in de statuten. Anders ligt dit in het Duitse Aktienrecht. Daar heerst een aan artikel 2:25 BW verwante Satzungsstrenge, vervat in $\S 23 \mathrm{Abs}$. $5 \mathrm{AktG}$ :

"Die Satzung kann von den Vorschriften dieses Gesetzes nur abweichen, wenn es ausdrücklich zugelassen ist. Ergänzende Bestimmungen der Satzung sind zulässig, es sei denn, daß dieses Gesetz eine abschließende Regelung enthält." ${ }^{\prime 6}$

In Duitsland controleert de Registerrichter de statuten op conformiteit met de wet, zowel van de AG als de GmbH (§ 9c GmbHG).

De vraag is dan in hoeverre artikel 2:25 BW en $\S 23 \mathrm{Abs}$. $5 \mathrm{AktG}$ met elkaar overeenstemmen, en welke gevolgen dat heeft voor de mate van dwingendheid van het recht. Hopt noemt met name de 'uitdrukkelijkheid' als verschil tussen artikel 2:25 BW en $\S 23$ Abs. 5 AktG.' Dit zou betekenen dat van de Nederlandse wet ook zou mogen worden afgeweken indien de wet hiertoe niet uitdrukkelijk aanleiding geeft. Timmerman ziet juist als

Van Schilfgaarde, "Statuten zonder bezwaar", WNPR 2002, blz. 645. Zie ook De Kluiver/ Meinema, "Dwingend vennootschapsrecht na de Wet herziening preventief toezicht en de mogelijkheden van statutaire of contractuele afwijking en aanvulling", WPNR 2002, blz, 648 e.v.

6 De bepaling is pas in 1965 ingevoerd. De wetgever achtte het nodig de toenmalige heersende leer uitdrukkelijk weer te geven door dwingend recht als regel te stellen. Zie over de wetsgeschiedenis Hirte, Die aktienrechntiche Satzungsstrenge: Kapitalmarkt und sonstige Legitimationen versus Gestaltungsfreiheit, in ZGR Sonderheft 1998, blz. 63 en GeBler, Bedeutung und Auslegung des $\$ 23 \mathrm{Abs} .5 \mathrm{AktG}$, in: Festschrift fur Martin Luther, 1976, blz. 70.

Hopt, ZGR Sonderheft 1998, blz. 133. 
probleem van artikel 2:25 BW dat niet geheel duidelijk is, wanneer uit de wet blijkt dat een bepaling niet dwingend is. ${ }^{8}$

Voorts is de vraag in hoeverre de tegenstellingen tussen het dwingendrechtelijk kader van het Nederlandse recht en het Aktienrecht enerzijds, en de dwingendrechtelijke grenzen van het Engelse recht en het GmbH-recht anderzijds van invloed zijn op de reikwijdte, het aantal en de identificatie van dwingende regels.

Bij de beantwoording van deze vragen wordt in dit hoofdstuk de nadruk gelegd op de verhouding tussen de wet en de statuten. In hoeverre mogen statuten wettelijke bepalingen aanvullen? Wanneer worden statutaire bepalingen als afwijking van de wet beschouwd? In hoofdstuk 3 wordt de reikwijdte van dwingend vennootschapsrecht getoetst aan buitenstatutaire bepalingen als aandeelhoudersovereenkomsten.

\section{$\S 2.2$ Nederland}

\section{§2.2.1 De geschiedenis van artikel 2:25 BW}

Alvorens nader in te gaan op de plaats van artikel 2:25 BW in het wettelijk systeem, is het van belang na te gaan hoe artikel 2:25 BW in onze vennootschapswetgeving is terechtgekomen. Daartoe wordt teruggekeerd naar de voorlopers van de hedendaagse kapitaalvennootschappen. Enerzijds ontstond een soort kapitaalvennootschap in de praktijk, geëvolueerd uit de Romeinse societas, zonder tussenkomst van de overheid. Beperkte aansprakelijkheid werd, zo goed en zo kwaad als het ging, contractueel bewerkstelligd. Anderzijds ontstonden handelscompagnieën, zoals de Vereenigde Oost-Indische Compagnie, aan wie de overheid een octrooi verleende. Dit octrooi verschafte de compagnieën rechtspersoonlijkheid, gekoppeld aan een monopoliepositie. De verlening van een octrooi was niet aan regels gebonden noch verplicht; slechts de compagnieën die van de overheid een monopolie of andere voorrechten verlangden, onderwierpen zich aan overheidstoezicht.' Teneinde enerzijds misbruik van de 'vrije' rechtspersonen te voorkomen en anderzijds het overheidstoezicht te vrijwaren van willekeur, werd in de negentiende eeuw vennootschapswetgeving geïntroduceerd, te beginnen met de Code de Commerce. Het octrooistelsel werd vervangen

Timmerman, Gestaltungsfreiheit im niederlandischen Gesellschaftsrecht, ZGR Sonderheft 1998, blz. 218 .

Vgl. Kist-Visser, Beginselen van Handelsrecht, supplement deel III - De Naamlooze Vennootschap, 1929, blz 4 e.v. en Zeylemaker, Verleden, heden, en toekomst van de naamloze vennootschap, 1947, blz. 13 e.v. 
door een concessiestelsel: voor de oprichting van een naamloze vennootschap werd koninklijke bewilliging vereist. Het overheidstoezicht werd als noodzakelijke pendant gezien van de beperkte aansprakelijkheid. ${ }^{10}$

Het Wetboek van Koophandel van 1838 bevatte voor de naamloze vennootschap voornamelijk dwingende regels, in het bijzonder met het oogmerk crediteuren een minimum aan bescherming te bieden. Bepalingen omtrent de vennootschappelijke organisatie ontbraken vrijwel geheel." Wel boden deze regels de vennootschap tevens bescherming tegen de willekeur van de Kroon; ${ }^{12}$ met de invoering van het Wetboek van Koophandel 1838 kon de koninklijke bewilliging namelijk slechts op objectieve gronden worden geweigerd."

De koninklijke bewilliging kon echter niet tegengaan dat er misbruik werd gemaakt van vennootschappen. Al in de jaren zestig van de negentiende eeuw gingen stemmen op om het vennootschapsrecht beter aan te passen aan de eisen van de moderne tijd. Afschaffing van het concessiestelsel werd bepleit, met vervanging door het publiciteitsstelsel. ${ }^{4}$ Hierbij is het oprichten van de naamloze vennootschap aan de bemoeienis van het openbaar gezag onttrokken. Enerzijds worden regels gesteld, welke bij oprichting, inrichting en bestaan van dergelijke associaties in acht zijn te nemen, anderzijds wordt min of meer uitgebreide openbaarmaking van de voor het publiek belangrijke bijzonderheden betreffende oprichting en werking van deze lichamen gelast. ${ }^{15}$ Molengraaff stelde echter dat niet zozeer

10 Asser e.a., Het Wetboek van Koophandel met aantekeningen, 1845, blz. 19. Zie ook Huussen-De Groot, Rechtspersonen in de $19^{\circ}$ eeuw, 1976, blz. 120 e.v.

11 De artikelen 36 tot en met 56, die op de naamloze vennootschap van toepassing zijn, bevatten, naast omschrijving- en definitiebepalingen, gebods- en verbodsbepalingen, op twee uitzonderingen na: artikel 42 geeft twee alternatieven voor de wijze van overdracht van aandelen en op grond van artikel $54 \mathrm{kan}$ bij de akte van oprichting worden bepaald, op welke wijze het stemrecht wordt uitgeoefend, echter gebonden aan wettelijke voorwaarden.

Kist-Visser, 1929, blz. 6. Asser, 1845, blz, 20, vermeldt: "[M]en [heeft] hier te lande ingezien, dat het toezigt der Regering aan zekere regelen behoorde gebonden te zijn, opdat niet de toestemming tot het oprigten, en de goedkeuring der reglementen van naamlooze maatschappijen, of al te gemakkelijk ware te verkrijgen, of al te ligt geweigerd wierd, waarvan men het nadeel meermalen reeds had ondervonden. (...) Als regel en beginsel is aangenomen, dat het toezigt der Regering zich zoude bepalen tot de handhaving der goeder orde en zeden, en der voorschriften van deze Afdeeling, en eindelijk, dat dit toezigt, na het goedkeuren der statuten, geheel zoude ophouden."

13 Artikel 37 WvK 1838: Indien de vennootschap niet strijdt met de goede zeden of de openbare orde, en de akte geene bepalingen bevat tegen al hetgeen bij art. 38 tot en met art. 55 is voorgeschreven, wordt de koninklijke bewilliging verleend.

$14 \mathrm{Vgl}$. Molengraaff, Beschouwingen over de herziening van het vereenigingsrecht, 1903, blz 25. Het ontwerp van 1910 bevatte dan ook geen preventief toezicht. Uiteindelijk is toch als compromis de ministeriele verklaring van geen bezwaar in de Wet van 1928 terecht gekomen, zonder dat dit een inhoudelijke wijziging van het toezicht betrof.

15. Kist-Visser, Beginselen van Handelsrecht, supplement deel III - De Naamlooze Vennootschap, 1929, blz. 7 . 
de keuze tussen staatstoezicht of openbaarheid van belang was, als wel "meer of minder dwingend recht". ${ }^{16}$ Dat thema kreeg volop aandacht in het ontwerp van de wet op de naamlooze vennootschappen uit 1910. Over dwingend en aanvullend recht vermeldt de memorie van toelichting:

"Hoewel dit ontwerp grootendeels uit bepalingen bestaat, waarvan noch bij de akte van oprichting, noch door de algemeene vergadering van aandeelhouders, noch door wien ook, zal mogen worden afgeweken, bevatten toch niet alle bepalingen van dit wetsontwerp voorschriften van dwingend recht. Naast die, waarin de grondslagen van het ontwerp belichaamd zijn, is er een aantal, de inrichting en werking der naamlooze vennootschap betreffende, die als aanvullingsrecht gelden en waarvan dus bij de akte van oprichting kan worden afgeweken. Staat men een dergelijke afwijking niet toe, dan streeft men het doel der regeling voorbij, want, hoe deugdelijk en doeltreffend de in de wet vervatte regeling ook zijn moge, het is, bij de groote verscheidenheid in den aard, den omvang, het doel en de werking der vele naamlooze vennootschappen, niet mogelijk eene wettelijke regeling tot stand te brengen, die voor alle evenzeer geschikt is; men moet dus noodwendig aan de overeenkomsten van partijen de vrijheid laten van de wettelijke voorschriften af te wijken, voorzoover dit geschieden kan zonder inbreuk te maken op de grondbeginselen der wettelijke regeling." ${ }^{\prime 7}$

Vervolgens was de vraag hoe het onderscheid tussen dwingend en regelend recht in de wet tot uitdrukking diende te komen. De memorie van toelichting vervolgt:

"Bij de uitwerking van dezen gedachtengang is eenigszins anders te werk gegaan dan in het ontwerp der Staatscommissie is geschied. Dit ontwerp noemt in een zijner slotbepalingen (art. 118) de artikelen met name, van welke afwijking geoorloofd is, daarbij echter voorschrijvende dat die afwijking slechts dan geldig is, indien de wetsartikelen waarvan afgeweken wordt, in hun geheel in de akte zijn opgenomen. Deze methode nu komt den ondergeteekende uit een technisch oogpunt minder aanbevelenswaardig voor. Immers eerst door raadpleging van het artikel der slotbepalingen kan men de ware betekenis van ieder voorschift leeren kennen. Doeltreffender schijnt het te bepalen dat afwijking van het gestelde voorschrift slechts geoorloofd is, voor zooverre dit uit de betrokken wetsbepaling volgt. Ieder artikel verschaft op deze wijze in vollen omvang de kennis van zijne verbindbaarheid."

Molengraaff, 1903, blz. 26.

Belinfante, blz 39.

Belinfante, blz. 39 
Artikel $39 a$ van het ontwerp 1910 bepaalt derhalve: "Van de bepalingen dezer afdeeling mag slechts worden afgeweken, indien, en voor zooverre, dit uit die bepalingen zelve blijkt." $\mathrm{Bij}$ de specifieke toelichting op artikel $39 a$ vervolgt de minister:

"Voor hem, die ook slechts eenigermate met de practijk van het vennootschapswezen bekend is, kan het geen betoog behoeven, dat zelfs de best mogelijke wetgeving op dit stuk niet het papier, waarop zij gedrukt wordt, waard zoude zijn, zoo haar niet grootendeels een dwingend karakter werd toegekend. De ondervinding heeft duidelijk aangetoond, dat niet zelden de aandeelhouder, belust op hooge dividenden, zich aan de bepalingen der statuten weinig gelegen laat liggen en bereid wordt bevonden, onder welke voorwaarden ook in de naamlooze vennootschap deel te nemen, mits de winstverdeeling naar zijn zin is ingericht. Er blijven echter steeds bepalingen over, hoofdzakelijk die welke op de inwendige organisatie betrekking hebben, waarvan afwijking bij de akte van oprichting geoorloofd moet blijven."'!

Artikel $39 a$ is, in dezelfde bewoordingen, in de uiteindelijke Wet op de naamlooze vennootschappen van 2 juli 1928 terechtgekomen als artikel $37 d$, zonder verdere toelichting. ${ }^{20}$

Meijers heeft de op de naamloze vennootschap toepasselijke bepalingen met slechts enkele wijzigingen overgenomen uit het Wetboek van Koophandel, daar deze wet van nog betrekkelijk jonge datum was en in het algemeen goed voldeed. ${ }^{21}$ In het Ontwerp-Meijers was het dwingendrechtelijk uitgangspunt oorspronkelijk slechts overgenomen voor de vereniging en de naamloze vennootschap. Daar dit aanleiding zou kunnen geven voor a contrario redeneringen is een zelfde bepaling met betrekking tot de stichting toegevoegd. ${ }^{2 z}$ Artikel 25 is sinds 1983 van toepassing op alle in boek $2 \mathrm{BW}$ vervatte rechtsregels.

Het revolutionaire van artikel $37 d$ lijkt niet zozeer het dwingendrechtelijk uitgangspunt te zijn geweest, als wel de introductie van aanvullende regels, met name met betrekking tot de interne organisatie, waarvan bij de statuten kan worden afgeweken. Uit de wetsgeschiedenis kan worden afgeleid dat het doel van artikel $37 d$ (als voorloper van artikel 2:25 BW) was kennis te geven over de bindende werking van de afzonderlijke bepalingen. Het werd kennelijk gezien als een hulpmiddel bij de interpretatie van deze bepalin-

Belinfante, blz. 59 .

Staatsblad 216.

Meijers, Ontwerp voor een nieuw Burgerlijk Wetboek, toelichting Eerste Gedeelte, 1954, blz. 148.

32

Artikel 2.4.17, Parl. Gesch. boek 2, blz. 663 . 
gen. Dat minister Nelissen niettemin de contractsvrijheid van partijen voorop stelt met als grens de inbreuk op de grondbeginselen der wettelijke regeling, met een beroep op de verscheidenheid aan vennootschappen, wil $i k$ - bijna een eeuw later - graag onderstrepen.

In de literatuur werd niettemin de nadruk gelegd op het dwingendrechtelijk uitgangspunt, met relativerende opmerkingen over de mogelijkheid van nadere uitwerking. Zo schreef Kist-Visser:

"De regeling, welke de wet geeft, is dus in beginsel dwingend; het tegendeel moet uit den gegeven regel zelven blijken, d.w.z. moet daarin worden bepaald en kan niet door redeneering daaruit worden afgeleid. (...) Dat van een regeling niet mag worden "afgeweken", beteekent dat het in die regeling vervatte voorschrift niet door een ander mag worden vervangen, niet op de eene of andere wijze mag worden krachteloos gemaakt, niet minder, maar ook niet meer. Daarnevens blijft echter bestaan de bevoegdheid tot nadere uitwerking, tot meerdere preciseering, tot engere aansluiting van de behoeften eener bepaalde vennootschap aan de materie, welke in zoodanig voorschrift is geregeld; alleen is verboden het wettelijk voorschrift voorbij te gaan en door een eigen, daarmede strijdende regeling te vervangen. Mits in stand blijve hetgeen de wetgever door zijn bepaling heeft willen bereiken, staat het echter de akte van oprichting vrij aangaande het onderwerp dier bepaling nadere voorschriften en regelingen te geven."'s

\section{$\S 2.2 .2$ Dwingende en aanvullende regels}

Zoals blijkt uit de ontstaansgeschiedenis van artikel 2:25 BW, is de meerderheid van de vennootschapsrechtelijke bepalingen van boek 2 BW van dwingend recht. Met name van de bepalingen die dienen ter bescherming van crediteuren staat de wet geen afwijking toe. Zo komen verbodsbepalingen veelvuldig voor in het kapitaalbeschermingsrecht. Gebodsbepalingen betreffen onder meer de vorm en inhoud van de statuten en de besluitvorming van de algemene vergadering. Ook zijn de normen voor de bij de vennootschap betrokkenen als gebod geformuleerd: de plicht tot redelijk en billijk gedrag, of tot een behoorlijke taakvervulling.

Naast verbods- en gebodsbepalingen kent boek 2 BW dwingendrechtelijke bevoegdheden aan organen toe en rechten aan aandeelhouders. Zo heeft in beginsel iedere aandeelhouder stemrecht, recht op deelname aan de algemene vergadering, het recht om vernietiging van een besluit van een orgaan te vorderen. Daarnaast hebben aandeelhouders die ten minste tien procent van het geplaatste kapitaal vertegenwoordigen het recht om een

Kist-Visser, 1929, blz. 42. 
enquête te verzoeken en bijeenroeping van de algemene vergadering. ${ }^{24}$ Dwingende bevoegdheden van de algemene vergadering in een besloten vennootschap zijn onder meer de bevoegdheid tot statutenwijziging, tot benoeming en ontslag van bestuurders en commissarissen tot vaststelling van de jaarrekening.

\section{Aanvullend recht}

Aanvullende rechtsregels gelden, zolang de statuten niet anders bepalen. ${ }^{2 s}$ Van aanvullend recht zijn bijvoorbeeld de bevoegdheid van de algemene vergadering tot uitgifte van aandelen en de besluitvorming met volstrekte meerderheid. Wil de algemene vergadering een quorumeis stellen voor haar besluitvorming, dan is een statutaire bepaling noodzakelijk.

Ook aandeelhouders hebben een aantal rechten, die in de statuten of bij besluit kunnen worden beperkt: voorkeursrecht op uit te geven aandelen, recht op dividend, recht op opbrengst na vereffening, aanspraak op gelijke behandeling. In deze gevallen staat de wet uitdrukkelijk afwijking toe. Dit neemt niet weg dat ook aanvullend recht dwingende grenzen kent. Zo zijn aandeelhouders weliswaar vrij om de winstbestemming statutair vast te leggen, maar mag deze er niet toe leiden dat een aandeelhouder geheel wordt uitgesloten van de winst.

\section{'Optioneel' recht}

Terwijl aanvullend recht een 'vangnet'functie heeft en de vennootschap van een standaardinrichting voorziet, waarvan in de statuten kan worden afgeweken, biedt 'optioneel' recht de mogelijkheid de vennootschap zoveel mogelijk naar eigen inzicht in te richten, aanvullend ${ }^{26}$ op de wettelijke regeling. Een voorbeeld van optioneel recht is de mogelijkheid statutair te voorzien in een bindende voordracht voor het benoemen van bestuurders. Ook voor de mogelijkheid besluiten buiten vergadering te nemen kan statutair worden geopteerd. Beide regelingen geven tegelijkertijd voorwaarden waaraan het recht moet voldoen, omdat zij een inperking c.q. uitzondering vormen op bestaande - dwingende - regels.

Zie voorts $\$ 3.2 .3$.

Zie $\$ 1.4$.

Enigzins verwarrend is het gebruik van 'aanvullend' voor twee te onderscheiden situaties: de wet bevat aanvullend recht ten opzichte van statuten, hetgeen inhoudt dat in de statuten kan worden afgeweken van de wet, terwijl de statuten aanvullende regelingen kunnen bevatten ten opzichte van de wet, die hiertoe de mogelijkheid biedt (optioneel recht). Het is dus een kwestie van perspectief. 
Omzetting, fusie en splitsing zijn eveneens door de wetgever gecreëerde faciliteiten die aan dwingende regels zijn gebonden. Voorts kan onder meer worden geopteerd voor een beperking van het deelnamerecht aan de algemene vergadering en opschorting van het stemrecht als sanctie, voor het verbinden van bijzondere rechten aan aandelen en voor statutaire kwaliteitseisen voor bestuurders en commissarissen. Een ander voorbeeld van optioneel recht is de vrijwillige aanvaarding van het structuurregime. Steeds houdt de optie tegelijkertijd een beperking in.

\section{$\S 2.2 .3$ Afwijking of aanvulling?}

Uitgangspunt van de wet is dat afwijkingen slechts zijn toegestaan, voor zover dit uit de wet blijkt. Het is duidelijk dat van een wettelijk verbod niet mag worden afgeweken. Hierboven kwam aan de orde dat de wet uitdrukkelijk de gelegenheid kan bieden om ervan af te wijken, dan wel de wet 'aan te vullen'. ${ }^{27}$ Lastiger wordt het wanneer de wet niet expliciet het een of het ander bepaalt. Betekent het zwijgen van de wet dat een statutaire regeling niet is toegestaan, of bestaat er niettemin vrijheid om de wet 'aan te vullen' met statutaire bepalingen? Dit hangt mede af van de vraag of een wettelijke regeling als uitputtend wordt gekwalificeerd.

Indien een wettelijke regeling uitputtend is bedoeld, bestaat geen ruimte voor statutaire aanvullingen. Een voorbeeld biedt artikel 2:243 BW, op grond waarvan bestuurders kunnen worden benoemd door de algemene vergadering op basis van een bindende voordracht. Een dergelijke statutaire regeling heeft voor het eerst haar intrede gedaan in het Nederlandse recht na Koninklijke bewilliging te hebben verkregen in 1898 , als oligarchische clausule in de statuten van de Koninklijke Nederlandsche Maatschappij tot Exploitatie van Petroleumbronnen in Nederlandsch-Indië. Destijds had de bindende voordracht geen wettelijke basis. ${ }^{28}$ De oligarchische clausule werd als toelaatbare aanvulling op de dwingendrechtelijke bevoegdheid van de algemene vergadering beschouwd, met een beroep op het gevaar van buitenlandse overheersing. ${ }^{29}$

Maeijer meent dat bij de latere invoering van een wettelijke regeling aangaande de bindende voordracht de wetgever deze uitputtend en dwingendrechtelijk heeft willen regelen, zodat de bindende voordracht als enige

Zie $\$ 2.2 .2$.

In 1898 gold het oude Wetboek van Koophandel 1838, hoewel er inmiddels een wetsontwerp van de Staatscommissic uit 1890 was, later door minister Nelissen aangepast in het wetsontwerp van 1910 , zie voorts $\$ 2.2 .1$.

Niettemin leidde de verlening van de Koninklijke bewilliging tot kamervragen, vgl. Hand. 1917 1918 II, blz. 2508 e.v. 
mogelijke beperking op de bevoegdheid van de algemene vergadering tot benoeming moet worden beschouwd. Hij acht een statutair goedkeuringsrecht ten behoeve van een ander orgaan of een derde bij de benoeming van bestuurders derhalve niet mogelijk. ${ }^{30}$

Het zwijgen van de wet kan echter ook worden opgevat als het bieden van ruimte voor aanvullingen. Van deze benaderingswijze getuigt bijvoorbeeld de minister bij de invoering van artikel 2:210 lid $4 \mathrm{BW}$, dat bepaalt dat besluiten tot vaststelling van de jaarrekening in de statuten niet mogen worden onderworpen aan de goedkeuring van een orgaan of een derde. In de memorie van toelichting stelt hij dat besluiten van vennootschapsorganen op grond van de wet kunnen worden onderworpen aan de goedkeuring van een ander vennootschapsorgaan of van derden, maar dat van deze regel wordt afgeweken bij het besluit tot het opmaken of vaststellen van de jaarrekening, om geen afbreuk te doen aan een belangrijke bevoegdheid van onderscheidenlijk het bestuur en de algemene vergadering. ${ }^{31}$ In de nota naar aanleiding van het verslag wordt dit als volgt verduidelijkt: "Lid 4 is opgenomen omdat de wet vooralsnog geen uitdrukkelijke grondslag voor het bepalen van een goedkeuringsrecht geeft." ${ }_{22}$ Kennelijk is de minister van mening dat een goedkeuringsrecht geen uitdrukkelijke grondslag behoeft, maar een beperking ervan wel. Van Olffen plaatst weliswaar kanttekeningen bij deze redenering, maar stelt dat in de toekomst dankbaar gebruik zal worden gemaakt van deze noviteit." Men kan zich echter afvragen in hoeverre bijvoorbeeld de bevoegdheid tot statutenwijziging aan de goedkeuring van derden mag worden onderworpen. ${ }^{34}$

De Wet herziening preventief toezicht biedt ook overigens aanknopingspunten ten aanzien van de vraag of een statutaire regeling als aanvulling of als afwijking van de wet moet worden beschouwd. Uitgangspunt bij de omzetting van departementale richtlijnen in wettelijke regelingen is immers geweest dat alleen die richtlijnvoorschriften in boek 2

Asser-Maeijer 2-III Vertegenwoordiging en rechtspersoon, $2^{e}$ druk, 2001, nr. 313, Zie ook Van der Grinten, Handboek voor de naamloze en de besloten vennootschap, $12^{\circ}$ druk, 1992, nr. Volgens De Kluiver, Tijdschrift Contracteren, 2000, $\$ 2.1$, is er echter geen sprake van strijd met de wet, omdat degene die een goedkeuringsrecht heeft weliswaar een benoeming kan tegenhouden, maar nimmer de algemene vergadering kan dwingen een door hem gewenste kandidaat te benoemen.

$3 \quad$ TK 1998-1999, 26 277, nr. 3, blz. 9.

32. TK 1999-2000, $26277, \mathrm{nr} .5$, blz. 10.

3. Van Olffen, Inrichting van de statuten zonder preventief toezicht, in A-T-D, Opstellen aangeboden aan Prof. mr. P. van Schilfgaarde, 2000, blz. 340. Zie hierover ook Van Solinge/Nowak, "Bestuursbesluiten na afschaffing van het preventief toezicht", Ondernemingsrecht 2002, blz, 436 e.v. 
BW terechtkomen, die bij het vervallen daarvan leemtes in de wet zouden doen ontstaan. ${ }^{35}$ Uitsluitend richtlijnen die een keuze maken tussen verschillende interpretaties van een wettelijke bepaling, richtlijnen die als afwijking kunnen worden gezien van hetgeen in de wet wordt voorgeschreven, en sommige richtlijnen die een regeling treffen waar de wet zwijgt, behoeven een wettelijke grondslag, aldus de minister. ${ }^{36}$

Enigszins merkwaardig is dat er kennelijk vanuit wordt gegaan dat de richtlijnen afwijkingen bevatten van de wet. Dit blijkt onder meer uit de opvatting van de minister dat voor het ontnemen of beperken van het stemrecht een wettelijke basis is vereist, ${ }^{31}$ terwijl dit voorheen tot op zekere hoogte op basis van de departementale richtlijnen was toegelaten. Deze afwijkingen van dwingend recht dienen derhalve uitdrukkelijk in de wet te worden vervat, in artt. 2:195a en 2:195b BW, terwijl een wettelijke regeling voorheen ontbrak. Geen wettelijke basis is volgens de minister nodig voor het opschorten van de winstuitkering, daar artikel 2:216 BW een statutaire opschorting van het recht op uitkeringen niet verbiedt. ${ }^{38}$ Een uitdrukkelijk wettelijk verbod op de introductie van een plaatsvervangend commissaris acht de minister evenmin vereist, aangezien de wet en het wettelijke systeem geen aanknopingspunt geven voor een dergelijke functie, daar zij niet voorzien in een regeling aangaande belet en ontstentenis van commissarissen. ${ }^{19}$

Niet in een wettelijke regeling vervat is het departementale voorschrift dat, indien eisen voor aandeelhouderschap bij statutenwijziging worden ingevoerd, aangetoond dient te worden dat alle aandeelhouders die niet aan de te stellen eisen voldoen hetzij daarvan ontheffing krijgen hetzij met de statutenwijziging hebben ingestemd. ${ }^{40}$ De delegatiebevoegdheid aan het bestuur tot neerlegging van de statutenwijziging heeft evenmin een wettelijke basis gekregen. Aangezien de herziening van het preventief toezicht geen inhoudelijke wijziging beoogt," lijkt het erop dat de minister deze statutaire regelingen als toegelaten aanvullingen op de wet beschouwt. ${ }^{42}$

MvT, blz. 3

MvT, blz 5 .

MvT, blz. 7, 10. Dit is anders in het Duitse recht, zie $\$ 2.3 .1$.

Nota, blz 8 .

Nota, blz. 14.

Dep. rl. $\$ 34$. Zie $\$ 5.2 .5$.

MvT, blz. 3.

Zie hierover uitgebreider $\$ 5.2$. 


\section{Rechterlijke interpretatie}

Rechterlijke toetsing van de geldigheid van statutaire bepalingen is tot de afschaffing van het preventief technisch-juridisch toezicht vrij zeldzaam geweest; het departement waakte immers over de conformiteit van de statuten met de wet. ${ }^{33}$ Voor zover er jurisprudentie is gaat deze met name over de blokkeringsregeling. Zo oordeelde de rechter dat een statutaire uitbreiding van de vrije kring van betrokkenen in de blokkeringsregeling in strijd met dwingend recht was. De wettelijke vrije kring wordt kennelijk uitputtend geacht en laat geen statutaire aanvulling toe, daar deze het besloten karakter van de vennootschap doorbreekt.

Wilhelm Schmitz GmbH wil haar aandelen in Betonindustrie en Handelsmaatschappij Emmen BV (BHE) verkopen en biedt ze conform de aanbiedingsregeling aan haar mede-aandeelhouders aan. Uit meerdere geïnteresseerden kiest Schmitz Cemex BV. Ze komen overeen dat Cemex de aandelen zal overnemen via een derde vennootschap, Leeuwarden VIII, waarvan Cemex alle aandelen houdt. Dit geschiedt in overeenstemming met de statuten van BHE, die bepalen dat de aanbiedingsregeling niet van toepassing is indien de aandeelhouder de aandelen overdraagt aan een besloten vennootschap waarvan alle aandelen in zijn bezit zijn. De rechtbank oordeelde echter dat de statutaire aanbiedingsregeling in strijd met een dwingendrechtelijk voorschrift is en daarmee nietig, ondanks de verkregen verklaring van geen bezwaar. ${ }^{4}$

Uit het Verenigde-Bootliedenarrest blijkt dat de aanbieding- en goedkeuringsregeling als een minimum ter bescherming van de beslotenheid dienen te worden beschouwd. De Hoge Raad overweegt:

"Uit de tekst van art. 195 valt niet af te leiden dat een blokkeringsregeling volgens het goedkeuringsstelsel niet zou mogen worden gecombineerd met een blokkeringsregeling volgens het aanbiedingsstelsel. Ook de wetsgeschiedenis geeft (...) geen steun aan de opvatting dat een dergelijke combinatie ontoelaatbaar is. Evenmin valt in te zien dat het combineren van beide stelsels met de ratio van het in art. 195 neergelegde blokkeringsvereiste in strijd zou zijn.",'s

Binnen de wettelijke minimum- en maximumeisen zijn statutaire aanvullingen mitsdien toegestaan. ${ }^{46}$

De minister verwacht echter niet dat de afschaffing van het preventief toezicht tot grote aantallen procedures zal leiden, Nota n.a.v, verslag, blz. 3.

4 Rb Almelo, 6 maart 1991, NJ 1992, 485. Zie ook Hof Arnhem, 10 september 1991, NJ 1992, 486.

as HR 31 december 1993, NJ 1994, 436 .

4h $\mathrm{Vgl}$ AG Mok: "Het doel van blokkeringsregelingen is gelegen in bescherming van de beslotenheid en (althans oorspronkelijk) bescherming van buitenstaanders. Het minimum aan bescher- 


\section{$\S 2.3$ Duitsland}

\section{$\S$ 2.3.1 Satzungsstrenge in het Aktienrecht}

Zoals in de inleiding vermeld, heeft het Duitse Aktienrecht in $\S 23$ Abs. 5 AktG een equivalent van artikel 2:25 BW:

"Die Satzung kann von den Vorschriften dieses Gesetzes nur abweichen, wenn es ausdrücklich zugelassen ist. Ergänzende Bestimmungen der Satzung sind zulässig, es sei denn, daß dieses Gesetz eine abschließende Regelung enthält." ${ }^{47}$

De in $\S 23$ Abs. 5 AktG vervatte Satzungsstrenge brengt met zich mee dat aandeelhouders slechts binnen twee, door de wet gegeven, grenzen de vrijheid hebben de vennootschappelijke verhoudingen statutair vorm te geven: de statuten mogen afwijken van de wet, wanneer de wet dat uitdrukkelijk toestaat, en de wet aanvullen, wanneer deze geen uitputtende regeling biedt. Onder afwijking wordt in de Duitse literatuur verstaan, dat de wettelijke regeling door een andere, statutaire, wordt vervangen. De statuten regelen een bepaalde aangelegenheid dan anders dan de wet. ${ }^{48}$ Statutaire regelingen die de wet aanvullen, doen daarentegen geen andere rechtsgevolgen intreden dan de wet, maar voegen regelingen toe die een concrete invulling geven aan een wettelijk voorschrift of die een leemte opvullen.9

In sommige gevallen laat de wet uitdrukkelijk aanvulling of afwijking toe. De geijkte formulering luidt dan "die Satzung kann bestimmen", of "wenn die Satzung nichts anderes bestimmt". .0 $^{\text {.0 }}$ Zopaalt $\S 179$ Abs. 2 AktG dat in de statuten "weitere Erfordernisse" aan de besluitvorming van

ming (...) volgt uit de leden 3 en 4 van art. 2:195, er moet een blokkeringsregeling volgens het goedkeuringsstelsel zijn, tenzij er een zodanige regeling volgens het aanbiedingsstelsel is. Het karakter van minimum impliceert dat men daar bovenuit mag gaan, dus dat er ook een combinatie van beide stelsels mag zijn. Het maximum is geformuleerd in het zevende lid: de overdraagbaarheid mag niet zodanig beperkt zijn dat overdracht onmogelijk of uiterst bezwaarlijk wordt gemaakt. Tussen minimum- en maximumvereiste mag elke besloten vennootschap in haar statuten regelen hoe ver zij met de blokkering wil gaan."

De bepaling is pas in 1965 ingevoerd. De wetgever achtte het nodig de toenmalige heersende leer uitdrukkelijk weer te geven door dwingend recht als regel te stellen. Zie over de wetsgeschiedenis Hirte, Die aktienrechtliche Satzungsstrenge: Kapitalmarkt und sonstige Legitimationen versus Gestaltungsfreiheit, in ZGR Sonderheft 1998, blz. 63 en GeBler, Bedeutung und Auslegung des $\$ 23$ Abs. 5 AktG, in: Festschrift fur Martin Luther, 1976, blz. 70.

Huffer, Kurzkommentar AktG, $4^{\circ}$ druk, 1999, § 23, 35. Pentz, Münchener Kommentar zum Aktiengesetz, $3^{e}$ druk, 2000, $\S 23,152$. Röhricht, GroBkommentar zum Aktiengesetz, $4^{e}$ druk, $1997, \S 23,168$. GeBler, Bedeutung und Auslegung des $\S 23$ Abs. 5 AktG, in: Festschrift für Martin Luther, 1976, blz. 73. 
de algemene vergadering kunnen worden gesteld, terwijl op grond van $\S 55$ AktG extra verplichtingen aan aandeelhouders kunnen worden opgelegd."

Onduidelijkheid ontstaat zodra de wet de mogelijkheden tot afwijken of aanvulling in het midden laat. Zwijgt de wet over een bepaalde aangelegenheid, dan kan dit als een leemte (Regelungslücke) worden gekwalificeerd, zodat statutaire aanvulling is toegestaan. Voorbeelden hiervan zijn de instelling van een Beirat ${ }^{32}$ (mits de wettelijke bevoegdheidsverdeling niet wordt doorkruist) of het stellen van kwaliteitseisen aan leden van het bestuur (mits een zekere mate van keuzevrijheid gewaarborgd blijft)." Het criterium is of de wettelijke regeling in wezen onaangetast blijft.

Wettelijke regelingen, waarvan geen afwijkingen zijn toegestaan, worden aangetroffen op het gebied van de bevoegdheidsverdeling tussen de organen en de rechten van minderheidsaandeelhouders. Ook een statutaire arbitrageclausule wordt als ontoelaatbare afwijking beschouwd, voor zover de $\mathrm{AktG}$ in rechtsbescherming door de overheidsrechter voorziet. ${ }^{4}$ De vraag is dan in hoeverre aanvullende statutaire regelingen zijn toegestaan. Dit wordt pas duidelijk bij de interpretatie van elke bepaling afzonderlijk. ${ }^{5 s}$ Zo geldt een statutaire instructiebevoegdheid als een ontoelaatbare aanvulling op de bestuursautonomie. ${ }^{36}$

Een uitputtend bedoelde regeling is uitzonderlijk; aanvulling is regel. ${ }^{37}$ Zo ontbreekt een wettelijke sanctieregeling voor aandeelhouders die niet aan statutaire verplichtingen voldoen. Dergelijke sancties worden in beginsel toegestaan; de wet bevat een Regelungslücke.ss De gedachte hierachter is dat indien de statuten bijzondere voorwaarden stellen aan aandeelhouders, bijvoorbeeld met betrekking tot de deelname aan de algemene vergadering, de statuten ook de rechtsgevolgen mogen bepalen, ingeval niet aan de voorwaarden wordt voldaan, zoals opschorting van het deelnamerecht of het stemrecht. ${ }^{59}$ Een ander voorbeeld is het recht om wegens een

51

52

4

Uitgebreid Rohricht, Großkommentar, $\$ 23,177$ e.v.

De Beirat is een orgaan dat kan varierren van Honoratiorengremium, Gesellschafterausschuss (een soort commissie van aandeelhouders) tot Geschaftsfïhrungsgremium. In het GmbH-recht wordt een facultatieve Aufsichtsrat, die op grond van $\$ 52$ GmbHG kan worden ingesteld, meestal Beirat wordt genoemd. Zie hierover Reuter, Der Beirat der GmbH, Festschrift 100 Jahre GmbHG, 1992, blz. 631 e.v.

Rohricht, GroBkommentar, $\$ 23,190$.

Pentz, Munchener Kommentar, $\$ 23,156$. Zie voorts $\$ 3.3 .3$

GeBler, FS Luther, blz.74, 79. Rohricht, GroBkommentar, § 23, 193. Pentz, Münchener Kommentar, § 23, 153, 156. Huffer, Kurzkommentar AktG, § 23, 35, 36.

Rohricht, GroBkommentar, $\$ 23,194$.

Hoffer, Kurzkommentar AktG, $\S 23,37$. Rohricht, GroBkommentar, $\S 23,187,189$. Pentz, Munchener Kommentar, $\$ 23,157$.

In tegenstelling tot het Nederlandse recht, zie $\$ 2.2 .3$.

Rohricht, Großkommentar, \$23, 198 . Geßler, FS Luther, blz. 77. 
'wichtiger Grund' uit een AG te treden. Hoewel de AktG een dergelijk uittredingsrecht niet kent (de GmbHG evenmin), komt volgens Grunewald ook een aandeelhouder in een AG die zijn aandelen niet vrij kan overdragen, dit recht toe. ${ }^{60}$

\section{De ratio van $\$ 23 \mathrm{Abs} .5 \mathrm{AktG}$}

$\S 23$ Abs. 5 AktG is in 1965 in de wet terechtgekomen. Hoewel het dwingendrechtelijke uitgangspunt in de toenmalige literatuur algemeen was aanvaard, achtte de wetgever een 'Klarstellung' geboden, vanwege minder eenduidige jurisprudentie. ${ }^{61}$ Thans worden in de literatuur verschillende redenen aangevoerd ter rechtvaardiging van $\S 23$ Abs. 5 AktG. Hopt acht dwingende door de staat opgelegde normen een logisch vervolg op het negentiende-eeuwse concessiestelsel. Dwingend recht vormt zijns inziens een raison d'être voor de AG, als noodzakelijke voorwaarde voor het verkrijgen van rechtspersoonlijkheid. ${ }^{2}$ Volgens algemene opvatting beoogt $\S 23 \mathrm{Abs}$. $5 \mathrm{AktG}$ rechtszekerheid te bieden door standaardisatie van onder meer de organisatiestructuur, hetgeen de verhandelbaarheid van de aandelen ten goede zou komen. ${ }^{3}$ Het hanteren van een formeel criterium als 'uitdrukkelijk toelaten' bij het beantwoorden van de vraag of van de wet mag worden afgeweken draagt in deze optiek bij aan de verhoging van de rechtszekerheid. Onzekerheid steekt echter weer de kop op bij de vraag wanneer de wet uitputtend is.

De trend tot deregulering heeft in Duitsland tot de discussie geleid of $\S 23$ Abs. 5 AktG niet zou moeten worden herzien. ${ }^{64}$ Mertens noemt $\S 23$ Abs. 5 AktG "die eiserne Klammer, die der Gesetzgeber um die Aktiengesellschaft gelegt hat". ${ }^{65}$ Hopt pleit voor restrictieve interpretatie van $\S 23$ Abs. 5 AktG. ${ }^{66}$ Hirte betoogt dat $\S 23$ Abs. 5 AktG voor beursgenoteerde vennootschappen moet worden beschouwd als minimumnorm, hetgeen betekent dat de wettelijke voorschriften ook zouden kunnen worden vervangen door gelijkwaardige statutaire oplossingen, omdat de aandelen-

\footnotetext{
60 Grunewald, Das Recht zum Austritt aus der Aktiengesellschaft, in: Festschrift Claussen, 1997, blz. 103 e.v. Zie over het uittredingsrecht in het GmbH-recht $\$ 2.3 .2$.

Pentz, Münchener Kommentar, $\$ 23,148$.

Hopt, ZGR Sonderheft 1998, blz. 124. Zie ook Wiedemann, "Erfahrungen mit der Gestaltungsfreiheit im Gesellschaftsrecht", ZGR Sonderheft 1998, blz. 10.

Vgl. GeBler, FS Luther, blz. 70. Mertens, "Satzungs- und Organisationsautonomie im Aktien- und Konzernrecht", ZGR 1994, blz. 428. Rohricht, Großkommentar, $\S 23,167$. Pentz, Munchener Kommentar, $\$ 23,150$.

64 Vgl. Mertens, ZGR 1994, blz, 426 e.V.

Mertens, ZGR 1994, blz. 426.

Hopt, ZGR Sonderheft 1998, blz. 145.
} 
markt als controlemechanisme functioneert. ${ }^{67}$ Röhricht meent daarentegen dat deregulering beter kan plaatsvinden door afzonderlijke regels te herzien, in plaats van te tornen aan het uitgangspunt en de interpretatie van $\S 23$ Abs. 5 AktG. ${ }^{\text {s* }}$

\section{$\S 2.3 .2$ Gestaltungsfreiheit in het GmbH-recht}

Anders dan in het Aktienrecht, geldt in het GmbH-recht de Gestaltungsfreiheit als uitgangspunt; vrijheid behoeft geen rechtvaardiging, dwingend recht daarentegen wel. ${ }^{69}$ In beginsel moet in het $\mathrm{GmbH}$-recht per bepaling worden bezien of deze dwingend of regelend van aard is. Daarbij wordt een onderscheid gemaakt tussen bepalingen die betrekking hebben op de verhouding tussen de vennootschap en derden, de 'Außenverhältnis', waar dwingend recht regel is, en de 'Innenverhältnis', die eerder gekenmerkt wordt door Vertragsfreiheit. ${ }^{70}$ In de interne sfeer komt dwingend $\mathrm{GmbH}$ recht voor bij de bescherming van minderheidsaandeelhouders en in het raamwerk van de $\mathrm{GmbH} .{ }^{n}$ Voor het overige moet de vraag of een bepaling al dan niet dwingend is worden afgeleid uit de bewoordingen. ${ }^{n}$

Niettegenstaande het ontbreken van een algemeen wettelijk criterium, biedt ook de GmbHG aanknopingspunten voor de bepaling van de al dan niet dwingende aard van afzonderlijke bepalingen. Zo schrijft § $25 \mathrm{GmbHG}$ voor dat aandeelhouders van de rechtsgevolgen voortvloeiend uit $\S \S 21-24$ (aangaande kapitaalbeschermingsvoorschriften) niet kunnen worden bevrijd. Van het wettelijke recht op inlichtingen en inzage van de aandeelhouders kan evenmin in de statuten worden afgeweken, op grond van $\S 51 \mathrm{a}$ Abs. 3 GmbHG.

Aanvullend recht wordt bijvoorbeeld aangetroffen in $\S 45$ Abs. 2 GmbHG, dat $\S \S 46-51$ - aangaande de besluitvorming van de algemene vergadering en de rechten van individuele aandeelhouders - van toepassing verklaart, zolang niet daarvan in de statuten is afgeweken. Voorts geeft $\S 26 \mathrm{GmbHG}$ de mogelijkheid in de statuten te bepalen dat betalingen boven de stortingsplicht $($ Nachschuß $)$ worden opgelegd. Dwingend is dan wel dat de betalingsverplichting in proportie tot het aantal aandelen dient te zijn, § 26 Abs. 2 GmbHG.

Hirte, "Die aktienrechtliche Satzungsstrenge: Kapitalmarkt und sonstige Legitimationen versus Gestaltungsfreiheit", ZGR Sonderheft 1998, blz. 83, 97.

Rohricht, GroBkommentar, $\$ 23,167$.

K. Schmidt, blz. 106. Zollner, FS GmbHG, blz. 100.

Zollner, FS GmbHG, blz. 88.

Hommelhoff, "Gestaltungsfreiheit im GmbH-Recht", ZGR Sonderheft 1998, blz. 40 .

Zollner, FS GmbHG, blz. 89, geeft een inventarisatie van zijns inziens dwingende bepalingen. 
Indien de wet zwijgt, is, zoals gezegd, Gestaltumgsfreiheit het uitgangspunt. Dit blijkt bijvoorbeeld uit het feit dat de Bundesgerichtshof het opnemen van een uitstotingsclausule in de statuten toelaatbaar heeft geacht, zonder dat deze een wettelijke grondslag heeft. ${ }^{3}$ De vrijheid is echter wel beperkt; weliswaar mogen de statuten een uitstotingsclausule bevatten, maar deze dient steeds gebaseerd te zijn op een objectieve, in de statuten omschreven reden. ${ }^{7}$ Achterliggende gedachte hierbij is dat een aandeelhouder met een 'Damoklesschwert' boven zijn hoofd niet in staat zal zijn tot zelfstandige oordeelsvorming. ${ }^{75}$ Ook een uittredingsrecht in geval van een 'wichtiger Grund' is door in de rechtspraak als Grundmitgliedsrecht erkend, ondanks wettelijk zwijgen. ${ }^{76}$

Zo versterkt en corrigeert de rechter de liberale inslag van de GmbHG. ${ }^{n}$ Voor correctie heeft hij verschillende methoden tot zijn beschikking. In de eerste plaats kan de rechter nieuwe dwingende normen creëren, door bepalingen uit de AktG analogisch toe te passen. Een voorbeeld hiervan is de regeling van de nietigheid en vernietigbaarheid van besluiten conform $\S \S 241$ AktG e.v. Analogische toepassing veronderstelt evenwel niet automatisch dat deze normen ook in het $\mathrm{GmbH}$-recht dwingend zijn. ${ }^{78}$ $\mathrm{Zo}$ is de termijn waarop de vernietiging van een besluit kan worden gevorderd in het Aktienrecht één maand, terwijl deze in het GmbH-recht 'passend' moet zijn, en dus afwijkend van de - voor het overige analogische toepassing van $\S 243$ AktG.

In de tweede plaats kan hij aanvullende wettelijke bepalingen van dwingende grenzen voorzien. $\S 47$ Abs. 4 GmbHG bepaalt onder meer dat een aandeelhouder niet mag stemmen, indien hij een tegenstrijdig belang heeft. Blijkens $\S 45$ Abs. 2 GmbHG wordt dit als aanvullend recht beschouwd. De Bundesgerichtshof heeft echter geoordeeld dat een aandeelhouder niet over zijn eigen décharge als bestuurder mag stemmen. Het stemverbod van $\S 47$ Abs. 4 GmbHG kent derhalve dwingende grenzen. ${ }^{70}$ Ook aan andere aanvullende rechten worden dwingende grenzen gesteld. Zo mogen het stemrecht, het recht op dividend en het recht op

BGHZ 9, 157, 160. Een besluit tot uitstoting vereist wel een gekwalificeerde meerderheid van drie vierde van het aantal stemmen, vgl. BGH 13 januari 2003, II ZR 227/00, www. bundesgerichtshof.de.

Vgl. Noack, Gesellschaftervereinbarungen bei Kapitalgesellschaften, 1994, blz. 125. Zie ook $\$ 7.3 .3$.

Odersky, "Gestaltungsfreiheit und gerichtliche Kontrolle", ZGR Sonderheft 1998, blz. 109.

Zie o.m. Lutter/Hommelhoff $\$ 34,36$ e.v.

Vgl. Mertens, ZGR 1994, blz. 132. Zollner, FS GmbHG, blz. 90 e.v. Odersky, ZGR Sonderheft 1998, blz. 107 e.v.

Zollner, FS GmbHG, blz. 96.

BGHZ 108, 21, 27. Zie ook Baumbach/Hueck/Zollner § 47, 73. 
liquidatie-overschot slechts worden gewijzigd met de instemming van alle aandeelhouders, zonder dat de wet dit vereist. . $^{\text {s }}$

Deze dwingende grenzen worden veelal gemotiveerd met een beroep op algemene vennootschapsrechtelijke beginselen, waaraan de bij de vennootschap betrokkenen zich dienen te houden. Dat er een gegronde reden voor uitstoting moet bestaan is zo'n beginsel, evenals de Treupflicht en de Gleichbehandlungsgrundsatz. Discussie bestaat over de vraag of de rechter de statuten ook zou mogen onderwerpen aan een Angemessenheitskontrolle in de zin van $\S 242$ BGB (Treu und Glauben). ${ }^{\text {st }}$ Odersky meent dat de $\mathrm{GmbH}$ zich daarvoor niet leent, want de ratio van een dergelijke toetsing bestaat uit het compenseren van ongelijke onderhandelingsposities. Hiervan acht hij geen sprake in besloten vennootschappen. ${ }^{x_{2}}$ Zöllner ziet slechts ruimte voor toetsing van de uitoefening van de uit de statuten voortvloeiende rechten en verplichtingen aan de goede trouw, niet reeds in het stadium van de bepaling van de inhoud ervan..

\section{$\S 2.4$ Engeland}

\section{\$2.4.1 Statutes vs. common law}

Engelse auteurs wijden weinig woorden aan het algemene karakter van de Companies Act 1985 (CA 1985). "Either there is no clear philosophy underlying United Kingdom company law or it is very hard to discern," aldus Freedman. ${ }^{\mathrm{s}}$ Buiten de CA 1985 wordt het Engelse vennootschapsrecht aangetroffen in beginselen van common law en equity. ${ }^{.5}$

Wet en common law zijn zelfstandige rechtsbronnen, die naast elkaar bestaan. Doordat er geen sprake is van een hiërarchie tussen de wet en de common law, verloopt de interactie nogal eens moeizaam en lijkt het soms het karakter van een concurrentiestrijd te krijgen. ${ }^{\text {ss }}$ Indachtig deze concurrentiestrijd, is het niet vreemd

\footnotetext{
80

$\S 242$ BGB luidt: Der Schuldner ist verpflichtet, die Leistung so zu bewirken, wie Treu und Glauben mit Rocksicht auf die Verkehrssitte es erfordern.

Odersky, ZGR Sonderheft 1998, blz. 111.

Zollner, FS GmbHG, blz. 110.

Freedman, Reforming Company Law in: Perspectives on Company Law: I, F. Macmillan Patfield (ed.), 1995, blz. 208.

sis

Zie voor het onderscheid tussen common law en equity James' Introduction to English Law, 1996. Vennootschapsrecht valt onder de Chancery Court, vandaar dat veel beginselen als fiduciary duties een equity-basis ( $\mathrm{nl}$. de trust) hebben. Zie voorts Sealy, Company law and Commercial Reality, 1984, blz. 36.

M6

Het verschil tussen common law en statute is door Lord Reid eens vergeleken met "the difference between old-fashioned, hand-made, expensive, quality goods and the brash products of modern
} 
dat rechters geneigd zijn de wet een beperkte uitleg te geven. Als redenen voor restrictieve interpretatie van wetgeving worden aangevoerd dat dit de rechtszekerheid dient en het constitutionele argument dat de rechter niet op de stoel van de wetgever moet gaan zitten. ${ }^{87}$ Tot in de jaren zeventig van de vorige eeuw hanteerden rechters de "golden rule": bij de interpretatie van een wetsbepaling werden de woorden naar hun grammaticale en normale betekenis uitgelegd, tenzij dit tot een absurde of inconsistente uitkomst leidde. ${ }^{88}$ De "intention of Parliament" moest duidelijk blijken uit de woorden van de bepaling:

"We are seeking the meaning of the words which Parliament used. We are seeking not what Parliament meant but the true meaning of what they said."

De wetgever reageerde hierop door te trachten alle mogelijke situaties te ondervangen, hetgeen resulteerde in uiterst gedetailleerde en gecompliceerde wetgeving. ${ }^{\text {90 }} \mathrm{Zo}$ ontstond een vicieuze cirkel van letterlijk interpreterende rechters ("If the words of an Act are clear, you must follow them, even though they lead to a manifest absurdity" "1 ) en een "piecemeal patchwork" van onleesbare wetsbepalingen. Mede onder invloed van het Europese recht is de vicieuze cirkel doorbroken; sinds enkele decennia is er een trend in de richting van een meer teleologische interpretatie te onderkennen ${ }^{93}$ In de uitspraak Pepper v Hart uit 1993 heeft de House of Lords voor het eerst overwegingen uit de parlementaire geschiedenis in het oordeel betrokken:

"The days have long passed when the courts adopted a strict-constructionist view of interpretation which required them to adopt the literal meaning of the language. The courts now adopt a purposive approach which seeks to give effect to the true purpose of legislation and are prepared to look at much extraneous material that bears upon the background against which the legislation was enacted."

Ook de wetgever laat zich niet onbetuigd. Veel rechtsgebieden zijn hervormd of in een hervormingsproces verwikkeld. ${ }^{95}$ Ook het vennootschapsrecht is aan zo'n hervormingsproces onderworpen. ${ }^{\%}$

technology", geciteerd door Munday, "The common lawyer's philosophy of legislation", Rechtstheorie 1983, blz. 193. Beatson, "Has the Common Law a Future?", Cambridge Law Journal 1997, blz. 300, citeert Roscoe Pound, die spreekt van olie en water.

Munday, Rechtstheorie 1983, blz. 194.

Cross, Statutory Interpreation, $3^{\mathrm{e}}$ druk, 1995, blz. 16.

Lord Reid in Black-Clawson International Lid v Papienwerke Waldhof-Aschaffenburg AG [1975], geciteerd door Cross, 1995, blz. 26.

90 Munday, Rechtstheorie 1983, blz. 198. Sealy, 1996, blz. 12. Freedman, Reforming Company Law, in: Perspectives on Company Law: 1, F. Macmillan Patfield (red.), 1995, blz. 204.

Lord Esher in 1892 geciteerd door Munday, Rechtstheorie 1983, blz. 193.

Sealy, 1996, blz. 58, over de Companies Act 1980.

Cross, 1995, blz. 106. Sealy, 1996, blz. 4. Munday, Rechtstheorie 1983, blz. 203.

Lord Griffiths in Pepper v Hart, geciteerd door Cross, 1995, blz. 10.

Bijvoorbeeld de Civil Procedure Rules die in 1998 in werking zijn getreden, een codificatic van 
De CA 1985 beoogt geen codificatie van het vennootschapsrecht, maar is bedoeld als aanvulling op het bestaande recht, de common law. ${ }^{97}$ Inmiddels heeft het recht in de CA 1985 een zodanige omvang aangenomen, dat spreken van 'aanvulling' ongepast zou zijn. Nog steeds zijn echter belangrijke delen van het vennootschapsrecht onaangetast gelaten door de wetgever. Deze nevenschikking van common law en de CA 1985 verklaart wellicht ook waarom de wet niet voorziet in een coherente institutionele structuur, maar uitgaat van wat partijen (aandeelhouders) bij overeenkomst (memorandum en articles) regelen. ${ }^{98}$ Dit maakt het Engelse vennootschapsrecht al met al behoorlijk ingewikkeld. ${ }^{99}$

In het Final Report van het Department of Trade and Industry ter hervorming van het vennootschapsrecht wordt als uitgangspunt genomen dat het vennootschapsrecht primair 'enabling' of faciliterend zou moeten zijn:

"i.e. it should provide the means for those engaged in business and other corporate activity to arrange and manage their affairs in the way they believe is most likely to lead to mutual success and effective productive activity."

Regulerende interventie kan echter volgens de opstellers van het rapport in vier gevallen geboden zijn:

1. Indien zonder wettelijke bepaling het gewenste resultaat niet kan worden bereikt. Dit geldt bijvoorbeeld voor het verkrijgen van rechtspersoonlijkheid;

2. Indien het door partijen gewenste resultaat zo voorspelbaar is dat de wet kan voorzien in een aanvullende oplossing, zoals de standaard statuten van Table A;

3. Indien het risico bestaat dat de markt faalt, zodat aan partijen die niet in staat zijn om zichzelf te beschermen wettelijke bescherming moet worden geboden. Bepalingen die aandeelhouders beschermen tegen bestuurders en

het burgerlijke procesrecht. Tevens wordt voorgesteld het strafrecht te codificeren.

Zie $\$ 1.4$.

97 Sealy, 1984, blz. 35. Voor het verschil tussen codificerende en consoliderende wetgeving, zie Cross, 1995, blz 6 .

Vgl. Sealy, The Enforcement of Partnership Agreements, Articles of Association and Shareholder Agreements in: Equity and Commercial Relationships, P.D. Finn (red.), 1987, blz. 92.

Vgl. Cheffins, 1997, blz. 308: "UK companies legislation is unnecessarily complex und suffers from overly technical and prolix drafting."

(10) Zo reeds Sealy, "A Company law for Tomorrow's World", Company Lawyer 1982, blz. 195, die Ballantine citeert: "The primary purpose of corporation laws is not regulatory. They are enabling acts, to authorize businessmen to organize and operate their business, large or small, with the advantages of corporate mechanism." 
bepalingen die verplichten tot openbaarmaking van gegevens behoren tot deze categorie;

4. Indien er een algemeen belang met de activiteit in kwestie is gemoeid, hetgeen vereist dat betrokkenen verantwoording afleggen aan een wijdere kring dan de betrokkenen bij de vennootschap. ${ }^{101}$

\section{$\S 2.4 .2$ Dwingende en aanvullende regels}

Uit het Engelse systeem van nevengeschikte wet en common law enerzijds, en standaard statuten in Table A anderzijds, vloeit voort dat de regulerende functie de overhand heeft in de wet. Section 14(1) CA 1985 bepaalt dan ook:

"Subject to the provisions of this Act, the memorandum and articles, when Registered, bind the company and its members to the same extent as if they respectively had been signed and sealed by each member, and contained covenants on the part of each member to observe all the provisions of the memorandum and of the articles."

Vaak staat in de wettelijke bepaling zelf een toelichting over de reikwijdte ervan. Aanvullende bepalingen worden met name aangetroffen in Table A, bijvoorbeeld over de rechten en verplichtingen van aandeelhouders, maar bijvoorbeeld ook section $370 \mathrm{CA} 1985$ bevat aanvullend recht ("The following provisions have effect in so far as the articles of the company do not make other provisions in that behalf').

Op grond van section 379A CA 1985 kan een private company opteren voor het elective regime. Dit betekent dat de vennootschap wordt ontheven van de verplichting tot het voorleggen van de jaarstukken aan de algemene vergadering (section 252), van de verplichting tot het houden van een jaarlijkse algemene vergadering (section $366 \mathrm{~A}$ ) en van de verplichting tot de jaarlijkse benoeming van een accountant (section 386). Vereist is een elective resolution, met algemene stemmen van alle aandeelhouders. ${ }^{102} \mathrm{De}$ gedachte is dat in veel vennootschappen deze verplichtingen geen inhoudelijke relevantie bevatten en meer een papieren aangelegenheid zijn. In de White Paper worden regel en uitzondering zelfs omgedraaid; een vennoot-

101 DTI Final Report, 2001, blz. 5.

Een elective resolution heeft pas effect indien de aandeelhouders ten minste 21 dagen vantevoren bericht hebben gekregen en alle aandeelhouders die gerechtigd zijn tot deelname en stemming ermee hebben ingestemd, section 379A (2) CA 1985. 
schap die wel jaarvergaderingen e.d. wil houden, kan opteren voor het mandatory scheme. ${ }^{103}$

Hoewel in de wet vaak staat aangegeven of een bepaling als dwingend of aanvullend moet worden beschouwd, heeft de rechter het laatste woord over de vraag of er sprake is van een toegelaten aanvulling op de wet, of een afwijking in strijd met de wet. In Re Peveril Gold Mines Ltd werd een bepaling in de articles, die het wettelijke recht om ontbinding van de vennootschap te verzoeken beperkte, in strijd met de wet geacht. Een van de redenen hiervoor was, dat de bewoordingen van de wet niet uitdrukkelijk in de mogelijkheid van statutaire afwijking voorzagen. ${ }^{104}$

Niettemin achtte de House of Lords in de omstreden zaak Bushell $v$. Faith een statutaire bepaling die op gespannen voet stond met section 148 CA 1948 (thans section 303 CA 1985) toelaatbaar. ${ }^{105}$

In deze zaak ging het om een vennootschap met drie aandeelhouders, die elk een gelijk aantal aandelen bezaten. Zij waren tegelijkertijd bestuurders van de vennootschap. Section 148 CA 1948 luidt: "A company may by ordinary resolution remove a director before the expiration of his period of office, notwithstanding anything in its articles or in any agreement between it and him." Ter ontwijking van section 148 hadden de aandeelhouders bij de statuten bepaald dat, indien in een algemene vergadering een voorstel zou worden gedaan tot ontslag van een van hen als bestuurder, het stemrecht op de aandelen van de desbetreffende aandeelhouder met betrekking tot dit voorstel zou worden verdrievoudigd. Zo makten zij hun ontslag in feite onmogelijk.

Section 148 CA 1948 is op instigatie van het Cohen Committee in 1948 in de wet terechtgekomen, om het ontslag van bestuurders te vergemakkelijken. Vóór die tijd kon een bestuurder vaak alleen worden ontslagen bij special resolution of door statutenwijziging. ${ }^{106}$

Ondanks het feit dat s. 148 CA 1948 overduidelijk dwingend recht bevat ("notwithstanding anything in its articles or in any agreement between it and him"), overwoog Lord Reid:

"all that Parliament was seeking to do thereby was to make an ordinary resolution sufficient to remove a director. Had Parliament desired to go further and enact that every share entitled to vote should be deprived of its special rights under the

103 White Paper Modernising Company Law, juli 2002, blz. 18. Companies Bill, draft clause 128 , www.dti.gov.uk/companiesbill/whitepaper.htm.

Re Peveril Gold Mines Ltd [1898] 1 Ch 122. Zie ook \$ 3.4.1.

105

Bushell v. Faith [1970] AC 1099, [1970] 1 All ER 53, [1970] 2 WLR 272.

Vgl. Davies, blz. 188 
articles it should have said so in plain terms by making the vote on a poll one vote one share."

Volgens dissenting judge Lord Morris zou deze interpretatie van section 148 CA 1948 een "mockery of the law" maken, aangezien de uitkomst evident in strijd was met de bedoeling van de wetgever. De meerderheid van de Lords had echter oog voor andere belangen, $\mathrm{nl}$. de bescherming van minderheidsaandeelhouders in quasi-partnerships. In de woorden van Lord Donovan:

"When therefore it is said that a decision in favour of the respondent in this case would defeat the purpose of the section and make a mockery of it, it is being assumed that Parliament intended to cover every possible case and block up every loophole. I see no warrant for any such assumption. A very large part of the relevant field is in fact covered and covered effectively. And there may be good reasons why Parliament should leave some companies with freedom of manoeuvre in this particular matter. There are many small companies which are conducted in practice as though they were little more than partnerships, particularly family companies running a family business; and it is, unfortunately, sometimes necessary to provide some safeguard against family quarrels having their repercussions in the boardroom."

In continentale termen vervat, beschouwt de House of Lords de clausule in Bushell v. Faith kennelijk als statutaire aanvulling op de wet, in plaats van een afwijking, gelet op de uitwerking van de bepaling in de context van een familievennootschap. Het doorslaggevende criterium lijkt veeleer de concrete benadeling van derden te zijn, dan strijd met de wet sec.

\section{$\S 2.5$ Evaluatie}

Zowel artikel 2:25 BW als $\S 23$ Abs. 5 AktG scheppen een dwingendrechtelijk kader voor kapitaalvennootschappen. Als hulpmiddel bij de interpretatie van afzonderlijke bepalingen voorzien zij het Nederlandse vennootschapsrecht, resp. het Duitse Aktienrecht, van een dwingendrechtelijk uitgangspunt. Het is de wet die bepaalt in hoeverre ervan mag worden afgeweken. Bij nadere beschouwing van de respectievelijke wetteksten springen echter drie verschillen in het oog.

In de eerste plaats maakt $\S 23 \mathrm{Abs}$. $5 \mathrm{AktG}$ duidelijk dat het verbod tot afwijking zich beperkt tot de statuten. Uitsluitend de verhouding tussen de wet en de statuten wordt benadrukt. Dit blijkt niet expliciet uit artikel 2:25 $\mathrm{BW}$, waardoor de vraag opkomt of ook overeenkomsten worden geraakt. In de tweede plaats moet op grond van $\S 23$ Abs. 5 AktG de wet uitdrukkelijk 
afwijking toelaten, terwijl artikel 2:25 BW volstaat met de zinsnede "voor zover dit uit de wet blijkt". In de derde plaats verduidelijkt $\S 23$ Abs. 5 AktG dat aanvullende statutaire bepalingen zijn toegelaten, tenzij de wet uitputtend is bedoeld.

Net zo min als in het Aktienrecht mogen de statuten in Nederland afwijken van wettelijke bepalingen die niet uitdrukkelijk deze mogelijkheid bieden. Wel mogen de statuten dergelijke bepalingen aanvullen. Wanneer sprake is van een afwijking of van een aanvulling, blijft onduidelijk. Wat het Nederlandse vennootschapsrecht minder dwingend maakt dan het Aktienrecht, is naar mijn mening niet zozeer de vagere omschrijving van artikel 2:25 BW, maar veeleer het feit dat de Nederlandse wet meer bepalingen bevat, die uitdrukkelijk aangeven dat afwijking mogelijk is.

Men kan zich afvragen of de algemene interpretatievoorschriften in het Nederlandse recht en het Duitse Aktienrecht echt meer duidelijkheid bieden dan de bijzondere voorschriften in de afzonderlijke bepalingen in het Engelse recht en het Duitse GmbH-recht. Hoewel in de Duitse literatuur pogingen worden gedaan algemene interpretatierichtlijnen te geven, komt de vraag naar afwijking of aanvulling in wezen telkens neer op de interpretatie van elke bepaling afzonderlijk aan de hand van diens ratio, zoals ook blijkt uit de Nederlandse doctrine. Het verschil tussen een dwingendrechtelijk kader zoals gegeven door artikel 2:25 BW en $\S 23 \mathrm{Abs}$. 5 AktG enerzijds, en dwingendrechtelijke grenzen aan de contracts- en inrichtingsvrijheid in het Engelse en Duitse GmbH-recht anderzijds, is echter dat bij het zwijgen van de wet in het eerste geval dient te worden gerechtvaardigd waarom een statutaire regeling zou zijn toegestaan, terwijl in het laatste geval dient te worden gerechtvaardigd waarom een statutaire regeling zou zijn verboden.

Deze 'omkering van de bewijslast' kan met betrekking tot de statuten worden gerechtvaardigd met een beroep op de bescherming van de bij de vennootschap betrokkenen die niet of nauwelijks invloed kunnen uitoefenen op de totstandkoming van de statuten, zoals crediteuren, later toetredende aandeelhouders en tot op zekere hoogte ook minderheidsaandeelhouders. Reeds bij deze rechtvaardigingsgrond zijn kanttekeningen te plaatsen ten aanzien van besloten vennootschappen. ${ }^{107}$ Mijns inziens beoogt artikel 2:25 BW echter in ieder geval niet om deze 'omkering' ook ten aanzien van overeenkomsten tussen aandeelhouders te laten gelden. Hierop wordt verder ingegaan in het volgende hoofdstuk.

${ }^{107}$ Zie $\$ 4.5$ 
Naar mijn mening dient artikel 2:25 BW derhalve naar huidig recht te worden opgevat in de zin dat deze bepaling uitsluitend doelt op de verhouding tussen de wet en de statuten. Deze opvatting vindt steun in de ontstaansgeschiedenis van artikel 2:25 BW, waar in de memorie van toelichting slechts van afwijking bij de statuten gewag werd gemaakt en bovendien de contractsvrijheid werd vooropgesteld. Hoewel het dwingendrechtelijk uitgangspunt verdedigbaar is ten aanzien van de naamloze vennootschap met beleggers als aandeelhouder, pleit ik ervoor om in ieder geval voor de besloten vennootschap het uitgangspunt om te keren. Dit wordt nader uitgewerkt in hoofdstuk 4 . 



\section{Hoofdstuk 3 Afstand van recht}

\section{$\S 3.1 \quad$ Inleiding}

In hoofdstuk 2 is uiteengezet dat artikel 2:25 BW in ieder geval het wettelijk kader schept ten aanzien van statutaire afwijkingsmogelijkheden en wat in dit opzicht de betekenis is van dwingend recht. Minder duidelijk is in hoeverre artikel 2:25 BW van belang is voor buitenstatutaire rechtshandelingen. Wordt hetgeen bij statuten is verboden, wel toegestaan als dit bij overeenkomst wordt bepaald? In dit hoofdstuk wordt de proef op de som genomen aan de hand van de vraag in hoeverre aandeelhouders afstand kunnen doen van hun rechten.

De meeste rechten van aandeelhouders worden in boek $2 \mathrm{BW}$ dwingend omschreven. Zo heeft iedere aandeelhouder stemrecht, recht op deelname aan de algemene vergadering, het recht om vernietiging van een besluit van een orgaan te vorderen. Daarnaast hebben aandeelhouders die ten minste tien procent van het geplaatste kapitaal vertegenwoordigen het recht om een enquête te verzoeken en bijeenroeping van de algemene vergadering. Zonder wettelijke grondslag mogen deze rechten niet statutair worden ingeperkt.' De vraag is echter in hoeverre aandeelhouders vrij zijn om zelf deze rechten in te perken; anders gezegd, in hoeverre zij vrijelijk over hun rechten en bevoegdheden kunnen beschikken.

Indien aandeelhouders vrij zijn in de uitoefening van hun rechten, rijst de vraag of zij afstand kunnen doen van deze rechten en/of een nadere invulling kunnen geven aan hun bevoegdheden, bijvoorbeeld in een aandeelhoudersovereenkomst. Een andere vraag die in dit verband aan de orde komt is in hoeverre aandeelhouders afstand kunnen doen van hun recht de boordeling van geschillen aan de overheidsrechter te onderwerpen, met andere woorden: of de rechten en bevoegdheden van aandeelhouders in het kader van vennootschappelijke geschillen voor arbitrage vatbaar zijn.

Zie $\$ 2.2 .3$. 
Hiertoe wordt eerst onderzocht wat afstand van recht naar Nederlands recht eigenlijk inhoudt.

Bij het beantwoorden van deze vragen worden mede in ogenschouw genomen het Duitse en Engelse recht. In deze rechtsstelsels is het niet vanzelfsprekend dat rechten van aandeelhouders in besloten vennootschappen niet statutair mogen worden beperkt, aangezien de contractsvrijheid, dan wel Gestaltungsfreiheit het uitgangspunt is. Rechten van aandeelhouders zijn derhalve in deze stelsels in beginsel aanvullend van aard, tenzij de wet of de jurisprudentie dwingende grenzen stelt. Ook naar Engels en Duits recht rijst in dit verband de vraag in hoeverre aandeelhouders individueel afstand kunnen doen van hun recht(en). De toepassing van het leerstuk van afstand in het vennootschapsrecht verschilt echter. In het Engelse en Duitse recht dient een niet voor afstand vatbaar recht als dwingende grens aan aanvullende rechten te worden beargumenteerd, terwijl in Nederland het leerstuk van afstand van recht de dwingende kracht van een recht juist kan relativeren. Ook dit is geval van "omkering van de bewijslast".

\section{$\S 3.2$ Nederland}

\section{\$3.2.1 Afstand van recht}

Met afstand van recht wordt bedoeld de rechtshandeling, gericht op het doelbewust prijsgeven van een recht.' Het doelbewust prijsgeven laat onverlet dat afstand ook stilzwijgend kan geschieden. Veelal gaat het recht door de afstand teniet. Afstand van recht is op een aantal plaatsen geregeld in het BW. Zo kunnen rechthebbenden afstand doen van hun recht van eigendom op roerende zaken, van beperkte rechten en van vorderingsrechten, vgl. artt. 3:81 lid 2 sub c, 5:18, 6:160 BW. Als een bijzondere vorm van afstand wordt voorts wel de bevestiging van een vernietigbare rechtshandeling in de zin van art. 3:55 BW aangemerkt. Hiermee wordt afstand gedaan van de bevoegdheid zich op een vernietigingsgrond te beroepen. ${ }^{*}$

Dat afstand van recht op een aantal plaatsen in de wet geregeld is, betekent niet dat afstand steeds een wettelijke grondslag behoeft. Aangeno-

Zie $\$ 2.5$.

Zie hierover Aaftink, Afstand van vermogensrechten, 1974 en Tjittes, Afstand van recht, 1992.

Vgl. onder het oude BW HR 1 december 1938, NJ 1938, 459 (Illustra/Reinartz): "dat bekrachtiging in wezen is het doen van afstand van een tevoren bestaand recht om beroep te doen op de nietigheid." Uitgebreid Hijma, Nietigheid en vernietigbaarheid van rechtshandelingen, 1988, blz 162 e.v., die de bevestiging kwalificeert als indirecte afstand van recht. Zie ook Tjittes, 1992, nr. 40. 
men wordt dat men in beginsel afstand kan doen van subjectieve rechten. Meijers omschrijft een subjectief recht als een bijzondere door het recht iemand toegekende bevoegdheid, die hem verleend wordt om zijn belang te dienen. ${ }^{6}$ Aaftink meent, in navolging van Meijers, dat een bevoegdheid die een onderdeel is van een subjectief recht, zelf geen subjectief recht is. Hij noemt als voorbeeld de beschikkingsbevoegdheid bij het eigendomsrecht. Indien de eigenaar van een stuk grond met een ander overeenkomt dat hij die grond niet zal bebouwen, heeft hij geen afstand gedaan van zijn bevoegdheid de grond te bebouwen, maar zich slechts contractueel verplicht jegens de ander van deze bevoegdheid geen gebruik te maken. Het verschil is dat in geval van afstand deze bevoegdheid ook tegenover derden niet meer zou bestaan.?

Dit ligt zijns inziens anders met betrekking tot relatieve rechten, die in beginsel slechts bevoegdheden meebrengen tegenover één of meer personen. Komt men nu met de wederpartij overeen dat men van een bepaalde bevoegdheid zoals de bevoegdheid om het verschuldigde in rechte te vorderen, geen gebruik zal maken, dan bestaat die bevoegdheid tegenover niemand meer. Deze bevoegdheid is dus wel prijsgegeven, aldus Aaftink. ${ }^{8}$ In het huidige recht wordt deze vorm van afstand aangetroffen in artikel 6:160 BW. Tjittes vermeldt dat van een aantal bevoegdheden, die niet als subjectieve rechten zijn aan te merken, afstand kan worden gedaan, maar geeft niet aan welke.' Gedacht zou hierbij kunnen worden aan de eerder vermelde bevestiging in de zin van artikel 3:55 BW..$^{10}$

Afstand van recht is nietig als deze in strijd is met een dwingende wetsbepaling, de goede zeden of de openbare orde." In sommige gevallen is het doen van afstand uitdrukkelijk verboden. Zo bepaalt artikel 3:322 lid 3 BW dat geen afstand van het recht op het inroepen van verjaring kan worden gedaan, voordat de verjaring voltooid is. In andere gevallen blijkt het verbod van afstand uit de strekking van de wet, bijvoorbeeld vanwege strijd met het mededingingsrecht. ${ }^{12}$

Tjittes, 1992, nr. 2. Aaftink, 1974, blz. 33 e.v.

Meijers, Algemene Begrippen, blz. 86.

Aaftink, 1974, blz. 26/27.

Aaftink, 1974, blz. 69 .

Tjittes, 1992, nr. 2.

Zie De Kluiver/Meinema, "Dwingend vennootschapsrecht na de Wet herziening preventief toezicht en de mogelijkheden van statutaire of contractuele afwijking en aanvulling", WPNR 2002, blz. 648 e.v.

Tjittes, 1992, nr. 14.

Zo oordeelt het Hof van Justitie van de EG dat een niet-betwistingsbeding in een octrooilicentieovereenkomst op grond van de juridische en economische context het karakter kan hebben van een mededingingsbeperking in de zin van art. 85 (thans art. 81) lid 1 EEG-Verdrag, met als 
Een voorbeeld uit het Europese recht biedt het arrest Daddy's Dance Hall. Richtlijn 77/187/EEG beschermt werknemers in geval van overgang van ondernemingen. Het Hof van Justitie van de EG overweegt:

"Aangezien deze bescherming van openbare orde is en de partijen bij de arbeidsovereenkomst er dus niet over kunnen beschikken, zijn de bepalingen van de richtlijn, en met name die inzake de bescherming van werknemers tegen ontslag bij overgang, in zoverre als dwingend te beschouwen voor de werknemers dat er niet in ongunstige zin van mag worden afgeweken. Hieruit volgt, dat de werknemers niet kunnen afzien van de rechten die de richtlijn hun toekent, en dat hun rechten niet mogen worden verminderd; ook niet met hun instemming."13

De reden dat rechten niet voor afstand vatbaar zijn, kan zowel zijn gelegen in het feit dat derden door de afstand benadeeld worden, als vanwege de mogelijke benadeling van de zwakkere partij. ${ }^{4}$

\section{\$ 3.2.2 Afstand van vennootschapsrechten?}

In het vennootschapsrecht leidt de rechtsfiguur 'afstand van recht' een min of meer verborgen bestaan. Uitzondering hierop vormt art. 2:201 $a \mathrm{BW}$, dat bepaalt dat de rechter een vordering tot uitkoop tegen alle gedaagden afwijst, indien een eiser jegens een gedaagde afstand heeft gedaan van zijn bevoegdheid de vordering in te stellen. Voorts komt het doen van afstand in de literatuur sporadisch ter sprake. Zo meent Maeijer dat houders van bijzondere rechten in de verdwijnende rechtspersoon van deze rechten afstand kunnen doen. ${ }^{\text {s }}$ Volgens hem kunnen aandeelhouders niet bij voorbaat afstand doen van hun bevoegdheid een enquête te verzoeken, wegens het dwingendrechtelijk karakter ervan. ${ }^{16}$ Kennelijk acht hij afstand van de bevoegdheid in een concreet geval wél mogelijk. Dortmond beschouwt de stemovereenkomst strekkende tot het benoemen van de eigen bestuurder of commissaris als het doen van afstand van het recht om de bindende

sanctie nietigheid, zaak van 27 september 1988, NJ 1991, 61 (Bayer en Henneckes/Sullhofer).

HvJEG zaak 324/86, 10 februari 1988, Jur. 1988, blz. 739, NJ 1990, 423 (Daddy's Dance Hall). Zie hierover Van Straalen, Behoud van rechten van werknemers bij overgang van onderneming. 1999, blz. 144, e.v.

Zie $\$ 1.5$. Vgl, Aaftink, 1974, blz. 84, die enerzijds de openbare orde en de goede zeden als ratio onderscheidt, anderzijds de bescherming van de rechthebbende.

is Asser-Maeijer 2-III, nr. 577.

16. Asser-Maeijer 2-III, nr. 516. Zo ook Treurniet, NV 1974, blz 91 en Lubbers, NV 1975, blz. 124. 
voordracht te doorbreken. ${ }^{17}$ In de nota naar aanleiding van het verslag van de Wet herziening preventief toezicht wordt gesteld dat de algemene vergadering geen afstand kan doen van het recht om de jaarrekening vast te stellen. ${ }^{18}$

Uit OK 15 oktober 1992, NJ 1993, 210 (Heuga) kan indirect worden afgeleid dat de Ondernemingskamer het recht van advies van de Ondernemingsraad voor afstand vatbaar acht. De Ondernemingskamer overwoog namelijk dat de Ondernemingsraad in casu met het tekenen van de overeenkomst ten aanzien van de toepasselijkheid van het structuurregime geen afstand van het adviesrecht had gedaan.

De algemene vraag of rechten en bevoegdheden van aandeelhouders wel voor afstand vatbaar zijn, werd tot op heden niet gesteld. ${ }^{19}$

Uit artikel 2:25 BW vloeit reeds voort, dat rechten van aandeelhouders hen niet in de statuten kunnen worden ontnomen. De combinatie van rechten die de wet aan aandeelhouders heeft toegekend is niet alleen in het belang van de aandeelhouders zelf, maar heeft daarenboven de functie een machtsevenwicht in de vennootschap te bewerkstelligen, door aandeelhouders in staat te stellen toezicht uit te oefenen op het bestuur. Bij de behandeling in de Eerste Kamer van de Wet op de naamlooze vennootschappen 1928 meende minister Donner derhalve dat sommige rechten van aandeelhouders "onaantastbaar" moesten zijn, op grond van het algemeen belang:

"Het staat dus zoo, dat men niet kan zeggen (...): de wet geeft hier aan de aandeelhouders souvereine rechten, schept voor de aandeelhouders grondrechten. Neen, Mijnheer de Voorzitter, de zaak is eenvoudig zóó, dat naar de beginselen van ons privaatrecht de aandeelhouders die rechten hebben, en het is dus niet de vraag, of men die geven, maar of en in hoever men die ontnemen zal. Nu kan men natuurlijk zeggen - zooals ook hier gedaan is -: met dat ontnemen van dit recht aan de aandeelhouders heeft het recht zich niet te bemoeien; dat kan aan de contractsvrijheid worden overgelaten. Men kan dit negativisme allereerst bestrijden uit een oogpunt van bescherming van aandeelhouders tegen zich zelf of tegen een toevallige meerderheid uit hun midden. Het is, in overeenstemming met andere gebieden van het recht, dat men, ter bescherming, ik herhaal het, niet slechts van de aandeelhouders als groep, maar ook van de individueele aandeelhouders binnen de groep, een zeker minimum van rechten als onaantastbaar stelt. Maar - en hierop wil ik de nadruk leggen - het gaat bij een dergelijke beperking van het ontnemen der rechten niet slechts over het aandeelhoudersbelang, maar daarbovenuit ook over het algemeen belang. En hier sluit ik aan op wat ik daar juist heb gezegd over het

Dortmond, Stemovereenkomsten rondom de eeuwwisseling, 2000, blz. 10.

TK 1999-2000, 26277 , nr. 5, blz. 10.

Zie voor een eerste poging De Kluiver/Meinema, WPNR 2002, blz 652. 
bijzonder gevaar, dat de rechtsvorm schept (beperkte aansprakelijkheid, MM). De ondernemers hebben niet meer het geweldige lood aan de vleugelen, dat voor den buiten rechtpersoon werkenden ondernemer is gelegen in het besef, dat zijn gansche economische bestaan inzet is. Machtsophooping krijgt hier een accent van gevaar en óók daarom is het goed, dat niet volledige terugdringing mogelijk wordt, opdat eenig tegenwicht blijve. Men heeft hier gesmaald over "democratie", Mijnheer de Voorzitter! Daar heeft het niets mee te maken, het is eenvoudig een heel nuchtere quaestie van "psychologie", "no

Aandeelhouders kunnen naar mijn mening evenmin individueel afstand doen van deze rechten. Deze rechten kunnen mijns inziens worden beschouwd als afhankelijke rechten, verbonden met het aandeel, in de zin van artt. 3:7 jo. 3:82 BW. Een aandeel is een subjectief recht, waarover een aandeelhouder kan beschikken; hij kan het aandeel vervreemden en bezwaren. Rechten van aandeelhouders kunnen niet zelfstandig worden overgedragen; als afhankelijke rechten zijn zij zelf geen subjectieve rechten. Dit betekent dat aandeelhouders geen afstand kunnen doen van deze rechten in goederenrechtelijke zin. Iets anders is dat de wet kan bepalen dat het stemrecht kan worden toegekend aan een beperkt gerechtigde op het aandeel, of kan voorzien in rechten voor certificaathouders. ${ }^{21}$

Aandeelhouders kunnen wel afstand doen van een concreet vorderingsrecht, voortvloeiende uit een hen toekomend recht. Heeft een aandeelhouder recht op $x$ euro aan dividend in een bepaald jaar, dan kan hij afstand doen van de aanspraak op dividend, hetgeen leidt tot het tenietgaan van de verbintenis (vgl. artikel 6:160 BW). Een aandeelhouder kan eveneens afstand doen van de bevoegdheid tot het inroepen van de vernietigbaarheid van een concreet besluit. ${ }^{22}$ Zo kan de bevestiging op grond van artikel 2:15 lid $6 \mathrm{BW}$ als een vorm van afstand worden beschouwd. ${ }^{2}$ Naar mijn mening kan afstand van de vernietigingsbevoegdheid ook voortvloeien uit een bevestiging in de zin van artikel 3:55 BW. Een bevestiging is immers een eenzijdige, vormvrije rechtshandeling, die uitdrukkelijk of stilzwijgend kan geschieden. ${ }^{24}$ Afstand van dergelijke rechten kan niet bij voorbaat worden

Hand. 1927-1928 I, blz. 979.

Zie $\$ 3.2 .3$.

Een dergelijke bevoegdheid kan worden gekwalificeerd als wilsrecht, vgl. Aaftink, diss., blz. 63 e.v.

Zie ook $\$ 6.2 .5$.

Anders Asser-Van der Grinten-Macijer, 2-II, nr. 148, die meent dat artikel 3:55 BW, mede gezien de bijzondere voorziening van artikel 2:15 lid $6 \mathrm{BW}$, geen toepassing kan vinden ten aanzien van een vernietigbaar besluit. Wel acht hij denkbaar een afstand van de bevoegdheid om de vernietigingsvordering in te stellen. 
bewerkstelligd. ${ }^{25}$ Dit zou immers betekenen dat aandeelhouders hun rechten zouden opgeven, die vervolgens teniet zouden gaan. Zoals hierboven is betoogd, is dat niet mogelijk. ${ }^{26}$

\section{§3.2.3 Afzien van de uitoefening van individuele rechten}

De vraag rijst dan of aandeelhouders wel mogen overeenkomen dat zij geen gebruik zullen maken van hun rechten. Een dergelijke afspraak doet de rechten niet tenietgaan, maar heeft louter verbintenisrechtelijke werking. ${ }^{27}$ Dit onderscheid tussen 'afstand' met goederenrechtelijke werking en 'afzien' met verbintenisrechtelijke werking lijkt in de literatuur nauwelijks te worden gemaakt. ${ }^{2 \mathrm{~s}}$

Mijns inziens dient voorop te staan dat aandeelhouders vrij zijn om afspraken inzake de uitoefening van rechten en bevoegdheden te maken, tenzij deze in strijd zijn met artikel 3:40 BW. Het gaat er dan om, vast te stellen welke rechten uit oogpunt van algemeen belang c.q. de vennootschappelijke orde in besloten vennootschappen 'onaantastbaar' behoren te zijn, in de zin dat zij niet bij overeenkomst kunnen worden uitgesloten. De onaantastbaarheid vindt haar grondslag in het effect van de overeenkomst, die, hoewel slechts tussen partijen werkend, de machtsverhoudingen binnen de vennootschap op zodanige wijze verstoort, dat een aandeelhouder geen controlerende functie meer kan uitoefenen. ${ }^{20}$ De strekking van deze gedachte werd reeds verwoord door minister Donner bij de invoering van de Wet op de naamlooze vennootschappen 1928 :

"Wanneer men over de positie van de aandeelhouders spreekt, is de autonomie van de interne regeling heel ver doorgevoerd, maar er is een zekere grens gesteld; dat is de quaestie van de controleerende functie. Er is daarbij niets, dat verhindert, dat de zaak door de aandeelhouders ten volle wordt overgelaten aan de bestuurders. Dat zal ook in vele gevallen wel gebeuren. Maar er mag niet a priori worden vast-

25 Deze gedachte is met betrekking tot verjaring terug te vinden in artikel $3: 322 \mathrm{BW}, \mathrm{Vgl}$. ook artikel 3:55 "nadat de verjaringstermijn ter zake van het ontstaan van de rechtsvordering tot vernietiging op die grond een aanvang heeft genomen.

Timmerman, Waarom hebben wij dwingend vennootschapsrecht?, in: Ondernemingsrechtelijke contracten, 1991, blz. 9, lijkt een andere opvatting toegedaan. Hij noemt als voorbeeld een overeenkomst tussen aandeelhouders van een BV, inhoudende dat zij geen contante betaling zullen vorderen, indien zij hun aandelen ooit wensen over te dragen. Terwijl hij de afstand ingeval een aandeelhouder zijn aandelen daadwerkelijk aanbiedt zonder meer geldig acht, noemt hij de ongeldigheid van de afstand bij voorbaat bevoogdend.

$\mathrm{Vgl}$. het in het Wennex-arrest gemaakte onderscheid tussen de stemovereenkomst en de uitoefening van het stemrecht, zie voorts $\$ 7.2 .1$.

Vgl. De Kluiver/Meinema, WPNR 2002, blz. 652.

Zie ook \$ 7.2.3. 
gelegd, dat zij dat vertrouwen voor altijd zullen moeten geven. Door dat recht (...) hebben aandeelhouders de mogelijkheid van een zekere controleerende functie, waarvan zij niet a priori afstand kunnen doen. Nu kan men zeggen: maar waarom zal men hun ook dat niet toestaan? Hierin zie ik, Mijnheer de Voorzitter, een element, dat boven den engen kring der betrokkenen uitgaat. Ik vind het wenschelijk, dat, door vast te houden aan die grens, die trouwens in den rechtsvorm ligt en de consequentie is van den privaatrechtelijken opzet, er een zekere evenwichtstoestand is ten opzichte van het beleid. Ik zie in de beperkte aansprakelijkheid een groote bijzonderheid, die de behoefte aan een dergelijken evenwichtstoestand sterk op den voorgrond moet stellen." ${ }^{30}$

Voor de beoordeling of een overeenkomst tot het afzien van de uitoefening van een recht rechtsgeldig is, dient te worden vastgesteld in hoeverre het recht in kwestie essentieel is voor de controlerende functie van de aandeelhouder. Hieronder wordt een aantal rechten aan dit criterium getoetst. Bovendien mag het effect van de overeenkomst niet gelijk zijn aan afstand van recht. Dit betekent dat de overeenkomst tot het afzien van de uitoefening van rechten voldoende bepaalbaar moet zijn, i.e. geconcretiseerd tot bepaalde omstandigheden of een bepaalde overzienbare periode." Dit sluit enigszins aan bij het criterium voor afstand, namelijk dat het recht doelbewust wordt prijsgegeven.

De controlerende functie van de aandeelhouder daargelaten, bestaat een ander bezwaar tegen het afzien van de uitoefening van sommige rechten. Aan een aantal rechten van aandeelhouders ligt de redelijkheid en billijkheid als criterium ten grondslag. Zo hebben aandeelhouders het recht om vernietiging van een besluit te vorderen wegens strijd met de redelijkheid en billijkheid, het recht om uit de vennootschap te treden indien het voortduren van hun aandeelhouderschap naar redelijkheid niet langer van hen kan worden gevergd, omgekeerd het uitstotingsrecht indien het voortduren naar redelijkheid niet langer kan worden geduld. Ook in het enquêterecht met de open normen 'gegronde redenen om aan een juist beleid te twijfelen' en 'wanbeleid' speelt de redelijkheid en billijkheid een grote rol. Een overeenkomst waarin van de uitoefening van deze rechten wordt afgezien zet deze redelijkheid en billijkheid opzij. Dit acht ik in strijd met artikel 3:40 BW. Het recht dient altijd een uitweg te bieden om een geschil te beslechten, om patstellingen tussen aandeelhouders die schadelijk zijn voor de vennootschap te doorbreken. Wel kunnen de voorwaarden waar-

Hand. 1926-1927 II, blz. 1808.

Zie voorts $\$ 7.2 .3$. 
onder de rechten worden uitgeoefend in een overeenkomst worden uitgewerkt. Deze kunnen echter niet limitatief zijn.

\section{Het stemrecht}

Het aan een aandeel verbonden stemrecht zorgt ervoor, dat de individuele kapitaalverschaffer invloed kan uitoefenen in de algemene vergadering, die op haar beurt belangrijke bevoegdheden in de vennootschap uitoefent. Het stemrecht wordt echter niet altijd door de aandeelhouder uitgeoefend. Vruchtgebruiker en pandhouder kunnen onder omstandigheden gerechtigd worden tot het uitoefenen van het stemrecht. Voorts kan een aandeelhouder een volmacht tot het uitbrengen van een stem verlenen. Bovendien kunnen aandelen worden gecertificeerd om de zeggenschap van kapitaalverschaffers in te perken. Het administratiekantoor dat het stemrecht op aandelen uitoefent, heeft geen financieel belang bij de wijze van uitoefening, maar wel een plicht het stemrecht uit te oefenen in het belang van de certificaathouders, afgewogen tegen dat van de vennootschap. In dit geval is het echter nog steeds de aandeelhouder die het stemrecht uitoefent. Deze uitzonderingen op de verbondenheid van het stemrecht met het aandeel hebben gemeenschappelijk dat degene die de stem uitbrengt hetzij zelf een financieel belang heeft (vruchtgebruiker, pandhouder), hetzij een fiduciaire band met de aandeelhouder (gevolmachtigde, administratiekantoor). De koppeling tussen invloed en risico blijft derhalve gehandhaafd. ${ }^{32}$

Mijns inziens mag een aandeelhouder onder voorwaarden afzien van de uitoefening van zijn stemrecht. Doelbewust prijsgeven impliceert reeds dat een dergelijke afstand geschiedt voor een overzienbare periode, of voor bepaalde categorieën besluiten. Indien alle aandeelhouders partij zijn bij de overeenkomst, kan bijvoorbeeld worden bewerkstelligd dat de statuten niet gewijzigd zullen worden, of dat geen nieuwe aandelen uitgegeven zullen worden, of dat een bindende voordracht niet zal worden doorbroken. Zoals hierboven betoogd, gaat het steeds om contractuele afspraken die het bestaan van de rechten zelf onverlet laten. De toelaatbaarheid van dergelijke overeenkomsten komt voorts aan de orde in hoofdstuk 7. Daarenboven resten de aandeelhouder naar mijn mening voldoende andere zeggenschapsrechten waarmee hij invloed kan uitoefenen op de gang van zaken binnen de vennootschap.

Zie $\$ 1.5$. 


\section{Het recht om vernietiging van een besluit te vorderen}

Een aandeelhouder kan vernietiging van een besluit vorderen, indien er iets schort aan de procedure volgens welke het besluit is genomen, of als het besluit strijdig is met de redelijkheid en billijkheid, aldus artikel 2:15 BW. In beide gevallen worden aandeelhouders in staat gesteld voor hun eigen belangen op te komen. In tegenstelling tot de nietigheid, is de vernietiging van een besluit gericht op de behartiging van de belangen van diegenen die door het besluit worden geraakt, niet zozeer op behartiging van het belang van de vennootschap. Dit betekent dat aandeelhouders naar mijn mening in beginsel afstand kunnen doen van het recht vernietiging van een besluit te vorderen." Door deel te nemen aan de algemene vergadering zonder bezwaar te maken tegen de procedurele gebreken kunnen aandeelhouders mijns inziens worden geacht afstand te hebben gedaan van dit recht, dan wel hun recht te hebben verwerkt. ${ }^{34}$

De vraag is of aandeelhouders bij voorbaat mogen afzien van het inroepen van het recht op het vorderen van vernietiging. Zoals hierboven betoogd, kunnen aandeelhouders naar mijn mening niet bij voorbaat afzien van de wettelijke bescherming met betrekking tot de redelijkheid en billijkheid. Wordt door het afzien van de uitoefening van de procedurele vernietigingsbevoegdheid het machtsevenwicht in de vennootschap op ontoelaatbare wijze doorbroken? Procedurele waarborgen dienen in de eerste plaats de belangen van aandeelhouders zelf. Aandeelhouders mogen naar mijn mening afzien van de uitoefening van de bevoegdheid, voor een overzienbare termijn en voor een beperkte categorie gebreken. Zo mogen aandeelhouders overeenkomen dat zij, indien zij niet worden opgeroepen voor een algemene vergadering, geen vernietiging van het besluit zullen vorderen. Welke termijn in casu overzienbaar is, hangt af van omstandigheden als de professionaliteit van de aandeelhouder, de branche waarin de vennootschap opereert, etc.

\section{Het recht op dividend}

Het recht op dividend reflecteert de gedachte dat een aandeelhouder in een vennootschap investeert teneinde winst te maken, onder meer door het ontvangen van dividend. Het belang dat aandeelhouders hebben bij uitkering van de winst contrasteert echter met het belang dat de vennootschap heeft bij het opbouwen van een financiële reserve. Statutair kan dan 
ook worden bepaald dat alle winst wordt gereserveerd. Dit laat echter gerechtigdheid tot de winst onverlet. Daarvan kan een aandeelhouder dan ook niet worden uitgesloten, op grond van artikel 2:216 lid $9 \mathrm{BW}$. Zouden aandeelhouders bij voorbaat afzien van dividend, dan zou betoogd kunnen worden dat het financiële belang dat de aandeelhouder heeft bij het zorgvuldig uitoefenen van de zeggenschapsrechten vermindert. Hem zou daarmee deels de legitimatie van de uitoefening van de zeggenschapsrechten ontvallen..$^{35}$ Een overeenkomst waarin aandeelhouders voor een beperkt aantal jaren afzien van hun dividend is mijns inziens wel rechtsgeldig. Er blijft immers uitzicht op dividend.

\subsubsection{Onderwerping van rechten van aandeelhouders aan arbitrage}

Door een geschil aan arbitrage te onderwerpen, doen partijen afstand van hun recht op overheidsrechtspraak. ${ }^{36}$ Uitgangspunt is artikel 17 van de Grondwet, dat bepaalt dat niemand tegen zijn wil kan worden afgehouden van de rechter die de wet hem toekent. Het is de wet die de ruimte voor arbitrage schept. ${ }^{37}$ Artikel 1020 lid $1 \mathrm{Rv}$ bepaalt dat partijen bij overeenkomst geschillen die tussen hen uit een bepaalde, al dan niet uit een overeenkomst voortvloeiende, rechtsbetrekking zijn ontstaan dan wel zouden kunnen ontstaan, aan arbitrage kunnen onderwerpen. Onder overeenkomst wordt mede begrepen een arbitraal beding dat is opgenomen in de partijen bindende statuten of reglementen, aldus artikel 1020 lid $5 \mathrm{Rv}$.

Niet voor arbitrage vatbaar zijn geschillen waarvoor de wet voorziet in exclusieve rechtsmacht voor de overheidsrechter. Dit dient duidelijk uit de desbetreffende wet of haar geschiedenis te blijken.1. De arbitrageovereenkomst mag bovendien niet leiden tot de vaststelling van rechtsgevolgen welke niet ter vrije bepaling van de partijen staan, art. 1020 lid 3 Rv. ${ }^{39}$ Dit wordt niet snel aangenomen.

Zo heeft de Hoge Raad geoordeeld dat een geschil over de ontbinding van een arbeidsovereenkomst wegens gewichtige redenen ter vrije beschikking van partijen staat. Bovendien, aldus de Hoge Raad, blijkt uit de wetsgeschiedenis dat de

Zie $\$ 1.5$.

Vgl. Snijders in zijn noot onder HR 1 juli 1993, NJ 1994, 461.

Sanders, aant. 1020-1.1.

Sanders, aant. 1020-4.

Snijders, Nederlands arbitragerecht, Kluwer, Deventer 2000, blz. 59. Zie hierover voorts De Witt Wijnen, Ondernemingsrecht en arbitrage, in: Conflicten rondom de rechtspersoon, uitgave vanwege het Van der Heijdeninstituut, deel 62, 2000, blz. 106 e.v. 
wetgever niet heeft beoogd exclusieve competentie aan de overheidsrechter toe te kennen in dergelijke geschillen. ${ }^{40}$

Een zaak van openbare orde mag niet aan arbitrage mag worden onderworpen. Dit is bijvoorbeeld het geval bij een faillissement." Dit laat onverlet dat een arbiter wel over bepalingen van openbare orde of dwingend recht oordeelt. Een arbitraal vonnis dat in strijd is met de openbare orde kan door de rechter worden vernietigd, op grond van artikel 1065 lid $1 \mathrm{Rv} .^{.2}$

Eco Swiss China Time en Benetton voerden verschillende procedures, onder meer over de vraag of een arbitraal vonnis vernietigbaar was op grond van artikel 1065 $\mathrm{Rv}$ vanwege het niet ambtshalve toepassen van het mededingingsrecht. De Hoge Raad overwoog:

"Van strijd met de openbare orde als bedoeld in deze bepaling (artikel $1065 \mathrm{Rv}$, MM) is slechts sprake indien - voor zover thans van belang - de inhoud of uitvoering van het vonnis strijd oplevert met dwingend recht van een zo fundamenteel karakter dat de naleving ervan niet door beperkingen van procesrechtelijke aard mag worden verhinderd. Naar Nederlands recht zal in het algemeen de enkele omstandigheid dat door de inhoud of uitvoering van het arbitrale vonnis een verbodsbepaling uit het mededingingsrecht buiten toepassing blijft, niet meebrengen dat sprake is van strijd met de openbare orde als hier omschreven." ${ }^{, 3}$

De Hoge Raad twijfelde echter over de vraag in hoeverre het Europese mededingingsrecht van openbare orde moet worden geacht en legde deze vraag voor aan het Hof van Justitie. Het Hof van Justitie acht artikel 81 lid 1 EG-Verdrag wel van openbare orde. Het beschouwt artikel 81 als een fundamenteel beginsel van Europees recht, noodzakelijk voor het totstandbrengen van de interne markt. Bovendien dient de eenvormige uitleg van het Europese recht te worden gewaarborgd, hetgeen uitsluitend de overheidsrechter kan bewerkstelligen. Immers, arbiters mogen volgens vaste rechtspraak geen prejudiciële vragen stellen. Een nationale rechter dient derhalve een vordering tot vernietiging van een arbitraal vonnis toe te wijzen wanneer dat vonnis naar zijn oordeel in strijd is met artikel 81 EG-Verdrag, indien hij volgens de regels van zijn nationale procesrecht een vordering tot vernietiging op grond van strijd met de openbare orde moet toewijzen. ${ }^{4}$

HR 14 december 1973, NJ 1974, 92, m. nt. Zeben. Zie voorts De Witt Wijnen, 2000, blz. 112 e.v. Snijders, 2000 , blz. 60 .

Sanders, aant. 1020-3, blz. 24.

HR 21 maart 1997, NJ 1998, 207 (Eco Swiss China/Benetton).

HvJEG zaak C-126/97, I juni 1999, NJ 2000, 339. Zie hierover De Boer, "Internationale arbitrage en fundamenteel recht", AA 2003, blz die concludeert dat zaken die ter vrije bepaling van partijen staan, vatbaar zijn voor arbitrage, zelfs als regels van fundamenteel recht het eindresultaat kunnen bernvloeden. 


\section{Arbitrage van vennootschapsrechtelijke geschillen}

Over de vraag in hoeverre vennootschapsrechtelijke geschillen voor arbitrage vatbaar zijn wordt verschillend gedacht. Van der Grinten meent, dat geschillen die "de staat van de vennootschap" betreffen, zoals ontbinding van de vennootschap of vernietiging van een besluit van een vennootschapsorgaan, niet aan arbitrage kunnen worden onderworpen. Deze zouden behoren tot de exclusieve competentie van de overheidsrechter. ${ }^{45} \mathrm{De}$ vatbaarheid voor arbitrage beperkt zich in deze optiek tot geschillen tussen aandeelhouders onderling, of tussen de vennootschap en haar aandeelhouders. ${ }^{46}$ Een voorbeeld hiervan is het opdragen van een beslissing aan arbiters bij het staken der stemmen in de algemene vergadering, conform artikel 2:230 lid $1 \mathrm{BW}$. Een ander voorbeeld is de geschillenregeling.

Uit de wetsgeschiedenis blijkt dat de geschillenregeling een subsidiair karakter is toebedacht. In eerste instantie zouden in de visie van de wetgever statutaire of contractuele geschillenregelingen moeten worden benut, bijvoorbeeld in de vorm van een arbitrageclausule. In de literatuur is gediscussieerd over de vraag of de geschillenregeling zich eigenlijk wel voor toepassing van arbitrage leent." Sanders vraagt zich af of de arbiter wel hetzelfde resultaat kan bewerkstelligen als de rechter, namelijk overdracht van de aandelen tegen een door hem vastgestelde prijs. Hij betwijfelt of een arbiter andere aandeelhouders, die geen partij zijn bij de arbitrage, een verplichting tot overname van de aandelen tegen de door hem vastgestelde prijs zou kunnen opleggen. Daarenboven acht hij arbitrage in een geschillenregeling ongewenst, omdat op deze wijze de eenheid van uitleg door de Ondernemingskamer in hoger beroep verloren zou gaan. ${ }^{\text {s }}$

De Witt Wijnen pleit voor verruiming van de mogelijkheid om geschillen aan arbitrage te onderwerpen. Uit het feit dat artikel 1020 lid 5 $\mathrm{Rv}$ bepaalt dat onder de arbitrageovereenkomst mede wordt begrepen een arbitraal beding dat is opgenomen in de partijen bindende statuten of reglementen, leidt De Witt Wijnen af dat een ruime toepassing van arbitrage in het vennootschapsrecht is beoogd. Zijns inziens kunnen arbiters zich in beginsel ook uitspreken over geschillen tussen alle bij de vennoot-

\footnotetext{
45 Handboek, nr. 89. Zo ook Sanders, aant. 1020-5, blz. 36, Asser-Maeijer 2-II, nrs. 55a en 140 en H.J.MN Honée, AA 1995 Joint Ventures, blz 52.

Sanders, aant. 1020-8, blz 51. Snijders, 2000, blz. 73.

Vgl. Sanders, Van vennootschappelijk belang, 1988, blz. 254. Ch.E. Honée, "De wettelijke geschillenregeling vatbaar voor arbitrage?", NV 1995, blz. 94. Van den Ingh, "Beslechting van geschillen tussen aandeelhouders in arbitrage", NV 1995, blz 145, Slagter, Rechtspraak: enquêterecht; de geschillenregeling. TVVS 1995, blz. 76 en H.J.M.N. Honée, Arbitrage in het vennootschapsrecht, in: Rechtspleging in het ondernemingsrecht, IVO deel 26, 1997, blz. 27 e.v. 
schap betrokkenen, inclusief ontbinding van de vennootschap en vernietiging van een besluit. Uitzonderingen hierop vormen in zijn opvatting het enquêterecht, de fusie en de jaarrekeningprocedure, omdat de wet in deze gevallen voorziet in een bijzondere rechtsgang, hetgeen duidt op exclusieve overheidscompetentie."

Honée stelt daartegenover dat de vernietiging van besluiten zich zijns inziens niet leent voor arbitrage, omdat derden niet de mogelijkheid hebben om een eventueel recht op voeging of tussenkomst geldend te maken, terwijl niettemin een vonnis waarbij een vernietiging wordt uitgesproken krachtens artikel 2:16 lid $1 \mathrm{BW}$ voor een ieder bindend is..$^{50}$ De Witt Wijnen meent dat dit niet in de weg hoeft te staan aan de vatbaarheid voor arbitrage, daar een arbitragebeding onder omstandigheden kan doorwerken jegens een derde. ${ }^{\text {tt }}$

Het uitgangspunt van artikel 17 Grondwet brengt naar de mening van Honée met zich mee, dat de invoering van een statutaire arbitrageclausule de instemming van alle aandeelhouders vereist. ${ }^{32}$ Volgens De Witt Wijnen daarentegen, dient een aandeelhouder met de mogelijkheid rekening te houden dat de statuten op deze wijze worden gewijzigd, doordat de wet uitdrukkelijk voorziet in de mogelijkheid van een statutair arbitragebeding zonder daaraan nadere eisen te stellen. Toekomstige aandeelhouders moeten in zijn optiek worden geacht de statuten te hebben aanvaard door toe te treden, eventueel inclusief een arbitrageclausule."

In navolging van Honée meen ik dat voorop dient te staan dat niemand tegen zijn wil kan worden afgehouden van de rechter die de wet hem toekent. Dit sluit aan bij de gedachte, dat afstand van een recht doelbewust dient te geschieden. In geval van het onderwerpen van een geschil aan arbitrage, gaat het om afstand van toegang tot de overheidsrechter. Partijen dienen zelf te kiezen voor arbitrage. Het feit dat partijen zich bevinden in een vennootschappelijke verhouding leidt er naar mijn mening niet toe dat de wil om toe te treden tot de vennootschap en zich te onderwerpen aan de wil van de meerderheid mede impliceert de wil om zich te onderwerpen aan arbitrage. De invoering van een statutaire arbitrageclausule vereist in deze optiek de instemming van alle aandeelhouders.

In tegenstelling tot andere rechten van aandeelhouders kent boek 2 BW geen uitdrukkelijke bepaling die het onderwerpen van geschillen aan

De Witt Wijnen, 2000, blz. 122, 128.

H.J.M.N. Honée, 1997, blz. 36.

De Witt Wijnen, 2000, blz. 131.

H.J.M.N Honée, 1997, blz. 42.

De Witt Wijnen, 2000, blz. 133. 
arbitrage in de statuten mogelijk maakt. Wel verwijst artikel 1020 lid $5 \mathrm{Rv}$ naar "partijen bindende statuten". Is deze bepaling een uitdrukkelijke inperking van het recht om geschillen aan de overheidsrechter te onderwerpen? Naar mijn mening laat artikel 1020 lid $5 \mathrm{Rv}$ in het midden of een minderheidsaandeelhouder of later toegetreden aandeelhouder gebonden moet worden geacht aan de statutaire regeling.

Van de minderheidsaandeelhouder die wordt geconfronteerd met een voorstel tot invoering van een arbitrageclausule is evenwel direct duidelijk of hij al dan niet met de invoering instemt, terwijl een later toegetreden aandeelhouder wellicht pas indien een geschil optreedt met de clausule in aanraking komt. Hoewel mijn uitgangspunt is dat zijn toetreding niet de instemming impliceert, kan wellicht worden bezien of hij, nadat hij was toegetreden en geen bezwaar had gemaakt tegen de clausule, zijn recht op toegang tot de overheidsrechter heeft verwerkt.

Dat een arbitraal vonnis in beginsel slechts partijen bindt, betekent naar mijn mening dat een arbitrageovereenkomst ten aanzien van de vernietiging van besluiten slechts geldig is, voor zover alle aandeelhouders partij zijn en het besluit uitsluitend een geschil tussen aandeelhouders betreft. Dit zal niet zo snel het geval zijn bij een verzoek tot de ontbinding van de vennootschap.

\section{$\S 3.3$ Duitsland}

\section{\$3.3.1 Unentziehbare en unverzichtbare rechten van aandeelhouders}

In het GmbH-recht kunnen rechten van aandeelhouders in beginsel worden gewijzigd in de statuten. De wet gaat immers uit van de Gestaltungsfreiheit van aandeelhouders. ${ }^{54}$ Niettemin worden grenzen aan deze vrijheid gesteld; in de rechtspraak en literatuur wordt aangenomen dat sommige rechten van aandeelhouders 'unverzichtbar' dan wel 'unentziehbar' zijn."s

Het stemrecht en het recht op dividend worden unentziehbar geacht. Dit betekent dat deze rechten uitsluitend met instemming van de betrokken aandeelhouders statutair kunnen worden uitgesloten of beperkt. ${ }^{.6}$ Het Bundesgerichtshof heeft de mogelijkheid tot uitsluiting van deze rechten verder beperkt door te stellen dat:

Zie $\$ 2.3 .2$.

$\mathrm{Vgl}$. Rowedder/Schmidt-Leithoff/Pentz $\S 14,15$. Raiser, 2001, $\$ 27,4$.

Zie voorts $\$ 5.3 .1$ 
"ernstlich kaum bezweifelt werden [kann], daß derjenige, der kein Stimmrecht, kein Gewinnrecht und keinen Liquidationsanteil besitzt, kein Gesellschafter ist."

De aandeelhouder dient volgens het Bundesgerichtshof ten minste te beschikken over het recht op het liquidatie-overschot na vereffening om de kwalificatie 'aandeelhouder' inhoud te geven. ${ }^{5 x}$ Ontoelaatbaar is voorts dat alle aandeelhouders worden uitgesloten van het stemrecht, daar de algemene vergadering dan niet langer zou kunnen functioneren. ${ }^{59}$

Terwijl unentziehbare rechten uitsluitend met instemming van de betrokkenen kunnen worden ontnomen, worden als unverzichtbar aangemerkt de rechten waarvan een aandeelhouder geen afstand kan doen, noch in de statuten, noch bij eenstemmig besluit. ${ }^{60}$ De vraag of een aandeelhouder bij overeenkomst afstand kan doen van zijn rechten wordt in de Duitse literatuur niet in deze context aan de orde gesteld, wel in $\S 3.3 .2$.

Unverzichtbar zijn de rechten die een aandeelhouder in staat stellen deel uit te maken van de interne deelrechtsorde. Hiertoe behoren volgens Raiser het recht van aandeelhouders die meer dan 10 procent van het geplaatste kapitaal vertegenwoordigen om een algemene vergadering bijeen te roepen ( $\$ 50 \mathrm{GmbHG})$, om ontbinding van de vennootschap te vorderen ( $\$ 61 \mathrm{GmbHG})$ of om een curator te laten benoemen ( $\$ 66 \mathrm{GmbHG})$, het recht om vernietiging van een besluit van de algemene vergadering te vorderen, het recht op deelname aan de algemene vergadering, het recht op informatie en inzage ( $§ 51 \mathrm{a} \mathrm{GmbHG)}$ en tenslotte het recht op uittreding wegens een gegronde reden. ${ }^{61}$ Dit laatste recht heeft geen wettelijke basis, maar is in de rechtspraak ontwikkeld..$^{22}$ Fastrich noemt deze rechten absoluut dwingend, behorend tot het 'Kernbereich' van het aandeelhouderschap. ${ }^{3}$ Als ontoelaatbaar moet voorts worden aangemerkt een algemene uitsluiting van de vennootschappelijke Treupflicht. Evenmin kan het instemmingsvereiste in geval van het opleggen van extra verplichtingen statutair worden uitgesloten. ${ }^{64}$

57 BGH NJW 1954, blz. 1563.

s8 Baumbach/Hueck/Fastrich $\S 14,14$, acht maatgevend dat het aandeelhouderschap niet zinloos mag worden, in de zin dat een aandeelhouder een minimum aan zeggenschaps- en vermogensrechten moet resteren, van geval tot geval bezien. In dezelfde zin Rowedder/Schmidt-Leithoff/ Pentz $\$ 14,19$.

59 Baumbach/Hueck/Fastrich \& 14,14

(6) $\mathrm{Vgl}$. Hachenburg/Raiser $\$ 14,27$ e.v, Rowedder/Schmidt-Leithoft/Pentz $\$ 14,17$

61 Hachenburg/Raiser $\$ 14,28$. Zie ook Lutter/Hommelhoff $\$ 14,7$.

$62 \mathrm{Vgl}$. Lutter/Hommelhoff $\$ 34,36$ e.v. Zie ook $\$ 2.3 .2$.

63 $\mathrm{Vgl}$. Baumbach/Hueck/Fastrich, \& 14, 13.

64 Rowedder/Schmidt-Leithoff/Pentz $\$ 14,18$ 
De achterliggende reden van het verbod van afstand van het recht om vernietiging van een besluit te vorderen is dat het recht niet alleen als een middel ter bescherming van de belangen van de minderheidsaandeelhouder zelf wordt beschouwd, maar ook als een middel om toezicht uit te oefenen op de organen van de vennootschap. ${ }^{\text {s }}$ Het recht op deelname aan de algemene vergadering is niet voor afstand vatbaar, omdat het dient ter ondersteuning van een eventuele vernietigingsactie; door zijn aanwezigheid bij de algemene vergadering kan de aandeelhouder zich ervan vergewissen of de besluitvorming conform de wet en de statuten geschiedt. ${ }^{66}$ Van het recht op uittreding wegens een gegronde reden mag geen afstand worden gedaan, vanwege het principe dat in een duurzame rechtsverhouding partijen steeds de mogelijkheid moeten hebben om uit elkaar te gaan wegens een gegronde reden. ${ }^{67}$ Dergelijke rechten dienen in deze optiek niet alleen ter bescherming van individuele aandeelhouders, maar zijn (tevens) toegekend uit oogpunt van openbare orde..$^{68}$

\section{§3.3.2 Individuele afstand van rechten van aandeelhouders}

De vraag rijst dan of ook overeenkomsten tussen aandeelhouders om hun rechten niet uit te oefenen, in strijd zouden zijn met de openbare orde en de goede zeden. Zo meent Lutter dat overeenkomsten die de rechten op informatie en toezicht opzij zetten of overeenkomsten die een of meer aandeelhouders het recht geven de statuten naar eigen goeddunken te wijzigen, in strijd zijn met de minimumvoorwaarden die aan een systeem van machtenscheiding worden gesteld..$^{69}$ De hieraan voorafgaande vraag is of aandeelhouders naar Duits recht afstand van hun lidmaatschapsrechten kunnen doen.

Het aandeelhouderschap als Mitgliedschaft wordt in de Duitse literatuur als subjectief recht gekwalificeerd. ${ }^{70}$ De Mitgliedschaft omvat alle rechten en verplichtingen van aandeelhouders, voortvloeiend uit de vennootschappelijke verhouding, i.e. uit de wet of uit de statuten. ${ }^{71}$ Hiervan te

Vgl. Lutter, AcP 1980, blz. 140 e.v. Een GmbH-aandeelhouder heeft geen recht van enquete zoals in Nederland. Het Aktienrecht biedt wel de mogelijkheid van Sonderprüfung, maar deze wordt in de praktijk nauwelijks gebruikt. Zie hierover uitgebreid Gernoth/Meinema, "Niederlandisches Enqueterecht: Vorbild fur das deutsche Sonderprufungsrecht?", RIW 2000, blz 844. Hachenburg/Hüfer $\S 48,30$. Vgl. ook BGH 12 juli 1971, NJW 1971, blz 2225.

Vgl. Baumbach/Hueck $16^{\mathrm{c}}$ druk, Anh. § 34,1 .

Vgl. Noack, 1994, blz. 126.

Lutter, AcP 1980, blz, 151.

Vgl. Lutter, AcP 1980, blz. 101. Flume, 1983, blz. 258. Baumbach/Hueck/Fastrich $\S 14,5$. Raiser, 2001, §27, 1. Habersack, Die Mitgliedschaft - subjektives und "sonstiges" Recht, 1996.

Baumbach/Hueck/Fastrich, $\$ 14,10$. 
onderscheiden zijn de uit deze rechten voortvloeiende concrete aanspraken, bijvoorbeeld het vastgestelde dividend. Dit zijn zgn. Gläubigerrechte, die van verbintenisrechtelijke aard zijn en waarvan vrijelijk afstand kan worden gedaan." Louter verbintenisrechtelijke rechten en verplichtingen tussen aandeelhouders onderling vallen niet onder de Mitgliedschaft. ${ }^{35}$

Lidmaatschapsrechten worden gekenmerkt door hun accessoir karakter, hetgeen inhoudt dat de lidmaatschapsrechten in hun ontstaan, hun overdraagbaarheid en in hun bestaan van de in het aandeel belichaamde lidmaatschap afhankelijk zijn. ${ }^{4}$ Afzonderlijke overdracht (Abspaltung) van individuele lidmaatschapsrechten, in het bijzonder het stemrecht, is naar de heersende leer niet mogelijk. ${ }^{75}$ Het Bundesgerichtshof overwoog te dienaangaande:

"Die Verwaltungsrechte sind (...) mit dem Gesellschafteranteil notwendig verbunden und können von ihm nicht losgelöst und selbständig übertragen werden." $" 16$

Volgens het Bundesgerichtshof vloeit het Abspaltungsverbot voort uit de 'Einheitlichkeit des Mitgliedsehoff'" Schmidt rechnsaardigh het: Abspod-

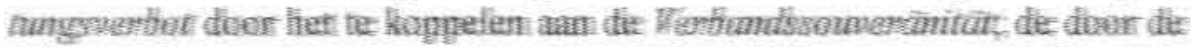

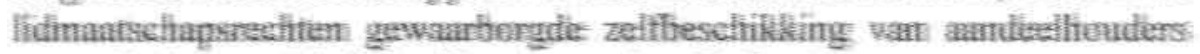

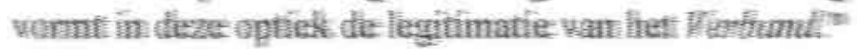

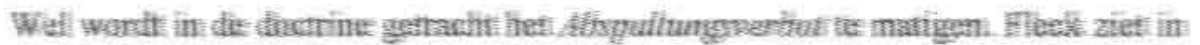

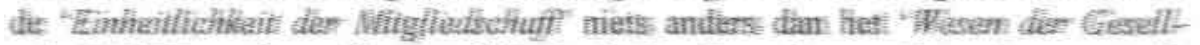

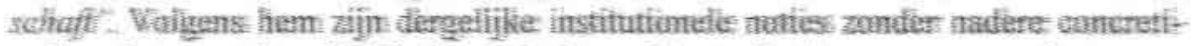

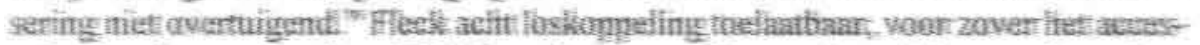

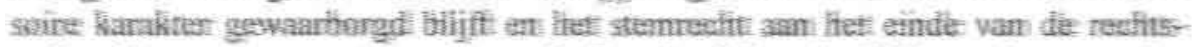

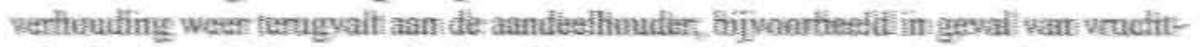

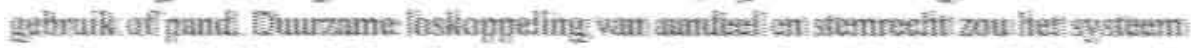

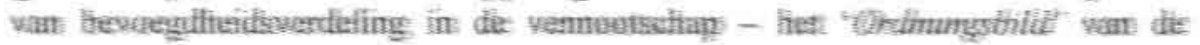

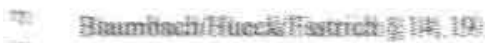

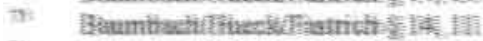

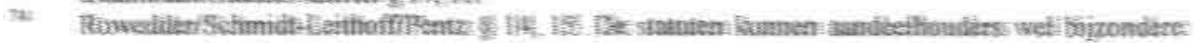

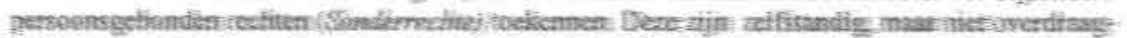

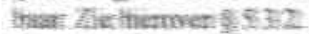

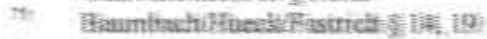

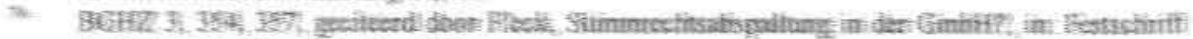

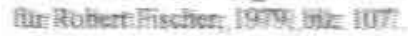

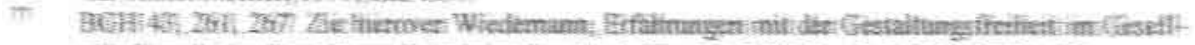

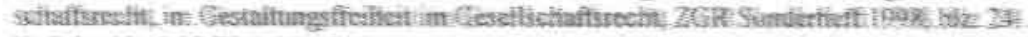

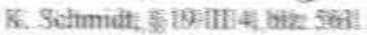

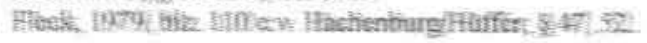


$\mathrm{GmbH}$ als georganiseerd samenwerkingsverband van aandeelhouders - verstoren. ${ }^{80}$ Degene die het stemrecht uitoefent dient dan wel onderworpen te worden aan de Treupflicht. ${ }^{\text {"1 }}$ Ook Koppensteiner stelt als voorwaarden aan de Abspaltung dat deze voor bepaalde tijd is en door opzegging beëindigbaar. Hij acht Abspaltung niet mogelijk ten aanzien van besluiten die het Kernbereich der Mitgliedschaft betreffen (m.n. statutenwijzigingen). ${ }^{\mathbf{s}}$

Volgens Pentz brengt het begrip 'Abspaltungsverbot' tot uitdrukking dat er van de uit het lidmaatschap voortvloeiende zeggenschapsrechten als onzelfstandige rechten niet afzonderlijk afstand kan worden gedaan. Zo acht hij de overdracht van het recht op dividend of het stemrecht aan een derde rechtens onmogelijk. Wel kan een aandeelhouder afstand doen van de uit het recht op dividend voortvloeiende aanspraken, of een derde een volmacht geven ten aanzien van de uitoefening van het stemrecht." Fastrich meent dat de afstand van toekomstige vorderingen een Abspaltung van het vermogensrecht als zodanig kan benaderen; dit acht hij in strijd met de Treupflicht, ingeval een dergelijke afstand voor een aandeelhouder in aanzienlijke mate nadelig is. ${ }^{\mathrm{H}}$

Noack maakt in dit verband een onderscheid tussen afstand bij voorbaat en afstand van een recht in een eenmalig, concreet geval. Terwijl hij afstand bij voorbaat als schadelijk voor de wettelijke institutionele orde aanmerkt, ziet hij in afstand van een recht in een concreet geval geen beletsel, daar het de aandeelhouder op dat moment vrij staat in zijn eigen belang te handelen. Een dergelijke overeenkomst maakt naar zijn opvatting deel uit van de interne vennootschappelijke verhoudingen en dient dan ook aan dezelfde geldigheidsvereisten als statuten te worden onderworpen." ${ }^{\text {ss }}$

\section{\$3.3.3 Onderwerping van vennootschapsrechtelijke geschillen aam arbitrage}

In beginsel worden vennootschapsrechtelijke geschillen, zowel tussen de vennootschap en haar aandeelhouders als tussen aandeelhouders onderling, naar Duits recht voor arbitrage vatbaar geacht." Een in de statuten neergelegd arbitragebeding kan zowel vennootschapsrechtelijke werking hebben

Fleck, 1979, blz. 113. Instemmend Lutter/Hommelhoff, $\S 47,2$, Rowedder/Schmidt-Leithoff/ Koppensteiner $\$ 47,24$ e.v.

Fleck, 1979, blz. 120.

Rowedder/Schmidt-Leithoff/Koppensteiner $\$ 47,26$.

Rowedder/Schmidt-Leithoff/Pentz $\$ 14,15$.

Baumbach/Hueck/Fastrich $\S 14,19$.

Noack, 1994, blz. 126. Zie ook $\$ 7.3 .4$.

Vgl. Lutter/Hommelhoff, Anh. $\$ 47,77$. 
als werking inter partes." Dit wordt bepaald al naar gelang de aard van de rechtsverhouding. Terwijl rechten van aandeelhouders jegens elkaar naar het oordeel van het Bundesgerichtshof uitsluitend in een arbitrage-overeenkomst kunnen worden vervat, kan een statutaire arbitrageclausule slechts betrekking hebben op rechtsverhoudingen tussen de aandeelhouders en de vennootschap. ${ }^{\mathrm{s}}$

In de literatuur speelt de discussie zich met name af ten aanzien van de vraag of het instellen van een Anfechtungsklage (vernietigingsactie tegen besluit) $^{s 0}$ voor arbitrage vatbaar is. Onder het oude recht heeft het Bundesgerichtshof in zijn uitspraak van 29 maart 1996 te dienaangaande afwijzend beschikt. ${ }^{* 0}$ Hoewel het recht van een individuele aandeelhouder, meerderheidsbesluiten van de algemene vergadering door een onafhankelijk gerecht op hun rechtmatigheid te laten toetsen, niet voor afstand vastbaar is, betekent dit volgens het Bundesgerichtshof echter niet noodzakelijkerwijs, dat de rechtmatigheidstoetsing door een statelijke instantie dient te geschieden. Het GmbH-recht kent immers geen equivalent van $\S 23 \mathrm{Abs}$. 5 AktG. Wat de vatbaarheid voor arbitrage naar de opvatting van het Bundesgerichtshof wel belemmert, is het feit dat de vernietiging van een besluit niet alleen de partijen bindt, maar gevolgen heeft voor alle aandeelhouders en alle organen van de vennootschap, ook al zijn deze geen partij in het geding. Het Bundesgerichtshof acht uitsluitend de wetgever bevoegd om de werking van een arbitraal vonnis uit te strekken over anderen dan partijen, met andere woorden om $\S 248 \mathrm{AktG}^{91}$ ook van toepassing te verklaren op arbitrale vonnissen.

Inmiddels is een nieuwe Zivilprozeßordnung totstandgekomen, waarbij de wetgever dit vraagstuk heeft doorverwezen naar de doctrine, die samen met de rechtspraak oplossingen voor de praktijk zou moeten ontwikkelen. ${ }^{92}$ Lutter/Hommelhoff stellen dat een statutaire arbitrageclausule dient te vermelden dat zij jegens alle betrokkenen bindend is, met uitdrukkelijke verwijzing naar $\S 248 \mathrm{AktG}$. Op deze wijze zouden ook toekomstige aandeelhouders voldoende worden geïnformeerd. Invoering bij latere statutenwijziging zou de instemming vereisen van alle aandeelhouders. ${ }^{93}$ Deze

Vgl. BGHZ 38, 155. Zie ook $\$ 4.3 .2$.

BGHZ 38, 155. Zie voorts met betrekking tot het verenigingsrecht Haas, "Zur Einfuhrung von Schiedsklauseln durch Satzungsănderungen in Vereinen", ZGR 2001, blz. 325 e.v.

Zie $\$ 6.3 .3$

BGHZ 132, 278.

$\$ 248$ Abs. 1, eerst zin AktG luidt: "Soweit der BeschluBdurch rechtskraftiges Urteil fur nichtig erklärt ist, wirkt das Urteil fur und gegen alle Aktionare sowie die Mitglieder des Vorstands und des Aufsichtsrats, auch wenn sie nicht Partei sind." Lutter-Hommelhoff, Anh. $\$ 47,77$

Lutter-Hommelhoff, Anh. $\S 47,79$. Hachenburg/Raiser, Anh. $§ 47,209$. Zie verder Baumbach/ 
opvatting leidt ertoe dat het recht om een vernietigingsactie aan arbitrage te onderwerpen als unentziehbar recht wordt gekwalificeerd. Unverzichtbar is het recht om een vernietigingsactie bij een onafhankelijke instantie in te stellen. ${ }^{4}$ Dit kan ook een arbiter zijn.

\section{$\S 3.4$ Engeland}

\section{\$3.4.1 Mandatory rights}

Net als in Duitsland zijn in Engeland onder meer het stemrecht en het recht op dividend aanvullend van aard. ${ }^{95}$ De Companies Act 1985 bevat wel een aantal dwingende "statutory rights" voor aandeelhouders. ${ }^{96}$ Zo hebben aandeelhouders die ten minste een tiende van het geplaatste kapitaal vertegenwoordigen het recht om een algemene vergadering bijeen te roepen (section $368 \mathrm{CA}$ 1985), het recht om een stemming aan te vragen (section $373 \mathrm{CA}$ 1985 ) en het recht om een enquête te verzoeken (section 431 CA 1985). ${ }^{\text {? }}$ Het meest controversiële recht is vervat in section 459 (1) CA 1985, dat een met het Nederlandse enquêterecht vergelijkbare regeling bevat, luidende:

"A member of a company may apply to the court by petition for an order under this Part on the ground that the company's affairs are being or have been conducted in a manner which is unfairly prejudicial to the interests of its members generally or of some part of its members (including at least himself) or that any actual or proposed act or omission of the company (including an act or omission on its behalf) is or would be so prejudicial."

Op grond van section $461 \mathrm{CA} 1985 \mathrm{mag}$ de rechter, in geval van een verzoek ex section 459 , alle maatregelen nemen die hij dienstig acht. Zo kan de rechter bijvoorbeeld gebieden dat de aandeelhouder die is ontslagen als bestuurder wordt uitgekocht.

De controversialiteit van section 459 CA 1985 schuilt in de actieve rol die de rechter van de wetgever krijgt toebedeeld, doordat de bepaling een

Hueck/Zollner, Anh. $\$ 47,18$ met verdere literatuurverwijzingen.

Zie $\$ 3.3 .1$.

Zie $\$ 5.4 .1$.

Een ander belangrijk recht van aandeelhouders wordt aangetroffen in s. 122 (1) jo. 124 Insolvency Act 1986: A company may be wound up by the court if $(\ldots)(\mathrm{g})$ the court is of the opinion that it is just and equitable that the company should be wound up.

97 Het enquêterecht wordt mogelijk hervormd, zie DTI Consultation Document Company Investigations: Powers for the 21 st Century, juli 2001, www.dti.gov.uk/cld/company_investigations.pdf. 
voor het Engelse recht relatief onbekende 'open norm' bevat, voorts in de 'populariteit' van de procedure. ${ }^{\mathrm{s}}$

Hoewel section 459 CA 1985 oorspronkelijk was bedoeld om minderheidsaandeelhouders een mogelijkheid te bieden die het vennootschapsrecht tot dan toe niet bood, bleek de procedure een enorme aantrekkingskracht op aandeelhouders uit te oefenen, met als gevolg langdurige en kostbare processen wegens het bewijzen van allerhande beschuldigingen. Sleutelwoord was of de aandeelhouder "legitimate expectations" had op bijvoorbeeld een aanstelling als bestuurder. In de zaak O'Neill v. Phillips heeft de House of Lords getracht de stroom verzoeken in te perken, door als uitgangspunt de tussen aandeelhouders onderling gemaakte afspraken te nemen. ${ }^{99}$ In het DTI Final Report waarin het Britse vennootschapsrecht wordt herzien onderschrijven de opstellers de beperking die de House of Lords in O'Neill v. Phillips heeft aangebracht, zodat geen verandering wordt voorgesteld voor section $459 \mathrm{CA} 1985 .^{100}$

Van deze dwingende 'statutory rights' mag in de statuten geen afstand worden gedaan, zo blijkt uit Re Peveril Gold Mines Ltd uit 1898:

Op grond van section $82 \mathrm{CA} 1862$ had elke aandeelhouder het recht om de ontbinding van de vennootschap voor de rechter te verzoeken. De statuten van de vennootschap beperkten dit recht. Mede op grond van de bewoordingen van de wettelijke bepaling, waarin niet uitdrukkelijk in de mogelijkheid van statutaire afwijking was voorzien, oordeelde Byrne $\mathrm{J}$ dat een aandeelhouder door toe te treden tot de vennootschap niet moet worden geacht afstand te hebben gedaan van zijn wettelijke recht om ontbinding te verzoeken. Hij overwoog:

"The 82nd section of the Companies Act, 1862, undoubtedly confers a right upon any single contributory (...) to present a petition, and the question really is, whether or not the petitioner has by becoming a shareholder entered into a contract, enforceable either by the company or by other individual shareholders, not to exercise the right which section 82 prima facie in terms confers upon him. (...) I consider that the terms of the section are intended to confer a right of which a contributory cannot be deprived, either entirely or in a modified way, by the terms of the articles of association, unless upon the footing that by becoming a shareholder the petitioner has done what is equivalent to validly releasing an individual legal right, and I am of the opinion that he has not done so. (...) If the articles are to be regarded as part of the terms of the contract between the company and the person applying for shares, I am of the opinion that the company had no right, having regard to the Act of Parliament, to enter into such contract as a O'Neill v Phillips [1999] I WLR 1092. Zie ook \$ 7.4.4.

DTI Modern Company Law - Final Report, 2001, blz. 163. 
condition and part of the general contract binding upon all shareholders, whatever separate or distinct bargain they might have the power to make with an individual who happened to be or desire to become a shareholder. This article appears to be one more attempt to remove a statutory safeguard of the inexperienced intending shareholder. Not one per cent. of intending shareholders read the articles before applying for or accepting a transfer of shares, and a shareholder does not expect to find that he has entered into a special contract waiving his statutory rights." ${ }^{10}$

\section{$\$ 3.4 .2$ Individuele afstand van rechten}

In de Engelse literatuur is omstreden of aandeelhouders bij overeenkomst afstand kunnen doen van hun 'statutory rights', met name of section 459 CA 1985 zich voor afstand bij overeenkomst leent. Riley betoogt dat section 459 CA 1985 "a mandatory, non-excludable provision" is. Hij acht de mogelijkheid voor een aandeelhouder om in rechte op te komen tegen "unfairly prejudicial behaviour" zo fundamenteel, dat uitsluiting van dit recht de vraag zou oproepen of partijen dit werkelijk zouden hebben gewild. ${ }^{102}$ Ook Cheffins lijkt uit te gaan van het in dit opzicht dwingendrechtelijke karakter van section 459 CA $1985 .{ }^{103}$

Reece Thomas en Ryan stellen daarentegen dat section 459 CA 1985 niet dwingend is, in de zin dat contractuele afstand onmogelijk zou zijn. Aandeelhouders kunnen volgens hen afstand doen van hun recht op basis van de doctrine of waiver, die inhoudt dat degene die door non-mandatory statutory provisions wordt beschermd afstand kan doen van zijn recht voor zover geen "wider public purpose" wordt geraakt. Section 459 CA 1985 is in hun optiek vooral bedoeld voor kleine quasi-partnership-companies, waar aandeelhouders in de regel niet de moeite nemen om uitgewerkte aandeelhoudersovereenkomsten te sluiten. Wanneer wel een dergelijke overeenkomst wordt gesloten geschiedt dit veelal door professionele partijen, bijgestaan door juridische adviseurs. Enerzijds hebben deze partijen de bescherming van section $459 \mathrm{CA} 1985$ niet nodig, zo betogen de auteurs, anderzijds hebben zij baat bij het uitsluiten van section $459 \mathrm{CA}$ 1985 wegens de hoge kosten die het voeren van een procedure met zich mee brengt, inclusief negatieve publiciteit, tijdverlies en andere risico's. Wel stellen zij als voorwaarde dat aan de criteria voor een redelijk buy-out aanbod is voldaan, conform de criteria gesteld in O'Neill $v$. Phillips, te

101 Re Peveril Gold Mines Ltd [1898] 1 Ch 122. Zie ook $\$ 2.4 .2$

102 Riley, "Contracting Out of Company Law: Section 459 of the Companies Act 1985 and the Role of the Courts", MLR 1992, blz. 797.

103

Cheffins, 1997, blz. 260. 
weten een 'fair price', waarvan de waarde wordt vastgesteld door een expert, indien partijen niet tot overeenstemming zijn gekomen. ${ }^{104}$

De vraag of een overeenkomst waarin aandeelhouders afzien van de uitoefening van hun recht toelaatbaar is, moet in de optiek van Reece Thomas en Ryan uitsluitend worden beoordeeld aan de hand van de openbare orde, terwijl Riley daarenboven de bescherming van de aandeelhouder tegen zichzelf als grond voor ongeldigheid van de overeenkomst aanmerkt. In de literatuur lijkt niet aan de orde te worden gesteld wat de gevolgen van een eventuele afstand van wettelijke rechten van aandeelhouders zijn.

De doctrine of waiver is ontwikkeld in de common law jurisprudentie en is verwant aan de election en promissory estoppel. Robert Walker LJ kwalificeert waiver als "any deliberate decision by a party not to stand on his strict rights". ${ }^{105}$ De doctrine of waiver maakt deel uit van het Engelse overeenkomstenrecht; het gaat om afstand van contractuele rechten. ${ }^{106}$ Men kan zich afvragen of de doctrine onverkort zou kunnen worden toegepast op wettelijke rechten. Uit Welton $v$. Saffery lijkt te kunnen worden afgeleid, dat afstand van wettelijke rechten louter verbintenisrechtelijke werking heeft. Lord Davey overwoog aldaar:

"Of course, individual shareholders may deal with their own interests by contract in such a way as they may think fit. But such contracts, whether made by all or some only of the shareholders, would create personal obligations, or an exceptio personalis against themselves only, and would not become a regulation of the company, or be binding on the transferees of the parties to it, or upon new or nonassenting shareholders." ${ }^{107}$

\section{\$3.4.3 Onderwerping van rechten van aandeelhouders aan arbitrage}

Naar Engels recht zijn geschillen tussen de vennootschap en haar aandeelhouders en tussen aandeelhouders onderling vatbaar voor arbitrage. ${ }^{108}$ Een bestuurder kan zich echter in beginsel niet beroepen op een statutaire arbi-

Reece Thomas en Ryan, "Section 459, public policy and freedom of contract", Company Lawyer 2001, blz. 178 e.v., 198 e.v.

Oliver Ashworth (Holdings) Ltd v. Ballard (Kent) Ltd [2000] Ch 12 CA.

$106 \mathrm{Vgl}$. Chitty on Contracts. Zie bijvoorbeeld ook Euro Brokers Holdings v, Monecor (London) Ltd [2002] EWHC 1480, waarin Kosmin QC oordeelt dat Monecor door zijn gedragingen zijn recht heeft verwerkt om zich te beroepen op procedurele gebreken van een besluit tot kapitaalverhoging.

107 Lord Davey in Welton v. Saffery [1897] AC 299, geciteerd door Byme J. in Re Peveril Gold Mines Ltd [1898] 1 Ch 122.

108 Zie bijvoorbeeld Hickman v. Kent or Romney Marsh Sheepbreeders' Association [1915] 1 Ch 881 , in Sealy, blz. 113. 
trageclausule. ${ }^{109}$ In de literatuur lijken bijzonderheden voortvloeiende uit het vennootschapsrecht, zoals de vraag of een arbitrageclausule de instemming van alle aandeelhouders vereist, niet aan de orde te worden gesteld. Ik zou willen aannemen dat naar Engels recht, ook in geval van arbitrage, het contractuele karakter van de statuten met zich meebrengt dat aandeelhouders, door toe te treden tot de vennootschap, zich in beginsel aan de wil van de meerderheid onderwerpen, hetgeen in geval van statutenwijziging een special resolution met drie vierde meerderheid van het aantal stemmen betekent.

\section{$\S 3.5$ Evaluatie}

Het dwingendrechtelijk uitgangspunt van artikel 2:25 BW verhindert dat rechten van aandeelhouders die in de wet zijn vastgelegd statutair worden uitgesloten. Er hoeft niet uitgebreid te worden gerechtvaardigd waarom deze rechten als dwingend worden beschouwd. In Duitsland en Engeland daarentegen, vloeien rechten van aandeelhouders in eerste instantie voort uit de statuten, terwijl de wet slechts grenzen stelt aan de inperking van sommige rechten. Daar de Companies Act 1985 noch de GmbHG een algemeen interpretatievoorschrift als artikel 2:25 BW kent, dient per bepaling te worden vastgesteld of hiervan kan worden afgeweken in de statuten.

Boek 2 BW kent - wellicht mede vanwege dit verschil - meer dwingende rechten aan aandeelhouders toe dan het Engelse en Duitse recht. In het oog springt het stemrecht, dat alleen in het Nederlandse recht een dwingende wettelijke basis heeft. Het Duitse recht compenseert het gebrek aan dwingende wettelijke rechten enerzijds door de creatie van dwingende rechten buiten de GmbHG om, zoals het uittredingsrecht en het recht om vernietiging van een besluit te vorderen, analoog aan $\S 243$ AktG, anderzijds door sommige rechten een unverzichtbar dan wel een unentziehbar karakter te geven, zodat ze niet resp. slechts met instemming van de betrokken aandeelhouders statutair kunnen worden beperkt. Dergelijke nuanceringen zijn aan het Engelse recht niet besteed. Slechts een beperkt aantal statutory rights van aandeelhouders is dwingend, de overige rechten kunnen met een special resolution statutair worden uitgesloten of beperkt. ${ }^{\text {.10 }}$ Ondanks het contractuele karakter van de statuten in Duitsland en Engeland, zijn de gevolgen die daaruit voortvloeien derhalve in beide stel- 
sels uiteenlopend. De verhouding tussen de wet en de statuten wordt voor de verschillende rechtsstelsels nader uitgewerkt in de hoofdstukken 4 en 5 .

Naar Engels recht mogen wettelijke rechten van aandeelhouders niet statutair worden ingeperkt, op basis van de uitspraak Re Peveril uit 1898. Later toetredende aandeelhouders kunnen niet worden geacht afstand te hebben gedaan van hun wettelijke rechten. Het enkele feit dat een aandeelhouder is toegetreden tot de vennootschap, levert geen 'deliberate decision' op, hetgeen voor een geldige afstand wel is vereist. De bewoordingen van een wettelijke bepaling dienen derhalve uitdrukkelijk statutaire inperking toe te laten. Dit betekent dat een statutaire inperking van wettelijke rechten evenmin geoorloofd is, indien alle aandeelhouders ermee instemmen.

Terwijl de statuten naar Engels recht een aandeelhouder derhalve zijn wettelijke rechten niet kumen ontnemen, worden in het Duitse recht grenzen gesteld aan statutaire afstand van rechten met een beroep op de toezichthoudende functie van aandeelhouders in het belang van de vennootschap. Het Duitse GmbHG geeft in § 5la Abs. 3 uitdrukkelijk aan, dat van het informatie- en inzagerecht van aandeelhouders in de statuten niet kan worden afgeweken. Van andere rechten wordt in de jurisprudentie en de literatuur eveneens aangenomen dat er in de statuten geen afstand van kan worden gedaan, hoewel dit niet uitdrukkelijk uit de wet blijkt. Het verbod van statutaire afstand wordt onder andere gemotiveerd met een beroep op het machtsevenwicht dat in een vennootschap onontbeerlijk wordt geacht; de aandeelhouders dienen steeds in staat te zijn toezicht uit te oefenen.

De vraag of aandeelhouders bij de statuten afstand van hun rechten kunnen doen rijst niet naar Nederlands recht, omdat artikel 2:25 BW een dergelijke afstand belet. Zonder artikel 2:25 BW zou statutaire afstand evenmin tot de mogelijkheden behoren, aangezien toetreding tot een vennootschap ook naar Nederlands recht niet kan worden gelijk gesteld met het doelbewust afstand doen van een recht. Dit is anders indien de wet statutaire afwijking mogelijk maakt. Dan is er geen sprake meer van afstand van recht, omdat het recht als zodanig reeds door de wet wordt beperkt.

Kunnen aandeelhouders dan wel bij overeenkomst afstand doen van hun rechten? Deze vraag is niet eenduidig te beantwoorden, mede omdat de precieze omvang van het leerstuk van afstand (doctrine of waiver, Verzicht/ Abtretung) moeilijk te bepalen is. Naar Duits recht wordt aangenomen dat de lidmaatschapsrechten van aandeelhouders afhankelijke rechten zijn, waarvan een aandeelhouder geen afstand kan doen. Dit neemt niet weg dat aandeelhouders wel afstand kunnen doen van concrete aanspraken die voortvloeien uit hun recht. In het tussenliggende schemergebied is de vraag of aandeelhouders bij voorbaat afstand kunnen doen van hun toekomstige aanspraken. Hierover wordt in de literatuur verschillend geoordeeld. 
Naar Engels recht wordt de vraag of een aandeelhouder contractueel afstand kan doen van zijn recht afhankelijk gesteld van de vraag of een dergelijk recht als dwingend ('mandatory') moet worden beschouwd. Van een dwingend recht mag geen afstand worden gedaan. Sommige auteurs beschouwen een recht uitsluitend als dwingend indien er sprake is van strijd met de openbare orde, terwijl anderen menen dat dwingend vennootschapsrecht ook kan dienen ter bescherming van de belangen van de aandeelhouders zelf. Aangenomen moet worden dat een overeenkomst waarin aandeelhouders afzien van de uitoefening van hun recht uitsluitend tussen partijen werkt.

Bovenstaande overwegingen kunnen naar mijn mening worden toegepast in het Nederlandse recht. Daarbij moet wel worden bedacht dat in het Engelse en Duitse recht het leerstuk van afstand van recht wordt toegepast door een niet voor afstand vatbaar recht als dwingende uitzondering van in beginsel aanvullende rechten te beschouwen, terwijl in Nederland het leerstuk van afstand van recht de dwingende kracht van een recht juist kan relativeren. Naar Nederlands recht kunnen aandeelhouders geen afstand doen van hun rechten, wel van daaruit voortvloeiende concrete aanspraken. Aandeelhouders kunnen dus wel afstand doen van hun vorderingsrecht jegens de vennootschap aangaande de in een bepaald jaar vastgesteld dividenduitkering, niet echter van hun recht op dividend als zodanig. Dit geldt naar mijn mening ook voor het recht om vernietiging van een besluit te vorderen; een aandeelhouder kan daarvan pas afstand doen nadat het besluit is genomen. Aandeelhouders kunnen echter niet bij voorbaat afstand doen van toekomstige aanspraken. Wel kunnen zij zich in beginsel verbinden tot het afzien van de uitoefening van dergelijke rechten. Deze overeenkomst heeft slechts verbintenisrechtelijke werking; het recht als zodanig blijft bestaan.

Zoals betoogd in hoofdstuk 2, meen ik dat artikel 2:25 BW de toelaatbaarheid van overeenkomsten tussen aandeelhouders niet raakt. Grenzen aan aandeelhoudersovereenkomsten worden gesteld door artikel 3:40 BW. De vraag is dan wanneer artikel 3:40 BW zich verzet tegen een overeenkomst waarin een aandeelhouder afziet van zijn recht. Niet rechtsgeldig zijn overeenkomsten die ertoe leiden dat een aandeelhouder van elke controlerende functie wordt ontheven en overeenkomsten die een beroep op de redelijkheid en billijkheid uitsluiten.

Naar mijn mening moeten aandeelhouders in besloten vennootschappen in sterkere mate dan in open vennootschappen zelf in staat worden geacht te bepalen welke machtsverhoudingen zij in de vennootschap wensen. Derhalve kan het 'Kernbereich' aan dwingende, niet voor 'afstand' vatbare rechten voor deze aandeelhouders worden beperkt tot het recht op 
het vorderen van vernietiging van besluiten, het verzoeken van een enquête of ontbinding van de vennootschap, het uittredings- en uitstotingsrecht. Concreet betekent dit dat aandeelhouders in beginsel mogen overeenkomen dat zij afzien van hun stemrecht, hun recht op deelname en hun recht op dividend. Wel dient de toelaatbaarheid van een dergelijke overeenkomst naar mijn mening te worden beperkt tot een overzienbare periode of concrete gevallen. De grenzen die worden gesteld aan aandeelhoudersovereenkomsten worden nader uitgewerkt in hoofdstuk 7.

Een bijzondere vorm van afstand is het onderwerpen van een geschil aan arbitrage. In dit geval wordt geen afstand gedaan van een recht, maar van de toegang tot de overheidsrechter. De vraag is of een aandeelhouder door toe te treden tot de vennootschap de mogelijkheid heeft aanvaard dat de meerderheid zou kunnen beslissen tot het onderwerpen van alle vennootschappelijke geschillen aan arbitrage. In deze lijken de Engelse en Duitse benadering uiteen te lopen. Terwijl in de Duitse literatuur het recht om vennootschappelijke geschillen aan de overheidsrechter voor te leggen de instemming van alle aandeelhouders vereist, lijkt het Engelse recht de onderwerping aan de besluitvorming bij meerderheid als uitgangspunt te nemen. Beide benaderingen hebben in Nederland pleitbezorgers.

Naar mijn mening kunnen vennootschappelijke geschillen slechts worden onderworpen aan arbitrage indien alle aandeelhouders hiermee instemmen. Het gaat om afstand van het recht om geschillen aan een overheidsrechter te onderwerpen, hetgeen doelbewust dient te geschieden. Deze opvatting brengt met zich mee dat een arbitrageovereenkomst ten aanzien van de vernietiging van besluiten slechts geldig is, voor zover alle aandeelhouders partij zijn en het besluit uitsluitend een geschil tussen aandeelhouders betreft. Dit zal niet zo snel het geval zijn bij een verzoek tot de ontbinding van de vennootschap. 


\section{Hoofdstuk 4 Statuten}

"Der Gesellschaftsvertrag ist der paradoxe Versuch, einem Unternehmensträgerverein und seinem Unternehmen eine dauerhafte Verfassung zu geben. Paradox ist dieser Versuch deshalb, weil solche Verfassungen statisch konzipiert werden, während Unternehmen sich dynamisch entwickeln, und zwar in einer rasch sich wandelnden Welt sich entwickeln müssen, wenn sie nicht aufhören wollen zu bestehen."

\section{$\S 4.1 \quad$ Inleiding}

In tegenstelling tot in het Engelse en Duitse recht, worden de statuten in de Nederlandse doctrine niet als overeenkomst gekwalificeerd, maar als rechtshandeling sui generis. In de Nederlandse rechtsliteratuur worden de statuten omschreven als "het fundament waarop de vennootschap is gebouwd" of "de eigen fundamentele organisatieregels van de individuele vennootschap," waarin de oprichters de vennootschappelijke verhoudingen gestalte geven. In een veel gebruikte metafoor vormen de statuten de vennootschappelijke 'constitutie'.'

In hoofdstuk 2 is gesteld, dat artikel 2:25 BW slechts de verhouding tussen de wet en de statuten betreft. Doel van dit hoofdstuk is om de functie van statuten in het naar uitgangspunt dwingende vennootschapsrecht te identificeren. In de Sluis-beschikking heeft de Ondernemingskamer gewezen op verschillende functies van statutaire bepalingen:

"De in de statuten van een vennootschap vervatte regels zijn enerzijds van belang voor haar organen, de met de vennootschap verbonden onderneming en derden die

Zollner, Die Anpassung von Personengesellschaftsvertrăgen an verănderte Umstände, 1979, blz. 11.

Van Schilfgaarde, nr. 124.

Handboek, nr. 149. Asser-Maeijer 2-II, nr. 35.

$\mathrm{Vgl}$ § $25 \mathrm{BGB}$ en draft clause 20 e.v. Companies Bill, www.dti.gov.uk/companiesbill/whitepaper.htm. 
met die vennootschap of onderneming enigerlei relatie onderhouden doch geven anderzijds weer hetgeen tussen de aandeelhouders op een bepaald moment is afgesproken ten aanzien van hun onderlinge verhouding."'

Aan dit onderscheid wordt in de Nederlandse literatuur geen rechtsgevolg verbonden. Men kan zich echter afvragen of alles wat in statutaire vorm is gegoten, ook als statutaire inhoud moet worden beschouwd.

Het rechtskarakter van statuten is van belang voor het vinden van de grondslag van de bindende kracht van statuten en voor de normerende werking ervan. ${ }^{6}$ Het is de vraag of het in Nederland gemaakte onderscheid tussen statuten en overeenkomsten zo fundamenteel is, dat dit een status aparte van statuten rechtvaardigt.

Daartoe worden statuten vergeleken met overeenkomsten. Het overeenkomstbegrip dient als ijkpunt voor de statuten; naast de statuten wordt de aandeelhoudersovereenkomst als instrument gebruikt om de vennootschappelijke organisatie gestalte te geven. Teneinde beide instrumenten op waarde te schatten is een 'vergelijkend warenonderzoek' geboden.

De overeenkomst is één van de basisbegrippen van het privaatrecht en vormt een uitdrukking van de individuele vrijheid, die binding tussen individuen met rechtsgevolg bewerkstelligt. Aan het overeenkomstenrecht ligt de contractsvrijheid ten grondslag. Iemand is in beginsel vrij om een overeenkomst te sluiten, vrij om zijn wederpartij te kiezen, vrij om de inhoud van de overeenkomst te bepalen. Keerzijde van die vrijheid is de gebondenheid die daarop volgt (pacta sumt servanda). De gebondenheid aan de overeenkomst vooronderstelt contractsvrijheid; iemand moet vrij zijn om zich te kunnen binden. ' Dat maakt de overeenkomst zowel een uitoefening van vrijheid als een inperking ervan. De contractsvrijheid vindt haar grenzen in de wet, de openbare orde en goede zeden en in rechtsnormen als de redelijkheid en billijkheid.

Naar de heersende opvatting verschillen statuten van overeenkomsten op grond van de volgende kenmerken: ten eerste is de inhoud van de statuten gebonden aan wettelijke beperkingen; ten tweede hebben statuten rechtsgevolgen voor derden; ten derde vindt de interpretatie van statuten plaats naar objectieve maatstaven; tenslotte geschiedt de wijziging van de statuten in beginsel bij meerderheid van stemmen. De vraag is dan, of hetgeen formeel in de statuten is neergelegd, steeds tevens als statuten in materiële zin heeft te gelden, anders gezegd, of alle (formele) statutaire

OK 24 januari 1991, NJ 1991, 224.

Vgl. Van der Velden, De vereniging-rechtspersoon en haar leden, 1969, blz 63.

Vgl. Asser-Hartkamp 4-II, nr. 35 e.v. 
bepalingen ook (materiële) statutaire werking hebben. Andersom is de vraag of er buiten de wettelijke bepalingen ten aanzien van de inhoud van de statuten 'fundamentele organisatieregels' kunnen worden geïdentificeerd, die statutaire vastlegging behoeven teneinde geldig te zijn.

Het is aan de hand van de contractsvrijheid en -gebondenheid enerzijds, en aan de hand van de verschillen tussen overeenkomsten en statuten anderzijds, dat hierna wordt gepoogd statuten nader te analyseren. Zijn statuten werkelijk zo verschillend van overeenkomsten, dat het scheppen van een dwingend wettelijk kader voor toegelaten statutaire afwijkingen is gerechtvaardigd? Deze vraag wordt extra gekleurd door de omstandigheid dat er sinds september 2001 geen inhoudelijk departementaal toezicht meer plaatsvindt. $\mathrm{Na}$ de afschaffing van de departementale richtlijnen rust de verantwoordelijkheid voor de overeenstemming van de statuten met de wet dus uitsluitend op de notaris.

\section{$\S 4.2$ Nederland}

\section{\$4.2.1 Het rechtskarakter van statuten}

"De statuten zijn de organisatie, de wet van een nieuwe persoon: zij zijn bestemd de rechtsverhoudingen van de persoon tot zijn leden en tot derden te bepalen. Zij zijn niet als de overeenkomst toevallig mede voor rechtsopvolgers van belang, maar zij hebben essentieel voor een onbepaald aantal personen rechtsgevolg, zij vormen het recht voor een niet van tevoren aan te wijzen kring van betrokkenen. Zij zijn abstract recht."

Deze opvatting van Paul Scholten over het rechtskarakter van statuten kan voor Nederland nog steeds als heersend worden aangemerkt. Volgens Maeijer bepalen de statuten voor een goed deel het eigen niet-contractuele rechtsregime van de vennootschap als rechtspersoon." Van Schilfgaarde meent dat de statuten samen met de wet een deelrechtsorde vormen: een zelfstandig juridisch systeem, deel uitmakend van een meeromvattend systeem, waartussen een voortdurende wisselwerking bestaat. ${ }^{10}$ In navolging van de opvatting van Scholten wordt in de literatuur verkondigd dat de statuten objectief recht zijn," dan wel "een zeker objectiefrechtelijk karakter" hebben. ${ }^{12}$

P. Scholten, Asser I-2, blz, 130.

Maeijer, "Rumoer rond de Holland-Amerika Lijn", NV 1966, blz. 119. Zie ook Handboek, nr. 36. Van Schilfgaarde, nr. 1.

Van der Velden, 1969, blz. 64. Van Mourik, "Statuten", S\&V 1987, blz 4. Buys, "Statuten, reglementen en besluiten beschouwen als algemene voorwaarden?", TVVS 1992, blz. I49. Dijk/ 
Objectief recht kan worden omschreven als het recht dat geldt voor de leden van een rechtsgemeenschap, ongeacht of zij daarmee hebben ingestemd. ${ }^{13}$ Buys baseert zich met name op de wetssystematiek om het objectiefrechtelijke karakter van de statuten aan te tonen. ${ }^{14}$ Volgens Van der Velden wordt het objectiefrechtelijk karakter versterkt door het preventief toezicht. ${ }^{15}$

Löwensteyn onttrekt zich aan deze consensus. Hij meent dat de statuten geen objectief recht vormen, daar de betrokkenen door toe te treden tot de vennootschap de statuten zoals zij gelden en zullen gelden hebben aanvaard. ${ }^{16}$ Van Duuren pleit voor een genuanceerde benadering, al naar gelang de aard van het vennootschappelijk samenwerkingsverband en naar de aard van de statutaire bepalingen. ${ }^{17}$

\section{$\S 4.2 .2$ Statuten in formele en/of materiële zin}

De wet stelt dwingende voorwaarden aan de vorm en de inhoud van de statuten. Zo dienen de statuten van een BV in de Nederlandse taal in een notariële akte te worden vervat. Wordt aan deze eisen niet voldaan, dan kan de rechter de vennootschap ontbinden. Voorts dienen de statuten te worden neergelegd in het handelsregister, opdat derden ervan kennis kunnen nemen. De wet stelt tevens minimumeisen ten aanzien van de inhoud aan statuten.

Zo dienen de statuten in ieder geval de naam, zetel en het doel van de vennootschap te bevatten, het bedrag van het maatschappelijk kapitaal en het bedrag van en eventueel de soorten aandelen. ${ }^{18}$ De akte van oprichting vermeldt het geplaatst en gestort kapitaal, en de bij de oprichting benoemde bestuurders. De statuten dienen tevens een regeling te bevatten in geval van belet of ontstentenis van bestuurders. Bij de BV dienen de statuten een blokkeringsregeling te bevatten.

In het kader van het bepalen van de reikwijdte van artikel 2:25 BW, rijzen verschillende vragen met betrekking tot situaties waarin vorm en inhoud van statuten niet parallel lopen. In de eerste plaats is de vraag, of hetgeen

Van der Ploeg, blz, 59.

Handboek, nr. 149. Asser-Maeijer 2-II, nr. 36.

Pitlo/Lowensteyn, $3^{\mathrm{e}}$ druk, nr. 2.7.

Buys, TVVS 1992, blz. 149.

Van der Velden, 1969, blz. 64

Pitlo-Lowensteyn, $3^{\circ}$ druk, nr. 2.7. Lowensteyn, diss., blz. 87.

Van Duuren, De joint venture-vennootschap, 2002, blz. 64.

Artt. 2:177 en 178 lid 1 BW. 
formeel in de statuten is neergelegd, steeds tevens als statuten in materiële zin heeft te gelden. Hebben alle (formele) statutaire bepalingen ook (materiële) statutaire werking? Waaijer acht de vorm waarin statuten zich presenteren doorslaggevend, met een beroep op de bedoelingen van de opstellers. ${ }^{19}$ Een andere visie zou ertoe leiden dat sommige bepalingen, die wel in de statuten zijn neergelegd, niettemin als overeenkomst kunnen worden beschouwd, met uitsluitend werking tussen partijen.

In de tweede plaats is de vraag of er buiten de wettelijke bepalingen ten aanzien van de inhoud van de statuten 'fundamentele organisatieregels' kunnen worden geïdentificeerd, die statutaire vastlegging behoeven teneinde geldig te zijn. De vraag is dan of een aandeelhoudersovereenkomst, waarin dergelijke fundamentele organisatieregels zijn neergelegd, nietig zou zijn wegens het niet voldoen aan een vormvereiste in de zin van artikel 3:39 BW. Bovendien zouden de statuten, bij het ontbreken van dergelijke fundamentele organisatieregels, niet aan de eisen der wet voldoen, hetgeen kan leiden tot ontbinding van de vennootschap.

Van Mourik stelt dat aangelegenheden waarover de wet zwijgt niet als fundamenteel kunnen worden aangemerkt. Hij noemt als twijfelgeval de goedkeuringsbevoegdheid van een gemeente bij bepaalde bestuursbesluiten. ${ }^{20}$ Inmiddels is in september 2001 in artikel 2:239 lid $3 \mathrm{BW}$ vastgelegd dat bestuursbesluiten slechts aan de goedkeuring van een orgaan (in de zin van artikel 2:189a BW) kunnen worden onderworpen. Goedkeuringsrechten ten aanzien van besluiten van andere organen hebben geen uitdrukkelijke wettelijke basis. Indien een goedkeuringsbevoegdheid als fundamentele organisatieregel zou worden beschouwd, zou dit met zich meebrengen dat bijvoorbeeld een goedkeuringsrecht ten behoeve van een individuele aandeelhouder voor de benoeming van een bestuurder, dat in een aandeelhoudersovereenkomst is neergelegd, nietig zou zijn op grond van artikel 3:39 BW.

Waaijer meent dat wanneer de wet aangeeft "de statuten kunnen bepalen", dit betekent dat deze regels uitsluitend door neerlegging in de statuten hun rechtskracht verwerven. ${ }^{21}$ In deze optiek zijn aanvullende bepalingen dwingend qua vorm, in de zin dat uitsluitend aanvulling bij statuten toelaatbaar wordt geacht, en niet bij overeenkomst. In zeker opzicht bestaat er dan een gelijkenis met 'driekwart' dwingend arbeidsrecht, waar afwijkingen van de wet uitsluitend in een collectieve arbeidsovereenkomst zijn toegestaan. Ook uit deze opvatting volgt dat een contractuele bepaling die

Waaijer, Statuten en statutenwijziging, 1993, blz. 7/8.

Van Mourik, S\&V 1987, blz 4.

Waaijer, 1993, blz. 8. 
bijvoorbeeld kwaliteitseisen aan aandeelhouders stelt nietig zou zijn op grond van artikel 3:39 BW.

Wanneer men dergelijke opvattingen beziet in het licht van artikel 2:25 BW, zou gesteld kunnen worden dat artikel 2:25 BW niet alleen de wettelijk vereiste inhoud van statuten bepaalt, maar ook de nietigheid van overeenkomsten die zich op het aan statuten voorbehouden terrein begeven met zich meebrengt. Het gaat er dan om te identificeren welk terrein exclusief aan de statuten is voorbehouden.

Naar mijn mening dient het dwingendrechtelijk uitgangspunt van artikel 2:25 BW echter uitsluitend om de verhouding tussen wet en statuten af te bakenen, en beoogt artikel 2:25 BW niet de nietigheid van overeenkomsten tussen aandeelhouders die de vennootschappelijke verhoudingen betreffen. ${ }^{22}$ De contracts- en inrichtingsvrijheid van oprichters en aandeelhouders dient te worden vooropgesteld. ${ }^{3}$ Dit kan aan de hand van de volgende voorbeelden worden verduidelijkt.

Artikel 2:230 lid 2 BW bepaalt dat de geldigheid van een besluit niet afhankelijk is van het ter vergadering vertegenwoordigd gedeelte van het kapitaal. Stel dat de aandeelhouders onderling hebben afgesproken dat alle besluiten de instemming van alle aandeelhouders behoeven, zonder dit in de statuten vast te leggen. Mijns inziens strekt artikel 2:230 lid 2 BW dan niet tot de nietigheid van een dergelijke overeenkomst. De aandeelhoudersovereenkomst kan echter in beginsel niet verhinderen dat een besluit genomen bij volstrekte meerderheid van de uitgebrachte stemmen geldig is, tenzij het besluit in strijd zou zijn met de redelijkheid en billijkheid.

Hetzelfde geldt in het volgende geval. Stel dat de statuten van een vennootschap de overdracht van aandelen binnen de vrije kring niet beperken, maar dat aandeelhouders zijn overeengekomen dat zij bij een dergelijke overdracht de aanbiedingsregeling zoals bedoeld in artikel 2:195 lid 5 BW zullen volgen. Wederom betekent dit mijns inziens niet dat een dergelijke overeenkomst nietig is, maar is het gevolg van het ontbreken van statutaire neerlegging uitsluitend dat een overdracht in strijd met de overeenkomst op zichzelf geldig is, (want in overeenstemming met de wet).

Een enigszins andere afweging zou kunnen worden gemaakt indien een overdracht plaatsvindt buiten de vrije kring terwijl in het (theoretische) geval een dwingende statutaire bepaling, nl. de blokkeringsregeling, zou ontbreken. Indien de aandeelhouders uitsluitend bij overeenkomst in een aanbiedingsregeling hebben voorzien, zou de contractuele aanbiedingsrege-

Zie \$ 7.2.3.

Zie reeds Van Schilfgaarde, Vrijheid van vennootschap, in: Vrijheid van recht: opstellen aangeboden aan prof, mr. E.H. s'Jacob, 1975, blz. 247 e.v. 
ling nietig kunnen zijn wegens strijd met artikel 3:39 BW. Ook in dit geval acht ik echter verdedigbaar dat de strekking van artikel $3: 39$ jo. $3: 40$ lid 3 BW niet is de nietigheid van de overeenkomst. Indien de statuten niet voldoen aan de eisen der wet, verdient het mijns inziens de voorkeur om te zorgen dat de statuten in overeenstemming komen met de wet. De nietigheid van een contractuele regeling draagt daar niet aan bij.

Een goedkeuringsbevoegdheid van een derde, zoals door Van Mourik genoemd, is daarentegen een aanvullende regeling, geen afwijking van de wet. Evenzeer aanvullend zijn bepalingen omtrent kwaliteitseisen voor aandeelhouders of een bindende voordracht voor de benoeming van bestuurders. Zijn dergelijke regelingen uitsluitend rechtsgeldig indien neergelegd in de statuten, zoals Waaijer stelt? Naar mijn opvatting is er geen bezwaar tegen een contractueel voordrachtsrecht voor een aandeelhouder of kwaliteitseisen in een aandeelhoudersovereenkomst. Dergelijke contractuele rechten kunnen echter in beginsel niet verhinderen dat een overdracht plaatsvindt aan een aandeelhouder die niet aan de eisen voldoet, of dat de voordracht kan worden doorbroken conform artikel 2:243 lid 2 BW. ${ }^{24}$

Een aan deze problematiek verwante vraag, die recentelijk aandacht heeft gekregen in de literatuur, is of in de statuten mag worden verwezen naar een aandeelhoudersovereenkomst (zgn. 'incorporation by reference') en wat het rechtsgevolg daarvan is. Buijn en Ten Berg achten een dergelijke verwijzing in de statuten nietig. ${ }^{25}$ Van Schilfgaarde heeft echter geen bezwaar tegen een dergelijke bepaling. ${ }^{26}$ Een dergelijke verwijzing is nietig, indien deze in strijd is met een dwingende wettelijke bepaling, de openbare orde of de goede zeden. Er bestaat geen wettelijke bepaling die een verwijzing als zodanig verbiedt. Wel moet een verwijzing naar een onderwerp dat op grond van de wet tot de minimuminhoud van de statuten behoort, mijns inziens ongeoorloofd worden geacht. Zo zou een statutaire bepaling met de tekst "het maatschappelijk kapitaal wordt vastgesteld in de aandeelhoudersovereenkomst" nietig zijn wegens strijd met artikel 2:178 lid $1 \mathrm{BW}$. Buiten deze dwingen-de minimuminhoud van de statuten, waartoe ook de blokkeringsregeling behoort, meen ik dat statuten vrijelijk mogen verwijzen naar aandeel-houdersovereenkomsten. Noch artikel 2:25 BW, noch de openbare orde verzetten zich hiertegen. Afspraken tussen aandeelhouders waarnaar de statuten verwijzen, vormen in mijn optiek een anvulling van de wettelijke minimuminhoud van statuten, geen afwijking.

\section{Zie $\$ 7.2 .3$.}

Buijn, "Statuten: terug naar de overeenkomst?", Ondernemingsrecht 1999, blz. 123. Ten Berg. Statuten versus aandeelhoudersovereenkomsten, preadvies KNB, 2002, blz. 186.

26. Van Schilfgaarde, "Statuten zonder bezwaar", WPNR 2002, blz. 641. 
Ik zie dan ook geen reden om dergelijke formele statutaire bepalingen nietig te achten. Op welke wijze een buitenstatutaire afspraak verschilt in rechtsgevolg van een statu-taire regeling, komt aan de orde in hoofdstuk 7.

\section{$\S 4.2 .3$ De interpretatie van de statuten}

Statuten zijn geen recht in de zin van art. $99 \mathrm{RO} ;{ }^{27}$ de uitleg van statuten kan niet in cassatie worden getoetst. ${ }^{2 \mathrm{~s}}$ Wel zijn de door de feitenrechter gehanteerde uitlegmaatstaven voor cassatie vatbaar. ${ }^{29}$ Dan rijst de vraag welke maatstaven de feitenrechter bij de interpretatie van statuten geacht wordt te hanteren.

Ten aanzien van de uitleg van schriftelijke overeenkomsten heeft de Hoge Raad de 'Haviltex-maatstaf' geïntroduceerd: het komt aan op de zin die partijen in de gegeven omstandigheden over en weer redelijkerwijs aan de bepalingen mochten toekennen en op hetgeen zij te dien aanzien redelijkerwijs van elkaar mochten verwachten. ${ }^{30}$ Dit kan niet zonder meer worden gelijkgesteld aan de subjectieve bedoelingen van partijen, veeleer gaat het om 'geobjectiveerde' bedoelingen, d.w.z. vastgesteld aan de hand van wat in het maatschappelijk verkeer gangbaar is." Met de Haviltex-norm wordt tot uitdrukking gebracht dat het bij de uitleg van overeenkomsten om het vaststellen van de betekenis van de verklaringen van partijen aan de hand van de redelijkheid en billijkheid gaat. ${ }^{32}$

Tot dusverre heeft de Hoge Raad zich niet uitgelaten over de te hanteren maatstaf voor de uitleg van statuten. In een geschil over de vraag of de enig overgebleven bestuurder van een stichting geldige besluiten kon nemen, terwijl de statuten voorschreven dat er tenminste twee bestuurders moesten zijn, hanteerde het hof een "redelijke uitleg" van de zinsnede in het licht van de statuten als geheel, waaruit voortvloeide dat de betrokken bestuurder geen rechtsgeldige besluiten kon nemen. Deze interpretatie achtte de Hoge Raad niet onjuist. ${ }^{3}$ Min of meer dezelfde maatstaf werd door het hof gebruikt in de Verenigde Bootlieden-zaak. Daar ging het hof ervan uit dat

Veegens/Korthals Altes/Groen, Cassatie in burgerlijke zaken, $3^{\mathrm{e}}$ druk, 1990, nr. 91.

HR 17 september 1993, NJ 1994, 213 (Meier Mattern/VHS). HR 31 december 1993, NJ 1994. 436 (Verenigde Bootlieden).

Stein, noot HR 24 september 1993, NJ 1994, 174 (Hol/EIM).

HR 13 maart 1981, NJ 1981, 635.

Veegens/Korthals Altes/Groen, 1990, blz. 215.

$\mathrm{Vgl}$. Asser-Hartkamp 4-II, nr. 280. Over de (beperkte) betekenis van de Haviltex-norm, zie Van Schaick, "Uitlegregels", WPNR 1998, blz. 272 e.v.

HR 17 september 1993, NJ 1994, 213 (Meier Mattern/VHS). 
de bepalingen van de statuten in hun onderlinge samenhang moeten worden uitgelegd, hetgeen werd gesanctioneerd door de Hoge Raad. ${ }^{34}$

In de Nederlandse literatuur spitst de discussie zich toe op de vraag in hoeverre de bedoelingen van degenen die de statuten hebben vastgesteld een rol mogen spelen bij de interpretatie van statuten. Maeijer vindt dat aan de subjectieve bedoelingen van de oprichters/aandeelhouders in ieder geval geen "doorslaggevende betekenis" mag worden gehecht." Dit zou volgen uit het objectiefrechtelijk karakter van de statuten. ${ }^{36}$ Indien de bewoordingen van de statuten duidelijk zijn, zijn de bedoelingen naar zijn mening geheel irrelevant. Zijn de bewoordingen minder duidelijk, dan gaat het om wat redelijk denkende mensen onder die bewoordingen mogen verstaan, gelet op de context en de inrichting van de rechtspersoon. Daarbij ziet Maeijer bij vennootschaps-interne verhoudingen een rol weggelegd voor de goede trouw. ${ }^{37}$ Waaijer onderschrijft de opvatting van Maeijer, maar maakt een uitzondering voor de gevallen waarin er geen derden zijn, bijvoorbeeld in een BV met twee aandeelhouders/bestuurders. ${ }^{35}$ Geïnspireerd door het Duitse recht pleit Smits voor een gedifferentieerde benadering, afhankelijk van de aard van de betrokken bepaling. Slechts statutaire bepalingen die ook voor derden van belang zijn, zouden objectief moeten worden geïnterpreteerd, d.w.z. zonder acht te slaan op de bedoelingen van oprichters. ${ }^{39}$

Een enigszins vergelijkbare discussie wordt gevoerd in het arbeidsrecht ten aanzien van de uitleg van bepalingen van een niet-algemeen verbindend verklaarde $\mathrm{CAO}^{40}$ Daaromtrent heeft de Hoge Raad geoordeeld dat "de bewoordingen daarvan, gelezen in het licht van de gehele tekst van die overeenkomst, in beginsel van doorslaggevende betekenis" zijn." Volgens de Hoge Raad zijn individuele werknemers en eventueel werkgevers doorgaans niet betrokken bij de totstandkoming van een $\mathrm{CAO}$, zodat aan hen geen andere gegevens ter beschikking staan dan de tekst. De bedoelingen van de bij de CAO betrokken partijen doen in dat geval niet ter zake. ${ }^{12}$ Wel kan bij de uitleg aan de bedoelingen van partijen

HR 31 december 1993, NJ 1994, 436, r.o. 5.

Asser-Maeijer 2-II, nr. 36. Evenzo Handboek, nr. 149.

Vgl. Van der Velden, 1969, blz 64.

Maeijer, NV 1966, blz. 120.

Waaijer, 1993, blz. 12.

Smits, "Over de uitleg van statuten ener rechtspersoon; een deels rechtsvergelijkende bijdrage", S\&V 1999, blz. 127. Zie ook Van Duuren, 2002, blz. 65 e.v.

to Een algemeen verbindend verklaarde CAO is recht in de zin van art. 99 (thans 79) RO, HR 2 november 1990, NJ 1991, 25.

HR 17 september 1993, NJ 1994, 173 (Gerritse/Hydro Agri Sluiskil).

Vgl. HR 24 september 1993, NJ 1994, 174 (Hol/EIM). Zie ook HR 18 december 1991, NJ 1992, 334 , waar de Hoge Raad aan wijziging boekjaar in statuten geen terugwerkende kracht verleent in verband met de kenbaarheid aan derden. 
betekenis worden toegekend, indien deze naar objectieve maatstaven volgen uit de CAO-bepalingen en de eventueel daarbijbehorende schriftelijke toelichting, en dus voor de individuele werknemers en werkgevers die niet bij de totstandkoming van de overeenkomst betrokken zijn geweest kenbaar zijn."

Het hanteren van een 'objectieve' interpretatiemethode hangt kennelijk af van de vraag of derden door de regeling worden geraakt. Paradoxaal is echter dat, hoewel de statuten als document voor derden kenbaar moeten zijn, de geschillen die zich voordoen naar aanleiding van onduidelijkheden in de statuten zich veelal afspelen in de interne sfeer, tussen aandeelhouders onderling. Dit geldt met name in persoonsgebonden BV's.

Voor zover de bedoelingen van partijen nader zijn geconcretiseerd in onderlinge afspraken, mag (of zelfs moet) de rechter mijns inziens daarmee rekening houden bij de interpretatie van de statuten. Dit wordt nader uiteengezet in $\S 7.2 .4$. De gepercipieerde tegenstelling tussen de interpretatie van statuten en overeenkomsten is naar mijn opvatting niet meer dan een schijntegenstelling. De 'redelijke' uitleg van statuten zoals door de Hoge Raad gesanctioneerd verschilt niet zoveel van de Haviltex-norm. De Haviltex-norm biedt althans genoeg ruimte om te differentiëren al naar gelang de belangen van het rechtsverkeer dit noodzakelijk maken. De redelijkheid brengt eveneens met zich mee dat niet uit de statuten kenbare bedoelingen van oprichters niet aan later toegetreden aandeelhouders kunnen worden tegengeworpen, indien zij hiervan op het moment van toetreding niet op de hoogte waren.

\section{$\S 4.2 .4$ Wijziging van de statuten bij meerderheidsbesluit}

Uit de grondslag van de gebondenheid aan een overeenkomst vloeit voort dat partijen een overeenkomst niet eenzijdig kunnen wijzigen. Wijziging kan in beginsel slechts geschieden met instemming van alle partijen, tenzij anders is overeengekomen. In geval van statuten is de hoofdregel echter dat statuten bij meerderheidsbesluit van de algemene vergadering van aandeelhouders kunnen worden gewijzigd (artikel 2:231 BW). Door toe te treden tot de vennootschap hebben aandeelhouders zich onderworpen aan de inzichten van de meerderheid. ${ }^{+}$

\footnotetext{
43 HR 28 juni 2002, RvdW 117. In zijn noot komt de Hoge Raad volgens Grapperhaus "as close as you can get "bij het Haviltex-criterium. 
De statuten kunnen echter een gekwalificeerde meerderheid en/of een quorum voorschrijven. ${ }^{45}$ Wordt een besluit tot statutenwijziging buiten de algemene vergadering genomen, dan kan dit uitsluitend met algemene stemmen, op grond van artikel 2:238 BW.

De parlementaire geschiedenis van de Wet op de naamlooze vennootschappen van 1928 geeft geen blijk van gedachtevorming over een speciale behandeling van besluiten tot statutenwijziging ten opzichte van andere besluiten. Minister Heemskerk geeft in de toelichting op artikel $44 d$ van het Gewijzigd Ontwerp 1925 - de voorloper van het huidige artikel 2:230 BW - wel aan, waarom voor de besluiten van de algemene vergadering in het algemeen geen gekwalificeerde meerderheid als uitgangpunt is genomen: "Het is den ondergeteekende niet duidelijk op welken grond de wet de minderheid zou moeten brengen in een sterkere positie tegenover een andere groep, die toch meer is dan de minderheid." 46

Zelfs als de bevoegdheid tot wijziging van de statuten is uitgesloten, kunnen de statuten niettemin worden gewijzigd met algemene stemmen in een vergadering waarin het gehele geplaatste kapitaal is vertegenwoordigd. Hetzelfde geldt voor een bepaling in de statuten, die de bevoegdheid tot wijziging van een of meer andere bepalingen uitsluit, aldus artikel 2:231 lid $1 \mathrm{BW}$.

Over de vraag of uitsluiting van de bevoegdheid tot statutenwijziging al dan niet mogelijk is bestaat in Nederland thans geen discussie meer. Bij de totstandkoming van de Wet op de naamlooze vennootschappen verschilde men daarover nog van mening. Anders dan in het ontwerp van de Staatscommissie, kon in artikel $46 f$ van het Ontwerp 1910 wijziging van de statuten worden uitgesloten. Minister Nelissen motiveerde dit verschil als volgt: "Volgens de gestrenge letter zou krachtens het ontwerp der Staatscommissie de algemeene vergadering bevoegd zijn ook wijziging te brengen in eene bepaling, die de akte onveranderbaar had verklaard. Hetgeen natuurlijk niet aangaat." ${ }^{\prime 7}$ Het nieuwe artikel 45 van het Gewijzigd Ontwerp, dat overeenkomt met de huidige bepaling, werd door minister Heemskerk met dezelfde vanzelfsprekendheid - in geheel tegenovergestelde zin - toegelicht: "Het ligt voor de hand, dat, zelfs als de bevoegdheid tot wijziging is buitengesloten, wijziging toch mogelijk moet zijn met medewerking van alle aandeelhouders." ${ }^{\prime 4}$ Ratio van het uitsluiten van de onveranderbaarheid van statuten is te verhinderen dat oprichters "over hun graf heen regeren". Later toegetreden aandeelhouders dienen, indien zij andere inzichten hebben over de inrichting van statuten, deze te

45

Art. 2:230 BW. Van Schilfgaarde, blz. 322, Sanders/Westbroek, blz. 256, Asser-Maeijer 2-III, nr. 540 .

Belinfante, Ontwerpen van wetten op de vennootschappen en andere, blz. 208.

Belinfante, blz. 82.

Belinfante, blz. 209. 
kunnen wijzigen. Bovendien zou een dergelijke clausule de vennootschappelijke ontwikkeling belemmeren.

Opdat de statutenwijziging daadwerkelijk van kracht wordt, is een notariële akte vereist en een ministeriële verklaring van geen bezwaar. ${ }^{49}$ Bovendien zijn de bestuurders verplicht de gewijzigde statuten bij het handelsregister te deponeren.

Waaijer pleit voor het hanteren van unanimiteit als uitgangspunt bij de besluitvorming van de algemene vergadering in een BV, tenzij daarvan statutair wordt afgeweken. Wijziging van de grondregels van de vennootschap bij volstrekte meerderheid zou volgens hem geen recht doen aan het persoonlijke karakter en de nauwe samenwerking binnen de BV. ${ }^{30} \mathrm{Ik}$ meen, dat er goede gronden zijn om voor een besluit tot statutenwijziging een gekwalificeerde meerderheid van twee derde van de stemmen als wettelijk uitgangspunt te nemen. In de eerste plaats sluit dit aan bij gedachte dat voor wijziging van de interne organisatieregels een versterkte meerderheid is vereist, als procedurele bescherming voor minderheidsaandeelhouders. In de tweede plaats past de gekwalificeerde meerderheid van twee derde in het wettelijk systeem, waar de keuzevrijheid van de algemene vergadering voorop wordt gesteld bij het doorbreken van de bindende voordracht voor de benoeming van bestuurders en de kwaliteitseisen voor bestuurders. ${ }^{51}$

\section{$\S 4.2 .5$ Beperking van de bevoegdheid tot statutenwijziging}

Naar algemene opvatting berust de bevoegdheid tot statutenwijziging dwingendrechtelijk bij de algemene vergadering, hetgeen inhoudt dat de bevoegdheid niet aan anderen mag worden toegekend. .2 Dit heeft de Nederlandse wetgever er niet van weerhouden om - uit praktische overwegingen - enigerlei vorm van delegatie aan anderen dan aandeelhouders toe te staan.

Zo kan de algemene vergadering op grond van artikel 2:234 lid 2 BW het bestuur of een of meer anderen machtigen de statuten conform de door

49 De verklaring wordt slechts geweigerd, indien de vennootschap een verboden karakter zou krijgen of dat gevaar bestaat dat zij voor ongeoorloofde doeleinden zou worden gebruikt, art. $2: 235$ lid 2 (nieuw). In de praktijk schijnt deze bepaling vooralsnog nauwelijks te worden nageleefd.

so Waaijer, 1993, blz. 45

51 Zie $\S 4.2 .5$ en $\S 6.2 .4$. Voor de NV is wellicht een extra argument dat deze gekwalificeerde meerderheid een aanknopingspunt zou kunnen vormen voor het instellen van een verplicht openbaar bod.

52. Handboek, nr. 342. Van Schilfgaarde, blz, 321. Asser-Maeijer 2-III, nr. 540. 
het departement gewenste aanpassingen te wijzigen.s Voorheen liet het departement statutaire bepalingen toe, inhoudende dat de beslissing tot het deponeren van de statutenwijziging in het handelsregister door een bepaald vennootschapsorgaan zal worden genomen en dat dit orgaan daartoe alleen in bepaalde omstandigheden zal mogen of moeten overgaan. ${ }^{54}$ In het geval dat het orgaan hiertoe over mag gaan, betekent dit dat het orgaan onder omstandigheden vrij is om een bepaalde statutenwijziging al dan niet ten uitvoer te brengen. Nu deze departementale richtlijn geen wettelijke basis heeft verkregen bij de herziening van het preventief toezicht, is de vraag of deze inbreuk op de dwingendrechtelijke toekenning van de bevoegdheid an de algemene vergadering toelaatbaar is. Bosse ziet geen probleem.s. Kennelijk beschouwt hij een dergelijke statutaire bepaling als een aanvulling op de dwingendrechtelijke bevoegdheid van de algemene vergadering, zonder dat deze een uitdrukkelijke wettelijke grondslag behoeft. ${ }^{56} \mathrm{Naar}$ mijn mening gaat het echter om een afwijking van de wet, daar een ander orgaan dan de algemene vergadering beslissende invloed kan uitoefenen op de al dan niet inwerkingtreding van de statutenwijziging. De toelaatbaarheid van een dergelijke bepaling lijkt mij dan afhankelijk van de voorwaarde dat de omstandigheden zo nauwkeurig zijn omschreven, dat er geen sprake is van enige discretie.

Naar heersende opvatting mag de bevoegdheid van de algemene vergadering ook anderszins worden beperkt, door aan een ander orgaan het recht van voorstel of goedkeuring van een statutenwijziging toe te kennen." Het verschaffen van een recht van voorstel of goedkeuring aan een derde is in de Nederlandse literatuur evenmin controversieel..$^{58}$ In de nota naar aanleiding van het verslag schrijft de minister: "Op grond van het nieuwe lid 4 (van artikel 2:210 BW, MM) mogen de statuten bepalen, dat een besluit van de algemene vergadering van aandeelhouders onderworpen is aan de goedkeuring van een derde, met uitzondering van het besluit tot vaststelling van de jaarrekening. De algemene vergadering van een gewone

\footnotetext{
33 Het lijkt erop of men bij de herziening van het preventief toezicht deze bepaling is vergeten te schrappen.

Departementale richtlijnen $1986 \S 4$.

Bosse, "De bruikbaarheid van de vervallen Departementale Richtlijnen", WPNR 2001, blz. 545.

Zie $\$ 2.2 .3$.

Van Schilfgaarde, blz. 317, Asser-Maeijer, nr. 540, Sanders/Westbroek, blz. 255. Anders Van der Ploeg, Het burgerlijk recht en de vrijwillige organisaties, diss. 1978, blz. 138 en Dijk/Van der Ploeg, Van vereniging en stichting, cooperatie en onderlinge waarborgmaatschappij, blz. 232, met betrekking tot statutenwijziging van verenigingen.

58 Asser-Maeijer, nr. 540, Sanders/Westbroek, blz. 255. Bosse, WPNR 2001, blz. 547. Terughoudender Van Olffen, Inrichting van de statuten zonder preventief toezicht, in: A-T-D, opstellen aangeboden aan Prof. mr. P. van Schilfgaarde, 2000, blz. 340.
} 
vennootschap kan geen afstand doen van dit recht ten aanzien van de jaarrekening. Lid 4 is opgenomen omdat de wet vooralsnog geen uitdrukkelijke grondslag voor het bepalen van een goedkeuringsrecht geeft." ${ }^{\prime 9}$ Wel blijkt indirect uit artikel 2:317 BW, dat een besluit tot fusie, evenals een besluit tot statutenwijziging, onderworpen kan zijn aan een statutair goedkeuringsvereiste. Lid 3 bepaalt namelijk: "Een besluit tot fusie wordt genomen op dezelfde wijze als een besluit tot wijziging van de statuten. Vereisen de statuten hiervoor goedkeuring, dan geldt dit ook voor het besluit tot fusie." Er wordt geen onderscheid gemaakt tussen de goedkeuring van een orgaan of die van een derde..$^{\infty 0}$

Ten gunste van de toelaatbaarheid van een goedkeuringsbevoegdheid bij statutenwijziging van een derde redeneert Waaijer als volgt: "De statuten kunnen de bevoegdheid tot wijziging geheel uitsluiten. Beperking van de wijzigingsbevoegdheid van de algemene vergadering moet dan mogelijk zijn". ${ }^{61}$ Dit neemt niet weg dat de beperking in casu kan bestaan uit het uitbreiden van invloed van anderen dan de algemene vergadering. ${ }^{62}$ Waaijer heeft hier geen onoverkomelijke bezwaren tegen, want "hoe men het ook draait of keert, het is de algemene vergadering die uitmaakt of de statuten gewijzigd worden." ${ }^{\text {"s }}$ Wanneer de algemene vergadering daarvoor echter afhankelijk is van het initiatief of de goedkeuring van een ander, maakt dat mijns inziens wel degelijk een verschil. Sanders/Westbroek achten het ontbreken van goedkeuring niet aan de geldigheid van het besluit in de weg staan. De argumentatie is dat de algemene vergadering steeds bevoegd is de statuten met algemene stemmen te wijzigen. ${ }^{-4}$

Naar mijn mening is de bevoegdheid tot statutenwijziging een belangrijke bevoegdheid van de algemene vergadering, waarmee aandeelhouders de statutaire inrichting kunnen aanpassen aan de vennootschappelijke ontwikkeling. De keuzevrijheid van aandeelhouders in dit opzicht mag naar mijn mening niet te zeer worden beperkt. Ik zou willen aannemen dat de algemene vergadering in ieder geval met algemene stemmen de statuten mag wijzigen, voorbijgaand aan een statutair goedkeuringsrecht, analoog aan de keuzevrijheid die de algemene vergadering heeft bij het doorbreken van de bindende voordracht en statutaire kwaliteitseisen aan bestuurders. ${ }^{65}$ Een recht van initiatief tot statutenwijziging mag mijns inziens niet exclu-

\footnotetext{
TK 1999-2000, 26277 , nr. 5, blz. 10.

Zie ook Asser-Maeijer 2-III, nr, 582.

Waaijer, 1993, blz 119.

Vgl. Van Schilfgaarde, WPNR 2002, blz. 645.

Waaijer, 1993, blz. 120.

Sanders/Westbroek, blz. 255, Zie ook $\$ 4.5 .3$.

Vgl. $\S 4$.
} 
sief zijn; de algemene vergadering moet ook op eigen initiatief - zij het met algemene stemmen - de statuten kunnen wijzigen.

\section{$\S 4.3$ Duitsland}

\section{$\S 4.3 .1$ Het rechtskarakter van de Satzung ${ }^{60}$}

In Duitsland worden zowel de 'institutionele' als de 'contractuele' opvatting ten aanzien van statuten van rechtspersonen in de literatuur aangetroffen. ${ }^{67}$ Aanhangers van de Vertragstheorie zien de statuten als overeenkomst tussen de leden, waarop de regels van het burgerlijk recht van toepassing zijn. Nieuwe leden treden toe tot de rechtspersoon en accepteren zodoende de statuten. Tegenover de contractuele opvatting stelde Von Gierke de Normentheorie. In deze optiek vormen de statuten een op de Vereinsautonomi $^{6 x}$ gebaseerde objectieve wet, die ontstaat door een Gesamtakt. ${ }^{60}$ De statuten zijn 'korporationsrechtlich' van aard, hetgeen inhoudt dat de bij de vennootschap betrokkenen zijn onderworpen aan de statuten, ongeacht of zij ermee hebben ingestemd. De Gestaltungsfreiheit wordt in deze visie slechts bepaald door de wet. ${ }^{0}$ Volgens Reuter is het wezenlijke onderscheid tussen Norm en Vertrag dat een overeenkomst het resultaat is van een compromis tussen individuele belangen, terwijl een Norm een ordening verschaft ter verwezenlijking van een doel, dat uitstijgt boven de individuele belangen."

In de heersende leer wordt getracht beide opvattingen met elkaar te verenigen. Voor het verenigingsrecht heeft het Bundesgerichtshof een tussenoplossing gekozen. Het beschouwt de statuten van een vereniging bij de oprichting als overeenkomst, daarna als een voor de leden als objectief geldende wet:

66. Hoewel de wettelijke term voor de statuten van een GmbH 'Gesellschaftsvertrag' is, wordt dit in het spraakgebruik uitsluitend voor de oprichtingsakte gebruikt. 'Satzung' is de gangbare term voor de statuten, Baumbach/Hueck/Fastrich $\$ 2,3$.

Flume, Allgemeiner Teil des Bürgerlichen Rechts - Die juristische Person, 1983, blz. 316. Hadding, Korporationsrechtliche oder rechtsgeschaftliche Grundlagen des Vereinsrechts?, in: Festschrift für Robert Fischer, 1979, blz. 165 e.v. Soergel/Schultze-v. Lasaulx, Kommentar zum BGB, $11^{\complement}$ druk, 1978, $\$ 25,11$. Wiedemann, Gesellschaftsrecht, 1980, blz. 160.

Zie $\$ 4.3 .5$.

Noack, Gesellschaftervereinbarungen bei Kapitalgesellschaften, 1994, blz 106. Zie hierover ook Asser-Scholten 1-II, blz. 129.

Vgl. Reuter, $\$ 25,9$.

Reuter, $\$ 25,10$ e.v. 
"Sobald der Verein ins Leben getreten ist, gilt seine Satzung nicht mehr als Vertrag, sondern als seine Verfassung, der sich die Mitglieder unterworfen haben und die für sie kraft Korporationsrecht gilt."'?2

Dit wordt de modifizierte Normentheorie genoemd. ${ }^{3}$ In het kapitaalvennootschapsrecht worden de statuten daarentegen door de meeste auteurs gekwalificeerd als een overeenkomst van bijzondere aard, een Organisationsvertrag met zowel verbintenisrechtelijke als korporationsrechtliche trekken. $^{74}$

\section{§ 4.3.2 Statuten in formele en/of materiële zin}

Ook in Duitsland dienen de statuten te worden vervat in een notariële akte en te worden gedeponeerd in het handelsregister. Op het moment van inschrijving in het handelsregister verkrijgt de $\mathrm{GmbH}$ rechtspersoonlijkheid. Bij de inschrijving worden de statuten onderworpen aan een beperkte inhoudelijke controle door het Registerrichter. Wanneer de statuten niet aan de eisen der wet voldoen, wordt de inschrijving geweigerd..$^{75}$ Ingeval de inschrijving niettemin heeft plaatsgevonden, kan geen beroep meer worden gedaan op de nietigheid indien drie jaren zijn verlopen, op grond van $\S 242$ Abs. 2 AktG, dat analogische toepassing vindt. ${ }^{76}$

$\S 3 \mathrm{GmbHG}$ geeft de minimuminhoud van de statuten: de naam, de zetel en het doel van de vennootschap, het bedrag van het geplaatst kapitaal en het bedrag dat elke aandeelhouder heeft gestort. Indien de vennootschap voor een bepaalde tijd is opgericht, of indien naast de storting andere verplichtingen voor aandeelhouders gelden, behoeven deze eveneens vermelding in de statuten. Ook de mogelijkheid om tot intrekking van aandelen over te gaan dient op grond van $\S 34 \mathrm{GmbHG}$ op de statuten te berusten. Andere bepalingen die de wettelijke organisatieregels aanvullen of ervan afwijken, d.w.z. bepalingen met betrekking tot de bevoegdheidsverdeling van organen en over de verhouding tussen de vennootschap en de aandeelhouders, behoren volgens Ulmer eveneens tot de noodzakelijke statutaire bepalingen." Deze worden 'korporative' of 'materielle' bepalingen ge-

$n$ BGHZ 21, 370, 373. BGHZ 47, 172, 179, in Noack, 1994, blz. 106. Zie ook K. Schmidt, Gesellschaftsrecht, $4^{e}$ druk, 2002, $\$ 51$

73 Reuter, $\$ 25,9$. Noack, 1994, blz. 106. Soergel/Schultze-v. Lasaulx, $\$ 25,14$.

74 Hachenburg/Ulmer, $\S 2,5$. Baumbach/Hueck/Fastrich, $\$ 2,5$. K. Schmidt, 2002, blz. 77. Lutter, "Theorie der Mitgliedschaft", AcP 1980, blz. 95. Raiser, § 26, 14. Soergel/Schultze-v. Lasaulx, $\$ 25,10$.

Lutter/Hommelhoff, $\$ 9 \mathrm{c}, 1$ e.v.

Rohricht, Großkommentar, $\S 23,204$. Pentz, Munchener Kommentar, $\S 23,164$.

Hachenburg/Ulmer $\$ 53,12$ c.v. Priester, Rechtskontrolle und Registerpublizitat als Schranken 
noemd. ${ }^{76}$ Deze bepalingen moeten in de statuten worden neergelegd, op straffe van nietigheid. Een verwijzing in de statuten naar dergelijke regelingen volstaat niet. Het lot van de statuten richt zich in dat geval naar $\S 139$ BGB, terwijl de vennootschap kan worden ontbonden door middel van een Auflösungsklage. ${ }^{79}$

Naast statutaire bepalingen in materiële zin worden 'unechte' of 'blo $\beta$ formelle' bepalingen onderscheiden. Dergelijke bepalingen ontlenen hun geldigheid niet aan de statuten; doordat zij in de statuten zijn neergelegd behoren zij alleen feitelijk tot de statuten, niet rechtens. Klassieke voorbeelden zijn de benoeming van de eerste bestuurders, de vermelding van de oprichters en een tantièmeregeling..$^{\text {so }}$ Andere voorbeelden betreffen statutaire 'Nebenabreden', in de statuten neergelegde afspraken tussen aandeelhouders onderling, zoals een concurrentieverbod, het toekennen van rechten aan bepaalde aandeelhouders, aanbiedingsverplichtingen of een arbitrageclausule. ${ }^{81}$ Evenmin worden bepalingen die de verhouding tussen de vennootschap en derden regelen tot de statuten in materiële zin gerekend. ${ }^{32}$

De kwalificatie van een regeling als een materiële dan wel als een louter formele statutaire bepaling is in verschillende opzichten relevant. In de eerste plaats hebben alleen materiële bepalingen körperschaftsrechtliche werking. Dit betekent dat zij gelden voor de vennootschap, inclusief (leden van) andere organen en later toegetreden aandeelhouders. Louter formele bepalingen werken daarentegen uitsluitend tussen partijen. In de tweede plaats verschilt de wijze van interpretatie van deze bepalingen. ${ }^{* 3}$ Bovendien zijn de vereisten voor statutenwijziging uitsluitend van toepassing op statutaire bepalingen in materiële zin. Ingeval rechten aan derden zijn toegekend, bijvoorbeeld in geval van de benoeming van een nieuwe bestuurder, kunnen deze bepalingen in louter formele zin bij volstrekte meerderheid worden gewijzigd, terwijl statutaire Nebenabreden in formele zin uitslui-

satzungsgleicher Gesellschaftervereinbarungen bei der GmbH?, in: Festschrift für Claussen, 1997 , blz. 332, ziet wel ruimte voor een Beirat op basis van een aandeelhoudersovereenkomst.

Vgl. Priester, "Nichtkorporative Satzungsbestimmungen bei Kapitalgesellschaften", DB 1979, blz. 681 . Baumbach/Hueck/Zollner $\S 53,3$.

Michalski, $\$ 3,35 / 36$.

Zie bijvoorbeeld BGHZ 18, 205, 207, BGHZ 38, 155, 161 en OLG Hamm, GmbHR 1992, 380.

Baumbach/Hueck/Zollner, $\S 53,4$. Priester DB 1979, blz. 681. Hachenburg/Ulmer $\S 53,18$.

Priester, DB 1979, blz. 682 .

Hachenburg/Ulmer, $\S 53,17$. Noack, 1994, blz. 64. Westermann, Das Verhaltnis von Satzung und Nebenordnungen im Gesellschaftsrecht, 1994, blz. 33. Zie over de toelaatbaarheid van een goedkeuringsrecht aan een derde, $\$ 3.3 .4$.

Zie $\$ 3.3 .3$. 
tend door middel van de instemming van alle partijen kunnen worden gewijzigd. ${ }^{\text {.4 }}$

Ingeval sprake is van in de statuten neergelegde afspraken tussen aandeelhouders onderling, kunnen deze bepalingen hetzij 'körperschaftsrechtlich' zijn beoogd, d.w.z. met vennootschappelijke werking, hetzij uitsluitend verbintenisrechtelijk. ${ }^{\text {ss }}$ Wanneer de statuten uitsluitend verwijzen naar de overeenkomst, of wanneer de Nebenabrede slechts "toevallig" in de statuten is neergelegd, vormt deze een louter formele bepaling. ${ }^{{ }^{* 6}}$ Winkler meent dat onderlinge afspraken tussen aandeelhouders tot de statuten in materiële zin behoren, wanneer de $\mathrm{GmbH}$ persoonsgebonden van aard is." In dat geval wordt met 'statuten in materiële zin' bedoeld, dat de aandeelhoudersovereenkomst vennootschappelijke werking heeft, en niet dat een dergelijke overeenkomst nietig is omdat deze niet tot de formele statuten behoort. ${ }^{\text {us }}$

Het Bundesgerichtshof heeft uitgemaakt dat het afhankelijk is van de wil van de partijen of de omstandigheden van het geval of een bepaling statutaire dan wel verbintenisrechtelijke werking heeft. ${ }^{89}$ In casu ging het om een aan de statuten aangehecht arbitrair beding. Het feit dat afspraken tussen aandeelhouders in de statuten zijn neergelegd, wordt overigens een indicatie geacht ten faveure van vennootschapsrechtelijke werking. ${ }^{{ }^{\circ}}$ Indien een aandeelhouder geen tegenprestatie heeft bedongen, wordt aangenomen dat het gaat om een statutaire verplichting en niet om een verplichting tussen aandeelhouders die toevallig in de statuten is neergelegd. ${ }^{91}$

Onder omstandigheden kan ook een buiten-statutaire afspraak tussen aandeelhouders als statutaire bepaling in materiële zin worden gekwalificeerd. Hüffer meent dat een Nebenabrede als materiële bepaling kan worden aangemerkt, indien alle aandeelhouders partij zijn of indien dit zou blijken uit bijkomende omstandigheden. ${ }^{92}$ Een dergelijke overeenkomst

\footnotetext{
4. Hachenburg/Ulmer $\S 53,10$. Raiser, Recht der Kapitalgesellschaften, $3^{\epsilon}$ druk, 2001, $\S 33,43$. Zie voorts $\$ 3.3 .4$.

s5 Vgl. BGH NJW 1973, 1039, 1040 en BGH NJW 1969, I31. Zie ook Hachenburg/Ulmer, § 2, 8.

so Baumbach/Hueck/Zollner $\$ 47,77$.

"7 Winkler, "Materielle und formelle Bestandteile in Gesellschaftsverträgen und Satzungen und ihre verschiedene Auswirkungen", DNotz 1969, blz. 401. In dezelfde zin Priester, DB 1979, blz. 683. Zie over de vennootschappelijke werking van aandeelhoudersovereenkomsten $\S 5$.

s9 BGHZ 38, 155, 161. BGH DB 1993, blz. 829. Zo ook Baumbach/Hueck/Zollner, § 53, 5. Noack, 1994, blz 64. Winkler, DNotZ 1969, blz 402.

\%o Priester, DB 1979, blz. 684. Baumbach/Hueck/Zollner \$ 53, 5 ,

91 OLG Dresden, GmbHR 1997, blz. 747. Andere voorbeelden bij BGH DB 1993, blz. 829 en OLG Brandenburg, GmbHR 2001, blz. 624.

91

Hachenburg/Hoffer $\S 47,70$. Zie ook $\S 5$.
} 
heeft dan vennootschappelijke werking. Dit wordt nader uiteengezet in $\S 7.3 .4$.

\section{$\S 4.3 .3$ De interpretatie van de Satzung}

In tegenstelling tot Gesellschaftsverträge van Gesellschafte naar burgerlijk recht (vergelijkbaar met de maatschap in Nederland), worden de statuten van de $\mathrm{GmbH}$ in beginsel geïnterpreteerd naar objectieve maatstaven."3 Deze objectieve interpretatie houdt in, dat de statuten als eenheid, "aus sich heraus" worden uitgelegd, de tekst en het doel van de regeling in aanmerking nemend. Ook eerdere versies van in het handelsregister gedeponeerde statuten kunnen bij de interpretatie worden betrokken. Daarentegen blijven de niet uit de statuten kenbare wil van partijen en de ontstaansgeschiedenis van de statuten buiten beschouwing."

Wanneer de statuten over een bepaalde aangelegenheid zwijgen, is de vraag of teruggegrepen moet worden op de - aanvullende - wet, of op de wil van partijen. ${ }^{95}$ Indien de statuten een 'Regelungslücke' bevatten, geeft Zöllner voorrang aan de aanvullende wettelijke regeling, zelfs indien deze analoog moet worden toegepast. ${ }^{96}$ Wiedemann meent dat de aanvullende interpretatie ('ergänzende Vertragsauslegung') voor dient te gaan, met als uitgangspunt het doel van de statuten."

De hierboven besproken differentiatie tussen statutaire bepalingen in materiële, dan wel in louter formele zin, bepaalt mede de wijze waarop deze bepalingen geïnterpreteerd worden. Objectieve interpretatie geldt slechts voor körperschaftsrechtliche bepalingen. De individualrechtliche bepalingen worden aan de hand van de algemene regels van verbintenissenrecht geïnterpreteerd conform $\S 133$ ("wirkliche Wille") en $\S 157$ ("Treu und Glauben") BGB. In de literatuur is wel gepleit voor verdere differentiatie, hiertoe aangezet door het Bundesgerichtshof:

"Das Reichsgericht hat mehrfach den Standpunkt vertreten, daß die Auslegung des Gesellschaftsvertrages einer GmbH der freien Nachprüfung durch das Revisions-

93 BGH NJW 1973, 1039. BGHZ 134, 364, 368. Hachenburg/Ulmer, \$ 2, 139. K. Schmidt, 2002. blz. 89. Lutter/Hommelhoff, $\S 2$, 11. Wiedemann, 1980, blz. 165. Uitgebreid Grunewald, "Die Auslegung von Gesellschaftsvertragen und Satzungen", ZGR 1995, blz. 68 e.v. BGH NJW 1983, 1910. BGHZ 116, 359, 366. BGH NJW 1987, 1890, 1891. Instemmend Hachenburg/Ulmer $\$ 3,118$. Vgl. Wiedemann, 1980, blz. 171. Zie ook Odersky, "Gestaltungsfreiheit und gerichtliche Kontrolle", Sonderheft ZGR 1998, blz. 116.

\% Zöllner, Inhaltsfreiheit bei Gesellschaftsvertragen in: Festschrift 100 Jahre GmbH-Gesetz, 1992. blz. 95 .

Wiedemann, 1980, blz. 171. 
gericht unterliege. Dieser Auffassung ist jedenfalls beizutreten, soweit es um die Auslegung der satzungsmäßigen Regelung körperschaftsrechtlicher Fragen geht. Der Grund hierfür liegt darin, daß der Gesellschaftsvertrag einer $\mathrm{GmbH}$, mindestens soweit er körperschaftsrechtliche Angelegenheiten behandelt, für einen unbestimmten Personenkreis, insbesondere für die Gläubiger und künftigen Gesellschafter, bestimmt ist und nur einheitlich ausgelegt werden kann. Das gilt auch für den Gesellschaftsvertrag einer Familiengesellschaft, soweit er, wie bei der Festlegung des Stimmverhältnisses für eine Satzungsänderung, das Verhältnis zu Dritten, insbesondere den Kreditgebern, angeht und, wie hier, Familienfremden nicht die Mitgliedschaft verwehrt."

Sommige schrijvers willen aanknopen bij de vennootschappelijke 'Realstruktur'. Aangezien in een persoonsgebonden $\mathrm{GmbH}$ weinig aandeelhouderswisselingen voorkomen, en de weinige kopers veelal bekend met de vennootschap zijn, zou er geen noodzaak bestaan voor objectieve interpretatie., De belangen van crediteuren zouden bovendien reeds in voldoende mate worden beschermd door dwingende wettelijke bepalingen. ${ }^{100}$ Andere auteurs maken een onderscheid tussen bepalingen die zich uitsluitend richten op aandeelhouders en bepalingen die ook voor crediteuren van belang zijn. Alleen de laatste zouden objectieve interpretatie vereisen. ${ }^{101}$ Het Bundesgerichtshof lijkt echter geen verdere differentiatie te beogen en stelt onomwonden:

"Subjektive Absichten und Erwägungen der Gesellschafter, die für die Allgemeinheit nicht erkennbar sind, haben für die Auslegung der Satzung außer Betracht zu bleiben." "102

Dit uitgangspunt, dat op niet voor derden kenbare verklaringen van partijen - waaronder afspraken tussen aandeelhouders - geen acht mag worden geslagen bij de interpretatie van de materiële statuten, wordt echter op verschillende wijzen ondermijnd. ${ }^{103}$ In de eerste plaats wordt de vraag, of er sprake is van statutaire bepaling in materiële, dan wel louter formele zin, beantwoord door af te gaan op de wil van de partijen. In de tweede plaats kunnen statutaire Nebenabreden wel dienen ter interpretatie van de mate-

98

in.

100 
riële statuten. Deze zijn immers voor derden kenbaar. ${ }^{104}$ Op hun beurt worden de statutaire Nebenabreden weer geïnterpreteerd aan de hand van de wil van de partijen.

Het is overigens de algemene vergadering die bij volstrekte meerderheid mag besluiten op welke wijze de statuten worden uitgelegd, mits dit niet in strijd komt met de wet of de statuten..$^{105}$

\section{$\S 4$ 4.4 Wijziging van de Satzung bij meerderheidsbesluit}

Op grond van $\S 53$ Abs. $2 G m b H G$ kan de algemene vergadering van aandeelhouders de statuten wijzigen met een meerderheid van drie vierde van de uitgebrachte stemmen. Daarenboven kunnen de statuten "andere Erfordernisse" stellen, zoals een quorum of unanimiteit. ${ }^{106}$ Dit laatste moet worden onderscheiden van het vereiste dat een besluit de instemming van alle aandeelhouders behoeft. Het verschil zit hem in het feit dat een eenstemmig besluit ook zonder de aanwezigheid van alle aandeelhouders kan worden genomen. ${ }^{107}$

Zolang een besluit nog niet bij het handelsregister is gedeponeerd, kan de algemene vergadering het met volstrekte meerderheid weer intrekken. ${ }^{108}$ Achterliggende gedachte achter de gekwalificeerde meerderheidseis is dat deze als procedurele bescherming van minderheidsaandeelhouders wordt opgevat. ${ }^{109}$ De wijzigingsprocedure geldt uitsluitend voor statutaire bepalingen in materiële zin. Statutaire Nebenabreden kunnen in beginsel slechts worden gewijzigd met instemming van alle partijen, terwijl louter formele bepalingen die betrekking hebben op derden in beginsel met volstrekte meerderheid kunnen worden gewijzigd. ${ }^{10}$

\footnotetext{
104 Vgl. Winter, "Organisationsrechtliche Sanktionen bei Verletzung schuldrechtlicher Gesellschaftervereinbarungen?", ZHR 1990, blz. 264. BGH 13 januari 2003, II ZR 227/00, www.bundesgerichtshof.de.

106 Zie Zollner, Die Schranken mitgliedschaftlicher Stimmrechtsmacht bei den privatrechtlichen Personenverbanden, 1963, blz. 93. Priester, Drittbindung des Stimmrechts und Satzungsautonomie, in: Festschrift fur Winfried Werner, 1984, blz. 663. Baumbach/Hueck/Zollner, $\S 53,33$. Hachenburg/Ulmer, $\S 53,82$. Lutter-Hommelhoff, $\$ 53,12$.

Vgl. OLG Hamm, WM 2002, 855, 857.

Baumbach/Hueck/Zollner, $\S 53,35$. Hachenburg/Ulmer, $\S 53,73$.

Hachenburg/Ulmer, $\S 53,52$. Baumbach/Hueck/Zollner, $\S 53,31$.

Zie $\$ 5.3 .3$.
} 


\section{$\S 4.3 .5$ De Satzungsautonomie}

Naar Duits recht mag de bevoegdheid tot statutenwijziging niet in de statuten worden uitgesloten, noch aan anderen worden toegekend."' Aangenomen wordt dat de bevoegdheid tot statutenwijziging tot de "unentziehbare Zuständigkeit der Gesellschafter" behoort."12 De algemene vergadering is dus steeds bevoegd de statuten te wijzigen. Dit wordt afgeleid uit de Satzungsautonomie. Dit beginsel vindt haar wettelijke grondslag in $\S \S 45$ Abs. 1 en 53 Abs. 1 GmbHG."'

Satzungsautonomie betekent dat aan de aandeelhouders de exclusieve bevoegdheid toekomt naar eigen inzicht de inhoud van de statuten te bepalen en zonodig te wijzigen. ${ }^{14}$ In de contractuele opvatting wordt deze Satzungsautonomie afgeleid uit de Privatautonomie. De statuten vormen dan het resultaat van een uit de Privatautonomie voortvloeiende rechtshandeling. ${ }^{115}$ Volgens de institutionele opvatting kan de Satzungsautonomie worden afgeleid uit de Verbandssouveränität, ook wel 'Verbandsautonomie' of 'Vereinsautonomie' genoemd. ${ }^{116}$ Deze omvat zowel de zelfbeschikking van het Verband ten opzichte van de buitenwereld, als de zelfbeschikking van de leden binnen het Verband. ${ }^{17}$ Het Bundesverfassungsgericht overweegt over de Verbandsautonomie:

"Sein Ziel ist, der Privatautonomie vergleichbar, den Charakter des Vereins als eines vornehmlich von der Willensbestimmung und -betätigung seiner Mitglieder getragenen Personenverbandes zu wahren. Es gehört zu dieser Autonomie, den mit ihr ausgestatteten Einrichtungen das Recht einzuräumen, sich die ihren Zwecken entsprechende Organisation selbst zu geben und diese frei zu bestimmen, soweit dem nicht zwingende Vorschriften oder dem Wesen der entsprechende Institution zu entnehmende Grundsätze entgegenstehen." "ıs

III Flume, blz. 194. Hachenburg/Ulmer, $\S 53,2,82$ e.v. Mertens, "Satzungs- und Organisationsautonomic im Aktien- und Konzernrecht", ZGR 1994, blz. 439. Lutter-Hommelhoff, $§ 53,7$. Vgl. BGHZ 43, 261, 264.

112 K. Schmidt, 2002, blz. 84, Zie $\$ 3.3 .1$.

i13 Baumbach/Hueck/Zollner $\$ 45,5$,

it Flume, blz. 193. K. Schmidt, 2002, blz. 84. Baumbach/Hueck/Zollner $\S 45,5$. Beuthien/Gatsch, ZHR 1992, blz 473.

115 Flume, blz. 318. Staudinger/Coing, $\$ 25,15$. Lutter, AcP 1980, blz. 94. Rittner, Die werdende juristische Person, 1973, blz. 248. Zollner, Festschrift 100 Jahre GmbHG, blz. 85 Staudinger/Coing, Vorbemerkungen zu $\$ \S 21-54,30$.

116 Flume, blz. 193. K. Schmidt, 2002, blz. 84.

in Zollner, Festschrift 100 Jahre GmbHG, blz. 119. Priester, Festschrift Werner, blz. 663.

I1\% BverfG, 5.2.1991, NJW 1991, 2624. Zie ook Beuthien/Gatsch, "Vereinsautonomie und Satzungsrechte Dritter", ZHR 1992, blz. 461. 
De gedachte achter de Verbandsautonomie is dat alleen diegene die de lidmaatschapsverplichtingen op zich heeft genomen en de risico's daarvoor draagt over het Verband mag beslissen. Op deze wijze behoedt de Verbandsautonomie de leden ervoor, zichzelf 'onder curatele' te stellen; het lot van het Verband mag niet in de handen van buitenstaanders worden gelegd. ${ }^{119}$ In het vennootschapsrecht zijn de aandeelhouders de rechtssubjecten aan wie het zelfbeschikkingsrecht toekomt; zij bezitten de Satzungsautonomie. De Satzungsautonomie bepaalt dus wie er over de statuten beslist, terwijl de Gestaltungsfreiheit betrekking heeft op de inhoud van de statuten. De Satzungsautonomie beperkt in die zin de Gestaltungsfreiheit. ${ }^{20}$

In het algemeen wordt op basis van het voorgaande een statutair goedkeuringsrecht ten gunste van derden voor besluiten van de algemene vergadering ontoelaatbaar geacht. ${ }^{121}$ Dit geldt ook voor andere organen als de Aufsichtsrat, een Beirat of een bestuurder ${ }^{122}$ Weliswaar bepaalt $\S 53$ Abs. $3 \mathrm{GmbHG}$ dat "andere Erfordernisse" aan de besluitvorming van de algemene vergadering kunnen worden gesteld, ${ }^{123}$ maar het Reichsgericht heeft uitgemaakt dat deze eisen uitsluitend zien op de wijze van besluitvorming. ${ }^{124}$ Wel mag de goedkeuring van individuele of alle aandeelhouders worden vereist. ${ }^{125}$

Verschillende redenen worden aangevoerd voor het verbod van een goedkeuringsrecht voor derden. Uit de Verbandssouveränität zou volgen dat derden geen invloed mogen uitoefenen, omdat de vennootschap zich naar buiten toe als eenheid presenteert. De exclusieve bevoegdheid tot statutenwijziging van de algemene vergadering wordt in deze optiek als

119 Vgl. Wiedemann, "Der Gesellschaftsvertrag der Personengesellschaften", WM 1990, blz. 20. Zollner, Festschrift 100 Jahre GmbHG, blz. 119. Priester, Festschrift Werner, blz. 663. Tegelijkertijd was de Verbandssonveränität bij de totstandkoming van de $A k t G$ in 1884 vanuit het oogpunt van de wetgever een middel om het toezicht op kapitaalvennootschappen over te hevelen van de staat naar de aandeelhouders zelf, zie Hommelhoff, Eigenkontrolle statt Staatskontrolle, in: Hundert Jahre modernes Aktienrecht, ZGR Sonderheft 1985, blz. 90.

120 Wiedemann, "Erfahrungen mit der Gestaltungsfreiheit im Gesellschaftsrecht", ZGR Sonderheft 1998, blz, 24. Hommelhoff, "Gestaltungsfreiheit im GmbH-Recht", ZGR Sonderheft 1998, blz. 45. K. Schmidt, 2002, blz. 84.

121 Baumbach/Hueck/Zollner, § 54, 43, 44. Lutter/Hommelhoff, § 3, 53. Omstreden is in hoeverre een contractueel goedkeuringsrecht, eventueel via een stemovereenkomst, verenigbaar is met de Verbandsautonomie, zie hierover $\$ 7.3 .3$.

122 Baumbach/Hueck/Zollner $\S 53,44$. Volgens de heersende mening is een stemovereenkomst waarin een aandeelhouder zich verbindt volgens instructie van een bestuurder te stemmen evenmin toelaatbaar, zie $\$ 7.3 .3$.

Flume, blz. 195, en Priester, Festschrift Werner, blz. 662, erkennen dat zuiver grammaticaal de "andere Erfordenisse" een goedkeuringsrecht aan derden kunnen inhouden.

124 RGZ 169, 65, 81. Instemmend Baumbach/Hueck/Zollner, $\$ 53,43,44$. Hachenburg/Ulmer, $\$ 53$, 84.

12s Zie Zollner, 1963, blz. 93. Priester, Festschrift Werner, blz. 663. Baumbach/Hueck/Zollner, $\$ 53$, 42. Hachenburg/Ulmer, $\S 53,82$. Lutter-Hommelhoff, $\S 53,7$. Zie ook $\$ 5.3 .2$. 
noodzakelijke voorwaarde beschouwd voor de privaatrechtelijke verenigingsvrijheid. ${ }^{126}$ Ook het rechtskarakter van de statuten als Organisationsvertrag zou een belemmering vormen voor een statutair goedkeuringsrecht aan derden. ${ }^{127}$ Een ander argument is dat derden niet gebonden zijn aan de vennootschappelijke Treupflicht. ${ }^{12 \pi}$

Beuthien/Gätsch nemen een afwijkend standpunt in. Huns inziens vormt het verbod derden een goedkeuringsrecht toe te kennen zelf een beperking van de Satzungsautonomie en is het beroep op dit beginsel een cirkelredenering. ${ }^{129} \mathrm{Zij}$ achten een dergelijk verbod uitsluitend gerechtvaardigd indien de belangen van minderheidsaandeelhouders en crediteuren worden geschonden. Daar dit naar hun mening niet het geval is, menen zij dat statutenwijzigingen afhankelijk mogen worden gemaakt van de goedkeuring van derden. Wel stellen zij als voorwaarde dat de aandeelhouders het goedkeuringsrecht weer ongedaan kunnen maken, zonder dat daarvoor de goedkeuring van de derde is vereist. ${ }^{130}$ Ook Zöllner gaat uit van de gedachte dat de door de statuten gecreëerde facultatieve organen vallen onder de Satzungsautonomie, d.w.z. dat de algemene vergadering kan besluiten deze organen weer af te schaffen. ${ }^{13 t}$

\section{$\S 4.4$ Engeland}

\section{\$ 4.4.1 Het rechtskarakter van de articles}

De statuten van een Engelse vennootschap bestaan uit twee documenten: het memorandum en de articles of association. Het memorandum is een in beginsel kort document, dat ten minste vermeldt de naam van de vennootschap, de doelomschrijving, de plaats van registratie, het aandelenkapitaal, het feit dat de aansprakelijkheid van de aandeelhouders beperkt is en of het een public of private company is. ${ }^{132}$ In de articles wordt vervolgens de vennootschappelijke organisatie vormgegeven. Lord Cains LC verwoordde

Priester, Festschrift Werner, blz. 666. Vgl. K. Schmidt, 2002, blz. 85. Lutter/Hommelhoff, $\S 53$, 7 , stoelen het verbod op de Satzungsautonomie.

Ulmer, Begrandung von Rechten furr Dritte in der Satzung einer GmbH? in: Festschrift fur Winfried Werner, 1984, blz. 924. Hachenburg/Huffer, $\S 47,34$.

.

Beuthien/Gatsch, ZHR 1992, blz. 473.

Beuthien/Gatsch, ZHR 1992, blz. 477. Vgl. Sanders/Westbroek, blz. 255.

Baumbach/Hueck/Zollner $\$ 45,13$.

Davies, blz. 14. De lengte van het document wordt voornamelijk bepaald door de doelomschrijving. Tot de wetswijziging in 1989 was deze vaak zeer uitvoerig vanwege de strenge ultra vires leer. 
in Ashbury Railway Carriage and Iron Co Ltd v. Riche ${ }^{133}$ het onderscheid als volgt:

"The memorandum is, as it were, the area beyond which the actions of the company cannot go; inside that area the shareholders may make such regulations for their own government as they think fit."

In hun onderlinge verhouding zijn de articles ondergeschikt aan het memorandum. ${ }^{134}$

De tweedeling tussen memorandum en articles is een overblijfsel uit de tijd dat de voorlopers van de huidige limited company, de statutory en chartered corporations, slechts mochten worden opgericht na goedkeuring van het charter (memorandum) door de Kroon of het parlement. Het charter mocht niet worden veranderd, tenzij wederom goedkeuring was verkregen. Voor de company in zijn huidige vorm is de goedkeuring door de Kroon of het parlement vervangen door de registratie. Daarnaast is in de loop der tijd wijziging van het memorandum gemakkelijker geworden. ${ }^{135}$ Dit heeft ertoe geleid dat op dit moment wordt gediscussieerd of het nog zinvol is het onderscheid te handhaven. ${ }^{136}$

In Engeland staat het contractuele karakter van het memorandum en de articles buiten kijf. Dit blijkt uit section 14 (1) CA 1985 :

"Subject to the provisions of this Act, the memorandum and articles, when registered, bind the company and its members to the same extent as if they respectively had been signed and sealed by each member, and contained covenants on the part of each member to observe all the provisions of the memorandum and of the articles."

In deze bewoordingen ${ }^{137}$ wordt tot uitdrukking gebracht dat het memorandum en de articles zijn te beschouwen als een overeenkomst tussen de vennootschap en haar aandeelhouders en tussen de aandeelhouders onderling. ${ }^{138}$ Niettemin verschillen het memorandum en de articles op een

13. Ashbury Railway Carriage and Iron Co Ltd v, Riche [1875] LR 7 HL 653, geciteerd in Farrar, blz. 116.

134 Farrar, blz. 116. Guinness v. Land Corporation of Ireland [1882] 22 Ch D 349.

13s Davies, blz. 14. Zie $\$ 4.4 .4$

136 The Company Law Review Steering Group, Modern Company Law for a Competitive Economy, The Strategic Framework, DTI Consultation Document, 1999, blz. 75.

137 De oorsprong van section 14 gaat terug tot de Joint Stock Companies Act 1844, zie Law Commission, Shareholder Remedies, Consultation Paper, \$ 2.7.

138 Law Commission, Shareholder Remedies, Consultation Paper, § 2.9. Davies, blz. 116. Hoewel members geen aandeelhouders hoeven te zijn en aandeelhouders geen members, (Davies, blz. 119) wordt in deze tekst uitgegaan van synonimiteit. 
aantal punten van 'gewone' overeenkomsten. Sommige auteurs kwalificeren de articles als een 'relationele' overeenkomst, hetgeen inhoudt dat ze de verhouding tussen partijen regelen voor de langere termijn. ${ }^{139}$ In de White Paper over de Companies Bill van juli 2002 zijn het memorandum en de articles samengevoegd tot de company's constitution, zonder dat hiervan een definitie wordt gegeven. ${ }^{1+0}$

\section{\$ 4.4.2 Statuten in formele en/of materiële zin}

In Engeland ontstaat een vennootschap na registratie bij de Registrar in Cardiff, Wales. ${ }^{111}$ Deze controleert of aan de formele inschrijvingsvereisten is voldaan, waarna hij een certificate of incorporation afgeeft. Naast het memorandum, dat de naam, het type, het doel, de zetel en het aandelenkapitaal van de vennootschap dient te bevatten, zijn de gegevens van de eerste bestuurder(s) en secretaris(sen) vereist. ${ }^{1{ }^{12}}$ Anders dan in Nederland en Duitsland is een vennootschap niet verplicht om articles te laten registreren. Bij afwezigheid van articles zijn namelijk de bepalingen uit Table A van toepassing. Dit zijn standaard articles, die als annex tot de Companies Act behoren. De bepalingen uit Table A gelden, voor zover de articles de toepassing van Table A niet uitsluiten of wijzigen, section 8(2) CA $1985 .^{1.3}$

De articles mogen geen bepalingen bevatten die in strijd zijn met de wet of de openbare orde. Dit vloeit voort uit section 14(1) CA 1985, dat bepaalt dat het memorandum en de articles onderworpen zijn aan de bepalingen van deze wet. ${ }^{14}$ De bij de oprichting betrokken solicitor of een bestuurder of secretaris van de vennootschap dient bij de registratie een verklaring te voegen, inhoudende dat aan alle vereisten van de wet is voldaan, section 12 CA $1985 .{ }^{145}$ In theorie ziet de Registrar erop toe dat aan alle vereisten is voldaan, maar gezien het feit dat hij vrijwel nooit een inschrijving weigert, geldt in de praktijk dat de verklaring voor hem reeds voldoende is. ${ }^{146}$

Een onderscheid tussen statuten in formele of materiële zin lijkt in Engeland niet te worden gemaakt. De problematiek speelt ook niet als

\footnotetext{
139 Sealy, blz 116. Cheffins, blz 459. Drury, "The relative Nature of a Shareholder's Right to Enforce the Company Contract", CLJ 1986, blz. 221.

140 Companies Bill, section 5 (1) (j) jo. 9 (3) (e), www.dti.gov.uk/companiesbill/whitepaper.htm, juli 2002.

141 Op internet te vinden onder www.companies-house.gov.uk.

142 Vgl. Farrar, blz. 97 e.v.

14 Zie reeds $\$ 1.3$.

i4. Zie ook $\$ 2.4 .2$

145 Davies, blz. 111

146. Farrar, blz. 118.
} 
zodanig, omdat de bepalingen van Table $A$ van toepassing zijn, voor zover de articles de toepassing ervan niet uitsluiten of wijzigen. ${ }^{147}$ Wel wordt een onderscheid gemaakt met betrekking tot de vraag wie zich op de statuten kunnen beroepen. ${ }^{148}$ Farrar vraagt zich af of bepalingen in de articles die buitenstaanders rechten geven wel kunnen worden beschouwd als echte articles. Hoe meer een bepaling afwijkt van Table A, hoe moeilijker hij de bepaling te kwalificeren acht als deel uitmakend van de articles. ${ }^{199} \mathrm{Hij}$ geeft echter niet aan wat voor gevolgen deze kwalificatie met zich mee zou brengen.

\section{$\S 4.4 .3$ De interpretatie van de articles}

In Engeland staat de objectieve interpretatie van de articles voorop. Articles of association worden beschouwd als 'commercial documents' die moeten worden geïnterpreteerd met het oogmerk "to give them reasonable business efficacy". ${ }^{\text {so }}$ Op de bedoelingen van partijen wordt geen acht geslagen, indien deze niet in de articles zijn neergelegd. Achterliggende gedachte hierbij is dat een dergelijke interpretatie in feite zou neerkomen op een wijziging van de statuten door de rechter, hetgeen in strijd wordt geacht met de dwingende exclusieve bevoegdheid van de algemene vergadering om de statuten te wijzigen. ${ }^{\text {st }}$ Wel kunnen 'implied terms' in de articles worden gelezen, indien dit blijkt uit de tekst van de articles. Buiten de articles liggende omstandigheden kunnen hiertoe echter geen aanleiding geven. Dit zou namelijk kunnen leiden tot verschillende uitkomsten voor verschillende aandeelhouders. ${ }^{152}$ Voorop staat mitsdien de bescherming van toekomstige aandeelhouders; zij moeten op de articles kunnen afgaan zoals ze zijn geregistreerd..$^{153}$

\section{Section 8(2) CA 1985.}

its Zie $\$ 5.4 .3$.

149 Farrar, blz 122.

Jenkins L in Holmes $v$. Keyes [1959] Ch 143, CA: "I think that the articles of association of a company should be regarded as a business document and should be construed so as to give them reasonable business efficacy, where a construction tending to that result is admissible on the language of the articles, in preference to a result which would or might prove unworkable." Davies, blz. 117. Farrar, blz. 117. Scott v. Frank F Scott (London) Lid [1940] Ch 794 in Sealy, blz. 119.

152 Bratton Seymour Services Co. Lts v. Oxborough [1992] BCLC 693, CA, in Sealy, blz 120. Zie ook Towcester Racecourse Co Lid v. The Racecourse Association Lid [2002] EWHC 2141 (Ch), [2003] I BCLC 260.

158 Davies, blz 117. Ferran, Company Law and Corporate Finance, 1999, blz 317, noemt dit business efficacy. Kritisch ten opzichte van de restrictieve benadering is Copp, "Company law and alternative dispute resolution: an economic analysis", Company Lawyer 2002, blz. 364 . 


\section{§ 4.4.4 Wijziging van de articles}

In Engeland is het uitgangspunt van section 9 CA 1985 dat de vennootschap haar articles mag wijzigen bij special resolution, in overeenstemming met de door de wet en het memorandum gestelde voorwaarden. Dit houdt in dat drie vierde meerderheid van stemmen is vereist. ${ }^{134}$ De gekwalificeerde meerderheidseis wordt gerechtvaardigd met een beroep op de bescherming van de minderheidsaandeelhouders. ${ }^{\text {iss }}$

Section 9 CA 1985 bevat dwingend recht. Dit houdt in dat dit vereiste van een gekwalificeerde meerderheid niet statutair mag worden verhoogd. ${ }^{16}$ Indien echter de besluitvorming buiten vergadering plaatsvindt, dienen alle aandeelhouders in te stemmen met de wijziging (section 381A CA 1985). Volgens vaste Engelse rechtspraak mag een vennootschap haar eigen bevoegdheid om de articles te wijzigen evenmin uitsluiten:

"[t]he company is empowered by the statute to alter the regulations contained in its articles from time to time by special resolutions; and any regulations or article purporting to deprive the company of this power is invalid on the grounds that it is contrary to the statute: Walker v. London Tramways Co."'s?

Het memorandum mag daarentegen in beginsel juist niet worden gewijzigd, tenzij dit uitdrukkelijk in de wet is voorzien. ${ }^{138}$

Bij de invoering van de Joint Stock Companies Act in 1856 mocht het memorandum in het geheel niet worden gewijzigd. Tegenwoordig kent elke bepaling in het memorandum zijn eigen wijzigingsprocedure. Grootste knelpunt was lange tijd de wijziging van de doelomschrijving, hetgeen tot een strikte ultra vires doctrine leidde. Sinds 1989 kan de vennootschap de doelomschrijving wijzigen bij special resolution. ${ }^{159}$

Derden kunnen naar Engels recht via de articles geen invloed uitoefenen op de bevoegdheid tot statutenwijziging. Daar deze bevoegdheid niet statutair

\footnotetext{
194 Section 378(2) jo. (1) CA 1985.

155 Davies, blz 709.

156. Malleson v National Insurance Corporation [1894] 1 Ch 200, aangehaald door Stedman \& Jones, Shareholders' Agreements, 1998, blz 74. Voor de contractuele mogelijkheden in deze, zie $\$ 7.4 .3$.

157 Allen v. Gold Reefs of West Africa Lid [1900] 1 Ch 656, CA, in Sealy, blz. 132. Zie ook Russell v Northern Bank Development Corporation Ltd [1992] I WLR 588: "[a] provisions in a company'articles which restricts its statutory power to alter those articles is invalid". Uitgebreid McGlynn, Company Lawyer 1994, blz. 301 e.v.

158 Section 2(7) CA 1985.

159 Uitgebreid Farrar, blz 99 e.v.
} 
mag worden beperkt, mag deze ook niet aan anderen worden toegekend, noch mag aan anderen een goedkeuringsrecht worden verschaft. Overigens zou een derde een in de articles vervat recht ook niet kunnen afdwingen. ${ }^{160}$ Dit laat onverlet dat een derde met een of meer aandeelhouders kan overeenkomen dat zij volgens zijn instructies stemmen, of dat alle aandeelhouders kunnen overeenkomen de statuten niet te zullen wijzigen. ${ }^{61}$ Deze contractuele mogelijkheden komen hierna aan de orde in $\S 7.4$.

\section{$\S 4.5$ Evaluatie}

Zowel in Engeland als in Duitsland worden de statuten van besloten vennootschappen primair als een (bijzondere) overeenkomst beschouwd. Ook de statuten van een BV dienen naar mijn mening als een overeenkomst van bijzondere aard te worden gekwalificeerd. In geval van een eenpersoonsvennootschap vloeien uit statuten in ieder geval verbintenissen voort tussen de aandeelhouder en de vennootschap. Door statuten te beschouwen als bijzondere overeenkomst staat de instemming van betrokkenen centraal als grondslag van de bindende kracht. De nadruk wordt gelegd op de vrijwillige binding. Dit brengt met zich mee dat van de statuten kan worden afgeweken met instemming van de aandeelhouders. ${ }^{162}$ Bovendien worden de statuten meer ingebed in het algemene privaatrecht. Dwingend vennootschapsrecht stelt weliswaar grenzen aan de inrichting van de statuten, maar de vrijheid van inrichting dient mijns inziens als uitgangspunt te worden genomen. ${ }^{163} \mathrm{Op}$ basis van dit uitgangspunt wordt in hoofdstuk 5 geanalyseerd in hoeverre aandeelhouders vrij zijn om hun rechten en verplichtingen in de statuten uit te breiden en/of in te perken en welke grenzen hieraan worden gesteld.

De door dwingend vennootschapsrecht gestelde grenzen vinden hun ratio in de omstandigheid dat statuten ook van belang zijn voor nietpartijen, zoals crediteuren en toekomstige aandeelhouders. De interne organisatieregels, met name in persoonsgebonden vennootschappen, zijn echter vooral van belang voor de aandeelhouders. Crediteuren worden beschermd door dwingende wettelijke bepalingen, terwijl toekomstige aandeelhouders vanwege de beperkte overdraagbaarheid van de aandelen veelal individueel zullen onderhandelen met een aandeelhouder over de overdracht, en aldus

Zie $\$ 5.4 .3$.

Zie uitgebreid $\$ 7.2 .3$.

Zie 6.2.4.

Zo reeds Van Schilfgaarde, Vrijheid van vennootschap, in: Vrijheid van recht: opstellen aangeboden aan prof. mr. E.H. s'Jacob, 1975, blz. 247 e.v. 
in staat zijn zich van de inhoud van de statuten te vergewissen. Dwingend vennootschapsrecht dient slechts te verhinderen dat zij te zeer in hun rechten worden beperkt. ${ }^{164}$

In het Duitse recht wordt een onderscheid gemaakt tussen statuten in materiële zin en statuten in louter formele zin. In de eerste plaats dient dit onderscheid om aan te geven welke regelingen noodzakelijkerwijs in de statuten moeten worden neergelegd om rechtsgeldig te zijn. Voldoet een regeling die tot de noodzakelijke statutaire inhoud behoort, niet aan de statutaire vormvereisten, dan wordt deze nietig geacht. In de tweede plaats brengt het onderscheid tot uitdrukking dat niet alles wat formeel in de statuten is neergelegd, ook materieel als zodanig heeft te gelden. Er wordt primair gekeken naar de inhoud van de bepaling om deze als statutair te kwalificeren, met de daaraan verbonden gevolgen voor interpretatie en wijziging. In het Duitse recht wordt niet zozeer de formele kwalificatie van statuten of overeenkomsten van belang geacht, maar het inhoudelijke onderscheid tussen regelingen met vennootschappelijke werking en regelingen die uitsluitend partijen binden. Doel van dit onderscheid is zowel minderheidsaandeelhouders, toekomstige aandeelhouders als crediteuren adequate bescherming te bieden.

Zonder een a priori onderscheid te maken worden ook in het Engelse recht verschillende rechtsgevolgen verbonden aan statutaire bepalingen, al naar gelang de ratio van de regeling in kwestie. Dit wordt hierna verder uitgewerkt in $\S 6.4 .3$. Ook naar Nederlands recht zou mijns inziens meer de inhoud en ratio van vennootschappelijke regelingen bepalend moeten worden geacht voor de daaruit voortvloeiende rechtsgevolgen.

De bescherming van toekomstige aandeelhouders en crediteuren brengt in alle drie onderzochte rechtsstelsels met zich mee dat statuten in beginsel objectief worden geïnterpreteerd. De paradox die ontstaat door enerzijds de verplichting dat de statuten als document voor derden kenbaar moeten zijn, en anderzijds dat de geschillen die zich voordoen naar aanleiding van onduidelijkheden in de statuten zich veelal afspelen in de interne sfeer, kan op verschillende wijzen worden opgelost. Voor zover de bedoelingen van partijen zijn geconcretiseerd in afspraken tussen aandeelhouders, dienen deze onder omstandigheden te worden gehonoreerd. Dit komt nader aan de orde in hoofdstukken 6 en 7 . Wel kan worden opgemerkt dat de bedoelingen van de oprichters hun relevantie zullen verliezen naarmate de vennootschap zich verder ontwikkelt en wellicht nieuwe aandeelhouders zijn toegetreden.

164

Zie ook hoofdstuk 3 en 7. 
Dwingend vennootschapsrecht waarborgt mede de ontwikkeling van de vennootschap door de oprichters niet toe te staan om "over hun graf heen te regeren' en statuten onveranderbaar te maken. Dit biedt tegelijkertijd bescherming aan later toetredende aandeelhouders. In het Engelse recht is het de ontwikkeling van de vennootschap die wordt voorop gesteld, doordat voor een besluit tot statutenwijziging zowel minimaal als maximaal drie vierde van de stemmen als vereiste mag worden gesteld, terwijl in het Nederlandse en Duitse recht daarentegen juist de gedachte doorslaggevend is, minderheidsaandeelhouders te beschermen door besluitvorming bij unanimiteit mogelijk te maken. ${ }^{165}$

In hoeverre derden invloed mogen uitoefenen op de bevoegdheid van de algemene vergadering tot statutenwijziging, is in Duitsland omstreden. De Verbandsautonomie verbiedt de aandeelhouders het lot van de vennootschap in andere handen te leggen. Zelfbeschikking van de aandeelhouders vormt in deze optiek de legitimatie van het Verband, waarbij de aandeelhouders ook steeds in staat dienen te zijn om deze zelfbeschikking uit te oefenen. Daar komt bij dat een statutair goedkeuringsrecht toekomstige aandeelhouders beperkt in de uitoefening van hun dwingendrechtelijke bevoegdheid. Deze redenen indachtig, meen ik dat naar Nederlands recht een statutair goedkeuringsrecht steeds moet kunnen worden doorbroken door een besluit van de algemene vergadering genomen met algemene stemmen. In Engeland spelen deze problemen overigens niet, daar derden geen rechten aan de statuten kunnen ontlenen.

Overigens wordt in de Companies Bill White Paper van juli 2002 de mogelijkheid gecreēerd om "entrenching provisions" in de constitutie op te nemen, die speciale modaliteiten geven waaronder andere statutaire bepalingen mogen worden gewijzigd. Deze entrenching provisions mogen slechts worden gewijzigd of afgeschaft met de instemming van alle aandeelhouders, section 21 Companies Bill, www.dti.gov.uk/companiesbill/whitepaper.htm. 



\section{Hoofdstuk 5 Uit de statuten voortvloeiende rechten en verplichtingen}

\section{$\S 5.1 \quad$ Inleiding}

Naast de wettelijk vereiste minimuminhoud van statuten,' kunnen de statuten aanvullende rechten en verplichtingen voor aandeelhouders bevatten, zowel jegens elkaar als jegens de vennootschap. Hoewel de wet in veel gevallen een grondslag biedt voor aanvullende rechten en verplichtingen, is onduidelijk in hoeverre deze wettelijke grondslag is vereist en welke dwingende grenzen aan aanvullende rechten en verplichtingen worden gesteld. ${ }^{2}$ Dit hoofdstuk beoogt meer duidelijkheid ter zake te bieden.

Door middel van statutaire uitbreiding en/of inperking van hun rechten kunnen aandeelhouders de vennootschappelijke verhoudingen binnen de besloten vennootschap naar eigen inzicht gestalte geven. Op deze wijze kunnen minderheidsaandeelhouders een bepaalde invloed in de vennootschap waarborgen. Zou de meerderheid deze statutaire rechten bij statutenwijziging weer kunnen ontnemen, dan is de invloed beperkt. Een kernvraag in dat verband is derhalve in hoeverre aandeelhouders in dit opzicht moeten worden beschermd. Dezelfde vraag geldt voor het opleggen van extra verplichtingen. Aandeelhouders kunnen ook besluiten in de statuten extra verplichtingen op te nemen, naast hun stortingsplicht. Zo wordt het intuitu personae karakter van de vennootschap versterkt.

In geval van aanvullende rechten en verplichtingen dient die bescherming van minderheidsaandeelhouders te worden afgewogen tegen het belang van de ontwikkeling van de vennootschap. Een instemmingsvereiste dient evident de bescherming van de minderheidsaandeelhouder. Daartegenover staat het belang van de vennootschap, die in het algemeen gebaat is bij een soepele besluitvorming, zodat de vennootschappelijke ontwikkeling en de statutair vereiste aanpassingen hand in hand kunnen gaan.

Zie $\$ 4.2 .2$.

Zie hoofdstuk 2. 
Bescherming van aandeelhouders door toepassing van de redelijkheid en billijkheid is dan een flexibeler instrument. Overigens kan de uitbreiding van rechten van sommige aandeelhouders ten koste gaan van de rechten van andere aandeelhouders. In dat geval zijn het bovendien de belangen van de verschillende aandeelhouders die tegen elkaar moeten worden afgewogen.

Tenslotte komt in dit hoofdstuk aan de orde in hoeverre in de statuten aanvullende rechten aan derden kunnen worden toegekend, en welke bescherming derden aan een statutaire regeling van hun rechten kunnen ontlenen. Onderzocht wordt in hoeverre dwingend vennootschapsrecht grenzen stelt aan de invloed die derden op basis van de statuten kunnen uitoefenen op de gang van zaken in de vennootschap. In dit verband zij opgemerkt dat aandeelhouders onder omstandigheden als derde kunnen worden gekwalificeerd en uit dien hoofde worden beschermd tegen het ontnemen van hun rechten.

\section{$\S 5.2$ Nederland}

\section{§ 5.2.1 Statutaire rechten van aandeelhouders}

Zoals vermeld in hoofdstuk 3 , kunnen dwingende wettelijke rechten van aandeelhouders in de statuten niet worden beperkt of ontnomen, zelfs niet indien alle aandeelhouders ermee instemmen. Boek $2 \mathrm{BW}$ bevat echter ook aanvullende bepalingen waarin aandeelhouders rechten worden toegekend. De statuten kunnen deze rechten uitsluiten, of aandeelhouders deze rechten bij latere statutenwijziging ontnemen. Zo kan het voorkeursrecht bij de uitgifte van nieuwe aandelen op grond van artikel 2:206a lid $1 \mathrm{BW}$ in de statuten worden beperkt, zonder dat hiervoor de instemming van alle aandeelhouders is vereist. Een ander voorbeeld biedt de wettelijke blokkeringsregeling, waaruit een recht op aanbieding van aandelen kan voortvloeien. In het Tonnema-arrest illustreert het hof de belangenafweging tussen de aandeelhouder en de vennootschap als volgt:

"De bewuste aanbiedingsregeling in de te wijzigen statuten kende geen absolute bescherming in die zin, dat voor wijziging ervan een unaniem besluit van de algemene vergadering van aandeelhouders vereist was. Dit betekent, dat Lampe vanaf het moment dat hij tot de rijen van aandeelhouders van Tonnema toetrad er rekening mee heeft moeten houden, dat hij, gegeven de samenstelling van de algemene vergadering van aandeelhouders van de familievennootschap, welke Tonnema is, en de individuele hoedanigheden en wensen van juist deze aandeelhouders alsmede zijn eigen betrekkelijk gering pakket aandelen en dus geringe 
stemkracht, geconfronteerd kon worden met een wijziging van de statuten met betrekking tot de aanbiedingsregeling." 3

Slechts indien aan aandelen bijzondere rechten inzake de zeggenschap zijn verbonden biedt de wet expliciet bescherming door te bepalen dat deze uitsluitend met instemming van de gerechtigde kunnen worden ingetrokken (artikel 2:208 lid $2 \mathrm{BW}$, tenzij anders vermeld in de statuten). ${ }^{+}$Het staat andeelhouders overigens vrij om in de statuten te bepalen dat alle besluiten met algemene stemmen van alle aandeelhouders dienen te worden genomen.

\section{\$5.2.2 'Bijzondere' rechten van aandeelhouders}

Op grond van artikel 2:201 lid 3 BW kunnen de statuten bepalen dat aan aandelen van een bepaalde soort bijzondere rechten als in de statuten omschreven inzake de zeggenschap in de vennootschap aan aandelen zijn verbonden. Dergelijke aandelen worden in het algemeen prioriteitsaandelen genoemd, maar kunnen ook in klassen zijn onderverdeeld. Deze bijzondere rechten zijn verbonden aan het aandeel, niet aan de persoon van de aandeelhouder. Zij kunnen niet los van het aandeel worden overgedragen. ${ }^{6}$

Prioriteitsaandelen kunnen bij de oprichting worden gecreëerd, of later in de statuten ingevoegd bij statutenwijziging. Indien er meer houders van prioriteitsaandelen met dezelfde bevoegdheden zijn, worden deze bevoegdheden uitgeoefend door de gezamenlijke prioriteitsaandeelhouders, die als orgaan worden beschouwd in de zin van artikel 2:189a BW. Aan dit orgaan kunnen bevoegdheden worden toegekend als het recht tot goedkeuring van de overdracht van de aandelen in de zin van artikel 2:195 lid $4 \mathrm{BW}$, van de uitgifte van aandelen, de bevoegdheid te bepalen welk deel van het resultaat van het boekjaar wordt gereserveerd of hoe het verlies wordt verwerkt, en de goedkeuring van bestuursbesluiten. Daarnaast worden andere bijzondere rechten toelaatbaar geacht, zonder uitdrukkelijke wettelijke grondslag. Voorbeelden van dergelijke zeggenschapsrechten zijn een recht van bindende voordracht voor de benoeming van bestuurders of commissarissen, een goedkeuringsrecht bij besluiten van de algemene vergadering

Hof Leeuwarden, in HR 17 mei 1991. NJ 1991, 645.

Zie $\$ 5.2 .2$.

In OK 2 mei 2002, JOR 2002, nr. 156, heeft de Ondernemingskamer in een geschil over uitkoop het statutaire vereiste dat voor elk besluit eenstemmigheid is vereist, als een bijzonder recht inzake de zeggenschap gekwalificeerd, omdat een dergelijke bepaling het verienen van zeggenschap door het uitgeven van prioriteitsaandelen overbodig zou maken.

Asser-Maeijer 2-III, nr. 196. 
of een recht van initiatief.' Overigens mogen de bijzondere rechten inzake de zeggenschap, die aan prioriteitsaandelen zijn verbonden, niet leiden tot wijziging van de wettelijke verdeling van taken en bevoegdheden tussen de organen van de vennootschap. ${ }^{8}$ Dit betekent in ieder geval dat dwingende wettelijke bevoegdheden niet kunnen worden toegekend aan prioriteitsaandeelhouders.

Prioriteitsaandelen kunnen slechts worden ingetrokken bij besluit van de algemene vergadering met instemming van alle houders van deze aandelen, tenzij bij de uitgifte in de statuten is bepaald dat zij kunnen worden ingetrokken met terugbetaling (artikel 2:208 lid $2 \mathrm{BW}$ ). Niet geheel duidelijk is echter of een wijziging in de bevoegdheden die aan de prioriteitsaandelen zijn verbonden eveneens de instemming van de betrokken prioriteitsaandeelhouders vereist. Zaman stelt dat de instemming van de betrokken aandeelhouders is vereist, zodra de wijziging extra verplichtingen met zich meebrengt in de zin van artikel 2:192 BW, op grond waarvan een aandeelhouder niet tegen zijn wil extra verplichtingen kunnen worden opgelegd.' Voorts acht hij artikel 2:96 lid 2 BW analoog toepasbaar, dat voor de geldigheid van een emissiebesluit de goedkeuring van de houders van elke soort aan wier rechten de uitgifte afbreuk doet vereist. ${ }^{10} \mathrm{Ik}$ meen dat wijziging van de bevoegdheden verbonden aan prioriteitsaandelen in dit geval het mindere is van intrekking. In deze optiek is instemming vereist, analoog aan artikel 2:208 lid $2 \mathrm{BW}$.

\section{Positie overige aandeelhouders}

Indien prioriteitsaandelen bij statutenwijziging worden gecreëerd, brengt dat verandering in de bestaande zeggenschapsverhoudingen, doordat de bevoegdheden van de algemene vergadering, i.e. de houders van gewone aandelen, indirect worden ingeperkt. De vraag is of een dergelijke wijziging de instemming vereist van alle 'benadeelde' aandeelhouders. Door de creatie van prioriteitsaandelen wordt de principiële gelijke positie van aandeelhouders doorbroken. In Duitsland wordt op deze grond aangenomen dat de instemming van alle aandeelhouders is vereist." Uit de bewoordingen van artikel 2:201 lid $1 \mathrm{BW}$ is een dergelijke instemmingseis echter niet af te leiden.

Vgl. Asser-Maeijer 2-III, nr. 401.

TK 1998-1999, 26277 , nr.3.

Zie $\$ 5.2 .4$.

Zaman, "Conversie van aandelen", NV 1991, blz. 9. Anders Van Olffen, "Conversie van aandelen", WPNR 1997, blz. 50.

Zie $\$ 5.3 .2$. 
Volgens Cremers gebiedt de goede trouw dat bij de uitgifte van prioriteitsaandelen de instemming van alle aandeelhouders is vereist, tenzij een zeer zwaarwegend belang van de vennootschap zich daartegen verzet, bijvoorbeeld in geval van een dreigende overname. ${ }^{12}$ Zaman meent daarentegen dat in beginsel de rechten van aandeelhouders door statutenwijziging mogen worden gewijzigd, omdat een aandeelhouder weet dat hij zich door toetreding onderwerpt aan de macht van de meerderheid. ${ }^{13}$

Naar mijn opvatting is een (gekwalificeerde) meerderheid voldoende voor een besluit tot invoering van prioriteitsaandelen. Het gaat steeds om aanvullende rechten, die de dwingende wettelijke bevoegdheidsverdeling intact laten. De bevoegdheden van de aandeelhouders zelf veranderen niet. Ik zou de opvatting van Cremers willen omdraaien: in beginsel een (gekwalificeerd) meerderheidsbesluit, tenzij het uitgeven van prioriteitsaandelen in strijd zou zijn met de redelijkheid en billijkheid.

\section{$\S 5.2 .3$ Rechten van derden}

Behalve rechten en verplichtingen van aandeelhouders jegens de vennootschap en jegens elkaar, kunnen de statuten ook rechten toekennen aan anderen dan aandeelhouders als zodanig. Dergelijke rechten zijn bijvoorbeeld bijzondere voordelen die aan oprichters worden verschaft, zoals het recht op gebruik van de woning boven het bedrijfspand. Op grond van artikel 2:204 BW dienen deze worden neergelegd in de akte van oprichting. ${ }^{4}$ De wet beschermt derden tegen een statutenwijziging die hen deze rechten weer zou ontnemen door in artikel 2:232 BW te bepalen:

"Wijziging van een bepaling der statuten, waarbij aan een ander dan aan aandeelhouders der vennootschap als zodanig enig recht is toegekend, kan indien de gerechtigde in de wijziging niet toestemt, aan diens recht geen nadeel toebrengen; tenzij ten tijde van de toekenning van het recht de bevoegdheid tot wijziging bij die bepaling uitdrukkelijk was voorbehouden."

Artikel 2:232 BW doelt op anderen dan aandeelhouders als zodanig. Dit kunnen bestuurders zijn, commissarissen, houders van oprichtersbewijzen of participatiebewijzen. Dat zij eventueel ook aandeelhouder zijn is voor de toepassing van artikel 2:232 BW niet van belang. ${ }^{15}$ In de - schaarse -

Cremers, Prioriteitsaandelen, 1971, blz. 54.

Zaman, NV 1991, blz 9.

Vgl. Asser-Maeijer 2-III, nr. 99.

Vgl. Schwarz, Losbl. Rp., art. 122-2. Handboek, nr. 344. Waaijer, Statuten en statutenwijziging,

Statuten en statutenwijziging, 1993, blz. 77. 
jurisprudentie ging het tot nu toe voornamelijk om acties van houders van oprichtersbewijzen, aan wier rechten werd getornd. ${ }^{16}$

Niet geheel duidelijk is wanneer een recht van een derde als recht in de zin van artikel 2:232 BW dient te worden gekwalificeerd. Aangenomen wordt in ieder geval dat in wezen contractuele rechten, zoals een recht op tantième, rechten zijn in de zin van artikel 2:232 BW. De meningen zijn echter verdeeld over de vraag in hoeverre zeggenschapsrechten ook als zodanig kunnen worden gekwalificeerd. Volgens Van Schilfgaarde zijn noch rechten van aandeelhouders als zodanig, zoals prioriteitsrechten, noch rechten van leden van andere organen als zodanig, rechten in de zin van artikel 2:232 BW. ${ }^{17}$ Van der Grinten hanteert als criterium dat de rechten in het persoonlijk belang van de gerechtigde zijn gegeven; dit geldt niet voor bevoegdheden. Een bepaling op grond waarvan een bestuurder slechts met gekwalificeerde meerderheid kan worden ontslagen, vormt in zijn optiek geen recht in de zin van art. 2:232 BW. Hij beschouwt een statutaire bepaling waarin een bestuurder met name wordt genoemd echter wel als een recht in de zin van artikel 2:232 BW.18 Maeijer meent dat het recht een financieel belang moet weerspiegelen en sluit alle zeggenschapsrechten uit. Hij kwalificeert een recht tot benoeming van een commissaris of het doen van een bindende voordracht dan ook niet als een recht in de zin van artikel 2:232 BW. ${ }^{19}$

Artikel 2:232 BW beoogt anderen dan aandeelhouders als zodanig te beschermen tegen een hen onwelgevallige statutenwijziging. Terwijl aanvullende rechten van aandeelhouders in beginsel met volstrekte meerderheid weer van hen kunnen worden afgenomen bij statutenwijziging, is voor het wijzigen van rechten van anderen dan aandeelhouders als zodanig in hun nadeel hun instemming vereist. Door zeggenschapsrechten te beschouwen als recht in de zin van artikel 2:232 BW zouden bijzondere rechten kunnen worden verbonden aan de persoon van de aandeelhouder, niet slechts aan de aandelen. Op deze wijze zou aandeelhouders extra bescherming kunnen worden geboden. Een zeggenschapsrecht wordt een aandeelhouder echter per definitie 'als zodanig' toegekend. Bovendien zou de ruime opvatting tot gevolg hebben dat aan anderen dan aandeelhouders een sterkere positie in de vennootschappelijke organisatie wordt gegeven dan

Rb. Haarlem, 19 januari 1932, NJ 1932, 1235. Hof 's Gravenhage, 12 april 1940, NJ 1940, 928. Rb. Amsterdam, 11 januari 1950, NJ 1950, 498. Rb. Rotterdam, 21 februari 1951, NJ 1951, 644. In Rb. Maastricht, I december 1960, NJ 1960, 152, ging het om cen derde-tantiémist.

Van Schilfgaarde, nr. 124.

Handboek, nr. 344. Zo ook Schwarz, Losbl. Rp., art. 122-2.

Asser-Maeijer 2-III, nr. 542, Zo ook Schwarz, Losbl. Rp., art. 122-2 en Waaijer, 1993, blz. 78 
aan aandeelhouders 'als zodanig'. Dit lijkt mij niet de bedoeling van artikel 2:232 BW.

Waaijer vraagt zich af of artikel 2:232 BW niet overbodig is, omdat uit de gewone regels van verbintenissenrecht al voldoende rechtsbescherming zou voortvloeien voor de wederpartij van de vennootschap. ${ }^{20}$ Naar mijn mening beoogt artikel 2:232 BW echter duidelijk te maken dat de vennootschap geen wanprestatie kan plegen door de statuten te wijzigen. Weliswaar zou een gerechtigde ook zonder artikel 2:232 BW kunnen ageren op grond van wanprestatie indien aan zijn recht afbreuk zou worden gedaan, maar dan bestaat het risico dat de rechter oordeelt dat de algemene vergadering nu eenmaal bevoegd is om de statuten te wijzigen. ${ }^{21}$

\section{§5.2.4 Extra verplichtingen voor aandeelhouders}

Artikel 2:192 BW bepaalt dat aan een aandeelhouder niet, zelfs niet door wijziging van de statuten, tegen zijn wil enige verplichting boven de storting van het nominale bedrag van het aandeel kan worden opgelegd. Extra verplichtingen mogen dus uitsluitend mét instemming van de aandeelhouder in de statuten worden neergelegd. In het algemeen wordt aangenomen dat dit betekent dat tot het opleggen van verplichtingen bij statutenwijziging slechts kan worden besloten met de instemming van de aandeelhouders aan wie de verplichting wordt opgelegd. Een besluit tot statutenwijziging dat aan aandeelhouders een extra verplichting oplegt leidt in deze optiek tot een vetorecht voor iedere aandeelhouder. Dit maakt de afbakening van het begrip 'verplichting' van belang. Van Veen betoogt op mijns inziens goede gronden dat artikel 2:192 BW een besluit tot statutenwijziging waarmee niet alle aandeelhouders hebben ingestemd niettemin mogelijk is, maar dat hieruit geen verplichtingen voortvloeien voor de aandeelhouder die de verplichting niet heeft geaccepteerd. ${ }^{22}$

Algemeen wordt aangenomen dat het leveren van producten, het verrichten van diensten, of het bijdragen aan de door de vennootschap geleden verliezen als verplichting in de zin van artikel 2:192 BW geldt. ${ }^{3}$ Over de verdere interpretatie van het begrip 'verplichting' bestaat minder eensgezindheid. Sommige schrijvers menen dat artikel 2:192 BW uitsluitend de verhouding tussen aandeelhouders en vennootschap betreft, gezien de plaats in het wetboek, en niet ziet op verplichtingen tussen aandeelhouders

Waaijer, 1993, blz. 75, beantwoordt de vraag, als ik hem goed begrijp, uiteindelijk bevestigend.

Vgl. Van Schilfgaarde, nr. 124

Van Veen, "Over het aandeelhouderschap en statutaire verplichtingen", WPNR 2003, blz. 144.

Asser-Maeijer 2-III, nr. 98. Van Schilfgaarde, nr. 21. 
onderling. ${ }^{24}$ Volgens Maeijer is de strekking van artikel 2:192 BW te voorkomen dat aan een aandeelhouder zonder zijn bewilliging extra verplichtingen worden opgelegd door besluiten van organen van de vennootschap. ${ }^{2 s}$ Van Veen beperkt de extra verplichtingen tot verplichtingen tot inbreng of andere prestatie ten behoeve van de vennootschap, boven de overeengekomen storting. ${ }^{26}$

Rensen ziet daarentegen geen reden voor een onderscheid tussen verplichtingen jegens elkaar of jegens de vennootschap, daar hij van opvatting is dat juist de ratio van de bepaling is dat aan het aandeelhouderschap niet zonder meer verplichtingen kunnen worden verbonden. Het is dan niet van belang jegens wie de aandeelhouder is verplicht. ${ }^{27}$ Dortmond betoogt dat verplichtingen die voortvloeien uit een wijziging in de structuur en organisatie van de vennootschap geen extra verplichtingen zijn. ${ }^{2 s} \mathrm{De}$ invoering of wijziging van de blokkeringsregeling wordt niet als extra verplichting opgevat. Timmerman meent dat dit impliciet kan worden afgeleid uit het Tonnema-arrest. ${ }^{29}$ Voorts wordt de wijziging van aandelen aan toonder in aandelen op naam plus de registratie niet als extra verplichting beschouwd. ${ }^{30}$ Hetzelfde geldt voor de conversie van preferente in gewone aandelen." Slagter kwalificeert de verplichting tot certificering van aandelen wel als verplichting in de zin van artikel 2:192 BW. ${ }^{32}$

In de voorheen geldende richtlijnen stond dat de verplichting nauwkeurig moet zijn omschreven. ${ }^{33}$ Hoewel het voorschrift geen wettelijke status heeft verkregen, kan uit de overweging dat de Wet herziening preventief toezicht geen inhoudelijke wijziging van de wet beoogt worden

24 Westbroek, "De nieuwste druk van het Handboek", NV 1977, blz. 149. Zo ook Van den Ingh, "De verplichting tot overname van niet vrij overdraagbare aandelen", WPNR 1989, blz. 137. Asser-Maeijer 2-III, nr. 98.

Asser-Maeijer 2-III, nr. 98.

Van Veen, WPNR 2003, blz. 144.

Rensen, "Statutaire aanbiedings- en overnameverplichtingen van aandeelhouders", Ondernemingsrecht 2001, blz. 484. Zie ook Leijten, Geschillen tussen aandeelhouders, in: Conflicten rondom de rechtspersoon, Serie Monografieen vanwege het Van der Heijden Instituut deel 62, 2000 , blz. 12 ,

Dortmond, Enige beschouwingen rondom aandelen, 1989, blz. 43. Zie ook Losbl. Rechtspersonen, 1992, art. 192-2.

HR 17 mei 1991. NJ 1991, 645 (Lampe/Tonnema). Timmerman, noot Tonnema, TVVS 1991, blz. 190. Overigens beschouwt hij de omzetting van een aanbiedingsregeling in een goedkeuringsregeling eerder als het ontnemen van een recht dan als het opleggen van een verplichting. Asser-Maeijer 2-III, nr. 98 . Vgl. ook $\$ 27$ dep. rl.

Sanders/Westbroek, nr. 8.3.5.

Slagter, Compendium, blz 213. Ook Maeijer vindt dit te ver gaan. Anders: Westbroek, NV 1977, 149.

$\$ 30$ Departementale Richtlijnen 1986. 
afgeleid dat het voorschrift nog steeds geldt. ${ }^{34}$ Maeijer meent dan ook dat de statuten niet mogen bepalen dat bij besluit van een vennootschapsorgaan aandeelhouders extra verplichtingen worden opgelegd." Van der Grinten brengt hierop een nuancering aan, in de zin dat de statuten wel kunnen bepalen dat bij besluit van een vennootschapsorgaan aan aandeelhouders extra verplichtingen kunnen worden opgelegd. Deze verplichtingen moeten dan wel nauwkeurig in de statuten zijn omschreven. ${ }^{36}$

Voor het verenigingsrecht heeft het hof Amsterdam in de uitspraak Feyenoord/KNVB geoordeeld dat "noodzakelijk is, dat de aard van de desbetreffende verplichting (d.w.z. een verplichting opgelegd aan leden $e x$ artikel 2:46 BW, MM) in de statuten wordt omschreven", onder meer vanwege het fundamentele recht op zelfbeschikking, dat zou worden aangetast indien de leden de KNVB een blanco volmacht zouden geven."

De vraag is of een dergelijk zelfbeschikkingsrecht ook voor aandeelhouders geldt. Terwijl een voetbalclub lid van de KNVB moet zijn om te kunnen spelen, treden aandeelhouders vrijwillig toe tot een vennootschap. Bovendien opereren aandeelhouders in een commerciële context, waarin mijns inziens aan de autonomie van de aandeelhouder geen zelfstandige betekenis toekomt. Een aandeelhouder wordt tegen onredelijke verplichtingen beschermd door artikel $2: 15$ jo. $2: 8 \mathrm{BW}$, terwijl het gelijkheidsbeginsel ervoor zorgt dat alle aandeelhouders gelijke verplichtingen worden opgelegd. Wel zou betoogd kunnen worden dat de vennootschappelijke orde in gevaar komt indien een aandeelhouder niet vrij is om te stemmen zoals het hem goeddunkt, omdat hij 'gestraft' kan worden doordat de algemene vergadering kan besluiten extra verplichtingen op te leggen. Ook dit gevaar wordt mijns inziens echter grotendeels gepareerd door de redelijkheid en billijkheid en de gelijke behandeling. Wel acht ik het in strijd met de vennootschappelijke orde indien de algemene vergadering zou kunnen besluiten een overdrachts- of overnameverplichting op te leggen. ${ }^{3 \mathrm{x}}$

Mijns inziens dient de vraag of een extra verplichting nauwkeurig in de statuten moet zijn omschreven te worden beantwoord aan de hand van het verschil in strekking tussen statutaire en contractuele bepalingen. De strekking van het voorschrift lijkt mij gelegen in de bescherming van de later toetredende aandeelhouders, omdat zij ook gebonden kunnen zijn aan de besluiten van de algemene vergadering waarin extra verplichtingen

\footnotetext{
Vgl. Rensen, Ondernemingsrecht 2001, blz. 486.

Asser-Maeijer 2-III, nr, 98.

Handboek, $\mathrm{nr} .172$.

Hof Amsterdam, 8 november 1996, NJ 1998, 681 (Feyenoord/KNVB).

Zie infra.
} 
worden opgelegd. Dit betekent dat aandeelhouders wel kunnen overeenkomen dat de algemene vergadering dergelijke verplichtingen oplegt, maar dit niet in de statuten kunnen opnemen. ${ }^{19}$

\section{Sancties}

Indien een aandeelhouder zijn statutaire verplichting niet nakomt, biedt de wet uiteenlopende sanctiemogelijkheden. In de eerste plaats mogen de statuten bepalen dat een aandeelhouder niet gerechtigd is tot uitoefening van het stemrecht zolang hij in gebreke is te voldoen aan een wettelijke of statutaire verplichting, aldus artikel 2:228 lid $1 \mathrm{BW}$. In de tweede plaats voorziet artikel 2:195a BW in de mogelijkheid dat een aandeelhouder, in gevallen, in de statuten omschreven, gehouden is zijn aandelen aan te bieden en over te dragen. Volgens Rensen is dit een extra verplichting in de zin van artikel 2:192 BW, die slechts met de instemming van alle aandeelhouders in de statuten kan worden neergelegd. ${ }^{* 0}$

Art. 2:195a BW stelt als vereiste voor de statutaire overdrachtsverplichting dat deze ontstaat "in gevallen, in de statuten omschreven". In de memorie van toelichting wordt deze ruime categorie slechts beperkt door de redelijkheid en billijkheid. De tot de verplichting leidende omstandigheden dienen wel objectief bepaalbaar te zijn en nauwkeurig in de statuten te zijn omschreven." Zo worden als redelijke gronden voor een overdrachtsverplichting genoemd: het niet (langer) voldoen aan statutaire kwaliteitseisen en het faillissement, de surséance of de ondercuratelestelling van een aandeelhouder. Schoonbrood noemt voorts de 'change-ofcontrol' bepaling, dat de zeggenschap in de aandeelhouder-rechtspersoon overgaat. ${ }^{21}$ Rensen brengt wel een beperking aan en meent dat een statutaire aanbiedings- en overdrachtsplicht slechts kan zien op omstandigheden die samenhangen met de persoon van de aandeelhouder die tot aanbieding verplicht is. Deze samenhang ontbreekt, ingeval aandeelhouders verplicht zijn hun aandelen aan te bieden, zodra een openbaar bod op de aandelen wordt gedaan. ${ }^{.1}$

Ik zou menen dat de aandeelhouders in beginsel vrij zijn om te bepalen, in welke omstandigheden zij elkaar gehouden achten hun aandelen

Zie $\$ 7.2 .3$

Rensen, Ondernemingsrecht 2001, blz 486. Zo ook Schoonbrood, De in de wet overgenomen bepalingen van de Departementale Richtlijnen 1986, in: Statuten zonder bezwaar, preadvies KNB 2002, blz.83

TK 1998-1999, 26277 , nr. 3, blz. 8

Schoonbrood, 2002, blz. 76.

Rensen, Ondernemingsrecht 2001, blz. 487 . 
aan te bieden, temeer indien zij daar allen mee dienen in te stemmen. In het instemmingsvereiste ligt mijns inziens in de eerste plaats de waarborg tegen onredelijke verplichtingen. Voor de later toetredende aandeelhouders gaat het er om, dat zij niet kunnen worden geacht te hebben ingestemd met het opleggen van verplichtingen waarvan zij de inhoud en omvang niet kennen. Dit wordt onderkend met het vereiste van de nauwkeurigheid en objectieve bepaalbaarheid van de verplichting.

In de literatuur zijn de meningen voorts verdeeld over de toelaatbaarheid van een statutaire overnameverplichting. Zonder uitdrukkelijke wettelijke basis zou deze in strijd zijn met de autonomie van de aandeelhouder. ${ }^{4}$ Leijten kwalificeert een afnameplicht in het kader van een statutaire geschillenregeling als een verplichting in de zin van artikel 2:192 BW.4s Alle aandeelhouders dienen derhalve met een statutaire overnameverplichting in te stemmen. Dienen aandeelhouders daarenboven te worden beschermd tegen het invoeren van een overnameverplichting?

Naar mijn mening gelden voor de verplichting tot overname van de aandelen in beginsel dezelfde overwegingen als voor de aanbiedings- en overdrachtsverplichting. Voorop staat de vrijheid van de aandeelhouders om met ieders instemming aanvullende statutaire verplichtingen in de statuten neer te leggen. De vraag is echter of een uitdrukkelijke wettelijke basis voor dergelijke verplichtingen is vereist, opdat toekomstige aandeelhouders met deze mogelijkheid rekening houden en geacht kunnen worden te hebben ingestemd met een dergelijke verplichting. Mijns inziens blijkt uit artt. 2:192 en 2:337 BW dat verplichtingen aan aandeelhouders kunnen worden opgelegd. Ik zie niet in waarom een overnameverplichting uitdrukkelijke wettelijke vermelding zou vereisen. Wel dienen naar mijn mening de voorwaarden waaronder de verplichting wordt geëffectueerd, zoals vermeld, nauwkeurig in de statuten te zijn omschreven.

\section{$\S 5.2 .5$ Statutaire kwaliteitseisen aan aandeelhouders}

Naast de mogelijkheid om extra verplichtingen aan aandeelhouders in de statuten neer te leggen bestaat de mogelijkheid om statutaire kwaliteitseisen aan aandeelhouders te stellen. Dat blijkt uit artikel 2:195b BW, dat een scala aan sancties biedt ingeval een aandeelhouder niet aan de statutair gestelde eisen voldoet. ${ }^{46}$ In de eerste plaats kunnen het stemrecht, het recht

\footnotetext{
4

Van den Ingh, "WPNR 1989, blz. 137. Anders Van Veen, WPNR 2003, blz. 138, die in het vereisen van instemming voor een verplichting juist een uitoefening van de autonomie ziet. Leijten, 2000, blz. 12. Zo ook Rensen, Ondernemingsrecht 2001, blz. 489.

Voor die tijd bleek de geoorloofdheid van het stellen van kwaliteitseisen uit $\$ 34$ van de departe-
} 
op deelname aan de algemene vergadering en/of het recht op uitkeringen worden opgeschort. Opschortingen van andere aandeelhoudersrechten acht de minister niet toelaatbaar. ${ }^{47}$ In de tweede plaats kan een aandeelhouder worden verplicht zijn aandelen aan te bieden en over te dragen conform een statutaire overdrachtsverplichting in de zin van art. 2:195a BW.

Als voorbeeld van een statutaire kwaliteitseis noemt de memorie van toelichting dat alleen natuurlijke personen aandeelhouder mogen zijn, of dat het aandeelhouderschap is voorbehouden aan een bepaald overheidslichaam. ${ }^{48}$ In de literatuur worden onder meer als kwaliteitseis gekwalificeerd: het bevoegd zijn tot uitoefening van een bepaald beroep, het zijn van werknemer bij de vennootschap", het zijn van partij bij een joint-ventureovereenkomst $^{50}$ of bij een stemovereenkomst ${ }^{51}$, het bezitten van ten hoogste ${ }^{52}$ of ten minste ${ }^{31} x \%$ van de aandelen.

Het stellen van kwaliteitseisen aan aandeelhouders kan blijk geven van een intuitu personae karakter van de vennootschap. ${ }^{54}$ De kring van (potentiële) aandeelhouders wordt beperkt. Echter, de kwaliteitseisen mogen de overdraagbaarheid van de aandelen niet zodanig beperken dat de overdracht onmogelijk of uiterst bezwaarlijk wordt. De vraag is of de eis dat een aandeelhouder partij is bij een joint-venture-overeenkomst de overdraagbaarheid niet te zeer beperkt. ss $^{\text {s. }}$

Net als statutaire verplichtingen dienen statutaire kwaliteitseisen nauwkeurig in de statuten te worden omschreven. ${ }^{56}$ De vraag is of aandeelhouders kunnen worden verplicht om te voldoen aan statutaire kwaliteitseisen door een statutenwijziging. Uit $\S 34$ van de departementale richtlijnen bleek dat de instemming van aandeelhouders voor het invoeren van een dergelijke regeling was vereist, tenzij ontheffing werd verleend. Deze regeling is met de invoering van artikel $2: 195 b \mathrm{BW}$ echter verloren gegaan. De

mentale richtiijnen 1986 .

TK 1998-1999, 26277 , nr. 3.

Vgl. HR 31 december 1993, NJ 1994, 436 (Verenigde Bootlieden).

Den Boogert, Aandeelhouderscontracten en joint-venture-bv's, in: Ondernemingsrechtelijke contracten, uitgave vanwege het Instituut voor Ondernemingsrecht deel 14, 1991, blz. 75. Ten Berg, Statuten versus aandeelhoudersovereenkomsten, in: Statuten zonder bezwaar, preadvies KNB 2002, blz. 198.

Den Boogert, "Aanpassing van boek 2 BW voor joint-venture-doeleinden?", AA 1995, blz. 359.

Vgl. Asser-Macijer 2-1II, nr. 98.

Honé, Statutair gedwongen uitkoop. in: A-T-D, opstellen aangeboden aan Prof. mr. P. van Schilfgaarde, 2000, blz. 156.

$\mathrm{Vgl}$. Schwarz, Blokkering van aandelen, serie vanwege het Van de Heijden Instituut deel 27. 1986, blz. 18.

Zie hierover Ten Berg, 2002, blz. 198 en Portengen, "Aandeelhoudersovereenkomst als kwaliteitseis?". WPNR 2002, blz. 842 e.v.

Zie Schoonbrood, 2002, blz. 79 e.v 
vraag is dan of dit vereiste zo vanzelfsprekend wordt geacht dat het expliciete vermelding overbodig maakt, ${ }^{37}$ of dat impliciet ruimte wordt gecreëerd om de bestaande praktijk te veranderen. De memorie van toelichting zwijgt.

Voor zover aan het niet voldoen aan de statutaire kwaliteitseisen een aanbiedings- en overdrachtsverplichting als sanctie is verbonden, behoeft de invoering van kwaliteitseisen in ieder geval de instemming van alle aandeelhouders. ${ }^{58}$ Niet duidelijk is echter of dit instemmingsvereiste ook geldt, indien uitsluitend de aandeelhoudersrechten worden opgeschort. Uit het tweede lid van artikel 2:195b BW blijkt, dat een aandeelhouder wiens rechten zijn opgeschort, van de kwaliteitseisen wordt ontheven wanneer de vennootschap niet binnen drie maanden na een verzoek daartoe van de aandeelhouder gegadigden heeft aangewezen aan wie hij al zijn aandelen zal kunnen overdragen volgens een regeling in de statuten. Hoewel er dan geen overdrachtsverplichting bestaat, heeft de aandeelhouder de keuze tussen de overdracht van de aandelen of het niet kunnen uitoefenen van zijn rechten. Volgens Schoonbrood komt dit in de praktijk op hetzelfde neer, omdat een aandeelhouder die zijn rechten niet kan uitoefenen weinig belang zal hebben bij het voortduren van zijn aandeelhouderschap..9 Daarenboven dient mijns inziens vermeden te worden dat het instemmingsvereiste van artikel 2:192 BW zou kunnen worden terzijde gesteld door een extra verplichting als eis te formuleren. ${ }^{60}$ Gesteld zou kunnen worden dat het moeten voldoen aan een statutaire kwaliteitseis steeds een extra verplichting in de zin van artikel 2:192 BW is.

Het tweede lid van artikel 2:195b BW bepaalt dat, indien de aandeelhouder een of meer rechten niet kan uitoefenen en de aandeelhouder niet gehouden is zijn aandelen aan te bieden en over te dragen, hij onherroepelijk van de in de statuten gestelde eisen is ontheven wanneer de vennootschap niet binnen drie maanden na een verzoek daartoe van de aandeelhouder gegadigden heeft aangewezen aan wie hij al zijn aandelen zal kunnen overdragen volgens een regeling in de statuten. De statuten mogen deze termijn van drie maanden niet verlengen. De algemene vergadering zou anders steeds kunnen besluiten de termijn te verlengen, terwijl de van stemrecht ontheven aandeelhouder daarop geen invloed zou kunnen uitoefenen.

\footnotetext{
Vgl. Bosse, "De bruikbaarheid van de vervallen Departementale Richtlijnen", WPNR 2001, blz. 570.

Vgl. Rensen, Ondernemingsrecht 2001, blz. 487. Schoonbrood, 2002, blz. 83.

Schoonbrood, 2002, blz. 81.

Vgl. Van Veen, WPNR 2003, blz 138, die als voorbeeld noemt een statutaire eis inhoudende dat slechts diegenen die zich jegens derden voor schulden van de vennootschap hebben verbonden, aandeelhouder kunnen zijn van de vennootschap.
} 


\section{$\S 5.3$ Duitsland}

\section{\$ 5.3.1 Aanvullende rechten van aandeelhouders}

In het $\mathrm{GmbH}-$-recht worden de rechten van aandeelhouders met betrekking tot aangelegenheden van de vennootschap naar uitgangspunt in de statuten bepaald; de Gestaltungsfreiheit staat voorop. ${ }^{61} \S 45$ GmbHG luidt:

"1. Die Rechte, welchen den Gesellschaftern in den Angelegenheiten der Gesellschaft, insbesondere in bezug auf die Führung der Geschäfte zustehen, sowie die Ausübung derselben bestimmen sich, soweit nicht gesetzliche Vorschriften entgegenstehen, nach dem Gesellschaftsvertrag.

2. In Ermangelung besonderer Bestimmungen des Gesellschaftsvertrages finden die Vorschriften der $\S \S 46$ bis 51 Anwendung."

De wet bevat aanvullend recht ten aanzien van de bevoegdheden van de algemene vergadering, de wijze van oproeping en de besluitvorming in de algemene vergadering en het stemrecht. Aandeelhouders zijn derhalve in beginsel vrij om af te wijken van de wettelijke bepalingen, tenzij dit in strijd komt met dwingende voorschriften of met de grenzen die door het 'wezen' van de vennootschap worden gesteld. ${ }^{62}$ Het is bijvoorbeeld niet verplicht om een jaarlijkse algemene vergadering te houden. Andere rechten van aandeelhouders zijn niet uitdrukkelijk in de wet vermeld, zoals het recht op dividend.

In beginsel kunnen deze rechten van aandeelhouders door middel van een statutenwijziging worden gewijzigd of ingetrokken, met een meerderheid van drie vierde van het aantal stemmen ( $\$ 53$ Abs. 2 GmbHG). ${ }^{63}$ Zo kan een blokkeringsregeling met een besluit tot statutenwijziging worden ingevoerd, dan wel opgeheven, zonder dat de instemming van alle aandeelhouders is vereist. ${ }^{-4}$

In $\S 3.3 .1$ is reeds vermeld, dat sommige rechten unentziehbar worden geacht, in de zin dat deze slechts met instemming van de gerechtigde(n) kunnen worden gewijzigd. Dit geldt bijvoorbeeld voor het recht op divi-

Zie $\$ 2.3 .2$

BGH, NJW 1954, 1563. Zie ook $\S 2.3 .2$. Strijd met het wezen van de vennootschap is een van de nietigheidsgronden voor besluiten, zie $\$ 6.3 .2$.

Hachenburg/Ulmer $\$ 53,78$. Zie $\$ 4.3 .4$.

Lutter/Hommelhoff $\$ 53,21$. 
dend en het recht op liquidatie-overschot na vereffening."s De reden hiervoor is, dat door het afzien van het recht op dividend of het toekennen van een liquidatie-overschot aan een ander het doel van de vennootschap wordt gewijzigd. Op grond van $\S 33 \mathrm{BGB}$ is voor de wijziging van de doelomschrijving van een vereniging de instemming van alle leden vereist. Als algemeen beginsel van rechtspersonenrecht is dit ook van toepassing op aandeelhouders in een $\mathrm{GmbH}^{6}{ }^{6}$

Ook het stemrecht kan slechts met instemming van de betrokken aandeelhouders worden uitgesloten, tenzij bij de uitgifte van de aandelen reeds was voorzien in deze mogelijkheid. De Unentziehbarheit van het stemrecht vindt haar grondslag in de Gleichbehandlungsgrundsatz. Op basis hiervan kan een aandeelhouder of een groep aandeelhouders uitsluitend met zijn of hun instemming worden achtergesteld ten opzichte van andere aandeelhouders, tenzij er sprake is van een 'wichtiger Grund'. Hoewel stemrechtloze aandelen derhalve mogelijk zijn, schijnen deze overigens in de praktijk nauwelijks voor te komen. ${ }^{67}$

Complementair aan de bescherming van aandeelhouders tegen ongelijkheid is de bescherming die wordt geboden, indien aan aandelen bijzondere rechten worden verbonden. Deze 'Sonderrechte' kunnen evenmin zonder de instemming van de gerechtigde worden gewijzigd. Hetzelfde geldt voor bijzondere voordelen die aan aandeelhouders en/of derden bij gelegenheid van de oprichting van de vennootschap zijn toegekend. ${ }^{69}$ Door de instemming van aandeelhouders te vereisen voor een verandering in hun rechtspositie worden in feite dwingende grenzen gesteld aan aanvullende rechten van aandeelhouders. ${ }^{70}$

Indien geen instemming is vereist, wordt een minderheidsaandeelhouder beschermd doordat hem een uittredingsrecht is toegekend, bijvoorbeeld in geval van fusie en omzetting. Eén van de redenen voor de verregaande bescherming van minderheidsaandeelhouders is het feit dat een minderheidsaandeelhouder vrij gemakkelijk de besluitvorming lam kan leggen door een Anfechtungsklage in te stellen, waardoor het besluit niet kan worden uitgevoerd zolang de uitspraak geen gezag van gewijsde heeft verkregen. ${ }^{71}$

\footnotetext{
6s Hachenburg/Raiser $\S 14,27$ e.v. Baumbach/Hueck/Fastrich $\S 14,16$. Rowedder/SchmidtLeithoff/Pentz $\$ 14,21$.

Lutter/Hommelhoff $\$ 53,19$.

Baumbach/Hueck/Zollner \$ 47, 43a.

Zie \$ 5.3.2.

Zie $\$ 5.3 .3$.

Zie \$ 2.3.2.

Zie \$ 6.3.2.
} 


\section{\$.3.2 Sonderrechte}

In het Duitse recht worden de aandelen waaraan bijzondere rechten (Sonderrechte) zijn verbonden als Vorzugsgeschäftsanteile aangeduid." Een Sonderrecht wordt gedefinieerd als een bijzonder lidmaatschapsrecht, dat aan individuele aandeelhouders of aan een bepaalde groep aandeelhouders een voorkeurspositie verschaft. ${ }^{\text {"s }}$ Naast Sonderrechte verbonden aan aandelen kent het Duitse recht persoonsgebonden Sonderrechte, die zich onderscheiden van de eerste categorie doordat zij onafhankelijk van het aandeel bestaan. ${ }^{4}$ Niettemin kunnen slechts aandeelhouders aanspraak maken op een Sonderrecht; derden kunnen in beginsel geen rechten ontlenen aan de statuten. ${ }^{75}$ Sonderrechte vinden hun wettelijke grondslag in $\S 35 \mathrm{BGB}$, dat als regel van verenigingsrecht ook van toepassing wordt geacht op de $\mathrm{GmbH} .^{76}$

Een Sonderrecht kan zowel vermogensrechtelijk als organisatierechtelijk van aard zijn. Voorbeelden van Sonderrechte zijn een recht op extra dividend, meervoudig stemrecht, een recht tot benoeming als bestuurder, een recht op benoeming van een bestuurder, of goedkeurings- of vetorechten ten opzichte van bepaalde besluiten. Ook een goedkeuringsrecht in geval van overdracht van aandelen of een recht op verwerving van aandelen die worden vervreemd kunnen als een Sonderrecht worden aangemerkt." Een aandeelhouder die in de statuten als bestuurder wordt genoemd, heeft een Sonderrecht op het bestuurderschap, indien op basis van objectieve interpretatie uit de tekst van de statuten blijkt dat de aandeelhouders hebben beoogd een Sonderrecht te vestigen. ${ }^{78}$ Aanwijzingen hiervoor kunnen zijn dat de aandeelhouder/bestuurder voor het leven is benoemd, of dat zijn bestuursfunctie eindigt met de overdracht van zijn aandelen. Dit betekent dat een Sonderrecht op het bestuurderschap steeds persoonsgebonden is."

$n \quad$ Hachenburg/Ulmer $\$ 5,161$.

$73 \quad$ Uitgebreid Waldenberger, "Sonderrechte der Gesellschafter einer GmbH - ihre Arten und ihre rechtliche Behandlung", GmbHR 1997, blz. 52. Zie ook Hachenburg/Raiser $\$ 14,17$ e.v. Flume, Allgemeiner Teil des bürgerlichen Rechts - Die juristische Person, 1983, blz. 272. Reuter, $\S 35$, 2. Staudinger/Coing, $\$ 35,8$ c.v. Baumbach/Hueck/Fastrich, $\$ 14,17$.

Hachenburg/Ulmer $\S 5,161,173$. Hachenburg/Raiser $\$ 14,22$. Junker, "Der Sondervorteil im Sinne des $\$ 26$ AktG", ZHR 1995, blz. 211.

7 Zie $\$ 5.3 .3$

76. $\$ 35$ BGB luidt: Sonderrechte eines Mitglieds können nicht ohne dessen Zustimmung durch Beschluß der Mitgliederversammlung beeintrachtigt werden.

$n \quad$ Hachenburg/Ulmer $\$ 5,160,166$ e.v. Hachenburg/Raiser $\$ 14,19$.

7. BGH WM 1981, 438. Hachenburg/Raiser $\$ 14,21$. Waldenberger, GmbHR 1997, blz. 51. Zie $\$ 4.3 .3$.

79. Hachenburg/Ulmer $\$ 6,18$. 
Sonderrechte mogen niet ingrijpen in dwingendrechtelijke bevoegdheden. Zo kan de bevoegdheid tot statutenwijziging niet worden toegekend aan een aandeelhouder in de vorm van een Sonderrecht. Deze bevoegdheid komt immers de algemene vergadering toe op basis van $\S 53 \mathrm{GmbHG}^{80}$

Op grond van $\S 35$ BGB kunnen Sonderrechte slechts met instemming van de gerechtigde worden ingetrokken of gewijzigd." Wijziging zonder instemming maakt het besluit jegens de gerechtigde umwirksam. ${ }^{{ }^{22}}$ Aan het instemmingsvereiste mag echter worden voorbijgegaan, indien sprake is van een 'wichtiger Grund' ${ }^{33}$ Een voorbeeld hiervan biedt $\S 38$ Abs. 2 GmbHG, op grond waarvan een bestuurder steeds mag worden ontslagen wegens een wichtiger Grund, ook al heeft hij een Sonderrecht op het bestuurderschap. ${ }^{.4}$ De als bestuurder ontslagen aandeelhouder heeft daarop het recht om uit de vennootschap te treden. ${ }^{\text {ss }}$ Waldenberger pleit voor het gebruik van de Treupflicht om af te wijken van het instemmingsvereiste. ${ }^{86}$

$\mathrm{De} \mathrm{GmbH}$ biedt vanwege het uitgangspunt van de Gestaltungsfreiheit veel ruimte tot de vestiging van allerhande Sonderrechte, hetgeen met name van belang is bij persoonsgebonden GmbH's. ${ }^{\text {s7 }}$ In de negentiende eeuw werden Sonderrechte gecreëerd als tegenwicht voor de besluitvorming bij meerderheid van stemmen. ${ }^{88}$ Sonderrechte bleken echter de noodzakelijke aanpassingen van Verbände aan de in de tijd veranderende omstandigheden te bemoeilijken en werden derhalve restrictief geïnterpreteerd.

Tegenwoordig is de beschermingsfunctie van minderheidsaandeelhouders door Sonderrechte overgenomen door meer flexibele beginselen als de Treupflicht en de Gleichbehandlungsgrundsatz." Deze ontwikkelingen hebben ertoe geleid dat de betekenis van Sonderrechte als beschermingsinstrument voor minderheidsaandeelhouders is afgenomen. ${ }^{90}$ De effectiviteit van de beschermende functie van Sonderrechte is voorts aangetast door de Gleichbehandlungsgrundsatz, die met zich meebrengt dat alle niet-bevoordeelde aandeelhouders met de vestiging van een Sonder-

\footnotetext{
Hachenburg/Raiser $\$ 14,20$.

Hachenburg/Ulmer $\S 5,165,181$. Hachenburg/Raiser $\S 14,23$.

Waldenberger, GmbHR 1997, blz. 55. Lutter/Hommelhoff, $\$ 38,34$.

Baumbach/Hueck/Fastrich, $\S 14,18$. Reuter, $\$ 35,7$.

Vgl. BGH NJW 1969, 131; BGH WM 1981, 438, 439. Hachenburg/Raiser $\$ 14,19$.

Lutter/Hommelhoff, $\S 38,23$.

Waldenberger, GmbHR 1997, blz. 54.

Winkler, "Materielle und formelle Bestandteile in Gesellschaftsverträgen und Satzungen und ihre verschiedene Auswirkungen", DNotz 1969, blz. 413. K. Schmidt, 1991, blz. 379. Waldenberger, GmbHR 1997, blz. 49, 5 I.

Flume, 1983, blz. 271.

Reuter, $\S 35,2$.

Zöllner, Die Schranken mitgliedschaftlicher Stimmrechtsmacht bei den privatrechtlichen Personenverbanden, 1963, blz. 110.
} 
recht dienen in te stemmen. ${ }^{\text {"1 }}$ Niettemin zijn Sonderrechte in de praktijk van belang en bezitten ook commerciële waarde, daar zij de gerechtigde aandeelhouders bijzondere voordelen verschaffen. ${ }^{n}$ Dit geldt overigens in mindere mate voor persoonsgebonden rechten; deze zijn immers niet overdraagbaar.

\section{§5.3.3 Rechten van derden}

Naar Duits recht kunnen derden geen rechten ontlenen aan de statuten." Rechten van derden behoren in beginsel niet tot de statuten in materiële zin, tenzij een derde als orgaan wordt gekwalificeerd. ${ }^{94}$ Een goedkeuringsrecht bij bestuursbesluiten of een ontslagrecht kan uitsluitend ten behoeve van een derde worden gevestigd indien deze als orgaan van de vennootschap wordt beschouwd. ${ }^{\text {s }}$ De vraag rijst dan natuurlijk wanneer een derde deel uitmaakt van een orgaan of zelf orgaan wordt.

Ulmer beschouwt de toekenning van een recht aan een derdebuitenstaander ad personam niet als het creëren van een orgaan. ${ }^{*}$ Beuthien/ Gätsch zijn echter van mening, dat de derde juist door de statutaire toekenning van rechten een vennootschapsorgaan wordt. ${ }^{y 2}$ Het gaat dan kennelijk steeds om rechten, die van invloed zijn op de interne organisatie, niet om in wezen contractuele rechten. Volgens Zöllner kunnen organen uitsluitend door de statuten worden ingesteld, voor zover zij taken vervullen in het belang van de vennootschap en interne beslissingsbevoegdheid hebben." Zo heeft het Bundesgerichtshof een bij de statuten ingesteld Schiedsgericht als orgaan gekwalificeerd, omdat het deel uitmaakt van de organisatie van de vennootschap."

Wel kunnen aan aandeelhouders en/of derden Sondervorteile worden toegekend bij gelegenheid van de oprichting van een $\mathrm{GmbH}$. $§ 26$ Abs. 1 AktG (dat analoog van toepassing is op de $\mathrm{GmbH}$ ) luidt:

9) Staudinger/Coing, $\S 35,8$. Hachenburg/Raiser $\$ 14,21$. Hachenburg/Ulmer $\S 5,163$ en $\S 53,120$. Baumbach/Hueck/Fastrich $\S 13,37, \S 14,15$. Waldenberger, GmbHR 1997, blz. 50. Zie ook \$ 5.3.1.

Waldenberger, GmbHR 1997, blz 49.

Baumbach/Hueck/Fastrich $\$ 3,27$ a.

Hachenburg/Ulmer $\S 53,17$. Baumbach/Hueck $\S 3,27$ a. Zie $\S 4.3 .2$.

Lutter/Hommelhoff $\S 37,16$ en $\S 38,3$.

Ulmer, Begrundung von Rechten fur Dritte in der Satzung einer $\mathrm{GmbH}$ ? in: Festschrift fur Winfried Werner, 1984, blz, 923.

Beuthien/Gatsch, "Vereinsautonomie und Satzungsrechte Dritter", ZHR 1992, blz. 468.

Baumbach/Hueck/Zollner $\$ 45,13$.

BGHZ 43, 261, 263. 
"Jeder einem einzelnen Aktionär oder einem Dritten eingeräumte besondere Vorteil muß in der Satzung unter Bezeichnung des Berechtigten festgesetzt werden."

Voorbeelden hiervan zijn een recht op gebruik van een bedrijfspand, aanspraak op een percentage van de omzet of winst, het recht om ingebrachte zaken terug te kopen. Weliswaar dienen Sondervorteile in de statuten te worden neergelegd, maar in wezen vormen zij de inhoud van een overeenkomst tussen de vennootschap en de begunstigde. ${ }^{101}$ De neerlegging in de statuten is veeleer een vormvoorschrift, waarop als sanctie nietigheid wordt gehanteerd, teneinde derden inzicht te kunnen geven in de financiële verplichtingen van de vennootschap. ${ }^{102}$

Op grond van § 26 Abs. 4 AktG kunnen Sondervorteile slechts worden gewijzigd na een Sperrfrist van vijf jaar, daarna uitsluitend met instemming van de gerechtigden. ${ }^{103}$ Wordt daarentegen een recht van een derde gewijzigd, dat niet als Sondervorteil wordt gekwalificeerd, dan kan hij daar niets tegen doen. ${ }^{10+}$ De vraag is dan wanneer een recht tegelijkertijd een Sondervorteil is. Volgens sommige auteurs kunnen niet alleen vermogensrechten, maar ook zeggenschapsrechten als Sondervorteil worden gekwalificeerd, bijvoorbeeld een recht op benoeming als bestuurder, of een recht op benoeming van een bestuurder. Enerzijds betekent dit dat het recht uitsluitend met instemming van de gerechtigde kan worden gewijzigd, anderzijds dat dergelijke rechten uitsluitend geldig zijn indien zij in de statuten zijn vervat. ${ }^{105}$ Lutter/Hommelhoff menen daarentegen dat een bestuurder zich niet kan verzetten tegen een statutenwijziging waarin de voorwaarden voor ontslag worden verminderd. ${ }^{106}$. Voorts is omstreden of het recht om leden van de Aufsichtsrat te ontslaan als Sondervorteil kan worden toegekend. ${ }^{107}$

Ook indien een recht in de statuten wordt toegekend aan een aandeelhouder, dient door interpretatie te worden vastgesteld of het gaat om een lidmaatschapsrecht of een in wezen contractueel recht. Alle rechten van aandeelhouders jegens de vennootschap, die hem onafhankelijk van zijn aandeelhouderschap zijn toegekend, worden geacht in wezen contractuele

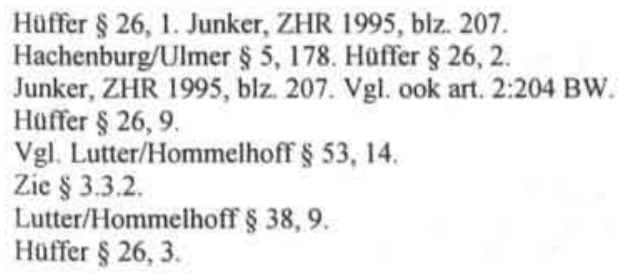


rechten (Drittrechte) te zijn. Een besluit tot statutenwijziging kan geen afbreuk doen aan contractuele rechten van aandeelhouders zonder hun instemming. ${ }^{108}$

\section{§5.3.4 Nebenleistungen}

§ 3 Abs. 2 GmbHG voorziet in de mogelijkheid tot het in de statuten creëren van extra verplichtingen voor aandeelhouders, zgn. Nebenleistumgen. De wet geeft aan dat bepalingen die "andere Verpflichtungen gegenüber der Gesellschaft" opleggen in de statuten dienen te worden neergelegd. ${ }^{109}$ Indien Nebenleistungen bij een besluit tot statutenwijziging worden opgelegd of gewijzigd, is de instemming van de (belaste) aandeelhouders vereist. Dit vloeit voort uit $\S 53$ Abs. $3 \mathrm{GmbHG}$. ${ }^{110}$ Wel volstaat een besluit tot statutenwijziging, ingeval de Nebenleistungen worden afgeschaft."

Terwijl § 55 AktG de toelaatbare Nebenleistungen beperkt tot duurzame verplichtingen in natura, worden aan de Nebenleistungen bij de $\mathrm{GmbH}$ geen inhoudelijke beperkingen gesteld. Alles wat voorwerp van een overeenkomst kan zijn, is ook als Nebenleistung mogelijk. ${ }^{112}$ De verplichting kan bestaan uit een handelen of uit een nalaten, zoals een concurrentieverbod. ${ }^{13}$ Ook kunnen de statuten aandeelhouders verplichten om steeds vóór een voorgedragen kandidaatbestuurder te stemmen. Deze verplichting is overigens niet absoluut; indien tegen de kandidaat een gegrond bezwaar bestaat, hoeft niet aan de verplichting te worden voldaan. ${ }^{114}$

Verplichtingen jegens de vennootschap moeten op straffe van nietigheid in de statuten worden vervat, zo blijkt uit $\S 3$ Abs. 2 GmbHG. Achterliggende gedachte hierbij is dat een aandeelhouder uit de statuten moet kunnen afleiden welke verplichtingen van hem worden verwacht. De verplichting jegens de vennootschap is een verplichting uit 'Mitgliedschaft', hetgeen maakt dat de verplichting bij overdracht van het aandeel overgaat op de nieuwe aandeelhouder, tenzij de verplichting persoonsgebonden is. ${ }^{11}$

Hachenburg/Raiser \$ 14, 30

Lutter/Hommelhoff $\S 3,17$. Hachenburg/Ulmer $\S 3,72$. Baumbach/Hueck/Fastrich $\S 3,32$ c.v.

$110 \$ 53$ Abs. 3 GmbHG luidt: "Eine Vermehrung der den Gesellschaftern nach dem Gesellschaftsvertrag obliegenden Leistungen kann nur mit Zustimmung samtlicher beteiligter Gesellschafter beschlossen werden." Baumbach/Hueck/Fastrich $\S 3,38$. Hachenburg/Ulmer $\$ 53,73$.

Hachenburg/Ulmer $\$ 3,65,75$.

Lutter/Hommelhoff $\$ 3,22$. Hachenburg/Ulmer $\S 3,65,82$.

Baumbach/Hueck/Zollner $\$ 76 \mathrm{~b}$. Rowedder/Koppensteiner $\S 47,20$.

Lutter/Hommelhoff $\S 3,27$. Huffer $\S 55,3$. Baumbach/Hueck/Fastrich $\S 3,35,50$.
} 
Een statutaire verplichting hoeft overigens niet voor alle aandeelhouders te gelijk te zijn. ${ }^{116}$

Verplichtingen tussen aandeelhouders onderling vormen, ook al zijn ze in de statuten neergelegd, geen statutaire bepalingen in materiële zin." ${ }^{17}$ Doordat Nebenleistungen zowel statutair als contractueel kunnen worden aangegaan, is het afhankelijk van de wil van de partijen en/of de omstandigheden van het geval of partijen vennootschapsrechtelijke werking hebben beoogd, of louter verbintenisrechtelijke. Zo wordt een overdrachtsverplichting aan de vennootschap corresponderend met een aankooprecht voor de overige aandeelhouders wel als een verplichting in de zin van $\S 3 \mathrm{Abs} .2 \mathrm{GmbHG}$ aangemerkt, maar een rechtstreekse verplichting tot overdracht aan de andere aandeelhouders niet. ${ }^{118}$ De omstandigheid dat voor een verplichting geen tegenprestatie is verlangd, duidt op vennootschapsrechtelijke werking. Dit betekent dat een contractuele regeling waarin aandeelhouders zich jegens de vennootschap verplichten, nietig is wegens het ontbreken van een notariële akte."19

De verplichting dient bepaald of bepaalbaar te zijn, hetgeen inhoudt dat reeds bij de vastlegging van de verplichting de latere omvang voor de aandeelhouders is te overzien. ${ }^{120}$ Dit neemt niet weg dat de inwerkingtreding van een verplichting afhankelijk kan worden gesteld van een besluit van een vennootschapsorgaan. Indien de concrete inhoud niet in de statuten zelf is omschreven, maar de bepaling ervan aan een orgaan of een derde is overgelaten, dan dient dit 'nach billigem Ermessen' te geschieden, conform $\S \S 315,317$ BGB. ${ }^{12}$ Dit betekent dat het orgaan of een derde geen onredelijke verplichtingen mag opleggen. Een algemene onderwerping aan de wil van de meerderheid is echter met het doel van $\S 53 \mathrm{Abs} .3 \mathrm{GmbHG}$ onverenigbaar, tenzij tevens in een Austrittsrecht in de statuten is voorzien. ${ }^{122}$

Hachenburg/Ulmer $\S 3,86$.

Zie $\$$ 4.3.2.

Hachenburg/Ulmer § 3, 80. Zie ook Baumbach/Hueck/Fastrich § 3, 58 .

Vgl. BGH DB 1993, blz. 829. OLG Dresden, GmbHR 1997, blz. 746.

Lutter/Hommelhoff $\S 3,25$. Hachenburg/Ulmer $\S 3,87$.

$\S 315$ Abs. I BGB luidt: "Soll die Leistung durch einen der Vertragschließenden bestimmt werden, so ist im Zweifel anzunehmen, daB die Bestimmung nach billigem Ermessen zu treffen ist." $\$ 317$ Abs 1. BGB: "Ist die Bestimmung der Leistung einem Dritten aberlassen, so ist im Zweifel anzunehmen, daß sie nach billigem Ermessen zu treffen ist." Lutter/Hommelhoff $\S 3,25$. Hachenburg/Ulmer § 3, 88. Baumbach/Hueck/Fastrich § 3, 39.

Hachenburg/Ulmer $\$ 53,74$. 


\section{Sancties}

Wordt een verplichting niet nagekomen, dan is de vraag welke sancties daaraan kunnen worden verbonden. In het Duitse recht zijn de algemene regels van verbintenissenrecht zoveel mogelijk van overeenkomstige toepassing. ${ }^{12}$ Daarenboven kunnen de statuten in andere sancties voorzien, bijvoorbeeld door op niet-nakoming een boete en/of een dwangsom te stellen, analoog aan $\S 55$ Abs. 2 AktG. ${ }^{124}$ Tevens kunnen de statuten intrekking van de aandelen als sanctie op het niet nakomen van een verplichting stellen op grond van $\S 34 \mathrm{GmbHG}{ }^{123}$ Indien een aandeelhouder in strijd met een statutaire stemverplichting stemt, is zijn stem ongeldig. ${ }^{126}$

Uit $\S 34$ Abs. 2 GmbHG blijkt dat intrekking van aandelen zonder de instemming van de betrokken aandeelhouder slechts kan plaatsvinden, wanneer de voorwaarden voor intrekking voorafgaande aan de toetreding van de betrokken aandeelhouder tot de vennootschap reeds in de statuten waren vastgelegd. Een statutaire bepaling die de intrekking afhankelijk maakt van een meerderheidsbesluit of het eigen inzicht van een aandeelhouder wordt in beginsel ontoelaatbaar geacht vanwege de bescherming van minderheidsaandeelhouders tegen de willekeur van de meerderheid. ${ }^{127}$ In de rechtspraak zijn echter dergelijke clausules gehonoreerd met een beroep op buitengewone omstandigheden. ${ }^{128}$

Naast statutaire sancties kan de niet-nakoming van een verplichting een gegronde reden vormen voor een Ausschließungsklage ${ }^{129}$ of voor de ontbinding van de vennootschap. Er dient dan sprake te zijn van een voortdurende onmogelijkheid om de verplichtingen na te komen, terwijl de vennootschappelijke verhoudingen door de niet-nakoming wezenlijk worden beïnvloed. ${ }^{130}$ In tegenstelling tot de Zwangseinziehung van $\S 34 \mathrm{GmbHG \text {, }}$ die bij besluit geschiedt en meteen wordt geëffectueerd, behoudt de aandeelhouder in geval van een Ausschließungsklage alle met het aandeel

\footnotetext{
123 Lutter/Hommelhoff $\$ 3,28$. Hachenburg/Ulmer $\$ 3,90$.

124 Hachenburg/Ulmer $\$ 3,95$.

125 Vgl. BGH NJW 1977, blz. 2316. OLG Numberg, GmbHR 1994, blz. 253. $\$ 34$ GmbHG luidt: "1 Die Einziehung (Amortisation) von Geschaftsanteilen darf nur erfolgen, soweit sie im Gesellschaftsvertrag zugelassen ist. 2. Ohne die Zustimmung des Anteilsberechtigten findet die Einziehung nur statt, wenn die Voraussetzungen derselben vor dem Zeitpunkt, in welchem der Berechtigte den Geschaftsanteil erworben hat, im Gesellschaftsvertrag festgesetzt waren."

Baumbach/Hueck/Zoliner $\$ 76$ b.

Lutter/Hommelhoff $\$ 34,18$.

BGHZ 112, 108 .

Zie \$ 2.3 .2

Hachenburg/Ulmer $\S 3,97$.
} 
verbonden rechten en verplichtingen - dus inclusief zijn stemrecht -, totdat de gerechtelijk uitspraak tot uitstoting gezag van gewijsde heeft gekregen. ${ }^{31}$

\section{$\S 5.3 .5$ Kwaliteitseisen aan aandeelhouders}

De overdracht van aandelen kan aan statutaire voorwaarden worden verbonden, bijvoorbeeld door het stellen van kwaliteitseisen aan aandeelhouders, conform $\S 15$ Abs. 5 GmbHG:

"Durch den Gesellschaftsvertrag kann die Abtretung der Geschäftsanteile an weitere Voraussetzungen geknüpft, insebesondere von der Genehmigung der Gesellschaft abhängig gemacht werden."

Voorbeelden van dergelijke eisen zijn het behoren tot een bepaalde familie, het hebben bereikt van een bepaalde leeftijd, of het hebben voltooid van een bepaalde opleiding. ${ }^{132}$ De vennootschap keurt de overdracht dan goed, indien de koper aan de gestelde eisen voldoet. Priester noemt als voorbeeld dat de goedkeuring afhankelijk kan worden gesteld van het toetreden tot een aandeelhoudersovereenkomst. ${ }^{13}$

Dergelijke eisen kunnen ook bij statutenwijziging worden ingevoerd, maar dan is omstreden of deze invoering de instemming van alle aandeelhouders vereist. Lutter/Hommelhoff menen dat invoering ook bij meerderheidsbesluit kan geschieden, mits het belang van de vennootschap de invoering vereist. ${ }^{134}$ Het verliezen van statutair vereiste kwaliteitseisen kan een grond zijn voor intrekking van de aandelen in de zin van $\S 34$ GmbHG. ${ }^{13}$

Onduidelijk is in hoeverre kwaliteitseisen in de statuten moeten worden neergelegd, op straffe van nietigheid. Aangenomen kan worden dat dit uitsluitend geldt voor die kwaliteitseisen die ook als Nebenleistung kunnen worden gekwalificeerd.

OLG Nurnberg, GmbHR 1994, blz. 254

Lutter/Hommelhoff $§ 15,23$,

Priester, Rechtskontrolle und Registerpublizităt als Schranken satzungsgleicher Gesellschaftervereinbarungen bei der GmbH?, in: Festschrift fur Claussen, 1997, blz. 335.

Lutter/Hommelhoff $\$ 15,25$.

Lutter/Hommelhoff, $\$ 34,16$. 


\section{$\S 5.4$ Engeland}

\section{§ 5.4.1 Aanvullende rechten van aandeelhouders}

Op grond van section $370 \mathrm{CA} 1985$ is aan ieder aandeel één stem verbonden, tenzij de statuten anders bepalen. ${ }^{136}$ Dit houdt in dat in de articles stemrechtloze aandelen kunnen worden gecreëerd. Voor het overige vloeien de rechten verbonden aan aandelen voort uit de aanvullende bepalingen van Table A. Article 2 Table A bepaalt:

"Subject to the provisions of the Act and without prejudice to any rights attached to any existing shares, any share may be issued with such rights or restrictions as the company may by ordinary resolution determine."

Zo kunnen het recht op deelname aan de algemene vergadering en het recht op dividend worden vastgelegd in de articles, hetgeen impliceert dat ook deze rechten statutair kunnen worden beperkt of uitgesloten. ${ }^{137}$ Het stemrecht is gekoppeld aan het recht op deelname aan de algemene vergadering. Indien een aandeelhouder geen stemrecht heeft, mag hij in beginsel ook niet deelnemen aan de algemene vergadering. ${ }^{138}$

$\mathrm{Bij}$ besluit tot statutenwijziging kunnen rechten aan aandeelhouders worden ontnomen. Hiervoor is een special resolution vereist, hetgeen een meerderheid van drie vierde van het aantal stemmen veronderstelt. ${ }^{139}$ Wel dient de bevoegdheid tot statutenwijziging bona fide for the benefit of the company as a whole te worden uitgeoefend:

"The power (...) must, like all other powers, be exercised subject to those general principles of law and equity which are applicable to all powers conferred on majorities and enabling them to bind minorities. It must be exercised, not only in the manner required by law, but also bona fide for the benefit of the company as a whole, and it must not be exceeded. These conditions are always implied, and are seldom, if ever, expressed." ${ }^{1 * 0}$

Hoewel geen duidelijke richtlijnen te geven zijn wanneer een besluit niet bona fide is, mag een statutenwijziging er niet toe leiden dat de

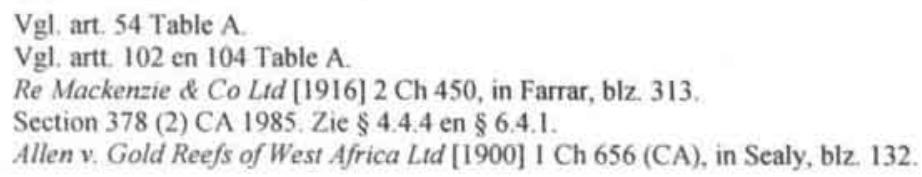


meerderheid van de aandeelhouders zich bevoordeelt ten koste van de minderheidsaandeelhouders. ${ }^{141}$

In de jurisprudentie en de doctrine is de aandacht met name gericht op het achterhalen van de concrete betekenis van de term 'bona fide for the benefit of the company as a whole'. Strijdpunt daarbij is de vraag of dit een subjectief of een objectief criterium is. In het eerste geval is het voldoende dat de aandeelhouders zelf op het moment van de statutenwijziging in de veronderstelling verkeerden dat deze in het belang van de vennootschap was, zodat de rechter alleen ingrijpt wanneer geen redelijk denkend mens de statutenwijziging in het belang van de vennootschap zou achten. De voorkeur voor de subjectieve benadering kan worden verklaard door de terughoudendheid van de rechters om zich in interne aangelegenheden van de vennootschap te mengen. ${ }^{142}$

Ferran meent dat voor een statutenwijziging waarbij belangrijke rechten als het stemrecht worden ontnomen, speciale bescherming voor aandeelhouders gerechtvaardigd is. Dergelijke rechten zouden onder omstandigheden als class rights kunnen worden gekwalificeerd, zodat deze slechts met instemming van de betrokken aandeelhouders kunnen worden gewijzigd. ${ }^{13}$

\section{$\oint 5.4 .2$ Class rights}

Het Engelse recht kent zogenaamde 'class rights'. Dit zijn rechten, verbonden aan bepaalde aandelen of toebehorend aan bijzondere groepen aandeelhouders. Gebruikelijke class rights zijn een recht op dividend behorende bij preference shares, of meervoudig stemrecht voor een bepaalde klasse van aandelen. In joint-ventures is het gebruikelijk aandelen onder te verdelen in letter-aandelen met daaraan gekoppelde rechten. ${ }^{1+4}$ Class rights zijn zeer moeilijk te wijzigen zonder de instemming van de class rights houders. Voor zover de articles of het memorandum geen procedure bevatten voor de wijziging van class rights, geldt een - vrij ingewikkelde procedure, voorzien in section 125-127 CA 1985.

It Vgl. Peter's American Delicacy Co Ltd v. Heath [1939] 61 CLR 457 (High Court of Australia), in Sealy, blz. 139, Greenhalgh v. Arderne Cinemas Ltd [1951] Ch 286 [1950] 2 All ER 1120 (CA), in Sealy, blz. $143 \mathrm{en} \mathrm{Redwood} \mathrm{Master} \mathrm{Fund} \mathrm{and} \mathrm{others} \mathrm{v.} \mathrm{TD} \mathrm{Bank} \mathrm{Europe} \mathrm{Ltd} \mathrm{and} \mathrm{others} \mathrm{[2002]}$ All ER (D) 141.

Bretten, "Alteration of Articles and Protection of Minorities", JBL blz. 191 e.v. Rixon, "Competing interests and conflicting principles: an examination of the power of alteration of articles of association", MLR 1986, blz. 455. Goulding, blz. 82. Zie ook $\$ 6.4 .2$.

143 Ferran, Company Law and Corporate Finance, 1999, blz. 347.

i4 Ferran, 1999, blz. 333. Reynolds, "Shareholders' Class Rights: A New Approach", JBL 1996, blz. 555 . 
Verschillende scenario's kunnen worden gevolgd, afhankelijk van de vraag of de class rights zijn neergelegd in het memorandum of in de articles. Op grond van section 125(2) CA 1985 kunnen class rights worden gewijzigd indien de houders van meer dan drie vierde van de nominale waarde van de aandelen van die class ermee instemmen door middel van een extraordinary resolution. ${ }^{145} \mathrm{Zijn}$ de class rights vastgelegd in het memorandum, en is er geen wijzigingsprocedure voorzien, dan kunnen de class rights slechts worden gewijzigd met algemene stemmen. ${ }^{146}$ Section 127(2) CA 1985 kent daarenboven houders van ten minste 15 procent van de aandelen van de class het recht toe de wijziging te laten vernietigen, indien deze "would unfairly prejudice the shareholders of the class". Ook de afschaffing van de rechten wordt als wijziging beschouwd.

\section{In Cumbrian Newspapers Group Ltd v. Cumberland \& Westmorland} Herald Newspaper \& Printing Co. Ltd ${ }^{\text {th }}$ zijn class rights niet langer beperkt tot rechten verbonden aan aandelen, maar kunnen ook persoonsgebonden rechten, die een aandeelhouder als zodanig toekomen, class rights zijn. Het begrip 'class rights' is door deze uitspraak erg ruim gedefinieerd.

Cumbrian Newspaper Group (CNG) en Cumberland \& Westmorland Herald Newspaper \& Printing Co. (C \& W) gaven elk een krant uit in de regio Cumberland. Teneinde deze kranten voor de regio te behouden kwamen beide uitgevers overeen dat de krant van CNG zou opgaan in de Cumberland \& Westmorland Herald, terwijl CNG voor $10 \%$ zou deelnemen in C \& W. Onderdeel van de overeenkomst was de wijziging van de statuten van $\mathrm{C} \& \mathrm{~W}$, in de zin dat $\mathrm{CNG}$ een voorkeursrecht (right of pre-emption) verkreeg op de uitstaande en nieuw uit te geven aandelen en het recht tot benoeming van een bestuurder, zolang CNG ten minste $10 \%$ van het geplaatste kapitaal zou bezitten. Na enige jaren riep het bestuur een buitengewone algemene vergadering bijeen en stelde een statutenwijziging voor waarin deze rechten van CNG werden geschrapt. Daarop startte CNG een procedure, stellende dat deze rechten class rights waren die niet zonder haar instemming konden worden gewijzigd. Scott $\mathrm{J}$ onderschreef dit standpunt en onderbouwde zijn beslissing door drie categoriee̋n speciale rechten te onderscheiden:

"First, there are rights or benefits which are annexed to particular shares. Classic examples of rights of this character are dividend rights and rights to participate in surplus assets on a winding up. If articles provide that particular shares carry particular rights not enjoyed by the holders of other shares, it is easy to conclude

145 Zie ook $\$ 6.4 .1$.

146 Zie hierover Ferran, 1999, blz. 340. Sealy, blz. 469. Farrar, blz. 233,

147 Cumbrian Newspapers Group Ltd v. Cumberland \& Westmorland Herald Newspaper \& Printing Co. Ltd [1987] 3 WLR 26. 
that the rights are attached to a class of shares, for the purpose of section 125 of the Act of 1985."

"A second category of rights or benefits which may be contained in the articles, would cover rights or benefits conferred on individuals not in the capacity of members or shareholders of the company but, for ulterior reasons, connected with the administration of the company's affairs or the conduct of its business. (...) It is, perhaps, obvious that rights or benefits in this category cannot be class rights. They cannot be described as rights attached to a class of shares." ${ }^{48}$

"That leaves the third category. This category would cover rights or benefits, that, although not attached to any particular shares, were nonetheless conferred on the beneficiary in the capacity of member or shareholder of the company."

"In my judgment, a company which, by its articles, confers special rights on one or more of its members in the capacity of member or shareholder thereby constitutes the shares for the time being held by that member or members, a class of shares for the purposes of section 125 . The rights are class rights."

Een ander voorbeeld van een class right is volgens Scott $\mathrm{J}$ de clausule, waarin iedere aandeelhouder wiens ontslag als bestuurder op de agenda staat, drievoudig stemrecht heeft (gesanctioneerd in Bushell v. Faith ${ }^{\prime v 0}$ ). Deze clausule maakt immers onderscheid tussen aandeelhouders die gedurende een bepaalde tijd bestuurder zijn en zij die dat niet zijn. Tevens schaarde hij het recht van de aandeelhouders om hun aandelen aan het bestuur te verkopen onder de class rights..$^{150}$

Class rights zijn derhalve niet alleen rechten verbonden aan bepaalde aandelen, maar ook in de statuten toegekende rechten aan één of meer aandeelhouders in hun hoedanigheid als aandeelhouder. Zo bieden class rights minderheidsaandeelhouders bescherming tegen het ontnemen van hun rechten. Dit is de achtergrond van de ruime interpretatie. Class rights hoeven bovendien niet per se in de statuten te worden neergelegd; ook rechten voortvloeiend uit een aandeelhoudersovereenkomst kunnen als class rights worden aangemerkt, dan echter alleen jegens aandeelhouders die partij zijn bij de overeenkomst.

In Harman v. BML Group Ltd bevatten de statuten van de vennootschap een quorumeis voor de besluitvorming in de algemene vergadering van ten minste twee aandeelhouders. Tussen de aandeelhouders Harman, Mills en Blumenthal was overeengekomen dat geen quorum aanwezig was zonder de houder van Baandelen, Blumenthal. Harman wilde aan de quorumeis voorbijgaan en verzocht daarom de rechter een algemene vergadering bijeen te roepen. Section $371 \mathrm{CA}$

Vgl. $\$ 5.4 .3$.

Bushell v. Faith [1969] 2 Ch 438. Zie ook $\$ 2.4 .2$.

Zie Rayfield v. Hands [1960] Ch 1, [1958] 2 All ER 194, in Sealy, blz 117. Zie ook \$ 5.4.4. 
1985 geeft een aandeelhouder dit recht om de rechter te verzoeken een algemene vergadering bijeen te roepen. Henry LJ overwoog:

"[I] am persuaded that Mr Blumenthal's rights were entrenched as a class right in the shareholders' agreement; that those rights gave him an effective veto and that, as the company was deliberately set up this way, section 371 should not be pressed to rewrite the shareholders' agreement." 1 si

Ferran oppert om zelfs stemrechten verbonden aan gewone aandelen onder omstandigheden als class rights aan te merken, teneinde minderheidsaandeelhouders te beschermen tegen het ontnemen van stemrechten bij statutenwijziging. ${ }^{152}$

Wat met de ene hand wordt gegeven, wordt echter met de andere hand weer weggenomen, doordat het begrip 'wijziging' restrictief wordt geïnterpreteerd. In de jurisprudentie wordt een onderscheid gemaakt tussen het class right zelf en het genot van het class right. Hoewel het genot van een class right vermindert bij de uitgifte van nieuwe aandelen, kan een class rights houder zich niet tegen de uitgifte verzetten. Alleen indien de wijziging betrekking heeft op het class right zelf, wordt de procedure van section $125 \mathrm{CA} 1985$ van toepassing geacht. ${ }^{153}$

Een voorbeeld biedt Greenhalgh v. Arderne Cinemas Ltd. ${ }^{154}$ In casu had de vennootschap een aandelenkapitaal verdeeld in aandelen van $10 \mathrm{p}$ en van $50 \mathrm{p}$, waarbij aan elk aandeel één stem was verbonden. Splitsing van de aandelen van $50 \mathrm{p}$ in vijf van $10 \mathrm{p}$ werd niet aangemerkt als een wijziging van de class rights van de $10 \mathrm{p}$ aandeelhouder, hoewel het relatieve gewicht van zijn stemrecht zodanig was verminderd dat hij de zeggenschap over de vennootschap verloor.

Davies acht het onbevredigend dat een besluit tot halvering van stemrechten wel als een wijziging van class rights wordt aangemerkt, maar een besluit tot verdubbeling van stemrechten van de gewone aandelen niet, terwijl het effect hetzelfde is. ${ }^{\text {is }}$ Daarom pleit Reynolds ervoor om ook bij een indirecte wijziging van class rights de procedure van section 125-127 CA 1985 van toepassing te achten. ${ }^{156}$ Keerzijde is echter dat een ruime

\footnotetext{
151 Harman v. BML Group Lid [1994] I WLR 893, [1994] BCC 502.

152 Ferran, 1999, blz 347 .

153 Ferran, 1999, blz 341 e.v.

154 Greenhalgh v. Arderne Cinemas Ltd [1946] 1 All ER 512, CA, in Farrar, blz. 232

155. Davies, blz. 726. Kritisch ook Farrar, blz. 232. Vgl. de rol van de Gleichheitsgrundsatz in $\$ 5.3 .2$

156. Reynolds, JBL 1996, blz. 554.
} 
interpretatie aan de class rights houders een vetorecht zou verstrekken over besluiten die op enige wijze het genot van het recht beïnvloeden. ${ }^{157}$

\section{$\oint 5.4 .3$ Outsider rights}

Derden kunnen geen rechten ontlenen aan de articles of association. Dit vloeit voort uit de privity rule uit de common law, inhoudende dat derden geen rechten aan een overeenkomst kunnen ontlenen, daar zij geen partij zijn bij de overeenkomst en geen consideration hebben verschaft. ${ }^{15 \pi}$ Weliswaar is de privity rule door de Contracts (Rights of Third Parties) Act 1999 afgeschaft, maar de wet is niet van toepassing op de articles en het memorandum in de zin van section $14 \mathrm{CA} 1985 .{ }^{159}$ Dit betekent dat eventuele statutaire rechten van derden kunnen worden gewijzigd zonder instemming van de gerechtigde, zelfs al is deze tegelijkertijd aandeelhouder.

Een voorbeeld biedt de zaak Eley v. Positive Life Assurance Co. ${ }^{160}$ Eley was solicitor van de vennootschap en werd als zodanig in de statuten vermeld. Toen de vennootschap een andere solicitor in de arm nam, kon hij zich niet op de statutaire vermelding beroepen, ook al was hij aandeelhouder van de vennootschap. Een bestuurder kan zich evenmin verzetten tegen een besluit van de algemene vergadering waarin de ontslaggronden voor bestuurders worden uitgebreid. ${ }^{161}$

De vraag is wanneer een recht toebehorend an een aandeelhouder als lidmaatschapsrecht (right qua member) moet worden aangemerkt en wanneer als recht van een derde (outsider right). De leading case op dit gebied is Hickman v. Kent or Romney Marsh Sheepbreeders' Association, waar Astbury $\mathbf{J}$ een onderscheid maakt tussen rechten betreffende de vennootschappelijke organisatie en contractuele rechten:

"An outsider to whom rights purport to be given the articles in his capacity as such outsider, whether he is or subsequently becomes a member, cannot sue on those articles treating them as contracts between the company and himself to enforce those rights. Those rights are not part of the general regulations of the company applicable alike to all shareholders and can only exist by virtue of some contract between such person and the company, and the subsequent allotment of shares to

Ferran, 1999, blz 342.

Dunlop Pneumatic Tyre Co. Ltd v. Selfridge \& Co. Ltd [1915] AC 847 HL, in Andrews, "Strangers to justice no longer: the reversal of the privity rule under the Contracts (Rights of Third Parties) Act 1999, CLJ 2001, blz. 354. Zie ook Davies, blz. 118.

Section 6(2) van de Contracts Act 1999. Andrews, CLJ 2001, blz. 372.

Eley v. Positive Life Assurance Co [1876] 1 Ex D 88.

Shuttleworth v. Cox Bros \& Co (Maidenhead) Ltd [1927] 2 KB 9 CA, in Sealy, blz. 137.
} 
an outsider in whose favour such an article is inserted does not enable him to sue the company on such an article to enforce rights which are res inter alios acta and not part of the general rights of the corporators as such..."

"...but I think this much is clear, first, that no article can constitute a contract between the company and a third person; secondly, that no right merely purporting to be given by an article to a person, whether a member or not, in a capacity other than that of a member, as, for instance, as solicitor, promoter, director, can be enforced against the company; and, thirdly, that articles regulating the rights and obligations of the members generally as such do create rights and obligations between them and the company respectively..." ${ }^{162}$

Aandeelhouders kunnen zich derhalve uitsluitend beroepen op statutaire rechten die hen als zodanig zijn toegekend. ${ }^{63}$

\section{§ 5.4.4 Extra verplichtingen aan aandeelhouders}

Op grond van section $16 \mathrm{CA} 1985$ kan een aandeelhouder niet tegen zijn wil worden verplicht tot het nemen van meer aandelen dan hij op het moment van statutenwijziging bezit, tot het verhogen van zijn aansprakelijkheid of tot het verhogen van zijn bijdrage aan de vennootschap boven de stortingsplicht. Andere verplichtingen kunnen voortvloeien uit article 2 Table A, dat bepaalt:

"Subject to the provisions of the Act and without prejudice to any rights attached to any existing shares, any share may be issued with such rights or restrictions as the company may by ordinary resolution determine." 164

Ook uit Hickman's case blijkt dat verplichtingen in de articles kunnen worden neergelegd:

"that articles regulating the rights and obligations of the members generally as such do create rights and obligations between them and the company respectively..." ${ }^{\prime 65}$

\footnotetext{
162 Hickman v. Kent or Romney Marsh Sheepbreeders 'Association [1915] 1 Ch 881, in Sealy, blz. 113.

163 Kritisch over deze benadering is Copp, "Company law and alternative dispute resolution: an economic analysis", Company Lawyer 2002, blz. 364 . Zie ook $\$ 6.4 .1$.

104 Zie ook $\$ 5.4 .1$.

105 Hickman v. Kent or Romney Marsh Sheepbreeders' Association [1915] 1 Ch 881, in Sealy, blz 113.
} 
Zo kunnen aandeelhouders bijvoorbeeld in het kader van een blokkeringsregeling worden verplicht tot het afnemen van aandelen. ${ }^{160}$ Een voorbeeld biedt Rayfield $v$. Hands:

De articles van de vennootschap kenden aandeelhouders het recht toe om hun aandelen op elk gewenst moment aan te bieden, gekoppeld aan de verplichting van het bestuur om de aangeboden aandelen van de aandeelhouders te kopen. Rayfield bood zijn aandelen aan, maar het bestuur weigerde aan de afnameverplichting te voldoen. Daarop ging Rayfield naar de rechter. Vaisley J kwalificeerde de verplichting van het bestuur als een verplichting in de hoedanigheid van een aandeelhouder, vergelijkbaar met de verplichtingen van partners in een partnership, die kon worden afgedwongen. ${ }^{167}$

Buiten de in section 16 CA 1985 genoemde categorieën, lijkt uit article 2 Table $A$ voort te vloeien dat de vennootschap bij meerderheidsbesluit verplichtingen aan aandeelhouders kan opleggen. Wordt een verplichting geïntroduceerd bij statutenwijziging, dan dient het besluit wel bona fide for the benefit of the company as a whole te zijn. ${ }^{16 \mathrm{~B}}$ In Sidebottom v. Kershaw, Leese \& Co Ltd werd een statutenwijziging, inhoudende dat het bestuur een recht tot uitstoting werd verschaft ingeval aandeelhouders concurrerende activiteiten ondernamen, bona fide geacht. ${ }^{169}$ Het recht van uitstoting correspondeert met een verplichting tot overdracht.

Niet alle overdrachtsverplichtingen kunnen echter de goedkeuring van de rechters wegdragen. Zo oordeelde Peterson $\mathrm{J}$ in Dafen Tinplate Co Ltd $v$. Llanelly Steel Co (1907) Ltd dat met de introductie van een onbeperkte algemene overdrachtsverplichting, op elk gewenst moment door de algemene vergadering bij volstrekte meerderheid te bepalen, de belangen van de vennootschap met die van de meerderheid werden verward. ${ }^{170}$ Uit de jurisprudentie lijkt te kunnen worden afgeleid dat minderheidsaandeelhouders slechts worden beschermd tegen apert onredelijke verplichtingen. In beginsel hebben zij geen instemmingsrecht.

Davies, blz. 345 .

Rayfield v. Hands [1960] Ch 1, [1958] 2 All ER 194, in Sealy, blz. 117. Zie ook \$ 5.4.2.

Allen v. Gold Reefs of West Africa Ltd [1900] 1 Ch 656 (CA), in Sealy, blz. 132. Zie ook $\$ 5.4 .1$.

Sidebottom v. Kershaw, Leese \& Co Lid [1920] 1 Ch 154 (CA), in Sealy, blz. 134.

Dafen Tinplate Co Lid v. Llanelly Steel Co (1907) Ltd [1920] 2 Ch 124, in Sealy, blz. 136. Zie over de uitstotingszaken, Davies, blz. 709 e.v.
} 


\section{$\S 5.5$ Evaluatie}

Naast de rechten en verplichtingen die op grond van de wet aan het aandeelhouderschap verbonden zijn, kunnen aandeelhouders in de statuten aanvullende rechten en verplichtingen vastleggen, zowel jegens elkaar als jegens de vennootschap. Omdat in Engeland en Duitsland de contracts- en inrichtingsvrijheid voorop staat, is aanvullend recht in Table A of in het GmbHG geen voorwaarde voor de geldigheid van statutaire bepalingen waar rechten en verplichtingen van aandeelhouders zijn vastgelegd. ${ }^{17}$ Naar Nederlands recht, waar dwingend recht regel is, geeft de wet statutaire mogelijkheden weer, inclusief een arsenaal aan sancties. Dit betekent niet dat deze wettelijke bepalingen ook noodzakelijk zijn voor de geldigheid van statutaire bepalingen. Het gaat veeleer om een verduidelijking van de uit de praktijk van de departementale richtlijnen bekende gevallen. $\mathrm{Bij}$ het zwijgen van de wet moet mijns inziens ook de contracts- en inrichtingsvrijheid van aandeelhouders de doorslag geven. Dit betekent dat aandeelhouders in beginsel vrij zijn rechten en verplichtingen in de statuten te concretiseren.

Grenzen worden aan de inhoud van de rechten en verplichtingen gesteld. Aanvullende rechten, zoals bijzondere rechten verbonden aan aandelen, mogen de dwingende wettelijke bevoegdheidsverdeling niet doorkruisen. Bovendien moeten naar Nederlands en Duits recht verplichtingen duidelijk in de statuten zijn omschreven, teneinde aandeelhouders te beschermen tegen willekeur, en om later toetredende aandeelhouders inzicht te geven in de verplichtingen waaraan zij dienen te voldoen. Naar Engels recht lijken deze overwegingen geen rol te spelen.

Voorts worden aan aanvullende rechten en verplichtingen dwingende grenzen gesteld, doordat voor het creëren van sommige rechten en verplichtingen de instemming van alle aandeelhouders is vereist. Minderheidsaandeelhouders worden op deze wijze ex ante beschermd. Hiertegenover staat dat deze wijze van bescherming verstarrend kan werken op de besluitvorming in de algemene vergadering en daarmee de ontwikkeling van de vennootschap kan belemmeren. Ex post kunnen (minderheids)aandeelhouders besluiten van de algemene vergadering laten vernietigen of verzoeken om uittreding. De afweging is voortdurend welke combinatie van bescherming de belangen het beste in evenwicht brengt. In elk rechtsstelsel worden daarin andere keuzes gemaakt. Wel is het uitgangspunt in alle rechtsstelsels dat aanvullende rechten bij statutenwijziging kunnen worden 
gecreëerd dan wel ontnomen. De besluitvorming dient wel redelijk en billijk, resp. bona fide for the benefit of the company as a whole te zijn, dan wel te voldoen aan de Treupflicht.

In Duitsland wordt minderheidsaandeelhouders ex ante bescherming geboden, allereerst doordat de Gleichbehandlungsgrundsatz vereist dat alle aandeelhouders instemmen, indien door de invoering of afschaffing van rechten of aandeelhouders in een ongelijke positie komen. Zo verhindert de Gleichbehandlungsgrundsatz dat het stemrecht op bepaalde aandelen kan worden afgeschaft zonder instemming van de betrokken aandeelhouders. Tevens belemmert het beginsel dat Sonderrechte worden gecreëerd zonder de instemming van de 'benadeelde' aandeelhouders. Zijn eenmaal Sonderrechte aan aandeelhouders toegekend, dan kunnen deze niet zonder hun instemming worden gewijzigd. Ook bij wijziging van het doel van de vennootschap is instemming van alle aandeelhouders vereist. In de statuten vervatte contractuele rechten van aandeelhouders of derden zijn evenmin voor wijziging vatbaar zonder instemming van de gerechtigde. Heeft een aandeelhouder geen instemmingsrecht, dan wordt hij gecompenseerd met een recht op uittreding.

In Engeland geldt de majority rule veel sterker. Het uitgangspunt is dat de aandeelhouder door toe te treden tot de vennootschap zich onderwerpt aan de wil van de meerderheid, en dat de meerderheid zoveel mogelijk in staat moet worden gesteld de vennootschap te ontwikkelen. De wet is gericht op de bescherming van de vennootschap tegen de verstarrende werking van veto's van halsstarrige aandeelhouders. Zo mag niet worden getornd aan de dwingende statutory powers van de vennootschap en mogen aan de aandeelhouders in beginsel extra verplichtingen worden opgelegd zonder hun instemming, tenzij het gaat om de limitatief opgesomde verplichtingen in de zin van section 16 CA 1985. Uitsluitend class rights mogen niet zonder instemming van de betreffende aandeelhouder(s) worden ontnomen. In de rechtspraak wordt het begrip class right wel ruim geïnterpreteerd, om minderheidsaandeelhouders te beschermen.

In Nederland hebben (minderheids)aandeelhouders meer dwingende rechten dan in de andere stelsels. De bescherming door het vereisen van instemming is dan ook beperkt tot prioriteitsaandelen en contractuele rechten. Het gelijkheidsbeginsel lijkt in Nederland in ieder geval geen grond voor een instemmingsvereiste van benadeelde aandeelhouders te bieden, omdat het veeleer als een verbod op willekeur wordt beschouwd in plaats van een handhaving van de gelijkheid.

Wat de verplichtingen aangaat, geldt zowel in Nederland als in Duitsland dat deze niet tegen de wil van de betrokkenen kunnen worden opgelegd, in Engeland geldt dat slechts voor enkele specifieke verplich- 
tingen. Alleen de Nederlandse wet biedt uitdrukkelijke sancties ingeval een statutaire verplichting niet wordt nagekomen; in Engeland en Duitsland zijn aandeelhouders vrij statutaire sancties te bedenken. Een bijzondere categorie vormen de verplichtingen die als sanctie voortvloeien uit het niet nakomen van opgelegde verplichtingen. Terwijl in het Duitse recht de verplichtingen ruim worden opgevat, bestaat in Nederland discussie over de reikwijdte van het begrip.

De mate waarin derden statutaire rechten kunnen afdwingen verschilt per stelsel. In het Engelse recht kunnen derden geen contractuele rechten ontlenen aan de statuten, in tegenstelling tot het Nederlandse en Duitse recht, waar contractuele rechten van derden juist dienen te worden gerespecteerd, en slechts met hun instemming kunnen worden gewijzigd. Of dit ook geldt voor zeggenschapsrechten, is niet geheel duidelijk. In Duitsland kunnen derden slechts zeggenschapsrechten uitoefenen, indien zij orgaan van de vennootschap zijn, hetgeen betekent dat zij gehouden zijn om het belang van de vennootschap te behartigen. Rechten in de zin van artikel $2: 232 \mathrm{BW}$ dienen naar mijn mening restrictief te worden geïnterpreteerd, in de zin dat deze uitsluitend contractuele rechten omvatten.

Men kan zich afvragen of het vereisen van instemming voor het ontnemen van rechten of het opleggen van verplichtingen noodzakelijk is in een besloten vennootschap. Zou de wet niet kunnen volstaan met ex post bescherming door middel van de vernietiging van een besluit of de uittreding? De gedachte is dan dat, indien aandeelhouders aanvullende bescherming wensen, zij dit dienen overeen te komen. Ik meen echter dat het instemmingsvereiste dient te prevaleren. Uitgangspunt van het aandeelhouderschap is het verschaffen van kapitaal op voorwaarde dat de aansprakelijkheid wordt beperkt. Indien de aandeelhouder deze verplichting heeft vervuld, mogen hem niet tegen zijn wil andere verplichtingen worden opgelegd. Door het vereisen van instemming hoeft de redelijkheid van de verplichting bovendien slechts in uitzonderlijke gevallen te worden getoetst. Dit neemt niet weg, dat het instemmingsvereiste uitsluitend in statutair opzicht dwingend is; aandeelhouders mogen wel overeenkomen dat hen bij meerderheidsbesluit verplichtingen worden opgelegd. ${ }^{172}$ 


\section{Hoofdstuk 6 Besluiten}

\section{$\$ 6.1$ Inleiding}

In de voorgaande hoofdstukken werd de dwingende aard van het vennootschapsrecht verkend ten opzichte van de statuten. In dit hoofdstuk staat de dwingende aard van het vennootschapsrecht ten opzichte van besluiten van de algemene vergadering van aandeelhouders centraal. Aandeelhouders geven met een besluit, genomen op de algemene vergadering van aandeelhouders, de vennootschappelijke ontwikkeling gestalte; zij besluiten tot benoeming of ontslag van bestuurders, tot vaststelling van de jaarrekening, tot statutenwijziging, tot emissie, tot ontbinding.

Een besluit van de algemene vergadering van aandeelhouders verschilt in een aantal opzichten van een aandeelhoudersovereenkomst. In de eerste plaats worden formele vereisten aan de besluitvorming gesteld, bijvoorbeeld aan de oproeping, agendering, deelname en frequentie. In de tweede plaats kan een besluit met volstrekte meerderheid van stemmen worden aangenomen. Dit houdt in, dat aandeelhouders die tegen het besluit hebben gestemd niettemin aan het besluit gebonden zijn. In de derde plaats is een besluit van de algemene vergadering niet alleen bindend voor de aandeelhouders, maar voor alle bij de vennootschap betrokkenen. Zo is het bestuur gehouden uitvoering te geven aan besluiten genomen door de algemene vergadering en gelden deze besluiten ook voor later toegetreden aandeelhouders.

De dwingende aard van het vennootschapsrecht wordt mede bepaald, doordat besluiten niet mogen afwijken van de wet en/of de statuten, op straffe van nietigheid of vernietigbaarheid. De wet en de statuten vormen het 'constitutionele kader' waarbinnen de algemene vergadering opereert. De vraag rijst of dit kader altijd passend is, en, indien deze vraag ontkennend wordt beantwoord, wat voor mogelijkheden het vennootschapsrecht de algemene vergadering van aandeelhouders biedt om buiten dit kader te treden. Te denken valt bijvoorbeeld aan het terzijdestellen van procedure- 
vereisten aan de besluitvorming indien alle aandeelhouders ermee instemmen.

In het Engelse recht worden zowel statuten als besluiten opgevat als bijzondere overeenkomsten. Gecombineerd met Zöllners paradox, dat statuten statisch geconcipieerd worden, terwijl de vennootschap zich dynamisch ontwikkelt,' kan de opvatting postvatten dat een later genomen besluit van de algemene vergadering onder omstandigheden vóór de eerder vastgelegde statuten gaat. Omgekeerd kan een besluit, hoewel in overeenstemming met de statuten, onder omstandigheden toch in strijd met beginselen van vennootschapsrecht worden geacht.

De geldigheid van besluiten die afwijken van de statuten kan op verschillende wijze worden bewerkstelligd. Allereerst kan de wet afwijkingen toelaten; wettelijke bepalingen zijn dan niet dwingend maar aanvullend van aard. Voorts kan als sanctie vernietigbaarheid in plaats van nietigheid worden gehanteerd. In dat geval is het besluit geldig, indien en zolang geen beroep op de vernietigbaarheid wordt gedaan. Een besluit kan ook geldig worden door bekrachtiging. Tenslotte kan een nietig besluit onder omstandigheden worden geconverteerd in een geldige overeenkomst. In de navolgende paragrafen wordt uitgewerkt, in hoeverre van deze mogelijkheden in de verschillende rechtsstelsels gebruikt wordt gemaakt en welke mogelijkheden het Nederlandse systeem te bieden heeft.

\section{$\S 6.2$ Nederland}

\section{$\S$ 6.2.1 Besluiten van de algemene vergadering}

Een besluit van de algemene vergadering komt tot stand, indien het met een meerderheid van de stemmen wordt genomen op een daartoe bijeengeroepen vergadering. De statuten kunnen ook bepalen dat besluitvorming van aandeelhouders op andere wijze dan in een vergadering kan geschieden (tenzij met medewerking van de vennootschap certificaten zijn uitgegeven). Een dergelijke besluitvorming dient schriftelijk plaats te vinden, met algemene stemmen van de stemgerechtigde aandeelhouders, aldus artikel 2:238 BW.

Maeijer meent dat voor de kwalificatie als besluit in elk geval een gezamenlijke wilsuiting van de betrokken aandeelhouders nodig is om het met het besluit beoogde rechtsgevolg tot stand te brengen. De wilsuiting hoeft echter niet uitdrukkelijk te geschieden, maar kan zijns inziens ook

Zie $\$ 4.1$. 
worden afgeleid uit een of meer gedragingen. ${ }^{2}$ Het Prisma-arrest biedt hiervan een voorbeeld. In deze zaak werd een arbeidsovereenkomst met een bestuurder aangemerkt als een - zij het formeel niet rechtsgeldig - besluit.

De echtgenoten Van Boxel, beiden houders van alle aandelen in Prisma Shoes NV, hebben een arbeidsovereenkomst getekend met Snoeren, die als directeur van Prisma Shoes zou functioneren. De dag voor de ondertekening van de arbeidsovereenkomst worden alle prioriteitsaandelen in Prisma Shoes overgedragen aan NV Frans van den Assum Overlederfabriek. Hoewel Snoeren op instigatie van de Overlederfabriek directeur van Prisma Shoes werd, behoorde de Overlederfabriek niet tot de ondertekenaars van de arbeidsovereenkomst. Na drie maanden ontkent Prisma Shoes het bestaan van de arbeidsovereenkomst, althans ontslaat Snoeren, waarop Snoeren betaling van zijn salaris vordert. De Hoge Raad overweegt:

"dat het hof blijkbaar de overwegingen van de rechtbank (...) in deze zin heeft begrepen, dat naar het oordeel van de rechtbank de echtgenoten Van Boxel, de houders van de gewone aandelen in Prisma, door de ondertekening van het arbeidscontract zich schriftelijk hebben uitgesproken over en voor de aanstelling van Snoeren tot directeur van Prisma en dat ook de Overlederfabriek, houdster van de prioriteitsaandelen in Prisma, door het optreden van haar directeur Frans van den Assum zich althans mondeling daarvoor heeft verklaard; dat de rechtbank daaruit de conclusie heeft getrokken, dat de aandeelhouders van Prisma aldus het besluit hebben genomen Snoeren aan te stellen tot directeur van Prisma; dat de rechtbank dit besluit formeel niet rechtsgeldig heeft genoemd, omdat het niet in een vergadering van aandeelhouders is genomen, terwijl volgens art. 43 van Prisma's statuten de aandeelhouders om buiten een vergadering een geldig besluit tot stand te brengen zich schriftelijk over het voorstel moeten uitspreken, hetgeen te dezen niet het geval is geweest nu de Overlederfabriek zich niet schriftelijk heeft uitgelaten." De termijn voor het inroepen van de nietigheid was echter verstreken, zodat het besluit toch geldig werd geacht. ${ }^{3}$

Voor de kwalificatie van een overeenkomst als schriftelijk besluit is derhalve wel vereist dat de statuten schriftelijke besluitvorming buiten vergadering mogelijk maken. ${ }^{+}$

Asser-Maeijer 2-III, nr. 260.

HR 12 november 1971, NJ 1972, 41.

Dumoulin, Besluitvorming in rechtspersonen, 1999, blz. 71, pleit voor het schrappen van het vereiste van statutaire grondslag voor schriftelijke besluitvorming. 


\section{$\S 6.2 .2$ Nietigheid als uitgangspunt}

Artikel 14 lid $1 \mathrm{BW}$ bepaalt dat een besluit van een orgaan van een rechtspersoon, dat in strijd is met de wet of de statuten, nietig is, tenzij uit de wet iets anders voortvloeit. Naar uitgangspunt is derhalve nietigheid de sanctie op met de wet en/of de statuten strijdige besluiten. Zo overwoog de Hoge Raad in het Forumbank-arrest "ook de algemene vergadering de bij wet en statuten getrokken grenzen harer bevoegdheid niet mag overschrijden". $\mathrm{Al}$ eerder had de Hoge Raad gewag gemaakt van het aan de wet ten grondslag liggende stelsel van volstrekte nietigheid van met de statuten strijdige besluiten van de algemene vergadering, waarop slechts de wet uitzonderingen toelaat.

Een bestuurder van NV Nederlandsche Fabriek en Handelmaatschappij (voorheen: Van Gulpen en Swerts) had privé-schulden bij Eugen Mehler. Ter voldoening daarvan vestigde hij een hypotheek op onroerende zaken die toebehoorden aan de vennootschap, ten behoeve van Eugen Mehler. Aan de hypotheekakte was een uittreksel van de notulen van de algemene vergadering gehecht, inhoudende dat het gehele geplaatste kapitaal was vertegenwoordigd en dat het voorstel tot verlening van de voormelde hypotheek met algemene stemmen was aangenomen. Het hof achtte de hypotheekverlening in strijd met het statutaire doel. Niettemin behoefde dit naar 's hofs mening niet tot nietigverklaring te leiden, nu 1) de algemene vergadering het besluit had genomen met algemene stemmen; 2) niet is uitgesloten dat de aandeelhouders meenden het belang van de vennootschap te dienen; 3) niet gebleken is, dat het besluit de belangen van de vennootschap, haar schuldeisers of anderen schendt; 4) het besluit niet in strijd is met de openbare orde of de goede zeden. De Hoge Raad oordeelde echter anders:

"dat toch de akte van oprichting eener naamlooze vennootschap (...) regelen stelt, die - behoudens wijziging met inachtneming van wat daaromtrent geldt - rechtens onaantastbaar zijn voor elk orgaan van de NV, dus ook voor de algemeene vergadering van aandeelhouders."

"dat de wet geen grond oplevert om aan te nemen, dat een besluit der algemeene vergadering de kracht der statuten wèl vermag te breken, indien het is genomen met de stemmen van alle aandeelhouders, integendeel, de geschiedenis der wet daartegen spreekt."

"dat dus ook blijkens de geschiedenis der wet haar bijzondere bepalingen, waarin de mogelijkheid van afwijking van zekere voorschriften van wet of statuten wordt erkend, mits zulks geschiedt met medewerking van alle aandeelhouders, slechts

HR 21 januari 1955, NJ 1959, 43. Een soortgelijke casus deed zich voor in Hof 's Hertogenbosch 16 juni 1993, NJ 1994, 249, waar aandeelhouders ten laste van de vennootschap onkostenvergoedingen aan zichzelf hadden toegekend. 
zijn te beschouwen als uitzondering op het aan de wet ten grondslag liggende stelsel van volstrekte nietigheid van met de statuten strijdige besluiten van de algemeene vergadering van aandeelhouders". 6

Dit door de Hoge Raad in 1938 geformuleerde uitgangspunt is nog steeds te herkennen in artikel $2: 14$ jo. $2: 25 \mathrm{BW}$.

Uitzonderingen op deze nietigheid als uitgangspunt dienen voort te vloeien uit de wet, aldus artikel 2:14 lid 1 BW. Niet geheel duidelijk is wat hiermee precies wordt bedoeld. In de memorie van toelichting wordt volstaan met het geven van voorbeelden waarin de wet in een speciale rechtsgang voorziet, zoals de procedure van artikel 999 Rv. e.v. en de beroepsprocedure op grond van artikel 26 WOR.?

Een belangrijke uitzondering wordt aangetroffen in artikel 15 lid 1 $\mathrm{BW}$ : een besluit van de algemene vergadering is vernietigbaar wegens strijd met wettelijke of statutaire bepalingen die het tot stand komen van besluiten regelen, strijd met de redelijkheid en billijkheid of strijd met een reglement. In tegenstelling tot een nietig besluit, moet de vernietigbaarheid van een besluit door een rechter worden vastgesteld en is het inroepen ervan aan een termijn gebonden. De vernietiging behoort tot de exclusieve competentie van de overheidsrechter en kan niet geschieden door een buitengerechtelijke verklaring. ${ }^{\text {. }}$

\section{\$6.2.3 Uitzondering op de nietigheid: besluiten in afwijking van procedurevoorschriften}

De wet bepaalt op een aantal plaatsen zelf dat procedurevoorschriften inzake de besluitvorming in de algemene vergadering terzijde kunnen worden gesteld. Proceduregebreken met betrekking tot de oproeping, de agenda en de terinzagelegging van besluiten kunnen worden geheeld door de algemene instemming van alle aandeelhouders op basis van artt. 2:208 lid 5, 224 lid 2, 225 en 233 lid 2 BW. De statuten kunnen zelfs bepalen dat geheel wordt afgezien van besluitvorming in de algemene vergadering, mits de besluitvorming schriftelijk plaatsvindt met algemene stemmen, aldus art.

HR 8 april 1938, NJ 1938, 1076 (Eugen Mehler). Dezelfde overwegingen bewerkstelligden in HR 16 juni 1944, NJ 19944/45, 443 (Keymel/Merito) de nietigheid van het ontslagbesluit. Keymel vorderde nietigverklaring van het besluit van de algemene vergadering dat leidde tot zijn ontslag als directeur. Weliswaar had de algemene vergadering met algemene stemmen Keymel ontslagen, maar de statutair vereiste oproepingsvoorschriften waren niet in acht genomen, terwijl niet alle aandeelhouders aanwezig waren. Tegenwoordig zou dit besluit vernietigbaar zijn.

Memorie van Toelichting, blz. 59.

Asser-Van der Grinten-Maeijer 2-II, nr. 145. Zie ook \$3.2.4. 
2:238 BW. Deze bepalingen zijn derhalve aanvullend van aard, met de dwingende voorwaarde dat alle aandeelhouders instemmen. ${ }^{9}$

Achterliggende gedachte van het terzijde stellen van procedurevoorschriften met betrekking tot de besluitvorming in de algemene vergadering is dat deze er toe dienen om aandeelhouders in staat te stellen voldoende geïnformeerd deel te nemen aan de vergadering en hun stem uit te brengen. De instemming van alle aandeelhouders maakt de manier waarop het besluit is totstandgekomen irrelevant. In zekere zin zou de instemming kunnen worden beschouwd als een door de wet gesanctioneerde vorm van rechtsverwerking van een beroep op een proceduregebrek.

Indien niet alle aandeelhouders hebben ingestemd, is een besluit vernietigbaar op grond van artikel 2:15 lid $1 \mathrm{BW}$, voor zover het is genomen in strijd met wettelijke of statutaire bepalingen die het tot stand komen van besluiten regelen. Is bijvoorbeeld een quorumeis niet nageleefd, dan kan iedere belanghebbende het betreffende besluit aanvechten. Het ontbreken van een notariële akte van een besluit tot statutenwijziging leidt evenwel tot de nietigheid van het besluit, zo bepaalt artikel 2:234 lid 1 BW. Een vernietigbaar besluit kan definitieve geldigheid verkrijgen, doordat het wordt bevestigd. Vereist is dan een daartoe strekkend besluit, dat wel aan de vereisten voldoet, conform lid 6 van artikel 2:15 BW.

\section{\$ 6.2.4 Uitzondering op de nietigheid: wettelijke doorbreking van statutaire bepalingen}

Andere wettelijke uitzonderingen op de nietigheid van met de statuten strijdige besluiten worden aangetroffen in de artt. 2:242 lid 2, 2:243 en $2: 252 \mathrm{BW}$. Indien de statuten voor de benoeming van bestuurders een bindende voordracht voorschrijven of eisen stellen aan te benoemen bestuurders en/of commissarissen, kan de algemene vergadering deze steeds doorbreken met een twee derde meerderheid van de stemmen, die meer dan de helft van het geplaatste kapitaal vertegenwoordigen. Een bijzonder voorbeeld is voorts artikel 2:231 lid $3 \mathrm{BW}$ : zelfs als de statuten wijziging hebben uitgesloten, is wijziging van de statuten niettemin mogelijk met algemene stemmen op een vergadering waar het gehele geplaatste kapitaal is vertegenwoordigd.

Tot september 2001 had alleen de doorbreking van de bindende voordracht voor de benoeming van bestuurders een uitdrukkelijke wettelijke basis. Dat statutaire kwaliteitseisen voor bestuurders eveneens met een

Zie $\$ 2.2 .2$ 
twee derde meerderheid kunnen worden doorbroken, is bepaald in het Van Rees-arrest. De Hoge Raad achtte in casu een besluit tot benoeming van een bestuurder, die niet voldeed aan de statutaire kwaliteitseisen, niettemin rechtsgeldig.

Er was sprake van een conflict tussen twee groepen aandeelhouders in de familievennootschap NV Scheepsbouwwerf (voorheen: C.M. van Rees). De weduwe van Marinus van Rees, één van beide oprichters, vocht het besluit tot benoeming van Van der Weele als bestuurder van de NV Scheepsbouwwerf aan, onder meer op de grond dat hij niet in het bezit was van de 15 statutair vereiste aandelen in de NV. Zij zag liever dat haar eigen zoon bestuurder werd, over wiens geschiktheid gerede twijfel bestond. De Hoge Raad overweegt:

dat de vraag hoe ver een beperking van de vrijheid van de algemene vergadering tot de benoeming van een bestuurder door middel van statutaire vereisten kan gaan "zonder in strijd te komen met het wettelijk stelsel volgens het welk in beginsel de keuze van bestuurders aan de algemene vergadering toekomt, voor een algemene beantwoording niet vatbaar is."

"dat zich hier echter blijkens de vaststellingen van het hof het geval voordoet, dat an het statutaire vereiste met betrekking tot het aandelenbezit van de te benoemen bestuurder niet kon worden voldaan alléén ten gevolge van feit dat een minderheid van de aandeelhouders met gebruikmaking van een blokkeringsbepaling in de statuten de overdracht van aandelen aan de te benoemen bestuurder kon beletten en in feite heeft belet; dat onder die omstandigheden (...) met het wettelijk stelsel van benoeming van bestuurders door de algemene vergadering van aandeelhouders in ieder geval als onverenigbaar moet worden beschouwd, dat een zodanig statutair vereiste voor de benoembaarheid van een bestuurder een benoeming zou kunnen beletten, waarvoor de algemene vergadering zich met twee derde van de uitgebrachte stemmen, vertegenwoordigende meer dan de helft van het geplaatste kapitaal, heeft uitgesproken." 10

Het statutaire vereiste van vijftien aandelen staat derhalve niet in de weg aan de rechtsgeldigheid van de benoeming van Van der Weele.

Hoewel de Hoge Raad de nadruk legde op de specifieke omstandigheden van het geval, vindt de doorbreking van statutair gestelde kwaliteitseisen thans in algemene zin haar wettelijke grondslag in artikel 2:242 lid 2 BW. De wetgever laat de keuzevrijheid van de algemene vergadering prevaleren boven aanvullende statutaire eisen. Dat er door de benoeming van bestuurders of commissarissen die niet voldoen aan de statutaire eisen een van de statuten afwijkende situatie ontstaat, wordt kennelijk van ondergeschikt

HR 19 maart 1976, NJ 1978, 52. 
belang geacht ten opzichte van de keuzevrijheid van de aandeelhoudersvergadering.

\section{$\S 6.2 .5$ Uitbreiding van de vernietigbaarheid als sanctie?}

Bovenstaande voorbeelden geven een nadere invulling van de uitzondering op de nietigheid van een besluit in strijd met de wet of de statuten op basis van het criterium van artikel 2:14 lid 1 BW "tenzij uit de wet anders voortvloeit." Steeds gaat het om wettelijke bepalingen, die uitdrukkelijk in een andere sanctie dan nietigheid voorzien. De vraag rijst of een andere sanctie ook impliciet uit de wet kan voortvloeien.

Het centrale kenmerk van het nietigheidsleerstuk is volgens Hijma dat partijbelangen slechts kunnen worden gehonoreerd voor zover zij met het algemeen belang niet strijden." Hijma onderscheidt het belang van wetshandhaving en ongeschreven maatschappelijke belangen, verdisconteerd in de openbare orde en goede zeden. ${ }^{12} \mathrm{Zijn}$ uitgangspunt is dat de nietigheid niet verder ingrijpt dan door de ratio van de betrokken regel wordt geëist." Hieruit vloeit voort dat steeds dient te worden onderzocht in hoeverre de aan de rechtshandeling toegekende rechtsgevolgen achterwege dienen te

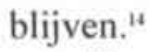

Hoewel wet en statuten in artikel 2:14 lid $1 \mathrm{BW}$ op één lijn worden gesteld, is nietigheid als sanctie op een besluit in strijd met de statuten mijns inziens lang niet altijd wenselijk. Nietigheid is geboden, voor zover de bepalingen derden beogen te beschermen, zoals crediteuren of toekomstige aandeelhouders. Ook de vennootschap zelf kan in dit geval als beschermenswaardige derde worden beschouwd. Indien de statuten echter aanvullende bepalingen bevatten over rechten en verplichtingen tussen aandeelhouders onderling, raken deze bepalingen uitsluitend de belangen van aandeelhouders. In dergelijke gevallen moet naar mijn mening aansluiting worden gezocht bij artikel 3:40 lid $2 \mathrm{BW}$, dat bepaalt:

"Strijd met een dwingende wetsbepaling leidt tot nietigheid van de rechtshandeling, doch, indien de bepaling uitsluitend strekt ter bescherming van één der partijen bij een meerzijdige rechtshandeling, slechts tot vernietigbaarheid, een en ander voor zover niet uit de strekking van de bepaling anders volgt."

Hijma, Nietigheid en vernietigbaarheid van rechtshandelingen, 1988, blz. 109

Hijma, 1988, blz 52 .

Hijma, 1988, blz. 74

Vgl. Hijma, 1988, blz. 77 . 
Indien de dwingende wetsbepaling de strekking heeft de geldigheid van de rechtshandeling aan te tasten, is de rechtshandeling vernietigbaar, voor zover de bepaling uitsluitend strekt tot bescherming van één partij. Deze bepaling heeft ook op andere rechtsterreinen ingang gevonden. Zo werd in het arbeidsrecht een met een verdrag strijdige arbeidsvoorwaarde toch slechts vernietigbaar geacht, omdat deze verdragsbepaling uitsluitend strekt ter bescherming van werknemers.

Een aantal scheepswerven in Harlingen bood alle werknemers een winstuitkeringsregeling, die slechts zou worden uitbetaald indien in het betreffende jaar niet was gestaakt. Hierop vorderden de vakbonden dat de werkgevers tot betaling van de winstuitkering werden veroordeeld, alsmede een verklaring voor recht dat de koppeling van de niet-stakingsvoorwaarde aan de winstuitkering niet geoorloofd was. De Hoge Raad overweegt:

"Voor de beantwoording van de vraag of een beding waaraan een ongeoorloofde voorwaarde is verbonden geldig dan wel nietig is, moet dat beding met inachtneming van artikel 3:40 BW in zijn geheel worden beoordeeld. In aanmerking genomen dat het ongeoorloofde karakter van de voorwaarde berust op strijd met een verdragsbepaling die strekt ter bescherming van de werknemers, moet worden aangenomen, en heeft klaarblijkelijk ook de Rechtbank aangenomen, dat hier overeenkomstig de gedachte die tot uitdrukking komt in artikel 3:40 lid 2, sprake is van vernietigbaarheid uitsluitend ingevolge een beroep van de werknemers en dat, wanneer van de zijde van de werknemers op deze grond voor vernietiging een beroep wordt gedaan ingeval een staking heeft plaatsgevonden, zulks niet tot het ongerijmde gevolg kan leiden dat, evenals wanneer de voorwaarde wél als geoorloofd zou zijn aangemerkt, geen uitkering verschuldigd is."15

De achter artikel 3:40 lid 2 BW schuilende beschermingsgedachte lijkt te zijn dat de 'sterke partij', die bij machte is de voorwaarden aan de zwakkere partij op te leggen, zich niet vervolgens mag beroepen op de nietigheid. De wijze waarop dit wordt bewerkstelligd is de nietigheid te transformeren in vernietigbaarheid.

Ik meen dat artikel 3:40 lid 2 BW zich voor analogische toepassing leent op met de statuten strijdige besluiten, die uitsluitend de belangen van aandeelhouders raken. Op grond van artikel 3:59 is artikel 3:40 BW ook van toepassing buiten het vermogensrecht, voor zover de aard van de rechtshandeling of van de rechtsbetrekking zich daar niet tegen verzet.

HR 24 september 1999, NJ 1999, 737. 
Besluiten van rechtspersonen worden dan ook, buiten artt. 2:14 en 15 BW, reeds getoetst aan artikel 3:40 lid $1 \mathrm{BW} .{ }^{16}$

In een persoonsgebonden $\mathrm{BV}$ zal een besluit eerder dan in een open $\mathrm{NV}$ uitsluitend de belangen van aandeelhouders raken. Niet alleen zijn er in een persoonsgebonden vennootschap veelal geen externe bestuurders, maar ook zullen de statuten vaker aanvullende rechten en verplichtingen voor aandeelhouders bevatten. In feite gaat het om een ontheffing van statutaire eisen of verplichtingen, zonder dat deze mogelijkheid in de statuten is vermeld. Dit is met name van belang voor de aandeelhouders. Een voorbeeld biedt de situatie dat de statuten bepalen dat iedere aandeelhouder partij dient te zijn bij een aandeelhoudersovereenkomst, en dat de statuten voor overdracht van aandelen buiten de vrije kring goedkeuring van de algemene vergadering vereisen. Wanneer de algemene vergadering vervolgens een overdracht goedkeurt aan een aandeelhouder die niet aan de statutair gestelde eisen voldoet, acht ik nietigheid niet de meest passende sanctie. De aandeelhouder die tegen het besluit heeft gestemd wordt afdoende beschermd doordat hij vernietiging van het besluit kan vorderen.

\section{Rechtsverwerking door instemming}

Op grond van artikel 2:15 BW kan eenieder met een redelijk belang de vernietiging van een besluit vorderen. Een belanghebbende is allereerst de aandeelhouder. Deze kan echter niet zonder meer een vordering tot vernietiging instellen; hij moet daartoe steeds stellen en bewijzen dat hij in een eigen belang is of dreigt te worden geschaad. ${ }^{17}$ Uit de jurisprudentie blijkt voorts dat onder omstandigheden ook werknemers belanghebbende kunnen zijn in de zin van artikel 2:15 BW." Als andere mogelijke belanghebbenden worden crediteuren en de ondernemingsraad genoemd. ${ }^{19}$

Een vernietigbaar besluit kan naar mijn mening onaantastbaarheid verkrijgen, indien alle aandeelhouders met het besluit hebben ingestemd en er in casu geen andere redelijk belanghebbenden zijn. De afwezigheid van andere belanghebbenden doet zich voor, wanneer het besluit uitsluitend de belangen van aandeelhouders zelf raakt, bijvoorbeeld indien eenmalig de blokkeringsregeling buiten werking wordt gesteld. Consequentie van deze

\footnotetext{
16. Een besluit tot belastingontduiking wordt in strijd met de openbare orde en de goede zeden geacht, vgl. HR 8 juli 1991, NJ 1991, 765.

17. HR 31 mei 1996, NJ 1996, 694 (Lampe/Videoworks).

is Hof 's Hertogenbosch 8 april 1992, NJ 1992, 701 (kort geding). Vgl. ook Van Schilfgaarde, nr. 84.

19. Asser-Van der Grinten-Maeijer 2-II, nr. 136.
} 
redenering is dat besluiten in strijd met statutaire bepalingen niettemin geldig zijn indien alle aandeelhouders instemmen.

Hierbij wordt uitgegaan van de veronderstelling dat aandeelhouders die hebben ingestemd met een bepaald besluit, niet alsnog vernietiging ervan kunnen vorderen..$^{20}$ Maeijer acht dit in strijd met de redelijkheid en billijkheid. ${ }^{21}$ Door in te stemmen hebben aandeelhouders naar mijn mening hun recht om vernietiging te vorderen verwerkt. Een enigszins vergelijkbare redenering voor een vordering uit onrechtmatige daad wordt door de Hoge Raad in het arrest Van Andel/Chipshol niet ongegrond geacht.

Chipshol trachtte via de rechter de benoeming van Van Andel als gedelegeerd commissaris van Landinvest ongedaan te maken. Van Andel stelde dat Chipshol het recht heeft verwerkt bezwaar te maken tegen diens benoeming, omdat Chipshol niet op de oproep voor de vergadering van aandeelhouders heeft gereageerd met de mededeling dat Van Andel niet aanvaardbaar was als gedelegeerd commissaris, noch dit in de vergadering van aandeelhouders heeft aangevoerd, terwijl er correspondentie is gevoerd met Van Andel in zijn hoedanigheid van gedelegeerd commissaris. De Hoge Raad overweegt:

"Van deze stelling kan [...] niet reeds aanstonds worden gezegd dat zij ongegrond is. Daarbij is mede van belang dat van een aandeelhouder die zich op grond van onrechtmatige daad tegen een volgens wet en statuten rechtsgeldig tot stand gekomen benoemingsbesluit van de algemene vergadering van aandeelhouders wil verzetten, mag worden verwacht dat hij zijn bezwaren daartegen en zijn voornemen tot het daarop te gronden verzet onverwijld duidelijk maakt."2z

Winter leidt uit de uitspraak af dat niet steeds van rechtsverwerking sprake hoeft te zijn en raadt aan aanvullende bepalingen in de overeenkomst op te nemen omtrent het maken van bezwaren, teneinde de onzekerheid op dit punt weg te nemen. ${ }^{2}$ De instemming kan eventueel worden opgevat als een bevestiging in de zin van artikel 3:55 BW..4

\section{Positie later toetredende aandeelhouders}

De vraag is of besluiten die afwijken van aanvullende statutaire bepalingen de belangen van later toetredende aandeelhouders raken. Deze gaan af op

\footnotetext{
Vgl. Sanders/Westbroek, blz. 248.

Asser-Van der Grinten-Maeijer 2-II, nr. 136.

HR 29 november 1996, NJ 1997, 345. Winter, TVVS 1997, blz. 85, meent dat deze rechtsregel ook geldt indien het verzet niet op onrechtmatige daad wordt gebaseerd, maar rechtstreeks op de aandeelhoudersovereenkomst. Vgl. ook Rb. Utrecht, 21 maart 2001, JOR 2002, nr. 48.

Winter, TVVS 1997, blz. 85.

Anders Asser-Van der Grinten-Maeijer 2-II, nr. 148. Zie ook $\$ 3.2 .2$.
} 
de statuten zoals zij deze aantreffen, en worden geacht bij toetreding deze statuten te hebben aanvaard. Daarom is het van belang dat de statuten de bestaande praktijk van de vennootschap zoveel mogelijk reflecteren.

Wanneer aandelen vrij overdraagbaar zijn, moeten toekomstige aandeelhouders kunnen afgaan op de statuten van de vennootschap, die objectief worden uitgelegd. In persoonsgebonden vennootschappen ligt dat anders. Er vindt dan bijna steeds overleg plaats tussen koper en verkoper alvorens tot de koop van de aandelen wordt overgegaan, waarbij de vennootschappelijke verhoudingen nadrukkelijk aan de orde zullen komen. Dit betekent dat een koper in de meeste gevallen op de hoogte zal zijn van de vennootschappelijke verhoudingen, zoals die zijn weergegeven in statuten, besluiten en aandeelhoudersovereenkomsten. Aangezien wisselingen in het aandeelhoudersbestand in persoonsgebonden vennootschappen niet vaak zullen voorkomen, is de vraag of een besluit de belangen van toekomstige aandeelhouders raakt, voornamelijk theoretisch. De geschillen naar aanleiding van een besluit zullen zich vaak afspelen tussen bestaande aandeelhouders. Dit neemt niet weg, dat een besluit dat nietig wordt geacht vanwege de repercussies voor later toetredende aandeelhouders, in aanmerking komt voor conversie in een aandeelhoudersovereenkomst, ${ }^{25}$ met vennootschappelijke werking, ${ }^{26}$ zodat hetzelfde resultaat kan worden bewerkstelligd als een rechtsgeldig besluit.

\section{§ 6.2.6 Bekrachtiging}

Ondanks de hierboven genoemde uitzonderingen wordt een besluit dat afwijkt van wettelijke of statutaire bepalingen in beginsel nietig geacht. Dit hoeft echter niet te betekenen dat het besluit nooit meer geldigheid kan verkrijgen. Op verschillende wijzen kan een nietig besluit door bekrachtiging met terugwerkende kracht alsnog geldig worden.

\section{Bekrachtiging op grond van artikel 2:14 lid $2 \mathrm{BW}$}

Bevoegdheidsgebreken in de besluitvorming kunnen worden geheeld door bekrachtiging. Nietige besluiten kunnen worden bekrachtigd door degene, aan wiens bevoegdheid tot het verrichten van een voorafgaande handeling of mededeling is voorbij gegaan, aldus artikel 2:14 lid 2 BW. Door de bekrachtiging wordt met terugwerkende kracht geldigheid verleend aan een besluit. Als 'voorafgaande handeling' wordt bijvoorbeeld een bindende 
voordracht of een voorstel tot statutenwijziging aangemerkt. Indien voor een besluit wettelijk of statutair de goedkeuring van een orgaan of derde is vereist, komt dit besluit slechts voor bekrachtiging in aanmerking, indien de goedkeuring als een aan het besluit voorafgaande handeling wordt gekwalificeerd, als een soort machtiging. Indien de goedkeuring naderhand dient te worden verleend, zoals de goedkeuring van bepaalde bestuursbesluiten, is er geen sprake van bekrachtiging, omdat het besluit (nog) niet nietig is.

Een ander voorbeeld van een voorafgaande handeling deed zich voor in het arrest VBNA/Helms, waar de statuten een delegatiebesluit van het bestuur vereisten, voordat het dagelijks bestuur bevoegd werd om bindende besluiten te nemen. ${ }^{27}$

Helms was aangesloten bij de Vereeniging ter Behartiging van den Nederlandschen Aardappelhandel (VBNA). De statuten bepaalden dat het bestuur bepaalde bevoegdheden kon overdragen aan het dagelijks bestuur, waaronder het nemen van bindende besluiten. Zonder dat het bestuur een delegatiebesluit had genomen, besloot het dagelijks bestuur dat degene die na 1 januari 1941 lid van de NSB of vergelijkbare organisaties was geweest, of zich tijdens de bezetting had misdragen, geen aangeslotene kon zijn. Eerst na dit zuiveringsbesluit nam het bestuur conform de statuten een delegatiebesluit. Vervolgens had het dagelijks bestuur Helms ontslagen als aangeslotene wegens zijn lidmaatschap van de NSB. Helms stelde dat beide besluiten van het dagelijks bestuur nietig waren, omdat het dagelijks bestuur hiertoe niet bevoegd zou zijn. De Hoge Raad oordeelde echter dat:

"deze nietigheid niettemin wordt geheeld, indien het eerstgenoemde orgaan (het bestuur, MM) door bekrachtiging achteraf van het onbevoegdelijk genomen besluit te kennen heeft gegeven, dat het bij de - weliswaar voorbarige, doch volgens de statuten in beginsel mogelijke - uitoefening van dat deel zijner taak dat het andere orgaan (het dagelijks bestuur, MM) de daarbij betrokken belangen van vereniging en leden voldoende gewaarborgd heeft geacht." ${ }^{\prime 2 s}$

Het naderhand genomen delegatiebesluit wordt kennelijk opgevat als een 'voorafgaande handeling', die tot bekrachtiging van het besluit leidt. 


\section{Bekrachtiging op grond van artikel 3:58 BW}

Een aantal auteurs neemt aan dat, naast artikel 2:14 lid 2 BW, ook bekrachtiging volgens artikel 3:58 BW via de schakelbepaling van artikel 3:59 BW in het vennootschapsrecht mogelijk is. ${ }^{29}$ Artikel 3:58 lid 1 BW luidt:

"Wanneer eerst na het verrichten van een rechtshandeling een voor haar geldigheid gesteld wettelijk vereiste wordt vervuld, maar alle onmiddellijk belanghebbenden die zich op dit gebrek hadden kunnen beroepen, in de tussen de handeling en de vervulling van het vereiste liggende tijdsruimte de handeling als geldig hebben aangemerkt, is daarmede de rechtshandeling bekrachtigd."

Voor de toepassing van 3:58 BW is dus noodzakelijk dat een wettelijk gesteld vereiste voor de geldigheid van een rechtshandeling alsnog wordt vervuld. Een voorbeeld hiervan is een besluit dat buiten vergadering is genomen, maar later pas schriftelijk wordt vastgelegd. In de hierboven vermelde zaak VBNA/Helms kan het delegatiebesluit worden opgevat als een statutair gesteld vereiste voor de geldigheid van het besluit. Aangenomen moet worden dat ook in dat geval sprake is van bekrachtiging.

Deze situatie moet worden onderscheiden van het geval dat sprake is van een herhalingshandeling door het wél bevoegde orgaan. Wanneer de rechtshandeling gelijk staat aan het wettelijk gesteld vereiste, is er geen sprake van de vervulling van een vereiste, maar van een herhalingshandeling. ${ }^{30}$ Wordt bijvoorbeeld een bestuurder benoemd door de raad van commissarissen in plaats van door de bevoegde algemene vergadering, dan wordt het besluit van de raad van commissarissen niet bekrachtigd door een benoemingsbesluit van de algemene vergadering, maar vormt dit laatste besluit een nieuw besluit, op basis waarvan de bestuurder wordt benoemd. Het door de raad van commissarissen genomen besluit blijft nietig.

Het hof 's Hertogenbosch lijkt in zijn uitspraak van 18 juni 1990 uit te gaan van een andere benadering. In casu werd een bestuurder ontslagen door de raad van commissarissen, zoals bepaald in zijn aanstellingsovereenkomst, in plaats van door de statutair bevoegde algemene vergadering van aandeelhouders. Aangezien de commissarissen ook aandeelhouders waren, proberen zij om de vergadering van de raad van commissarissen voor een algemene vergadering van aandeelhouders te laten doorgaan, daar

\footnotetext{
29 Vgl. Timmerman, RM Themis 1992, blz. 156. De Kluiver, Bekrachtiging van rechtshandelingen en besluiten, in: Vertegenwoordiging en tussenpersonen, 1999, blz, 82. Zo ook Van Schilfgaarde. nr. 94. Asser-Van der Grinten-Maeijer, 2-II, nr. 129a.

Vgl. Hijma, diss. blz. 364
} 
de commissarissen tevens aandeelhouders waren. Het hof wees deze constructie af, maar overwoog wel:

"Het bevoegde vennootschappelijke orgaan kan een door een ander orgaan van de vennootschap onbevoeglijk genomen besluit bekrachtigen. Dit kan betekenen dat de vennootschap zich niet meer op die onbevoegdheid tegenover een derde kan beroepen." 1

Volgens Van Schilfgaarde komt een besluit genomen door een onbevoegd orgaan echter niet in aanmerking voor bekrachtiging, wegens de strikte scheiding van de bevoegdheden van organen in het wettelijk systeem en de daaraan gekoppelde verantwoordelijkheden. ${ }^{32}$ Maeijer ziet het belang van de nietigheid in dit soort gevallen gelegen in de zekerheid die de direct bij de rechtspersoon betrokkenen moeten hebben omtrent het ordelijk naleven van de bepalingen betreffende de bevoegdheidsverdeling in de rechtspersoon. ${ }^{33}$ Van den Ingh hanteert daarentegen als leidende gedachte, dat nietigheden die zijn veroorzaakt door aantasting van een bevoegdheid zoveel mogelijk hersteld moeten kunnen worden. Hij pleit voor analogische toepassing van artikel 2:14 lid $2 \mathrm{BW}$ op deze categorie besluiten. ${ }^{34}$ Maeijer wijst op de consequentie dat betrokkenen toch gedwongen worden actie te ondernemen om zekerheid te verkrijgen over een bekrachtiging, op de voet van artikel 2:14 lid $3 \mathrm{BW} \cdot{ }^{35}$ In dat geval moet het bevoegde orgaan binnen een redelijke termijn een besluit nemen over het wel of niet bekrachtigen.

Ik zou willen aannemen dat artikel 2:14 lid 2 BW een specifieke invulling geeft aan artikel 3:58 BW. ${ }^{36}$ Weliswaar is artikel 14 lid 2 BW ruimer, daar het niet als vereiste stelt dat alle onmiddellijk belanghebbenden de rechtshandeling als geldig moeten hebben aangemerkt en het ook ziet op statutair gestelde vereisten, maar het is ook beperkter, omdat uitsluitend een voorafgaande handeling of mededeling worden genoemd als gebreken die vatbaar zijn voor bekrachtiging. Het ligt mijns inziens niet voor de hand om de toepassing van artikel 2:14 lid 2 BW uit te breiden tot categorieën besluiten die de wettelijke bevoegdheidsverdeling schenden, zoals Van den

31 Hof 's Hertogenbosch, 18 juni 1990, NJ 1991, 32 (Tapper/Gartner). Het hof vervolgde: "Een dergelijke bekrachtiging kan echter bij een externe rechtshandeling waarvan de derde belanghebbende inmiddels de rechtskracht heeft betwist, niet ten nadele van die derde terugwerken."

Van Schilfgaarde, nr. 94.

Maeijer, in: Maeijers belangstellingen, serie Monografieèn vanwege het Van der Heijden Instituut deel 57, 1997, blz. 112.

Van den Ingh, Bekrachtiging van onbevoegd genomen besluiten, in: Maeijers belangstellingen, 1997, blz. 6.

Maeijer, Maeijers Belangstellingen, blz. 113.

Vgl. De Kluiver, 1999, blz. 87. 
Ingh bepleit, die zelfs niet door artikel 3:58 BW worden gedekt, aangezien het gaat om een herhalingshandeling. Besluiten genomen door onbevoegde organen zijn als herhalingshandeling naar mijn mening niet vatbaar voor bekrachtiging.

\section{Bekrachtiging door statutenwijziging?}

Een variant op het voorgaande betreft de vraag of een nietig besluit kan worden bekrachtigd door een statutenwijziging, die alsnog de belemmering voor de geldigheid wegneemt. Timmerman meent dat op deze wijze bijvoorbeeld een besluit tot uitgifte van aandelen, waarbij het maatschappelijk kapitaal wordt overschreden, zich leent voor bekrachtiging op de voet van artikel 3:58 BW. Door alsnog het maatschappelijk kapitaal te verhogen, wordt achteraf voldaan aan het wettelijk gestelde vereiste. ${ }^{37}$ Van Schilfgaarde acht eveneens voor bekrachtiging vatbaar een besluit dat het doel van de vennootschap overschrijdt, door wijziging van de doelomschrijving. ${ }^{38}$ De Kluiver noemt als voorbeeld de bekrachtiging van een overdracht van aandelen door een goedkeuringsbesluit overeenkomstig artikel 2:195 lid 3 BW. De overdracht zou zijns inziens ook kunnen worden bekrachtigd door een statutenwijziging, waardoor de goedkeuring niet langer is vereist, bijvoorbeeld door uitbreiding van de vrije kring. ${ }^{39}$ In dit laatste voorbeeld wordt echter geen nietig besluit bekrachtigd, maar een nietige overdracht.

Kan een statutenwijziging de bekrachtiging van een onbevoegd genomen besluit bewerkstelligen? Stel dat het dagelijks bestuur uit de casus VBNA/Helms door een statutenwijziging alsnog bevoegd zou worden gemaakt tot het nemen van bindende besluiten, in plaats van door een delegatiebesluit. Een ander voorbeeld is een emissiebesluit door het bestuur, dat pas later door een statutenwijziging tot uitgifte bevoegd wordt. Worden dergelijke onbevoegd genomen besluiten door deze statutenwijziging bekrachtigd?

Van den Ingh acht bekrachtiging door middel van een statutenwijziging die een onbevoegd orgaan bevoegd maakt, niet mogelijk, omdat dan achteraf de spelregels zouden worden veranderd. ${ }^{\text {to }}$ De Kluiver meent daar-

37 Timmerman, RM Themis 1992, blz. 156. Anders hof Amsterdam 20 mei 1986, NJ 1987, 733, dat het besluit tot uitgifte van meer aandelen dan de omvang van het maatschappelijk kapitaal toeliet, nietig verklaarde. Het sloeg geen acht op het feit dat bij een latere statutenwijziging het maatschappelijk kapitaal alsnog werd verhoogd.

38 Van Schilfgaarde, nr. 58, die artikel 3:58 BW in een dergelijk geval - vernietigbaarheid analogisch toepasbaar acht. Andere voorbeelden in nr. 59.

De Kluiver, 1999, blz. 82.

Van den Ingh, in: Maeijers belangstellingen, 1997, blz. 6. 
entegen dat, indien wijziging van de wet tot bekrachtiging kan leiden, dit ook voor statutenwijziging geldt. Voorwaarde is wel steeds dat alle onmiddellijk belanghebbenden het besluit als geldig hebben aangemerkt. ${ }^{.1}$ Dit zou in de zaak VBNA/Helms overigens bekrachtiging in de zin van artikel 3:58 BW hebben verhinderd, omdat Helms het besluit van aanvang af niet geldig achtte. Naar mijn mening kan een statutenwijziging bekrachtiging van een onbevoegd genomen besluit met zich meebrengen in de zin artikel 3:58 BW. Juist het vereiste dat alle onmiddellijk betrokkenen het besluit als geldig hebben aangemerkt biedt mijns inziens de rechtvaardiging voor het beperken van de nietigheid.

Samenvattend kan worden gesteld, dat een onbevoegd genomen besluit kan worden bekrachtigd door het bevoegde orgaan, indien de nietigheid voortvloeit uit het ontbreken van een voorafgaande handeling of mededeling, of door statutenwijziging, indien alle onmiddellijk belanghebbenden het besluit voor geldig hebben gehouden. Een door een onbevoegd orgaan genomen besluit kan niet worden bekrachtigd doordat het bevoegde orgaan hetzelfde besluit neemt.

\section{$\S 6.2 .7$ Conversie}

Komt een nietig besluit niet voor bekrachtiging in aanmerking, dan is de vraag of een nietig besluit wellicht wordt geconverteerd in een aandeelhoudersovereenkomst en op die wijze geldigheid verkrijgt. Stel dat alle aandeelhouders besluiten de statutair voorgeschreven aanbiedingsplicht af te schaffen en daarmee afstand doen van hun rechten voortvloeiende uit de aanbiedingsregeling. Dit besluit is nietig, omdat een blokkeringsregeling wettelijk verplicht is. Een aandeelhoudersovereenkomst met dezelfde inhoud hoeft echter niet noodzakelijkerwijs nietig te zijn, nu het immers geen werking heeft jegens later toetredende aandeelhouders. ${ }^{42}$

De mogelijkheid tot conversie blijkt uit artikel 3:42 BW:

"Beantwoordt de strekking van een nietige rechtshandeling in een zodanige mate an die van een andere, als geldig aan te merken rechtshandeling, dat aangenomen moet worden dat die andere rechtshandeling zou zijn verricht, indien van de eerstgenoemde wegens haar ongeldigheid was afgezien, dan komt haar de werking van die andere rechtshandeling toe, tenzij dit onredelijk zou zijn jegens een belanghebbende die niet tot de rechtshandeling als partij heeft medegewerkt."

De Kluiver, 1999, blz. 86.

Zie $\$ 3.2 .3$ en $\$ 7.2 .3$. 
Ratio van de conversie is dat aan de nietigheid van een rechtshandeling geen verdere gevolgen behoren te worden verbonden dan een doelmatig functioneren van de rechtsorde vereist. ${ }^{43}$ De rechter kan ambtshalve overgaan tot conversie. ${ }^{4}$

De conversie komt alleen tot stand indien de inhoud van het nietige besluit wel rechtsgeldig zou zijn als overeenkomst tussen aandeelhouders. Dit betekent dat de overeenkomst niet in strijd mag zijn met dwingende wetsbepalingen, de openbare orde of de goede zeden. ${ }^{45}$ Voorts dient de conversie plaats te vinden tussen dezelfde partijen die ook betrokken zijn bij de nietige rechtshandeling. ${ }^{4}$ Alleen de aandeelhouders die hebben ingestemd met het besluit kunnen worden geacht partij te zijn bij de aandeelhoudersovereenkomst. Indien een besluit in potentie nadelig is voor later toetredende aandeelhouders, kan het als geconverteerde overeenkomst tussen de aandeelhouders eventueel vennootschappelijke werking krijgen, indien alle aandeelhouders met het besluit hebben ingestemd. ${ }^{47}$

\section{§6.3 Duitsland}

\section{§ 6.3.1 Besluiten}

Besluiten van de algemene vergadering worden in beginsel met volstrekte meerderheid genomen, op een daartoe bijeengeroepen vergadering, tenzij de gezamenlijke aandeelhouders met algemene stemmen schriftelijk hun instemming betuigen ex $\S 48$ Abs. 2 GmbHG. Dit hoeft niet uitdrukkelijk in de statuten te worden neergelegd. Een schriftelijke overeenkomst tussen alle aandeelhouders kan derhalve worden aangemerkt als besluit. Een voorbeeld hiervan biedt BGH NJW 1960, 866 .

Alle aandeelhouders hadden met elkaar afgesproken, dat zij de statutaire uitstotingsclausule tijdelijk buiten werking zouden stellen. Het Bundesgerichtshof overweegt:

"Im allgemeinen können die Gesellschafter einer GmbH allerdings eine solche Vereinbarung treffen, denn im Hinblick auf die Vertragsfreiheit haben sie, ohne daß dazu der Weg der Satzungsänderung beschritten werden muB, die Möglichkeit,

Asser-Hartkamp 4-II, nr. 494. Zie voorts Hijma, 1988, blz. 302 e.v.

HR 22 november 2002 , NJ 2003, 34.

Zie $\$ 7.23$.

Asser-Hartkamp 4-1I, nr. 497. Vgl. ook HR 10 mei 1996, NJ 1996, 692 over een nietige vennootschap onder firma.

Zie $\$ 7.2 .4$. 
die in der Satzung vorgesehene Befugnis zur Ausschließung zeitweilig zu beseitigen. Eine derartige Vereinbarung ist auch für die Geschäftsführer verbindlich $(. .$.$) ."$

Oog voor toekomstige aandeelhouders heeft men later pas. ${ }^{49}$

\section{§6.3.2 Nietigheid als limitatieve categorie}

Het GmbHG bevat geen sancties op besluiten die strijdig zijn met de wet of de statuten. De regels met betrekking tot nietige en vernietigbare besluiten worden ontleend aan $\S \S 241-249$ AktG, die zoveel mogelijk analogisch op het $\mathrm{GmbH}$-recht van toepassing worden geacht. ${ }^{50} \S 241 \mathrm{AktG}^{\mathrm{geeft}}$ een in beginsel limitatieve opsomming van nietigheidsgronden voor besluiten van de algemene vergadering: ${ }^{51}$

"Ein Beschluß der Hauptversammlung ist [...] nur dann nichtig, wenn er

1. in einer Hauptversammlung gefaßt worden ist, die unter Verstoß gegen $\S 121$ Abs. 2 und 3 oder 4 einberufen war,

2. nicht nach $\S 130$ Abs. 1,2 und 4 beurkundet ist,, 2

3. mit dem Wesen der Aktiengesellschaft nicht zu vereinbaren ist oder durch seinen Inhalt Vorschriften verletzt, die ausschließlich oder überwiegend zum Schutze der Gläubiger der Gesellschaft oder sonst im öffentlichen Interesse gegeben sind,

4. durch seinen Inhalt gegen die guten Sitten verstößt,

5. auf Anfechtungsklage durch Urteil rechtskräftig für nichtig erklärt worden ist,

6. nach $\S 144$ Abs. 2 des Gesetzes über die Angelegenheiten der freiwilligen Gerichtsbarkeit auf Grund rechtskräftiger Entscheidung als nichtig gelöscht worden ist." 53

Volgens Noack fungeert $\S 241$ AktG als lex specialis ten opzichte van de algemene nietigheidsbepalingen van $\S \S 134$ en 138 BGB. ${ }^{54}$

BGH NJW 1960, blz. 868.

Zie $\$ 6.3 .4$.

Hachenburg/Raiser, Anh. \& 47, 3. Kritisch hierover Zollner/Noack, Geltendmachung von Beschlußmangeln im GmbH-recht, ZGR 1989, biz. 532.

Lutter/Hommelhoff, Anh. $\$ 47,9$. Baumbach/Hueck/Zollner Anh. $\$ 47,31$ b. Rowedder/SchmidtLeithoff/Koppensteiner, $\$ 47,94$.

Voor de $\mathrm{GmbH}$ geldt dit slechts voor bepaalde besluiten, zoals het besluit tot statutenwijziging.

Dit is de rechtsgrond waarop de Registerrichter een besluit nietig kan verklaren, indien een besluit in het Handelsregister wordt gedeponeerd. Zie $\$ 4.3 .2$.

Noack, 1989, blz. 35. Zie ook $\$ 7.3 .3$. 
$\S 134$ BGB luidt: "Ein Rechtsgeschäft, das gegen ein gesetzliches Verbot verstößt, ist nichtig, wenn sich nicht aus dem Gesetz ein anderes ergibt."

$\S 138$ Abs. 1 BGB luidt: "Ein Rechtsgeschäft, das gegen die guten Sitten verstößt, ist nichtig."

Nietigheid van een besluit van de algemene vergadering acht Zöllner slechts gepast, voor zover bepaalde zwaarwegende redenen dit vereisen, zoals het schaden van de rechtszekerheid, de goede zeden en de bescherming van de belangen van buitenstaanders, met name crediteuren. In alle andere gevallen is uitsluitend het respecteren van de interne vennootschappelijke orde in het geding. Bepalingen die daarop zien vallen naar Zöllners oordeel niet onder de Verbotsgesetze in de zin van $\S 134$ BGB. Zijns inziens zijn aanvullende wettelijke bepalingen in de regel evenmin als Verbotsgesetz te kwalificeren. Dit houdt in dat een besluit in strijd met aanvullende wettelijke bepalingen slechts vernietigbaar is.

Lutter/Hommelhoff menen dat besluiten in strijd met de unverzichtbare $^{5 s}$ rechten van aandeelhouders (zoals het recht op deelname, op informatie en op het vorderen van vernietiging van een besluit), nietig zijn wegens strijd met het wezen van de vennootschap. ${ }^{36}$ Koppensteiner ziet deze nietigheidsgrond uitsluitend voor gevallen, waarin de $\mathrm{GmbH}$ niet langer als eigen Institution herkenbaar zou zijn." Wel acht hij de nietigheid van besluiten die in strijd zijn met de belangen van toekomstige aandeelhouders gerechtvaardigd als strijd met het algemeen belang, vanwege het feit dat toekomstige aandeelhouders niet aan de besluitvorming hebben kunnen deelnemen en geen vernietiging van een besluit kunnen vorderen. ${ }^{58}$

Nietige besluiten kunnen niet worden bekrachtigd. Een 'bevestigingsbesluit' van een nietig besluit wegens procedurele gebreken geldt steeds $e x$ nunc en moet aan alle vereisten voldoen. ${ }^{59}$ Slechts indien een notariële akte ontbreekt, kan de nietigheid van het besluit worden geheeld doordat het besluit bij het handelsregister wordt gedeponeerd, conform $\S 242 \mathrm{AktG}^{\omega 0}$

Zie $\$ 3.3 .1$.

Lutter/Hommelhoff, Anh. $\S 47,17$. Zo ook Rowedder/Schmidt-Leithoff/Pentz $\S \quad 14,20$ Baumbach/Hueck/Zoliner Anh. $\$ 47,23$, vindt dit te ver gaan.

Rowedder/Schmidt-Leithoff/Koppensteiner $\$ 47,104$.

Rowedder/Schmidt-Leithoff/Koppensteiner $\$ 47,102$.

Baumbach/Hueck/Zollner Anh. \$ 47,38.

BGH 6 november 1995, DB 1996, blz. 31. Zie ook BGH WM 2000, blz 1545. 


\section{$\oint 6.3 .3$ Vernietigbaarheid als restcategorie}

Besluiten die in strijd zijn met de wet of statuten, die niet onder de eerder genoemde nietigheidscategorieën vallen, zijn vernietigbaar op grond van $\S 243$ Abs. 1 AktG. ${ }^{61}$ Tot de gronden voor vernietiging behoren ook de overtreding van de Gleichheitsgrundsatz en de Treupflicht..$^{12}$ Vernietiging van een besluit geschiedt door middel van een Anfechtungsklage. ${ }^{63}$

Een aandeelhouder hoeft in beginsel geen eigen belang bij de vernietiging aan te tonen; iedere aandeelhouder heeft een rechtens te respecteren belang om de overeenstemming van een besluit met de wet of de statuten in rechte te laten vaststellen. ${ }^{64}$ Een bestuurder heeft slechts een vernietigingsrecht, wanneer het besluit aanwijzingen aan de bestuurder bevat of wanneer de algemene vergadering haar bevoegdheid overschrijdt. ${ }^{65}$ Het Anfechtungsrecht kan verder worden uitgebreid in de statuten tot leden van andere organen. ${ }^{66}$ Omgekeerd kan de bevoegdheid tot het instellen van een Anfechtungsklage ook statutair worden beperkt, maar uitsluitend voor zover het gaat om in strijd met de statuten of in strijd met aanvullend recht genomen besluiten. ${ }^{67}$

De termijn waarbinnen een vernietigingsactie kan worden ingesteld, is volgens $\S 246 \mathrm{AktG}$ ten hoogste een maand na het nemen van het besluit. Voor het GmbH-recht wordt aangenomen dat de termijn 'passend' moet zijn, hetgeen betekent dat de termijn van één maand als uitgangspunt wordt genomen. In de statuten kan de termijn worden verlengd. ${ }^{6}$ Analoog aan § 244 AktG kunnen aandeelhouders een vernietigbaar besluit bevestigen. Dit bevestigingsbesluit dient dan wel aan alle vereisten te voldoen en werkt ex munc. ${ }^{69}$

Een besluit dat nog niet aan alle wettelijke vereisten voldoet is niet vernietigbaar, maar "schwebend unwirksam". Er is dan geen sprake van strijd met de wet, maar het besluit is onvolledig, omdat nog niet alle vereisten voor de werkzaamheid ervan zijn vervuld. Is voor een besluit bijvoor-

\footnotetext{
Hachenburg/Raiser, Anh. $\S 47,87,101$ e.v.

Baumbach/Hueck/Zollner, Anh. \$47, 43. Hachenburg/Raiser, Anh. $\$ 47,113$ e.v.

In de literatuur wordt gepleit voor buitengerechtelijke vernietiging, vgl. Baumbach/Hueck/Zollner Anh. $\$ 47,2$ e.v., Casper, ZHR 1999, blz. 76. Zie ook $\$ 3.3 .3$.

Hachenburg/Raiser, Anh. $\$ 47,167$, Lutter/Hommelhoff, Anh. $\$ 47,61$.

Vgl. Baumbach/Hueck/Zollner Anh. \$47, 75; Hachenburg/Raiser, Anh. $\$ 47,163$.

Hachenburg/Raiser, Anh. $\$ 47,165$.

Baumbach/Hueck/Zollner, Anh. \$ 47, 16. Hachenburg/Raiser, Anh. \$47, 145.

Lutter/Hommelhoff, Anh. $\S 47,60$. Baumbach/Hueck/Zollner, Anh. $\S 47,78$ e.v. Hachenburg/ Raiser, Anh. $\$ 47,177$ ev. Zie ook Zollner/Noack, Geltendmachung von Beschlußmangeln im GmbH-Recht, ZGR 1989, blz. 529.
}

Baumbach/Hueck/Zollner Anh. $\S 47,70$. 
beeld de goedkeuring van een aandeelhouder vereist op grond van een hem toebehorend Sonderrecht, dan is het besluit zonder de goedkeuring schwebend unwirksam, totdat de goedkeuring wordt gegeven. Hetzelfde geldt voor een besluit tot statutenwijziging, dat nog niet in het handelsregister is neergelegd. ${ }^{70}$ Derden mogen zich op de Unwirksamkeit van het besluit beroepen, terwijl een unwirksam besluit niet mag worden uitgevoerd door de bestuurders en evenmin worden neergelegd in het handelsregister (tenzij dat natuurlijk de oorzaak van de schwebende Unwirksamkeit is). ${ }^{n}$

\section{Rechtsverwerking door instemming}

De nietigheid die ontstaat door oproepingsgebreken kan worden geheeld door de aanwezigheid van alle aandeelhouders, op grond van $\S 51$ Abs. 3 GmbHG. Alle gebreken die een besluit vernietigbaar maken, worden geheeld door de instemming van alle aandeelhouders. Dit geldt dus ook voor alle gebreken in de besluitvorming die zien op de interne vennootschappelijke orde, die niet tot nietigheid in de zin van $\S 241$ AktG leiden. Dit betekent dat besluiten die afwijken van aanvullende wettelijke bepalingen geldig zijn, indien en zolang zij niet worden vernietigd. ${ }^{n}$

Dat aandeelhouders die hebben ingestemd met een besluit niet vervolgens de vernietigbaarheid ervan kunnen inroepen, vloeit voort uit $\S 245$ AktG, dat in beginsel analoog van toepassing is in het $\mathrm{GmbH}$-recht. Terwijl $\S 245$ AktG de eis stelt dat een aandeelhouder tegen het besluit moet hebben gestemd om ertegen actie te kunnen ondernemen, wordt meer soepelheid betracht ten aanzien van de $\mathrm{GmbH}$-aandeelhouder. Door in te stemmen met een besluit dat in strijd is met de wet of de statuten verliest de aandeelhouder het recht om dit besluit aan te vechten. Hetzelfde geldt indien hij afstand heeft gedaan van de uitoefening van zijn recht ten aanzien van een concreet besluit, of nadien zijn instemming met het besluit betuigt. $^{n}$ Overigens verkrijgt een vernietigbaar besluit ook zonder de instemming van alle aandeelhouders snel onaantastbaarheid, vanwege de korte termijn waarbinnen de vernietigingsactie moet worden ingesteld, namelijk in beginsel één maand.

Vgl. OLG Hamm, WM 2002, blz, 858. Raiser, blz. 459. Rowedder/Schmidt-Leithoft/ Koppensteiner, $\S 47,88$.

Rowedder/Schmidt-Leithoff/Koppensteiner, $\S 47,88$.

Baumbach/Hueck/Zollner Anh. § 47, 1 .

Vgl. Baumbach/Hueck/Zollner Anh. $\S 47,73$, Hachenburg/Raiser, Anh. $\S 47,152$, Lutter/ Hommelhoff, Anh. $\$ 47,57$. 


\section{§6.3.4 Satzungsdurchbrechung als uitzondering op de vernietigbaarheid}

Door de beperkte gronden voor nietigheid van besluiten enerzijds, en het relatieve gemak waarmee vernietigbare besluiten onaantastbaarheid verkrijgen anderzijds, lijkt het Duitse recht relatief veel ruimte te bieden aan andeelhouders die in afwijking van de wet of de statuten willen besluiten, mits het gaat om een interne aangelegenheid. Het zijn met name 'lakse' andeelhouders die niet binnen een maand actie ondernemen, en later toetredende aandeelhouders die hiervan de dupe kunnen worden. Het Duitse recht biedt daarom (potentiële) minderheidsaandeelhouders verdere bescherming in het leerstuk van de Satzungsdurchbrechung. Dit houdt in dat een besluit dat afwijkt van de statuten (zgn. Satzungsverletzung) onder omstandigheden kan worden gekwalificeerd als een besluit tot statutenwijziging waarbij de formaliteiten niet in acht zijn genomen. Een besluit tot statutenwijziging dient immers met minimaal driekwart van het aantal stemmen te worden genomen, vervat in een notariële akte en neergelegd in het handelsregister op grond van $\S 53$ Abs. 4 jo. $\S 54$ Abs. 1 GmbHG. ${ }^{74} \mathrm{Het}$ niet voldoen aan deze vereisten maakt het besluit nietig, resp. unwirksam.

Onder de noemer van de Satzungsdurchbrechung heeft men in de rechtspraak en de literatuur getracht criteria te ontwikkelen voor het onderscheid tussen een - vernietigbaar - besluit dat afwijkt van de statuten en een - nietige resp. unwirksame - verkapte statutenwijziging. Aanvankelijk stelde het Bundesgerichtshof zich ruimhartig op ten aanzien van afwijkingen van de statuten. ${ }^{75}$

In 1981 nam de algemene vergadering met algemene stemmen een besluit tot vaststelling van een afwijkende bezoldiging voor leden van de Beirat. Het Bundesgerichtshof meent dat er geen sprake is van een statutenwijziging, indien

"dem Gesellschaftsvertrag nicht für die Zukunft generell eine andere Form oder ein anderer Inhalt gegeben werden soll, sondern der Gesellschafterbeschluß nur im Einzelfall von der geltenden Satzung abweicht, ohne sie auf Dauer ändern zu wollen." ${ }^{16}$

Priester maakte een onderscheid tussen eenmalige ("punktuelle") en duurzame ("zustandsbegründende") afwijkingen van de statuten. Volgens Priester doet een eenmalige Satzungsdurchbrechung zich voor, wanneer

Zie $§ 4.3 .4$.

Zie ook BGH NJW 1960, 899, $\$ 4.3 .1$.

BGH WM 1981, 1218, geciteerd door Priester, "Satzungsanderung und Satzungsdurchbrechung", ZHR 1987, blz 47 . 
met het nemen van het besluit de werking ervan is uitgeput, bijvoorbeeld indien de benoeming van een bestuurder voor één keer door de algemene vergadering geschiedt in plaats van door de statutair bevoegde Aufsichtsrat. Een duurzame Satzungsdurchbrechung daarentegen stelt een van de statuten afwijkende toestand in werking, ook al is het besluit eenmalig, zoals de benoeming van een bestuurder die niet aan de statutaire kwaliteitseisen voldoet." Daar de eenmalige Satzungsdurchbrechung volgens Priester geen noodzaak oplevert derden door middel van openbaarheid te beschermen, acht hij neerlegging in het handelsregister niet geboden, zoals voor statutenwijziging vereist. Besluiten die duurzame veranderingen aanbrengen, dienen aan alle formele vereisten voor statutenwijziging te voldoen. Dergelijke besluiten hebben niet alleen interne werking, maar zijn ook voor toekomstige aandeelhouders van belang. In een uitspraak uit 1993 heeft het Bundesgerichtshof het onderscheid van Priester overgenomen.

In casu hadden de aandeelhouders besloten, dat de ambtstermijn van de leden van de Aufsichtsrat, in afwijking van de statutair voorgeschreven drie jaar, telkens met een jaar stilzwijgend zou worden verlengd, teneinde voor beide leden een permanente plaats in de Aufsichtsrat veilig te stellen. Van het besluit was geen notariële akte opgemaakt, noch was dit in het handelsregister gedeponeerd. Het Bundesgerichtshof overweegt:

"Eine einen Einzelfall regelnde "Satzungsdurchbrechung" ist nach der Rechtsprechung des Senats im Grundsatz auch ohne Einhaltung der formellen Voraussetzungen einer Satzungsänderung jedenfalls nicht nichtig; ob sie anfechtbar ist, hat der Senat offengelassen (...). [D]ie Zulässigkeit von nicht formgültigen Satzungsdurchbrechungen beschränkt sich jedenfalls auf Fälle einer "punktuellen" Regelung, bei denen sich die Wirkung des Beschlusses in der betreffenden Maßnahme erschöpft. Satzungsdurchbrechungen, die einen von der Satzung abweichende Zustand begründen, sind dagegen ohne Einhaltung der für eine Satzungsänderung geltenden Formvorschrifen auch dann unwirksam, wenn dieser Zustand auf einen bestimmten Zeitraum begrenzt ist (...). Der Grund dafür liegt vor allem darin, daß solche eine Dauerwirkung entfaltenden Abweichungen von der Satzung nicht nur gesellschaftsinterne Bedeutung haben, sondern auch den Rechtsverkehr einschließlich etwaiger später eintretender Gesellschafter berühren."”»

De uitspraak heeft wel tot enige kritiek geleid. Zo pleit Noack voor een enge uitleg van de Satzungsdurchbrechung. Wanneer elke inhoudelijke

Anders Baumbach/Hueck/Zollner § 53, 23b.

BGH, 7 juni 1993, NJW 1993, 2246. Zie ook OLG Koln, DB 1996, bl. 466: "Auch die "Erweiterung" oder "Ergànzung" der Satzung der Gesellschaft ist eine Satzungsănderung und daher den Regeln der $\$ \S 53,54$ GmbHG unterworfen." 
Satzungsverletzung als Satzungsdurchbrechung zou worden opgevat, zou dit naar zijn mening $\S 243$ AktG overbodig maken, en daarmee de rechtszekerheidsdoelstellingen die met vernietigbaarheid worden beoogd ondergraven. Een statutenwijziging doet zich volgens hem slechts voor indien de statutaire regel wordt veranderd, niet indien ervan wordt afgeweken in een concreet geval. ${ }^{9}$

Ook Zöllner maakt een onderscheid tussen algemene bevrijding van statutaire verplichtingen en een bevrijding in concrete gevallen, bijvoorbeeld de benoeming van leden van organen die niet aan de statutaire vereisten voldoen of de bestemming van de winst, of bevrijding van concurrentieverbod in concreet geval. Niet zinvol schijnt hem een verdere differentiatie naar de duurzaamheid van de regeling. Toekomstige aandeelhouders moeten naar zijn mening bij de verkoper informeren en eventueel daar schadevergoeding vorderen. Uitsluitend indien in het besluit is verklaard dat statutenwijziging wordt beoogd, moet het worden neergelegd in het handelsregister. Slechts die besluiten, die abstracte regelingen bevatten voor toekomstige situaties zonder aan de vereisten voor statutenwijziging te voldoen, zijn in Zöllners optiek ongeldig. ${ }^{.0}$

\section{$\S$ 6.3.5 Satzungsdurchbrechung als geldig besluit}

Het leerstuk van de Satzungsdurchbrechung speelt niet alleen een rol bij de inperking van de geldigheid van besluiten in afwijking van de statuten, maar de Satzungsdurchbrechung kan ook dienen om juist de geldigheid van afwijkende besluiten te bewerkstelligen. De achterliggende gedachte is dat indien de statuten kunnen worden gewijzigd met drie vierde meerderheid, een besluit dat afwijkt van de statuten ook rechtsgeldigheid kan verwerven indien drie vierde meerderheid van de aandeelhouders ermee instemt, zonder dat het besluit bij het handelsregister wordt gedeponeerd. Dit betekent dat besluiten die niet van belang zijn voor buitenstaanders, zodat het zinloos en omslachtig zou zijn deze besluiten aan alle vereisten van statutenwijziging te onderwerpen, niet vernietigbaar zouden zijn indien meer dan drie vierde van de aandeelhouders vóór het besluit stemmen. Wel wordt dan een notariële akte vereist geacht.

Volgens deze redenering vormt de eenmalige Satzungsdurchbrechung een aparte categorie tussen de (vernietigbare) Satzungsverletzung en de (nietige) Satzungsänderung; naast de voor een statutenwijziging vereiste

Noack, 1994, blz. 140 e.v.

Baumbach/Hueck/Zoliner $\$ 53,23 \mathrm{a}$. 
gekwalificeerde meerderheid is wel een notariële akte vereist, maar het besluit hoeft niet te worden gedeponeerd bij het handelsregister. Boesebeck noemt als voorbeeld dat een buitenlander tot bestuurder wordt benoemd, terwijl de statuten de Duitse (thans EU) nationaliteit voor bestuurders vereisen. Hij acht het zinloos in een dergelijk geval tot neerlegging te verplichten, daar hetzelfde resultaat wordt bewerkstelligd door de statuten twee keer te wijzigen." Raiser gaat nog verder en noemt als voorbeeld van een punktuelle Satzungsdurchbrechung de goedkeuring van de overdracht van een aandeel door de algemene vergadering in plaats van door de statutair bevoegde Aufsichtsrat. Volgens hem maakt het ontbreken van de notariële akte het besluit niet vernietigbaar. ${ }^{82}$

Andere auteurs zien geen ruimte voor een dergelijke tussencategorie. Habersack meent dat voor Satzungsdurchbrechung niet alleen een op de regeling van een concrete situatie, maar ook een op ad-hoc-statutenwijziging gerichte wil van de aandeelhouders wordt verondersteld. Wanneer de werking van het besluit ophoudt bij de concrete regeling, gaat het volgens Habersack om een Satzungsverletzung, waarna het betreffende besluit vernietigbaar is op grond van $\S 243$ lid 1 AktG. Besluiten, gericht op statutenwijziging, moeten daarentegen aan alle formele vereisten voor statutenwijziging voldoen. Zijns inziens geldt dit zowel voor eenmalige als voor duurzame Satzungsdurchbrechungen, omdat niet alleen de openbaarheid een rol speelt, maar ook de rechtszekerheid en de toetsing van de statuten door de Registerrichter. Dit laatste is ook voor bestaande aandeelhouders van belang. Het onderscheid tussen eenmalige en duurzame Satzungsdurchbrechungen acht hij wel van belang bij de vaststelling van de wil van de aandeelhouders. Duurzame besluiten zijn gericht op verandering van de vennootschappelijke organisatie, hetgeen een wil tot statutenwijziging impliceert. In geval van eenmalige Satzungsdurchbrechung zou de wil kunnen worden afgeleid uit de omstandigheden."

"1 Boesebeck, "Satzungsdurchbrechung im recht der AG und GmbH", NJW 1960, blz. 2267. Theoretisch bestaat de mogelijkheid om eerst de statutaire eis af te schaffen, vervolgens de bestuurder te benoemen en tenslotte de eis weer in te voeren.

22 Raiser, Recht der Kapitalgesellschaften, $3^{c}$ druk, 2001, $\$ 33,41$.

s3 Habersack, "Unwirksamkeit "zustandsbegründender" Durchbrechungen der GmbH-Satzung sowie darauf gerichteter schuldrechtlicher Nebenabreden", ZGR 1994, blz. 362 e.v. Het Bundesgerichtshof lijkt inderdaad uit te gaan van vernietigbaarheid van een met de statuten strijdig besluit, indien niet alle aandeelhouders hebben ingestemd, BGH 13 januari 2003, II ZR 227/00, www bundesgerichtshof.de 


\section{$\S 6.3 .6$ Conversie}

Indien een van de wet of de statuten afwijkend besluit nietig wordt bevonden, is de vraag of het besluit van de aandeelhouders kan worden geconverteerd in een overeenkomst. De mogelijkheid tot conversie (Umdeutung) vloeit voort uit § 140 BGB:

"Entspricht ein nichtiges Rechtsgeschäft den Erfordernissen eines anderen Rechtsgeschäfts, so gilt das letztere, wenn anzunehmen ist, daß dessen Geltung bei Kenntnis der Nichtigkeit gewollt sein würde."

Niet de inhoud, maar de vorm van het besluit leidt tot diens nietigheid. Doel van de conversie is dat het resultaat van het gebrekkige besluit toch op een andere manier kan worden bereikt. ${ }^{\mathrm{H}}$ Het gaat erom dat het gekozen middel in strijd is met het recht, niet het doel.

Het Bundesgerichtshof erkent in beginsel de mogelijkheid dat een 'satzungsdurchbrechendes' besluit wordt omgezet in een aandeelhoudersovereenkomst:

"Ein satzungsdurchbrechender Gesellschafterbeschluß mag auch unter Umständen in eine schuldrechtliche Nebenabrede umgedeutet werden können. Dabei geht es aber (...) jeweils um bestimmte, im allgemeinen auf die Abstimmung in der Gesellschafterversammlung bezogene Verhaltens- oder Unterlassungspflichten, deren Durchsetzung unter Umständen auch mit gesellschaftsrechtlichen Mitteln zugelassen wird. Eine außerhalb des Gesellschaftsverhältnisses getroffene Abrede kann aber nicht bewirken, daß eine bestimmte organisationsrechtliche Regelung der Satzung ohne weiteres geändert wird."'ss

Uit de uitspraak blijkt, dat het Bundesgerichtshof met name doelt op stemovereenkomsten. Het noemt als voorbeelden een overeenkomst die een uitstotingsregeling buiten werking stelt, ${ }^{36}$ of die de instemming van alle aandeelhouders vereist voor het ontslag van een bestuurder. ${ }^{87}$ Overeenkomsten kunnen volgens het Bundesgerichtshof echter niet bewerkstel-

BGH, NJW 1993, 2247. Zie ook Baumbach/Hueck/Zollner $\S 53,23$ e. Hachenburg/Ulmer $\S 53$, 34. Lutter/Hommelhoff $\S 53,28$. Priester, ZGR 1987, blz. 58. Noack, blz. 141. Ulmer, Gesellschafterbeschlusse in Personengesellschaften - Zur Bindung der Gesellschafter an ihre Stimmabgabe -, in Festschrift fur Hubert Niederlănder, 1991, blz. 424 e.v., gaat uitgebreid in op de kwalificatie van het besluit als overeenkomst. 
ligen, dat een interne organisatieregel zonder meer wordt gewijzigd. Dit betekent echter niet, dat een dergelijke overeenkomst nietig zou zijn.

Habersack ziet vrijwel geen bestaansrecht voor conversie van een 'satzungsdurchbrechendes' besluit in een aandeelhoudersovereenkomst. Indien de wil van de aandeelhouders op statutenwijziging is gericht, kan een overeenkomst zijns inziens slechts de verplichting inhouden om tot hernieuwde besluitvorming over te gaan ten aanzien van de aangelegenheid in kwestie."s

\section{$\S 6.4$ Engeland}

\section{§ 6.4.1 Besluiten}

Het Engelse vennootschapsrecht kent verschillende categorieën besluiten. In principe besluit de algemene vergadering met volstrekte meerderheid van stemmen (ordinary resolution). Zowel een extraordinary resolution als een special resolution vereisen een drie vierde meerderheid van de stemgerechtigde aandeelhouders, de laatste met voorafgaande aankondiging van het voorgenomen besluit gedurende ten minste 21 dagen. ${ }^{89}$ Voor een statutenwijziging is bijvoorbeeld een special resolution vereist, ${ }^{\$ \infty}$ terwijl class rights slechts kunnen worden gewijzigd door middel van een extraordinary resolution. ${ }^{\text {" Het verschil in aankondigingstermijn wordt inmiddels }}$ als achterhaald beschouwd; in de White Paper wordt dan ook voorgesteld uitsluitend de special resolution te hanteren. ${ }^{92}$

Nog strengere voorwaarden worden gesteld aan een elective resolution; niet alleen is een voorafgaande aankondiging van 21 dagen vereist, maar ook de instemming van alle aandeelhouders, aldus section 379A CA 1985. Een elective resolution is bijvoorbeeld vereist, indien de vennootschap besluit af te zien van het houden van een jaarlijkse algemene vergadering. Tenslotte bepaalt section 381A CA 1985 dat alle besluiten van de algemene vergadering ook zonder vergadering en zonder voorafgaande aankondiging mogen plaatsvinden, mits schriftelijk en door alle aandeelhouders ondertekend.

Habersack, ZGR 1994, blz. 374. Priester, Rechtskontrolle und Registerpublizitat als Schranken satzungsgleicher Gesellschaftervereinbarungen bei der GmbH?, in: Festschrift für Claussen, 1997. blz. 331, ziet wel mogelijkheden.

Section 378 CA 1985. Zie Farrar, blz. 320.

Zie ook $\$ 4.4 .4$.

Zie $\$ 5.4 .2$

Vgl. White Paper, Modernising Company Law: The Government's Policy, blz 6, www.dti, gov.uk/companiesbill/whitepaper htm. 
Alle special, extraordinary en elective resolutions dienen te worden geregistreerd, evenals andere unanieme besluiten of overeenkomsten tussen aandeelhouders die een van deze bijzondere besluitvormen vereisen, zo bepaalt section $380 \mathrm{CA} 1985$. De verplichte registratie geldt ook voor andere besluiten, zoals een besluit tot kapitaalverhoging, inkoop van eigen aandelen, vrijwillige ontbinding van de vennootschap of goedkeuring van bepaalde transacties met bestuurders. Op het niet registreren staat een boete, maar dit tast de geldigheid van het besluit niet aan. Zolang het besluit niet is geregistreerd, mag de vennootschap zich echter niet beroepen op het besluit jegens derden. ${ }^{33}$

Ondanks alle formaliteiten, is in de jurisprudentie aangenomen dat informele overeenstemming tussen alle aandeelhouders hetzelfde effect heeft als een formeel besluit." Een voorbeeld hiervan biedt Re Duomatic Ltd.

De private company Duomatic Ltd had zeven aandeelhouders, waarvan drie tevens bestuurder waren. De articles schreven voor dat de bezoldiging van de bestuurders van tijd tot tijd door de algemene vergadering werd vastgesteld, conform art. 76 Table A. Hoewel er nooit formeel een besluit was genomen over de toekenning van salaris aan de bestuurders, geschiedde dit met de wetenschap en instemming van alle aandeelhouders. Nadat Duomatic failliet ging, vorderde de curator terugbetaling van het uitbetaalde salaris, omdat het niet volgens de geijkte procedure bij besluit van de algemene vergadering was vastgesteld. Buckley J overwoog:

"The fact that [the shareholders] did not take that formal step [i.e. a formal resolution at a general meeting] but that they nevertheless did apply their minds minds to the question of whether drawings by [the directors] should be approved (...) seems to lead to the conclusion that I ought to regard their consent as being tantamount to a resolution of the general meeting of the company. In other words, I proceed upon the basis that where it can be shown that all shareholders who have a right to attend and vote at a general meeting of the company assent to some matter which a general meeting of the company could carry into effect, that assent is as binding as a resolution in general meeting would be." ${ }^{95}$

Ook in Cane $v$. Jones werd een aandeelhoudersovereenkomst als besluit aangemerkt. In de woorden van Wheeler QC:

"I should add that the evidence in the case before me is that the 1967 agreement (de aandeelhoudersovereenkomst in kwestie, MM) was signed by 'the two sides' separately and that they did not meet together, however informally, for the purpose

Farrar, blz. 322.

Goulding, blz. 105.

Re Duomatic Ltd [1969] 2 Ch 365, [1969] 1 All ER 161, [1969] 2 WLR 114. Zie voorts $\$ 6.4 .3$. 
of signing the document. But it is clear beyond doubt that the agreement did represent a meeting of minds which is, after all, the essence of a meeting and the passing of a resolution."

Het gaat om de instemming van de aandeelhouders, de vorm wordt in dit geval niet relevant geacht."

\section{\$ 6.4.2 Nietige en vernietigbare besluiten}

Het Engelse recht kent geen wettelijke regeling inzake de nietigheid en vernietigbaarheid van besluiten. ${ }^{9 *}$ Dit is het terrein van de common law, hetgeen betekent dat uit uiteenlopende uitspraken wordt getracht algemene lijnen te distilleren. Besluiten in strijd met dwingende wettelijke bepalingen worden in beginsel nietig geacht. Anders ligt dit voor besluiten in strijd met de articles. Niet zozeer wordt dan de nadruk gelegd op de eventuele ongeldigheid van het genomen besluit, als wel op de vraag onder welke omstandigheden een aandeelhouder een actie kan instellen wegens schending van zijn recht, of namens de vennootschap wegens schending van haar recht (de $\mathrm{zgn}$. derivative action). Een dergelijke actie kan leiden tot de vernietiging van een besluit."

Niet geheel duidelijk is in welke omstandigheden een aandeelhouder zich tegen een besluit kan verzetten. In de Engelse literatuur wordt getracht coherentie aan te brengen ten aanzien van deze vraag. ${ }^{100}$ In ieder geval kan een aandeelhouder vernietiging van een besluit vorderen waarin zijn personal rights worden geraakt, zoals het recht om te stemmen, het recht om hun aandelen over te dragen of het recht op dividend. ${ }^{10 t}$ Voor alle andere gevallen geldt dat in beginsel de vennootschap als 'proper plaintiff'

Cane v Jones [1981] 1 All ER 533. Zie voorts § 6.4.3.

Vgl. Monecor (London) Limited v. Euro Brokers Holdings Limited [2003] EWCA Civ 105, waarin $\mathrm{L}$ oordeelde: "It does not matter whether the formal procedures in question are stipulated for in the Articles of Association, in the Companies Acts or in a separate contract between the members of the company concerned. What matters is that all the members have reached an agreement,"

In het DTI Final Report, blz 170, wordt voorgesteld besluiten tot statutenwijziging in strijd met verplichting tot waarborg in acht nemen belangen van de vennootschap en de members as a whole ongeldig te verklaren, zonder dat er recht op schadevergoeding wordt toegekend.

Vgl. Wedderburn, CL 1957, blz. 213. Davies, blz. 708.

Zie o.a. Lord Wedderburn, "Shareholders' rights and the Rule in Foss v. Harbottle", CLJ 1957, blz. 194-215, vervolgd in CLJ 1958, blz. 93-106; Goldberg, "The enforcement of outsider-rights under section 20(1) of the Companies Act 1948", MLR 1972, blz. 362-374; Bastin, "The Enforcement of a Member's Rights", JBL 1977, blz. 17-28; Drury, "The relative nature of a shareholder's right to enforce the company contract", CLJ 1986, blz. 219-246.

Vgl. Edwards v. Halliwell [1950] 2 All ER 1064, in Sealy, blz. 514. Pender v. Lushington [1877] $6 \mathrm{Ch} 70$, in Sealy, blz. 517. Zie ook Wedderbum, CLJ 1957, blz 210. 
wordt beschouwd. De gedachte is dat, wanneer de vennootschap nadeel ondervindt van een handeling, het in beginsel ook de vennootschap is, die hiertegen actie zou moeten ondernemen. Dit vloeit voort uit 'the Rule' uit Foss v. Harbottle:

"It is an elementary principle of the law that the court will not interfere with the internal management of companies acting within their powers, and in fact has no jurisdiction to do so. Again, it is clear law that in order to redress a wrong done to the company, or to recover money or damages alleged to be due to the company, the action should prima facie be brought by the company itself. These cardinal principles are laid down in the well-known cases of Foss v. Harbottle and Mozley v. Alston." "102

'The Rule' uit Foss $v$. Harbottle is van toepassing, indien het gaat om een interne aangelegenheid van de vennootschap, of indien de handeling voor bekrachtiging vatbaar is. ${ }^{103}$ Van oudsher zijn de Engelse rechters huiverachtig zich te mengen in wat zij noemen "interne aangelegenheden van de vennootschap".$^{104}$ De gedachte hierachter wordt verwoord door Mellish LJ in MacDougall v. Gardiner:

"In my opinion, if the thing complained of is a thing which in substance the majority of the company are entitled to do, or if something has been done irregularly which the majority of the company are entitled to do regularly, or if something has been done illegally which the majority of the company are entitled to do legally, there can be no use in having a litigation about it, the ultimate end of which is only that a meeting has to be called, and then ultimately the majority gets its wishes." 105

Er zijn echter uitzonderingen op 'the Rule'. Indien een besluit wordt genomen met volstrekte meerderheid van de stemmen, terwijl een gekwalificeerde meerderheid is vereist om de handeling uit te voeren of te bekrachtigen, kan een aandeelhouder dit besluit aanvechten. ${ }^{106}$ Een voorbeeld hiervan biedt Salmon v. Quin \& Axtens Ltd.

\footnotetext{
Burland v. Earle [1902] AC 83, geciteerd in Wedderburn, CLJ 1957, blz. 195, Zie ook Farrar, blz. 430 e.v.

Knox J in Smith v. Croft (No 2) [1987] 3 All ER, geciteerd in Sealy, blz 438.

1at Beroemd is de uitspraak van Lord Eldon in Carlen v. Drury [1812] I V. \& B. 154 : "This Court is not to be required on every Occasion to take the Management of every Playhouse and Brewhouse in the Kingdom", onder meer geciteerd door Wedderburn, CLJ 1957, blz. 197.

Vgl. Farrar, blz. 433.
} 
De statuten van de vennootschap bevatten een clausule, waarin de goedkeuring van beide bestuurders werd vereist voor het aangaan van bepaalde transacties. Salmon, een van de bestuurders, weigerde toestemming te geven voor de aankoop van een nieuw pand. De algemene vergadering besloot daarop met volstrekte meerderheid toch tot aankoop over te gaan. Hierop stelde Salmon, die tevens aandeelhouder was, een actie in. Farwell $\mathrm{J}$ wees de vordering toe na te hebben overwogen:

"In truth this is an attempt to alter the terms of the contract between the parties by a simple resolution instead of by a special resolution." 107

Een andere uitzondering op 'the Rule' vormt de derivative action of representative action. De actie wordt in dat geval ingesteld door een (groep) minderheidsaandeelhouder(s), als vertegenwoordiger van de vennootschap resp. alle aandeelhouders. De claim wordt gehonoreerd, indien er sprake is van fraud on the minority. Dit houdt in dat de meerderheid van de aandeelhouders de minderheid heeft overstemd ten aanzien van een handeling in strijd met de wet of de statuten die niet voor bekrachtiging vatbaar is. ${ }^{\text {is }}$ Dit komt met name voor, in geval van een breach of duty door bestuurders. Het is de handeling in kwestie die al dan niet een fraud on the minority oplevert, niet het stemgedrag van de aandeelhouders. ${ }^{109}$ Uit de jurisprudentie blijkt dat de derivative action succesvol is, indien de vennootschap is benadeeld, terwijl degene die handelde daarmee een persoonlijk gewin beoogde. ${ }^{110}$ De mogelijkheid om een derivative action in te stellen is verder ingeperkt in Smith v. Croft (No. 2), waarin werd bepaald dat een minderheidsaandeelhouder pas namens de vennootschap schadevergoeding kan vorderen, indien de meerderheid van de onafhankelijke aandeelhouders wil ageren." ${ }^{\prime \prime}$

Er treedt een zekere spanning op tussen enerzijds de afkeer van rechterlijke inmenging in interne aangelegenheden van de vennootschap en anderzijds de daadwerkelijke erkenning van de contractuele aard van de articles, zodat nakoming kan worden gevorderd. ${ }^{112}$ Lord Wedderburn betoogt dat elke aandeelhouder een personal right heeft op naleving van de

\footnotetext{
107 Een special resolution vereist drie vierde van het aantal stemmen, met voorafgaande oproep van drie weken.

tos Vgl. Farrar, blz. 435. In Redwood Master Fund and others v. TD Bank Europe Ltd and others [2002] All ER (D) 141, stelt Rimer J dat er sprake is van fraud on the minority indien het besluit tot gevolg heeft dat een onderscheid wordt gemaakt tussen meerderheids- en minderheidsaandeelhouders, in de zin dat meerderheidsaandeelhouders worden bevoordeeld ten opzichte van minderheidsaandeelhouders.

to9 Payne, "A Re-examination of Ratification", CLJ 1999, blz, 614.

11i Hannigan, JBL 2000, blz. 502 .

III Smith v Croft (No. 2) [1987] 3 All ER, vgl. Hannigan, JBL 2000, blz. 503.

112 Davies, blz 120, 662
} 
statuten, tenzij het gaat om een interne aangelegenheid die vatbaar is voor bekrachtiging. ${ }^{113}$ Drury stelt dat het recht van een aandeelhouder om naleving van een bepaling in de articles af te dwingen moet worden afgewogen tegen de rechten van andere aandeelhouders in de vennootschap. ${ }^{114}$

De problematiek lijkt met de invoering van section 459 CA 1985 enigszins aan belang te hebben ingeboet, doordat aandeelhouders een eenvoudigere weg hebben gevonden om te procederen. ${ }^{15}$ Het verschil tussen beiden is dat de gevraagde remedie op basis van section $459 \mathrm{CA}$ 1985 vaak uittreding uit de vennootschap is, terwijl het afdwingen van een recht ten opzichte van een besluit juist de positie van de aandeelhouder in de vennootschap moet versterken. Bij section 459 CA 1985 gaat het niet zozeer om de rechten van aandeelhouders, als wel om "justice, equity and fairness", ${ }^{116}$ In die zin valt er wel wat te zeggen voor de benadering van Drury, die het bestaan van absolute rechten van aandeelhouders afwijst. Bovendien lijkt dit een rem -op een al te makkelijke procesgang; de aandeelhouder kan niet voor elke inbreuk naar de rechter, er moet aantoonbaar nadeel zijn.

\section{$\$ 6.4 .3$ De 'unanimous consent rule'}

\section{Besluiten in strijd met procedurevoorschriften}

Indien wettelijke of statutaire procedurevoorschriften inzake de besluitvorming van de algemene vergadering niet zijn nageleefd, is het besluit niettemin geldig indien alle aandeelhouders ermee hebben ingestemd. Dit wordt de unanimous consent rule genoemd, ook wel het Duomatic principle, naar de bovengenoemde uitspraak Re Duomatic Ltd." ${ }^{\text {' }}$ Section 381C (2) CA 1985, dat schriftelijke besluitvorming buiten vergadering mogelijk maakt, laat uitdrukkelijk de unamimous consent rule intact.

Als achterliggende gedachte van deze regel wordt aangemerkt dat het doel van de besluitvorming de overeenstemming tussen aandeelhouders is, terwijl de procedurevoorschriften middelen zijn om dit doel te bereiken. ${ }^{11}$ Ten aanzien van de ratio van de unanimous consent rule overweegt Oliver J in Re New Cedos Engineering Co Ltd:

Wedderburn, CLJ 1957, blz. 212. Zo ook Davies, blz. 120.

Drury, CL 1986, blz. 224.

Zie $\$ 3.4 .1$ en $\$ 7.4 .4$.

Sealy, CfiLR 1997, blz. 181.

Zie $§ 6.4 .1$.

Vgl. Grantham, "The Unanimous Consent Rule in Company Law", CLJ 1993, blz. 249. 
"the ratio of Buckley J's decision (in Re Duomatic, MM) is that where that what has been done informally could, but for an oversight, have been done formally and was assented to by $100 \%$ of those who could have participated in the formal act, if one had been carried out, then it would be idle to insist upon formality as a precondition to the validity of the act which all those competent to effect it had agreed should be effected. But, as I see it, this necessarily rests upon the postulate that the persons assenting were, in fact, competent to the effect the act to which they have assented. There is nothing whatever in the decision which justifies, much less compels, the conclusion that if they were not competent to do it formally at a meeting, they could do it informally without a meeting."119

De ontwikkeling van de unamimous consent rule verloopt op een case by case basis. Zo blijkt uit onderstaande voorbeelden dat de unamimous consent rule niet opgaat, indien de procedurevoorschriften mede zijn opgesteld ter bescherming van crediteuren. ${ }^{120}$ In dat geval dient aan alle besluitvormingsregels te worden voldaan.

In Re RW Peak (Kings Lynn) Ltd ${ }^{12}$ verkocht Ronald Peak, die samen met zijn zoon Nicholas alle aandelen in RW Peak (Kings Lynn) Ltd hield, zijn gehele aandelenkapitaal aan de vennootschap, die bij deze transactie werd vertegenwoordigd door Nicholas. De vraag was of deze transactie in strijd was met de inkoopregeling van section $164 \mathrm{CA} 1985$, die voorafgaande goedkeuring van de algemene vergadering vereist. Lindsay $\mathrm{J}$ citeert eerst de overweging van Oliver $\mathrm{J}$ in Re New Cedos Engineering Co Ltd. Dan vervolgt hij:

" [i]t is far from clear to me just how far formalities required by statute as apparent preconditions for the efficacy of company arrangements can or cannot in general be brushed aside by reference to Duomatic as formalities overlooked by oversight and curable by assent. (...) I shall accordingly leave the subject of a more general view of the tensions between the requirements stipulated by Parliament on the one hand and the Duomatic principle on the other to be decided in some case in which such a general view is necessary. It is not, I think, necessary here as there are, as I shall explain, particular provisions of the 1985 Act which, in my judgment, suggest that on the facts of this particular case and in this particular area, namely the detailed requirements of section 164, the Duomatic principle, if applied as the

119 Re New Cedos Engineering Co Ltd [1994] I BCLC 797. De uitspraak stamt uit 1975, maar is pas in 1994 gerapporteerd.

129. Vgl. Cabrelli, "BDG Roof Bond Ltd v. Douglas: further observations on the application of the Duomatic relief", Company Lawyer 2001, blz. 130. Zie bijvoorbeeld Precision Dippings Ltd v. Precision Dippings Marketing LId [1985] 3 WLR 812, CA. waar dividend werd uitgekeerd zonder dat een accountantsverklaring was afgegeven, en Bairstow v. Queen's Moat [2001] BCLC $2531 \mathrm{CA}$, waar een dividenduitkering in strijd met s. $270 \mathrm{CA} 1985$ werd gedaan. 
company urges it should be, would represent such an anomaly that it ought not to be available to override a want of compliance with the statutory provisions."

Wanneer de procedurevoorschriften uitsluitend beogen aandeelhouders te beschermen, kunnen deze afzien van deze bescherming. Doordat alle aandeelhouders instemmen worden zij geacht afstand te hebben gedaan van de uit de procedurevoorschriften voortvloeiende bescherming.

Wright Air Conditioning Ltd werd opgericht door Wright, die samen met zijn vrouw aandeelhouder en bestuurder was. Toen hij de pensioengerechtigde leeftijd had bereikt, verkocht hij zijn aandelen aan Wheway plc, waarbij werd overeengekomen dat Wright en zijn vrouw een levenslange aanstelling als bestuurder zouden behouden, tegen een jaarlijks inkomen van elk 10.000 pond. Nadat Wright Air Conditioning Ltd werd overgenomen door Atlas Wright Ltd, riepen de nieuwe bestuurders van Atlas Wright (voorheen Wright Air Conditioning Ltd) de nietigheid van de aanstellingsovereenkomsten in. Potter LJ citeert wederom Oliver $\mathrm{J}$ in New Cedos en gaat in op de overwegingen van Lindsay $\mathrm{J}$ in Re RW Peak:

"While, as Lindsay observed, the various authorities decided upon the Duomatic principle do not make clear just how far formalities required by statute as apparent preconditions for the efficacy of the company arrangements can be ignored as formalities overlooked by oversight and curable by assent, it seems to me appropriate to approach that question on the basis of a consideration of the purpose and underlying rationale of the particular formality in question. (...) In this case it is plain that real consent was given by the sole shareholder of the company for an act which was intra vires the company's powers. Further, it does not seem to me plain that there is any statutory purpose underlying the provisions of section 319 (3) and (5) beyond the benefit and protection of the shareholders of the company. (...) sub-s. (5) (...) seems to me no more than a "back up" formality in the nature of a notice provision designed to ensure the opportunity for fully informed consent by the shareholders. It is thus amenable to waiver by the class for whose protection it is designed, in circumstances where it is clear that there was in fact fully informed consent in respect of an agreement known to the sole shareholder for longer than the 15 day period provided for in sub-s. (5)." ${ }^{122}$

In BDG Roof-Bond Ltd v. Douglas and others was de geldigheid van een besluit tot inkoop van eigen aandelen aan de orde, nu het voorgenomen besluit niet gedurende vijftien dagen ter inzage had gelegen conform section 164 (6) CA 1985, opdat aandeelhouders ervan kennis kunnen nemen. In casu had de vennootschap twee aandeelhouders, waarvan de een de aandelen verkocht en de ander namens de

122 Wright v Atlas Wright (Europe) Ltd [1999] BCC 163 CA. 
vennootschap optrad. Park J herhaalt overweging van Potter LJ in Atlas en vervolgt:

"These observations seem equally applicable to the requirement of section 164(6) that an agreement for an own-shares purchase should be available for inspection by members in the registered office for 15 days. (...) Section 164(6) is a provision designed solely for the benefit of shareholders. There is no element of creditor protection in it at all." 123

Zoals de hierboven geschetste ontwikkeling aantoont, wordt in de jurisprudentie een onderscheid gemaakt tussen bepalingen die de belangen van aandeelhouders behartigen, en bepalingen die beogen crediteuren te beschermen. Alleen in het eerste geval geldt de unanimous consent rule, i.e. indien alle aandeelhouders met de inhoud instemmen, wordt deze instemming aangemerkt als rechtsgeldig besluit. De instemming wordt beschouwd als het doen van afstand van (procedurele) bescherming. Geen afstand kan worden gedaan van rechten die beogen derden te beschermen. ${ }^{124}$

Onduidelijk is overigens in hoeverre de unanimous consent rule zich uitstrekt over bevoegdheden van andere organen. In de hierboven geciteerde uitspraak Re New Cedos Engineering Co Ltd overwoog Oliver J dat de algemene vergadering bij de toepassing van de unamimous consent rule wel binnen haar bevoegdheden dient te blijven. In Euro Brokers Holdings $v$. Monecor (London) Ltd werd dit minder van belang geacht. Op grond van de aandeelhoudersovereenkomst was het bestuur bevoegd tot uitgifte van nieuwe aandelen, terwijl in casu de aandeelhouders hiertoe besloten. Kosmin QC (als plaatsvervangend rechter) overwoog:

"The Duomatic principle is specifically designed to fill the gap where matter have been agreed informally by all the relevant members and the procedural aspects of the matter are not to be treated as essential. For this purpose the shareholders are the company and can agree to proceed in a less formal manner that that stipulated in the articles of association or any shareholder's agreement."12s

\section{Besluiten in strijd met de statuten}

Het ligt voor de hand dat wettelijke voorschriften meer elementen van crediteurenbescherming in zich bergen dan statutaire regelingen. Neuberger

125 Euro Brokers Holdings v. Monecor (London) Ltd [2002] EWHC 1480. 
J wijst in Re Torvale Group Ltd voorzichtig op een verschil in behandeling van statutaire en wettelijke voorschriften:

"The authorities do not suggest, at least tot my mind, that there is any necessary distinction between a case where the articles of a company appear to require a particular procedure or a case where the Companies Acts require that procedure. However, it seems to me that it is not insignificant that those cases where the court has concluded that the Duomatic principle does not or may not apply are cases involving a statutory procedure rather than a procedure laid down in a company's articles." ${ }^{126}$

Minder acht wordt geslagen op de beschermende functie van procedures ten aanzien van later toetredende aandeelhouders. In de zaak Cane v. Jones wordt een overeenkomst tussen alle aandeelhouders, die een statutaire bepaling terzijde stelt, gehonoreerd. Ook dit wordt onder de unamimous consent rule geschaard.

De aandelen in een familiebedrijf van twee broers komen na het terugtreden van de broers in handen van hun kinderen. De articles kennen de voorzitter van het bestuur de doorslaggevende stem toe ingeval de stemmen in de algemene vergadering staken. Later - in 1967 - ondertekenen alle vier aandeelhouders een overeenkomst, waarin dit recht wordt terzijdegesteld. De kinderen raken met elkaar in conflict en er ontstaat een patstelling. Cane stelt dat de overeenkomst ongeldig is, omdat de articles slechts kunnen worden gewijzigd met inachtneming van de procedure neergelegd in section 10 van de Companies Act (thans section $9 \mathrm{CA}$ 1985), die een special resolution vereist. Michael Wheeler QC overweegt:

"In my judgment, section 10 of the Act is merely laying down a procedure whereby some only of the shareholders can validly alter the articles; and, if, as I believe to be the case, it is a basic principle of company law that all the corporators, acting together, can do anything which is intra vires the company, then I see nothing in section 10 to undermine this principle."'127

De achterliggende gedachte van deze redenering lijkt te zijn dat de wet een uitzondering biedt op het algemene beginsel dat aandeelhouders met algemene stemmen een overeenkomst kunnen wijzigen, teneinde statutenwijziging te vergemakkelijken. In deze optiek wordt section 9 CA 1985 louter als procedurevoorschrift beschouwd. ${ }^{128}$. Wheeler QC en ook Neuberger J

\footnotetext{
12. Re Torvale Group Ltd [1999] 2 BCLC 605.

izs Cane $v$ Jones [1981] I All ER 533. Zie ook $\$ 6.4 .1$.

izs Een radicaal andere benadering dat de Duitse inzake de Satzungsdurchbrechung, zie $\$ 6.3 .4$.
} 
zien dan ook weinig kwaads in toepassing van het algemene beginsel van overeenstemming. In de woorden van Neuberger J:

"As he (Wheeler MM) said, there is nothing offensive to, or inconsistent with, this statutory requirement if all members of the group concerned, rather than merely a majority, agree on a course which would require a special procedure if a minority of the group did not agree to the proposed course." 29

Kennelijk worden de wettelijke vereisten voor statutenwijziging uitsluitend als bescherming voor de bestaande aandeelhouders (in hun hoedanigheid als partij bij de overeenkomst) gezien, als procedurevoorschriften, zonder oog te hebben voor het inhoudelijke resultaat dat de statuten niet langer weergeven hoe de besluitvorming in de algemene vergadering plaatsvindt. Sealy heeft kritiek geuit op de uitspraak inzake Cane $v$. Jones, aangezien aan een overeenkomst tussen aandeelhouders vennootschappelijk effect wordt gegeven, terwijl deze ook voor toekomstige aandeelhouders van belang is. ${ }^{130}$

De jurisprudentie inzake de unanimous consent rule toont aan, dat in het Engelse recht niet bijzonder veel aandacht bestaat voor de dogmatische verschillen tussen statuten, besluiten en overeenkomsten. ${ }^{13}$ De eerste twee worden beschouwd als bijzondere vormen van de derde. In tegenstelling tot overeenkomsten vereisen besluiten speciale procedures. Van deze vereisten kan worden afgezien, zodra degene voor wiens bescherming de procedures zijn bedoeld met de afwijking instemmen. Later toetredende aandeelhouders worden niet alleen geacht de statuten te hebben aanvaard, maar ook eventuele overeenkomsten gesloten door hun voorgangers.

Het Engelse recht kent evenmin speciale sancties voor besluiten. Net als overeenkomsten zijn zij nietig, wanneer zij strijdig zijn met dwingend recht. Een besluit is vernietigbaar, indien een aandeelhouder wordt aangetast in zijn recht en hij een actie instelt. Ook dit is vergelijkbaar met het vorderen van nakoming in geval van schending van een overeenkomst.

Re Torvale Group Ltd [1999] 2 BCLC 605.

Vgl, Sealy, Cases, blz. 194. Zie ook \$ 7.4.4.

Vgl. Euro Brokers Holdings v. Monecor (London) Ltd [2002] EWHC 1480, Kosmin QC: "There does not appear to me to be any necessary distinction between cases where the articles of association of a company require a particular procedure to be adopted and cases where a shareholders' agreement imposes such a requirement. Indeed, the very decision of shareholders to utilise a shareholders' agreement outside the articles for important provisions regulating their affairs can sometimes suggest a desire to adapt strict statutory procedures to greater informality. The prescribed procedure in a shareholders' agreement will therefore not normally be treated as being of the essence. However, the outcome of each case will depend on the proper construction of the contractual provision in question." 


\section{$\S 6.5$ Evaluatie}

Dwingend vennootschapsrecht ten aanzien van de besluitvorming in de algemene vergadering komt tot uitdrukking doordat sancties worden gesteld op besluiten die afwijken van de wet en/of de statuten. De sancties beogen verschillende categorieën betrokkenen bij de vennootschap te beschermen: crediteuren, (minderheids)aandeelhouders, toekomstige aandeelhouders. In elk onderzocht rechtsstelsel worden de belangen op verschillende wijze afgewogen.

In Nederland is het uitgangspunt dat besluiten in strijd met de wet of de statuten nietig zijn. Op deze wijze wordt aangegeven dat de wet en de statuten voor alle bij de vennootschap betrokkenen van belang zijn, niet alleen voor de aandeelhouders. Het 'gemak' waarmee in het Nederlandse recht besluiten naar de inhoud in strijd met de wet of de statuten nietig worden geacht, spoort niet direct met de genuanceerde benadering in het Engelse en Duitse recht. In die rechtsstelsels wordt gedifferentieerd tussen besluiten in strijd met de wet of met de statuten, terwijl steeds de ratio van de betreffende wettelijke of statutaire bepaling in ogenschouw wordt genomen bij het vaststellen van de sanctie.

De Nederlandse wet noemt wel een aantal besluiten die ondanks strijd met de statuten niet nietig zijn. Het gaat om besluiten, waarbij de algemene vergadering met twee derde meerderheid van de stemmen, die meer dan de helft van het geplaatste kapitaal vertegenwoordigen, aanvullende statutaire bepalingen kan doorbreken, zoals een bindende voordracht voor de benoeming van bestuurders of kwaliteitseisen aan bestuurders of commissarissen. De dwingendrechtelijke keuzevrijheid van de algemene vergadering bij de benoeming van bestuurders en commissarissen wordt onder deze voorwaarden voorrang gegeven boven statutaire beperkingen hierop.

In het Duitse recht zijn uitgangspunt en uitzondering omgedraaid. Besluiten in strijd met de wet, de statuten en de vennootschappelijke Treupflicht zijn niet nietig, maar in beginsel vernietigbaar, tenzij er sprake is van strijd met voorschriften ter bescherming van crediteuren, het wezen van de vennootschap, het algemeen belang of de goede zeden. Deze besluiten zijn nietig. Naar Duits recht hebben aandeelhouders die voor een besluit hebben gestemd, hun recht verspeeld om de vernietiging van het besluit te vorderen. Een vernietigbaar besluit is derhalve geldig, indien alle aandeelhouders met het besluit hebben ingestemd, voorts ook na afloop van de termijn van in beginsel één maand.

Een vernietigbaar besluit kan echter ook gevolgen hebben voor later toetredende aandeelhouders. Deze zijn immers aan besluiten van de ven- 
nootschap gebonden. De gedachte is dat zij niet op de hoogte zijn van de inhoud van dergelijke besluiten en derhalve slechts kunnen worden beschermd door de nietigheid van een besluit. Een besluit dat afwijkt van de statuten, zou ook kunnen worden beschouwd als een verkapte statutenwijziging, waarbij de vereiste formaliteiten niet in acht zijn genomen. Besluiten tot statutenwijziging moeten namelijk in een notariële akte worden vervat en worden neergelegd in het handelsregister, op straffe van nietigheid. De afweging is dan onder welke omstandigheden een besluit dat afwijkt van de statuten (zonder in strijd te zijn met één van de limitatief opgesomde nietigheidsgronden), als een verkapte statutenwijziging nietig moet worden geacht. Dit is het leerstuk van de Satzungsdurchbrechung.

In de Duitse rechtspraak en literatuur wordt een underscheid gemaakt tussen eenmalige en duurzame doorbrekingen. Uitsluitend duurzame statutenwijzigingen zouden van belang zijn voor toekomstige aandeelhouders, en derhalve inschrijving in het handelsregister vereisen. Wel wordt een notariële akte voor beide categorieën onontbeerlijk geacht. Eventueel komen nietige duurzame doorbrekingen in aanmerking voor conversie in een aandeelhoudersovereenkomst. Daarnaast pleiten sommige auteurs voor de geldigheid van een eenmalige doorbreking van statutaire bepalingen, indien aan de meerderheidsvereisten voor statutenwijziging is voldaan en het besluit in een notariële akte is opgemaakt. Dit is een strengere variant van de Nederlandse uitzonderingen voor het doorbreken van de bindende voordracht en kwaliteitseisen aan bestuurders en commissarissen, echter wel veralgemeniseerd tot eenmalige afwijkingen.

Het Engelse recht kent geen aparte wettelijke sancties voor besluiten. Evenals een overeenkomst is een besluit in strijd met dwingende wettelijke voorschriften ten behoeve van derden nietig. In de Engelse jurisprudentie is de unanimous consent rule ontwikkeld. Van wettelijke of statutaire voorschriften die uitsluitend in het belang van de aandeelhouders zijn gegeven, kunnen aandeelhouders bij algemene instemming afzien. De achterliggende gedachte is dat aandeelhouders afstand mogen doen van rechten die op hun eigen bescherming zijn gericht. Besluiten die van belang zijn voor toekomstige aandeelhouders en crediteuren dienen wel te worden geregistreerd, maar dit tast de geldigheid van het besluit niet aan. Uitsluitend indien het besluit de belangen van crediteuren schaadt, is een afwijking van wettelijke of statutaire bepalingen nietig.

Ik meen dat het Nederlandse recht ruimte laat voor een genuanceerde, op Engels en Duits recht geïnspireerde benadering. Zo kan ook naar Nederlands recht de instemming van aandeelhouders worden beschouwd als een wettelijke vorm van rechtsverwerking van het recht om vernietiging van een besluit te vorderen. De vernietigbaarheid van een besluit brengt 
met zich mee, dat degene die met het betreffende besluit heeft ingestemd, niet vervolgens de vernietiging ervan mag vorderen. Dit maakt een vernietigbaar besluit, dat is genomen met algemene stemmen van alle aandeelhouders, geldig.

Ook in andere gevallen dan de uitdrukkelijk in de wet genoemde hoeft een besluit dat afwijkt van een aanvullende statutaire bepaling niet nietig te worden geacht, maar vernietigbaar, indien het uitsluitend de belangen van aandeelhouders raakt. Dit vloeit voort uit een analogische toepassing van artikel 3:40 lid 2 jo. 2:14 lid 1, laatste zinsnede, BW, Het gaat dan om gevallen waarin een statutaire regeling een dwingende wettelijke bevoegdheid van aandeelhouders beperkt, terwijl de bevoegdheid op grond van de wet aan aandeelhouders toekomt. Een voorbeeld hiervan is een besluit dat beperkingen aan de overdraagbaarheid van aandelen, zoals statutaire eisen aan aandeelhouders, terzijde stelt.

Besluiten die afwijken van de statuten, waarbij ook de belangen van toekomstige aandeelhouders worden geraakt, zijn nietig, maar de inhoud van het besluit kan worden geconverteerd in een aandeelhoudersovereenkomst. Een dergelijke aandeelhoudersovereenkomst kan vervolgens vennootschapsrechtelijke werking worden toegekend. ${ }^{32}$ Een andere manier waarop nietigheid op basis van interne aangelegenheden kan worden geheeld is via bekrachtiging, hetzij door het verrichten van een vereiste handeling of mededeling achteraf, hetzij door statutenwijziging. Voor het overige zijn besluiten in strijd met wettelijke of statutaire bepalingen die crediteuren benadelen nietig.

Zie $\$ 7,2.4$. 



\section{Hoofdstuk 7 Aandeelhoudersovereenkomsten}

"There is in fact every chance that this "institutionalising" of the shareholder agreement will be the beginning of a slippery slope which will inevitably lead to a blurring of the differences between these agreements and the memorandum and articles of association - differences which at present provide the draftsman with a useful flexibility. What are now straightforward issues of contract would cease to be so; there would be a gradual infiltration of rules of substantive company law into the construction and interpretation of shareholder agreements, with "implied terms" lurking ready to be discovered, and public policy arguments waiting in the wings."

\section{$\S 7.1$ Inleiding}

In het voorgaande is uiteengezet, in hoeverre dwingend vennootschapsrecht grenzen stelt aan statuten en besluiten. In dit hoofdstuk staat de verhouding tussen dwingend vennootschapsrecht en aandeelhoudersovereenkomsten centraal. Overeenkomsten tussen aandeelhouders komen in verschillende varianten voor. Door middel van een stemovereenkomst verbinden aandeelhouders zich om hun stem in de algemene vergadering op een in de overeenkomst voorgeschreven wijze uit te brengen. Voorts kan een aandeelhoudersovereenkomst statutaire rechten en verplichtingen van aandeelhouders aanvullen, bijvoorbeeld in het kader van de blokkeringsregeling of de geschillenregeling, of in de plaats treden van een statutaire regeling, indien bijvoorbeeld extra verplichtingen worden overeengekomen, zoals het leveren van diensten, of een non-concurrentiebeding. Met name in besloten vennootschappen met een beperkte kring van aandeelhouders kunnen aandeelhoudersovereenkomsten een belangrijke rol vervullen, bijvoorbeeld in geval van een joint-venture.

Sealy, The Enforcement of Partnership Agreements, Articles of Association and Shareholder Agreements, in: Equity and Commercial Relationships, Finn (red.), 1987, blz. 112. 
Dit neemt niet weg dat in de vennootschappelijke praktijk aandeelhoudersovereenkomsten veelvuldig worden gebruikt. Een aandeelhoudersovereenkomst biedt enkele voordelen ten opzichte van een statutaire regeling. Allereerst kan een overeenkomst vormvrij worden gesloten, zonder verplichte inschakeling van de notaris. Voorts hoeft de inhoud van de overeenkomst niet te worden openbaar gemaakt door neerlegging in het handelsregister. Bovendien kan een overeenkomst slechts met instemming van alle partijen worden gewijzigd, terwijl een dergelijke wijziging niet aan vormvereisten is gebonden. Daar staat tegenover dat de overeenkomst in beginsel slechts voor partijen bindend is. ${ }^{2}$ Dit laatste onderscheid is essentieel, omdat het dwingende karakter van het vennootschapsrecht juist wordt gerechtvaardigd doordat statuten en besluiten voor meer personen gelden dan uitsluitend partijen bij de overeenkomst.

Vanuit verbintenisrechtelijk perspectief is dan de vraag in hoeverre de contractsvrijheid van aandeelhouders wordt begrensd door dwingend vennootschapsrecht, terwijl vanuit vennootschapsrechtelijk oogpunt juist wordt bezien in hoeverre aandeelhouders bij overeenkomst mogen afwijken van de wet of de statuten, dan wel deze aanvullen. In hoofdstuk 3 werd hierop reeds ingegaan met betrekking tot de vraag of aandeelhouders bij overeenkomst afstand mogen doen van de hen toebehorende rechten. In dit hoofdstuk staan de toelaatbaarheid, grenzen en werking van aandeelhoudersovereenkomsten in het algemeen centraal. Met name overeenkomsten over de uitoefening van het stemrecht blijken een duurzame bron van discussie, waarbij heldere grenzen moeilijk lijken af te bakenen. De wisselwerking tussen vennootschapsrecht en verbintenissenrecht kan zich ook manifesteren in omgekeerde richting. Dan is de vraag in hoeverre overeenkomsten doorwerken in de vennootschappelijke besluitvorming, eventueel een normerende werking hebben op statuten en besluiten.

In de kern gaat het erom of het vennootschapsrecht en het verbintenissenrecht los van elkaar moet worden beschouwd, in de zin dat overeenkomsten zijn onderworpen aan de regels van het verbintenissenrecht en statuten aan de vennootschapsrechtelijke voorschriften, of dat overeenkomsten, gesloten in een vennootschappelijke context, ook naar vennootschapsrechtelijke maatstaven moeten worden beoordeeld. Hoewel in alle onderzochte rechtsstelsels traditioneel de scheiding van stem en overeenkomst het vertrekpunt is, blijkt de praktijk weerbarstiger en de wederzijdse beïn-

Zie ook $\$ 4.1$. 
vloeding van aandeelhoudersovereenkomsten en de vennootschappelijke besluitvorming onontkoombaar. ${ }^{3}$

\section{$\S 7.2$ Nederland}

\section{§7.2.1 De toelaatbaarheid van aandeelhoudersovereenkomsten}

Terwijl het vennootschapsrecht in beginsel als dwingend wordt beschouwd, staat in het verbintenissenrecht de contractsvrijheid voorop. De vraag rijst in hoeverre het aandeelhouders vrij staat om overeenkomsten over vennootschappelijke aangelegenheden te sluiten. In de literatuur en rechtspraak is met name de toelaatbaarheid van stemovereenkomsten ter discussie gesteld. Stemovereenkomsten, waarbij één of meer aandeelhouders zich verbinden ten aanzien van de uitoefening van hun stemrecht in de algemene vergadering, komen in de praktijk veelvuldig voor, maar over hun principiële geldigheid en reikwijdte bestaat nog steeds onzekerheid. ${ }^{4}$ Het beroep op de behoeften van de praktijk lijkt wel te fungeren als standaardargument pro stemovereenkomst. ${ }^{\text {s }}$

Volgens oudere opvattingen uit het begin van de vorige eeuw waren stemovereenkomsten ongeoorloofd. Petit hanteerde als uitgangspunt dat het stemrecht een functie is die aan de leden van een georganiseerde gemeenschap in het belang van de gemeenschap is toegekend. Dientengevolge achtte hij overeenkomsten, waarbij men zich verbindt tot het al dan niet, of op een bepaalde wijze uitoefenen van het stemrecht, onzedelijk. ${ }^{6} \mathrm{Bij}$ de uitoefening van het stemrecht moet zijns inziens het belang van de gezamenlijke leden tot uitdrukking komen.?

Raaijmakers, Enkele beschouwingen over joint ventures, preadvies NVVR, 1992, blz. 25, 54 c.v. acht de regels van maatschap van analogische toepassing op contractuele joint venture vennootschappen. Zie over het versterken van het contractuele karakter van het vennootschapsrecht Copp. "Company law and alternative dispute resolution: an economic analysis", Company Lawyer 2002, blz. 373 e.v.

Vgl. Mohr, Spijkers, 1993 en Dortmond, Stemovereenkomsten rondom de eeuwwisseling, 2000.

Zie bijvoorbeeld Kamphuisen, "Overeenkomsten betreffende het stemrecht in een naamlooze vennootschap.", NV 1941, blz. 350 en Maeijer, De stemovereenkomst van aandeelhouders, in: Recht zo die gaat, opstellen aangeboden aan prof, mr. P.W, van der Ploeg, 1976, blz. 96.

Petit, Overeenkomsten in strijd met de goede zeden, 1920, blz. 203. Zie hierover ook Brenninkmeijer, Stemovereenkomsten van aandeelhouders, 1973, blz. 112 en Mendel, Stemrecht, minderheidsaandeelhouders en ongelijkheidscompensatie, in: Ongelijkheidscompensatie als roode draad in het recht, Liber Amicorum voor prof.mr. M.G. Rood, 1997, blz. 209.

Petit, 1920, blz. 204. Brenninkmeijer, 1973, blz. 99, noemt dit het beginsel van de Abstimmungsfreiheit: de besluitvorming van de algemene vergadering mag niet van buitenaf worden beĭnvloed, omdat de aandeelhouder zijn stem dient uit te oefenen in het belang van de gemeenschap waartoe hij als kapitaalverschaffer behoort. 
Kamphuisen pleitte vóór de toelaatbaarheid van stemovereenkomsten. Hij stelde, dat iemand, die als aandeelhouder van een vennootschap in een bijzondere belangengemeenschap met zijn mede-aandeelhouders verenigd is, hun belangen in het bijzonder heeft te ontzien." Wanneer enkele aandeelhouders de rechtmatige belangen van hun mede-aandeelhouders door het sluiten van een stemovereenkomst dermate aantasten, dat de grens van het betamelijke is overschreden, dan is het volgens Kamphuisen denkbaar, dat die overeenkomst daardoor in strijd met de goede zeden is. Dit acht hij echter pas het geval, indien de overeenkomst tot onbetamelijkheid moet leiden, niet reeds als zij daartoe kan leiden. Zijn uitgangspunt was derhalve dat stemovereenkomsten geoorloofd zijn.

Duynstee daarentegen, achtte stemovereenkomsten in het algemeen nietig. Het stemrecht is naar zijn opvatting een recht, dat te goeder trouw moet worden uitgeoefend, omdat het uitbrengen van een stem uitvoering is van de oprichtingsovereenkomst. De goede trouw, die aandeelhouders jegens de vennootschap en elkaar hebben in acht te nemen, brengt zijns inziens met zich mee, dat de aandeelhouders stemmen zoals hun eigen redelijk inzicht in het belang van de vennootschap op het ogenblik der stemming bepaalt."

De Hoge Raad volgde de opvatting van Kamphuisen. In een drietal arresten werd de toelaatbaarheid van stemovereenkomsten in beginsel erkend..$^{10}$

In de zaak Wennex waren de twee oprichters en aandeelhouders van NV Wennex, Wennekes en Van Neck, overeengekomen dat er in het geval van een patstelling gestemd zou worden volgens het bindend advies van een commissie." Toen de stemmen aangaande de benoeming van drie (tijdelijke) commissarissen staakten doordat Wennekes tegen stemde, vorderde Van Neck dat Wennekes werd veroordeeld tot het stemmen vóór de benoeming. De rechtbank wees de vordering toe, waarop het hof de beslissing vernietigde. De Hoge Raad overwoog:

"dat een dergelijke contractuele gebondenheid van een aandeelhouder ten aanzien van zijn in de algemeene vergadering eener N.V. uit te brengen stem, vennootschapsrechtelijk zijn stemrecht volkomen onaangetast laat;

dat toch de aandeelhouder, ondanks deze gebondenheid jegens zijn medecontractant en de rechten die deze bij niet nakoming tegen hem heeft, in de vennootschap

Kamphuisen, NV 1941, blz. 352.

Duynstee, reactie op "Overeenkomsten betreffende het stemrecht in een naamlooze vennootschap". NV 1942, blz. 114 e.v.

10 HR 30 juni 1944, NJ 1944, 465 (Wennex), HR 13 november 1959, NJ 1960, 472 (Distilleerderij Melchers) en HR 19 februari 1960, NJ 1960, 473 (Aurora).

11. HR 30 juni 1944, NJ $1944,465$. 
de macht over de door hem uit te brengen stem behoudt, zoodat hij over de uitoefening van het stemrecht ter algemeene vergadering beslist en de door hèm uitgebrachte stem geldig is, zelfs al is gestemd in strijd met zijn contractueele verplichting;

dat daarom een overeenkomst als bovenstaande bedoeld op zichzelve niet in strijd komt met de wettelijke bepalingen, welke voor de N.V. de bevoegdheid van de aandeelhouders om in de algemeene vergadering stemrecht uit te oefenen en de macht dezer vergadering in de vennootschap regelen;

dat echter ook het feit, dat door deze contractueele gebondenheid de vrije uitoefening van het stemrecht van den aandeelhouder in de algemeene vergadering zijdelings wordt aan banden gelegd, niet zonder meer medebrengt dat een dergelijke overeenkomst met de goede zeden strijdt;

dat toch den aandeelhouders eener N.V. in het hem verleende stemrecht niet een recht in het belang van anderen is toevertrouwd, doch een eigen recht is gegeven om zijn belang in de vennootschap te dienen;

dat dit medebrengt, dat het den aandeelhouder - in overeenstemming met de vrijheid, die hij heeft om van zijn stemrecht in de algemeene vergadering naar goeddunken gebruik te maken, mits dit niet ontaardt in misbruik van recht - ook vrijstaat zich ten aanzien van de uitoefening van zijn stemrecht ter algemeene vergadering contractueel jegens anderen te binden, mits dit niet geschiede op een wijze of onder omstandigheden, waardoor de overeenkomst tot maatschappelijk onbetamelijke gevolgen zou leiden;"

De Hoge Raad beschouwt het stemrecht als een eigen recht van de aandeelhouder, dat hij in beginsel naar eigen goeddunken mag uitoefenen. Uit die vrijheid vloeit voort, dat een aandeelhouder zich contractueel jegens anderen mag binden ten aanzien van de uitoefening van zijn stemrecht. Daarbij makt de Hoge Raad een onderscheid tussen de rechtsgeldigheid van de overeenkomst en de rechtsgeldigheid van de stem. Een stem uitgebracht in strijd met de overeenkomst tast de rechtsgeldigheid van het besluit niet aan. Deze overwegingen vormen de basis voor de principiële erkenning van de stemovereenkomst. De status van de wederpartij, aandeelhouder of derde, acht de Hoge Raad niet van belang. ${ }^{12}$

De toelaatbaarheid van stemovereenkomsten blijkt thans ook indirect uit artikel 2:24a BW, dat als criterium voor een dochtermaatschappij hanteert dat een rechtspersoon "al dan niet krachtens overeenkomst met andere stemgerechtigden, alleen of samen meer dan de helft van de bestuurders of van de commissarissen kunnen benoemen of ontslaan, ook als alle stemgerechtigden stemmen". Ook andere aandeelhoudersovereenkomsten hebben

Vgl. HR 19 februari 1960, NJ 1960, 473 (Aurora). Zie § 7.2.3. 
wettelijke erkenning gekregen, bijvoorbeeld in de vorm van een alternatieve geschillenregeling in de zin van artikel 2:337 BW.

\section{Grenzen aan de uitoefening van het stemrecht}

De principiële erkenning van de stemovereenkomst laat onverlet dat de uitoefening van het stemrecht aan grenzen gebonden is. De argumenten van Petit en Duynstee vinden tot op zekere hoogte nog steeds weerklank bij de vraag naar de grenzen aan de toelaatbaarheid van stemovereenkomsten. Zo wordt gewezen op het collectieve karakter van de besluitvorming als een belemmering voor de toelaatbaarheid van stemovereenkomsten. De aandeelhouder zou als deelgenoot van het vennootschappelijke samenwerkingsverband pas na afweging van alle belangen na voorafgaand beraad ter vergadering zijn keuze dienen te bepalen. ${ }^{3}$ Dortmond hecht aan de veronderstelling dat een besluit als vrucht van onderling overleg tot stand komt daarentegen geen betekenis meer. ${ }^{14}$

Tevens worden kanttekeningen geplaatst bij het uitgangspunt dat het stemrecht een 'eigen recht' van de aandeelhouder is, hem gegeven om zijn belang in de vennootschap te dienen. ${ }^{15} \mathrm{Bij}$ de uitoefening van het stemrecht sluit Van Schilfgaarde niet uit dat de aandeelhouder verplicht wordt geacht dat recht te gebruiken onder afweging van alle bij de vennootschap betrokken belangen, zij het dat bij deze belangenafweging zijn eigen belang een gewichtige rol mag spelen. ${ }^{16}$ Dortmond meent dat een aandeelhouder zich niet behoeft te richten naar het belang van de vennootschap, tenzij de behartiging van zijn eigen belangen in een bepaald geval strijdig zou zijn met de redelijkheid en billijkheid in de zin van artikel 2:8 BW. ${ }^{n}$

De belangenafweging die een aandeelhouder dient te maken bij de uitoefening van zijn stemrecht komt bijvoorbeeld aan de orde in de uitspraak van de rechtbank Assen van 17 december $1993 .{ }^{18}$ In casu wilde de meerderheidsaandeelhouder om fiscale redenen de vennootschap BHE ontbinden, tegen de zin van de minderheidsaandeelhouders. Deze waren bereid de aandelen van de meerderheidsaandeel-

Vgl. in deze richting Van Schilfgaarde, NV 1974, blz. 72, naar aanleiding van het Wijsmullerarrest. Kritisch hierover Dorhout Mees, NV 1974, blz. 104.

Dortmond, 2000, blz. 15

15. Vgl. Cahen, De invloed van de belangenverbreding op het handelen van de aandeelhouder in: Honderd jaar rechtsleven, De Nederlandse Juristenvereniging 1870-1970, 1970, blz. 71 e.v. en Mohr, Hoe schatplichtig is de vennootschap aan het vrije contractenrecht?, in: J.L.P. Cahen bundel, 1997, blz. 217 e.v.

16. Van Schilfgaarde, $\mathrm{nr} .67$

17. Dortmond, 2000, blz 12

18

Vgl. over de belangenafweging van de aandeelhouder ook OK 11 maart 1999, NJ 1999, 351 (Breevast) en OK 29 mei 1999, NJ 2000, 199 (Cromwilld/Versatel). 
houder over te nemen. Zonder te onderhandelen werd een algemene vergadering uitgeroepen, waarin werd voorgesteld tot ontbinding van de vennootschap over te gaan. Hierop vorderden de minderheidsaandeelhouders een stemverbod. Dit werd toegewezen, onder de overweging, dat:

"hoewel een aandeelhouder in beginsel het hem toekomende stemrecht uit mag oefenen in zijn eigen belang, dit niet betekent dat het hem onder alle omstandigheden vrij staat zich uitsluitend te laten leiden door dat eigen belang. Met name mag de aandeelhouder zich niet uitsluitend door zijn eigen belangen laten leiden ten detrimente van de vennootschap als geheel." 19

\section{§7.2.2 Contractuele sancties op niet-nakoming van stemovereenkomsten}

Het door de Hoge Raad gemaakte onderscheid tussen de contractuele gebondenheid en de vennootschapsrechtelijke uitoefening van het stemrecht contrasteert tot op zekere hoogte met de effectieve werking van stemovereenkomsten in de praktijk. Het feit dat schending van de overeenkomst kan leiden tot het betalen van schadevergoeding of een boete zal de aandeelhouder in de regel afhouden van het stemmen in strijd met de overeenkomst. Bovendien kan de wederpartij nakoming van de overeenkomst vorderen, eventueel in kort geding. ${ }^{20} \mathrm{Zo}$ werd in de Wennex-zaak gevorderd dat Wennekes vóór het besluit tot benoeming van drie commissarissen zou stemmen, conform de overeenkomst. ${ }^{21}$ Een aandeelhoudersovereenkomst heeft derhalve wel degelijk invloed op de vennootschappelijke verhoudingen, ondanks het juridische onderscheid tussen de uitoefening van het stemrecht en de contractuele gebondenheid.

Nakoming van de stemovereenkomst kan echter niet steeds worden afgedwongen. Uiteraard is een aandeelhouder niet verplicht te stemmen conform een nietige overeenkomst. Desalniettemin is een op basis van een nietige overeenkomst uitgebrachte stem in beginsel geldig. Indien een aandeelhouder meent dat nakoming van de overeenkomst in strijd zou zijn met zijn vennootschappelijke verplichtingen, kan hij zich volgens Maeijer beroepen op art. 6:248 lid $2 \mathrm{BW}$, in de zin dat onder de gegeven omstandigheden nakoming naar maatstaven van redelijkheid en billijkheid onaanvaardbaar zou zijn. Dit is bijvoorbeeld het geval indien het besluit nietig of vernietigbaar zou zijn. ${ }^{22}$ De redelijkheid en billijkheid van artikel 6:248 lid

Rb Assen, 17 december 1993, KG 1994, 90.

Vgl, Van Schilfgaarde, nr. 67. Asser-Maeijer 2-III, nr. 289. Zie ook Waaijer, Aandeelhoudersovereenkomsten, 1996, blz. 30 e.v.

HR 30 juni 1944, NJ 1944, 465.

Asser-Maeijer 2-III, nr. 289. 
$2 \mathrm{BW}$ wordt dan ingekleurd door de redelijkheid en billijkheid in de zin van artikel 2:8 BW."

Een voorbeeld biedt een uitspraak van de rechtbank Alkmaar van 15 december 1976. Vier drukkerijen houden tezamen vrijwel alle aandelen in de BV Verenigde Noordhollandse Dagbladen (hierna: VND). Drie van de vier aandeelhouders hebben een voorvergader-overeenkomst gesloten met een boeteclausule. VND staat op het punt te voldoen aan de criteria voor het doen van opgaaf in de zin van art. 2:263 BW. In de voorvergadering wordt met twee tegen één besloten in de algemene vergadering vóór het voorstel te stemmen om ten laste van de algemene reserves aan aandeelhouders een dividend ter beschikking te stellen van vijf miljoen gulden onder gelijktijdige teruglening van dit bedrag als crediteur aan de vennootschap. Voordat de algemene vergadering werd gehouden vordert tegenstemmer Coster in kort geding een verbod om een dergelijk besluit te nemen en een verbod om hem tot nakoming van de overeenkomst te dwingen. De rechtbank overweegt:

"Het door middel van het concept-besluit (langer) houden van VND als besloten vennootschap buiten de potentiële kring van structuurvennootschappen is (...) in redelijkheid niet verantwoord door enig vennootschapsbelang of belang van de onderneming in ruime zin en valt als dienend tot verijdeling van de werking van dwingendrechtelijke bepalingen dan ook te beschouwen als wetsontduiking. De onderhavige wetsontduiking (...) is naar Ons voorlopig oordeel nietig als in strijd met de goede zeden en in strijd met het dwingend recht. (...) Een en ander impliceert, dat Coster niet te goeder trouw gehouden kan worden aan zijn verplichting krachtens de geciteerde stemovereenkomst om te stemmen voor het omstreden voorstel/concept-besluit." ${ }^{24}$

Ingeval nakoming wordt gevorderd, is het de rechter die de contractuele gebondenheid afweegt tegen de vennootschappelijke besluitvorming. Indien de inhoud van het besluit in strijd is met de wet, de statuten of de redelijkheid en billijkheid zal de vordering niet worden gehonoreerd.

\section{$\S$ 7.2.3 Grenzen aan aandeelhoudersovereenkomsten}

Aan de vrijheid van aandeelhouders om overeenkomsten te sluiten worden grenzen gesteld door artikel 3:40 BW: strijd met de openbare orde, de goede zeden of een dwingende wetsbepaling die strekt tot de nietigheid van de betreffende overeenkomst. De Hoge Raad heeft in het Wennex-arrest

\footnotetext{
23

Vgl. ook Hof Amsterdam, 25 april 2002, JOR 2002, nr. 128 (Gorillapark) en OK 15 november 2001, JOR 2002, nr. 6 (Decidewise).

24 Rb Alkmaar 15 december 1976, NJ 1978, 319.
} 
grenzen aan de toelaatbaarheid van stemovereenkomsten gesteld, daar waar de overeenkomst tot "maatschappelijk onbetamelijke gevolgen" zou leiden. In de latere jurisprudentie is deze overweging niet herhaald, noch zijn concrete onbetamelijke gevolgen vastgesteld.

Sommige auteurs stellen in het algemeen dat stemovereenkomsten in strijd met dwingend vennootschapsrecht nietig zijn. ${ }^{3}$ Volgens Timmerman kan de dwingende aard van vennootschapsrechtelijke regels meebrengen dat het niet mogelijk geacht moet worden om bij overeenkomst af te wijken van de desbetreffende regels. ${ }^{3.6}$ Sanders/Westbroek achten daarentegen een stemovereenkomst die dwingende wetsbepalingen terzijde stelt niet per se ongeoorloofd. De enkele omstandigheid, dat dwingende wetsbepalingen niet meer "aan de orde komen", levert huns inziens geen strijd met de openbare orde en de goede zeden op. ${ }^{27}$ Niet geheel duidelijk is wat zij hiermee bedoelen.

Buijn makt een onderscheid tussen de verhouding van aandeelhouders ten opzichte van de vennootschap en die ten opzichte van medeaandeelhouders en derden. Terwijl aandeelhouders zijns inziens contractueel "niet kunnen komen" tot een resultaat dat in de verhouding ten opzichte van de vennootschap verboden wordt door de wet en de statuten, met name niet indien die contractuele relatie ingrijpt in de interne verhoudingen binnen de vennootschap, acht hij dit anders ten aanzien van de uitoefening van de rechten die voortvloeien uit het aandeelhouderschap. De uitoefening van die rechten raakt volgens hem in beginsel de rechten van derden niet. $^{28}$

\section{Eigen opvatting}

Doordat de principiële rechtsgeldigheid van de stemovereenkomst is gemotiveerd met het onderscheid tussen de contractuele gebondenheid en de vennootschappelijke uitoefening van het stemrecht, speelt artikel 2:25 BW geen rol bij de beoordeling van de rechtsgeldigheid van de stemovereenkomst. De grenzen aan aandeelhoudersovereenkomsten worden derhalve uitsluitend bepaald door artikel 3:40 BW.

Op grond van artikel 3:40 lid 2 BW zijn aandeelhoudersovereenkomsten in strijd met dwingende wettelijke bepalingen nietig. Bepalingen, die

25 Hendriks-Jansen, NV 1982, blz. 9. Blanco Fernández, "Vennootschapsrechtelijke werking van stemovereenkomsten", Ondernemingsrecht 1999, blz. 150.

Timmerman, Waarom hebben wij dwingend vennootschapsrecht? in: Ondernemingsrechtelijke Contracten, uitgave van het Instituut voor Ondernemingsrecht deel 14, 1991, blz. I.

Sanders/Westbroek, blz. 128.

Buijn, "Statuten: terug naar de overeenkomst?", Ondernemingsrecht 1999, blz. 122. 
uitdrukkelijk een aandeelhoudersovereenkomst verbieden, kent boek $2 \mathrm{BW}$ niet. Een aandeelhoudersovereenkomst is nietig, indien in strijd met de openbare orde of de goede zeden, of indien de strekking van een bepaling de nietigheid met zich meebrengt. Er treedt een paradoxale spanning op tussen enerzijds de erkenning van de stemovereenkomst, gebaseerd op het onderscheid tussen stem en overeenkomst, en anderzijds de grenzen aan stemovereenkomsten vanwege de feitelijke invloed van de overeenkomst op de stem (de gevolgen van de overeenkomst). Consistent zou zijn, om ofwel uitsluitend het onderscheid tussen contractuele binding en vennootschappelijke uitoefening van aandeelhoudersrechten in aanmerking te nemen, hetgeen uitsluitend het aangaan van overeenkomsten die in strijd zijn met de openbare orde of de goede zeden zou verbieden, ofwel steeds ook de gevolgen van de overeenkomst op de uitoefening van de rechten, maar dan zou de motivering van het juridische onderscheid tussen stem en overeenkomst niet volstaan om de rechtsgeldigheid van de stemovereenkomst aan te nemen. Waarom wordt er dan zowel aan het onderscheid als aan de gevolgen gerefereerd?

Ik doe een poging om deze paradoxale spanning op te heffen. Het juridische onderscheid tussen stem en overeenkomst bewerkstelligt dat slechts de aandeelhouders gebonden zijn aan de overeenkomst en niet de vennootschap. Door het onderscheid wordt duidelijk dat aandeelhouders in beginsel het recht hebben de rechten en bevoegdheden die voortvloeien uit het aandeelhouderschap 'op maat' te maken, zolang het 'op maat maken' niet betekent dat latere aandeelhouders daaraan gebonden zijn. Dit vormt de grondslag voor het onderscheid tussen statutaire en contractuele regelingen. De gevolgen van de overeenkomst worden wel in aanmerking genomen, maar worden niet a priori "maatschappelijk onbetamelijk" geacht.

Wanneer leiden op maat gemaakte rechten en bevoegdheden wel tot "maatschappelijk onbetamelijke gevolgen"? Dit dient te worden bepaald aan de hand van artikel 3:40 BW. "Maatschappelijk onbetamelijk" is derhalve een overeenkomst waarvan de inhoud in strijd is met de openbare orde of de goede zeden, of waarvan het gevolg in strijd is met een dwingende wetsbepaling. Het gevolg van een overeenkomst is "maatschappelijk onbetamelijk", indien uit de strekking van een dwingende wetsbepaling grenzen voortvloeien waaraan aandeelhouders zijn gebonden bij het op maat maken van hun rechten en bevoegdheden. Deze grenzen zijn dwingend c.q. van openbare orde.

Zoals reeds betoogd in hoofdstuk 3, dient dwingende aard van het vennootschapsrecht er naar mijn mening in de eerste plaats toe om andere belanghebbenden dan partijen bij de rechtshandeling te beschermen, zoals crediteuren en toekomstige aandeelhouders. Indien partijen zelf willen 
afzien van bescherming, staat hen dat in beginsel vrij, tenzij de overeenkomst in strijd is met de vennootschappelijke orde, in de zin een individuele aandeelhouder geen enkele juridische mogelijkheid meer heeft om invloed uit te oefenen in de vennootschap en de algemene vergadering geen mogelijkheid meer heeft toezicht uit te oefenen op het bestuur. Naar mijn mening dient voor de besloten vennootschap een dergelijk minimum aan machtsevenwicht gewaarborgd te zijn, dat in de volgende voorbeelden nader wordt geconcretiseerd.

\section{'Stemmenkoop'}

Hoewel aandeelhoudersovereenkomsten, zoals vermeld, niet uitdrukkelijk worden verboden, is naar vrijwel algemene opvatting een overeenkomst waarbij de aandeelhouder zijn stem 'verkoopt' voor bijzondere financiële of materiële voordelen, nietig. Een dergelijke overeenkomst wordt in strijd met de goede zeden geacht, omdat de aandeelhouder op deze wijze zijn stemrecht tot bron van inkomsten maakt. ${ }^{29}$ Daarmee zou het rechtskarakter van het stemrecht worden aangetast ${ }^{30}$ doordat het stemrecht haar onzelfstandigheid verliest. ${ }^{31}$

De Kluiver schetst daarentegen ook de voordelen van dergelijke overeenkomsten, doordat deze de financiering van vennootschappen zouden vergemakkelijken en zouden bijdragen aan een snellere en goedkopere besluitvorming. Een concentratie van feitelijke zeggenschap zou er echter toe kunnen leiden dat bepaalde personen speciale voordelen verkrijgen, waarvoor geen economische rechtvaardiging bestaat, bijvoorbeeld het sluiten van lucratieve overeenkomsten tussen de vennootschap en de instructiegever. Is dit het geval, dan acht De Kluiver de stemovereenkomst nietig. ${ }^{32}$

Het is moeilijk vast te stellen wanneer er sprake is van het 'kopen' van een stem. Een aandeelhouder die een stemovereenkomst met een derde sluit zal steeds daaraan voordeel denken te ontlenen. Achterliggende gedachte bij het verbieden van 'stemmenkoop' in ruime zin lijkt te zijn dat stemovereenkomsten in beginsel wederkerig dienen te zijn, d.w.z. dat alle partijen

Van der Grinten, AA 1959, blz. 59. Brenninkmeijer, 1973, blz. 164. Maeijer, 1976, blz. 96. Hendriks-Jansen, NV 1982, blz. 9. Sanders/Westbroek, blz. 127. Van Schilfgaarde, nr. 67. AsserMaeijer, 2-III, nr. 288.

Van der Grinten, AA 1959, blz. 59.

Brenninkmeijer, 1973, blz. 139.

De Kluiver, AA 1995, blz 434, 441. Eveneens genuanceerd Koelemeijer, Redelijkheid en billijkheid in kapitaalvennootschappen, 1999, blz. 140. 
zich tot dezelfde prestatie verbinden. Dit plaatst instructie-overeenkomsten met derden in een verdachte hoek. ${ }^{3 \prime}$

Een algemeen verbod van 'stemmenkoop' zou erop neerkomen dat ook een instructie-overeenkomst met een derde, die een concreet geval behelst, ongeoorloofd wordt geacht indien de derde de aandeelhouder bijzondere financiële of materiële voordelen in het vooruitzicht stelt in ruil voor het stemmen naar zijn instructie. In het Aurora-arrest, waar de aandeelhouders zich hadden verbonden om overeenkomstig de instructies van Aurora te stemmen in ruil voor het kopen van de aandelen, overwoog de Hoge Raad "dat het Hof heeft vastgesteld, dat ten tijde van het sluiten van de optiecontracten kon worden aangenomen, dat bedoelde overdracht vermoedelijk een voor Olva voordelige transactie zou zijn." Voorwaarde voor de geldigheid van een dergelijke instructie-overeenkomst lijkt te zijn dat deze mede in het belang van de vennootschap is. Naar mijn mening moet het verbod van 'stemmenkoop' dan ook worden beperkt tot die gevallen, waarin sprake is van omkoping. Een aanwijzing voor omkoping doet zich voor indien een aandeelhouder zijn eigen - financiële - belang ten koste van het belang van de vennootschap laat prevaleren.

\section{Instructie-overeenkomst met bestuurder}

Een overeenkomst waarbij een aandeelhouder zich verplicht te stemmen volgens de instructies van het bestuur of de raad van commissarissen wordt ongeoorloofd geacht. ${ }^{35}$ Als redenen hiervoor worden gegeven dat een dergelijke overeenkomst in strijd is met het dualistisch karakter van de vennootschap, ${ }^{36}$ waartoe de scheiding tussen de aandeelhouders- en bestuurdersfunctie behoort, ${ }^{37}$ of in strijd is met de vennootschappelijke orde,$^{38}$ omdat deze zou leiden tot een verstoring van het door de wet beoogde evenwicht tussen de organen." Met het dualistisch karakter van de vennootschap wordt bedoeld de 'machtenscheiding' tussen het bestuur van de vennootschap enerzijds en het toezicht op het bestuur door algemene vergadering of raad van commissarissen anderzijds. De machtenscheiding dient zodanig te zijn, dat tussen de organen een 'machtsevenwicht' bestaat. ${ }^{40}$

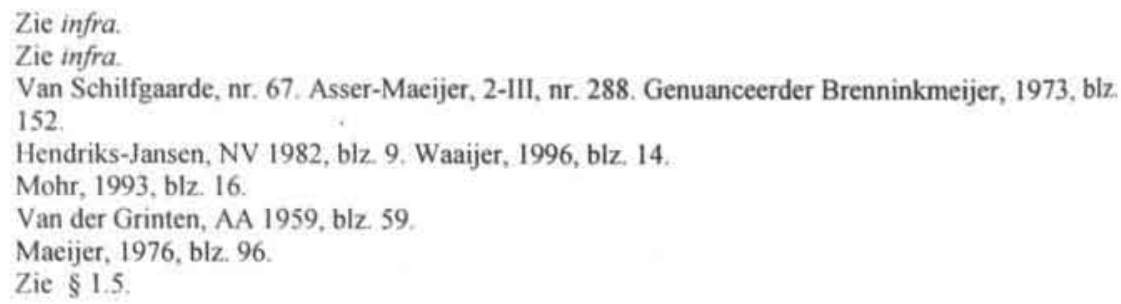


Terwijl aandeelhouders in beursgenoteerde vennootschappen wellicht bescherming behoeven tegen stemovereenkomsten met bestuurders, moeten andeelhouders in besloten vennootschappen naar mijn mening in principe in staat worden geacht zelf te kunnen beoordelen of een stemovereenkomst om op aanwijzing van het bestuur te stemmen in hun eigen belang is. Ik meen dat stemovereenkomsten tussen aandeelhouders en bestuurders niet per definitie nadelig zijn voor de vennootschap. Bestuurders zouden echter geen instructies mogen geven over besluiten waarbij zij een tegenstrijdig belang hebben, zoals hun herbenoeming, décharge of ontslag. ${ }^{.1}$

\section{Instructie-overeenkomst}

Algemeen wordt aangenomen dat het stemrecht niet los kan worden overgedragen van het aandeel. ${ }^{2}$ Dit vloeit voort uit de strekking van artikel 2:228 lid $1 \mathrm{BW}$. Sommige auteurs menen dat stemovereenkomsten ongeoorloofd zijn, wanneer het effect van de overeenkomst is dat een ander dan de aandeelhouder feitelijk de zeggenschap uitoefent. Een overeenkomst waarbij de aandeelhouder zich in het algemeen voor een langere periode verbindt om volgens de instructies van een ander te stemmen, zou volgens Maeijer neerkomen op een vervreemding van het stemrecht en derhalve nietig zijn. Dit leidt hij a contrario af uit het Aurora-arrest. ${ }^{43}$

In deze zaak wilde levensverzekeringsmaatschappij Aurora de branchegenoot Olva overnemen en bood daartoe $150 \%$ van de toenmalige koers. De meerderheid van de aandeelhouders van Olva had met Aurora een optie-overeenkomst gesloten, waarbij de aandeelhouders zich hadden verbonden, ingeval het bestuur of de raad van commissarissen van Olva niet aan het onderzoek van de boekhouding van Olva wilde meewerken, andere bestuurders of commissarissen te benoemen. Vervolgens bood levensverzekeringsmaatschappij Utrecht $200 \%$ van de koers. De aandeelhouders gingen op het tweede bod in. Aurora klaagde daarop de aandeelhouders aan wegens wanprestatie. Deze verweerden zich door de nietigheid van de optie-overeenkomst in te roepen. Wederom herhaalde de Hoge Raad de overweging dat het stemrecht een eigen recht is van de aandeelhouder en dat de enkele omstandigheid

4Vgl. $\$ 47$ Abs. 4 GmbHG: Ein Gesellschafter, welcher durch die BeschluBfassung entlastet oder von einer Verbindlichkeit befreit werden soll, hat hierbei kein Stimmrecht und darf ein solches auch nicht für andere ausuben. Dasselbe gilt von einer BeschluBfassung, welche die Vornahme cines Rechtsgeschăfts oder die Einleitung oder Erledigung eines Rechtsstreites gegenuber einem Gesellschafter betrifft.

42 Zie $\$ 3.2 .1$.

43 Asser-Maeijer 2-III, nr. 288. Zo ook Van Schilfgaarde, nr. 67. Hendriks-Jansen, "Stemovereenkomsten", NV 1982, blz. 10. In het Distilleerderij-Melchers-arrest heeft de Hoge Raad daarentegen uitgemaakt dat het geen verschil maakt, voor welke duur een aandeelhouder zich mocht hebben verbonden. 
dat hij anders zou hebben gestemd zonder binding, die overeenkomst niet onbetamelijk doet zijn;

"dat dit niet enkel geldt voor het recht van den aandeelhouder om zijn stem over enig besluit uit te brengen, maar ook voor de rechten welke het hem mogelijk maken stemming over enig besluit te verkrijgen; dat het vorenomschrevene evenzeer geldt met betrekking tot de uitoefening van de rechten van den aandeelhouder ten aanzien van benoeming en ontslag van commissarissen; dat bij de onderhavige bedingen de optiegevers niet zich in het algemeen jegens Aurora hebben verbonden hun stemrecht uit te oefenen tot vervanging van de commissarissen van Olva, maar uitsluitend tot vervanging voor het geval, dat het onderzoek, dat aan de overdracht der aandelen vooraf moest gaan, en de overdracht zelve bij de in functie zijnde commissarissen op tegenstand mocht stuiten; dat het Hof heeft vastgesteld, dat ten tijde van het sluiten van de optiecontracten kon worden aangenomen, dat bedoelde overdracht vermoedelijk een voor Olva voordelige transactie zou zijn; dat onder deze omstandigheden - wat er zij van hetgeen (...) omtrent de eisen van redelijkheid en goede trouw met betrekking tot het nemen van een besluit tot ontslag van commissarissen in het algemeen wordt gesteld - de onderhavige bedingen voor de aandeelhouders geen verdergaande verplichtingen inhielden dan zij vrij waren op zich te nemen;"

Terwijl Maeijer de nadruk legt op de gevolgen van de stemovereenkomst, stelt Waaijer het juridische onderscheid tussen stem en overeenkomst voorop. Hij betoogt dat een stemovereenkomst onverlet laat dat het stemrecht onlosmakelijk is verbonden met het aandeel. Het feit dat vervreemding van het stemrecht goederenrechtelijk ongeoorloofd is, hoeft zijns inziens nog niet te betekenen dat dit verbintenisrechtelijk evenzeer het geval is. Het stemrecht wordt immers hoe dan ook uitgeoefend door de aandeelhouder, en niet door degene van wie hij zijn instructies ontvangt. ${ }^{45}$

Achterliggende gedachte bij de bezwaren tegen het indirect toekennen van invloed aan een derde lijkt te zijn dat een aandeelhouder het beste in staat wordt geacht het belang van de vennootschap te waarborgen, aangezien hij door zijn deelname in het kapitaal van de vennootschap risico loopt. Aan een derde die een dergelijk risico niet loopt, zou derhalve niet teveel invloed mogen worden verschaft, tenzij deze deel uitmaakt van een orgaan en uit dien hoofde het belang van de vennootschap heeft te respecteren. Het verbod van vervreemding van stemrecht strekt zich in deze optiek uit over contractuele bindingen die hetzelfde effect bereiken. De vraag is dan wanneer het onderscheid tussen de contractuele binding en de 
vennootschapsrechtelijke uitoefening van het stemrecht zodanig vervaagt dat een loskoppeling van het stemrecht en het aandeel wordt benaderd. Dit is mijns inziens eerst het geval indien de stemovereenkomst voor onbepaalde tijd voor alle besluiten geldt en niet opzegbaar is.

Naast het bezwaar van de materiële vervreemding van het stemrecht bestaat er tegen algemene instructie-overeenkomsten voor langere duur een ander bezwaar, namelijk dat zij het de aandeelhouder bij voorbaat onmogelijk zouden maken tot een zelfstandige oordeelsvorming te komen. ${ }^{46}$ Maeijer meent dat een stemovereenkomst nietig is, indien deze bij voorbaat een belangenafweging van de aandeelhouder tussen zijn eigen belang en het belang van de vennootschap onmogelijk maakt." Zo beperkt hij de geoorloofdheid van een instructie-overeenkomst tot het concrete geval uit bijvoorbeeld het Aurora-arrest, de zgn. vote anticipé. ${ }^{8}$ Ook Van Schilfgaarde beschouwt een stemovereenkomst, die de betrokkenen iedere mogelijkheid tot zelfstandige belangenafweging op grond van ter vergadering of daarvóór te verkrijgen informatie ontneemt, als strijdig met het vennootschapsrecht. ${ }^{49}$ In deze bezwaren klinken wederom Petit en Duynstee door..$^{50}$

De moeilijkheid is om te bepalen wanneer een aandeelhouder nog in staat is om zelfstandig een oordeel te vormen. Mijns inziens zijn aandeelhouders vrij zich te binden om overeenkomstig de instructies van een ander te stemmen, voor zover de gevolgen van de overeenkomst overzienbaar zijn. Dit betekent dat de instructie gekoppeld moet zijn aan bepaalde categorieën transacties of beperkt in tijd..$^{\text {st }}$

\section{Instructie-overeenkomst en blokkeringsregeling}

Een complicerende factor doet zich voor, indien een instructie-overeenkomst is gesloten, terwijl een blokkeringsregeling van kracht is. Een dergelijke overeenkomst zou ertoe strekken de wettelijke blokkeringsregeling te frustreren..$^{52}$ Maeijer acht een contractuele regeling, waarbij de be-

Maeijer, AA 1969, blz. 345. Maeijer, Het belangenconflict in de naamloze vennootschap, 1964 , blz. 17. Asser-Maeijer 2-III, nr. 288. Zo ook Hendriks-Jansen, NV 1982, blz. 8.

47 Maeijer, De stemovereenkomst van aandeelhouders, in: Recht zo die gaat, opstellen aangeboden aan prof. mr. P.W. van der Ploeg, 1976, blz. 100, verwijzend naar zijn oratie, blz. 17.

Asser-Maeijer 2-III, nr. 288.

Van Schilfgaarde, nr. 67.

Zie $\$ 7.2 .1$.

Zie ook $\$ 3.2 .2$.

Hendriks-Jansen, NV 1982, blz. 10. Wachter, Blokkeringsclausules en stemrecht, in: Verzekering van vriendschap, rechtsgeleerde opstellen aangeboden aan prof. mr. T.J. Dorhout Mees, 1974, blz. 236. Van Schilfgaarde, WPNR 1994, blz. 213. 
oogde beslotenheid van de vennootschap wezenlijk wordt ondermijnd en gefrustreerd, ongeoorloofd." Waaijer maakt een onderscheid al naar gelang het type blokkeringsregeling. Is er sprake van een vrije kring, dan acht hij stemovereenkomsten met instructies binnen die kring geldig. In geval van een aanbiedingsregeling zijn stemovereenkomsten met instructiebevoegdheid naar zijn mening ongeoorloofd. Bij een goedkeuringsregeling hangt er het zijns inziens vanaf of de stemovereenkomst de door de aandeelhouders gewilde machtsverhoudingen doorbreekt." ${ }^{4}$

Dortmond meent daarentegen dat het al dan niet bestaan van een blokkeringsregeling voor de geldigheid van de stemovereenkomst niet relevant is, omdat een blokkeringsregeling zijns inziens niet wil belemmeren dat een aandeelhouder zijn eigen recht - zonder dat te vervreemden - zodanig uitoefent of aanwendt als hij dienstig oordeelt."s

De afweging is dan of de strekking van artikel 2:195 BW zich beperkt tot het blokkeren de overdracht van een aandeel, of dat de bepaling zich tevens uitstrekt over contractuele bindingen. Achterliggende gedachte van het verplichte karakter van de blokkeringsregeling is het waarborgen van het besloten karakter van het samenwerkingsverband, waardoor de besloten vennootschap zich onderscheidt van de naamloze vennootschap. ${ }^{66}$ Dit is een overweging van de wetgever, niet noodzakelijkerwijze van de oprichters/ aandeelhouders van een BV. Mijns inziens moet het verplichte karakter van de blokkeringsregeling dan ook niet zo ruim worden geïnterpreteerd, dat deze ook aan contractuele bindingen van aandeelhouders in de weg zou staan. Ook in een besloten vennootschap mag een aandeelhouder naar mijn mening zich in beginsel vrijelijk verbinden over de uitoefening van zijn stemrecht. Wel acht ik een instructie-overeenkomst nietig, indien deze is gesloten met als enige doel de blokkeringsregeling te ontduiken.

\section{Overeenkomst strekkende tot de benoeming van 'eigen' bestuurders}

Met name in joint-venture-verhoudingen bestaat de behoefte te bewerkstelligen dat iedere aandeelhouder een bestuurder benoemt. Dit kan geschieden door in de joint-venture-overeenkomst op te nemen dat de aandeelhouders zich verbinden steeds vóór de in de bindende voordracht voorgestelde kandidaat te stemmen. Bij sommige auteurs stuit dit op bezwaren. De overeenkomst zou de ter wille van het evenwicht gegeven

Waaijer, 1996, blz. 17.

Dortmond, 2000 , blz. 18

5. Zie Schwarz, Blokkering van aandelen, 1986. 
regels inzake de doorbreking van de bindende voordracht te frustreren. ${ }^{37}$ Dortmond stelt daarentegen dat de aandeelhouders met het sluiten van de overeenkomst bewust afstand doen van de mogelijkheid de bindende voordracht te doorbreken. ${ }^{58}$ In navolging van Dortmond meent nu ook Van Schilfgaarde dat een dergelijke overeenkomst rechtsgeldig is, gelet op artikel 2:24a BW.59

Met een dergelijke overeenkomst zien de aandeelhouders af van het uitoefenen van hun stemrecht ten aanzien van besluiten ter doorbreking van de bindende voordracht. De vraag naar de geoorloofdheid van een dergelijke overeenkomst hangt af van de strekking van artikel 2:243 BW. Vormt de bepaling een essentiële voorwaarde voor het machtsevenwicht in de vennootschap, of is deze dwingend, teneinde later toetredende aandeelhouders te beschermen door hun rechten niet te zeer in te perken?

Mijns inziens is de gedachte achter artikel 2:243 BW dat de algemene vergadering steeds vrij moet kunnen zijn de door een meerderheid van twee derde van het aantal stemmen gewilde bestuurders te benoemen, in plaats van de bestuurder die wordt voorgedragen. ${ }^{60}$ Het machtsevenwicht in de vennootschap wordt naar mijn mening niet zodanig aangetast, dat de algemene vergadering onvoldoende middelen heeft om toezicht uit te oefenen op het bestuur, indien aandeelhouders overeenkomen dat zij zullen instemmen met de voorgedragen kandidaten. De algemene vergadering kan de betreffende bestuurder immers steeds ontslaan of weigeren de jaarrekening vast te stellen. Ratio van het dwingende karakter van de bepaling is mijns inziens gelegen in de bescherming van toekomstige aandeelhouders, zodat deze een bindende voordracht wel kunnen doorbreken. ${ }^{61}$

\section{Overeenkomst strekkende tot het niet uitoefenen van bevoegdheden van de algemene vergadering}

De vraag rijst of een aandeelhoudersovereenkomst waarin is bepaald dat geen nieuwe aandelen worden uitgeven, of geen wijziging van de statuten wordt voorgesteld, geoorloofd is. In zekere zin zien aandeelhouders in dat geval af van het uitoefenen van hun stemrecht voor deze categorieën besluiten. Is een dergelijke overeenkomst in strijd met de vennootschappelijke

Asser-Maeijer 2-III, nr, 288. Brenninkmeijer, 1973, blz. 161. Hendriks-Jansen, NV 1982, blz. 10. Dortmond, 2000, blz. 10. Zo ook De Kluiver, "De ondernemingsrechtelijke contractspraktijk: onderhandelen in de schaduw van de wet", Tijdschrift Contracteren 2001, $\$ 2.1$.

Van Schilfgaarde, nr. 67. Zo ook Sanders/Westbroek, blz. 128. Overigens is ook Maeijer coulanter geworden ten opzichte van joint venture-overeenkomsten".

Vgl. $\$ 6.2 .4$.

Zie ook $\$ 3.2 .2$. 
orde, of is het doel van het toekennen van de bevoegdheid aan de algemene vergadering veeleer de bescherming van toekomstige aandeelhouders?

Het effect van een dergelijke overeenkomst is dat de vennootschap zich voor een bepaalde periode vastlegt ten aanzien van de inhoud van haar statuten en/of haar aandelenkapitaal, omdat de algemene vergadering niet langer deze bevoegdheden uitoefent. De ontwikkeling van de vennootschap stokt derhalve in deze opzichten. Naar mijn mening zijn het echter in beginsel de aandeelhouders die de mate van ontwikkeling van de vennootschap bepalen, en zijn zij vrij om zich vast te leggen om bovenstaande bevoegdheden niet uit te oefenen. Zouden deze beperkingen in de statuten worden neergelegd, dan zouden ook later toetredende aandeelhouders hieraan worden gebonden. Dit mag niet. Overigens mogen de statuten wel bepalen dat alle aandeelhouders dienen in te stemmen met een statutenwijziging of een emissie.

Aandeelhouders mogen mijns inziens niet overeenkomen om geen nieuwe bestuurders te benoemen of de jaarrekening niet vast te stellen. Deze bevoegdheden zijn wettelijke geboden, waaraan aandeelhouders zich niet kunnen onttrekken. Een overeenkomst waarbij aandeelhouders afspreken steeds vóór de décharge van het bestuur te stemmen, of steeds de jaarrekening goed te keuren, acht ik eveneens in strijd met de vennootschappelijke orde, omdat aandeelhouders zich op deze wijze verbinden om geen toezicht meer uit te oefenen.

Mogen aandeelhouders overeenkomen dat geen van hen als bestuurder zal worden ontslagen? De vraag is dan of artikel 2:244 BW van openbare orde is, of dat met name de bescherming van toekomstige aandeelhouders wordt beoogd. Een dergelijke overeenkomst beschermt minderheidsaandeelhouders in hun hoedanigheid als bestuurder, maar kan leiden tot patstellingen in het bestuur. Mijns inziens dient het belang van de vennootschap in dit geval te prevaleren, in zoverre dat een bestuurder steeds wegens een gegronde reden moet kunnen worden ontslagen. Een minderheidsaandeelhouder die is ontslagen als bestuurder kan eventueel om uittreding verzoeken.

\section{Overeenkomst strekkende tot het niet overdragen van aandelen}

Den Boogert twijfelt over de geldigheid van een contractuele bepaling waarin de overdracht van aandelen in een joint-venture-vennootschap voor onbepaalde tijd niet is toegestaan, gegeven het wettelijk uitgangspunt dat aandelen vrij overdraagbaar zijn. ${ }^{62}$ Artikel 2:195 lid 8 BW bepaalt immers

Den Boogert, "Aanpassing van boek 2 BW voor joint-venture-doeleinden?, AA 1995, blz. 359. 
dat beperking van de overdraagbaarheid van aandelen niet zodanig kan geschieden, dat die overdraagbaarheid onmogelijk of uiterst bezwaarlijk wordt gemaakt.

Naar mijn mening ziet de wet uitsluitend op statutaire beperkingen van de overdraagbaarheid. Aandeelhouders mogen zichzelf binden de aandelen niet over te dragen gedurende een bepaalde tijd. Dit laat onverlet dat aandeelhouders hun aandelen - in strijd met de overeenkomst - kunnen overdragen. Bovendien kan een aandeelhouder uit de vennootschap treden, indien het voortduren van zijn aandeelhouderschap niet langer in redelijkheid van hem kan worden gevergd.

\section{Overeenkomst strekkende tot verplichte overdracht c.q. overname van aandelen}

In $\S 5.2 .4$ is aan de orde geweest in hoeverre de statuten aandeelhouders de verplichting mogen opleggen hun aandelen over te dragen of over te nemen. Ik heb uiteengezet dat ik dergelijke verplichtingen toelaatbaar acht, voor zover alle aandeelhouders ermee hebben ingestemd en deze nauwkeurig in de statuten zijn omschreven. Naar mijn mening geldt het bepaalbaarheidsvereiste ook voor contractuele overdrachtsverplichtingen. Een aandeelhouder mag mijns inziens niet bij overeenkomst de beslissing wanneer tot overdracht wordt overgegaan aan een derde overlaten, omdat hij het voortduren van zijn aandeelhouderschap op deze wijze afhankelijk zou stellen van de willekeur van een ander en daardoor niet voldoende in staat zou zijn zelfstandig te oordelen. Ik meen dat dit anders is voor contractuele overnameverplichtingen. Een aandeelhouder moet zelf in staat worden geacht een afweging te maken onder welke omstandigheden hij zich wil verplichten andere aandelen over te nemen.

Aandeelhouders mogen evenmin overeenkomen dat zij aan bij een vennootschapsorgaan gestelde eisen moeten voldoen. Aan de eisen zullen in het algemeen tegelijkertijd sancties zijn gekoppeld ingeval aandeelhouders er niet aan voldoen. Het is mijns inziens niet aanvaardbaar dat aandeelhouders zich onderwerpen aan sancties waarvan zij de grondslag niet kennen, zelfs al doen zij dat willens en wetens.

Een voorbeeld van een contractuele regeling met eisen en verplichtingen biedt HR 31 december 1993, NJ 1994, 436 (Verenigde Bootlieden). Alle aandeelhouders van de vennootschap waren in een intentieverklaring overeengekomen dat aandeelhouders die werden ontslagen als werknemer, verplicht waren hun aandelen over te dragen. Het hof achtte een dergelijke overeenkomst niet in strijd met artikel 2:195 lid 7 (thans lid 8) BW, want 
"[d]e strakkere voorwaarden hebben geen ander doel dan extra zekerheid te creëren dat de aandelen niet in verkeerde handen komen. Dat doel is gelet op de achtergrond ten volle gerechtvaardigd en met dat doel hebben de aandeelhouders, onder wie Van den Berge (de eiser in kwestie, MM), zich destijds ook verenigd. De beperkingen zijn onder die omstandigheden geen onnodig of onredelijk bezwarende beperkingen. Mitsdien acht het hof onvoldoende gronden aanwezig van schending van art. 195. Daarbij weegt mee dat dat artikel er juist toe strekt het binnen bepaalde grenzen mogelijk te maken de verhandelbaarheid van de aandelen in de BV te beperken."

\section{Overeenkomst strekkende tot vrije overdracht van aandelen}

Artikel 2:195 BW verplicht naar mijn mening uitsluitend de vennootschap om een blokkeringsregeling in haar statuten op te nemen, maar verbiedt aandeelhouders niet om overeen te komen hun aandelen vrij aan te bieden en over te dragen.

Grenzen aan aandeelhoudersovereenkomsten in verband met de positie van minderheidsaandeelhouders

Hoewel de gevolgen van een aandeelhoudersovereenkomst zodanig maatschappelijk onbetamelijk kunnen zijn, dat dit leidt tot de nietigheid ervan, kunnen deze gevolgen ook met zich meebrengen dat de uitoefening van het stemrecht conform een rechtsgeldige overeenkomst in strijd met de redelijkheid en billijkheid wordt geacht. Onder de redelijkheid en billijkheid valt volgens Dortmond mede de vraag in hoeverre een grootaandeelhouder rekening moet houden met de belangen van minderheidsaandeelhouders. ${ }^{6}$ Zo kunnen stemovereenkomsten nadelig zijn voor minderheidsaandeelhouders die geen partij zijn bij de overeenkomst, die worden geconfronteerd met blokvorming. Hiervan was sprake in het eerder genoemde Distilleerderij Melchers-arrest. De Hoge Raad acht een dergelijke stemovereenkomst pas nietig, indien het doel van de overeenkomst gericht is op blokvorming, niet indien de overeenkomst blokvorming tot gevolg heeft.

Een aantal aandeelhouders in N.V. Distilleerderij Melchers, die samen de meerderheid van de aandelen bezaten, had een stemovereenkomst gesloten. De overeenkomst bepaalde dat er vóór iedere algemene vergadering van aandeelhouders een voorvergadering zou worden gehouden, waarna op de algemene vergadering alle deelnemende partijen zouden stemmen conform het meerderheidsbesluit in de voorvergadering. De overeenkomst was voorzien van een boetebeding, voor onbepaalde tijd aangegaan en niet opzegbaar. Twee aandeelhouders die geen partij 
waren bij de overeenkomst vorderden de nietigverklaring ervan. De Hoge Raad herhaalt de overweging dat het stemrecht een eigen recht van de aandeelhouder is, zodat

"het hem in beginsel vrij staat dat recht op zodanige wijze uit te oefenen als hij daartoe dienstig oordeelt, en dus ook op zodanige wijze als waartoe hij zich, omdat hij dat in zijn belang achtte, verbonden heeft;

dat de enkele omstandigheid, dat de overeenkomst waarbij hij zich daartoe verbonden heeft tot gevolg kan hebben, dat zijn stem wordt uitgebracht in een anderen zin dan waarin hij, niet gebonden zijnde, gestemd zou hebben op grond van zijn inzicht op dat ogenblik, al zou dit inzicht op zichzelf redelijk zijn, die overeenkomst niet onbetamelijk doet zijn;"

In casu stelden de minderheidsaandeelhouders, dat de overeenkomst nietig, onrechtmatig of in strijd met de goede trouw was, omdat deze gericht was tegen hen en ten doel had hun invloed in de naamloze vennootschap zoveel mogelijk te beknotten. De Hoge Raad overwoog echter dat het hof had vastgesteld dat de overeenkomst ten doel had het familiekarakter der vennootschap te bewaren. De overeenkomst werd geldig bevonden. ${ }^{64}$

Openbaarmaking van een stemovereenkomst zou volgens De Kluiver een remedie kunnen bieden tegen het probleem dat stemovereenkomsten het zicht op de werkelijke machtsverhoudingen versluieren, zodat onduidelijkheid wordt gecreëerd bij andere of toekomstige aandeelhouders. ${ }^{65}$ Ook zonder een stemovereenkomst kan een minderheidsaandeelhouder overigens bij voortduring worden geconfronteerd met een afwijkend meerderheidsstandpunt. Ik meen dat een minderheidsaandeelhouder in deze omstandigheden uit de vennootschap zou mogen treden, indien de meerderheid van de aandeelhouders (al dan niet via een stemovereenkomst) beoogt de minderheidsaandeelhouder te isoleren. ${ }^{66}$

\section{\$7.2.4 Vennootschapsrechtelijke werking van aandeelhoudersovereen- komsten}

Niet alleen doordat een aandeelhouder kan worden veroordeeld tot nakoming werken aandeelhoudersovereenkomsten door in de vennootschappelijke besluitvorming. Een overeenkomst kan eveneens doorwerken in de

HR 13 november 1959, NJ 1960, 472.

De Kluiver, "Joint ventures en stemovereenkomsten. Een rechtsvergelijkend perspectief", AA 1995, blz. 434. Koelemeijer, 1999, blz. 143, acht openbaarmaking uitsluitend wenselijk in geval van beursgenoteerde vennootschappen.

Vgl, OK 9 december 1993, NJ 1994, 296 (Nootebos/Van Eyk). 
vennootschappelijke verhoudingen door deze te kwalificeren ais besluit." Onder omstandigheden kan een aandeelhouder zich beroepen op de overeenkomst jegens de vennootschap, ook al is deze geen partij bij de overeenkomst. In de jurisprudentie en literatuur zijn enige aanzetten gegeven voor de erkenning van deze vennootschapsrechtelijke werking van overeenkomsten tussen aandeelhouders.

\section{Niet-nakoming als onrechtmatige daad}

In HR 29 november 1996, NJ 1997, 345 heeft de Hoge Raad het feit dat een vennootschap nalatig is in het opheffen van de gevolgen van de nietnakoming van een aandeelhoudersovereenkomst onder omstandigheden als onrechtmatig gekarakteriseerd.

De Chipshol-groep had een samenwerkingsovereenkomst gesloten met Granaria Beheer BV, strekkende tot de oprichting van Landinvest NV. Van Andel was als statutair directeur van één van de Chipshol-vennootschappen betrokken bij de totstandkoming van de overeenkomst. In deze overeenkomst was onder meer bepaald dat een eventuele gedelegeerd commissaris van Landinvest niet verbonden mocht zijn aan één van beide aandeelhouders. Van Andel trad in dienst bij Granaria en liet zich tegelijkertijd benoemen tot gedelegeerd commissaris bij Landinvest. Hierop stapte Chipshol naar de rechter. Hof en Hoge Raad oordeelden dat Van Andel, formeel geen partij bij de overeenkomst, onrechtmatig handelde jegens Chipshol als aandeelhouder door zich te laten benoemen tot gedelegeerd commissaris in strijd met de overeenkomst, "mede gelet op zijn nauwe betrokkenheid bij de totstandkoming van bedoelde overeenkomst".

Niet alleen Van Andel handelde volgens het hof onrechtmatig jegens Chipshol, maar ook Landinvest zelf, "aangezien het haar niet vrijstaat de onrechtmatige handelwijze van Van Andel mogelijk te (blijven) maken." De Hoge Raad overweegt:

"Het Hof is (...) ervan uitgegaan dat haar bestuur (van Landinvest, MM) niet bereid is tot het treffen van maatregelen - zoals het doen van een behoorlijk toegelicht ontslagvoorstel aan een daartoe bijeen te roepen algemene vergadering van aandeelhouders - die Van Andel het verder fungeren of optreden als gedelegeerd commissaris te beletten. Door het nalaten van die maatregelen als een onrechtmatige handelwijze van de vennootschap aan te merken, heeft het Hof geen blijk gegeven van een onjuiste rechtsopvatting. Anders dan het onderdeel klaarblijkelijk aanneemt, brengt de omstandigheid alleen dat de algemene vergadering van aandeelhouders de gedelegeerd commissaris kan benoemen en ontslaan, niet mee 
dat het uitblijven van een ontslagbesluit niet aan de vennootschap zou kunnen worden toegerekend."

Zowel de nalatigheid van het bestuur om een ontslagbesluit uit te lokken als het uitblijven van het ontslagbesluit van de algemene vergadering worden toegerekend aan de vennootschap. ${ }^{69}$

Winter acht voor het onrechtmatig handelen van de vennootschap vooral relevant of de aandeelhouders die in de overeenkomst verplichtingen zijn aangegaan, beslissende invloed in de vennootschap hebben. ${ }^{70}$ Mohr uit zijn verontwaardiging over de uitspraak, omdat een aandeelhoudersovereenkomst doorwerkt jegens de vennootschap zonder dat er zelfs maar acht wordt geslagen op het vennootschapsbelang: "Waarom (...) moet het bestuur van de vennootschap dienst doen als loopjongen voor een aandeelhouder jegens wie een andere aandeelhouder contractbreuk pleegt? Waarom laten hof en Hoge Raad partijen (...) hun eigen boontjes niet doppen (met gebruikmaking van: eisen tot schadevergoeding, boetes, dwangsommen, pogingen tot reële executie, acties tot vernietiging van besluiten en wat dies meer zij) en de vennootschap in lijdelijkheid toezien? Waarom moet (het bestuur van) de vennootschap, die zelf geen partij is bij de overeenkomst, in actie komen?" De Hoge Raad blinkt inderdaad niet uit in de motivering. $\mathrm{Er}$ is een benoemingsbesluit geweest op grond waarvan Van Andel tot gedelegeerd commissaris is benoemd. Als partij bij de overeenkomst had Chipshol Granaria kunnen aanspreken tot nakoming, door herroeping van het benoemingsbesluit of ontslag. Dat Chipshol rechtstreeks de vennootschap heeft aangesproken, en hof en Hoge Raad hieraan gevolg hebben gegeven, levert een geval van omgekeerde doorbraak van aansprakelijkheid op. Het is nu niet de moedervennootschap c.q. enig aandeelhouder, die aansprakelijk wordt geacht, maar de (dochter)vennootschap. In casu was de gelaedeerde mede-aandeelhouder. Deze toerekening vindt ook in het enquêterecht plaats, waar gedragingen van de algemene vergadering wanbeleid van de vennootschap kunnen opleveren, bijvoorbeeld ingeval de vennootschap weigert dividend uit te keren of weigert mee te werken aan een statutenwijziging te dienaangaande..$^{72}$ Onduidelijk is echter wat voor

is HR 29 november 1996, NJ 1997, 345 (Chipshol/Van Andel), m. nt. Maeijer.

6. $\mathrm{Vgl}$. Advocaat-Generaal Mok: "Een onrechtmatige gedraging van de aandeelhoudersvergadering (zowel het benoemen als het laten functioneren van Van Andel als gedelegeerd commissaris) als orgaan moet extern aan de vennootschap worden toegerekend. Voor degene jegens wie onrechtmatig wordt gehandeld is het niet van belang op welke wijze in de vennootschap consequenties aan de onrechtmatigheid en het verbod kunnen worden verbonden."

Winter, TVVS 1997, blz. 85.

Mohr, 1997, blz. 224.

HR 9 juli 1990, NJ 1991, 51 (Sluis), m. nt. Maeijer, die moeite heeft met de toerekening van 
omstandigheden bij de toerekening aan Landinvest een rol hebben gespeeld: het feit dat het ging om een joint-venture, de vraag of alle aandeelhouders partij waren bij de overeenkomst, de vraag of de inhoud van de overeenkomst in het belang van de vennootschap was? Dit lijken mij allemaal relevante omstandigheden, die (ver)dienen te worden genoemd.

Had Chipshol niet beter tegen Granaria kunnen ageren op grond van wanprestatie? In geval van het uitblijven van een dividendbesluit, stelt Van der Grinten dat een aandeelhouder weliswaar van zijn mede-aandeelhouders kan vorderen dat zij meewerken aan een dergelijk besluit, maar hij betitelt deze weg in navolging van Van Schilfgaarde als een omweg, omdat de rechtsstrijd niet wordt gevoerd tegen de vennootschap zelf - die de uitkering zal moeten doen - doch tegen mede-aandeelhouders die zelf niet uitkeringsplichtig zijn. Bovendien zou een in het geding geroepen aandeelhouder zijn aandelen kunnen overdragen. ${ }^{3}$ De kans bestaat dat dergelijke overwegingen voor een vergelijkbare situatie mede hebben geleid tot de keuze van de Hoge Raad om rechtstreeks de vennootschap aansprakelijk te stellen.

\section{Niet-nakoming als wanbeleid}

Dat betrokkenen hun toevlucht nemen tot vorderingen die op wanprestatie of onrechtmatige daad zijn gegrond, komt volgens Winter doordat een besluit in strijd met contractuele afspraken niet via de vennootschapsrechtelijke weg kan worden aangetast. ${ }^{74}$ Inmiddels heeft de Ondernemingskamer een opening geboden om aandeelhoudersovereenkomsten te betrekken bij de beoordeling van de vraag of er sprake is van gegronde redenen om aan een juist beleid van de vennootschap te twijfelen.

Versatel Telecom BV was een joint-venture van drie aandeelhouders, waaronder Cromwilld, die allen circa een derde van het aandelenkapitaal bezaten. Zij hadden een aandeelhoudersovereenkomst gesloten waarin onder meer afspraken met betrekking tot de besluitvorming in de vennootschap waren neergelegd. Op een buitengewone vergadering van aandeelhouders, waarvoor Cromwilld een volmacht had verstrekt aan een commissaris van de vennootschap, werd besloten tot uitgifte van nieuwe aandelen. Nadat Cromwilld tevergeefs had geprobeerd de besluiten terug te draaien, wendde zij zich tot de Ondernemingskamer met een enquêtever-

onredelijke gedragingen van aandeelhouders aan de vennootschap. Hij prefereert een rechterlijk bevel jegens de aandeelhoudersgroepering om op een bepaalde wijze te stemmen.

Van der Grinten, "Minderheidsrechten". NV 1992, blz. 273.

Winter. TVVS 1997, blz 85. 
zoek, terwijl zij nu nog slechts $19 \%$ van het aandelenkapitaal vertegenwoordigde. Cromwilld voerde onder meer aan dat de wijze waarop zij werd geïnformeerd en de wijze waarop zij bij de besluitvorming werd betrokken en haar belangen als (minderheids)aandeelhouder werden geschaad, in strijd is met tussen de aandeelhouders gemaakte afspraken en met datgene wat zij als aandeelhoudster redelijkerwijze mag verwachten. Daarop overwoog de Ondernemingskamer:

"Cromwilld betoogt onder verwijzing naar onder meer de aandeelhoudersovereenkomst terecht dat zij, hoezeer zij (slechts) minderheidsaandeelhoudster is, op grond van die verhoudingen en samenwerking aanspraak kan maken op een andere gedragslijn van Versatel jegens haar dan in het algemeen van een vennootschap jegens minderheidsaandeelhouders en zelfs aandeelhouders in het algemeen gevergd kan worden. (...) [D]e samenwerking tussen de oorspronkelijke partijen [heeft] het karakter van een joint-venture. De daaruit voor Cromwilld voortvloeiende bijzondere aanspraken kunnen aan Cromwilld niet zonder meer ontnomen worden enkel op de grond dat besluitvorming naar regels van vennootschapsrecht in striktere zin op correcte wijze heeft plaatsgevonden. (...) Daaruit volgt echter niet (...) dat de totstandkoming en de uitvoering van het beleid alleen maar kunnen plaatsvinden indien ieder van de partners in de joint-venture zich daarachter zou kunnen scharen. (...) Zij kunnen dus als aandeelhouders van de vennootschap de besluitvorming niet verhinderen als zij aan het beleid of aan die besluitvorming niet hun instemming hebben gegeven op de grond dat de vennootschap het karakter heeft van een joint-venture. Dit is slechts anders indien daarover tussen de aandeelhouders daartoe ruimte latende afspraken zijn gemaakt. Cromwilld heeft wel gesteld dat zulke afspraken tot stand zijn gekomen doch die stelling heeft zij niet aannemelijk gemaakt (curs. MM)."'

De Ondernemingskamer noemt de joint-venture-verhouding wel als een bijzondere omstandigheid. Blanco Fernández leidt uit de uitspraak af dat een aandeelhouder zich in beginsel kan verzetten tegen een besluit van de algemene vergadering dat in strijd is met een aan hem in de aandeelhoudersovereenkomst toegekend recht. ${ }^{76}$ Indien er sprake zou zijn van wanbeleid, kan de Ondernemingskamer het besluit in strijd met de aandeelhoudersovereenkomst vernietigen op grond van artikel 2:356 BW.

OK 20 mei 19999, NJ 2000, 199 (Cromwilld/Versatel).

Blanco Fernández, nt. JOR 2000, nr. 72. Inmiddels heeft de Ondernemingskamer deze lijn voortgezet in haar uitspraak van 8 mei 2002, JOR 2002, nr. 112, waarin het miskennen van het uit de joint-venture-overeenkomst voortvloeiende recht op informatie als gegronde reden om aan een juist beleid te twijfelen werd aangemerkt. Anders: Rb. Arnhem, 6 september 2001, JOR 2002, nr. 50. 


\section{Niet-nakoming als vernietigingsgrond van een besluit}

De Kluiver wil de toetsing van stemovereenkomsten laten plaatsvinden binnen het kader van art. 2:8 en 2:15 BW. Hij pleit voor het in acht nemen van de volgende uitgangspunten: stemovereenkomsten waarbij alle aandeelhouders partij zijn, zijn geldig en bepalen, binnen het kader van art. 2:8 en 2:15 BW, of besluiten geldig of aantastbaar zijn; stemovereenkomsten tussen aandeelhouders waarbij niet alle aandeelhouders zijn betrokken, inclusief stemovereenkomsten met derden, zijn slechts geldig als deze schriftelijk zijn aangegaan, en het bestaan ervan wordt gemeld bij het handelsregister."

Volgens Blanco Fernández heeft schending van een overeenkomst niet alleen wanprestatie tot gevolg, maar ook de ongeldigheid van het besluit dat genomen is in strijd met de overeenkomst. Deze 'vennootschapsrechtelijke werking' van stemovereenkomsten vindt zijns inziens haar verklaring in het feit dat tussen de aandeelhouders en de algemene vergadering een zekere identiteit bestaat, die rechtvaardigt dat de algemene vergadering niet mag handelen in strijd met de overeenkomst die de aandeelhouders zijn aangegaan. Hij stelt dat stemovereenkomsten slechts vennootschapsrechtelijke werking hebben, ingeval de vennootschap een gerechtvaardigd vertrouwen van aanvaarding van de gelding van de overeenkomst heeft gewekt, dan wel waarbij tussen de contractspartijen en de vennootschap een 'bijzondere relatie' bestaat, bijvoorbeeld indien alle aandeelhouders partij zijn bij de overeenkomst. Over de wijze waarop deze vennootschappelijke werking zou worden bewerkstelligd is Blanco Fernández niet geheel duidelijk. Een besluit zou vernietigbaar kunnen zijn op grond van strijd met de redelijkheid en billijkheid, maar hij ziet ook ruimte voor analogische toepassing van art. 2:14 BW."

Van vernietiging van een besluit als voorziening in het enquêterecht is het een kleine stap naar vernietiging van een besluit in strijd met een aandeelhoudersovereenkomst op grond van de redelijkheid en billijkheid. Door deze te plaatsen in het kader van de redelijkheid en billijkheid blijft de afweging tussen de verschillende belangen voorop staan.

\section{Eigen opvatting}

Naar mijn mening dient als uitgangspunt te worden gehanteerd dat een besluit van de algemene vergadering in strijd met een aandeelhoudersover-

77 De Kluiver, AA 1995, blz. 441.

78 Blanco Fernàndez, Ondernemingsrecht 1999, blz. 148 e.v. 
eenkomst vernietigbaar is, indien alle aandeelhouders partij zijn bij de overeenkomst ten tijde van het nemen van het besluit, tenzij nakoming van de overeenkomst c.q. het besluit in strijd zou zijn met de redelijkheid en billijkheid. ${ }^{7}$ De bewijslast ligt dan op degene die handelt in strijd met de overeenkomst.

Een overeenkomst tussen alle aandeelhouders heeft voor aandeelhouders dezelfde werking als statuten; zij hebben ermee ingestemd. Een rechtsgeldige overeenkomst veronderstelt dat crediteuren niet zijn benadeeld, en toekomstige aandeelhouders zijn er (nog) niet. Dit geldt ook indien een nietig besluit is geconverteerd in een overeenkomst, ${ }^{{ }^{* 0} 0}$ of indien aandeelhouders bij overeenkomst hebben afgezien van de uitoefening van één of meer van hun rechten." Bij de afweging tussen de nakoming van de overeenkomst en de redelijkheid en billijkheid is de ontwikkeling van de vennootschap mede van belang. Hieronder volgt een aantal voorbeelden ter illustratie.

\section{Extra verplichtingen}

Stel dat aandeelhouders zijn overeengekomen dat ieder zal bijdragen in de verliezen van de vennootschap, indien nodig. Indien vervolgens de algemene vergadering met volstrekte meerderheid conform de overeenkomst besluit dat alle aandeelhouders dienen bij te dragen in de verliezen van de vennootschap, kan een aandeelhouder zich daartegen in beginsel niet verzetten, mits alle aandeelhouders partij zijn bij de overeenkomst ten tijde van het nemen van het besluit.

\section{Blokkeringsregeling}

Stel dat de statuten van een vennootschap een blokkeringsregeling bevatten, inhoudende dat de algemene vergadering bevoegd is tot goedkeuring van de overdracht. De aandeelhouders zijn bovendien overeenkomen dat zij in de algemene vergadering steeds vóór goedkeuring zullen stemmen. Indien de algemene vergadering niettemin besluit haar goedkeuring aan een overdracht te onthouden, kan de vervreemdende aandeelhouder in beginsel vernietiging van het besluit vorderen, indien alle aandeelhouders partij zijn bij de overeenkomst ten tijde van het nemen van het besluit. De andere aandeelhouders zullen dan moeten aantonen dat het niet redelijk is om aan de overeenkomst uitvoering te geven.

\footnotetext{
$\mathrm{Vgl}$, de overwegingen ten aanzien van een arbitragebeding, in $\$ 3.2 .3$.

Zie $\$ 6.2 .6$.

Zie $\$ 3.2 .2$.
} 


\section{Uitgifte van aandelen}

Aandeelhouders mogen overeenkomen dat zij geen nieuwe uitgifte zullen doen, althans geen gebruik zullen maken van hun stemrecht ten aanzien van een emissiebesluit. ${ }^{n 2}$ Besluit de algemene vergadering niettemin tot uitgifte, dan kan de aandeelhouder die tegen uitgifte is, de vernietiging vorderen van het besluit, indien alle aandeelhouders partij zijn bij de overeenkomst ten tijde van het nemen van het besluit, tenzij de emissie noodzakelijk is voor het voortbestaan van de vennootschap.

Stel dat in de statuten geen bijzondere meerderheid voor een besluit van de algemene vergadering tot emissie staat vermeld. De aandeelhouders hebben zich echter in een aandeelhoudersovereenkomst verplicht slechts bij eenstemmigheid tot emissie te besluiten. Indien met volstrekte meerderheid wordt besloten tot emissie, kan een aandeelhouder vernietiging van het besluit vorderen, mits alle aandeelhouders partij zijn bij de overeenkomst ten tijde van het nemen van het besluit, tenzij de emissie noodzakelijk is voor het voortbestaan van de vennootschap.

Aandeelhouders mogen overeenkomen dat zij de overdracht van de emissiebevoegdheid niet zullen herroepen. Indien de algemene vergadering niettemin de overdracht herroept, kan een aandeelhouder vernietiging van het besluit vorderen wegens strijd met de overeenkomst, indien alle aandeelhouders partij zijn bij de overeenkomst ten tijde van het nemen van het besluit, tenzij het herroepen van de bevoegdheid noodzakelijk is voor het voortbestaan van de vennootschap.

\section{Statutenwijziging}

Aandeelhouders mogen overeenkomen de statuten niet te wijzigen. ${ }^{83}$ Indien de algemene vergadering niettemin besluit de statuten te wijzigen, kan een aandeelhouder vernietiging van het besluit vorderen, indien alle aandeelhouders partij zijn bij de overeenkomst ten tijde van het nemen van het besluit, tenzij de statutenwijziging noodzakelijk is voor het voortbestaan voor de vennootschap.

\section{Benoeming van bestuurders}

Aandeelhouders mogen overeenkomen dat zij steeds voor elkaars kandidaten zullen stemmen. ${ }^{4}$ Indien de algemene vergadering vervolgens in

\footnotetext{
Zie $\$ 7.2 .3$

Zie $\$ 7.2 .3$

Zie $\$ 7.2 .3$
} 
strijd met de overeenkomst besluit met twee derde meerderheid van de stemmen een voorgedragen kandidaat af te wijzen, dan is het besluit in beginsel rechtsgeldig. De wet bepaalt immers dat de algemene vergadering steeds de voordracht kan doorbreken, dus ook indien het besluit in strijd is met een overeenkomst. Op het stemmen in strijd met de overeenkomst kunnen in dit geval louter contractuele sancties worden gesteld.

\section{$\S 7.3$ Duitsland}

\section{§7.3.1 De toelaatbaarheid van stemovereenkomsten}

Al in de jaren twintig van de vorige eeuw heeft het Reichsgericht de stemovereenkomst in principe toelaatbaar geacht. In een serie arresten werd het initiële wantrouwen tegen deze potentiële vorm van misbruik van meerderheidsmacht omgezet in een meer pragmatische benadering, mede gezien de rol van de stemovereenkomst in de praktijk. Het Reichsgericht stelde de Vertragsfreiheit als uitgangspunt, die als zodanig niet werd beperkt door bijzondere vennootschapsrechtelijke overwegingen. Tevens maakte het een onderscheid tussen de contractuele binding en de vennootschapsrechtelijke uitoefening van het stemrecht. ${ }^{85}$ Het Bundesgerichtshof heeft de benadering van het Reichsgericht overgenomen.

Een meerderheidsaandeelhouder houdt 17 aandelen in een $\mathrm{GmbH}$, waarvan 16 namens zijn vrouw, die hiervoor het kapitaal verschaft. Hij sluit met haar een overeenkomst, waarin hij zich verplicht tot overdracht van de aandelen aan haar, zodra zij dit verlangt. Toen zij verzocht om de aandelen over te dragen, riep haar man een algemene vergadering bijeen, waarin werd besloten de overdracht te weigeren. Daarop startte de vrouw een procedure. Volgens het Bundesgerichtshof impliceert de overdrachtsverplichting tevens een verplichting in de algemene vergadering vóór de goedkeuring van de overdracht te stemmen. Een dergelijke stemovereenkomst acht het Bundesgerichtshof rechtsgeldig:

"An Abstimmungsvereinbarungen und ihrer Durchsetzbarkeit besteht ein berechtigtes Interesse. (...) Wer sich schuldrechtlich bindet, schränkt im Rahmen der eingegangenen Verpflichtung seine Entschließungsfreiheit ein. So erwünscht es auch ist, daß Gesellschafter den in einer Gesellschafterversammlung angestellten Überlegungen und Erörterungen zugänglich sind, so wenig kann doch geleugnet werden, daß die Zahl der Gesellschafter, die sich bereits in bestimmter Weise

RGZ 107, 67, 70, in Fischer, Zur Methode revisionsrichterlicher Rechtsprechung auf dem Gebiet des Gesellschaftsrechts, blz 28, oorspronkelijk in: Recht und Rechtsleben in der sozialen Demokratic. Festgabe für Otto Künze zum 65, Geburtstag, Berlijn 1969. 
festgelegt haben und von ihrer vorgefaßten Meinung nicht mehr abzubringen sind, sehr gro $\beta$ ist. Das aus der Entschließungsfreiheit hergeleitete Argument kan daher nur die Bedeutung haben, daß nicht noch die durch eine Abstimmungsvereinbarung gebundenen Gesellschafter die Zahl der ohnehin festliegenden Gesellschafter vermehren soll. In die Willensbildung der Gesellschaft wird nicht eingegriffen, denn der Vollstreckungszwang richtet sich nicht gegen die Gesellschaft, sondern gegen den aus der Abstimmungsvereinbarung verpflichteten Gesellschafter." ${ }^{\text {"s }}$

Uitgangspunt is dat een onderscheid wordt gemaakt tussen de uitoefening van het stemrecht en de contractuele binding. Zo is de stem conform een ongeldige stemovereenkomst niettemin geldig, tenzij het uitoefenen van het stemrecht reeds ongeldig is. Aan de andere kant is een stem ook geldig, indien deze in strijd met een geldige stemovereenkomst wordt uitgeoefend.

\section{Grenzen aan de uitoefening van het stemrecht}

De contractsvrijheid van de aandeelhouder is echter niet absoluut. In de literatuur wordt ervan uitgegaan dat een rechtsgeldige binding slechts kan ontstaan binnen het kader van de vrijheid van de aandeelhouder bij de uitoefening van zijn stemrecht. ${ }^{87}$ Die vrijheid wordt beperkt, doordat het hem niet vrijstaat het stemrecht uitsluitend in zijn eigen belang uit te oefenen. Hij is mede gehouden het belang van de vennootschap in ogenschouw te nemen en gebonden aan de goede trouw. ${ }^{.8}$ Zöllner heeft deze grenzen aan de uitoefening onderverdeeld in "starre" en "flexibele" grenzen. Terwijl hij de Stimmverbote van $\S 47 \mathrm{Abs} .4 \mathrm{GmbHG}^{* 9}$ als starre grenzen kwalificeert, zijn de goede zeden, de Treupflicht en de Gleichbehandlungsgrundsatz flexibel, i.e. afhankelijk van de omstandigheden van het geval. Volgens Zöllner bestaat er geen algemene verplichting dat aandeelhouders elkaar zouden moeten informeren over het bestaan van een stemovereenkomst. ${ }^{\infty}$

Wel binnen de contractsvrijheid van de aandeelhouder valt de vrije partijkeuze; ook een stemovereenkomst met een derde is in beginsel toelaatbaar.." In de praktijk komen overigens stemovereenkomsten met derden, zoals de overeenkomst tot verplichting tot kapitaalverhoging, de verplichting tot het inroepen van advies in een patstelling, de verplichting tot het

Wh

BGHZ 48, 163, 171

Baumbach/Hueck/Zollner $\$ 47,77$. Rowedder/Schmidt-Leithoff/Koppensteiner $\S 47,31$.

$\mathrm{Vgl}$. Fischer. Die Grenzen bei der Ausubung gesellschaftlicher Mitgliedschaftsrechte, in Fischer, blz 111 e.v, oorspronkelijk NJW 1954. Baumbach/Hueck, $\S 13,27, \S 14,12$. Zie hierover uitgebreid Zollner, Zu Schranken und Wirkung von Stimmbindungsvertrăgen, ZHR 1991, blz, 168 c.v. Zie ook \$2.3.2.

Baumbach/Hueck/Zollner $\$ 47,82$.

Rowedder/Schmidt-Leithoff/Koppensteiner $\$ 47,29$. Zie voor beperkingen $\$ 7.3 .3$. 
stemmen volgens de aanwijzingen van een Treugeber, volgens Zütt niet vaak voor. ${ }^{92}$

\section{\$7.3.2 Contractuele sancties aan de niet-nakoming van stemovereenkom- sten}

Indien anders wordt gestemd dan de overeenkomst bepaalt, kan een verplichting tot het vergoeden van de schade ontstaan, of een boete worden opgelegd. ${ }^{93}$ Het Bundesgerichtshof heeft geoordeeld dat tevens nakoming van de stemovereenkomst kan worden afgedwongen, aangezien het niet de vennootschap is die zich heeft gebonden, maar individuele aandeelhouders. Schadevergoeding volstaat in de regel niet."4

Omstreden is of nakoming ook in kort geding kan worden gevorderd. Vanwege de praktische problemen die het afdwingen van nakoming met zich mee brengt, indien het besluit reeds is genomen, pleit Zütt voor de mogelijkheid een stemverbod of gebod in kort geding te kunnen vorderen teneinde nakoming van de overeenkomst te bewerkstelligen. ${ }^{95}$ Ook Lutter/ Hommelhoff achten een kort geding procedure mogelijk. Een uitspraak in kort geding loopt huns inziens niet op ongeoorloofde wijze vooruit op de bodemprocedure, omdat de bij de overeenkomst betrokken aandeelhouders zichzelf reeds hebben gebonden. ${ }^{6}$ Zöllner meent daarentegen dat een aandeelhouder in geen geval in kort geding tot nakoming mag worden veroordeeld. ${ }^{n 7}$

In de lagere rechtspraak - het Bundesgerichtshof heeft zich tot nu toe nog niet uitgesproken over deze vraag - lijken zich enkele voorwaarden uit te kristalliseren waaronder een stemverbod of -gebod mogelijk wordt geacht. Enerzijds dient er sprake te zijn van een duidelijke rechtspositie of een bijzondere beschermingsbehoefte aan de kant van de eiser, anderzijds dient te worden voldaan aan het vereiste dat geen minder ingrijpende mogelijkheid voorhanden is. ${ }^{\text {" }}$ Het Oberlandesgericht München motiveert de principiële erkenning van de mogelijkheid tot het instellen van een kortgedingprocedure als volgt:

\footnotetext{
Zutt, "Stimmbindungen gegenúber Dritten - Ergebnisse einer Umfrage", ZHR 1991, blz. 213.

Baumbach/Hueck/Zollner $\S 47,80$.

BGHZ 48, 163, 171.

Zatt, "Einstweiliger Rechtsschutz bei Stimmbindungen", ZHR 1991, blz. 190 e.v. Zo ook Lutter/

Hommelhoff $\S 47,6$.

Lutter/Hommelhoff $\S 47,6$.

Baumbach/Hueck/Zollner $\$ 47,81$.

Vgl. OLG Stuttgart, GmbHR 1997, blz. 312. OLG München, GmbHR 1999, blz. 719.
} 
"In den letzten Jahren hat in Abkehr der früher vorherrschenden Ansicht die Auffassung stark an Boden gewonnen, daß mit den Mitteln des einstweiligen Rechtsschutzes durchaus in den Bereich der Willensbildung in einer Gesellschaft, insbesondere in das Abstimmungsverhalten von Gesellschaftern, eingegriffen werden darf (...). Daß gerade bei Auseinandersetzungen in Gesellschaften das Bedürfnis schon nach vorläufigem Rechtsschutz besteht, zeigt nicht nur die gerichtliche Praxis, sondern drängt sich auch aus wirtschaftlicher Sicht auf. Einstweiligen Rechtsschutz in solchen Fällen deshalb zu verweigern, weil die Gefahr der Vorwegnahme einer Entscheidung in der Hauptsache bestehe, läßt sich mit einem von einem Rechtsstaat zu gewährenden effektiven Rechtsschutz nicht vereinbaren. Zudem bestünde sonst die Gefahr, daß fehlerhafte Gesellschafterbeschlüsse vielfach zu vollendeten Tatsachen führten. Der Grundsatz der Autonomie der innergesellschaftlichen Willensbildung an sich rechtfertigt keine auch nur vorübergehen rechtsfreien Räume. Ob dann im Einzelfall vorläufiger Rechtsschutz zu gewähren ist, ist daher allein Frage von dessen Begründetheit."

Niet steeds kan echter nakoming worden gevorderd; het sluiten van een rechtsgeldige aandeelhoudersovereenkomst laat onverlet dat een aandeelhouder de plicht heeft in een concreet geval anders te stemmen indien het belang van de vennootschap dit vereist. ${ }^{100}$

\section{$\S 7.3 .3$ Grenzen aan aandeelhoudersovereenkomsten}

Aandeelhoudersovereenkomsten in strijd met een wettelijk verbod of de goede zeden, zijn nietig. ${ }^{101}$ Het Duitse equivalent van artikel 3:40 BW is $\S 134$ BGB:

"Ein Rechtsgeschăft, das gegen ein gesetzliches Verbot verstoßt, ist nichtig, wenn sich nicht aus dem Gesetz ein anderes ergibt."

Niet alle dwingende wetsbepalingen zijn echter 'Verbotsgesetze' in de zin van $\S 134$ BGB. Dit hangt af van het doel en de strekking van de wettelijke bepaling. Deze hebben niet alleen betekenis voor de vraag of uit de wet iets anders voortvloeit, maar zien vooreerst op de vraag of er wel sprake is van een wettelijk verbod waarop een sanctie is gesteld. ${ }^{102}$ Indicaties voor een wettelijk verbod zijn het wettelijk taalgebruik (mag niet, kan niet etc.), de

m OLG Munchen, GmbHR 1999, blz. 719. Zie hierover uitgebreid Beyer, "Vorbeugender Rechtsschutz gegen die BeschluBfassung GmbH-Gesellschafterversammlung", GmbHR 2001, blz. 467 e.v:

Lutter/Hommelhoff, $\$ 47,5$.

Rowedder/Schmidt-Leithoff/Koppensteiner $\$ 47,31$.

Mayer-Maly, §134, 38 . 
dwingende aard van de bepaling in kwestie en de kring van adressaten tot wie de norm zich richt. ${ }^{103}$

Volgens Mayer-Maly zijn dwingende bepalingen in het vennootschapsrecht in beginsel Verbotsgesetze, daar zij beogen crediteuren en aandeelhouders te beschermen ${ }^{104}$ Noack meent daarentegen dat de kwalificatie als Verbotsgesetz afhangt van het doel van de nietigheid als sanctie, i.e. de beperking van de Privatautonomie door het niet erkennen van rechtshandelingen in het belang van derden of het algemeen belang. ${ }^{105}$ Dwingend vennootschapsrecht strekt in zijn optiek ertoe afwijkende statutaire bepalingen te verhinderen; het moet niet worden opgevat als een algeheel verbod op elke privatautonome regeling. ${ }^{106}$

Ook Wiedemann stelt aandeelhoudersovereenkomsten in beginsel buiten het dwingende vennootschapsrecht. ${ }^{107}$ Dat houdt in dat dergelijke overeenkomsten regelingen kunnen bevatten, die statutair niet toelaatbaar zouden zijn ${ }^{108}$ Een voorbeeld hiervan is het opleggen van Nebenleistungspflichte (extra verplichtingen) aan aandeelhouders die verder gaan dan de "wiederkehrende, nicht in Geld bestehende Leistungen" zoals bepaald in $\S 55$ AktG. ${ }^{109}$ Volgens Noack is het doel van $\S 55 \mathrm{AktG}$ juist te voorkomen dat (toekomstige) aandeelhouders extra verplichtingen worden opgelegd, zonder te beogen dat het aandeelhouders zelf wordt verboden om extra verplichtingen aan te gaan. ${ }^{110}$

In het GmbH-recht, waar de Gestaltungsfreiheit voorop staat, zijn minder voorschriften te kwalificeren als Verbotsgesetz dan in het Aktienrecht. Aanvullende bepalingen zijn in ieder geval geen Verbotsgesetze. In plaats van een verbod wordt een regeling immers aan de keuze van partijen overgelaten, doordat in de statuten kan worden afgeweken van de wettelijke regeling. ${ }^{11}$ Noack kwalificeert uitsluitend die bepalingen, waarvan de aandeelhouders niet kunnen afwijken vanwege de bescherming van belangen van crediteuren en het algemeen belang, als Verbotsgesetze. ${ }^{112}$ In deze optiek omvat $\S 134$ BGB niet meer nietigheidsgronden dan zijn omschreven in $\S 241 \mathrm{nr} .3 \mathrm{AktG}$, namelijk het wezen van de vennootschap, voorschriften die uitsluitend of in overwegende mate ter bescherming van credi-

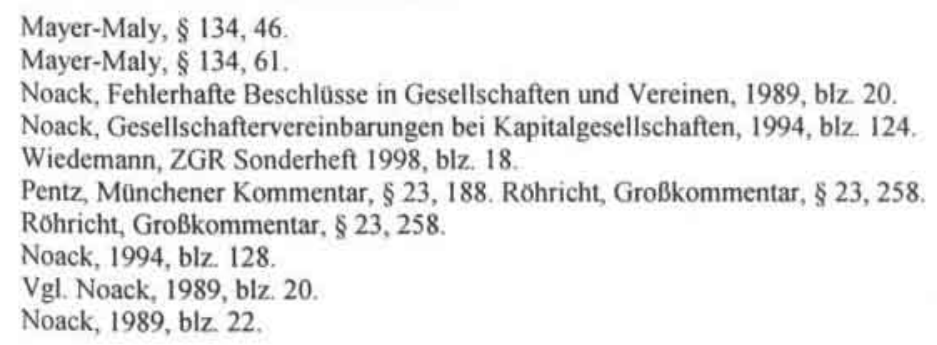


teuren of het algemeen belang zijn gegeven. ${ }^{113}$ Noack pleit er dan ook voor om $\S 241$ AktG bij de interpretatie van $\S 134$ BGB te betrekken. ${ }^{14}$ Dit houdt in dat aandeelhoudersovereenkomsten nietig zijn, indien zij in strijd zijn met het wezen van de vennootschap, of met wettelijke voorschriften die in overwegende mate ter bescherming van crediteuren of het algemeen belang zijn gegeven. Ook Koppensteiner acht een overeenkomst ongeldig, indien de inhoud ervan zou leiden tot een nietig of vernietigbaar besluit."1s Overigens zal een aandeelhoudersovereenkomst die in strijd wordt geacht met het wezen van de vennootschap, veelal eveneens in strijd worden geacht met de goede zeden, op basis van $\S 138$ BGB.

\section{Instructie-overeenkomst met bestuurder}

Het $\mathrm{GmbHG}$ bevat geen ondubbelzinnige verbodsbepalingen voor aandeelhoudersovereenkomsten. Dit is anders in het AktG; $\S 136$ Abs. 2 AktG bepaalt dat een overeenkomst, waarbij een aandeelhouder zich verplicht te stemmen naar instructie van de vennootschap, het bestuur of de Aufsichtsrat, nietig is. Achterliggende gedachte van het verbod is dat de overeenkomst de invloed van het bestuur duurzaam vergroot ten koste van de invloed van de kapitaalverschaffers, hetgeen in strijd wordt geacht met de wettelijke bevoegdheidsverdeling. ${ }^{116} \mathrm{De}$ vraag is dan in hoeverre deze bepaling richtinggevend is voor het $\mathrm{GmbH}$-recht.

Zöllner acht $\S 136$ Abs. 2 AktG analogisch van toepassing op de GmbH. ${ }^{17}$ Daarenboven meent Hüffer dat een instructie-overeenkomst met een individuele bestuurder evenmin toelaatbaar is. ${ }^{118}$ Het verbod van $\S 136$ Abs. 2 AktG laat volgens Zöllner een stemovereenkomst met een individuele bestuurder dat hij uitsluitend in geval van een gegronde reden mag worden ontslagen onverlet."

\section{Instructie-overeenkomst in geval van een Stimmverbot}

Op grond van $\S 47$ Abs. 4 GmbHG mag een aandeelhouder niet stemmen, noch het stemrecht voor anderen uitoefenen wanneer de algemene vergadering besluit over zijn décharge als bestuurder, over het verrichten van een

Zie $\$ 4$.

Noack, 1989, blz. 39.

Rowedder/Schmidt-Leithoff/Koppensteiner $\$ 47,31$.

Huffer, $\$ 136,25$.

Baumbach/Hueck/Zollner, $\$ 47,78 \mathrm{a}$. In vergelijkbare zin Rowedder/Schmidt-Leithoff/Koppensteiner $\$ 47,32$.

Hachenburg/Haffer, $\$ 47,78$

119 Baumbach/Hueck/Zollner $\$ 47,77$. 
rechtshandeling tussen hem en de vennootschap, of over het instellen van een actie in rechte jegens hem. Statutaire afwijking van dit verbod acht het Bundesgerichtshof in strijd met $\S 138$ BGB. ${ }^{120}$ Achterliggende gedachte is dat een aandeelhouder niet als 'rechter in eigen zaak' mag optreden. ${ }^{121}$

Het Stimmverbot geldt ook voor aandeelhoudersovereenkomsten. In de literatuur wordt $\S 47$ Abs. $4 \mathrm{GmbHG}$ als Verbotsgesetz beschouwd in de zin van $\S 134 \mathrm{BGB}$, aangezien een aandeelhoudersovereenkomst waarin een Stimmverbot terzijde wordt gesteld, op grond van $\S 134$ BGB nietig wordt geacht. ${ }^{122}$ Hüffer noemt als voorbeeld een overeenkomst waarin aandeelhouders afspreken elkaar wederzijds te déchargeren. Dit acht hij een ontoelaatbare ontduiking van het Stimmverbot. ${ }^{12}$

\section{Overeenkomst over de benoeming en het ontslag van bestuurders}

Op grond van $\S 46 \mathrm{GmbHG}$ zijn de aandeelhouders bevoegd tot het benoemen en ontslaan van bestuurders. Hiervan kan op basis van $\S 45$ Abs. 2 GmbHG in de statuten worden afgeweken, tenzij de bevoegdheid dwingend toekomt aan de Aufsichtsrat. ${ }^{124}$ De statuten kunnen de benoemings- en ontslagbevoegdheid bijvoorbeeld toekennen aan de Aufsichtsrat, een Beirat, of - als Sonderrecht $t^{125}$ - aan individuele aandeelhouders. ${ }^{126}$ Omstreden is of de bevoegdheid aan een derde mag worden toegekend. De vraag is of een derde dan orgaan van de vennootschap wordt en daarmee het belang van de vennootschap behoort te behartigen. ${ }^{127}$

Hoewel de statuten een derde volgens de heersende opvatting geen recht mogen toekennen om bestuurders te benoemen, acht Zöllner in ieder geval een stemovereenkomst met een derde ten aanzien van de benoeming van een bestuurder toelaatbaar. Volgens Zöllner is het onderscheid tussen de statutaire binding van de vennootschap en de individuele binding van de aandeelhouder doorslaggevend. ${ }^{128}$

BGHZ 108, 21. Zie ook $\$ 2.3 .2$.

Lutter/Hommelhoff, $\$ 47,13$.

Hachenburg/Huffer, $\$ 47,77$. Lutter/Hommelhoff, $\S 47,5,15$. Fleck, FS Fischer, 1979, blz. 127. Noack, 1994, blz 123. Baumbach/Hueck/Zollner \$ 47, 78. Rowedder/Schmidt-Leithoff/Koppensteiner $\$ 47,31$, Zo reeds BGHZ 48, 163, 166.

Hachenburg/Huffer, $\$ 47,77$.

$\$ 31$ MitbestG. Hier ga ik verder niet op in.

Zie $\$ 5.3 .2$.

Lutter/Hommelhoff, $\$ 46,11$.

Lutter/Hommelhoff, $\S 38,3$ en $\S 46,11$. Zie ook Beuthien/Gatsch, "Einfluß Dritter auf die Organbesetzung und Geschaftsfuhrung bei Vereinen, Kapitalgesellschaften und Genossenschaften," ZHR 1993, blz. 486. Zie $\$ 5,3.3$.

Zollner, ZHR 1991, blz 180.
} 
Aangezien de statuten aandeelhouders mogen verplichten steeds vóór een voorgedragen kandidaat-bestuurder te stemmen, ${ }^{129}$ moet worden aangenomen dat een aandeelhoudersovereenkomst met dezelfde inhoud evenzeer toelaatbaar is. Wel wordt een aandeelhoudersovereenkomst die het ontslag van een bestuurder onmogelijk maakt, zelfs in geval van een gegronde reden, nietig geacht. ${ }^{130}$

\section{'Stimmenkauf'}

Bij gebrek aan een wettelijk verbod, komt $\S 138$ BGB in aanmerking als toetsingsmaatstaf. $\S 134$ BGB wordt namelijk gezien als een lex specialis ten opzichte van $\S 138$ BGB. ${ }^{13}$ Zo wordt het 'kopen' van een stem in strijd met de goede zeden geacht. ${ }^{13}$ Dit vloeit voort uit de algemene opvatting dat omkoping verboden is. ${ }^{133}$ In het vennootschapsrecht is de gedachte dat een aandeelhouder die zijn stem afhankelijk maakt van het verkrijgen van bijzondere voordelen, zijn eigen belang op ontoelaatbare wijze nastreeft ten koste van de vennootschap. ${ }^{134}$

Wanneer echter precies sprake is van Stimmenkauf, blijft duister. Zo acht Zöllner een stemovereenkomst tussen de verkoper en koper van een aandeel in een $\mathrm{GmbH}$ met een blokkeringsregeling, inhoudende dat de verkoper in de algemene vergadering vóór de goedkeuring van de overdracht zal stemmen, ongeldig. Indien aandeelhouders met elkaar afspreken dat zij elkaar tot bestuurder zullen benoemen, is dit zijns inziens geen Stimmenkauf. ${ }^{\text {.s }}$

\section{Overeenkomst tot uitstoting/uittreding}

Aangezien AktG noch GmbHG een wettelijke geschillenregeling kent, is deze in de rechtspraak ontwikkeld. De Gestaltungsfreiheit brengt met zich mee dat de statuten uitstotings- en uittredingsclausules mogen bevatten. Grenzen aan deze clausules worden gesteld met behulp van $\S 138$ BGB. Zo wordt een regeling die aandeelhouders het recht verschaft om naar eigen goeddunken andere aandeelhouders uit de vennootschap te stoten nietig geacht. Wel mag een aandeelhouder steeds in geval van een wichtigen

\footnotetext{
129. Rowedder/Schmidt-Leithoft/Koppensteiner $\S 47,20$.

130 Rowedder/Schmidt-Leithoff/Koppensteiner $\S 47,31$.

131 Sack, Staudinger BGB, $13^{\mathrm{c}}$ druk, $\$ 138,96$

132 Hachenburg/Hoffer, $\S 47,77$. Baumbach/Hueck/Zollner, $\$ 47,78$. Noack, 1994, blz. 145

13 Rowedder/Schmidt-Leithoff/Koppensteiner $\$ 47,33$.

134 Hachenburg/Haffer, $\$ 47,77$.

135 Baumbach/Hueck/Zollner $\$ 47,78$. Anders Rowedder/Schmidt-Leithoff/Koppensteiner $\$ 47,33$.
} 
Grumd uit de vennootschap worden gestoten. ${ }^{136}$ Indien zich een wichtiger Grund voordoet, heeft een aandeelhouder eveneens het recht om zelf uit de vennootschap te treden, als dwingend, unverzichtbar recht. ${ }^{37}$ De statuten mogen een afkoopsom bepalen, maar deze beperkt het uittredingsrecht op ontoelaatbare wijze, indien de afkoopsom zodanig onder de werkelijke waarde blijft, dat deze niet in verhouding staat tot de beperking aan het uittredingsrecht in het belang van de vennootschap. ${ }^{138}$ Aangenomen moet worden dat dezelfde normen van toepassing zijn op aandeelhoudersovereenkomsten. De door de goede zeden opgelegde grenzen gelden niet alleen ten behoeve van toekomstige aandeelhouders, maar juist ook voor de aandeelhouders die de statuten/overeenkomsten hebben opgesteld.

\section{Instructie-overeenkomsten met derden}

Zonder dat uitdrukkelijk wordt verwezen naar een wettelijk verbod of de goede zeden, achten sommige auteurs aandeelhoudersovereenkomsten nietig vanwege strijd met vennootschappelijke beginselen. Hüffer meent dat instructie-overeenkomsten met derden in principe ontoelaatbaar moeten worden geacht omdat deze het Abspaltungsverbot ondergraven. ${ }^{139}$ Het Abspaltungsverbot houdt in dat de lidmaatschapsrechten van aandeelhouders - in tegenstelling tot individuele hieruit voortvloeiende aanspraken - niet mogen worden losgekoppeld van het aandeel. ${ }^{1+0}$ Volgens Hüffer zijn stemovereenkomsten met derden in strijd met de aan het Abspaltungsverbot ten grondslag liggende overwegingen dat aan derden geen invloed in de vennootschap mag worden verschaft zonder dat zij in het kapitaal deelnemen en risico dragen. Voorts zou een stemovereenkomst met een derde zijns inziens de noodzakelijke samenhang tussen de uitoefening van het stemrecht en de vennootschappelijke Treupflicht van de aandeelhouder verbreken. ${ }^{141}$ Wel maakt hij een uitzondering voor overeenkomsten met derden die een eigen rechtens erkend belang bij het aandeel hebben, zoals een pandhouder of een koper van een aandeel. ${ }^{1+2}$

Andere auteurs achten een stemovereenkomst met een derde in beginsel toelaatbaar, tenzij deze betrekking heeft op besluiten tot statutenwijziging of structurele veranderingen. Dan zou de overeenkomst in strijd

Sack, Staudinger BGB, $\S 138,117$. Zie ook $\S 2.3 .2$.

Zie $\$$ 3.3.1.

BGHZ 116, 359 .

Hachenburg/Huffer $\S 47,75$. Vgl. ook Flume, blz. 242. Mayer-Maly, Munchener Kommentar, $3^{\mathrm{e}}$ druk, $\$ 134,19$ acht een stemovereenkomst die leidt tot Abspaltung nietig.

K. Schmidt, $\$ 19 \mathrm{III} \mathrm{4,} \mathrm{blz.} \mathrm{560.} \mathrm{Zie} \$ 3.3 .2$.

Hachenburg/Hüfer $\$ 47,78$.

Hachenburg/Huffer, $\$ 47,78$. Anders Rowedder/Koppensteiner, $\$ 47,19$. 
komen met de Satzungsautonomie, die in deze opvatting niet ter vrije beschikking van de aandeelhouders staat. ${ }^{133} \mathrm{Bij}$ andere besluiten wordt de aandeelhouder aan instructies van een derde gebonden geacht, voor zover dit niet tegen het belang van de vennootschap indruist. ${ }^{14}$ Fleck acht alleen duurzame stemovereenkomsten met derden ontoelaatbaar, daar deze zijns inziens hetzelfde effect hebben als een goederenrechtelijke loskoppeling. ${ }^{\text {14 }}$

Zöllner ziet geen grond om stemovereenkomsten met derden ontoelaatbaar te achten, omdat hij het onderscheid tussen de verbintenisrechtelijke stembinding en de vennootschappelijke stemrechtsuitoefening als doorslaggevend beschouwt. ${ }^{1+6} \mathrm{Hij}$ kwalificeert het beroep op de Verbandsautonomie als petitio principii. ${ }^{177}$ De ratio van het Abspaltungsverbot is zijns inziens niet gelegen in de veronderstelling dat loskoppeling per se tot ongewenste resultaten zou leiden, maar veeleer in het feit dat ter wille van de rechtszekerheid institutionele grenzen dienen te worden gesteld aan het gestalte geven aan de rechten van aandeelhouders. Deze ratio hoeft volgens hem niet te leiden tot een verbod op stemovereenkomsten met derden. Daarbij maakt hij voor statutenwijzigingen geen uitzondering. ${ }^{145}$

\section{Instructie-overeenkomst in geval van een blokkeringsregeling}

In de literatuur wordt ook getracht aan aanvullende statutaire bepalingen een dwingend karakter te geven. Op grond van $\S 15$ Abs. 5 GmbHG kunnen de statuten voorwaarden verbinden aan de overdracht van aandelen, in het bijzonder door de overdracht afhankelijk te maken van de goedkeuring van de vennootschap. Een blokkeringsregeling is echter niet dwingend voorgeschreven. Lutter/Grunewald betogen dat een instructie-overeenkomst met een derde de statuten op ontoelaatbare wijze ontduikt, indien de vennootschap een blokkeringsregeling kent. Op deze overeenkomsten passen zij de Normanwendungstheorie toe. Dit houdt in dat de wettelijke norm ook van toepassing wordt geacht op rechtshandelingen die de norm

143 Priester, Drittbindung des Stimmrechts und Satzungsautonomie, in: Festschrift fur Winfried Werner, 1984, blz. 672. Lutter/Hommelhoff, $\$ 47,5, \S 53,7$. K. Schmidt, 2002, blz. 85, acht het in strijd met de Verbandssouveranitat. Lutter/Grunewald, "Zur Umgehung von Vinkulierungsklauseln in Satzungen von Aktiengesellschaften und Gesellschaften mbH", AG 1989, blz III, spreken van de "nicht disponible Kern der Verbandsautonomie". Zie hierover ook § 4.3.5.

Lutter/Grunewald, AG 1989, blz. 111.

Fleck, FS Fischer, 1979, blz. 117.

Zo ook Noack, 1994, blz. 150.

Vgl. ook Beuthien/Gatsch, "Vereinsautonomic und Satzungsrechte Dritter", ZHR 1992, blz. 473.

Zie voorts $\$ 4.3 .5$.

Baumbach/Hueck/Zollner $\S 47,77$. Zo ook Rowedder/Schmidt-Leithoff/Koppensteiner $§ 47,32$. 
ontduiken, indien de interpretatie van de feiten aan de hand van het objectieve doel van de norm dit rechtvaardigt. ${ }^{199}$

In geval van een blokkeringsregeling is volgens Lutter/Grunewald van belang of het objectieve doel van de blokkeringsregeling vereist dat ook andere rechtshandelingen dan de overdracht aan de goedkeuring van de vennootschap dienen te worden onderworpen. De blokkeringsregeling kan dienen om het persoonsgebonden karakter van de vennootschap te waarborgen, om de nakoming van verplichtingen te vergemakkelijken, of om ongewenste machtsconcentratie te voorkomen. Indien het effect van de 'ontduikende' rechtshandeling overeenkomt met een overdracht, dient deze volgens hen aan de goedkeuring van de vennootschap te worden onderworpen. Zij maken daarbij een onderscheid tussen instructie-overeenkomsten in een concreet geval en algemene instructie-overeenkomsten. Alleen deze laatste behoeven de goedkeuring van de vennootschap. ${ }^{150}$ Het gevolg hiervan is dat de overeenkomst unwirksam is zolang deze niet is goedgekeurd..$^{151}$

Zöllner is daarentegen van mening dat de geldigheid van een stemovereenkomst niet afhankelijk is van de goedkeuring van de vennootschap. Hij acht stemovereenkomsten met derden in beginsel toelaatbaar, ook in geval van een blokkeringsregeling. ${ }^{152}$

\section{\$7.3.4 Vennootschapsrechtelijke werking van aandeelhoudersovereenkom- sten}

Hoewel een stemovereenkomst volgens het Bundesgerichtshof in beginsel niet ingrijpt in de "Willensbildung" van de vennootschap, daar niet de vennootschap gebonden is aan de overeenkomst, maar individuele aandeelhouders, ${ }^{153}$ kan onder omstandigheden een stemovereenkomst niettemin doorwerken in de vennootschappelijke besluitvorming en zo de vennootschap binden. Het Bundesgerichtshof heeft in twee controversiële uitspraken een besluit van de algemene vergadering vernietigd wegens strijd met een onderlinge afspraak tussen alle aandeelhouders (Nebenabrede), waarin een nadere invulling werd gegeven aan statutaire regelingen. Zolang alle aandeelhouders partij zijn, moet de overeenkomst volgens het Bundesgerichts-

\footnotetext{
149 Lutter/Grunewald, AG 1989, blz, 110.

Lutter/Grunewald, AG 1989, blz. 111/112.

Noack, 1994, blz. 138. Zie ook $\$ 6.3 .2$.

Baumbach/Hueck/Zollner, $\$ 47,77$.

BGHZ 48, 163, 171. Zie $\S 7.3 .1$.
} 
hof worden beschouwd als "eine solche der Gesellschaft". Het eisen van nakoming van de stemovereenkomst zou onnodig omslachtig zijn.

In de eerste zaak besloot een vennootschap, die als statutair doel de productie van machine-onderdelen had, tot de overname van een producent van Kerbnägel (een soort spijkers). Een minderheidsaandeelhouder van de vennootschap, tevens aandeelhouder van een concurrerend Kerbnägelbedrijf, stelde een vernietigingsactie tegen het overnamebesluit in, omdat de aandeelhouders hadden afgesproken dat de vennootschap niet op die markt actief zou worden. Het Bundesgerichtshof overwoog:

"Die Gesellschafter können sich jederzeit außerhalb der Satzung ihren Mitgesellschaftern schuldrechtlich verpflichten, in der Gesellschafterversammlung in bestimmter Weise abzustimmen. Deshalb bestehen rechtlich auch keine Bedenken gegen ein Übereinkommen aller Gesellschafter mit der $\mathrm{GmbH}$ in einem bestimmten, von deren satzungsmäßigem Zweck gedeckten Geschäftszweig nicht tätig zu werden. Verletzt ein Gesellschafter ein solches mit einem Mitgesellschafter getroffenes Abkommen, indem er abredewidrig abstimmt, so ist zwar der auf diese Weise zustandgekommene Beschluß grundsätzlich nicht anfechtbar, vielmehr der Streit um die Rechtsfolgen des Verstoßes unter den an der Bindung Beteiligten und nicht mit der Gesellschaft auszutragen.

Etwas anderes gilt aber dann, wenn der Beschluß gegen eine von allen Gesellschaftern eingegangene Bindung verstößt. Haben alle Gesellschafter eine die Gesellschaft betreffende Angelegenheit unter sich einverständlich geregelt, so ist diese Regelung - auch ohne Bestandteil der Satzung zu sein - zumindest solange zugleich als eine solche der Gesellschaft zu behandeln, als dieser nur die aus der Abrede Verplichteten angehören. In diesem Fall besteht kein Grund, die vertragswidrig überstimmten Gesellschafter auf den umständlichen Weg einer Klage gegen die Mitgesellschafter zu verweisen, um durch deren Verurteilung zu einer gegenteiligen Stimmabgabe den Beschluß aus der Welt zu schaffen. Die uberstimmten Gesellschafter können den Beschluß vielmehr durch Klage gegen die Gesellschaft anfechten." 1.34

In de tweede zaak ging het om het ontslag van een minderheidsaandeelhouder als bestuurder. De minderheidsaandeelhouder stelde een vernietigingsactie in tegen het ontslagbesluit, omdat zijns inziens de instemming van alle aandeelhouders, inclusief die van hem, voor een dergelijk besluit was vereist. Het Bundesgerichtshof overwoog:

"Schuldrechtliche Bindungen (...) werden im Schriftum innerhalb gewisser Grenzen durchweg für zulässig erachtet. (...) Sie können auch durch das Einverständnis der Gesellschafter begründet werden, die Satzung der Gesellschaft in 
einem bestimmten Sinne auszulegen. (...) Ist die Bindung von sämtlichen Gesellschaftern eingegangen worden, so kann sie auch im Wege der Anfechtungs- oder Nichtigkeitsklage geltend gemacht werden. Es ist kein Grund ersichtlich, warum für das Einverständnis, daß die Abberufung eines Gesellschafters aus seiner Stellung als Geschäftsführer nur mit seiner Zustimmung erfolgen soll, etwas anderes gelten müßte."'ss

Beide uitspraken zijn in de literatuur hevig bekritiseerd. In de eerste plaats zou met deze uitspraken de verplichting tot openbaarmaking van de statuten worden ondermijnd en daarmee de belangen van derden worden veronachtzaamd. ${ }^{156}$ Onderlinge afspraken zouden ten gevolge van de beide uitspraken "satzungsgleiche" hoedanigheden krijgen, zonder dat daarbij de wettelijke vorm- en publiciteitsvoorschriften in acht hoeven te worden genomen. ${ }^{157} \mathrm{De}$ gedachte is dat indien aandeelhouders overeenkomsten sluiten, onder andere om de notariskosten te drukken, zij daarvan ook de gevolgen moeten dragen, inclusief de hogere proceskosten wegens omslachtige procedures in geval van conflicten. ${ }^{15 s}$

In de tweede plaats wordt kritiek geuit op de ogenschijnlijke tegenstrijdigheid tussen de objectieve interpretatie van de statuten enerzijds en de Nebenabrede als basis voor een Anfechtungsklage anderzijds. ${ }^{159}$ Terwijl niet uit de statuten kenbare afspraken tussen aandeelhouders niet in aanmerking mogen worden genomen bij de interpretatie van statuten, ${ }^{160}$ leiden diezelfde afspraken, mits tussen alle aandeelhouders, wel tot de vernietigbaarheid van een besluit genomen in strijd met deze afspraken. Dit wordt niet consequent geacht; bij de objectieve interpretatie van de statuten wordt vastgehouden aan de functie van statuten voor derden, met name later toetredende aandeelhouders, terwijl bij de vernietigbaarheid van een besluit de feitelijke omstandigheden (namelijk het niet aanwezig zijn van derden) doorslaggevend worden geacht. De consequentie van beide uitspraken is volgens Ulmer, dat het succes van de vernietigingactie afhangt van toevallige omstandigheden zoals de verkoop van een aandeel aan een derde in de

Ulmer, "Verletzung schuldrechtlicher Nebenabreden als Anfechtungsgrund im GmbH-recht?". NJW 1987, blz. 1854 .

137 Winter, "Organisationsrechtliche Sanktionen bei Verletzung schuldrechtlicher Gesellschaftervereinbarungen?", ZHR 1990, blz. 268.

is Hoffmann-Becking, "Der Einfluß schuldrechtlicher Gesellschaftervereinbarungen auf die Rechtsbeziehungen in der Kapitalgesellschaft", ZGR 1994, blz. 450. Vgl. Ten Berg, blz. 186, die dit "van twee wallen eten" noemt.

Ulmer, NJW 1987, blz. 1854. Winter, ZHR 1990, blz. 270.

Zie \$ 4.3.3.
} 
tussentijd. ${ }^{161}$ Tenslotte meent Winter dat de vennootschap, vertegenwoordigd door het bestuur, als verwerende partij niet noodzakelijkerwijs over de vereiste informatie met betrekking tot de inhoud van de overeenkomst beschikt. $^{1 / 2}$

Ulmer concludeert dan dat sprake is van Rechtsfortbildung, i.e. door de rechter gecreëerd recht, en noemt het een Durchgriff probleem. De auteurs pleiten dan ook voor een beperkte uitleg van de uitspraken. Ulmer acht de Anfechtungsklage wegens strijd met een Nebenabrede in beginsel ontoelaatbaar, tenzij het gaat om misbruik van het vennootschapsrecht door de overige aandeelhouders. ${ }^{163}$ Winter zoekt aansluiting bij de Satzungsdurchbrechungsproblematiek; ${ }^{164}$ alleen wanneer de Nebenabrede ziet op een eenmalige situatie en de belangen van derden niet worden benadeeld, zou een Anfechtungsklage tegen een besluit in strijd met een Nebenabrede gehonoreerd mogen worden. ${ }^{165}$

Andere auteurs onderschrijven de uitkomst van de beslissingen wel. Volgens Hoffmann-Becking kunnen onderlinge afspraken tussen aandeelhouders in aanmerking worden genomen bij het beoordelen van een besluit in strijd met de Treupflicht. ${ }^{166}$ Westermann schetst het dilemma tussen enerzijds de Nebenabrede als publiciteitsschuw instrument, dat dan ook slechts met verbintenisrechtelijke sancties gehandhaafd zou mogen worden, en anderzijds het gevaar van 'lege' statuten, waarbij alle belangrijke regelingen in Nebenabreden zijn vervat. Om nog enige invloed op de vennootschappelijke verhoudingen te hebben zou het vennootschapsrecht zijn invloed over de Nebenabreden moeten uitstrekken. ${ }^{167}$ Door de doorwerking van Nebenabreden in de vennootschappelijke besluitvorming verwerven zij de status van statuten in materiële zin ${ }^{168}$

De vennootschappelijke werking wordt naar de mening van Zöllner gerechtvaardigd door het feit dat de aandeelhouders afspraken hebben gemaakt, die zij gehouden zijn na te komen. Indien zij in strijd met die onderlinge afspraken stemmen, mogen zij zich vervolgens niet op het

\footnotetext{
161 Ulmer, NJW 1987, blz 1854

162 Winter, ZHR 1990, blz 274

163 Ook Hachenburg/Hoffer $\$ 47,84$ en Hachenburg/Ulmer $\$ 3,125$ zijn voorstanders van strikte Trennung. Hachenburg/Raiser Anh. $\$ 47,142$, ziet zelfs geen ruimte voor uitzonderingen.

De Satzungsdurchbrechungsproblematiek gaat over de vraag, onder welke omstandigheden een besluit dat in strijd is met de statuten niettemin geldig zou kunnen zijn en aan welke vereisten dit zou moeten voldoen, zie $\$ 6.3 .4$ :

las Winter, ZHR 1990, blz. 278

166 Hoffmann-Becking, ZGR 1994, blz 459.

167 Westermann. Das Verhăltnis von Satzung und Nebenordnungen im Gesellschaftsrecht, 1994, blz 51. 
tegenovergestelde resultaat beroepen. Zouden evenwel de statuten worden gewijzigd na het sluiten van de overeenkomst, dan kan een aandeelhouder die niets heeft ondernomen tegen de statutenwijziging, zich later niet verzetten tegen een besluit dat is genomen in overeenstemming met de statuten, maar in strijd met de overeenkomst. ${ }^{169}$

\section{§7.4 Engeland}

\section{$\S 7.4 .1$ De toelaatbaarheid van stemovereenkomsten}

In het Engelse recht wordt het stemrecht beschouwd als een property right, dat een aandeelhouder mag uitoefenen zoals het hem goeddunkt. Dit is vaste rechtspraak sinds Pender v. Lushington uit 1877.

In deze zaak had Pender een deel van zijn aandelen overgedragen aan stromannen om de statutaire stemrechtbeperking te ontwijken. Daarop weigerde de bestuurder de uitgebrachte stemmen op deze aandelen te erkennen. Jessel MR overwoog:

"In all cases of this kind, where men exercise their rights of property, they exercise their rights from some motive adequate or inadequate, and $I$ have always considered the law to be that those who have the rights of property are entitled to exercise them, whatever their motives may be for such exercise."1ro

Ratio van deze uitspraak is volgens Hannnigan dat 'commercial certainty' is te verkiezen boven de onzekerheid dat een besluit kan worden aangetast op grond van de motieven van individuele aandeelhouders bij het uitoefenen van hun stemrecht. ${ }^{171}$ Dit is tevens de reden dat aandeelhouders hun stemrecht ook mogen uitoefenen indien zij een persoonlijk belang hebben, dat eventueel conflicteert met het belang van de vennootschap; het Engelse recht kent geen equivalent van het Stimmverbot. ${ }^{172}$

Uit de overweging dat een aandeelhouder zijn stemrecht naar eigen goeddunken kan uitoefenen, volgt dat het hem in beginsel vrijstaat stemovereenkomsten te sluiten. Ook stemovereenkomsten met derden worden toelaatbaar geacht. Het navolgende arrest biedt een illustratie.

Baumbach/Hueck/Zollner $\S 47,79$.

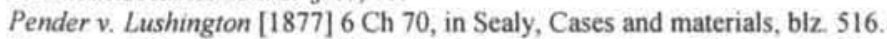

Hannigan, "Limitations on a Shareholder's Right to Vote - Effective Ratification Revisited", JBL 2000 , blz. 495. Vgl. het leerstuk van fraud on the minority, $\$ 6.4 .1$.

Vgl. North-West Transportation Co. Ltd v. Beatty [1887] 12 AC 589, in Hannigan, JBL 2000, blz. 511 . 
Greenhalgh had een vennootschap in nood de helpende hand toegestoken en in haar geïnvesteerd. Daar stond tegenover dat hij zeggenschap wilde in de vennootschap. In het kader van de financieringsoperatie had hij met de andere aandeelhouders een stemovereenkomst gesloten dat zij volgens zijn instructies zouden stemmen. Op een zeker moment verkochten de andere aandeelhouders hun aandelen. Greenhalgh poogde deze verkoop voor de rechter ongedaan te maken. Lord Greene MR overwoog dat de stemovereenkomst geen verbod op overdracht van de aandelen behelsde en de overeenkomst was beëindigd op het moment dat de aandelen waren overgedragen. ${ }^{13}$ Aan de rechtsgeldigheid van de stemovereenkomst als zodanig werd geen woord gewijd.

Finn schetst de aandeelhoudersovereenkomst als een bijzonder effectief instrument ter waarborging van de belangen van minderheidsaandeelhouders. Niet alleen kunnen overeenkomsten oplossingen bieden om 'oppression', 'locking-in' of 'squeezing-out' te voorkomen, maar ook verschaffen zij aandeelhouders meer rechtszekerheid bij het afdwingen van hun rechten. Het gecompliceerde vraagstuk van het afdwingen van lidmaatschaps- of andere statutaire rechten wordt op deze wijze omzeild. ${ }^{174}$

\section{\$ 7.4.2 Contractuele sancties op niet-nakoming van stemovereenkomsten}

Een aandeelhouder staan in beginsel alle contractuele rechtsmiddelen ter beschikking om de naleving van de overeenkomst af te dwingen. Niet alleen kan schadevergoeding worden gevorderd, maar ook nakoming, eventueel in de vorm van mandatory en restraining injunctions. ${ }^{175}$ Zo werd in de hieronder volgende uitspraak Russell v. Northern Bank Development Corporation Ltd een stemverbod wegens strijd met een aandeelhoudersovereenkomst gevorderd. ${ }^{176}$

\section{\$ 7.4.3 Grenzen aan de geldigheid van aandeelhoudersovereenkomsten}

Aandeelhoudersovereenkomsten mogen geen dwingende wettelijke bepalingen, die beogen crediteuren te beschermen, terzijde stellen. ${ }^{177}$ Daar-

173 Greenhalgh v. Mallard [1943] 2 All ER 234.

174 Finn, "Shareholder Agreements", ABLR 1978, blz. 98, 103. Zie uitgebreid Stedman \& Jones, Shareholders' Agreements, 1998, blz. 142 c.v. Zie verder $\$ 6.4 .1$.

175 Sealy, The Enforcement of Partnership Agreements, Articles of Association and Shareholder Agreements, in: Equity and Commercial Relationships, P.D. Finn (ed.), 1987, blz. 107. Finn, ABLR 1978, blz. 103. Een gebod om te stemmen conform de overeenkomst is voor het eerst opgelegd in Puddephatt v. Leith [1916] I Ch 200, in Sealy, Cases and Materials, blz. 203.

176 Russell v Northern Bank Development Corporation Ltd [1992] 1 WLR 588. Zie reeds Greenwell v. Potter [1902] 1 Ch 530 .

17) Zie $\$ 6.4 .3$ over de grenzen aan de unanimous consent rule. 
enboven lijkt het Engelse recht weinig beperkingen te stellen aan de toelaatbaarheid van aandeelhoudersovereenkomsten, met name met betrekking tot de interne organisatie van de vennootschap. Baanbrekende uitspraak is in dit verband Russell v. Northern Bank Development Corporation Ltd. In deze zaak wordt een onderscheid gemaakt tussen een statutaire beperking van dwingendrechtelijke bevoegdheden van de vennootschap en de contractuele binding van aandeelhouders. Terwijl een beperking van de vennootschap in de uitoefening van haar bevoegdheden ongeoorloofd zou zijn, laat dit onverlet dat aandeelhouders zich rechtsgeldig ten aanzien van de uitoefening van deze bevoegdheden kunnen verbinden.

In het kader van een herstructurering van twee bouwbedrijven wordt een nieuwe holding company opgericht, Tyrone Brick Ltd (hierna: TBL). De vier bestuurders van de bouwbedrijven, waaronder Russell, houden ieder 10 procent van de aandelen, terwijl de bank 60 procent van de aandelen houdt. Teneinde de belangen van de minderheidsaandeelhouders veilig te stellen, komen de aandeelhouders en TBL overeen dat er geen nieuwe aandelen zullen worden uitgegeven zonder de instemming van alle aandeelhouders. Op grond van section 121 CA 1985 volstaat echter een besluit van de algemene vergadering genomen met volstrekte meerderheid voor de uitgifte van nieuwe aandelen. De aan de orde gestelde rechtsvraag is of een aandeelhoudersovereenkomst de wettelijke bevoegdheid van de vennootschap om haar aandelenkapitaal te verhogen mag beperken. Lord Jauncey overwoog:

"While a provision in a company's articles which restricts its statutory power to alter those articles is invalid, an agreement dehors the articles between shareholders as to how they exercise their voting rights on a resolution to alter the articles is not necessarily so. In Welton $v$. Saffery which concerned an ultra vires provision in the articles of association authorising the company to issue shares at a discount, Lord Davey said: "Of course, individual shareholders may deal with their own interests by contract in such a way as they may think fit. But such contracts, whether made by all or some only of the shareholders, would create personal obligations, or an exceptio personalis against themselves only, and would not become a regulation of the company, or be binding on the transferees of the parties to it, or upon new or non-assenting shareholders..." I understand Lord Davey there to be accepting that shareholders may lawfully agree inter se to exercise their voting rights in a manner which, if it were dictated by the articles, and were thereby binding on the company would be unlawful."178

17n. Russell v Northern Bank Development Corporation Ltd [1992] I WLR 588. 
Als overeenkomst tussen aandeelhouders achtte Lord Jauncey de overeenkomst wel toelaatbaar. "This agreement is purely personal to the shareholders who execute it and (...) does not purport to bind future shareholders." In casu was echter TBL partij bij de overeenkomst. Diens contractuele gebondenheid was naar zijn mening "as obnoxious as if it had been contained in the articles of association and therefore is unenforceable as being contrary to the provisions of article 131 of the Companies (Northern Ireland) Order 1986 (vergelijkbaar met section 121 CA 1985, MM)." Hij ontleende steun voor deze argumentatie aan Bushell v Faith, waarin Russell LJ overwoog "A company cannot by its articles or otherwise deprive itself of the power by special resolution to alter its articles." ${ }^{119}$ Door toepassing van de doctrine of severance werd de geldigheid van de overeenkomst bewerkstelligd, voor zover deze uitsluitend de aandeelhouders bond. ${ }^{180}$

In de Engelse literatuur is uitgebreid gediscussieerd over de reikwijdte van deze uitspraak. ${ }^{11}$ In het algemeen wordt aangenomen dat de uitspraak ertoe leidt dat een vennootschap niet haar statutory powers mag beperken, noch statutair, noch bij overeenkomst, terwijl aandeelhouders zich daarentegen wel mogen verbinden op afgesproken wijze te stemmen. Doordat de overeenkomst slechts tussen partijen geldt, worden toekomstige aandeelhouders beschermd. ${ }^{182}$

Andere schrijvers leggen de nadruk op het effect van de uitspraak, dat door middel van een aandeelhoudersovereenkomst hetzelfde resultaat zou worden bereikt als wanneer de vennootschap zelf zou worden gebonden, waarmee een vrijbrief zou worden gegeven om dwingende wettelijke bepalingen te omzeilen. McGlynn onderkent het dilemma tussen enerzijds een dwingende bepaling van vennootschapsrecht en anderzijds de contractsvrijheid van aandeelhouders, maar vervolgt "lip-service is paid to statute, leaving enterprising shareholders to by-pass its provisions." ${ }^{183}$ Ook Shapira ziet in beide uitspraken een "triumph of formalism over substance", als niet echt bevredigende uitweg om minderheidsaandeelhouders in persoonsgebonden vennootschappen te beschermen. ${ }^{184}$

179 Bushell v Faith [1969] 2 Ch 438, [1969] 1 All ER 1002, [1969] 2 WLR 1067.

$180 \mathrm{Vgl}$. Sealy, "Shareholders'Agreements - An Endorsement and a Warning from the House of Lords". CLJ 1992, blz. 438. De doctrine of severance is vergelijkbaar met partiele nietigheid.

Vgl. onder meer Davenport "What did Russell v. Northern Bank Development Corporation Ltd. decide?", LQR 1993, blz. 553 e.v, en Ferran, "The decision of the House of Lords in Russell v. Northern Bank Development Corporation Limited", CLJ 1994, blz. 343 e.v. Colt Telecom Group ple [2002] EWHC 2815 (Ch), [2002] All ER (D) 347 oordeelde Jacob J dat een overeenkomst tussen crediteuren om geen "administration order" te verzoeken evenmin de rechten van de vennootschap aantastte en derhalve rechtsgeldig was.

McGlynn, "The constitution of the company: mandatory statutory provisions v. private agreements", The Company Lawyer 1994, blz. 304.

ist Shapira, "Voting Agreements and Corporate Statutory Powers", LQR 1993, blz. 214. Vgl. ook 
Toekomstige aandeelhouders kunnen volgens Riley beter worden beschermd door verplichte openbaarmaking van overeenkomsten. ${ }^{1 \text { ss }}$ Ook de aandeelhouders die partij zijn bij de overeenkomst verdienen volgens Riley enige mate van bescherming, omdat zij door de lange duur van de vennootschappelijke overeenkomsten de gevolgen niet altijd kunnen overzien. Hij pleit voor rechterlijke controle achteraf, met inachtneming van de duur van de overeenkomst en eventuele gewijzigde omstandigheden.

Ondanks het onderscheid tussen contractuele binding en de uitoefening van vennootschapsrechtelijke bevoegdheden, worden in de literatuur tegen sommige stemovereenkomsten bezwaren geuit. Finn beschouwt het kopen van een stem als illegal. Als reden hiervoor merkt hij aan dat dit leidt tot omkoping en bedrog jegens de andere aandeelhouders, die er vanuit mogen gaan dat een aandeelhouder "is exercising his own judgment and sense of equity". Deze bezwaren zouden niet opgaan indien alle aandeelhouders zich openlijk jegens elkaar verbinden. ${ }^{186}$ Ook Riley meent dat elke aandeelhouder er vanuit mag gaan dat alle andere aandeelhouders een onafhankelijk oordeel zullen vormen. Wordt een aandeelhouder toch steeds geconfronteerd met blokvorming, dan zou hij om uittreding kunnen verzoeken op de grond dat de vennootschap hem "unfairly prejudicial" heeft behandeld, conform section 459 CA $1985 .{ }^{117}$ Dit laat de stemovereenkomst als zodanig overigens onverlet.

\section{\$ 7.4.4 Vennootschapsrechtelijke werking van aandeelhoudersovereen- komsten}

Hoewel het Engelse recht een in beginsel strikte scheiding hanteert tussen vennootschaps- en verbintenissenrecht, kunnen aandeelhoudersovereenkomsten niettemin doorwerken in het Engelse vennootschapsrecht. Zowel besluiten als statuten worden als bijzondere overeenkomsten beschouwd, zodat niet altijd acht wordt geslagen op het formele onderscheid zolang aandeelhouders overeenstemming hebben bereikt. ${ }^{18 t}$ Bovendien is in het Engelse recht niet zozeer van belang, onder wat voor omstandigheden een besluit vernietigbaar is, als wel onder wat voor omstandigheden een aandeelhouder zich kan verzetten tegen schending van de overeenkomst, in welke vorm dan ook. Zo is in de jurisprudentie een recht voortvloeiende uit

Ferran, CLJ 1994, blz. 346 en Farrar, blz. 133. 
een aandeelhoudersovereenkomst als 'class right' in de zin van section 125 CA 1985 aangemerkt. ${ }^{1 * 0}$ De strikte scheiding, zoals in Russell gehanteerd, wordt vloeiend als het aankomt op bescherming van minderheidsaandeelhouders. De gedachte is dat afspraken dienen te worden nagekomen. Formele verschillen doen daar niets aan af.

Diezelfde bescherming van minderheidsaandeelhouders door middel van het honoreren van afspraken geschiedt eveneens via de equitable bepalingen van section $459 \mathrm{CA} 1985$ ('unfairly prejudicial conduct') de 'just and equitable' redenen om de vennootschap te ontbinden, in de zin van section 122 (g) Insolvency Act 1986. Zo kan een aandeelhouder die wordt geconfronteerd met een besluit in strijd met een onderlinge afspraak om uittreding verzoeken. Daar ontbinding van de vennootschap als ultimum remedium wordt beschouwd, dient eerst een beroep te worden gedaan op section 459 CA 1985.

In de 'leading case' Ebrahimi v. Westbourne Galleries oordeelde de House of Lords dat ontbinding van de vennootschap 'just and equitable' kon zijn ingeval een bestuurder werd ontslagen in strijd met een tussen de aandeelhouders bestaande afspraak.

Ebrahimi en Nazar hadden sinds tien jaar een gezamenlijke tapijthandel, totdat zij in 1958 besloten hun partnership om te zetten in een limited company. Beiden werden bestuurder en bezaten elk de helft van het aandelenkapitaal. Na enige tijd trad Nazars zoon ook toe tot het bestuur, terwijl hij tegelijkertijd een derde van het aandelenkapitaal kreeg. Ebrahimi was nu in de minderheid. Na onenigheid besloot de algemene vergadering hem op grond van de toenmalige section 184 CA 1948 te ontslaan. Ebrahimi vorderde daarop de ontbinding van de company "on just and equitable grounds". Terwijl een aandeelhouder normaal gesproken zijn ontslag heeft te accepteren, achtte Lord Wilberforce in dit geval ontbinding gerechtvaardigd, daar Ebrahimi was overgeleverd aan de goede wil van de Nazars ten aanzien van de toekenning van dividend en de verkoop van zijn aandelen. Hij overwoog:

"The just and equitable provision nevertheless comes to his assistance if he can point to, and prove, some special underlying obligation of his fellow (members) in good faith, or confidence, that so long as the business continues he shall be entitled to management participation, an obligation so basic that if broken, the conclusion must be that the association must be dissolved." ${ }^{\text {(9) }}$

\footnotetext{
189 Harman v, BML Group Ltd [1994] 1 WLR 893, [1994] BCC 502. Zie \$ 5.4.2.

(90) Zie $\$ 3.4 .1$.

191. Ebrahimi v Westbourne Galleries [1973] AC 360, [1972] 2 All ER 492.
} 
Section 459 CA 1985 is pas later ingevoerd. In O'Neill v. Phillips heeft de House of Lords zich voor de toepassing van section 459 CA 1985 aangesloten bij de redenering van Lord Wilberforce in Ebrahimi, die schending van de onderlinge afspraken tussen aandeelhouders als voorwaarde voor ontbinding, c.q. uittreding vooropstelt.

O'Neill was werkzaam bij de vennootschap Phillips Ltd, waarvan Phillips enig aandeelhouder en bestuurder was. Daar O'Neill hard werkte en veel betrokkenheid toonde, schonk Phillips hem 25 van de 100 aandelen en benoemde hem tot bestuurder, daarbij de hoop uitsprekend dat O'Neill hem ooit zou opvolgen. Toen de zaken echter minder gingen, begon het gebrek aan managementcapaciteiten van O'Neill Phillips zorgen te baren. O'Neill werd weggepromoveerd naar de Duitse vestiging en Phillips nam de leiding weer over. Daarop stelde O'Neill een actie in op grond van section $459 \mathrm{CA}$ 1985. Lord Hoffmann overweegt:

"In the case of section 459, the background has the following two features. First, a company is an association of persons for an economic purpose, usually entered into with legal advice and some degree of formality. The terms of the association are contained in the articles of association and sometimes in collateral agreements between the shareholders. Thus the manner in which the affairs of the company may be conducted is closely regulated by rules to which the shareholders have agreed. Secondly, company law has developed seamlessly from the law of partnership, which was treated by equity, like the Roman societas, as a contract of good faith. One of the traditional roles of equity, as a separate jurisdiction, was to restrain the exercise of strict legal rights in certain relationships in which it considered that this would be contrary to good faith. These principles have, with appropriate modification, been carried over into company law. The first of these two features leads to the conclusion that a member of a company will not ordinaryly be entitled to complain of unfairness unless there has been some breach of the terms on which he agreed that the affairs of the company should be conducted. But the second leads to the conclusion that there will be cases in which equitable considerations make it unfair for those conducting the affairs of the company to rely upon their strict legal powers. Thus unfairness may consist in a breach of the rules or in using the rules in a manner which equity would regard as contrary to good faith. (...) So I agree with Jonathan Parker J. when he said in In re Astec (B.S.R.) plc [1998] 2 BCLC 556, 588: "in order to give rise to an equitable constraint based on 'legitimate expectations' what is required is a personal relationship or personal dealings of some kind between the party seeking to exercise the legal right and the party seeking to restrain such exercise, such as will affect the conscience of the former." (...) But I think that one useful cross-check in a case like this is to ask whether the exercise of the power in question would be contrary to what the parties, by words or conduct, have actually agreed. Would it conflict with the promises which they appear to have exchanged? (...) In a quasipartnership company, they will usually be found in the understandings between the 
members at the time they entered into association. But there may be later promises, by words or conduct, which it would be unfair to allow a member to ignore. Nor is it necessary that such promises should be independently enforceable as a matter of contract. A promise may be binding as a matter of justice and equity although for one reason or another (for example, because in favour of a third party) it would not be enforceable in law. ${ }^{192}$

Sealy acht de kans klein dat er veel ruimte overblijft voor "equitable considerations" indien er een duidelijke aandeelhoudersovereenkomst is gesloten. ${ }^{193}$ Dit wordt onderschreven door Riley, die opmerkt dat hoe gedetailleerder de overeenkomst, hoe sneller de rechter zal oordelen dat er niet sprake is van een quasi-partnership, maar van een "commercial body based upon contracting at arms-length". ${ }^{194}$ Niettemin kan ook het eisen van nakoming van een overeenkomst unfair worden geacht. ${ }^{195}$

\section{$\S 7.5$ Evaluatie}

De onderlinge verhoudingen binnen de vennootschap worden niet alleen bepaald door statuten en besluiten, maar kunnen tevens hun beslag krijgen in aandeelhoudersovereenkomsten. Deze overeenkomsten kunnen een nuttige functie vervullen, voor zover zij rechten en verplichtingen van aandeelhouders in de vennootschap nader bepalen. Immers, hoe duidelijker en gedetailleerder de rechten en verplichtingen van aandeelhouders jegens elkaar zijn geconcretiseerd, hoe beter aandeelhouders zichzelf beschermd achten. Daar staat tegenover dat het vastleggen van rechten en verplichtingen in een overeenkomst verstarrend kan werken op de besluitvorming in de vennootschap, doordat wijzigingen uitsluitend met instemming van alle partijen kunnen plaatsvinden.

Overeenkomsten tussen aandeelhouders die van invloed zijn op de vennootschappelijke verhoudingen worden in alle drie onderzochte stelsels in principe toelaatbaar geacht, met een beroep op de vrijheid van de

192 O'Neill v Phillips [1999] I WLR 1092. Zie ook \$ 3.4.1. In Re Phoenix Office Supplies Ltd, Phoenix Office Supplies Ltd and others v. Larvin [2002] EWCA Civ 1740, [2003] I BCLC 76, wordt $O$ 'Neill verder uitgelegd.

Sealy, 1987, blz. 108. Zie ook Stedman \& Jones, Shareholders' Agreements, 1998, blz. 142. Een voorbeeld hiervan biedt Redwood Master Fund Ltd and others v. TD Bank Europe Ltd and others [2002] All ER (D) 141, waarin Rimer J geen ruimte zag om het bona fide principe als implied term in de aandeelhoudersovereenkomst lezen.

194 Riley, MLR 1992, blz. 796. Zie over de rol van section 459 als een "gap-filling mechanism" Copp, "Company law and alternative dispute resolution: an economic analysis", Company Lawyer 2002, blz. 373 e.v.

195 Reece Thomas en Ryan, "Section 459, public policy and freedom of contract", The Company Lawyer 2001, blz. 181. Dit is de grondslag voor de doctrine of waiver. 
aandeelhouder om zijn rechten naar eigen goeddunken uit te oefenen. De erkenning van de toelaatbaarheid van stemovereenkomsten wordt gekoppeld aan het onderscheid tussen de contractuele gebondenheid van de aandeelhouder en de vennootschapsrechtelijke uitoefening van zijn stemrecht in de algemene vergadering, die de gebondenheid van de vennootschap kan bewerkstelligen. De geldigheid van de stem staat in beginsel los van de geldigheid van de overeenkomst. Enerzijds kan een stem uitgebracht in strijd met een overeenkomst geldig zijn, anderzijds de stem uitgebracht in overeenstemming met een nietige overeenkomst ook. Op deze wijze lijken vennootschapsrecht en verbintenissenrecht in de jurisprudentie van alle drie stelsels in beginsel gescheiden te worden gehouden.

Naar Nederlands recht onderstreept de scheiding tussen de contractuele gebondenheid en de vennootschapsrechtelijke uitoefening van het stemrecht het primaat van het verbintenissenrecht ten aanzien van aandeelhoudersovereenkomsten. Grenzen aan de geldigheid van overeenkomsten worden gesteld door artikel 3:40 BW; artikel 2:25 BW heeft daarop geen invloed. Dwingend vennootschapsrecht werkt wel door in het verbintenissenrecht, maar of de strekking van de bepaling nietigheid van de overeenkomst met zich meebrengt, wordt bepaald door artikel 3:40 BW.

Omgekeerd werkt het verbintenissenrecht door in het vennootschapsrecht, doordat nakoming van een stemovereenkomst kan worden gevorderd, en kan een overeenkomst vennootschapsrechtelijke werking worden toegekend, zodat de overeenkomst jegens de vennootschap kan worden ingeroepen, gelijk een besluit of statuten.

Enerzijds wordt de nadruk gelegd op het onderscheid tussen vennootschapsrecht en verbintenissenrecht, anderzijds is er sprake van een voortdurende wisselwerking tussen beide. Dat bij overeenkomst is toegestaan wat in de statuten zou zijn verboden, wordt mijns inziens gerechtvaardigd door het feit dat een overeenkomst in beginsel slechts werkt tussen partijen, terwijl de statuten voor alle bij de vennootschap betrokkenen bindend zijn, inclusief de vennootschap zelf en later toetredende aandeelhouders. Deze rechtvaardiging van het onderscheid is wellicht niet zozeer een kwestie van scheiding van vennootschapsrecht en verbintenissenrecht, maar vloeit veeleer voort uit dit verschil in functie en bindende kracht tussen overeenkomsten en statuten. Anders gezegd, rechtvaardigen de interne vennootschappelijke verhoudingen niet steeds een dwingendrechtelijke grens in de zin van artikel 3:40 BW.

Een overeenkomst waarbij een stem wordt 'gekocht' wordt in alle stelsels ongeoorloofd geacht. Dwingende vennootschapsrechtelijke grenzen waarop aandeelhoudersovereenkomsten stuiten, vloeien voort uit de bescherming van crediteuren en de bescherming van de vennootschappelijke 
institutionele orde. Het is met name de afbakening van de institutionele orde die in de jurisprudentie en literatuur van de verschillende rechtsstelsels tot verschillende keuzes leidt.

In met name de Duitse en Nederlandse literatuur wordt wel indirect uit de strekking van dwingende bepalingen of vennootschapsrechtelijke beginselen afgeleid dat bepaalde aandeelhoudersovereenkomsten ongeoorloofd zijn. De gevolgen van de overeenkomst worden in strijd geacht met de vennootschappelijke institutionele orde. Dit gaat op voor stemovereenkomsten met bestuurders en in Duitsland voor stemovereenkomsten met aandeelhouders die niet mogen stemmen wegens een Stimmverbot. Een belangrijke categorie vormt voorts de instructie-overeenkomst die een overdracht van stemrecht benadert, en zo een ander dan de betreffende aandeelhouder invloed geeft op de vennootschappelijke besluitvorming, zonder dat daar de verschaffing van risicodragend kapitaal als legitimatie tegenover staat. Afwisselend wordt een beroep gedaan op het afhankelijk karakter van het stemrecht, de verplichte zelfstandige oordeelsvorming van de aandeelhouder, de blokkeringsregeling om de ongeoorloofdheid van dergelijke overeenkomsten te beargumenteren.

In het Engelse recht lijkt minder plaats voor institutionele overwegingen ten aanzien van de uitoefening van bevoegdheden van de algemene vergadering. In Russell v. Northern Bank Development Corporation Ltd wordt de scheiding tussen stem en overeenkomst vooropgesteld, in plaats van de gevolgen die een dergelijke overeenkomst heeft op de uitoefening van de bevoegdheden door de algemene vergadering.

In de Nederlandse en Duitse literatuur wordt daarentegen door sommige auteurs met name acht geslagen op deze gevolgen, waardoor een overeenkomst die ertoe leidt dat de algemene vergadering wordt beperkt in de uitoefening van haar dwingende bevoegdheden ongeoorloofd wordt geacht. Andere auteurs stellen de scheiding voorop. Dit betekent in feite dat zij de gevolgen niet strijdig achten met de vennootschappelijke orde.

Zoals gezegd, vindt de scheiding tussen stem en overeenkomst naar mijn mening haar rechtvaardiging in het verschil in functie tussen overeenkomsten en statuten. Ik meen dat aandeelhouders in eerste instantie zelf verantwoordelijk moeten worden geacht voor de ontwikkeling en vormgeving van een besloten vennootschap en hun onderlinge verhouding, hetgeen met zich meebrengt dat zij in beginsel vrij zijn om hun onderlinge verhoudingen nader in te vullen. Een minimum aan 'machtsevenwicht' is mijns inziens gewaarborgd indien een overeenkomst de bevoegdheid van de algemene vergadering met betrekking tot de décharge en het ontslag van bestuurders en het vaststellen van de jaarrekening intact laat en individuele 
aandeelhouders enige mate van invloed op de gang van zaken binnen de vennootschap kunnen uitoefenen. ${ }^{196}$

$\mathrm{Nu}$ duidelijk is geworden dat niet alleen de scheiding tussen de contractuele gebondenheid van de aandeelhouder en de vennootschapsrechtelijke uitoefening van zijn stemrecht het doorslaggevende argument is voor de toelaatbaarheid van aandeelhoudersovereenkomsten, maar tevens de niet als schadelijk beoordeelde gevolgen voor de interne vennootschappelijke orde, wordt de weg vrijgemaakt voor de doorwerking van aandeelhoudersovereenkomsten in de vennootschappelijke besluitvorming, in de zin dat een aandeelhoudersovereenkomst onder omstandigheden dezelfde status krijgt als statuten: een bijzondere overeenkomst tussen aandeelhouders, die in principe dient te worden nagekomen (pacta sunt servanda). In het Engelse recht spreekt dit welhaast vanzelf, terwijl in met name de Duitse literatuur het verschil in formele status wordt benadrukt met alle consequenties voor de rechtsgeldigheid. Het Bundesgerichtshof heeft een besluit vernietigd wegens strijd met een overeenkomst, gesloten tussen alle aandeelhouders, omdat het ten eerste het omslachtig achtte om contractuele rechtsmiddelen te hanteren, indien er geen derden zijn die bescherming behoeven, en ten tweede doelmatiger om direct de vennootschap aan te spreken. In Nederland heeft de Hoge Raad de binding van de vennootschap aan de aandeelhoudersovereenkomst bewerkstelligd via het leerstuk van de onrechtmatige daad en wordt ook in de literatuur gepleit voor (aangepaste) navolging van het Duitse voorbeeld.

Het primaat van het aloude adagium 'pacta sunt servanda', zorgt ervoor dat minderheidsaandeelhouders die partij zijn bij de overeenkomst effectiever worden beschermd. Het Engelse recht maakt te dien aanzien geen onderscheid tussen statuten en aandeelhoudersovereenkomsten, terwijl daarnaast onderlinge afspraken van aandeelhouders die geen contract in strikte zin vormen, een invulling geven aan 'equitable considerations', op grond waarvan een aandeelhouder uit de vennootschap kan treden, of de vennootschap kan worden ontbonden. De Ondernemingskamer lijkt op vergelijkbare wijze ruimte te bieden aan afspraken tussen aandeelhouders bij de beoordeling van de vraag of van wanbeleid sprake is. Door de vennootschapsrechtelijke redelijkheid en billijkheid in te kleuren met tussen aandeelhouders onderling gemaakte afspraken blijft het mogelijk het belang van de ontwikkeling van de vennootschap af te wegen tegen het belang van de (minderheids)aandeelhouder in kwestie. Nakoming van gemaakte afspraken dient echter naar mijn mening het uitgangspunt te zijn.

\footnotetext{
196 Zie $\$ 3.5$.
} 
Indien alle aandeelhouders partij zijn bij de overeenkomst, bindt deze hen in gelijke mate als statuten en kan een besluit worden vernietigd wegens schending ervan. Een en ander neemt niet weg dat een overeenkomst buiten toepassing kan worden gelaten indien deze in een concreet geval in strijd met de redelijkheid en billijkheid blijkt te zijn. Aangezien een aandeelhoudersovereenkomst invloed heeft op de besluitvorming van de vennootschap, vloeit uit de aard van de overeenkomst voort dat partijen rekening houden met het belang van de vennootschap en de bij de vennootschap betrokkenen (artikel 6:248 BW). 


\section{Hoofdstuk 8 Conclusie}

\section{§ $8.1 \quad$ Inleiding}

Waarom hebben wij dwingend vennootschapsrecht? Deze vraag vormt de aanleiding en de basis voor het schrijven van dit boek. De vraag lijkt te veronderstellen dat dwingend vennootschapsrecht regel is. In Nederland wordt in het algemeen aangenomen dat dit zo is. Artikel 2:25 BW bepaalt immers: "Van de bepalingen van dit boek kan slechts worden afgeweken, voor zover dat uit de wet blijkt." Nu het departement de statuten niet langer aan een inhoudelijk onderzoek onderwerpt, blijkt veel onzekerheid te bestaan over de vraag welke ruimte de wet aan opstellers van statuten en aandeelhoudersovereenkomsten biedt. Bovendien klinkt steeds vaker de roep om het dwingendrechtelijk uitgangspunt om te keren.

Hoewel het aantal besloten vennootschappen vele malen talrijker is dan het aantal naamloze vennootschappen, ontbreekt het de BV aan een eigen juridisch gezicht, dat aansluit bij haar werkelijke structuur. Het wettelijk regime dat de besloten vennootschap beheerst stelt aandeelhouders enerzijds in staat een vennootschap op te richten en haar organisatie vorm te geven, anderzijds stelt de wet dwingende grenzen of geeft het de kaders aan waarbinnen vennootschappen dienen te functioneren. Dit boek gaat over de vraag in hoeverre aandeelhouders in een besloten vennootschap mogen afwijken van dwingend vennootschapsrecht, dan wel dwingend vennootschapsrecht mogen aanvullen.

\section{Contracts- en inrichtingsvrijheid van aandeelhouders}

Wat ik als grootste bezwaar van het dwingendrechtelijk uitgangspunt van het vennootschapsrecht beschouw, is dat het vooropstelt wat moet of niet mag, en zo miskent dat het vennootschapsrecht in de eerste plaats een middel zou moeten zijn voor ondernemers om hen in staat te stellen zo goed mogelijk te ondernemen. Geïnspireerd door het Engelse recht en Duitse $\mathrm{GmbH}$-recht, heb ik derhalve de keuzevrijheid van aandeelhouders 
centraal gesteld, i.e. de vrijheid om naar eigen inzicht de vennootschap gestalte te geven en te doen functioneren, met behulp van statuten, overeenkomsten en besluiten.

Het vooropstellen van de contracts- en inrichtingsvrijheid van aandeelhouders benadrukt in de eerste plaats de principiële gelijkwaardigheid van partijen. Aandeelhouders in een besloten vennootschap vormen een beperkte kring, die zelf in staat moeten worden geacht hun belangen in de vennootschap te waarborgen. Als actoren in het commerciële verkeer zijn zij niet a priori een zwakkere partij, die beschermd moet worden, zoals werknemers en consumenten. Dit vormt mijns inziens een essentieel verschil met beleggers in een naamloze vennootschap. In de tweede plaats wordt benadrukt dat aandeelhouders vrijwillig toetreden tot de vennootschap en zich vrijwillig binden. De instemming van de aandeelhouders vormt de grondslag van hun gebondenheid, eerder dan de objectieve wet. De wet voorziet juist in de naleving van de gebondenheid en biedt een model-vennootschap, waarvan aandeelhouders in individuele gevallen naar eigen goeddunken kunnen afwijken. Op deze wijze wordt het vennootschapsrecht ingebed in het algemene privaatrecht, waarvan het naar mijn mening onlosmakelijk deel uitmaakt. Hierdoor kunnen algemene regels van privaatrecht, met inachtneming van het bijzondere karakter van het vennootschapsrecht, zoveel mogelijk worden toegepast.

Dwingend vennootschapsrecht vormt een inbreuk op de principiële keuzevrijheid van aandeelhouders en dient derhalve gerechtvaardigd te worden. De vraag is dan niet langer in hoeverre aandeelhouders mogen afwijken van dwingend vennootschapsrecht, dan wel dwingend vennootschapsrecht mogen aanvullen, maar in hoeverre dwingend vennootschapsrecht grenzen mag stellen aan de keuzevrijheid van aandeelhouders om hun vennootschappelijke verhoudingen gestalte te geven.

\section{Verschillende gradaties van dwingend recht}

In de inleiding is uiteengezet dat dwingend vennootschapsrecht kan worden gerechtvaardigd doordat de belangen van bij de vennootschap betrokkenen, inclusief de vennootschap zelf, bescherming behoeven. Hoewel de kring van betrokkenen ruim kan worden getrokken, heb ik deze beperkt tot crediteuren, (minderheids)aandeelhouders, toekomstige aandeelhouders en de vennooschap. Aangezien de interne verhoudingen tussen aandeelhouders in dit boek centraal staan, gaat het met name om de vraag in hoeverre (minderheids)aandeelhouders en toekomstige aandeelhouders (moeten) worden beschermd. Het belang van een zeker 'machtsevenwicht' in de 
vennootschap is tegelijkertijd een belang van (minderheids)aandeelhouders, van de vennootschap zelf en daarmee indirect ook van crediteuren.

De wijze waarop en de mate waarin deze - elkaars deels overlappende - belangen worden beschermd, verschilt per rechtsstelsel en per type rechtshandeling. Het juridisch instrumentarium van aandeelhouders om de vennootschappelijke verhoudingen gestalte te geven bestaat uit statuten, besluiten en aandeelhoudersovereenkomsten. Elk instrument heeft zijn eigen functie en derhalve zijn eigen kring van betrokkenen die bescherming behoeven.

Terwijl overeenkomsten in beginsel slechts gelden tussen partijen, zijn de statuten bindend voor alle bij de vennootschap betrokkenen. Niet alleen vormen zij de basis van waaruit de vennootschap zich ontwikkelt, maar ook verschaffen zij informatie aan toekomstige aandeelhouders en crediteuren. Een overeenkomst kan, hoewel deze in beginsel slechts partijen bindt, niettemin gevolgen hebben voor derden. Een besluit verschilt op zijn beurt van een overeenkomst doordat het wordt genomen met meerderheid van stemmen in een formele procedure en bindend is niet alleen voor aandeelhouders, maar voor alle bij de vennootschap betrokkenen. Dit onderscheid tussen statuten, besluiten en overeenkomsten staat aan de basis van de verschillende gradaties van dwingend recht.

Juist vanwege het verschil in functie tussen statuten, overeenkomsten en besluiten, verschilt de reikwijdte van dwingend vennootschapsrecht. Artikel 2:25 BW en $\S 23$ Abs. 5 AktG scheppen een dwingendrechtelijk kader voor statutaire afwijkingen en aanvullingen, zoals artt. 2:14 en 15 BW en $\S \S 241$ en 243 AktG dwingende grenzen stellen aan besluiten. Artikel 2:25 BW noch $\S 23$ Abs. 5 AktG strekt zich uit over de toelaatbaarheid van aandeelhoudersovereenkomsten; slechts voor zover dwingende vennootschapsrechtelijke bepalingen de strekking hebben tot nietigheid van de overeenkomst te leiden, werkt het vennootschapsrecht door in het verbintenissenrecht, via artikel 3:40 BW of $\S \S 134$ en $138 \mathrm{BGB}$. Bovendien vloeit uit de aard van de aandeelhoudersovereenkomst voort dat aandeelhouders rekening houden met het belang van de vennootschap en andere bij de vennootschap betrokkenen. Deze algemene opmerkingen worden in het navolgende verder uiteengezet.

\section{$\$ 8.2$ Wat is dwingend vennootschapsrecht?}

In hoofdstuk 2 en 3 heb ik getracht een antwoord te vinden op de vraag wat dwingend vennootschapsrecht eigenlijk inhoudt. Wat maakt dwingend vennootschapsrecht dwingend? Terwijl in hoofdstuk 2 de verschillende wettelijke systemen en hun uitgangspunten zijn uiteengezet, waarbij de nadruk 
lag op de verhouding tussen de wet en de statuten, is in hoofdstuk 3 de notie van dwingend vennootschapsrecht getoetst aan de vraag in hoeverre aandeelhouders vrij zijn in de uitoefening van hun rechten, met name de vraag of zij van deze rechten afstand mogen doen.

\section{Het wettelijk systeem}

Centrale vraag in hoofdstuk 2 was in hoeverre het wettelijke uitgangspunt van invloed is op de reikwijdte, het aantal en de identificatie van dwingende regels. Het dwingendrechtelijk uitgangspunt van artikel 2:25 BW werd daartoe vergeleken met $\S 23$ Abs. 5 AktG, dat bepaalt: "Die Satzung kann von den Vorschriften dieses Gesetzes nur abweichen, wenn es ausdrücklich zugelassen ist. Ergänzende Bestimmungen der Satzung sind zulässig, es sei denn, daß dieses Gesetz eine abschließende Regelung enthält." In het Engelse recht en het Duitse GmbH-recht daarentegen, staat de contracts- en inrichtingsvrijheid van aandeelhouders voorop, waaraan de wet grenzen stelt.

Dit verschil in uitgangspunt heeft gevolgen voor de reikwijdte van dwingend recht; terwijl naar Nederlands recht en Duits Aktienrecht de toelaatbaarheid van statutaire afwijkingen en aanvullingen moet worden gemotiveerd binnen de ruimte die de wet geeft, moet naar Engels recht en Duits GmbH-recht worden beargumenteerd waarom dwingend recht zich tegen een afwijking of aanvulling zou verzetten. Beide uitgangspunten ontlopen elkaar in de praktische toepassing ervan echter niet zoveel. De systemen convergeren doordat enerzijds dwingende wettelijke bepalingen restrictief worden geïnterpreteerd, anderzijds aanvullende bepalingen dwingend worden geïnterpreteerd. Zo heeft de House of Lords toegestaan dat de dwingendrechtelijke ontslagbevoegdheid van de algemene vergadering in de statuten van zijn effect kan worden ontdaan, terwijl het Bundesgerichtshof een stemverbod voor aandeelhouders, een uitdrukkelijk aanvullende bepaling, niettemin als dwingend verbod gekwalificeerd. Het gaat in dergelijke individuele gevallen steeds om de achterliggende ratio van de regeling en de uitwerking daarvan in de concrete situatie.

Een argument voor het bieden van dwingendrechtelijk kader voor statuten is dat de verhandelbaarheid van aandelen gebaat is bij enige mate van standaardisatie van de statuten, zodat toekomstige aandeelhouders niet elke keer in het handelsregister de statuten van de beoogde vennootschap hoeven te raadplegen. Tegelijkertijd zorgt het dwingendrechtelijk kader voor machtsevenwicht tussen de verschillende organen, hetgeen in het belang van de vennootschap wordt geacht. Voorts worden toekomstige aandeelhouders door het dwingendrechtelijk kader beschermd tegen bin- 
ding aan statuten waarop zij zelf geen invloed hebben kunnen uitoefenen. Zo mogen rechten van aandeelhouders niet statutair worden ingeperkt, tenzij hiervoor een wettelijke basis is. Statuten moeten bovendien steeds gewijzigd kunnen worden. Op deze wijze is de invloed van later toetredende aandeelhouders verzekerd.

Terwijl het standaardisatie-argument in open vennootschappen van belang is, is dit argument minder relevant in besloten vennootschappen. Anders dan beleggers, kunnen aandeelhouders in besloten vennootschappen onderhandelen met mede-aandeelhouders over de gewenste vennootschappelijke verhoudingen. Zij kunnen echter niet "stemmen met de voeten". Dit betekent dat een aandeelhouder in een besloten vennootschap enerzijds zijn eigen belangen kan behartigen door statuten en overeenkomsten 'op maat' te maken, anderzijds dat hij meer bescherming nodig heeft omdat de aandelen niet gemakkelijk verhandelbaar zijn. Aangezien een aandeelhouder vrijwillig tot de vennootschap toetreedt en zich begeeft in het economisch verkeer, behoeft hij naar mijn mening op zichzelf geen bijzondere bescherming door middel van dwingend vennootschapsrecht. Wel dient er een zeker 'machtsevenwicht' in de vennootschap te worden gewaarborgd, teneinde de vennootschap te behoeden voor misbruik en haar zo goed mogelijk te laten functioneren. Terwijl het machtsevenwicht in open naamloze vennootschappen gevonden wordt in een dwingende bevoegdheidsverdeling tussen organen, is het machtsevenwicht in besloten vennootschappen veeleer een kwestie tussen aandeelhouders onderling. In het licht van het voorgaande meen ik dat een dwingendrechtelijk kader zoals voorzien door artikel 2:25 BW voor besloten vennootschappen niet nodig is en kan worden volstaan met het afbakenen van dwingendrechtelijke grenzen. Artikel 2:25 BW dient naar mijn mening dan ook vooral te worden beschouwd als een wetgevingstechniek, een hulpmiddel bij de interpretatie van individuele wettelijke regelingen.

\section{Afstand van recht}

De reikwijdte van dwingend vennootschapsrecht wordt niet alleen afgebakend in de interpretatie van statutaire afwijkingen of aanvullingen, maar ook in de wijze waarop aandeelhouders hun afspraken vormgeven. Strekt dwingend vennootschapsrecht zich tevens uit over aandeelhoudersovereenkomsten? Mogen aandeelhouders afstand doen van dwingende rechten? Dergelijke vragen kwamen aan de orde in hoofdstuk 3.

Een consequentie van het verschil tussen het dwingendrechtelijk uitgangspunt en het vooropstellen van de contracts- en inrichtingsvrijheid van aandeelhouders is gelegen in de wijze waarop het leerstuk van afstand 
van recht een rol speelt in het vennootschapsrecht. In het Duitse en Engelse recht wordt het leerstuk gebruikt om aan te geven dat bepaalde rechten een dwingend karakter hebben, en dat er derhalve niet statutair of buitenstatutair afstand van kan worden gedaan. Naar Nederlands recht daarentegen, speelt het leerstuk van afstand van recht in de statuten geen rol, omdat artikel 2:25 BW dat verhindert, terwijl de toelaatbaarheid van afstand van recht het vermeende dwingende karakter van een recht kan relativeren, ook omdat het buiten het bereik van artikel 2:25 BW valt.

Het verschil in gradatie van dwingend recht wordt geïllustreerd aan de hand van het leerstuk van afstand van recht. Boek 2 BW kent meer dwingende rechten aan aandeelhouders toe dan het Engelse recht en het Duitse GmbH-recht, bijvoorbeeld het stemrecht. Het Duitse recht compenseert het gebrek aan dwingende wettelijke rechten enerzijds door de creatie van dwingende rechten buiten de GmbHG om, zoals het uittredingsrecht en het recht om vernietiging van een besluit te vorderen, analoog aan $\S 243 \mathrm{AktG}$, anderzijds door sommige rechten een unverzichtbar dan wel een unentziehbar karakter te geven, zodat ze niet resp. slechts met instemming van de betrokken aandeelhouders statutair kunnen worden beperkt. Dergelijke nuanceringen zijn aan het Engelse recht niet besteed. Slechts een beperkt aantal statutory rights van aandeelhouders is dwingend.

Dwingend recht betekent in deze context in ieder geval dat de statuten wettelijke rechten niet mogen uitsluiten of beperken. Zo verhindert het dwingendrechtelijk uitgangspunt van artikel 2:25 BW dat rechten van aandeelhouders die in de wet zijn vastgelegd statutair worden uitgesloten. Terwijl de statuten naar Engels recht een aandeelhouder zijn wettelijke rechten niet kunnen ontnemen, worden in het Duitse recht grenzen gesteld aan statutaire afstand van rechten, met een beroep op de toezichthoudende functie van aandeelhouders in het belang van de vennootschap. De vraag is dan of aandeelhouders dan wel bij overeenkomst afstand kunnen doen van hun rechten.

Naar Duits recht wordt aangenomen dat de lidmaatschapsrechten van aandeelhouders afhankelijke rechten zijn, waarvan een aandeelhouder geen afstand kan doen. Niettemin kan een aandeelhouder wel afstand doen van een concrete aanspraak die voortvloeit uit zijn recht, bijvoorbeeld van zijn vorderingsrecht aangaande het vastgestelde dividend. Dit laat het wettelijke of statutaire recht op dividend onverlet. Ik meen dat dezelfde uitgangspunten gelden voor Nederlands recht. Aandeelhouders kunnen echter niet bij voorbaat afstand doen van toekomstige aanspraken, aangezien dit in feite zou neerkomen op afstand van recht. Wat goederenrechtelijk niet mogelijk is, kan echter wel tot stand worden gebracht via het verbintenissenrecht. Aandeelhouders mogen naar mijn mening in beginsel overeenkomen dat zij 
afzien van de uitoefening van hun rechten. Deze overeenkomst werkt slechts tussen partijen; het recht als zodanig blijft bestaan.

Niet rechtsgeldig zijn overeenkomsten die ertoe leiden dat een aandeelhouder van elke controlerende functie wordt ontheven en overeenkomsten die een beroep op de redelijkheid en billijkheid uitsluiten. Naar mijn mening moeten aandeelhouders in besloten vennootschappen in sterkere mate dan in open vennootschappen zelf in staat worden geacht te bepalen welke machtsverhoudingen zij in de vennootschap wensen. Derhalve kan het 'Kernbereich' aan dwingende, niet voor 'afstand' vatbare rechten voor deze aandeelhouders worden beperkt tot het recht op het vorderen van vernietiging van besluiten, het verzoeken van een enquête of ontbinding van de vennootschap, het uittredings- en uitstotingsrecht. Concreet betekent dit dat aandeelhouders in beginsel mogen overeenkomen dat zij afzien van hun stemrecht, hun recht op deelname en hun recht op dividend. Wel dient de toelaatbaarheid van een dergelijke overeenkomst naar mijn mening te worden beperkt tot een overzienbare periode of concrete gevallen.

Een bijzondere vorm van afstand is het onderwerpen van een geschil aan arbitrage. In dit geval gaat het om afstand van het recht om geschillen te laten beslechten door de overheidsrechter. Heeft een aandeelhouder door toe te treden tot de vennootschap de mogelijkheid aanvaard dat de meerderheid zou kunnen beslissen tot het onderwerpen van alle vennootschappelijke geschillen aan arbitrage, of is voor een dergelijke clausule zijn instemming vereist? Terwijl in de Duitse literatuur het recht om vennootschappelijke geschillen aan de overheidsrechter voor te leggen de instemming van alle aandeelhouders vereist, lijkt het Engelse recht de onderwerping aan de besluitvorming bij meerderheid als uitgangspunt te nemen. Een statutaire arbitrageclausule kan naar mijn mening slechts met instemming van alle aandeelhouders worden opgenomen. Andersom kan een arbitrage-overeenkomst ook vennootschapsrechtelijke werking hebben, indien alle aandeelhouders partij zijn en het geschil uitsluitend aandeelhouders raakt.

\section{$\S 8.3$ Statuten als bijzondere overeenkomst}

Hoofdstuk 4 biedt een nadere beschouwing over de aard en werking van statuten, teneinde inzichtelijk te maken waarom een onderscheid bestaat tussen statutaire en contractuele afwijking van dwingende wettelijke bepalingen. In het Engelse en tot op zekere hoogte ook het Duitse recht worden de statuten van de vennootschap gekarakteriseerd als een bijzondere overeenkomst, terwijl naar Nederlands recht wordt benadrukt dat statuten een rechtshandeling sui generis vormen. Of de statuten als rechtshandeling sui generis of als bijzondere overeenkomst worden beschouwd, maakt 
wellicht voor de concrete werking ervan niet direct verschil, het is meer een kwestie van regel en uitzondering. Ik zou er niettemin voor willen pleiten ook naar Nederlands recht de contractuele aard van statuten te benadrukken. Dit betekent dat de statuten duidelijker worden ingebed in het algemene overeenkomstenrecht, met contractsvrijheid en de instemming van partijen als basis. Wanneer de contracts- en inrichtingsvrijheid als uitgangspunt wordt genomen, wordt benadrukt dat aandeelhouders vrij zijn om 'aanvullende' rechten en verplichtingen in de statuten op te nemen. Bovendien kan bij de interpretatie van statuten meer rekening worden gehouden met afspraken van partijen.

Ook indien de statuten worden beschouwd als een bijzondere overeenkomst, neemt dit niet weg dat de bindende kracht van statuten zich uitstrekt tot de vennootschap, inclusief bestuurders en later toegetreden aandeelhouders. De functie van statuten als bron van verbintenissen voor later toetredende aandeelhouders en als basisdocument voor de vennootschappelijke ontwikkeling kan met zich meebrengen dat dwingende grenzen worden gesteld juist ter bescherming van deze belangen. Zo verhindert dwingend vennootschapsrecht dat de statuten een gesloten, niet voor wijziging vatbare overeenkomst vormen, zodat ook later toegetreden aandeelhouders invloed kunnen uitoefenen op de inhoud van de statuten en zo de ontwikkeling van de vennootschap gestalte kunnen geven.

In het Duitse recht wordt een onderscheid gemaakt tussen statuten in materiële zin en statuten in louter formele zin. In de eerste plaats dient dit onderscheid om aan te geven welke regelingen noodzakelijkerwijs in de statuten moeten worden neergelegd om rechtsgeldig te zijn. Voldoet een regeling die tot de noodzakelijke statutaire inhoud behoort, niet aan de statutaire vormvereisten, dan wordt deze nietig geacht. In de tweede plaats brengt het onderscheid tot uitdrukking dat niet alles wat formeel in de statuten is neergelegd, ook materieel als zodanig heeft te gelden. Er wordt primair gekeken naar de inhoud van de bepaling om deze als statutair te kwalificeren, met de daaraan verbonden gevolgen voor interpretatie en wijziging. In het Duitse recht wordt niet zozeer de formele kwalificatie van statuten of overeenkomsten van belang geacht, maar het inhoudelijke onderscheid tussen regelingen met vennootschappelijke werking en regelingen die uitsluitend partijen binden. Doel van dit onderscheid is zowel (toekomstige) (minderheids)aandeelhouders als crediteuren adequate bescherming te bieden. Ook in het Engelse recht worden verschillende rechtsgevolgen verbonden aan statutaire bepalingen, al naar gelang de ratio van de regeling in kwestie. De unamimous consent rule geeft afspraken tussen aandeelhouders, al dan niet in de vorm van een besluit, voorrang boven statutaire bepalingen die uitsluitend interne werking hebben. Ook naar 
Nederlands recht zou mijns inziens meer de inhoud en ratio van vennootschappelijke regelingen bepalend moeten worden geacht voor de daaruit voortvloeiende rechtsgevolgen. Hieronder wordt op deze gedachten voortgebouwd.

Tot wijziging van statuten kan zowel naar Duits recht als naar Engels recht eerst met drie vierde meerderheid van de stemmen worden besloten, als procedurele bescherming voor minderheidsaandeelhouders. Ik meen, dat er goede gronden zijn om naar Nederlands recht voor een besluit tot statutenwijziging een gekwalificeerde meerderheid van twee derde van de stemmen als wettelijk uitgangspunt te nemen. Dit sluit aan bij de gedachte dat voor wijziging van de interne organisatieregels een versterkte meerderheid is vereist, zonder hiervoor dat een uitdrukkelijke statutaire bepaling noodzakelijk is. De gekwalificeerde meerderheid van twee derde past in het wettelijk systeem, waar het doorbreken van de bindende voordracht voor de benoeming van bestuurders en de kwaliteitseisen voor bestuurders eveneens een twee derde meerderheid vereisen.

\section{Dwingende grenzen aan aanvullende rechten en verplichtingen}

Het verschil in gradatie van dwingend recht wordt voorts geïllustreerd doordat het vennootschapsrecht grenzen stelt aan aanvullende rechten en verplichtingen die aandeelhouders in de statuten kunnen vastleggen. In hoofdstuk 5 is onderzocht, op welke wijze aandeelhouders worden beschermd door aanvullende statutaire bepalingen, resp. tegen aanvullende statutaire bepalingen. Indien aandeelhouders aandelen met bijzondere rechten (Sonderrechte, class rights) hebben gecreëerd, verhindert dwingend recht dat deze hen bij statutenwijziging weer kunnen worden ontnomen, in de vorm van een instemmingsvereiste. Het opleggen van extra verplichtingen kan naar Nederlands en Duits recht in beginsel eveneens slechts met instemming van de betrokken aandeelhouders geschieden. Dergelijke instemmingsvereisten vormen een ex ante bescherming van minderheidsaandeelhouders, maar kunnen ook worden ingeroepen om een besluit te laten vernietigen. Wel kan deze wijze van bescherming verstarrend werken op de besluitvorming in de algemene vergadering en daarmee de ontwikkeling van de vennootschap belemmeren.

Ex post kunnen (minderheids)aandeelhouders besluiten van de algemene vergadering laten vernietigen of verzoeken om uittreding. De afweging is voortdurend welke combinatie van bescherming de belangen het beste in evenwicht brengt. Daarbij legt het Duitse recht meer de nadruk op de bescherming van minderheidsaandeelhouders, terwijl het Engelse recht de onderwerping aan het meerderheidsbeginsel meer voorop stelt. De mate 
van bescherming houdt derhalve geen verband met de kwalificatie van statuten als bijzondere overeenkomst. Terwijl veelal geconcentreerd wordt op de interpretatie van verschillende wettelijke begrippen, gaat het om de onderliggende vraag: wat mag een aandeelhouder redelijkerwijze van de wet verwachten.

Is in dat verband het vereisen van instemming voor het ontnemen van rechten of het opleggen van verplichtingen noodzakelijk in een besloten vennootschap? Zou de wet niet kunnen volstaan met ex post bescherming door middel van de vernietiging van een besluit of de uittreding? De gedachte is dan dat, indien aandeelhouders aanvullende bescherming wensen, zij dit dienen overeen te komen. Ik meen echter dat het instemmingsvereiste dient te prevaleren. Uitgangspunt van het aandeelhouderschap is het verschaffen van kapitaal op voorwaarde dat de aansprakelijkheid wordt beperkt. Indien de aandeelhouder deze verplichting heeft vervuld, mogen hem niet tegen zijn wil andere verplichtingen worden opgelegd. Het instemmingsvereiste geldt naar mijn mening ook voor het stellen van kwaliteitseisen aan aandeelhouders. Door het vereisen van instemming hoeft de redelijkheid van de verplichting bovendien slechts in uitzonderlijke gevallen te worden getoetst. Dit neemt niet weg, dat het instemmingsvereiste uitsluitend in statutair opzicht dwingend is; aandeelhouders mogen wel overeenkomen dat hen bij meerderheidsbesluit verplichtingen worden opgelegd, mits er ex post bescherming in de vorm van de mogelijkheid van vernietiging van een besluit of uittreding tegenover staat.

\section{$\S 8.4$ Besluiten als bijzondere overeenkomst}

In hoofdstuk 6 is onderzocht in hoeverre aandeelhouders bij besluit in de algemene vergadering mogen afwijken van de wet en/of de statuten en welke middelen de verschillende rechtsstelsels te bieden hebben om zoveel mogelijk de geldigheid van afwijkende besluiten te bewerkstelligen.

Besluiten van de algemene vergadering kunnen nietig of vernietigbaar zijn, indien zij in strijd zijn met de wet, de statuten of de redelijkheid en billijkheid. Daarbij kan een onderscheid worden gemaakt tussen besluiten die in strijd zijn met procedurevoorschriften en besluiten die qua inhoud afwijken van de wet of de statuten. Procedureel gebrekkige besluiten, bijvoorbeeld doordat niet is voldaan aan de oproepingsvereisten of aan het vereiste quorum, zijn in beginsel vernietigbaar. Een besluit is geldig, indien alle aandeelhouders ondanks de proceduregebreken aanwezig zijn, of geen beroep hebben gedaan op een vernietigingsgrond binnen de vastgestelde termijn. De achterliggende gedachte is dat procedurevereisten ertoe dienen om aandeelhouders te beschermen. Blijkt dat zij geen beroep willen doen 
op deze bescherming, dan is het besluit geldig. De belangen van toekomstige aandeelhouders en crediteuren spelen in dit geval geen rol. Deze gedachte is in het Nederlandse en Duitse recht met name in de wet vervat, terwijl zij in het Engelse recht de grondslag vormt van de unanimous consent rule. Deze houdt in dat aandeelhouders bij algemene instemming kunnen afzien van wettelijke of statutaire voorschriften die uitsluitend in het belang van de aandeelhouders zijn gegeven. De achterliggende gedachte is dat aandeelhouders afstand mogen doen van rechten die op hun eigen bescherming zijn gericht.

Besluiten die inhoudelijk in strijd zijn met de wet of de statuten, zijn naar Nederlands recht in beginsel nietig. De wet maakt in twee gevallen een uitzondering, waarin de algemene vergadering met een gekwalificeerde meerderheid aanvullende statutaire bepalingen (bindende voordracht voor de benoeming van bestuurders, kwaliteitseisen aan bestuurders of commissarissen) kan doorbreken. Deze besluiten zijn, ondanks strijd met de statuten, geldig. De dwingendrechtelijke keuzevrijheid van de algemene vergadering bij de benoeming van bestuurders en commissarissen wordt onder deze voorwaarden voorrang gegeven boven statutaire beperkingen hierop.

In het Duitse recht zijn de gronden van nietigheid gespecificeerd: strijd met voorschriften ter bescherming van crediteuren, het wezen van de vennootschap, het algemeen belang of de goede zeden. Overige met de wet strijdige besluiten zijn (slechts) vernietigbaar. Naar Duits recht hebben aandeelhouders die voor een besluit hebben gestemd, hun recht verspeeld om de vernietiging van het besluit te vorderen. Een vernietigbaar besluit is derhalve geldig, indien alle aandeelhouders met het besluit hebben ingestemd, voorts ook na afloop van de termijn van in beginsel één maand. Later toetredende aandeelhouders zouden in een dergelijk geval worden geconfronteerd met de gevolgen van een besluit dat afwijkt van de statuten. In de Duitse literatuur en rechtspraak biedt voor deze gevallen het leerstuk van de Satzungsdurchbrechung soelaas.

In geval van Satzungsdurchbrechung is de vraag of een besluit slechts afwijkt van de statuten, en derhalve vernietigbaar is, of in wezen een statutenwijziging behelst, zonder dat aan de vormvereisten is voldaan, hetgeen leidt tot nietigheid. Een onderscheid wordt gemaakt tussen eenmalige en duurzame doorbrekingen. Duurzame doorbrekingen zijn van belang voor toekomstige aandeelhouders, en derhalve vereisen inschrijving in het handelsregister, terwijl eenmalige doorbrekingen daarentegen uitsluitend de belangen van bestaande aandeelhouders raken. Eventueel komen nietige duurzame doorbrekingen in aanmerking voor conversie in een aandeelhoudersovereenkomst. 
Het leerstuk van de Satzungsdurchbrechung wordt tevens gebruikt om de geldigheid van een eenmalige doorbreking van statutaire bepalingen te bepleiten, indien aan de meerderheidsvereisten voor statutenwijziging is voldaan en het besluit in een notariële akte is opgemaakt. Dit is een strengere variant van de Nederlandse uitzonderingen voor het doorbreken van de bindende voordracht en kwaliteitseisen aan bestuurders en commissarissen, echter wel veralgemeniseerd tot eenmalige afwijkingen.

Het Engelse recht kent geen aparte wettelijke sancties voor besluiten. Evenals een overeenkomst is een besluit in strijd met dwingende wettelijke voorschriften nietig. De vraag is echter wanneer een wettelijke bepaling dwingend is. Hiervoor is in de Engelse jurisprudentie de bovengenoemde unanimous consent rule ontwikkeld. Uitsluitend indien het besluit de belangen van crediteuren schaadt, is een afwijking van wettelijke of statutaire bepalingen nietig. Wel dienen besluiten die van belang zijn voor toekomstige aandeelhouders en crediteuren te worden geregistreerd. Dit tast echter de geldigheid van het besluit niet aan.

Ik meen dat het Nederlandse recht ruimte laat voor een genuanceerde, op Engels en Duits recht geïnspireerde benadering. Zo kan ook naar Nederlands recht de instemming van een aandeelhouder worden beschouwd als een wettelijke vorm van rechtsverwerking van het recht om vernietiging van een besluit te vorderen. De vernietigbaarheid van een besluit brengt met zich mee, dat degene die met het betreffende besluit heeft ingestemd, niet vervolgens de vernietiging ervan mag vorderen. Dit maakt een vernietigbaar besluit, dat is genomen met algemene stemmen van alle aandeelhouders, geldig.

Steeds dient te worden afgevraagd of een van een aanvullende statutaire bepaling afwijkend besluit uitsluitend de belangen van aandeelhouders raakt, of ook de belangen van toekomstige aandeelhouders. Een dergelijk besluit is vernietigbaar, indien het uitsluitend de belangen van aandeelhouders raakt. Dit vloeit voort uit een analogische toepassing van artikel $3: 40$ lid 2 jo. 2:14 lid 1, laatste zinsnede, BW. Het gaat dan om gevallen waarin een statutaire regeling een dwingende wettelijke bevoegdheid van aandeelhouders beperkt, terwijl de bevoegdheid op grond van de wet aan aandeelhouders toekomt. Een voorbeeld hiervan is een besluit dat beperkingen aan de overdraagbaarheid van aandelen, zoals statutaire eisen aan aandeelhouders, terzijde stelt. Besluiten die afwijken van de statuten, waarbij ook de belangen van toekomstige aandeelhouders worden geraakt, zijn nietig. De inhoud van het besluit kan evenwel worden geconverteerd in een aandeelhoudersovereenkomst. Dit betekent dat het besluit uitsluitend gevolgen heeft voor de aandeelhouders die vóór het besluit hebben gestemd. 
Een andere manier waarop nietigheid op basis van interne aangelegenheden kan worden geheeld is via bekrachtiging, hetzij door het verrichten van een vereiste handeling of mededeling achteraf, hetzij door statutenwijziging. Voor het overige zijn besluiten in strijd met wettelijke of statutaire bepalingen die crediteuren benadelen nietig.

\section{§8.5 Aandeelhoudersovereenkomsten}

Aandeelhoudersovereenkomsten binden in beginsel slechts partijen. Wel kunnen overeenkomsten tussen aandeelhouders gevolgen hebben voor derden. In alle drie onderzochte stelsels wordt de contractsvrijheid van aandeelhouders voorop gesteld. In de jurisprudentie is steeds een onderscheid gemaakt tussen de contractuele binding van aandeelhouders ten aanzien van de uitoefening van hun recht en de vennootschapsrechtelijke uitoefening van het recht, die de gebondenheid van de vennootschap kan bewerkstelligen. Niettemin stelt dwingend vennootschapsrecht grenzen aan deze vrijheid, in de vorm van artikel 3:40 BW of $\S \S 134$ en 138 BGB. Artikel 2:25 BW noch $\S 23$ Abs. 5 AktG strekken zich uit over de toelaatbaarheid van aandeelhoudersovereenkomsten. Slechts voor zover dwingende vennootschapsrechtelijke bepalingen de strekking hebben tot nietigheid van de overeenkomst te leiden, werkt het vennootschapsrecht door in het verbintenissenrecht. Zo is het duidelijk dat aandeelhouders niet in strijd mogen handelen met bepalingen die gericht zijn op de bescherming van de belangen van crediteuren, ongeacht de juridische vorm van hun handeling. Bovendien vloeit uit de aard van de aandeelhoudersovereenkomst voort dat aandeelhouders rekening houden met het belang van de vennootschap en andere bij de vennootschap betrokkenen.

Niettegenstaande het onderscheid tussen de gebondenheid van de aandeelhouder en de gebondenheid van de vennootschap, heeft een aandeelhoudersovereenkomst wel degelijk van invloed op de vennootschap. Zo kan in rechte nakoming van de overeenkomst worden afgedwongen. Het is dan ook niet verwonderlijk dat in - met name de Duitse en Nederlandse literatuur vraagtekens worden gezet bij de rechtsgeldigheid van bepaalde aandeelhoudersovereenkomsten, met het oog op de gevolgen die de overeenkomst heeft op de institutionele orde. De afbakening van de grenzen is het meest precair bij overeenkomsten die dwingendrechtelijke bevoegdheden van de algemene vergadering raken en overeenkomsten die het wezen van het aandeelhouderschap raken, zoals stemovereenkomsten. Een controversiële categorie vormt de instructie-overeenkomst, die een ander dan de betreffende aandeelhouder invloed geeft op de vennootschappelijke besluitvorming, zonder dat daar de verschaffing van risicodragend kapitaal als 
legitimatie tegenover staat. Afwisselend wordt een beroep gedaan op het afhankelijk karakter van het stemrecht, de verplichte zelfstandige oordeelsvorming van de aandeelhouder en het besloten karakter van de vennootschap om de ongeoorloofdheid van dergelijke overeenkomsten te beargumenteren. Instructie-overeenkomsten met bestuurders of aandeelhouders met een Stimmverbot worden in ieder geval ontoelaatbaar geacht, evenals instructie-overeenkomsten waarbij de stem wordt "gekocht". In het Engelse recht lijkt minder plaats voor institutionele overwegingen ten aanzien van de uitoefening van bevoegdheden van de algemene vergadering. In Russell v. Northern Bank Development Corporation Ltd wordt de scheiding tussen stem en overeenkomst vooropgesteld, in plaats van de gevolgen die een dergelijke overeenkomst heeft op de uitoefening van de bevoegdheden door de algemene vergadering.

Naar mijn mening is voor de vraag welke grenzen dwingend recht aan aandeelhoudersovereenkomsten stelt, niet zozeer het onderscheid tussen de gebondenheid van de aandeelhouder en de gebondenheid van de vennootschap van belang, als wel de vraag of de gevolgen van de overeenkomst schadelijk zijn voor derden, waaronder de vennootschap. Indien bovengenoemd onderscheid wordt gehanteerd als argument, betekent dat in wezen niets anders dan dat de gevolgen van de overeenkomst op de vennootschap niet schadelijk worden geacht. De interne vennootschappelijke verhoudingen rechtvaardigen niet steeds een dwingendrechtelijke grens in de zin van artikel 3:40 BW. Niet rechtsgeldig zijn overeenkomsten die ertoe leiden dat een aandeelhouder van elke controlerende functie wordt ontheven en overeenkomsten die een beroep op de redelijkheid en billijkheid uitsluiten. Naar mijn mening moeten aandeelhouders in besloten vennootschappen in sterkere mate dan in open vennootschappen zelf in staat worden geacht te bepalen welke machtsverhoudingen zij in de vennootschap wensen. Ik meen dat in besloten vennootschappen een minimum aan 'machts-evenwicht' gewaarborgd is indien een overeenkomst de bevoegdheid van de algemene vergadering met betrekking tot de décharge en het ontslag van bestuurders en het vaststellen van de jaarrekening intact laat en individuele aandeelhouders enige mate van invloed op de gang van zaken binnen de vennootschap kunnen uitoefenen.

\section{Vennootschapsrechtelijke werking van aandeelhoudersovereenkomsten}

Indien als uitgangspunt wordt gehanteerd dat aandeelhoudersovereenkomsten geldig zijn, tenzij de gevolgen ervan schadelijk zijn voor derden (crediteuren, de vennootschap), wordt ruimte geboden om aandeelhoudersovereenkomsten vennootschapsrechtelijke werking toe te kennen, indien de 
gevolgen niet schadelijk zijn voor derden. Voorwaarde is wel dat alle aandeelhouders partij zijn bij de overeenkomst. Een aandeelhoudersovereenkomst krijgt in dat geval dezelfde status als statuten: een bijzondere overeenkomst tussen aandeelhouders, die in principe dient te worden nagekomen (pacta sunt servanda). Nakoming kan op verschillende wijze worden afgedwongen. Zo heeft het Bundesgerichtshof een besluit vernietigd wegens strijd met een overeenkomst, gesloten tussen alle aandeelhouders. De Hoge Raad heeft de binding van de vennootschap aan de aandeelhoudersovereenkomst bewerkstelligd via het leerstuk van de onrechtmatige daad, terwijl de Engelse unanimous consent rule zowel voor besluiten als voor overeenkomsten geldt.

Het aloude adagium 'pacta sunt servanda', zorgt ervoor dat minderheidsaandeelhouders die partij zijn bij de overeenkomst effectiever worden beschermd. Het Engelse recht maakt te dien aanzien geen onderscheid tussen statuten en aandeelhoudersovereenkomsten, terwijl daarnaast onderlinge afspraken van aandeelhouders die geen contract in strikte zin vormen, een invulling geven aan 'equitable considerations', op grond waarvan een aandeelhouder uit de vennootschap kan treden, of de vennootschap kan worden ontbonden. De Ondernemingskamer lijkt op vergelijkbare wijze ruimte te bieden aan afspraken tussen aandeelhouders bij de beoordeling van de vraag of van wanbeleid sprake is. Door de vennootschapsrechtelijke redelijkheid en billijkheid in te kleuren met tussen aandeelhouders onderling gemaakte afspraken blijft het mogelijk het belang van de ontwikkeling van de vennootschap af te wegen tegen het belang van de (minderheids) aandeelhouder in kwestie.

Nakoming van gemaakte afspraken dient echter naar mijn mening het uitgangspunt te zijn. Indien alle aandeelhouders partij zijn bij de overeenkomst, bindt deze hen in gelijke mate als statuten en kan een besluit worden vernietigd wegens schending ervan. Een en ander neemt niet weg dat een overeenkomst buiten toepassing kan worden gelaten indien deze in een concreet geval in strijd met de redelijkheid en billijkheid blijkt te zijn. Aangezien een aandeelhoudersovereenkomst invloed heeft op de besluitvorming van de vennootschap, vloeit uit de aard van de overeenkomst voort dat partijen rekening houden met het belang van de vennootschap en de bij de vennootschap betrokkenen (artikel 6:248 BW).

\section{§.6 Voorbeeld: de invloed van derden in de vennootschap}

Bovenstaande uitgangspunten worden geïllustreerd aan de hand van het volgende voorbeeld: in hoeverre kunnen aandeelhouders hun eigen bevoegdheden inperken door derden meer invloed te geven in de vennoot- 
schap en welke grenzen worden in de verschillende rechtsstelsels aan de uitoefening van invloed door derden gesteld?

Volgens Duits recht verbiedt de Verbandsautonomie, het zelfbeschikkingsrecht van de leden van het Verband, dat aandeelhouders hun bevoegdheid tot statutenwijziging aan derden toekennen. (Toekomstige) aandeelhouders dienen steeds in staat te zijn om zelfbeschikking uit te oefenen. De Verbandsautonomie verhindert eveneens dat het stemrecht wordt losgekoppeld van het aandeel (Abspaltungsverbot). De Verbandsautonomie is echter een rekbaar begrip. Zo strekt het zich volgens de heersende mening ook uit over het onderwerpen van de bevoegdheid tot statutenwijziging aan de goedkeuring van een derde en over instructie-overeenkomsten met derden, terwijl andere auteurs geen grond zien voor dergelijke beperkingen. Overige - in wezen contractuele - rechten van derden dienen juist te worden gerespecteerd en kunnen slechts met hun instemming worden gewijzigd. Derden kunnen in Duitsland namelijk slechts zeggenschapsrechten uitoefenen, indien zij orgaan van de vennootschap zijn, hetgeen betekent dat zij gehouden zijn om het belang van de vennootschap te behartigen.

Het Engelse recht kent eveneens dwingendrechtelijke beperkingen aan de invloed van derden, maar uitsluitend voor zover dit de statuten betreft. De privity rule verhindert dat derden rechten aan statuten kunnen ontlenen, onverschillig of dit zeggenschapsrechten zijn of in wezen contractuele rechten. Daarbuiten zijn aandeelhouders in beginsel vrij om derden bij overeenkomst invloed te verschaffen.

In Nederland lijkt er weinig dogmatische aandacht uit te gaan naar de invloed van derden in de vennootschap. De bevoegdheid tot statutenwijziging komt de algemene vergadering toe op grond van de wet, maar een goedkeuringsbevoegdheid aan een derde lijkt geen bezwaren op te leveren. Ik meen dat een statutair goedkeuringsrecht van een derde steeds moet kunnen worden doorbroken door een besluit van de algemene vergadering genomen met algemene stemmen. Doordat aandeelhouders het risicodragend kapitaal verschaffen en partij zijn bij de statuten, dienen zij uiteindelijk de zeggenschap over de vennootschap te hebben. Dit neemt niet weg dat een individuele aandeelhouder zich naar mijn mening in beginsel mag verbinden te stemmen naar de instructies van een derde, ook indien er een blokkeringsregeling is.

\section{§8.7 Slotopmerkingen}

Zowel voor statuten, besluiten als aandeelhoudersovereenkomsten geldt als grondslag dat aandeelhouders ermee hebben ingestemd. Aandeelhouders 
treden vrijwillig toe tot de besloten vennootschap en onderwerpen zich vrijwillig aan het meerderheidsbeginsel (of maken andere afspraken). Dit geeft bindende kracht aan statuten, besluiten en overeenkomsten, pacta sunt servanda. Partijen zijn in beginsel gebonden aan hetgeen zij hebben afgesproken, tenzij dit in strijd is met dwingend recht, artikel $3: 40$ jo. $2: 25$ $\mathrm{BW}$, of met de redelijkheid en billijkheid, artikel 2:8 jo. 6:248 BW.

Het vennootschapsrecht zou aandeelhouders middelen moeten verschaffen om contractuele afspraken af te dwingen, zonder dat toevlucht hoeft te worden genomen tot de redelijkheid en billijkheid. Een besluit dat is in strijd is met een overeenkomst tussen alle aandeelhouders, dient rechtstreeks vernietigbaar te zijn, zoals het Bundesgerichtshof heeft geoordeeld. Dit is ook de ratio van de unanimous consent rule in Engeland.

\section{Dwingend recht voor de besloten vennootschap}

Dwingend vennootschapsrecht beperkt afspraken tussen aandeelhouders, al dan niet in de vorm van statuten of besluiten, die ertoe strekken of ten gevolge hebben dat crediteuren worden benadeeld. Voor crediteuren is de vorm waarin deze afspraken worden gegoten niet relevant.

Dwingend vennootschapsrecht beschermt minderheidsaandeelhouders in de eerste plaats tegen de meerderheid, door verhoogde eisen te stellen aan de besluitvorming en het vereisen van instemming voor het opleggen van extra verplichtingen en het ontnemen van bijzondere rechten. (Minderheids)aandeelhouders kunnen echter tot op zekere hoogte afzien van deze bescherming, door af te zien van de uitoefening van hun rechten of deze anders in te vullen. Slechts de aandeelhouders die zelf hebben ingestemd met het afzien van bescherming, zijn hieraan gebonden. Indien alle aandeelhouders hebben ingestemd, gaat de latere overeenkomst voor de eerdere statuten. Dit geldt in beginsel ook voor latere besluiten.

Aandeelhouders kunnen echter niet onbeperkt afzien van hun rechten. Er dient een zeker 'machtsevenwicht' in de vennootschap te worden gewaarborgd, om de vennootschap te behoeden voor misbruik en haar zo goed mogelijk te laten functioneren. Derhalve kan het 'Kernbereich' aan dwingende, niet voor 'afstand' vatbare rechten voor aandeelhouders worden beperkt tot het recht op het vorderen van vernietiging van besluiten, het verzoeken van een enquête of ontbinding van de vennootschap en het uittredings- en uitstotingsrecht. Dwingend vennootschapsrecht beschermt op deze wijze minderheidsaandeelhouders niet alleen tegen de meerderheid, maar ook tegen zichzelf.

Dwingend vennootschapsrecht beschermt toekomstige aandeelhouders door te voorzien in wettelijke rechten en bevoegdheden, waarvan in de 
statuten niet of in beperkte mate van mag worden afgeweken. Voorts worden statuten onder meer met het oog op toekomstige aandeelhouders objectief geïnterpreteerd. Besluiten die afwijken van de statuten worden nietig geacht, mede vanwege toekomstige aandeelhouders. Grondslag van deze bescherming van toekomstige aandeelhouders is dat deze op het moment van het opstellen van de statuten of het nemen van het besluit geen partij was, maar door toe te treden tot de vennootschap wel gebonden wordt aan de statuten en besluiten. Enerzijds speelt hierbij de kenbaarheid van de afspraken een rol; bedoelingen van partijen voor zover niet uit de tekst van de statuten blijken hoeven niet kenbaar te zijn, besluiten die afwijken van de statuten evenmin, anderzijds moet ook deze toekomstige aandeelhouders worden beschermd tegen - weliswaar kenbare - scheve machtsverhoudingen in de vennootschap.

Hoe legitiem de bescherming van toekomstige aandeelhouders ook, enige relativering lijkt hierbij op zijn plaats. Aangezien aandelen in een besloten vennootschap niet vrij verhandelbaar zijn, kunnen toekomstige aandeelhouders veelal op individuele wijze met de verkoper onderhandelen. Bovendien vinden geschillen omtrent statuten en besluiten vaak plaats tussen aandeelhouders die wel 'partij' waren bij het opstellen van de statuten of het nemen van het besluit.

Ik pleit daarom voor een alternatieve manier van bescherming van toekomstige aandeelhouders, die zoveel mogelijk de instemming van bestaande aandeelhouders intact laat. Dit houdt in dat de instemming van aandeelhouders voorop staat, i.e. de in een afspraak geconcretiseerde bedoelingen van partijen, of het van de statuten afwijkende besluit. Partijen zijn hieraan gebonden. Indien een nieuwe aandeelhouder toetreedt, wordt hij pas gebonden als de afspraak, resp. het besluit aan hem kenbaar is gemaakt en hij ermee heeft ingestemd. Afspraken tussen alle aandeelhouders hebben in beginsel vennootschapsrechtelijke werking.

Door op de hierboven uiteengezette wijze aansluiting te zoeken bij het Engelse en Duitse recht, wordt het Nederlandse BV-recht naar mijn mening beter toegesneden op de economische werkelijkheid, beter ingebed in het algemene privaatrecht en beter afgestemd op gelijksoortige Europese vennootschappen. Dit neemt niet weg dat de doelstellingen van het BVrecht ook op andere wijze in de wet zouden kunnen worden vervat. Die taak is nu aan de hervormers van het Nederlandse vennootschapsrecht. 


\section{Zusammenfassung}

\section{Zwingendes Recht für die Besloten Vennootschap}

Das niederländische Gesellschaftsrecht unterscheidet zwei Gesellschaftstypen: die der deutschen Aktiengesellschaft entsprechenden Naamloze Vennootschap (NV) und die der GmbH entsprechenden Besloten Vennootschap (BV). Gesetzliche Regelungen bezüglich der NV und der BV finden sich vorwiegend im zweiten Buch des Burgerlijk Wetboek (BW). Die Regelungen sind für beide Gesellschaftsformen im wesentlichen identisch. Die Hauptunterschiede betreffen das Mindestkapitalerfordernis (18.000 Euro bei der BV, 50.000 Euro bei der NV) und die Beschränkung der Übertragbarkeit von BV-Anteile. Auch wenn das niederländische Gesellschaftsrecht vorrangig auf gesetzlichen Regelungen basiert, sind die gerichtlichen Entscheidungen von großer Bedeutung. Sie geben insbesondere den Generalnormen ihren Inhalt wie z. B. der Redlichkeit und Billigkeit in Art. 2:8 $\mathrm{BW}$.

Das Ausmaß der gesellschaftliche Normen ist in den Niederlanden während der letzten Dekaden stetig angestiegen. Ein großer Teil der Regelungen wird dabei als nicht dispositiv angesehen, da Art. 2:25 zufolge von den Vorschriften des zweiten Buches nur insoweit abgewichen werden kann, als sich dies aus dem Gesetz ergibt - ähnlich § 23 Abs. 5 AktG. Die Reichweite dieser Vorschrift ist allerdings bis heute noch nicht abschließend geklärt: Beispielsweise ist unklar, inwieweit schuldrechtliche Nebenabreden zulässig sind und welche Folgen sie im innergesellschaftsrechtlichen Bereich haben.

Die Unsicherheit über den Anwendungsbereich des Art. 2:25 BW ist auch infolge einer kürzlich vorgenommenen Gesetzesänderung verstärkt worden. Bis dahin unterstanden alle Satzungen einem ministeriellen Erlaubnisvorbehalt. Das Justizministerium hatte hierfür einen Katalog mit Mustervorschriften ausgearbeitet. Die so vom Ministerium gezogene Grenze wurde selten hinterfragt und war kaum Gegenstand der Rechtsprechung. Im September 2002 wurde die ministerielle Inhaltskontrolle jedoch abgeschafft. Die Kontrolle von möglichen Satzungsentwürfen unterliegt nunmehr der alleinigen Verantwortung der Notare. Eine Fehleinschätzung seitens des Notars kann somit entweder innovative Satzungen beschränken oder den Gesellschaftern ein böses Erwachen vor Gericht bescheren, wenn dieses die Satzung als mit dem BW unvereinbar ansieht.

Ziel dieses Buches ist es, den Geltungsbereich des zwingenden Gesellschaftsrechts mit Blick auf die Innenbeziehungen der Gesellschafter zu 
beleuchten. Der Schwerpunkt der Studie liegt dabei im Bereich der sogenannten closed company. Obwohl das niederländische Recht der BV und NV große Gemeinsamkeiten hat, stellen sich in der BV mit ihrer meist personalistischen Struktur und der geringen Zahl von Gesellschaftern andere Probleme als in der NV, die anderer Lösungsansätze bedürfen. Als "Quasi-Partnerschaft" in Joint Ventures oder als hundertprozentige Tochergesellschaft innerhalb eines Konzernverbundes - die BV bietet sich für verschiedenste Aufgaben an und bedarf daher auch eines flexiblen Korsetts, welches eine optimale Anpassung an die gestellten Aufgaben ermöglicht.

\section{Gestaltungsfreiheit im BV-Recht}

Die Verfasserin spricht sich für eine Stärkung der Gestaltungsfreiheit im BV-Recht aus. Gerade das Innenverhältnis zwischen den Gesellschaftern sollte der privatautonomen Ausgestaltung offenstehen. Denn personalistische Gesellschaften werden schon heute von einem einvernehmlichen Zusammenwirken der Gesellschafter geprägt - nicht selten werden in der Praxis in der Satzung oder in schuldrechtlichen Nebenabreden einstimmige Beschlüsse in einer Vielzahl von Fragen verlangt. Das Erfordernis, in diesen Punkten eine Übereinstimmung zu erzielen, ist die Grundlage der gesellschaftsrechtlichen Verbundenheit. Die Freiheit der Gesellschafter sollte daher nur dort eingeschränkt werden, wo der Schutz Dritter dies erfordert.

Zwingendes Recht als Eingriff in die Gestaltungsfreiheit braucht eine Rechtfertigung, sei es Gläubigerschutz, Schutz - gegenwärtiger oder zukünftiger - Gesellschafter und/oder Schutz der Gesellschaft als Institution. Dass aber in einer personalistischen BV der Schutz zukünftiger Gesellschafter oder der Schutz der Gesellschaft als Institution einen solchen Eingriff $\mathrm{zu}$ rechtfertigen vermag, erscheint im BV-Recht zweifelhaft. Wenn zudem Einstimmigkeit bei Beschlüssen gefordert wird, so kann eine solche Regelung kaum der Gestaltungsfreiheit der Gesellschafter mit der Begründung entzogen werden, der Minderheitsgesellschafter sei zu schützen. Schließlich kann sein Mitspracherecht gar nicht größer sein. Eine Rechtfertigung des Eingriffs in die Autonomie der Gesellschafter vermag daher kaum zu gelingen.

Ausgehend von diesen allgemeinen Überlegungen wurde das niederländische, deutsche und englische Recht miteinander verglichen. Gegenstand des Rechtsvergleichs war die Frage, inwieweit Gesellschafter vom Gesetz abweichen können bzw. das Gesetz ergänzen können, mit anderen Worten, inwieweit Satzung, Beschlüsse der Gesellschafterversammlung und schuldrechtliche Nebenabreden durch zwingendes Recht begrenzt 
werden. Ziel war die Herausarbeitung allgemeiner Grundsätze, welche zwingenden Vorschriften unumstößlich sind bzw. welche Vorschriften den Gesellschaftern zur Disposition gestellt werden können.

\section{Artikel 2:25 BW}

Auch wenn Art. 2:25 BW ein Abweichen von den gesetzlichen Bestimmungen grundsätzlich verbietet, bedeutet dies nicht, dass das niederländische BV-Recht lediglich zwingendes Recht enthält; nicht wenige gesetzliche Bestimmungen sind dispositiv. Aber in Gegensatz zum GmbHRecht und zum englischen Recht, ist die Binnenorganisation - die Kompetenzen der Gesellschafterversammlung und die Mitgliedschaftsrechte zum grössten Teil zwingend festgelegt. So gehören Bestellung und Abberufung der Geschäftsführer und die Feststellung des Jahresabschlusses unabdingbar zum Aufgabenkreis der Gesellschafterversammlung, zudem ergibt sich auch das Stimmrecht der Gesellschafter zwingend aus dem Gesetz. Folglich spielt die Frage, ob Mitgliedschaftsrechte unverzichtbar oder unentziehbar sind, in den Niederlanden keine Rolle, weil sich die Rechte zwingend aus dem Gesetz ergeben. In der praktischen Auswirkung unterscheiden sich die unterschiedlichen Ansätze in den verglichenen Rechtsordnungen allerdings nicht so sehr. So wird im deutschen $\mathrm{GmbH}$ Recht das zwingende Recht durch allgemeine Grundsätze der Verbandsautonomie und aktienrechtliche Normen ergänzt.

Artikel 2:25 BW hilft zwar bei der Interpretation einzelner Bestimmungen, aber er bietet keine Rechtfertigung für zwingendes Recht. Außerdem liegt die 'Beweislast' bei demjenigen, der vom Gesetz abweichen will - er hat darzulegen, dass die fragliche Norm ein Abweichen gestattet. Folglich sollte Artikel 2:25 BW restriktiv interpretiert werden. Obwohl nicht ausdrücklich im Gesetz erwähnt, beschränkt sich Artikel 2:25 BW wie $\S 23$ Abs. 5 AktG - somit auch auf die Satzung; schuldrechtliche Nebenabreden zwischen den Gesellschaftern werden von ihm nicht berührt.

\section{Die Satzung als besonderer Vertrag}

Sowohl im deutschen GmbH-Recht als auch im englischen Recht wird die Satzung als ein besonderer Vertrag qualifiziert. Zwingende Formvoraussetzungen und inhaltliche Anforderungen rechtfertigen sich aus Sicht der Bindung der - zukünftigen - Gesellschafter und der Gesellschaft selbst. Das Ausmaß des Minderheitenschutzes ist jedoch sehr unterschiedlich. Der Gleichbehandlungsgrundsatz hat nur im deutschen Recht eine weitreichende Bedeutung. Im englischen Recht steht das Mehrheitsprinzip im 
Vordergrund; nur für finanzielle Nebenleistungen und class rights wird die Zustimmung des Minderheitsgesellschafters vorausgesetzt.

Nach der herrschenden Meinung im niederländischen Schrifttum ist die Satzung zwar als „Quasi-Gesetz" zu verstehen. Der Minderheitenschutz ergibt sich jedoch vornehmlich aus dem Gesetz, das vorsieht, dass Nebenleistungen, Sonderrechte und Drittrechte nur mit Zustimmung der betroffenen Person modifiziert werden dürfen. Folglich kommt es für die Reichweite dieses Schutzes maßgeblich darauf an, ob eine Vertragsklausel unter einen dieser gesetzlichen Begriffe subsumiert werden kann. Interpretationsfragen sollten jedoch nicht von der wirklichen Frage ablenken: muss ein Minderheitsgesellschafter für seinen eigenen Schutz sorgen bzw. inwieweit würde eine Liberalisierung des Gesellschaftsrechts die Gefahr begründen, dass ein Minderheitsgesellschafter gegen seinen Willen zu Nebenleistungen verpflichtet wird.

\section{Beschlüsse als besondere Verträge}

Ein vom Gesetz oder von der Satzung abweichender Gesellschafterbeschluss ist nach niederländischem Recht grundsätzlich nichtig. Dies gilt nicht, wenn lediglich formelle Voraussetzungen an die Beschlussfassung nicht erfüllt sind oder der Beschluss der Redlichkeit und Billigkeit widerspricht. In diesen Fällen ist der Beschluss wirksam, er kann jedoch von jedem Gesellschafter mit einem berechtigten Interesse auf dem Klageweg angefochten werden.

Im deutschen Recht gilt hingegen: Ein fehlerhafter Beschluss ist grundsätzlich anfechtbar, es sei denn, er ist aufgrund § 241 AktG nichtig. Fehlerhafte Beschlüsse können jedoch dann nicht angefochten werden, wenn alle Gesellschafter mit der Satzungsabweichung einverstanden sind. Diese Satzungsdurchbrechung soll grundsätzlich hinzunehmen sein. Dies gilt aber dann nicht, wenn der Beschluss eine zustandsbegründende Satzungsdurchbrechung vorsieht. Denn diese kann auch für zukünftige Gesellschafter Bedeutung haben und muß deswegen zum Schutz Dritter den formellen Anforderungen einer Satzungsänderung genügen.

In der englischen Rechtsprechung werden die zukünftigen Gesellschafter dadurch geschützt, dass jeder Gesellschafterbeschluss ins Handelsregister einzutragen ist; die Verletzung dieser Verpflichtung bringt zwar nicht die Nichtigkeit des Beschlusses mit sich, die Gesellschafter können sich jedoch Dritten gegenüber nicht auf diesen berufen. Im übrigen ist der Beschluss auch dann rechtswirksam, wenn zwar die formellen Voraussetzungen nicht eingehalten worden sind, alle Gesellschafter aber einverstan- 
den sind und der Beschluss nicht gegen eine gläubigerschützende Bestimmung verstößt. Dies folgt aus der unanimous consent rule.

Die Verfasserin vertritt die Ansicht, dass auch das niederländische Recht Raum für eine Unterscheidung zwischen Beschlüssen mit Folgen nur für die Gesellschafter und Beschlüssen mit Folgen auch für Dritte bietet. Der Zweck des Gesetzes muss fehlerhafte Beschlüsse der erstgenannten Art nicht verbieten, wenn alle Gesellschafter zustimmen. Nichtige Beschlüsse der letztgenannten Art - können umgedeutet werden, es sei denn, sie verstoßen gegen Gläubigerschutzbestimmungen.

\section{Gesellschaftervereinbarungen}

Gesellschaftervereinbarungen (schuldrechtliche Nebenabreden) sind grundsätzlich zulässig. Allerdings rufen gerade Stimmbindungsvereinbarungen von jeher kontroverse Diskussionen über ihre Wirksamkeit hervor. Es ist daher auch nicht überraschend, dass die Rechtsprechung in allen drei Rechtssystemen unterscheidet zwischen der schuldrechtlichen Bindung der Gesellschafter und der gesellschaftsrechtlichen Ausübung des Stimmrechts, wodurch die Bindung der Gesellschaft entsteht.

Grundsätzlich steht es Gesellschaftern frei, sich schuldrechtlich zu verpflichten, ihr Stimmrecht in bestimmter Weise auszuüben. Nach der Trennungstheorie darf aber durch diese schuldrechtliche Verpflichtung die Gesellschaft nicht einmal mittelbar gebunden werden. Soweit diese Einschränkung beachtet wird, kann die Erfüllung der Vereinbarung jederzeit verlangt werden - sogar mittels einer einstweiligen Verfügung (noch umstritten in Deutschland).

Stimmenkauf ist in keinem der Rechtssysteme erlaubt, ohne dass allerdings deutlich wird, was vom Begriff des 'Stimmenkaufs' erfasst wird. Weitere Beispiele von unzulässigen Stimmbindungsvereinbarungen findet man vor allem im deutschen und niederländischen Schrifttum, wo institutionelle Argumente vorgebracht werden (Abspaltungsverbot, Stimmrecht als abhängiges Recht). Dabei soll verhindert werden, dass ein Dritter Einfluss in der - vinkulierten - Gesellschaft nehmen kann. Auch soll die Übertragbarkeit des Anteils nicht unmöglich gemacht werden und die Gesellschafterversammlung soll ihre Kompetenzen frei ausüben können.

Gesellschaftervereinbarungen werden darüber hinaus lediglich durch das allgemeine Privatrecht beschränkt ( $\S 134$ und 138 BGB, Artikel 3:40 BW). Folglich ist nicht so sehr die Trennung im oben dargestellten Sinn in den Vordergrund einer Diskussion zu stellen. Vielmehr stellt sich die Frage, ob die Folgen der Bindung im Widerspruch zu zwingendem Recht stehen. Darüber hinaus stellt sich die Frage, ob ein Gesellschafter schuld- 
rechtlich wirksam auf bestimmte Rechte verzichten kann. Letzteres erscheint nicht möglich, soweit ein 'Kernbereich' an Mitgliedschaftsrechten betroffen ist - namentlich das Anfechtungsrecht, das Austrittsrecht, das Ausschließungsrecht, das Enquêterecht und das Auflösungsrecht.

Hält man an dieser Stelle fest, dass die Rechtsgültigkeit von Gesellschaftervereinbarungen von den Folgen der Vereinbarung für die Gesellschaft abhängt, so kann hinzugefügt werden, dass diese Vereinbarungen körperschaftsrechtliche Wirkung bekommen, wenn sich alle Gesellschafter gebunden haben. Es gibt keine zukünftigen oder Minderheitsgesellschafter, die besondere Schutz brauchen.

\section{Fazit}

Obwohl das niederländische Gesellschaftsrecht auf den ersten Blick als nicht dispositiver Normenkatalog angesehen werden könnte, ist seine Wirkung tatsächlich eher tolerant. Im Endeffekt scheinen somit die untersuchten Rechtssysteme für die meisten Probleme mehr oder weniger vergleichbare Lösungen zu präsentieren. Dennoch scheinen der englische und der deutsche Ansatz doch deutlicher eine Rechtfertigung für die Verwendung zwingenden Rechts anzubieten. Eine solche Rechtfertigung der Begrenzung der persönlichen Gestaltungsfreiheit ist jedoch äußerst wichtig. Es bedarf daher in den Niederlanden einer kritischen Auseinandersetzung mit der Frage, welche Einschränkungen durch zwingendes Recht gerechtfertigt sind. Schon dies würde dem niederländischen Gesellschaftsrecht neue Perspektiven eröffnen. Darüber hinaus wäre gerade mit Hinblick auf die Erfordernisse der personalistischen BV eine Neufassung von Teilen des geltenden Gesetzeswerkes wünschenswert. 


\section{Summary}

\section{Mandatory law for private companies}

Dutch company law distinguishes between two forms of the limited liability company: the public limited company (naamloze vennootschap, hereafter NV) and the private limited company (besloten vennootschap, hereafter BV). Statutory law governing NVs and BVs can primarily be found in Book Two of the Dutch Civil Code (Burgerlijk Wetboek, hereafter BW). The statutory rules applying to NVs and BVs are identical for the most part. Two main differences are the minimum capital requirement -18.000 euro for a BV, as opposed to 50.000 euro for an NV - and a mandatory share transfer restriction regime for BVs to ensure its closed character (optional for NVs). Whereas partnerships are considered to be of a contractual nature, companies are viewed as 'institutions' under Dutch law. A company is generally regarded as being more than merely a shareholders' instrument. It is seen as an institution where the interests of several parties come together: shareholders, creditors and employees. A company operates through its organs. Although company law is codified in the Dutch legal system, it is case law which gives substance to the 'open norms' laid down in statute, e.g. the requirements of reasonableness and fairness of Art. 2:8 BW.

Dutch company law has gradually expanded during the past three decades. Due to national and European government action company law has become increasingly detailed and complex. A large part of the law is considered to be mandatory. According to Art. 2:25 BW, the provisions of Book Two may be modified only to the extent allowed by a given specific provision. Although it is generally held that Art. 2:25 BW is responsible for the mandatory nature of Dutch company law, the exact limits of its scope of application are not clear. In particular shareholders' agreements, which have become an almost indispensable tool for completing the structure and organization of private companies, have been a subject of much debate and discussion.

Uncertainty has increased about the scope of Art. 2:25 BW since a recent change in practice was legislated. Until recently all articles of association were subject to prior government approval. The Ministry of Justice was required to issue a 'statement of no objection' before a company could incorporate and before an alteration of its articles could take effect. The Ministry had issued guidelines as to which provisions in the articles were allowed and which were not. These limits were established by the Ministry and were rarely questioned in case law. As of September 2002, ministerial 
approval of a company's articles is no longer required. Civil law notaries are now entrusted with the sole responsibility of ensuring that articles of association are in compliance with statutory provisions.

The aim of this book is to clarify the scope of mandatory company law in respect of shareholder relations by examining the limits it purports to place on modifications of articles of association and shareholders' agreements. This study focuses on shareholders' relations in private companies. Despite the similarity in law, the company structure of a private company, with a limited number of shareholders, differs greatly in practice from the structure of a public company. In 'quasi-partnerships' as well as in joint ventures, shareholders often cooperate on the basis of unanimous consent. In $100 \%$ subsidiaries and in single person private companies only one shareholder gives his consent. This difference in practice should be reflected in law, which is not sufficiently clear in Dutch company law at this time.

\section{Freedom of contract in Dutch private company law}

The author's position is that Dutch private company law should be primarily facilitative and enabling of the business activities of entrepreneurs. Emphasis should be placed on the shareholders' freedom of contract and their freedom to organise their company structure. Mandatory law should limit this freedom no more than is necessary to protect third parties. The contractual framework of the company should be reinforced, recognizing the contractual nature of both the articles of association as well as shareholders' resolutions, which make them binding upon shareholders. Company law should ensure the honoring of agreements, and enable shareholders to challenge majority resolutions if they oppose a unanimous agreement, irrespective of form.

Mandatory company law may be justified on the grounds of protecting creditors, (minority) shareholders, future shareholders and/or the company as $a$ whole. Because of the quasi-partnership structure of many private companies, future shareholders will often be a hypothetical category. The interests of the company as a whole will differ little from the interests of the shareholders. Moreover, if decisions are made on the basis of unanimity, minority shareholders need no additional protection than to ensure that agreements be honored. The scope of mandatory company law may therefore be restricted with respect to private companies.

This thesis is based on a study of Dutch, English and German private company law case law and literature. The above-mentioned perspective has been inspired by the English and German approaches reflected in their 
respective private company law. The scope of mandatory company law can be determined only through the limitations the different laws place on articles of association, and shareholders' resolutions and agreements. Because of the differing functions of those instruments, their limits also differ. Mandatory company law is therefore characterized by a variety of gradations. These general remarks will be elaborated in greater detail below.

\section{The mandatory nature of Art. 2:25 BW}

As mentioned above, the provisions of Book Two BW may be modified only to the extent allowed by a given specific provision. Despite the mandatory nature of Book Two BW, quite a few provisions are optional or supplementary, offering the possibility to 'opt-in' or 'opt-out'. However, the law concerning the internal organisation of the BV - powers of the general meeting and rights of shareholders - is primarily mandatory, contrary to English private company law and German GmbH law. This means, for example, that the appointment of directors must take place at the general meeting of the shareholders, as well as the approval of the annual accounts, and that all shareholders have voting rights.

In my view, Art. 2:25 BW does no more than provide a formal criterion to distinguish mandatory from supplementary provisions. It is a matter of interpretation whether a provision in an article of association supplements or breaches the statutory law. I give the following example to illustrate this.

According to Art. 2:232 BW, the articles of association may be altered by ordinary resolution. Thus, it is the general meeting of the shareholders that will ultimately decide upon an alteration. The same applies to the Ltd and the $\mathrm{GmbH}$ (although in those cases a special resolution is required). None of the company laws provides for an optional veto right of an outsider. Under English law, the privity rule (still applicable for articles of association) prevents the creation of such a right. In Germany, the doctrine of Satzungsautonomie forbids outsider influence on the articles, including a veto right. No such arguments are availing under Dutch law. A veto right is generally considered to be a valid supplementary provision. A veto right may however not prevent the shareholders from altering the articles if they agree to do so unanimously, since the articles may always be altered with unanimous consent.

Since the mandatory nature of statutory rights is established by Art. 2:25 BW, the doctrine of waiver plays a different role in Dutch law than in English or German law. In the latter legal systems, statutory rights may not be waived in the articles of association, nor by a resolution. The mandatory 
nature of statutory rights excludes the possibility of waiver. In Dutch company law it is not necessary to mention the doctrine of waiver. The mandatory nature of statutory powers and rights does not, however, automatically apply to shareholders' agreements. In my opinion, Article 2:25 BW does not prohibit shareholders from agreeing among themselves as to how they will exercise their legal rights, including their right not to exercise them.

\section{The contractual nature of articles of association}

Once the articles of association are operative, they function as the 'constitution' of the company. Thus, resolutions of the company's organs in breach of statutory provisions or in breach of the articles are in principle null and void (Art. 2:14 BW). Similarly, provisions in articles of association which are in breach of mandatory statutory provisions, public policy and/or morality are null and void (art. 3:40 BW). Under Dutch law, the legal status of the articles of association is generally qualified as a legal act sui generis, whereas the contractual view of the nature of the articles of association predominates in English and German law. The special status in Dutch law is a consequence of the fact that the binding effect of the articles extends beyond the shareholders who agreed to them: minority shareholders, the company itself, directors and future shareholders. In my view, Dutch law does not prevent the articles of association from qualifying as a contract.

Irrespective of the legal nature of the articles of association, mandatory company law limits the creation of supplementary rights and obligations for shareholders, on the ground of minority shareholder protection. In Germany the principle of equality prohibits the creation of class rights without the consent of the ordinary shareholders. Their consent is similarly required for any obligation towards the company which is imposed upon them, other than the payment of the shares. Under English law, the majority rule prevails. Obligations other than financial contributions may be freely imposed as long as a majority of the shareholders consents. Only when shareholders' rights qualify as class rights is it prohibited for a majority decision to vary them without the consent of the class rights holder. Under Dutch law, no additional obligations may be imposed on a shareholder against his will, other than the payment of the nominal value of the share in full. Since an extensive interpretation of the word 'obligations' would subject virtually all alterations of the articles to a unanimous decision, authors have sought to limit the scope of the term to financial contributions made to the company, or by excluding obligations concerning the structure and organisation of the company. 
Thus, the level of minority shareholder protection in the different legal systems mainly depends on the interpretation of the various notions. These interpretation matters should not draw attention away from the real issue: how much minority shareholder protection a legal system should provide, and respectively, to what extent a shareholder should provide for his own protection. In my view, a shareholders' consent should be required for all increases of financial obligations and other requirements for which the articles of association may provide, such as being a party to a shareholders' agreement, if non-fulfillment of the requirements may lead to his exclusion.

\section{The contractual nature of shareholders' resolutions}

As mentioned above, the articles of association have a quasi-statutory status under Dutch law. A resolution of the general meeting in breach of statutory provisions or in breach of the articles is null and void, unless the provision is a procedural formality or the resolution is in breach of the requirements of reasonableness and fairness. In the latter cases, anyone with a legitimate interest may seek annulment of the resolution. Under German law resolutions in breach of statutory provisions or in breach of the articles may be annulled, whereas resolutions contrary to provisions of creditor protection, to "the essence of the company" or to public policy and/or morality are null and void. To ensure the protection of future shareholders, resolutions which constitute an alteration of the articles without having fulfilled necessary conditions are held to be null and void as well. English law does not contain statutory provisions regarding the consequences of a defective resolution. The common law unanimous consent rule, however, distinguishes between statutory provisions of creditor protection and procedural formalities. The unanimous consent of the shareholders prevails, unless it is contrary to provisions of creditor protection. Future shareholders are only bound to resolutions which have been registered.

In my view, Dutch law leaves room for the English and German-based distinction between resolutions which affect only the current shareholders and those which also affect future shareholders. In the first case, if all shareholders agree, a resolution in breach of the articles is valid. In the latter case, the resolution binds only the shareholders who agreed upon it, provided it does not interfere with statutory provisions protecting the interests of creditors. 


\section{Shareholders' agreements}

Dutch company law contains no general statutory provision on shareholders' agreements. As with the articles of association, shareholders' agreements find their limits in Art. 3:40 BW: mandatory provisions, public policy and morality. Whereas the articles of association must comply with mandatory company law due to Art. $2: 25 \mathrm{BW}$, it is uncertain to which extent mandatory company law affects the validity of shareholders' agreements.

In all three jurisdictions, shareholders' agreements are considered valid in principle. Voting agreements seem to be the most controversial. Their validity is acknowledged by distinguishing the shareholders' freedom of contract from the exercise of his voting right, which may bind the company. Thus, in Russell v. Northern Bank Development Corporation, Lord Jauncey considered: "While a provision in a company's articles which restricts its statutory power to alter those articles is invalid, an agreement dehors the articles between shareholders as to how they exercise their voting rights on a resolution to alter the articles is not necessarily so." The same approach is followed by the Hoge Raad, which held that, since a voting right is a right given to a shareholder to serve his own interest in the company, he is free to commit himself as to the exercise of his voting right, provided that this does not lead to "socially improper consequences". The mere fact that the agreement may imply that a vote cast by a shareholder may differ from his actual intention does not make the agreement improper.

In the German and Dutch literature primarily, certain categories of agreements are identified as improper on grounds of protecting the interests of the company as a whole. An indefinite contract with a general instruction clause is generally regarded as invalid. Moreover, a voting agreement is held to be contrary to public policy and morality when its aim or consequence is to evade the law, for instance to circumvent the mandatory share transfer restriction regime. Since the purpose of the statutory restrictions of share transfers is to ensure an intuitu personae character of the company - a wider aim than merely restricting shareholders' rights -, some authors contend that a shareholders' agreement contrary to the statutory provisions would be null and void. Other authors express a more liberal view, emphasizing the distinction between personal obligations and the binding of the company.

In my view, it is not so much the distinction between the personal obligations of the shareholder and the binding of the company which makes an agreement valid or invalid, as much as the effect of the agreement on third parties. Only when an agreement interferes with the interests of credi- 
tors or seriously disrupts the company's balance of power, should the agreement be held invalid. Thus, shareholders may not agree to waive their right to seek annulment, their statutory exit right, their right to order an investigation into the company's affairs or their right to order the company to be wound up. Other agreements are in principle valid, such as an agreement not to transfer shares for a certain period, or to exclude the share transfer restrictions.

Once the validity of the agreement is established, the company may under certain circumstances be bound by the agreement. This is the basis of the unanimous consent rule. When all shareholders agree, it should not matter whether all formalities are complied with (for articles or resolutions). A shareholder should be able to seek annulment of a resolution in breach of a shareholders' agreement if all shareholders agreed. The German Bundesgerichtshof has acknowledged this in two highly controversial decisions. Honouring agreements is also the underlying ratio of the House of Lords' decision in O'Neill v. Phillips regarding section 459 of the Companies Act 1985. In the Netherlands, the Hoge Raad has even held a company liable in tort for acting in breach of a shareholders' agreement.

\section{Final remarks}

A sharp contrast exists between the perceived mandatory nature of Dutch private company law and its de facto permissive effect. Although in effect the different legal systems seem to offer more or less the same solutions to problems which arise, the English and German approaches seem to offer a clearer justification of the ratio of mandatory law. I believe it is important to have a sound doctrinal basis for justifying the limitations imposed by mandatory law. Without actually needing to change the statutory law, the process of articulating the doctrinal basis for mandatory limitations regarding shareholder resolutions offers Dutch company law a new perspective. Nevertheless, more focus on the needs of private companies in statutory law would be desirable. 



\section{Lijst van aangehaalde literatuur}

\section{Nederland}

Aaftink, H.A.M.,

Afstand van vermogensrechten, diss. RUU, Kluwer, Deventer 1974

Asser, C.D., Berg van Dussen Muilkerk, W.E.J., Godefroi, M.H., Tyde-man, J.W. en De Vries, J.

Wetboek van Koophandel met aantekeningen, Johannes Müller, Amsterdam 1845

Belinfante

Ontwerpen van wetten op de vennootschappen en andere: wijziging en aanvulling van de bepalingen omtrent de naamlooze vennootschap en regeling van de aansprakelijkheid voor het prospectus, Den Haag, Belinfante 1929

Berg, J.A.M. ten

Statuten zonder bezwaar, preadvies KNB, Koninklijke Vermande, Den Haag 2002, p. $161-206$

Blanco Fernández, J.M.

"Vennootschapsrechtelijke werking van stemovereenkomsten", Ondernemingsrecht 1999, p. 148-151

Boer, Th. M. de

"Internationale arbitrage en fundamenteel recht. De schakel tussen Mitsubishi

(U.S. Supreme Court) en Benetton (Hof van Justitie EG)", AA 2003, p. 50-57 Boogert, M.W. den

“Aanpassing van boek 2 BW voor joint-venture-doeleinden?", AA 1995, p. 357-363

Boogert, M.W. den

Aandeelhouderscontracten en joint-venture-bv's, in: Ondernemingsrechtelijke contracten, uitgave vanwege het Instituut voor Onderne-mingsrecht deel 14, Kluwer, Deventer 1991, p. 71-79

Bosse, W.

"De bruikbaarheid van de vervallen Departementale Richtlijnen", WPNR 2001, p. $544-547$

Brenninkmeijer, A.M.

Stemovereenkomsten van aandeelhouders, diss. KUN, Kluwer, Deventer 1973

Buijn, F.K.

"De inrichting van statuten van vennootschappen", Ondernemingsrecht 2002, p. $265-268$

Buijn, F.K.

"Statuten: terug naar de overeenkomst?", Ondernemingsrecht 1999, p. 120123 
Buys, S.G.M.

"Statuten, reglementen en besluiten beschouwen als algemene voorwaarden?", TVVS 1992, p. 148-152

Cahen, J.L.P.

De invloed van de belangenverbreding op het handelen van de aandeelhouder in: Honderd jaar rechtsleven, De Nederlandse Juristenvereniging 1870-1970, Tjeenk Willink, Zwolle 1970, p. 71-84

Cremers, J.H.F.J.

Prioriteitsaandelen, diss. KUN, Kluwer, Deventer 1971

Dorhout Mees, T.J.

"Het Arrest inzake Wijsmuller en de stemafspraak", NV 1974, p. 104

Dortmond, P.J.

Stemovereenkomsten rondom de eeuwwisseling, oratie, Kluwer, Deventer 2000

Dortmond, P.J.

"Het preventieve toezicht bij naamloze en besloten vennootschappen", NV 1998 , p. $274-280$

Dortmond, P.J.

Enige beschouwingen rondom aandelen, diss. KUN, serie Monografieën vanwege het Van der Heijden Instituut deel 31, Kluwer, Deventer 1989

Dumoulin, S.H.M.A.

Besluitvorming in rechtspersonen, diss. RUG, Kluwer, Deventer 1999

Duuren, T.P. van

De joint venture-vennootschap: een persoonsgebonden kapitaalvennootschap,

diss. UvT, Boom Juridische Uitgevers, 2002

Duynstee, F.J.F.M.

reactie op "Overeenkomsten betreffende het stemrecht in een naamlooze vennootschap", NV 1942, p. 114-115, 169-170

Grapperhaus, F.B.J.

Rechtspraak: uitleg algemeen verbindend verklaarde CAO: de Hoge Raad schuift langzaam op in Haviltex, Ondernemingsrecht 2002, p. 423-424

Grinten, W.C.L. van der

Handboek voor de Naamloze en de Besloten Vennootschap, $12^{\mathrm{e}}$ druk, Tjeenk Willink, Zwolle 1992

Grinten, W.C.L. van der

"Minderheidsrechten", NV 1992, p. 271-274

Grinten, W.C.L. van der

"Rechtspraak: overeenkomsten betreffende de uitoefening van stemrecht in een n.v., onherroepelijke volmacht", AA 1959, p. 55-60

Groot, H. de

“Waarom krijgen wij geen LLC?", Ondernemingsrecht 2001, p. 254-261

Hartkamp, A.S.

Asser-Hartkamp deel 4-II Verbintenissenrecht. Algemene leer der overeenkomsten, $11^{\mathrm{c}}$ druk, Tjeenk Willink, Deventer 2001 
Heijden, E.J.J. van der

De ontwikkeling van de naamlooze vennootschap in Nederland voor de codificatie, diss. RUU, Amsterdam 1908

Hendriks-Jansen, Th.C.M.

"Stemovereenkomsten", NV 1982, p. 6-13

Hijma, Jac.

Nietigheid en vernietigbaarheid van rechtshandelingen, diss. RUL, Kluwer, Deventer 1988

Hondius, E.W.

De zwakke partij in het contractenrecht; over de verandering van paradigmata van het privaatrecht, in: Contractvrijheid, T. Hartlief \& C.J.J.M.Stolker (red.), Kluwer, Deventer 1999, p. 387 e.v.

Honée, Ch.E.

"De wettelijke geschillenregeling vatbaar voor arbitrage?", NV 1995, p. 9498

Honée, H.J.M.N.

Statutair gedwongen uitkoop, in: A-T-D, opstellen aangeboden aan Prof. mr.

P. van Schilfgaarde, Kluwer, Deventer 2000, p. 153-160

Honée, H.J.M.N.

Arbitrage in het vennootschapsrecht, in: rechtspleging in het ondernemingsrecht, uitgave vanwege het Instituut voor Ondernemingsrecht deel 26 , Kluwer, Deventer 1997, p. $27-42$

Honée, H.J.M.N.

Deadlock-situaties, AA 1995, p. 376-384

Huussen-De Groot, F.M.

Rechtspersonen in de $19^{c}$ eeuw: een studie van privaatrechtelijke rechtspersonen in de 19e-eeuwse wetgeving van Frankrijk, Nederland en Duitsland, diss. RUL, Tjeenk Willink, Zwolle 1976

Ingh, F.J.P. van den

Bekrachtiging van onbevoegd genomen besluiten, in: Maeijers belangstellingen, serie Monografieën vanwege het Van der Heijden Instituut deel 57 , Kluwer, Deventer 1997, p. 1-8

Ingh, F.J.P. van den

"Beslechting van geschillen tussen aandeelhouders in arbitrage", NV 1995, p. 145-149

Ingh, F.J.P. van den

"De verplichting tot overname van niet vrij overdraagbare aandelen", WPNR 1989, p. 136-138

Kamphuisen, P.W.

"Overeenkomsten betreffende het stemrecht in een naamlooze vennootschap.", NV 1941, p. 349-357, reactie op Duynstee, NV 1942, p. 144-145 
Kiersch, E.D.G.

Grensoverschrijdende samenwerking en de noodzaak van een eenvoudig bv recht, in: Nederlands ondernemingsrecht in grensoverschrijdend perspectief, uitgave vanwege het Instituut voor Ondernemingsrecht deel 40, 2003, p. 141 e.v.

Kiersch, E.D.G. en Ter Huurne, G.M

"Het statuut van de Europese vennootschap", Ondernemingsrecht 2001, p. $183-190$

Kist, J.G. en Visser, L.E.

Beginselen van Handelsrecht, supplement deel III De naamlooze vennootschap, Belinfante, Den Haag 1929

Kluiver, H.J. de, en Meinema, M.

"Dwingend vennootschapsrecht na de Wet herziening preventief toezicht en de mogelijkheden van statutaire of contractuele afwijking en aanvulling", WPNR 2002, p. 648-659

Kluiver, H.J. de

"De ondernemingsrechtelijke contractspraktijk: onderhandelen in de schaduw van de wet", Tijdschrift Contracteren 2001, p. 4-14

Kluiver, H.J. de

Bekrachtiging van rechtshandelingen en besluiten - over art. 3:58 als vangnet en trampoline, in: Vertegenwoordiging en tussenpersonen, (red. S.C.J.J. Kortmann, N.E.D. Faber, J.A.M. Strens), serie Onderneming en recht deel 17, Tjeenk Willink Deventer 1999, p. 69-88

Kluiver, H.J. de

"Mag het nog ietsje meer zijn?", NJB 1996, p. 1439-1451

Kluiver, H.J. de

"Joint ventures en stemovereenkomsten. Een rechtsvergelijkend perspectief", AA 1995, p. 432-441

Kluiver, H.J. de

"Het vennootschapsrecht dient te worden versoepeld... en verscherpt", TVVS 1994, nr.7, p. 174-179

Koelemeijer, M.K.

Redelijkheid en billijkheid in kapitaalvennootschappen, diss. UM, Kluwer, Deventer 1999

Leijten, A.F.J.A.

Geschillen tussen aandeelhouders, in: Conflicten rondom de rechtspersoon, serie Monografieèn vanwege het Van der Heijden Instituut deel 62, Kluwer, Deventer 2000, p. 12 e.v.

Löwensteyn, F.J.W.

Pitlo's Het Nederlands burgerlijk recht deel 2: Het rechtspersonenrecht, $3^{c}$ druk, Gouda Quint, Arnhem 1994

Löwensteyn, F.J.W.

Wezen en bevoegdheid van het bestuur van de vereniging en de naamloze vennootschap, diss. UVA, Tjeenk Willink, Zwolle 1959 
Lubbers,

NV 1975 , p. 124.

Maeijer, J.M.M.

Asser-Maeijer deel 2-III Vertegenwoordiging en rechtspersoon. De naamloze en de besloten vennootschap, $2^{\mathrm{C}}$ druk, Tjeenk Willink, Deventer 2000

Maeijer, J.M.M.

Asser-Van der Grinten-Maeijer deel 2-II Vertegenwoordiging en rechtspersoon. De rechtspersoon, $8^{\mathrm{e}}$ druk, Tjeenk Willink, Deventer 1997

Maeijer, J.M.M.

Repliek en slotwoord, in: Maeijers belangstellingen, serie Monografieën vanwege het Van der Heijden Instituut deel 57, Kluwer, Deventer 1997

Maeijer, J.M.M.

De stemovereenkomst van aandeelhouders, in: Recht zo die gaat, opstellen aangeboden aan prof. mr. P.W. van der Ploeg, Tjeenk Willink, Zwolle 1976, p. $95-106$

Maeijer, J.M.M.

"Beantwoording rechtsvraag: de geldigheid van stemovereenkomsten", AA 1969 , p. $342-347$

Maeijer, J.M.M.

"Rumoer rond de Holland-Amerika Lijn", NV 1966, p. 118-123

Maeijer, J.M.M.

Het belangenconflict in de naamloze vennootschap, oratie, Kluwer, Deventer 1964

Meijers, E.M.

Ontwerp voor een nieuw burgerlijk wetboek, Staatsdrukkerij en uitgevingsbedrijf, Den Haag 1954

Mendel, M.M.

Stemrecht, minderheidsaandeelhouders en ongelijkheidscompensatie, in: Ongelijkheidscompensatie als roode draad in het recht, Liber Amicorum voor prof.mr. M.G. Rood, Kluwer, Deventer 1997, p. 207-216

Mohr, A.L.

Hoe schatplichtig is de vennootschap aan het vrije contractenrecht?, in: J.L.P. Mohr, A.L.

Cahen bundel, Gouda Quint, Deventer 1997, p. 217-228

Spijkers. Ondernemingsrecht op de breuklijn van praktijk en wetenschap, oratie, Gouda Quint, Arnhem 1993

Mok, M.R.

Pacta sunt servanda; ja toch?, afscheidscollege, Tjeenk Willink, Zwolle 1997

Molengraaff, W.L.P.A.

Beschouwingen over de herziening van het vereenigingsrecht, preadvies, Bohn, Haarlem 1903

Monchy, C.W. de

"Op weg naar een joint-venture regime?", TVVS 1996, p. 2-5

Mourik, M.J.A. van

"Statuten", S \& V 1987, p. 3-5 
Olffen, M. van

Inrichting van de statuten zonder preventief toezicht, in: A-T-D, opstellen aangeboden aan Prof. mr. P, van Schilfgaarde, Kluwer, Deventer 2000, p. 337-342

Olffen, M. van

"Conversie van aandelen", WPNR 1997, p. 49-52

Overes, C.H.C., Ploeg, T. J. van der, Schwarz, C.A. en Veen, W.J.M.

Van vereniging en stichting, coöperatie en onderlinge waarborgmaatschappij, $4^{e}$ druk, Gouda Quint, Deventer 2002

Petit, Ch. J.J.M.

Overeenkomsten in strijd met de goede zeden, diss. RUL 1920

Ploeg, T.J. van der

Het burgerlijk recht en de vrijwillige organisaties, diss. VU, Kluwer, Deventer 1978

Portengen, H.J.

"Aandeelhoudersovereenkomst als kwaliteitseis?", WPNR 2002, p. 842-847

Raaijmakers, M.J.G.C.

"Herziening van het Nederlandse ondernemingsrecht", WPNR 2002, p. 683692

Raaijmakers, M.J.G.C.

Pitlo's Vennootschaps- en rechtspersonenrecht, $4^{\mathrm{e}}$ druk, Gouda Quint, Deventer 2000

Raaijmakers, M.G.J.C.

"'Besloten' vennootschappen: quasi-nv of quasi-vof?", AA 1994, p. 340-348

Raaijmakers, M.J.G.C.

Enkele beschouwingen over joint ventures, preadvies voor de Nederlandse Vereniging voor Rechtsvergelijking, Kluwer, Deventer 1992

Raaijmakers, M.J.G.C.

Over de rechtsbetrekkingen tussen aandeelhouders in een 'Quasi-Vof', in: In het nu, wat worden zal, opstellen aangeboden aan prof. mr. H.C.F. Schoordijk, Kluwer, Deventer 1991, p. 203-222

Raaijmakers, M.J.G.C.

Rechtspersonen tussen contract en instituut, oratie, Kluwer, Deventer 1987

Rensen, G.J.C.

"Statutaire aanbiedings- en overnameverplichtingen van aandeelhouders", Ondernemingsrecht 2001 , p. $484-489$

Ronse, J.

Vennootschaps- en verbintenissenrecht, in: Op de grenzen van komend recht, opstellen aangeboden aan prof. mr. Beekhuis, Kluwer, Deventer 1969

Sanders, P. en Westbroek, W.

BV en NV, bewerkt door F.K. Buijn en P.M. Storm, 7e druk, Kluwer, Deventer 1994

Sanders, P.

Het nieuwe arbitragerecht, $3^{\mathrm{e}}$ druk, Kluwer, Deventer 1996 
Sanders, P.

Geschillen in BV en NV. Twee voorstellen van wet, in: Van vennootschappelijk belang. Opstellen aangeboden aan prof. Mr. J.M.M. Maeijer, Tjeenk Willink 1988

Schaick, A.C. van

"Uitlegregels", WPNR 1998, p. 272-277

Schilfgaarde, P. van

"Statuten zonder bezwaar", WNPR 2002, p. 639-647

Schilfgaarde, P. van

Van de BV en de NV, 12e druk, Gouda Quint, Deventer 2001

Schilfgaarde, P. van

"De ontwikkeling van de rechtspersoon in het privaatrecht", NJB 2000, p. 1093-1098

Schilfgaarde, P. van

Blokkeringsregeling. Contractuele afwijking, WPNR 1994, p. 213-214

Schilfgaarde, P. van

Vrijheid van vennootschap, in: Vrijheid van recht: opstellen aangeboden aan prof. mr. E.H. s'Jacob, Tjeenk Willink, Zwolle 1975, p. 247-255

Scholten, P. en Scholten, G.J.

Asser's handleiding tot de beoefening van het Nederlands burgerlijk recht, Algemeen Deel, I-2, $3^{\mathrm{c}}$ druk Tjeenk Willink, Zwolle 1974

Schoonbrood, J.D.M.

De in de wet overgenomen bepalingen van de Departementale Richtlijnen

1986, in: Statuten zonder bezwaar, preadvies KNB, Koninklijke Vermande,

Den Haag 2002, p. 51-117

Schwarz, C.A.

Blokkering van aandelen, diss. VU, serie vanwege het Van de Heijden Insti-

tuut deel 27, Kluwer, Deventer 1986

Slagter, W.J., Bartel J.C.K.W., Beckman, H., Dorresteijn, A.F.M. en Timmerman, L.

Compendium van het Ondernemingsrecht, $6^{\mathrm{e}}$ druk, Kluwer, Deventer 1993

Slagter, W.J.

Rechtspraak: Enquêterecht: de geschillenregeling, TVVS 1995, p. 76-77

Smits, J.M.

"Over de uitleg van statuten ener rechtspersoon; een deels rechtsvergelijkende

bijdrage", Stichting \& Vereniging 1999, p. 123-127

Snijders, H.J.

Nederlands arbitragerecht; Een artikelsgewijze commentaar op de art. 1020-

1076 Rv, Kluwer, Deventer 2000

Snijders, H.J.

Maten van dwingend recht, in: Contractvrijheid, T. Hartlief \& C.J.J.M.Stolker

(red.), Kluwer, Deventer 1999, p. 153 e.v.

Solinge, G. van en Nowak, R.G.J.

"Bestuursbesluiten na afschaffing van het preventief toezicht", Ondernemingsrecht 2002, p. $432-439$ 
Straalen, P.W. van

Behoud van rechten van werknemers bij overgang van onderneming, diss.

RUG, Kluwer Deventer 1999

Timmerman, L.

"Kroniek van het vennootschapsrecht", NJB 2002, p. 1545 e.v.

Timmerman, L.

Onderstromen in het privaatrechtelijke rechtspersonenrecht, in: De ontwikkeling van de rechtspersoon in het publiekrecht en het privaatrecht

NJV preadvies, Tjeenk Willink, Deventer 2000, p. 105-165

Timmerman, L.

"Over de toekomst van het vennootschapsrecht", RM Themis 1999, p. 43-51

Timmerman, L.

Gestaltungsfreiheit im niederländischen Gesellschaftsıecht, in: Gestaltungs-

freiheit im Gesellschaftsrecht, ZGR Sonderheft 1998

Timmerman, L.

"Het krakende gebouw van het vennootschapsrecht", TVVS 1995, p. 178-181 Timmerman, L.

"Is versoepeling van het Nederlandse n.v./b.v.-recht wenselijk?", TVVS 1992, p. 163-168

Timmerman, L.

"Waarom hebben wij dwingend vennootschapsrecht?" in: Ondernemingsrechtelijke contracten, uitgave van het Instituut voor Ondernemingsrecht deel 14,

Kluwer, Deventer 1991, p. 1-10

Tjittes, R.P.J.L.

Afstand van recht, diss. RUG, Kluwer, Deventer 1992

Treurniet, W.C,

Beschikking van de Ondernemingskamer van het Gerechtshof Amsterdam

d.d. 15 november 1973, NV 1974, p. 86-92

Veegens, D.J., Korthals Altes, E. en Groen, H.A.

Cassatie in burgerlijke zaken, $3^{\mathrm{e}}$ druk, Tjeenk Willink, Zwolle 1990

Veen, W.J.M.

"Over het aandeelhouderschap en statutaire verplichtingen", WPNR 2003, p. 137-147

Velden, P.A.L.M. van der

De vereniging-rechtspersoon en haar leden, diss. KUN, deel 2 in de serie Monografieën vanwege het Van der Heijden-Instituut, Kluwer, Deventer 1969

Waaijer, B.C.M.

Aandeelhoudersovereenkomsten, Ars Notariatus LXXVIII, Kluwer, Deventer 1996

Waaijer, B.C.M.

Statuten en statutenwijziging, diss. KUN, Kluwer, Deventer 1993

Waaijer, B.C.M.

"Verklaring van (geen) bezwaar", WPNR 1991, p. 471-475 
Wachter, B.

Blokkeringsclausules en stemrecht, in: Verzekering van vriendschap, rechtsgeleerde opstellen aangeboden aan prof. mr. T.J. Dorhout Mees, Kluwer, Deventer 1974, p. 232-242

Westbroek, W.

"Statutaire casu quo contractuele regelingen voor de tussenkomst van derden bij geschillen", NV 1982, p. 13-20

Westbroek, W.

"De nieuwste druk van het Handboek, NV 1977, p. 143-155

Winter, J.W.

"Rechtspraak: Benoeming gedelegeerd commissaris in strijd met overeenkomst", TVVS 1997, p. 85

Witt Wijnen, O.L.O. de

Ondernemingsrecht en arbitrage, in: Conflicten rondom de rechtspersoon, serie Monografieën vanwege het Van der Heijden Instituut deel 62, Kluwer, Deventer 2000, p. 103-134

Zaman, D.F.M.M.

"Conversie van aandelen", NV 1991, p. 7-10

Zeylemaker, J.B.

Verleden, heden en toekomst van de naamloze vennootschap, Tjeenk Willink, Zwolle 1947

\section{Duitsland}

Baumbach/Hueck

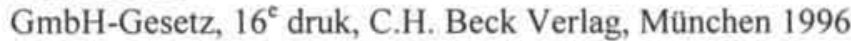

Bea, F.X., Scheurer, S. en Gutwein, D.

"Institutionalisierung der Kontrolle bei der $\mathrm{GmbH}$ durch einen Beirat", Der Betrieb 1996, p. 1193-1197

Beuthien, V. en Gätsch, A.

"Einfluß Dritter auf die Organbesetzung und Geschäftsführung bei Vereinen,

Kapitalgesellschaften und Genossenschaften", ZHR 1993, p. 483-512

Beuthien, V. en Gätsch, A.

"Vereinsautonomie und Satzungsrechte Dritter", ZHR 1992, p. 459-479

Boesebeck, E.

"Satzungsdurchbrechung" im Recht der AG und GmbH", NJW 1960, p. 2265-2267

Beyer, Th.C.W.

"Vorbeugender Rechtsschutz gegen die Beschlußfassung der GmbH-Gesellschafterversammlung", GmbHR 2001, p. 467-471 Casper, M.

"Das Anfechtungsklageerfordernis im GmbH-Beschlußmangelrecht", ZHR 1999, p. 54-86 
Fischer, $\mathrm{R}$.

Zur Methode revisionsrichterlicher Rechtsprechung auf dem Gebiet des Gesellschaftsrechts, in: Recht und Rechtsleben in der sozialen Demokratie. Festgabe für Otto Künze zum 65. Geburtstag, Duncker und Humblot, Berlin 1969 , p. $95-108$

Fischer, R.

"Die Grenzen bei der Ausübung gesellschaftsrechtlicher Mitgliedschaftsrechte", NJW 1954, p. 777-780

Fleck, H.J.

Stimmrechtsabspaltung in der GmbH?, in: Festschrift für Robert Fischer, Walter de Gruyter, Berlijn 1979, p. 107-129

Flume, W,

Allgemeiner Teil des bürgerlichen Rechts - Die juristische Person, Springer Verlag, Berlijn 1983

Geßler, E.

Bedeutung und Auslegung des $\S 23$ Abs. 5 AktG, in: Festschrift für Martin Luther, Verlag C.H. Beck, München 1976, p. 69 e.v.

Gernoth, J. en Meinema, M.

"Niederländisches Enqueterecht: Vorbild für das deutsche Sonderprüfungsrecht?", RIW 2000, p. 844-849

Grunewald, B.

Das Recht zum Austritt aus der Aktiengesellschaft, in: Festschrift für Carsten Peter Claussen: zum 70. Geburtstag, Heymann, Keulen 1997

Grunewald, B.

"Die Auslegung von Gesellschaftsverträgen und Satzungen", ZGR 1995, p. 68-92

Guyon, Y.

"Die Société par Actions Simplifiée (SAS) - eine neue Gesellschaftsform in Frankreich -", ZGR 1994, p. 551 e.v.

Haas, U.

"Zür Einführung von Schiedsklauseln durch Satzungsänderungen in Vereinen", ZGR 2001, p. 325-349

Habersack, M.

Die Mitgliedschaft - subjektives und sonstiges Recht, Mohr, Tübingen 1996

Habersack, M.

"Unwirksamkeit "zustandsbegründender" Durchbrechungen der GmbH-Satzung sowie darauf gerichteter schuldrechtlicher Nebenab-reden", ZGR 1994, p. 354-367

Hachenburg, M. en Ulmer, P.

Gesetz betreffend die Gesellschaften mit beschränkter Haftung: Großkommentar, $8^{\mathrm{e}}$ druk, Walter de Gruyter, Berlijn 1997

Hadding, W.

Korporationsrechtliche oder rechtsgeschäftliche Grundlagen des Vereinsrechts? in: Festschrift für Robert Fischer, Walter de Gruyter, Berlijn 1979, p. $165-196$ 
Hirte, $\mathrm{H}$.

"Die aktienrechtliche Satzungsstrenge: Kapitalmarkt und sonstige Legitimationen versus Gestaltungsfreiheit", in: Gestaltungsfreiheit im Gesellschaftsrecht, ZGR Sonderheft 1998, p. 61-98

Hoffmann-Becking, $M$.

"Der Einfluß schuldrechtlicher Gesellschaftervereinbarungen auf die Rechtsbeziehungen in der Kapitalgesellschaft", ZGR 1994, p. 442-464

Hommelhoff, P.

"Gestaltungsfreiheit im GmbH-Recht", in: Gestaltungsfreiheit im Gesellschaftsrecht, ZGR 1998 Sonderheft 13, p. 36-60

Hommelhoff, P.

Eigenkontrolle statt Staatskontrolle, in: Hundert Jahre modernes Aktienrecht, ZGR Sonderheft 1985 , p. 54 Hopt, K.J.

"Gestaltungsfreiheit im Gesellschaftsrecht in Europa - Generalbericht", ZGR Sonderheft 1998, p. 123-147

Hüffer, U.

Kurzkommentar AktG, $4^{\mathrm{e}}$ druk, C.H. Beck Verlag, München 1999

J. von Staudingers

Kommentar zum Bürgerlichen Gesetzbuch mit Einfulhrungsgesetz und Nebengesetzen, $12^{\mathrm{e}}$ druk, J. Schweitzer Verlag, Berlijn 1980 Junker, $\mathrm{M}$.

"Der Sondervorteil im Sinne des $§ 26$ AktG", ZHR 1995, p. 207-216 Kübler, F.

Gesellschaftsrecht, 4e druk, C.F. Müller Juristischer Verlag, Heidelberg 1994 Lutter, M. en Hommelhoff, P.

GmbH-Gesetz, Kommentar, $15^{\mathrm{c}}$ druk, Verlag Dr. Otto Schmidt, Keulen 2000 Lutter, M. en Grunewald, B.

"Zur Umgehung von Vinkulierungsklauseln in Satzungen von Aktiengesellschaften un Gesellschaften mbH", AG 1989, p. 109-117

Lutter, M.

"Theorie der Mitgliedschaft", Archiv für die civilistische Praxis, Mohr, Tübingen 1980, p. 84-159

Mertens, H-J.

"Satzungs- und Organisationsautonomie im Aktien- und Konzernrecht", ZGR 1994, p. 424-441

Münchener Kommentar zum Bürgerlichen Gesetzbuch, Allgemeiner Teil, $\$ \S 1-240,2^{\mathrm{e}}$ druk, C.H. Beck Verlag, München 1984

Münchener Kommentar zum Aktiengesetz,

$2^{\mathrm{e}}$ druk, $\S \S 1-53$, C.H. Beck Verlag, München 2000

Noack, U.

Gesellschaftervereinbarungen bei Kapitalgesellschaften, J.C.B. Mohr, Tübingen 1994 
Noack, U.

Fehlerhafte Beschlüsse in Gesellschaften und Vereinen, Carl Heymanns Verlag KG, Berlijn 1989

Odersky, W.

"Gestaltungsfreiheit und gerichtliche Kontrolle", in: Gestaltungsfreiheit im Gesellschaftsrecht, ZGR Sonderheft 1998, p. 103-121

Priester, H.J.

Rechtskontrolle und Registerpublizität als Schranken satzungsgleicher Gesellschaftervereinbarungen bei der GmbH?, in: Festschrift für Carsten Peter Claussen: zum 70. Geburtstag, Heymann, Keulen 1997, p. 332 e.v.

Priester, H.J.

"Satzungsänderung und Satzungsdurchbrechung", ZHR 1987, p. 40-58

Priester, H.J.

Drittbindung des Stimmrechts und Satzungsautonomie in: Festschrift für Winfried Werner, Walter de Gruyter, Berlijn 1984, p. 657-679

Priester, H.J.

"Nichtkorporative Satzungsbestimmungen bei Kapitalgesellschaften", DB 1979 , p. $680-687$

Raiser, Th.

Recht der Kapitalgesellschaften: ein Handbuch für Praxis und Wissenschaft, $3^{\mathrm{e}}$ druk, Franz Vahlen, München 2001

Reuter, D.

Der Beirat der GmbH in: Festschrift 100 Jahre GmbH-Gesetz, Verlag Dr. Otto Schmidt, Keulen 1992, p. 631-656

Reuter, D.

Privatrechtliche Schranken der Perpetuirung von Unternehmen, Athenäum, Frankfurt 1973

Rittner, F.

Die werdende juristische Person, J.C.B Mohr, Tübingen 1973

Röhricht, V.

Großkommentar zum Aktiengesetz, $4^{\mathrm{c}}$ druk, $\S \S 23-40$, Walter de Gruyter, Berlijn 1997

Rowedder, H. en Schmidt-Leithoff, Ch.

Gesetz betreffend die Gesellschaften mit beschränkter Haftung: Kommentar, $4^{\mathrm{c}}$ druk, Franz Vahlen, München 2002

Schmidt, K.

Gesellschaftsrecht, $4^{\mathrm{e}}$ druk, Carl Heymanns Verlag, Keulen 2002 Soergel

Bürgerliches Gesetzbuch mit Einführungsgesetz und Nebengesetzen, $11^{\mathrm{c}}$ druk, Verlag W. Kohlhammer, Stuttgart 1978

Ulmer, $\mathrm{P}$.

"Verletzung schuldrechtlicher Nebenabreden als Anfechtungsgrund im GmbH-recht?", NJW 1987, p. 1849-1855 
Ulmer, P.

Begründung von Rechten für Dritte in der Satzung einer $\mathrm{GmbH}$ ? in:

Festschrift für Winfried Werner, Walter de Gruyter, Berlin 1984

Waldenberger, A.

"Sonderrechte der Gesellschafter einer GmbH - ihre Arten und ihre rechtliche

Behandlung", GmbHR 1997, p. 49-56

Westermann, H.P.

Das Verhältnis von Satzung und Nebenverordnungen im Gesellschaftsrecht,

C.F. Müller, 1994

Wiedemann, $\mathrm{H}$.

"Erfahrungen mit der Gestaltungsfreiheit im Gesellschaftsrecht", in: Gestaltungsfreiheit im Gesellschaftsrecht, ZGR Sonderheft 1998, p. 5-32

Wiedemann, $\mathrm{H}$.

"Der Gesellschaftsvertrag der Personengesellschaften", WM 1990, p. 2-30

Wiedemann, $\mathrm{H}$.

Gesellschaftsrecht, Verlag C.H. Beck, München 1980

Wiedemann, $\mathrm{H}$.

"Die Auslegung von Satzungen und Gesellschaftsverträgen", DNotZ Sonderheft 1977, p. 99-111

Winkler, K.

"Materielle und formelle Bestandteile in Gesellschaftsverträgen und Satzungen und ihre verschiedene Auswirkungen", DNotZ 1969, p. 394-414

Winter, $\mathrm{M}$.

"Organisationsrechtliche Sanktionen bei Verletzung schuldrechtlicher Gesellschaftervereinbarungen?", ZHR 1990, p. 259-283

Zöllner, W.

Inhaltsfreiheit bei Gesellschaftsverträgen in: Festschrift 100 Jahre GmbHGesetz, 1992, p. 85-125

Zöllner, W.

" $\mathrm{Zu}$ Schranken und Wirkung von Stimmbindungsverträgen, insbesondere bei der GmbH', ZHR 1991, p. 168-189

Zöllner, W. en Noack, U.

"Geltendmachung von Beschlußmängeln im GmbH-recht", ZGR 1989, p. 532 e.v.

Zöllner, W.

Die Anpassung von Personengesellschaftsverträgen an veränderte Umstände, Müller Juristischer Verlag, Heidelberg 1979

Zöllner, W.

Die Schranken mitgliedschaftlicher Stimmrechtsmacht bei den privatrechtZütt, J. lichen Personenverbanden, Verlag C.H. Beck, München 1963

"Stimmbindungen gegenüber Dritten - Ergebnisse einer Umfrage", ZHR 1991 , p. 213-215

Zütt, J.

"Einstweiliger Rechtsschutz bei Stimmbindungen", ZHR 1991, p. 190-208 


\section{Engeland}

Andrews, N.

"Strangers to justice no longer: the reversal of the privity rules under the Contracts (rights of third parties) Act 1999", CLJ 2001, p. 353-381

Bastin, N.A.

"The Enforcement of a Member's Rights", JBL 1977, p. 17-28

Baxter, C.

"The role of the judge in enforcing shareholder rights", CLJ 1983, p. 96-117 Beatson, J.

"Has the Common Law a Future?", CLJ 1997, p. 291-314

Bretten, G.R.

"Alteration of Articles and Protection of Minorities", JBL, p. 185-197

Cabrelli, D.

"BDG Roof Bond Ltd v. Douglas: further observations on the application of the Duomatic relief', The Company Lawyer 2001, p. 130-133

Cheffins, B.R.

Trust, Loyalty and Cooperation in the Business Community: Is Regulation Required? in: The Realm of Company Law, B.A.K. Rider (ed.), Kluwer Law International, Londen 1998, p. 53-88

Cheffins, B.R.

Company law; theory, structure and operation, Clarendon Press, Oxford 1997

Chitty, J. en Beale, H.G.

Chitty on contracts, $28^{\mathrm{e}}$ druk, Sweet \& Maxwell, Londen 1999

Copp, S.

"Company law and alternative dispute resolutions: an economic analysis", The Company Lawyer 2002, p. 361-375

Cross, R.

Statutory Interpretation, $3^{\mathrm{e}}$ druk, Butterworths, Londen 1995

Davies, P.L.

Gower's Principles of Modern Company Law, $6^{\mathrm{c}}$ druk, Sweet \& Maxwell, Londen 1997

Davenport, B.J.

"What did Russell v. Northern Bank Development Corporation Ltd. decide?", LQR 1993, p. 553-572

Drury, R.R.

"The relative Nature of a Shareholder's Right to Enforce the Company Contract", CLJ (45) 1986, p. 219-246

DTI White Paper "Modernising company law", juli 2002, www.dti.gov.uk/cld/whitepaper.htm

DTI Modern Company Law - Final Report, 2001, www.dti.gov.uk/cld/review.htm

DTI Consultation Document Company Investigations:

Powers for the 21st Century, juli 2001, www.dti.gov.uk/cld/company_investigations.pdf. 
DTI Consultation Report,

Modern Company Law for a Competitive Environment Developing the Framework, 2000

DTI Consultation Paper,

Modern Company Law for a Competitive Economy, The Strategic Framework, 1999

Farrar, J.H. en Hannigan, B.M.

Farrar's Company Law, $4^{\mathrm{e}}$ druk, Butterworths, Londen 1998

Ferran, E.

Company Law and Corporate Finance, Oxford University Press, Oxford 1999 Ferran, E.

"The decision of the House of Lords in Russell v. Northern Bank Development Corporation Limited', CLJ 1994, p. 343-366

Finn, P.

"Shareholder Agreements", Australian Business Law Review 1978, p. 97-104 Freedman, J.

Reforming Company Law, in: Perspectives on Company Law: 1, F. Macmillan Patfield (ed.), Kluwer Law International, Londen 1995, p. 197-221

Freedman, J.

"Small Businesses and the Corporate Form: Burden or Privilege?" MLR 1994 , p. $555-584$

Goldberg, G.D.

"The Enforcement of Outsider-Rights under Section 20(1) of the Companies

Act 1948", MLR (35) 1972, p. 362-374

Grantham, R.

"The unanimous consent rule in company law", CLJ 1993, p. 245-271

Greenfield, K.

From Rights to Regulations in Corporate Law, in: Perspectives on Company Law: 2, F. Macmillan Patfield (ed.), Kluwer Law International, Londen 1997, p. 1-25

Griffiths,

"Professional Firms and Limited Liability: an Analysis of the Proposed Limited Liability Partnership", Company Financial and Insolvency Law Review 1998, p. 157 e.v.

Hannigan, B.

"Limitations on a Shareholder's Right to Vote - Effective Ratification Revisited", JBL 2000, p. 493-512

Ireland, $\mathrm{P}$.

"The Triumph of the Company Legal Form, 1856-1914, in: Essays for Clive Schmitthoff, J. Adams (ed.), Professional Books Limited, Abingdon 1983, p. 29-58

Jamers, Ph.S., Shears, P. en Stevenson, G.

James' Introduction to English Law, 13 ${ }^{\mathrm{e}}$ druk, Butterworths, Londen 1996

Law Commission

Shareholder Remedies, Consultation Paper 1996 
McGlynn, C.

"The constitution of the company: mandatory statutory provisions $\mathrm{v}$ private agreements", The Company Lawyer 1994, p. 301-306

Milman, D.

"The courts and the Companies Acts: the judicial contribution to company law", Lloyd's Maritime and Commercial Law Quarterly 1990, p. 401-415

Munday, R.

"The common lawyer's philosophy of legislation", Rechtstheorie 1983, p. 191-203

Payne, J.

"A re-examination of ratification", CLJ 1999, p. 604-626

Reece Thomas, K. en Ryan, Ch.L.

"Section 459, public policy and freedom of contract", The Company Lawyer 2001, p. 177-182, 198-206

Reynolds, B.

“Shareholders' Class Rights: A New Approach", JBL 1996, p. 554-575 Rickford, J.

"Forthcoming Change in Corporate Law in the UK - the British Company

Law Review and Beyond", Ondernemingsrecht 2002, p. 325-332

Riley, C.A.

"Contracting Out of Company Law: Section 459 of the Companies Act 1985 and the Role of the Courts", MLR 1992, p. 783-802

Riley, C.A.

"Vetoes and Voting Agreements: Some Problems of Consent and Knowledge", Northern Ireland Legal Quarterly 1993, p. 34-50

Rixon, F.G.

"Competing interests and conflicting principles: an examination of the power

of alteration of articles of association", MLR 1986, p. 446-475

Sealy, L.S

"Shareholders' Remedies in the Common Law World", Company, Financial and Insolvency Law Review 1997, p. 172-184

Sealy, L.S.

Cases and Materials in Company Law, $6^{\mathrm{e}}$ druk, Butterworths, Londen 1996

Sealy, L.S.

"Shareholders'Agreements - An Endorsement and a Warning from the House of Lords", CLJ 1992, p. 437-439

Sealy, L.S.

The Enforcement of Partnership Agreements, Articles of Association and Shareholder Agreements, in: Equity and Commercial Relationships, P.D. Finn (ed.), The Law Book Company Limited, Sydney 1987, p. 89-113 Sealy, L.S.

Company law and commercial reality, Sweet \& Maxwell, Londen 1984 Sealy, L.S.

"A Company Law for Tomorrow's World", The Company Lawyer 1982, p. 195-201 
Shapira, G.

"Voting Agreements and Corporate Statutory Powers", LQR 1993, p. 210215

Stedman, G. en Jones, J.

Shareholders' Agreements, $3^{\mathrm{e}}$ druk, Sweet \& Maxwell, Londen 1998

Wedderburn, K.W.

"Shareholders' rights and the rule in Foss v. Harbottle", CLJ 1957, p. 194215

\section{Overige literatuur}

Boucourechliev, J. (red.)

Propositions pour une société fermée européenne, CREDA Luxemburg 1997

Eisenberg, M.A.

"The Structure of Corporation Law", Columbia Law Review 1989, p. 1461 e.v.

Hansmann H.A. en Kraakman, R.A.

"The Essential Role of Organizational Law", Yale Law Journal 2000, p. 387 e.v.

Huizinga, M. en Meinema, M.

Report concerning the Netherlands, in: The European Company - All over Europe, Teichman/Oplustil (red.), De Gruyter, Berlijn 2003

Kluiver, H.J. de, en Van Gerven, W. (red.)

The European Private Company?, Maklu, Antwerpen 1995

La Société Privée Européenne:

une société de partenaires, Chambre de Commerce et d'industrie de Paris/ Conseil National du Patronat Français, 1998

Miller, T.A.

"Minority Shareholder Oppression in the Private Company in the European Community: A Comparative Analysis of the German, United Kingdom, and French "Close Corporation Problem", Cornell International Law Journal 1997, p. 385 e.v.

O'Neill, T.A.

"Toward a New Theory of the Closely-Held Firm", Seton Hall Law Review 1993 , p. $603-652$

Tilquin, T. en Simonart, V.

Traité des sociétés, deel 1, Kluwer Editions Juridiques Belgique, Diegem 1996 

Jurisprudentieregister

\section{Nederland}

Hof van Justitie van de Europese Gemeenschappen

HvJEG zaak 324/86, 10 februari 1988, Jur. 1988, blz. 739, NJ 1990, 432 (Daddy's Dance Hall)

HvJEG zaak 65/86, 27 september 1988, NJ 1991, 61

(Bayer en Henneckes/Sullhofer)

HvJEG zaak C-212/97, 9 maart 1999, NJ 2000, 48 (Centros)

HvJEG zaak C-126/97, 1 juni 1999, NJ 2000, 339

(Eco Swiss China/Benetton)

HvJ EG zaak 208/00, 5 november 2002, NJ 2003, 58 (Überseering)

\section{Hoge Raad}

HR 8 april 1938, NJ 1938, 1076 (Eugen Mehler)

HR 1 december 1938, NJ 1938, 459 (Illustra/Reinartz)

HR 16 juni 1944, NJ 19944/45, 443 (Keymel/Merito)

6.2 .2

HR 30 juni 1944, NJ 1944, 465 (Wennex)

$7.2 .1 ; 7.2 .2$

HR 21 januari 1955, NJ 1959, 43 (Forumbank)

6.2 .2

6.2 .6

HR 12 april 1957, NJ 1957, 345

HR 13 november 1959, NJ 1960, 472 (Distilleerderij Melchers)

$7.2 .1 ; 7.2 .3$

HR 19 februari 1960, NJ 1960, 473 (Aurora)

HR 12 november 1971, NJ 1972, 41

$7.2 .1 ; 7.2 .3$

HR 14 december 1973, NJ 1974, 92

6.2 .1

3.2 .4

HR 19 maart 1967, NJ 1978, 52

6.2 .4

HR 13 maart 1981, NJ 1981, 635

4.2 .3

7.2 .4

HR 9 juli 1990, NJ 1991, 51 (Sluis)

4.2 .3

HR 2 november 1990, NJ 1991, 25

5.2 .4

HR 17 mei 1991, NJ 1991, 645 (Lampe/Tonnema)

6.2 .5

HR 18 december 1991, NJ 1992, 334

4.2 .3

HR 1 juli 1993, NJ 1994, 461

3.2 .4

HR 17 september 1993, NJ 1994, 173 (Gerritse/Hydro Agri Sluiskil)

4.2 .3

HR 17 september 1993, NJ 1994, 213 (Meier Mattern/VHS)

4.2 .3

HR 24 september 1993, NJ 1994, 174 (Hol/EIM)

4.2 .3

HR 31 december 1993, NJ 1994, 436 (Verenigde Bootlieden)

HR 10 mei 1996, NJ 1996, 692

$2.2 .3 ; 4.2 .3 ; 5.2 .5$

HR 31 mei 1996, NJ 1996, 694 (Lampe/Videoworks)

$6.2 .5 ; 6.2 .7$

6.2 .5

HR 29 november 1996, NJ 1997, 345 (Chipshol/Van Andel)

$6.2 .5 ; 6.2 .7$

HR 21 maart 1997, NJ 1998, 207 (Eco Swiss China/Benetton)

3.2 .4

HR 24 september 1999, NJ 1999, 737 
HR 21 december 2001, RvdW 2002, 6 (SOBI/Hurks)

HR 28 juni 2002, RvdW 2002, 117

HR 18 oktober 2002, RvdW 2002

HR 22 november 2002, NJ 2003, 34

Ondernemingskamer

OK 24 januari 1991, NJ 1991, 224 (Sluis)

OK 9 december 1993, NJ 1994, 296 (Nootebos/Van Eyk)

OK 11 maart 1999, NJ 1999, 351 (Breevast)

OK 20 mei 1999, NJ 2000, 199 (Cromwilld/Versatel)

OK 15 november 2001, JOR 2002, 6 (Decidewise)

OK 2 mei 2002, JOR 2002, 156

5.2 .1

OK 8 mei 2002, JOR 2002, 112

Overige gerechtshoven

Hof 's Gravenhage, 12 april 1940, NJ 1940, 928

Hof Amsterdam, 20 mei 1986, NJ 1987, 733

Hof 's Hertogenbosch, 18 juni 1990, NJ 1991, 32 (Tapper/Gartner)

Hof Leeuwarden, in HR 17 mei 1991, NJ 1991, 645

Hof Arnhem, 10 september 1991, NJ 1992, 486

Hof 's Hertogenbosch 8 april 1992, NJ 1992, 701

Hof 's Hertogenbosch 16 juni 1993, NJ 1994, 249

Hof Amsterdam, 8 november 1996, NJ 1998, 681 (Feyenoord/KNVB)

Hof Amsterdam, 25 april 2002, JOR 2002, 128 (Gorillapark)

\section{Rechtbank}

Rb. Haarlem, 19 januari 1932, NJ 1932, 1235

Rb. Amsterdam, 11 januari 1950, NJ 1950, 498

Rb. Rotterdam, 21 februari 1951, NJ 1951, 644

Rb. Maastricht, 1 december 1960, NJ 1960, 152

Rb. Alkmaar 15 december 1976, NJ 1978, 319

Rb. Almelo, 6 maart 1991, NJ 1992, 485

2.2.3

Rb Assen, 17 december 1993, KG 1994, 90

7.2 .2

Rb. Utrecht, 21 maart 2001, JOR 2002, nr. 48

6.2 .5

Rb. Arnhem, 6 september 2001, JOR 2002, nr. 50 


\section{Duitsland}

Reichsgericht

RGZ 107, 67, 70

7.3 .1

RGZ 169, 65, 81

4.3.5

Bundesverfassungsgericht

BVerfG, 05.02.1991 - 2 BvR 263/86, NJW 1991, blz. 2623

\section{Bundesgerichtshof}

BGH 10.11.1951 - II ZR 111/50, BGHZ 3, 354, 357

BGH, 01.04.1953 - II ZR 235/52, BGHZ 9, 157

BGH, 09.06.1954 - II ZR 70/53, BGHZ 14, 25

4.3 .3

BGH, 14.07.1954 - II ZR 342/53, NJW 1954, blz. 1563

$3.3 .1 ; 5.3 .1$

4.3.2

4.3 .1

BGH 09.06.1960 - II ZR 164/58, BGHZ 21, 370, 373

$6.3 .1 ; 6.3 .4 ; 6.3 .5$
$3.3 .3 ; 3.3 .4$

BGH, 25.01.1960 - II ZR 22/59, NJW 1960, blz. 866

BGH, 25.10.1962 - II ZR 188/61, BGHZ 38, 155

4.3 .5

BGH, 25.02.1965 - II ZR 287/63, BGHZ 43, 261

$7.3 .1 ; 7.3 .2 ; 7.3 .4$

BGH, 29.05.1967 - II ZR 105/66, BGHZ 48, 163

$4.3 .2 ; 5.3 .2$

BGH, 04.11.1968 - II ZR 63/67, NJW 1969, 131

$4.3 .2 ; 4.3 .3$

BGH, 29.03.1973 - II ZR 139/70, NJW 1973, 1039

5.3 .4

BGH 19.09.1977 - II ZR 11/76, NJW 1977, blz. 2316

5.3 .2

BGH, 16.02.1981 - II ZR 89/79, WM 1981, 438 = GmbHR 1982, 129

6.3 .4

BGH 11.05.1981 - ZR 25/80, WM 1981, 1218

BGH, 27.10.1986 - II ZR 240/85, NJW 1987, 1890

$4.3 .3 ; 6.3 .6 ; 7.3 .4$

7.3 .3

7.3 .3

BGH, 16.12.1991 - II ZR 58/91, BGHZ 116, 359

5.3 .4

BGH, 08.02.1993 - II ZR 24/92, DB 1993, blz. 829

6.3 .4

BGH, 07.06.1993 - II ZR 81/93, BGHZ 123, 15

BGH, 29.03.1996 - II ZR 124/95, BGHZ 132, 278

BGH 19.06.2000 - II ZR 73/99, WM 2000, blz. 1545

6.3 .2

BGH 13.01.2003 - II ZR 227/00, www.bundesgerichtshof.de

Oberlandesgerichte

OLG Hamm, 24.04.1991, GmbHR 1992, blz. 380

OLG Nürnberg, 19.03.1992, GmbHR 1994, blz. 252

OLG Dresden, 17.06.1996, GmbHR 1997, blz. 746

OLG Stuttgart, 18.02.1998, GmbHR 1997, blz. 312

7.3 .2

OLG München, 20.07.1998, GmbHR 1999, blz. 718

7.3.2

OLG Brandenburg, 20.09.2000, GmbHR 2001, blz. 624 


\section{Engeland}

\section{House of Lords}

Ashbury Railway Carriage and Iron Co Ltd v. Riche [1875] LR 7 HL 653

Bushell v. Faith [1970] AC 1099, [1970] 1 All ER 53, [1970]

2 WLR 272

Carlen v. Drury [1812] 1 Ves \& B 154

Dunlop Pneumatic Tyre Co. Ltd v. Selfridge \& Co. Ltd [1915] AC 847

Ebrahimi v Westbourne Galleries [1973] AC 360, [1972] 2 All ER 492

O'Neill v. Phillips [1999] WLR 1092

Russell v Northern Bank Development Corporation Ltd [1992]

1 WLR 588

$4.4 .4 ; 7.4 .2 ; 7.4 .3$

Salomon v Salomon and Co. Ltd. [1897] AC 22

Welton v. Saffery [1897] AC 299

\section{Court of Appeal}

Allen v. Gold Reefs of West Africa Ltd [1900] 1 Ch 656

$4.4 .4 ; 5.4 .1 ; 5.4 .4$

Bairstow v. Queen's Moat [2001] BCLC 2531

Beattie v. E \& F Beattie Ltd [1938] Ch 708

Bratton Seymour Services Co. Lts v. Oxborough [1992] BCLC 693

Edwards v. Halliwell [1950] 2 All ER 1064

Eley v. Positive Life Assurance Co [1876] 1 Ex D 88

Greenhalgh v. Arderne Cinemas Ltd [1951] Ch 286 [1950]

2 All ER 1120

Greenhalgh v. Mallard [1943] 2 All ER 234

Guinness v. Land Corporation of Ireland [1882] 22 Ch D 349

Holmes v. Keyes [1959] Ch 143

MacDougall v. Gardiner [1875] 1 Ch D 13

Monecor (London) Limited v. Euro Broker Holdings Limited [2003] EWCA Civ 105

Oliver Ashworth (Holdings) Ltd v. Ballard (Kent) Ltd [2000] Ch 12

Peveril Gold Mines Ltd, Re [1898] 1 Ch 122

Precision Dippings Ltd v. Precision Dippings Marketing Ltd [1985]

3 WLR 812

Salmon v. Quin \& Axtens Ltd [1909] 1 Ch 311

Saul D. Harrison and Sons plc, $\operatorname{Re}$ [1995] 1 BCLC 14

Scott v. Frank F Scott (London) Ltd [1940] Ch 794 


\section{Overige}

BDG Roof-Bond Ltd v. Douglas and others [2000] 1 BCLC 401

Burland v. Earle [1902] AC 83 (Privy Council)

6.4 .2

Cane v Jones [1981] 1 All ER 533

$6.4 .1 ; 6.4 .3$

Colt Telecom Group plc, $\operatorname{Re}$ [2002] EWHC 2815 (Ch), [2002] All ER (D) 347

Cumbrian Newspapers Group Ltd v. Cumberland \& Westmorland

Herald Newspaper \& Printing Co. Ltd [1987] 3 WLR 26

Dafen Tinplate Co Ltd v. Llanelly Steel Co (1907) Ltd [1920] 2 Ch $124 \quad 5.4 .4$

Duomatic Ltd, $\operatorname{Re}$ [1969] 2 Ch 365, [1969] I All ER 161, [1969]

2 WLR 114

Euro Brokers Holdings v. Monecor (London) Ltd [2002] EWHC 1480

Greenwell v. Potter [1902] 1 Ch 530

Hickman v. Kent or Romney Marsh Sheepbreeders' Association [1915] $1 \mathrm{Ch} 881$

Mackenzie \& Co Ltd, $\operatorname{Re}[1916] 2 \mathrm{Ch} 450$

Malleson v National Insurance Corporation [1894] 1 Ch 200

New Cedos Engineering Co Ltd, Re [1994] I BCLC 797

North-West Transportation Co. Ltd and Beatty v. Beatty [1887] 12 AC 589

Pender v. Lushington [1877] $6 \mathrm{Ch} 70$

Peter's American Delicacy Co Ltd v. Heath [1939] 61 CLR 457 (High Court of Australia)

Phoenix Office Supplies Ltd, Re, Phoenix Office Supplies Ltd and others v. Larvin [2002] EWCA Civ 1740, [2003] 1 BCLC 76

Puddephatt v. Leith [1916] 1 Ch 200

Rayfield v. Hands [1960] Ch 1, [1958] 2 All ER 194 All ER (D) 141

Smith v. Croft (No 2) [1987] 3 All ER

Torvale Group Ltd, Re [1999] 2 BCLC 605 


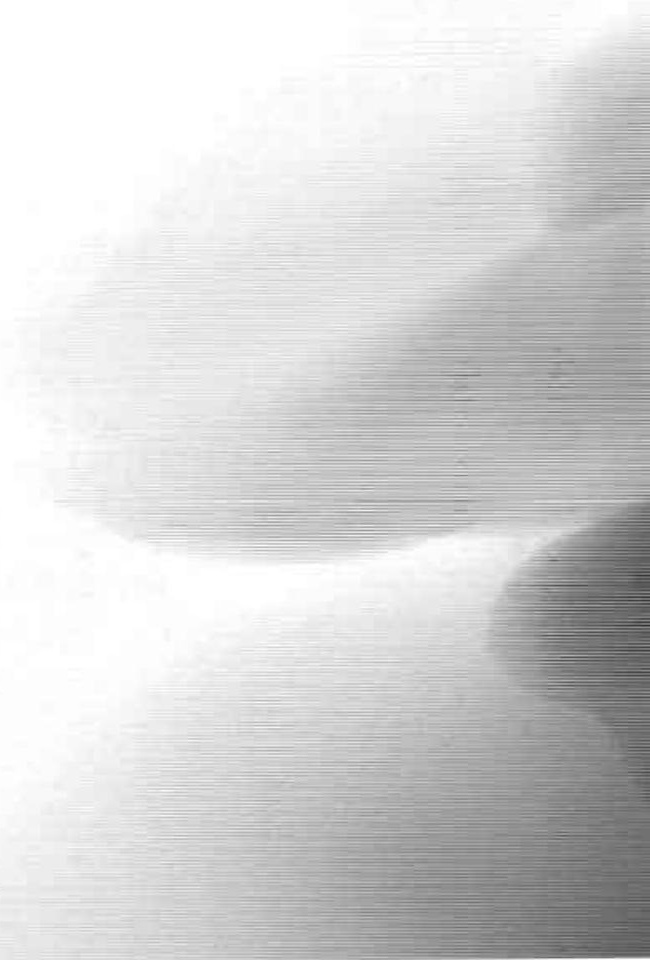




\section{Trefwoordenregister}

Aanbiedingsregeling, zie ook Blokkeringsregeling 80,108

Aanbiedingsverplichting, zie ook Uitstoting

statutaire -

Aandeelhouders, zie ook Minderheidsaandeelhouders

positie van -

conflicten tussen -

legitimatie zeggenschap van -

bescherming van -

$6,16,107$

toekomstige -

$6,16,107$

beleggers

Mitgliedschaft

5,16

Aandeelhoudersovereenkomst

Nebenabrede

toelaatbaarheid

$185,211,225$

niet-nakoming van een -

$189,213,226$

grenzen aan de toelaatbaarheid

openbaarmaking

vennootschapsrechtelijke werking

stemovereenkomst

instructie-overeenkomst

voorvergader-overeenkomst

- inzake uitgifte van aandelen

- inzake blokkeringsregeling

- inzake overdracht van aandelen

- inzake uitstoting

- inzake uittreding

$190,202.214,226$

203,229

- inzake benoeming van bestuurders

291.229

$195,211,-325$

194. 145, 216

- inzake ontslag van bestuurders

- inzake statutenwijziging

- inzake verplichtingen

\section{Aandelen}

overdracht van -

uitgifte van -

intrekking van -

stemrechtioze -

prioriteits -

Vorzugsgexchiffunateite 



\section{Trefwoordenregister}

Aanbiedingsregeling, zie ook Blokkeringsregeling 80,108

Aanbiedingsverplichting, zie ook Uitstoting statutaire -

Aandeelhouders, zie ook Minderheidsaandeelhouders

positie van -

conflicten tussen -

legitimatie zeggenschap van -

bescherming van -

$6,16,107$

toekomstige -

$17,60,152,160$

beleggers

5,16

Mitgliedschaft

Aandeelhoudersovereenkomst

Nebenabrede

toelaatbaarheid

$185,211,225$

niet-nakoming van een -

$189,213,226$

grenzen aan de toelaatbaarheid

$190,202,214,226$

openbaarmaking

203,229

vennootschapsrechtelijke werking

$152,203,221,229$

stemovereenkomst

$185,211,225$

$194,195,216$

instructie-overeenkomst

voorvergader-overeenkomst

$199,210,227$

- inzake uitgifte van aandelen

$80,157,197,220$

200,202

167,218

- inzake uitstoting

- inzake benoeming van bestuurders

$198,210,217$

- inzake ontslag van bestuurders

$167,200,217,222$

$199,210,222$

- inzake statutenwijziging

209

\section{Aandelen}

- inzake verplichtingen

overdracht van -

uitgifte van -

$81,103,137,156,196,200,202$

134,176

intrekking van -

$90,128,129$

stemrechtloze -

130

prioriteits -

109

Vorzugsgeschäftsanteile

122 
Aanvullend recht

kwalificatie

11,28

suppletory/default rules

ratio van -

aanvullende bepalingen

108,120

Table A

$10,40,100,130$

Aanvullende rechten en verplichtingen, zie ook Statuten, Optioneel recht

bijzondere rechten inzake de zeggenschap

Sonderrechte

Class rights

verplichtingen

Nebenleistungen

kwaliteitseisen

Afstand

- van recht

- van een subjectief recht

- van een vorderingsrecht

- van vennootschapsrechten

- bij voorbaat

50,52

doctrine of waiver

$69,70,175$

unverzichtbare rechten

$62,160,219$

afzien van de uitoefening van rechten

53,55

rechtsverwerking

$146,150,162$

arbitrage

$57,70,63$

bevestiging

Aktiengesetz, zie ook Duitsland geschiedenis

Satzungsstrenge

Arbitrage, zie ook Afstand, Geschillenregeling

statutaire arbitrageclausule

arbitraal beding

- van vennootschappelijke geschillen

Schiedsgericht

- en openbare orde 
Bekrachtiging, zie ook Nietigheid, Besluit van de algemene vergadering

- van een besluit

- van een rechtshandeling

- door statutenwijziging

België

Besloten Vennootschap met Beperkte Aansprakelijkheid

Benoeming van bestuurders, zie ook Bevoegdheden van de algemene

bindende voordracht vergadering

28,164

29,109

overeenkomst inzake de $198,210,217$

Besluit van de algemene vergadering

kwalificatie

vormvoorschrift aan een -

registratie

163,169

nietigheid van een -

144,159

vernietigbaarheid van een -

$145,161,207$

bekrachtiging van een -

bevestiging van een -

conversie van een -

$152,157,167$

Satzungsdurchbrechung

Satzungsverletzung

$163,165,166$

extraordinary resolution

132,168

elective resolution

$9,41,168$

special resolution

$42,71,168$

unanimous consent rule

Besluitvorming

procedure

45

eisen

schriftelijke -

$85,142,158,168$

eenstemmige -

85,102

\section{Bestuur}

bindende voordracht

29, 109

delegatiebesluit

Bevoegdheden van de algemene vergadering

delegatie van -

- tot ontslag van bestuurders

$28,42,123,154$

- tot benoeming van bestuurders

28,164

- tot statutenwijziging

28,84

- tot uitgifte van aandelen

28,176

- tot vaststellen van de jaarrekening

28,51

Bevestiging, zie ook Afstand, Vernietigbaarheid

- van rechtshandelingen

- van besluiten 
Bindende voordracht, zie ook Benoeming van bestuurders wetsgeschiedenis

bevoegdheid tot het doen van een -

doorbreking van een -

Blokkeringsregeling

vormvereisten

wijziging van de -

32,114

ratio

aanbiedingsregeling

goedkeuringsregeling

$32,109,122,150,166$

Vinkulierungsklausel

220

overnameverplichting

kwaliteitseisen aan aandeelhouders

besluit in strijd met -

Blo $\beta$ formelle bepaling, zie Statuten

CAO, zie ook Interpretatie interpretatie van -

\section{Certificaathouders} rechten van -

Class rights, zie ook Rechten van aandeelhouders kwalificatie

- bij overeenkomst

Common law, zie ook Engeland doctrine of severance

doctrine of waiver

$69,70,175$

unanimous consent rule

173

the Rule of Foss $v$. Harbottle

Companies Act 1985, zie ook Engeland

Company Law Review, zie ook Engeland

think small first

4,9

elective regime

constitution

Concessiestelsel, zie ook Oprichting

Concurrentieverbod, zie ook Verplichtingen van aandeelhouders

Constitution, zie Company Law Review, Statuten

Contractsvrijheid

Vertragsfreiheit

pacta sunt servanda

Conversie, zie ook Besluit, Nietigheid

Corporate governance

Crediteuren

$17,176,226$

bescherming van - 
Delegatie van bevoegdheden, zie ook Bevoegdheden van de algemene vergadering

- tot statutenwijziging

- delegatiebesluit

Departementale richtlijnen, zie ook Oprichting

Wet herziening preventief toezicht

Derivative action, zie ook Rechten van aandeelhouders fraud on the minority

Dividend, zie ook Rechten van aandeelhouders

recht op -

28,56

afstand van het recht op -

Doctrine of severance, zie ook Common law

69,175

Election

promissory estoppel

Doelomschrijving, zie ook Statuten

wijziging

doeloverschrijding

\section{Duitsland}

\section{Aktiengesetz}

GmbH-Gesetz

Rechtsfortbildung

8,224

Duomatic principle, zie Unanimous consent rule

Dwingend recht

semi-dwingend recht

driekwart-dwingend recht

verbodsbepalingen

gebodsbepalingen

openbare orde

Verbotsgesetz

$49,58,148,158$

mandatory rules 160,214

artikel 2:25 BW

geschiedenis van artikel 2:25 BW

ratio van artikel $2: 25 \mathrm{BW}$

ratio van -

Satzungsstrenge

Dwingende normen

redelijkheid en billijkheid

54,188

Verbandsautonomie

96,220

Satzungsautonomie

96,220

Treupflicht

Normanwendungstheorie

$38,62,65,123,212$

bona fide for the benefit of the company as a whole 


\section{Engeland}

verhouding statutes en common law

Companies Act 1985

Company Law Review

Limited liability partnership

Enquête, zie ook Rechten van aandeelhouders

recht van -

$28,47,54,60,205$

afstand van het recht van -

wanbeleid

Equity, zie ook Engeland section 459 CA 1985

winding-up on just and equitable grounds

$67,69,173,230$

230

European Private Company

Europese Vennootschap (SE)

Familievennootschap, zie ook Persoonsgebonden vennootschap

Frankrijk

Société à responsabilité limité

Société par Actions Simplifiée

Projet de loi sur l'initiative économique

Fraud on the minority, zie ook Derivative action

Gelijke behandeling

Gleichbehandlungsgrundsatz

Gesamtakt, zie ook Oprichting, Statuten

Geschillenregeling, zie ook Uitstoting; Uittreding

arbitrageclausule

aanbiedingsverplichting

overnameverplichting

Gesellschaftsvertrag, zie ook Statuten

GmbH-Gesetz, zie ook Duitsland

geschiedenis

Goedkeuring, zie ook Blokkeringsregeling goedkeuringsrecht goedkeuringsregeling

Groot-Brittannië, zie Engeland

Haviltex-maatstaf, zie ook Interpretatie

Ierland

Companies Bill

Implied terms, zie ook Interpretatie

Incorporation by reference, zie ook Statuten

Interpretatie

- van statuten

$82,93,101$

- van de wet

- van een CAO 
objectieve -

restrictieve -

Haviltex-maatstaf

82,84

implied terms

ergänzende Vertragsauslegung

Regelungslücke

Inrichtingsvrijheid

Gestaltungsfreiheit

$22,36,89,120,215$

17,160

Institutionenschutz

$194,195,216$

Instructieovereenkomst, zie ook Aandeelhoudersovereenkomst

Italië

hervorming Italiaans vennootschapsrecht

Jaarrekening, zie ook Bevoegdheden van de algemene vergadering vaststelling van de -

goedkeuringsrecht inzake de -

Körperschaftsrechtliche werking, zie ook Statuten, Vennoot-

schapsrechtelijke werking

Korporative bepalingen, zie ook Statuten

Kwaliteitseisen aan aandeelhouders, zie ook Aanvullende rechten en verplichtingen, Optioneel recht

kwalificatie

opleggen van -

$31,117,129$

doorbreken van -

wijziging van het -

Minderheidsaandeelhouders, zie ook Aandeelhouders

bescherming van -

$16,43,107,123,131,133,202$

bijeenroepen vergadering door -

47,62

vernietiging besluiten door-

54,56

Mitgliedschaft, zie ook Aandeelhouders

Nebenabrede, zie ook Aandeelhoudersovereenkomst

Nebenleistungen, zie ook Verplichtingen van aandeelhouders

Nietigheid

- van overeenkomsten

$80,192,214$

- van statuten

$80,81,90,91,125$

- van besluiten

144,159

ratio

148,160

- bekrachtiging

- conversie

Heilung

$\begin{array}{lr}\text { Normanwendungstheorie, zie ook Dwingende normen } & 220 \\ \text { Normentheorie } & 89\end{array}$

modifizierte Normentheorie 90 
$\begin{array}{ll}\text { Objectief recht, zie ook Statuten } & 77\end{array}$

Octrooistelsel, zie ook Oprichting 23

Oligarchische clausule, zie ook Bindende voordracht 29

Ondernemingsraad, zie ook Orgaan

adviesrecht van de - 51

- als belanghebbende 145

Onrechtmatige daad

- in geval van handelen in strijd met een aandeelhoudersovereenkomst $\quad 204$

Ontbinding, zie ook Rechten van aandeelhouders

- van de vennootschap

$59,79,128,230$

verzoek tot -

besluit tot -

Ontslag van bestuurders, zie ook Bevoegdheden van de alyemene vergadering bevoegdheid tot -

$42,123,154$ statutaire bepalingen inzake aandeelhoudersovereenkomst inzake $42,112,133,135$ uittredingsrecht in geval van $167,200,217,222$

Openbare orde, zie Dwingend recht

- en goede zeden

$49,58,148,158$

arbitrage en -

Oprichting, zie ook Preventief toezicht

concessiestelse 1

octrooistelsel

publiciteitsstelsel

Gesamtakt

inschrijving in het handelsregister

Optioneel recht

permissive rules

kwalificatie

kwaliteitseisen aan aandeelhouders

$10,11,118$

bindende voordracht

10,11

elective regime

\section{Orgaan}

begrip

bevoegdheidsverdeling

Aufsichtsrat

Beirat

ondernemingsraad

prioriteit

Schiedsgericht

Organisationsvertrag, zie Overeenkomst, Statuten 
Overeenkomst, zie ook Aandeelhoudersovereenkomst

Contractsvrijheid

pacta sunt servanda

Organisationsvertrag

'relational' -

arbeids -

57,143

- als besluit

$143,158,169$

privity rule

Overnameverplichting, zie ook Verplichtingen van aandeelhouders

- in een aandeelhoudersovereenkomst

Outsider rights, zie Rechten van derden

Pacta sunt servanda, zie ook Contractsvrijheid

150,152

147

familievennootschap

43,69

quasi-partnership

joint-venture

6,183

Preventief toezicht, zie ook Oprichting

octrooistelsel

concessiestelsel

departementale richtlijnen

Wet herziening preventief toezicht

30

Registerrichter

Registrar

$10,22,90,166$

100

Prioriteitsaandelen, zie ook Aandelen

vestiging

109,110

intrekking

wijziging

Qua member right, zie ook Rechten van aandeelhouders

\section{Rechten van aandeelhouders}

wijziging van -

legitimatie van -

class rights

qua member right

derivative action

Sonderrechte

unentziehbare rechten

unverzichtbare rechten

bijeenroepen algemene vergadering 
dividend

$28,62,67,120$

enquête $28,47,54,60$

ontbinding van de vennootschap

opbrengst na vereffening

$28,62,120$

stemrecht $55,62,67$

uitkoop

uitstoting

uittreding

54,62

vorderen van vernietiging van een besluit

54,56

Rechten van derden

kwalificatie

bijzondere voordelen

outsider rights

privity rule

Sondervorteile

goedkeuringsrecht

$30,81,87,97,103,109$

8,224

Rechtsfortbildung, zie Duitsland

$146,150,162$

Rechtsverwerking, zie Afstand

Redelijkheid en billijkheid, zie Dwingende normen

54,88

34,93

Regelungslücke, zie ook Interpretatie

Registerrichter, zie ook Oprichting

Representative action, zie Derivative action

$10,22,90,166$

170,172

171

Rule from Foss v. Harbottle, zie ook Common law

116,128

- op niet-nakoming statutaire verplichtingen

189,213

- op niet-nakoming aandeelhoudersovereenkomst

Unwirksamkeit

96,220

Satzungsautonomie, zie ook Dwingende normen

- als uitzondering op vernietigbaarheid

- als geldig besluit

punktuelle Satzungsdurchbrechung

Satzungsstrenge, zie Dwingend recht

22,33

ratio

Satzungsverletzung, zie ook Besluit van de algemene vergadering $163,165,166$

Schiedsgericht, zie ook Arbitrage; Orgaan

Sonderrechte, zie ook Rechten van aandeelhouders

kwalificatie

intrekking van -

wijziging van -

Sondervorteile, zie ook Rechten van derden

kwalificatie

121,125

wijziging van - 


\section{Spanje}

Ley 7/2003 Sociedad Limitada Nueva Empresa

4

Special resolution, zie ook Besluit van de algemene vergadering Statuten,

kwalificatie

$42,71,168$

Gesellschaftsvertrag

Gesamtakt

Constitution

Memorandum

100

articles of association

98

98

rechtskarakter van de -

$77,90,98$

- als objectief recht

Organisationsvertrag

functie

75

verschil met overeenkomst

Normentheorie

Vertragstheorie

- in formele zin

$91,94,100$

- in materiële zin

$90,94,100,127$.

interpretatie van de -

$91,82,93,101$

korporative bepaling

blo $\beta$ formelle bepaling

unechte bepaling

Incorporation by reference

minimuminhoud

aanvullende bepalingen

79,81

Körperschaftsrechtliche werking

Angemessenheitskontrolle

Statutenwijziging, zie ook Bevoegdheden van de algemene vergadering

bevoegdheid tot -

eisen aan -

beperking van de bevoegdheid tot -

Satzungsdurchbrechung

wijziging van het memorandum

bona fide for the benefit of the company as a whole goedkeuring van een besluit tot-
84,102

$85,95,102$

86

163,165

102

130,137

87,97

$193,218,229$

$194,195,216$

190

197 
Stemrecht, zie ook Rechten van aandeelhouders

187,225

ontnemen of beperken van -

$31,121,131$

Abspaltungsverbot

ratio

Stimmverbot

$37,212,216$

grenzen aan de uitoefening van het -

188,212

meervoudig -

133

Stimmenkauf, zie Aandeeihoudersovereenkomst

$193,218,229$

Stimmverbot, zie Stemrecht

$37,212,216$

$2,29,51$

52,63

Subjectief recht, zie Afstand

$10,40,100,130$

Table A, zie Aanvullend recht

Treupflicht, zie Dwingende normen

$38,62,65,123,212$

Uitgifte van aandelen, zie ook Bevoegdheden van de

bevoegdheid tot -

besluit tot -

aandeelhoudersovereenkomst inzake -

199,210

voorkeursrecht bij een -

$28,108,132$

Uitstoting, zie ook Rechten van aandeelhouders

uitstotingsclausule

aanbiedingsverplichting

Ausschließungsklage

Einziehung

Uittreding, zie ook Rechten van aandeelhouders

recht op -

$67,69,121$

Austrittsrecht

$35,37,127$

overnameverplichting

Umdeutung, zie ook Conversie

Common law

Unechte bepaling, zie Statuten

Unentziehbare rechten, zie ook Rechten van aandeelhouders

Unverzichtbare rechten, zie ook Afstand van recht,

Rechten van aandeelhouders

$62,160,219$

Unwirksamkeit, zie ook Sanctie

schwebende Unwirksamkeit

Vennootschapsrechtelijke werking, zie ook Aandeelhoudersovereenkomsten

körperschaftsrechtliche werking

- door middel van onrechtmatige daad

- door middel van het enquêterecht

Verbandsautonomie, zie Dwingende normen

96,220

Verbandssouveränität, zie Verbandsautonomie

Verbotsgesetz, zie Dwingend recht

160,214

Vereinsautonomie, zie Verbandsautonomie 


\section{Verenigde Staten}

law \& economics

Limited liability company

Vernietigbaarheid

- van besluiten

$145,161,170,178,189,207$

Anfechtungsklage

121,161

termijn

bevestiging

- van overeenkomsten

Vernietiging, zie ook Rechten van aandeelhouders bevoegdheid tot het inroepen van -

Verplichtingen aan aandeelhouders

kwalificatie

$52,56,150,161,170$

$34,110,136$

Nebenleistungen

113,126

126

niet-nakoming van -

116

overdrachtsverplichting

$115,116,127$

overnameverplichting

vestiging van -

concurrentieverbod

contractuele verplichtingen

Vertragstheorie, zie ook Statuten

Vote anticipé, zie ook Stemovereenkomst

Wanbeleid, zie ook Enquête

- wegens handelen in strijd met een aandeelhoudersovereenkomst

205,206

Werknemer

bescherming van -

$15,50,149$

- als aandeelhouder

118,201

Winstbestemming, zie ook Bevoegdheden van de algemene vergadering 



\section{Curriculum vitae}

Martha Meinema werd geboren op 7 maart 1972 in Koudekerke, gemeente Valkenisse. Zij groeide op in Lemmer en haalde in 1990 haar VWOdiploma aan het Zuyderzee College te Emmeloord. Daarna studeerde zij rechten in Groningen en een half jaar in Siena. Tijdens haar laatste jaar was ze student-assistent bij de vakgroep Handelsrecht en Europees Recht. Na zes jaar studeerde ze af in Nederlands recht, richting Ondernemingsrecht en Sociaal-economisch Recht, en in Internationaal recht. Vervolgens heeft ze vijf maanden in Amsterdam als intercedente bij Randstad Uitzendbureau gewerkt, waarna ze terecht kwam in Maastricht. Daar is ze achtereenvolgens AIO, junior-onderzoeker en docent geweest, terwijl ze aan haar proefschrift schreef. Sinds 1 februari 2003 is ze werkzaam als beleidsmedewerker bij het Ministerie van Economische Zaken. 
II 